\title{
Elementos para uma teoria política kaiowá e guarani
}

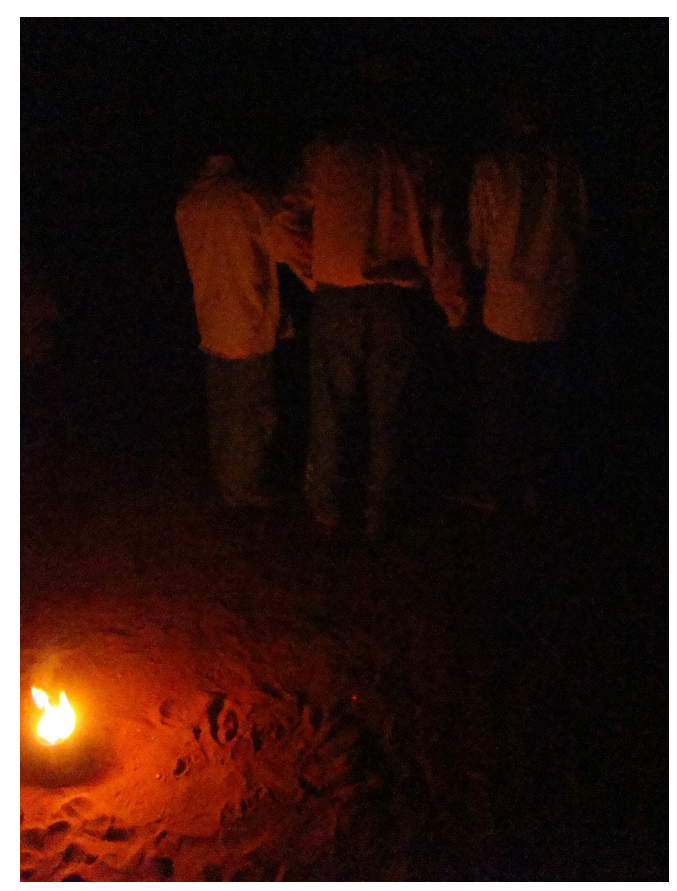

\begin{abstract}
Tese apresentada para a obtenção do grau de DOUTOR em ANTROPOLOGIA SOCIAL na Faculdade de Filosofia, Letras e Ciências Humanas da Universidade de São Paulo. Orientadora: Profa. Dra. Beatriz PerroneMoisés.
\end{abstract}

SÃO PAULO, 2012

VERSÃO REVISADA 
Resumo: O trabalho busca compor uma teoria etnográfica da política kaiowá, o que significa dizer que, a partir do trabalho de campo, elabora um modelo de compreensão dos movimentos coletivos desses indígenas de língua guarani e de suas formulações a esse respeito - as quais, na tradução proposta aqui, corresponderiam, em parte, ao que nós, ocidentais, entendemos como política (estabelecendo, ainda, conexão com o que se vem denominando “cosmopolítica”). As formas políticas em análise aqui estão agrupadas em torno de três figuras de maior rendimento para a exposição: tendotá, johexakáry e aty. Por vezes, as formulações dizem respeito também aos Guarani de MS (falantes de ñandeva), uma vez que parte da pesquisa os alcança, e parte não. Para que sejam mais bem compreendidas, mostramos como essas formas podem ser postas em diálogo com relatos sobre diversas experiências políticas ameríndias, de grupos como os Tupinambá quinhentistas, os Iroqueses e os Maya de Chiapas, México. O trabalho também discute como a noção de redes sociais pode ajudar a repensar a versão canônica da história da região hoje habitada pelos Kaiowá e Guarani, o sul de Mato Grosso do Sul.

Palavras-chave: formas políticas ameríndias, kaiowá, guarani, teoria etnográfica, antropologia política, redes ameríndias, autonomias indígenas, genocídio, conflitos de terra no Brasil, cosmopolítica, direitos humanos, antropologia anarquista, zapatismo, conselhos.

\begin{abstract}
The work aims to compose an ethnographic theory of kaiowa politics, which means that, based on the fieldwork, it formulates a model for understanding the collective movements of this guarani speaking group and its statements about this subject - which, in the translation proposed here, correspond in part to what we Westerners understand as politics (also establishing a connection with the so called "cosmopolitics"). The political forms under review are grouped around three characters of greater yield for discusssion: tendotá, johexakáry and aty. Sometimes, the statements also concern the Guarani (ñandeva speakers), as part of the research involves them, but not all of it. To promote a better understanding, we show how these forms can be brought into dialogue with accounts of diferent amerindian political experiences, among groups like the Tupinambá of sixteenth century, the Iroquois and the Maya of Chiapas, Mexico. The thesis also discusses how the notion of social networks can help to rethink the canonical version of the history of the region now inhabited by the Guarani and Kaiowá, the south of Mato Grosso do Sul
\end{abstract}

Key words: Amerindian political forms, kaiowá, guarani, ethnographical theory, political anthropology, Amerindian networks/meshworks, indigenous autonomies, genocide, land struggle in Brazil, cosmopolitics, human rights, anarchist anthropology, zapatism, councils. 


\section{Agradecimentos}

Em primeiro lugar, esse trabalho não existiria sem a permissão concedida pelos Kaiowá e Guarani para que eu pudesse conviver e aprender com eles ao longo dos últimos 16 anos. Como muitos deles certamente deixaram que eu me aproximasse em função de terem tido autorização dos Tekojára kuery, ou Tupanguéry, os Deuses, nossos Irmãos Maiores, é a Eles que devo gratidão, em primeiro lugar. Pela concessão, e pela proteção, em inúmeras ocasiões, a mim e a minha família.

Devo agradecimento especial a todos os habitantes da região do Apa, as comunidades de Ñanderu Marangatu, Pirakuá, Kokuei e Pysyry, que generosamente me receberam por tantas vezes. Espero fazer jus a sua sabedoria, seus dramas, as histórias de vida que compartilharam comigo. Minha gratidão, ainda, a todos os que têm assumido a frente da Aty Guasu nos últimos anos, e particularmente a Anastácio Peralta, Otoniel Ricardo, Eliseu Lopes, Oriel Benites, Tonico Benites. Este último merece menção especial, pois, além de liderança, é um colega antropólogo que divide comigo há vários anos seus valiosos insights. Também aos demais acadêmicos kaiowá e guarani com quem mantive diálogo, como Izaque João, Eliel Benites e tantos outros.

Ainda, a pessoas de muitas comunidades, que conheci nas Aty Guasu e que foram importantes em momentos variados: gente como Jorge Gomes, Valmir Cabrera, Erpídio Pires; Oriel, Aurélio e Delfino, da família do sr. Atanásio Teixeira; os Bro MC's e Higor Lobo; Clara Barbosa de Almeida; à família de Marçal de Souza, onde tudo começou (num encontro com Roberto, no Jaguapiru, em dezembro de 1996). Enfim, há tanta, mas tanta gente que não seria capaz, jamais, de nomear a todos, uma vez que essa pesquisa envolveu a interação com centenas de pessoas. Agradeço, na sequência, a minha orientadora, Beatriz Perrone-Moisés, que me acolheu, sempre, com enorme generosidade, constantemente renovada, ao longo dos últimos 13 anos. É do diálogo com ela que nasce esta pesquisa.

Devo, ainda, agradecer a todos que lutaram para que pudéssemos ter um sistema público de ensino. Sem a oportunidade de estudar gratuitamente na USP, ao longo dos últimos 20 anos, eu dificilmente poderia chegar a concluir esta tese. Além de não pagar, ainda pude contar com bolsas de estudo ao longo do doutorado. Só por isso pude deixar o trabalho como jornalista e dedicar-me inteiramente à pesquisa. Devo, assim, reconhecimento público à Capes (DS/Proap) e à Fapesp (2011/11200-5) - esta, além de apoiar a presente pesquisa em seus últimos meses, também financiou o Projeto Temático "Redes Ameríndias: geração e transformação de relações nas terras baixas sul-americanas", do Núcleo de História Indígena e do Indigenismo (NHII-USP) - FAPESP 05/57134-2. A Capes, ainda, apoiou meu estágio de pesquisa no México, por meio de uma bolsa 
PDEE (1290-10-0), o que muito colaborou para que chegasse aos resultados ora apresentados.

Aos parceiros do NHII, hoje Cesta (Centro de Estudos Ameríndios), lugar de diálogos fundamentais. Aos professores Dominique Gallois e Márcio Silva, particularmente, pela preciosíssima participação no exame de qualificação e pelas conversas em tantas outras ocasiões; ainda, a Renato Sztutman, Marta Amoroso, Eduardo Natalino, Eduardo Neves; a todos os colegas com os quais convivi em inúmeros seminários, colóquios, simpósios, conferências e botecadas, e particularmente aos que se tornaram parceiros de empreitada, nos cursos de extensão de "Introdução aos Estudos sobre os Povos Indígenas do Brasil": Joana Cabral de Oliveira, André Drago, Ana Yano, Marcele Guerra, Renato Soares, Pedro Lolli, Guilherme Falleiros, Leandro Mahalem. Aos nossos mais velhos, Uirá Garcia, Evelyn Zea, Gabriel Barbosa, Denise Fajardo, Rogério Duarte do Páteo, Luiz Fernando Pereira (in memorian). Aos parceiros guaraniólogos do litoral, com os quais tanto aprendi: Daniel Pierri, Valéria Macedo, Adriana Testa, Fábio N. da Silva, Eliza Castilla, Maria Lucia Bellenzani, Francisco de Paulo Jr., Maria Inês. E ainda a Frank, Lucas, enfim, a todos os que ajudam a manter acesa a chama da etnologia na USP! Aos comparsas Salvador Schavelzon, Bárbara Arisi, Rafael E., Waldo, Ernenek y Mariana, Bruno M., e quantos mais...

Vale registrar que, durante os quase 12 meses do processo de construção do presente texto, procurei pessoalmente, por correio eletrônico ou telefone, diversos colegas, que, de forma mui gentil, me ajudaram a esclarecer pontos sobre suas obras, compartilharam textos, ou até mesmo me deram verdadeiras aulas particulares sobre certos tópicos, especialmente na arqueologia e na história. Por isso, agradecimentos especiais pela generosidade e paciência a Eduardo Bespalez, Eduardo Neves, Fabíola Andréa Silva, André Soares, Joanna Overing, Celso Aoki, Adelina Pusineri, Frederico Silva, Luís Roberto de Paula, Jean Tible, além dos vários amigos do Cesta. Foi muita gente mesmo, portanto, perdão antecipado por qualquer falha de memória.

Agradecimentos, ainda, a Andre Drago, pelo diálogo constante em torno de nossas pesquisas, a Joana Cabral de Oliveira, pela crucial ajuda com a formatação final da tese, e ao irmão Danilo Kulaif, pela elaboração do mapa das terras indígenas kaiowá e guarani. Excetuando-se algumas poucas fotos creditadas, as demais que acompanham a tese foram feitas por mim e por Joana Moncau, a quem muito agradeço, também, por isso.

Um foco crucial de aprendizado, há muitos anos, é a convivência com outros pesquisadores que trabalham entre os Kaiowá e Guarani. Trata-se de uma realidade dura e triste, em função das muitas violências e injustiças cometidas contra os indígenas em MS. Por isso, deve-se reconhecer, é preciso grande firmeza no coração para não abandonar o barco. A quem não desiste, um forte abraço. Particularmente, esta tese surge de conversas e das leituras de trabalhos de gente como Levi Marques Pereira, Fábio Mura e Rubem Thomaz Almeida. Ainda que discordemos em alguns pontos, 
saibam que a inspiração do trabalho de vocês foi e continuará sendo fundamental. Também agradeço a Marcos Homero Lima, Alexandra Barbosa da Silva, Jorge Eremites, Diógenes Cariaga, Thiago Cavalcante, Deise Montardo, Tatiane Klein e a todos os outros que persistem. Um saludo especial a Graciela Chamorro, que teve participação crucial em vários momentos desta pesquisa, compartilhando textos, ajudando-nos com seu fino conhecimento da língua guarani e, na reta final, apresentando-me a Isabelle Combès, a quem também esta tese deve muitíssimo. Ainda, a toda a equipe do Cimi-MS, ao procurador Marco Antonio Delfino de Almeida, à turma da UFGD, UCDB, UEMS, todos que proporcionam importante apoio à luta kaiowá e guarani por seus direitos. E um brinde à memória de Antonio Brand.

Aos amigos que nada têm a ver com a antropologia, mas sem os quais eu não seria este que aqui está. E, particularmente, àqueles de quem o destino me deixou mais próximo nos últimos anos: a Leonardo Sakamotto, Mauricio, Verena, Marcel, toda a turma da Repórter Brasil; a Cristiano Navarro, Aloisio Milani, Rafael Gomes, Marina Amaral, Allan da Rosa e Luciane, Mateus Subverso (À Beira da Palavra/Toró), Christiane Peres, Byanca Pyl, Daniel, Danilo, Monica, Tati e famílias, Camila W., Lúcia, Elô, Fabio K. e família, Alvaro, Pedro e Antonio Biondi; Daniel M. e Juliana Nunes; Gabi, Angel e famílias; todo o povo das antigas, Guto e família, Marcelo, Marcos, Pedrão, Vander... A Eliane e Khalid, Danilo e Tati, Leonardo, Rodolfo, Álvaro, pelo abrigo e o amparo naqueles momentos difíceis de 2008.

E, ainda, a todos que proporcionaram espaço para as denúncias sobre a gravíssima situação vivida em MS e outros tantos absurdos que vêm atingindo os povos indígenas: Paulo Donizetti, Livia Perozim, Matheus Pichornelli, Ricardo, Claudio Angelo, Thiago Domenici, Leandro Fortes, Hamilton de Souza, Wagner Nabuco, Bob Fernandes, Eliane Brum e tantos outros jornalistas de valor... Aos parceiros do filme "Mbaraka - A Palavra que Age": Gianni, Edgar, Teju Muller Orue e todos os que trabalharam nas traduções. À Cese, pelo apoio à Caros Amigos Especial Indígena.

Aos amigos do México: a banda do Desinformémonos (Sergio, Amaranta, Marcela, Jaime, Carolina...), a Carlo Bonfiglioli, Alejandro Fujigaki e Isabel Martinez, a Miguel Vassallo e Ana Ortiz, Dolores Camacho Velázquez, Laura Romero, Saúl Millán... Enfim, a todos que nos receberam de forma tão calorosa na Unam, na Enah e em tantos outros espaços. E um saludo especial a Alfredo López Austin e Glória Muñoz Ramirez, sem os quais, por motivos muito distintos, a experiência nesse país apaixonante não teria sido possível.

Finalmente, a Joana, Tiê, Rosinha: minha base, sem a qual nada disso teria sentido. A toda a família, pois, dos cinco lados, e particularmente a Lena, Rema, Tania, Gabi, Júlio, Ivete, Jales, Clóvis, pelo apoio nos momentos cruciais. 


\section{Umas palavras, antes de começarmos...}

Em 2010, em entrevista a Joana Moncau', Manuela Carneiro da Cunha escrevia o seguinte, sobre o sentido da antropologia, hoje:

"Durante muito tempo, os antropólogos que estudavam sociedades indígenas no Brasil foram levados a desempenhar, por falta de alternativas, o papel de porta-vozes ou alto-falantes dessas populações. Hoje, salvo exceções isoladas, a voz dos índios se faz ouvir sozinha e com a devida força. E, com isso, as relações entre índios e antropólogos mudaram também. Para LéviStrauss, o papel do antropólogo é o de sensibilizar o ocidente às diferenças e, tentando entender as sociedades mais distantes de nós (em vez de fazer uma introspecção à la Descartes), fazê-lo perceber a verdadeira dimensão do humano. Acho que a antropologia teve e continuará tendo um papel importante na revalorização das diferenças e na crítica ao modelo assimilacionista que se faz. chamar de progresso".

Essas palavras me servem, aqui, como mote e inspiração. Espero que compreendam que não tenho a intenção de ser "mais um doutor em índio". Este é o trabalho de um karai que tem se esforçado para entender o que pensam e o que querem os Kaiowá e Guarani, a fim de buscar superar a situação de genocídio, de grave racismo e violência contra esses indígenas em Mato Grosso do Sul, minha terra natal. Penso que é somente para tornar-se aliado dessa causa maior que ainda faz sentido tornar-se antropólogo no Brasil, hoje. Nesta nossa antropologia concidadã, a denúncia é um dever.

\footnotetext{
${ }^{1}$ Publicada na revista Caros Amigos Especial Indígena, lançada em 2010. A edição foi organizada por mim e por Joana Moncau.
} 

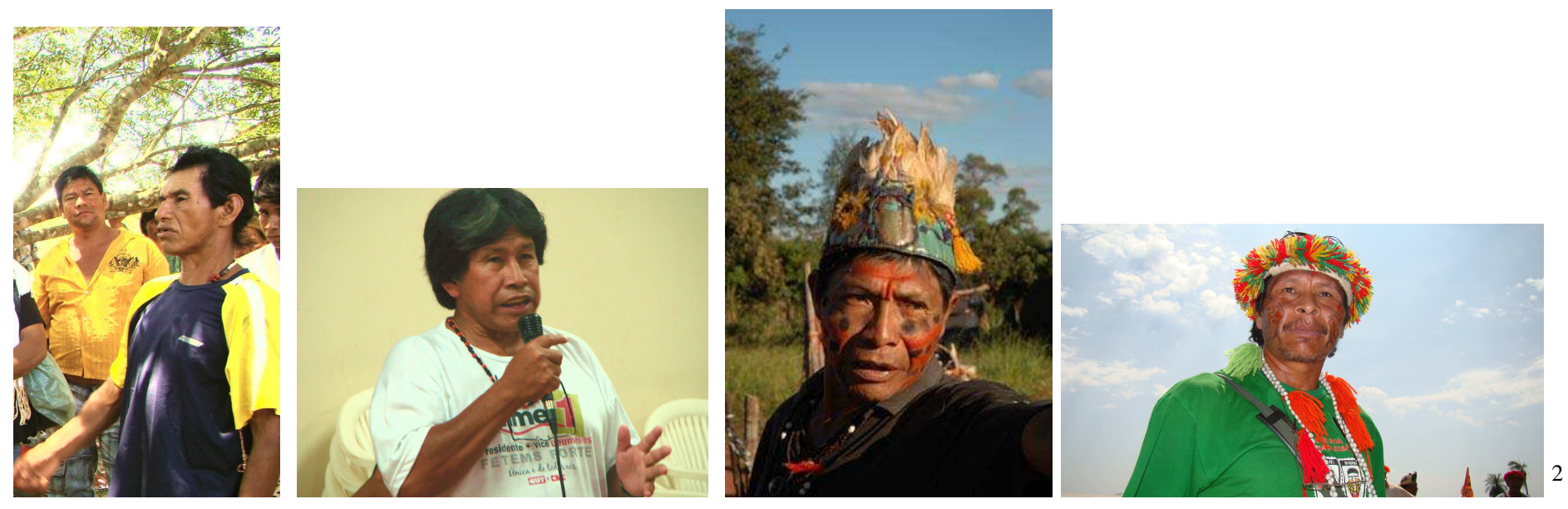

Este trabalho é dedicado às lideranças kaiowá e guarani mortas ao longo do período em que se realizou nossa pesquisa: à memória de Amilton Lopes, Zezinho (Laranjeira Ñanderu), Adélio (Mbarakay), Plácido (Ñanderu Marangatu), Nísio Gomes e Odúlia Mendes (Guaiviry), Rolindo e Jenivaldo Vera, Teodoro Ricarte (Ypo'i), e tantos outros...

Que este documento permaneça como (mais uma) prova das injustiças cometidas contra os povos indígenas há 512 anos.

"Digo apenas simplesmente o que vi com meus olhos" Chefe Momboré-uaçu - Essauap, Maranhão - 1612

\footnotetext{
${ }^{2}$ Da esquerda para a direita: Adélio, Amilton (fotos do autor), Nísio (foto: Rosa Gauditano), Zezinho (foto: Egon Heck)
} 


\section{Índice}

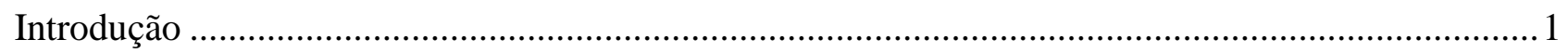

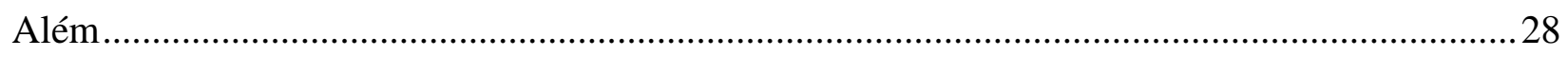

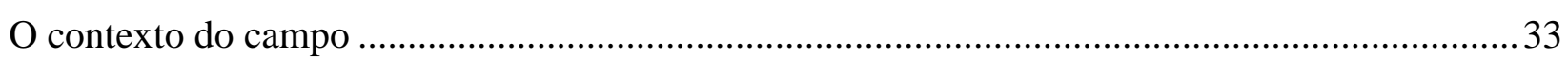

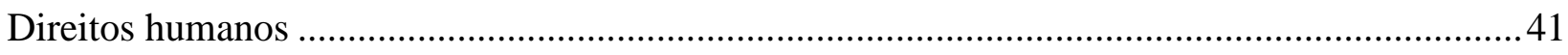

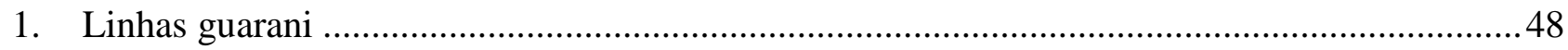

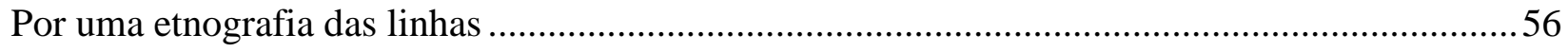

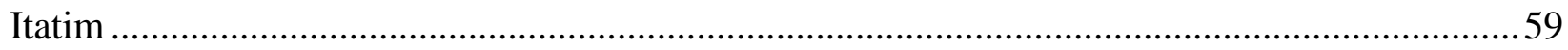

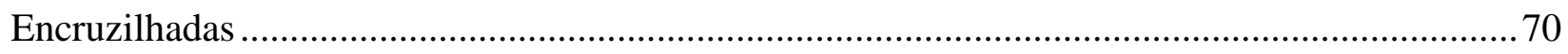

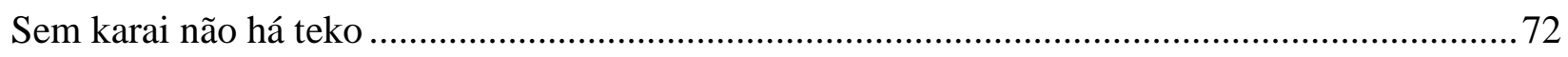

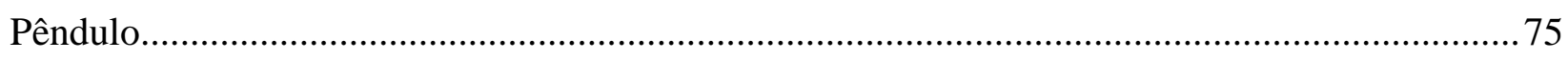

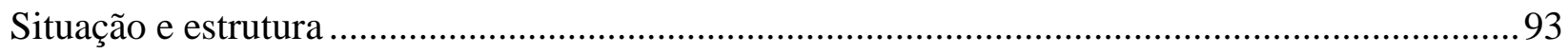

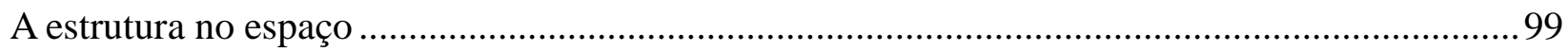

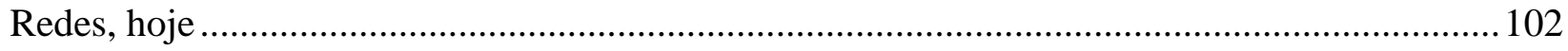

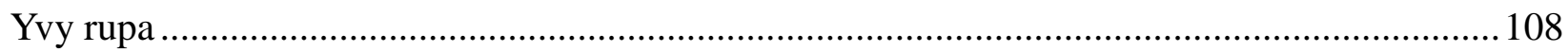

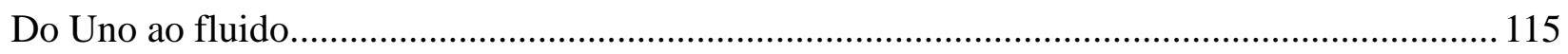

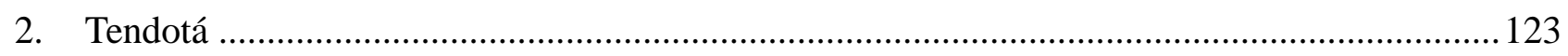

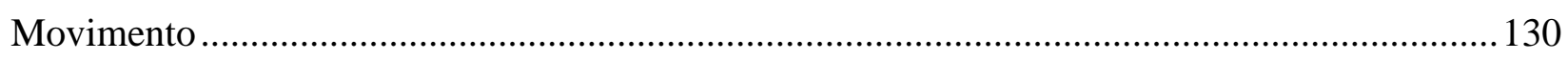

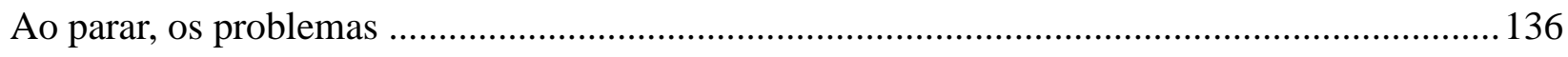

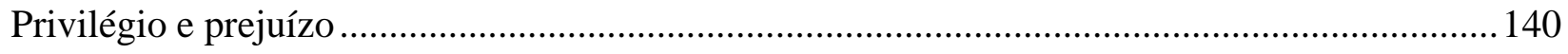

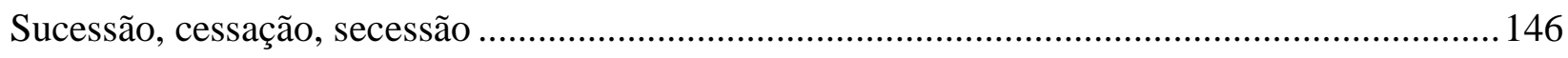

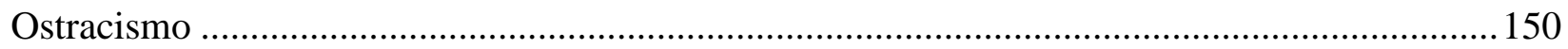

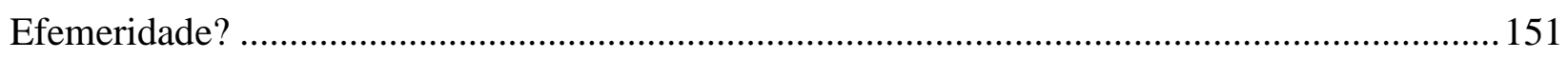

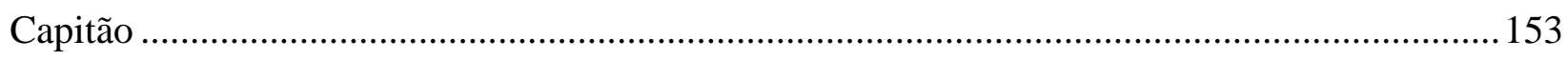

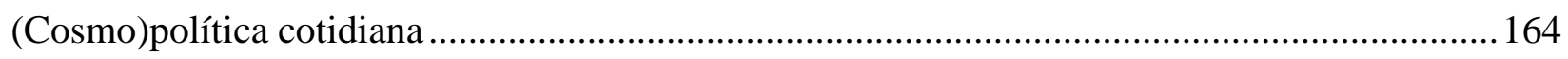

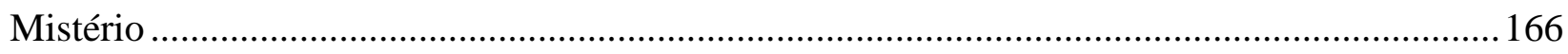

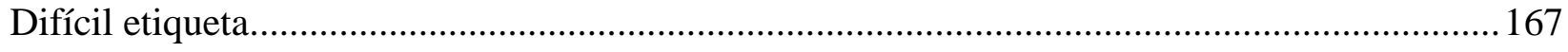

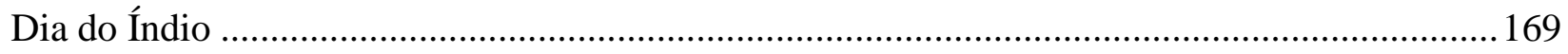

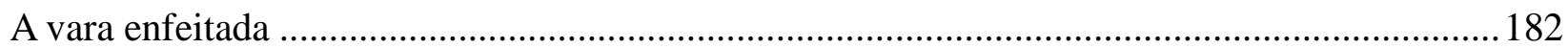

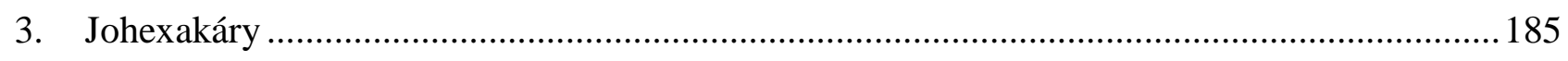

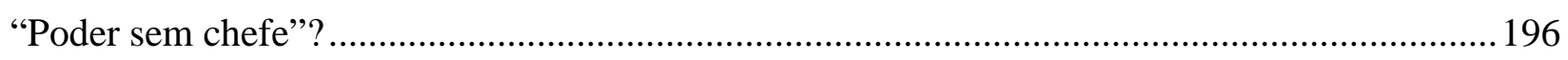

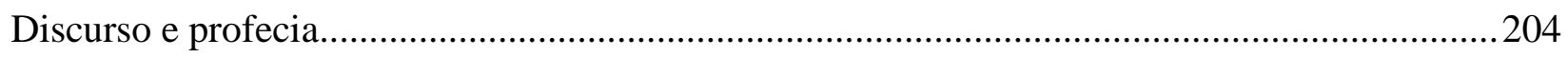




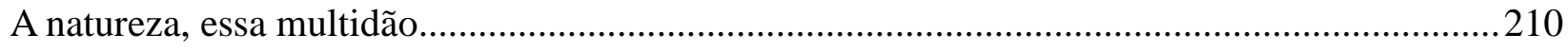

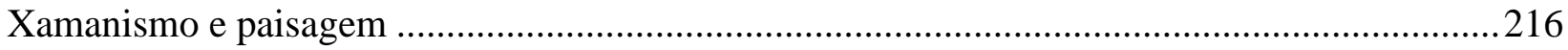

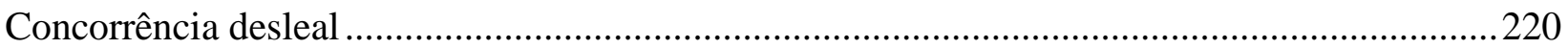

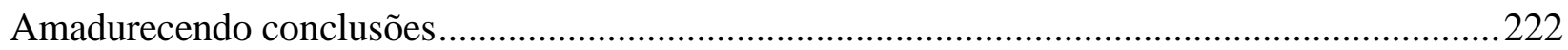

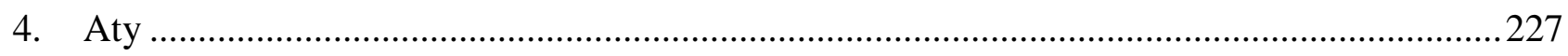

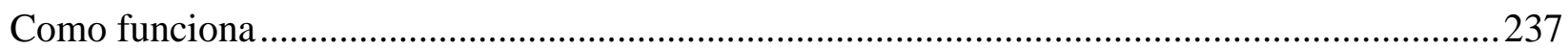

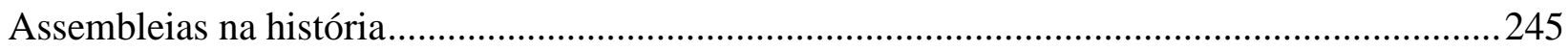

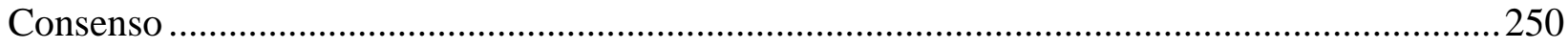

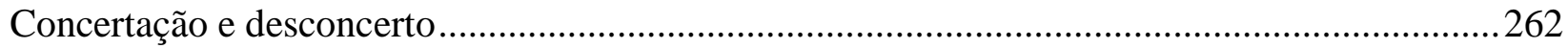

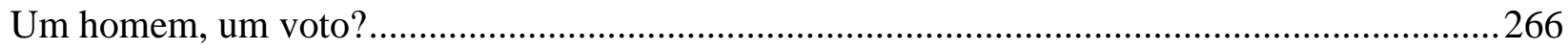

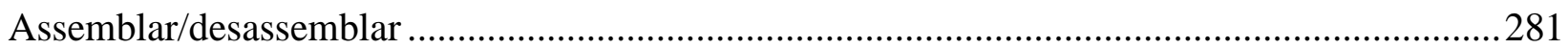

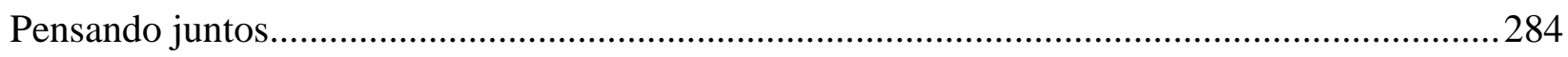

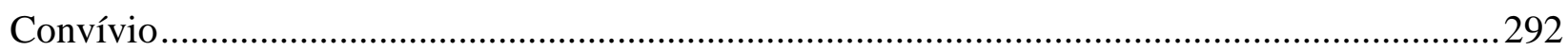

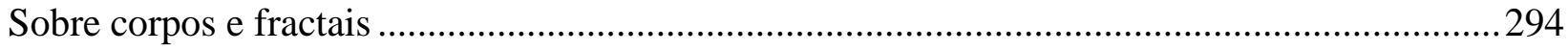

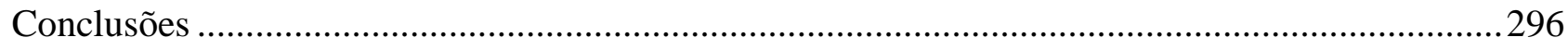

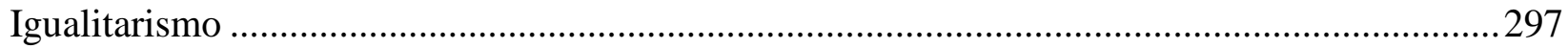

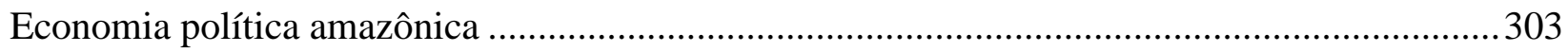

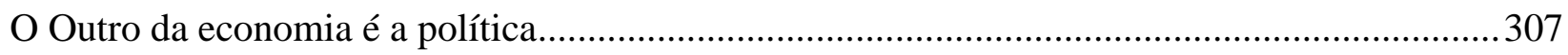

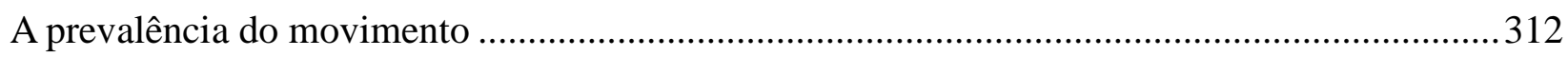

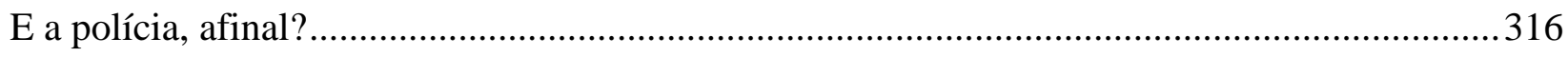

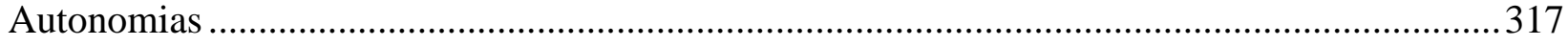

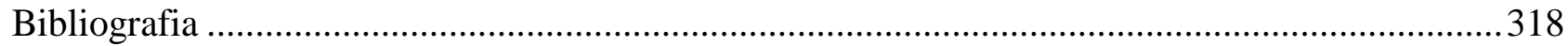

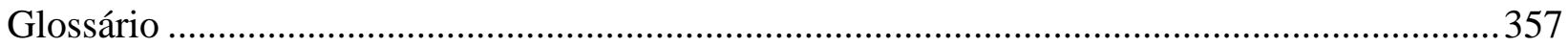

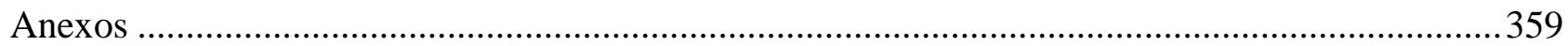




\section{Língua, convenção ortográfica e etnônimos}

Sendo a língua indígena das terras baixas mais difundida na atualidade, o guarani tem variadas possibilidades de transcrição e acentuação - algumas delas, conflitantes entre si. Para as palavras e frases em guarani, procuro seguir, aqui, em geral, as sugestões de Chamorro (2008) e procedo da seguinte maneira:

ch com o mesmo valor sonoro do dígrafo em português

g e $\mathbf{h}$ como no alemão

j corresponde ao som palatal fricativo [j]

k para a oclusiva surda velar

ñ como ñ em Espanhol

r como na palavra espanhola oro

$\mathbf{s}$ para a fricativa alveolar

v como em português

' (apóstrofe, como em $\mathrm{ka}^{\prime} a$ ) representa a oclusiva surda glotal, que marca um corte na pronúncia

$\mathbf{m b}, \mathbf{n d}$ e $\mathbf{n g}$ representam as oclusivas sonoras nasalizadas

y representa a sexta vogal do guarani (alta central)

Palavras oxítonas não são acentuadas; paroxítonas e proparoxítonas, sim. Quando os lexemas aglutinam sufixos monossilábicos ou polissilábicos átonos, permanece a acentuação original do lexema, o que é marcado graficamente. Quando o sinal de acento ' coincide com o sinal de nasalização , este acumula a função tônica.

Palavras em guarani bastante usadas no texto recebem acentos conforme as regras vigentes na língua portuguesa, a fim de facilitar sua pronunciação - é o caso de kaiowá e tendotá. Há palavras exclusivamente usadas em Mato Grosso do Sul, até onde verifico, e cuja grafia corrente pode ser definida em desacordo com certas regras. É o caso de guaxiré, em que se usa o x em vez do costumeiro ch. Nesses casos, adotarei a grafia corrente entre os indígenas. 
Sobre os etnônimos "kaiowá" e "guarani”: Tem se consolidado entre órgãos governamentais o uso do termo "guarani-kaiowá", designando o conjunto das populações de língua guarani em Mato Grosso do Sul (vide os dados do Censo 2010, em anexo). Geralmente, porém, os indígenas preferem utilizar, em documentos que divulgam, em trabalhos acadêmicos, ou mesmo na música pop (vide os raps do grupo Bro MC’s) a designação Kaiowá ha (e) Guarani, ou Guarani $h a$ Kaiowá - ou seja, frisando que são dois grupos que estão juntos, são aliados políticos, como veremos ao longo do trabalho, mas têm origens distintas. Por sinal, a ordem das menções depende do falante (se guarani ou kaiowá). O termo guarani-kaiowá guarda o inconveniente de ocultar, para leigos, essa composição, mas também é considerado aceitável pelos indígenas. Para facilitar a comunicação com um público mais amplo, eu mesmo costumo usar essa denominação em trabalhos jornalísticos, por exemplo.

Aqui, porém, usarei, ao longo do trabalho, formas como Kaiowá e Guarani, Guarani e Kaiowá, ou Guarani/Kaiowá. Também haverá menção à autodenominação Paĩ Tavyterã, muito usada no Paraguai e registrada em menor escala no Mato Grosso do Sul. No contexto de oposição aos não indígenas (karai, ou mbaíry), costuma-se, em toda essa região, usar como sinônimo de indígena o termo ava, pessoa (como o que se verifica na Amazônia entre os Awa-Guajá, ou os Asurini, por exemplo).

Quanto ao termo guarani, igualmente vem sendo utilizado de forma ampla, inclusiva (por exemplo, em função da recente realização de encontros internacionais dos Guarani - tanto os patrocinados por governos como independentes), mas não apenas. No contexto de Mato Grosso do Sul, o termo guarani é usado, historicamente, para denominar coletivos falantes do dialeto conhecido na literatura como ñandeva, em oposição aos falantes de kaiowá - muito embora, como sinaliza Dooley (2008), essas distinções dialetais já não sejam tão verificáveis, hoje, em função da intensa mistura entre os grupos e a força do avañe' $\bar{e}$, o guarani paraguaio oficial.

Note-se, ainda, que, no litoral do Sudeste e na região Sul, a situação é bem distinta da do Mato Grosso do Sul, e, grosso modo, o nome "guarani" é utilizado pelos falantes do dialeto conhecido na literatura como mbya, em oposição aos falantes de ñandeva, ditos, por vezes, mas nem sempre, tupi-guarani. O quadro todo é um pouco mais complexo que isso, mas menciono brevemente o fato para que se perceba quão contextuais e relativas podem ser essas denominações. 


\section{Introdução}

“A expressão reta não sonha. É preciso transver o mundo"

Romulo Quiroga. 

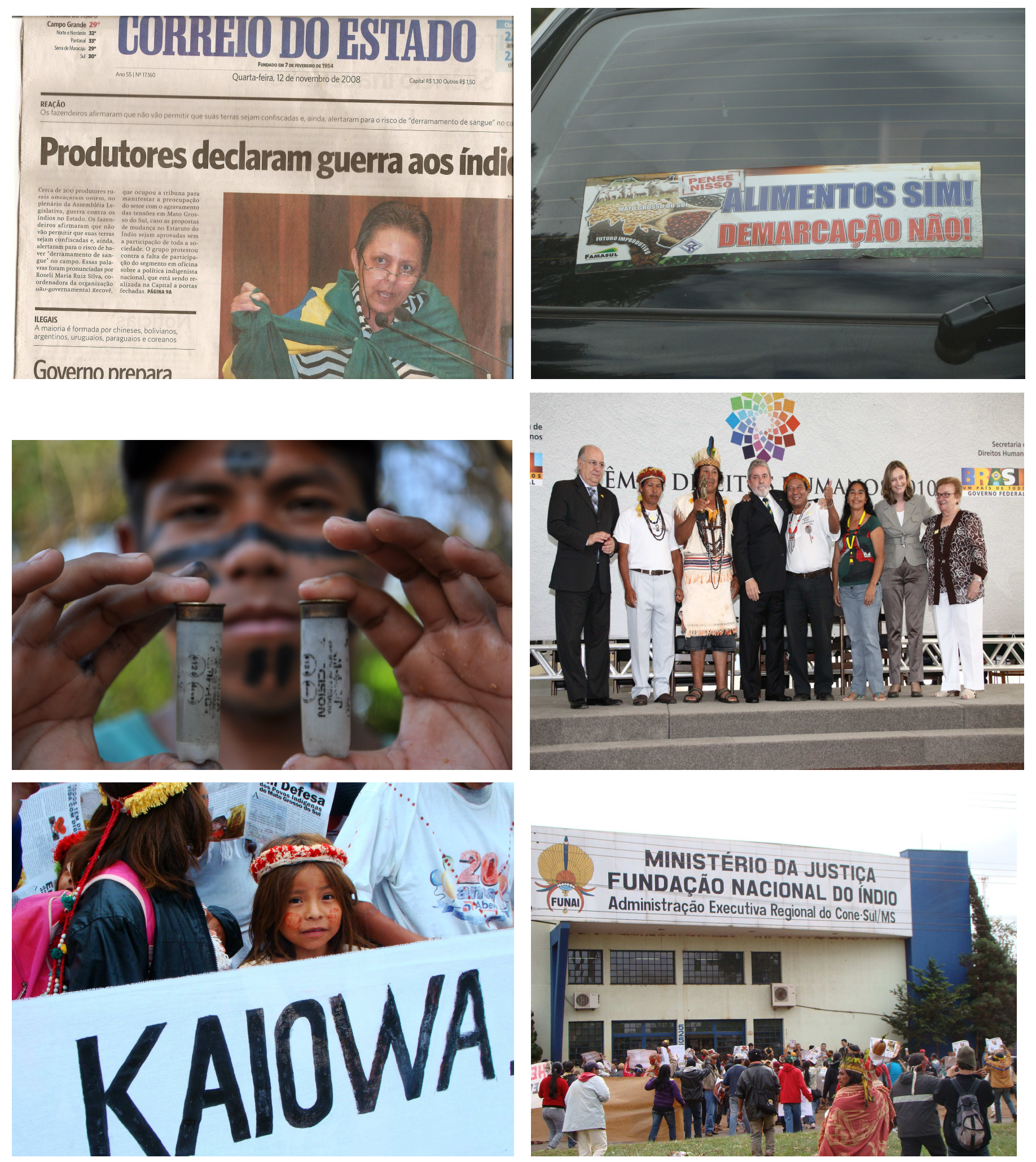

Acima, reações, em 2008, a ações da Funai para identificação de terras guarani/kaiowá. Ao centro: em 2010, após conflitos em acampamentos, volta a discussão dos direitos humanos em MS, e a Aty Guasu ganha prêmio da Presidência da República (foto: SDH/PR). Abaixo: em 2011, as demarcações continuavam caminhando a passos lentos, e novos protestos eclodiram. 


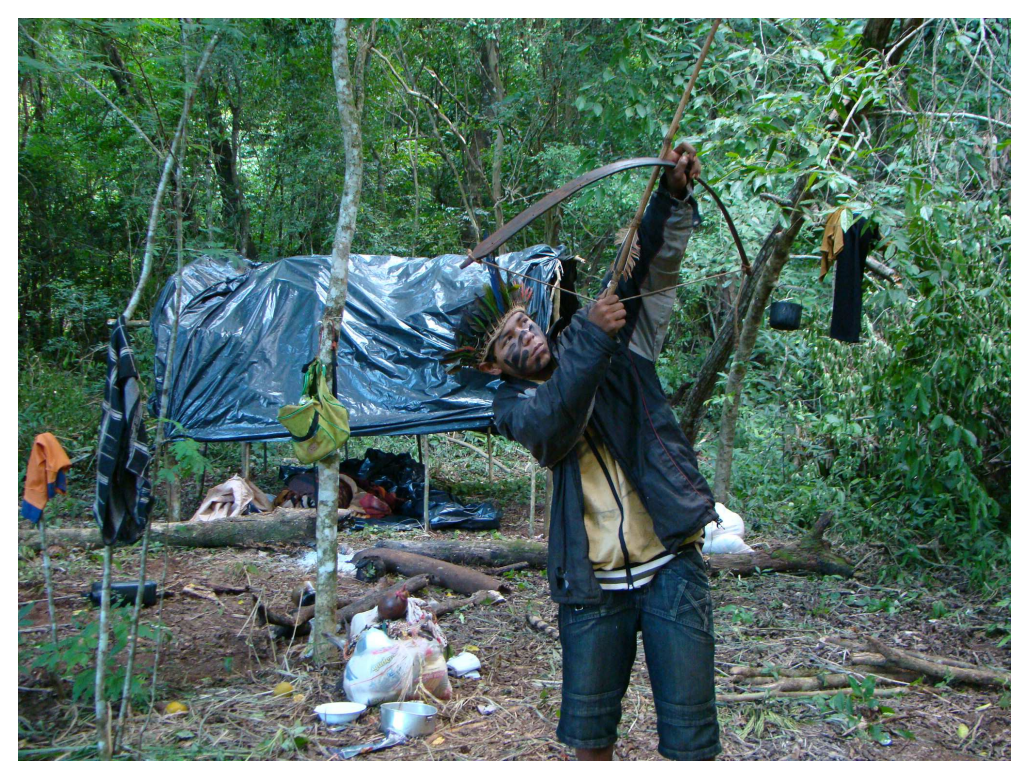

De cima para baixo:

acampamentos

kaiowálguarani de Guaiviry,

Laranjeira Nanderu e

Mbarakay/Pyelito Kue.
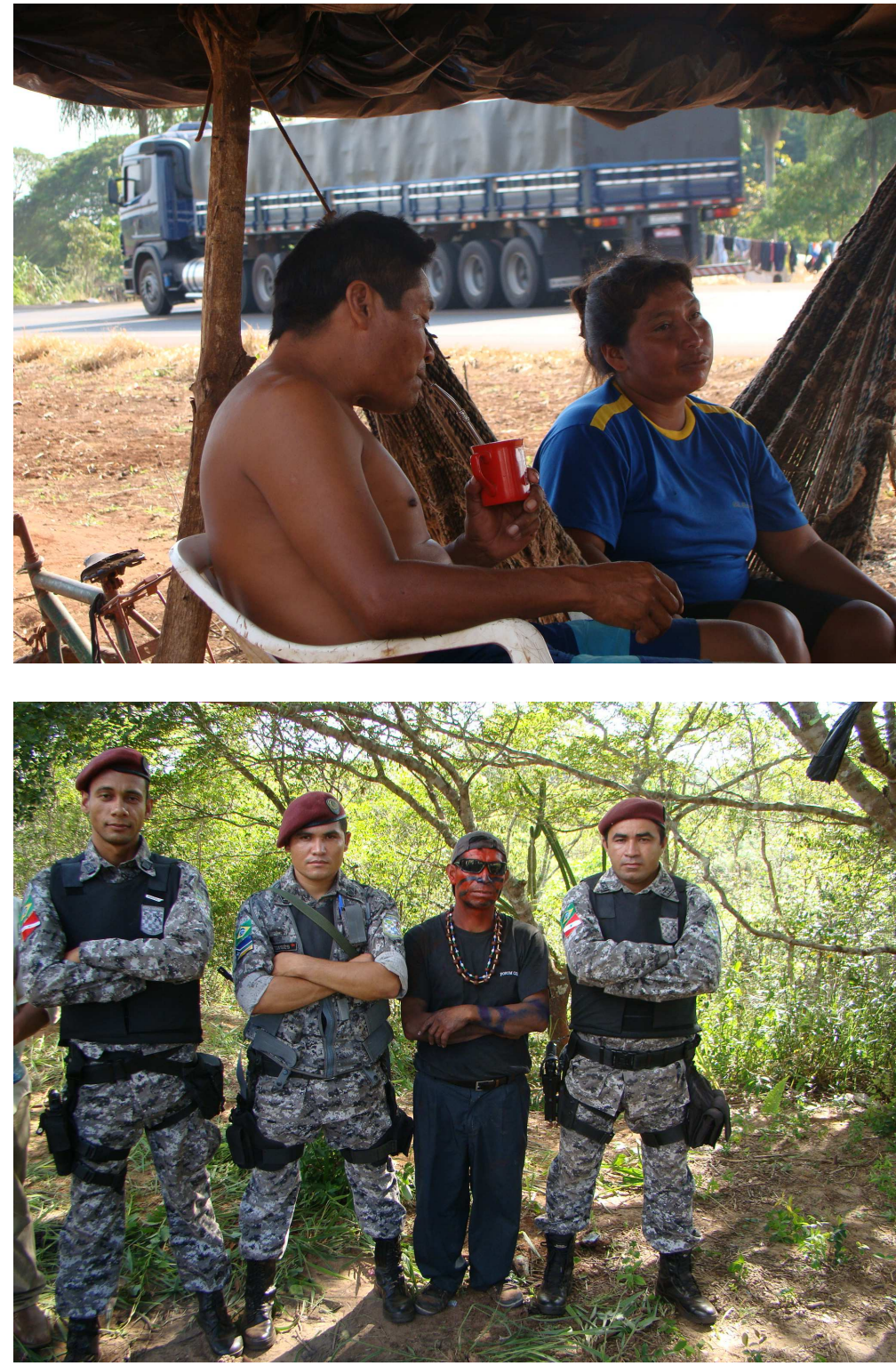

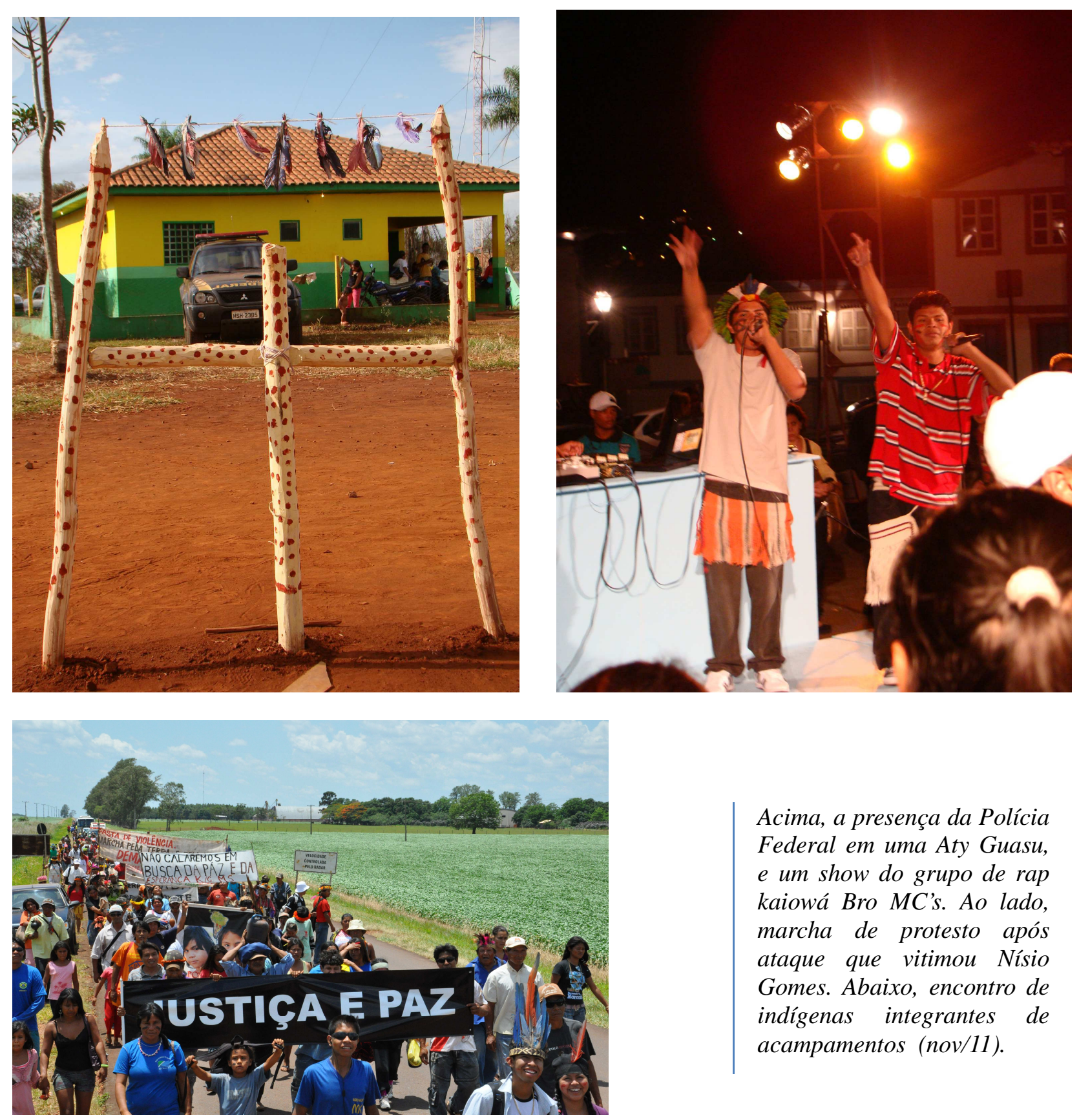

Acima, a presença da Polícia Federal em uma Aty Guasu, e um show do grupo de rap kaiowá Bro MC's. Ao lado, marcha de protesto após ataque que vitimou Nísio Gomes. Abaixo, encontro de indígenas integrantes de acampamentos (nov/11).

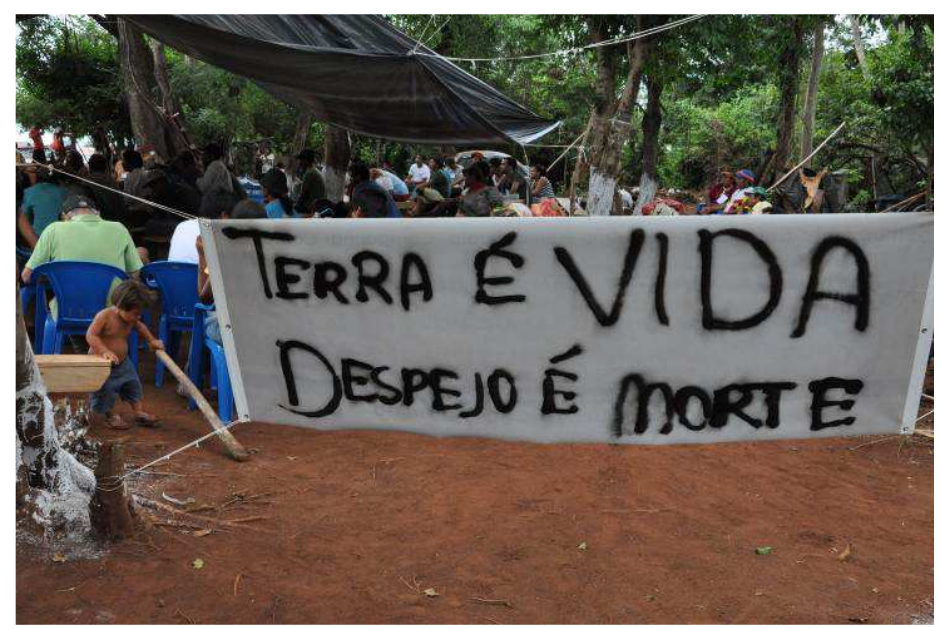




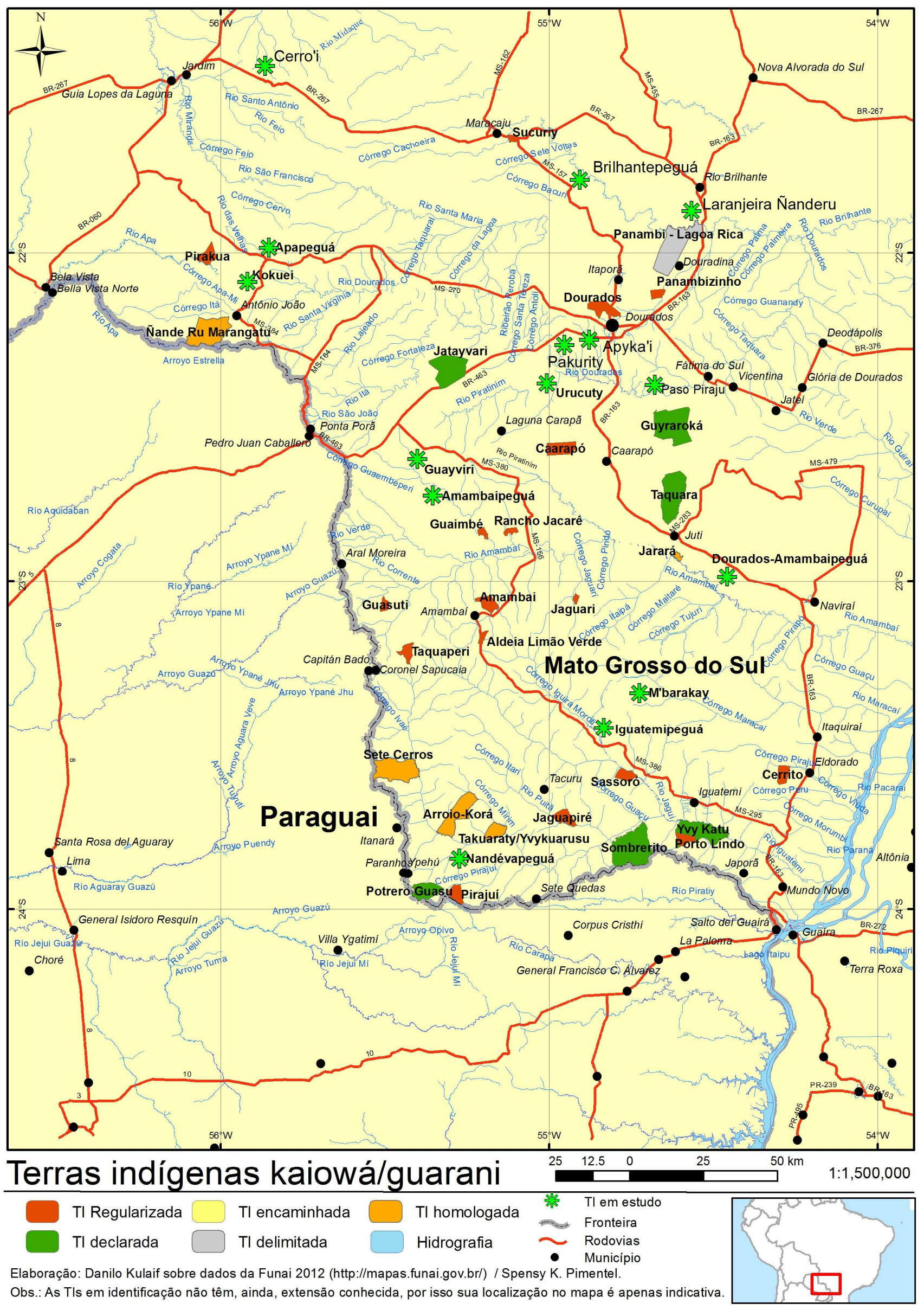


A bem da verdade, devo dizer que este trabalho, em seu cerne, foi iniciado há cerca de quinze anos. Por recomendação da professora Vera Penteado Coelho, passei a buscar, pelos sebos do bairro de Pinheiros, uma lista de livros que serviriam como introdução à Antropologia. Eu chegara a Vera por intermédio de uma amiga que era sua familiar. Ela me recebeu em sua casa, já não me lembro em que bairro paulistano. Ainda guardo essa lista, escrita a mão, em alguma pastaarquivo

Um volume editado em Portugal de Sociedade contra o Estado foi uma das primeiras aquisições. Vera dividira a lista em duas colunas. Em uma delas estavam os livros que provavelmente seriam exigidos numa seleção para o mestrado; na outra, os que, segundo ela, não tinham muito destaque, mas eu devia ler mesmo assim. O livro de Pierre Clastres estava incluído nessa segunda categoria. Por um desses caprichos da memória, lembro-me ainda do momento em que o encontrei numa das estantes do Red Star, ali na Fradique Coutinho, entre Teodoro Sampaio e Arthur de Azevedo. Como aconteceu com tantos outros antes - e depois - de mim, fui fisgado pelo estilo do francês.

Pois, creio que é de estilo que se trata. "Fazer algo perigoso com estilo é o que eu chamo de arte", discursa o Bukowski-Gazarra, no filme de Ferretti ${ }^{3}$. "Conheci mais homens com estilo na prisão do que fora dela", diz ele, ainda. Sim, muitos gostariam de meter Clastres nos calabouços da disciplina, em ferros. Mas, ele seguiu por muitos anos, resistindo pelos sebos da vida. Ultimamente - quem diria? -, ganhou edições de luxo. A antropologia pode ser arte - se tiver estilo ${ }^{4}$ (mas, isso é tão perigoso...).

Já andava balançado pela leitura de Darcy Ribeiro (1995), que tanto me ensinou sobre a terra onde passei a infância, o Mato Grosso do Sul, e por um texto de Lévi-Strauss em que ele dizia algo sobre trocas de palavras, coisas e mulheres como fundamento da sociedade (a originalidade dessa tríade tão heterogênea como uma lista de Borges me encanta até hoje).

3 Crônica de um Amor Louco ("Storie di ordinaria folia"), filme de 1981.

4 É disso, penso, que tem falado tanta gente - como Joanna Overing, em um seminário na Unicamp, em 2009. O desafio que os etnólogos terão para alcançar certas nuanças do pensamento ameríndio, como o humor, só poderá ser superado com estilo, e é preciso que a academia tenha sensibilidade para acolher novas formas, experimentações. Márcio Goldman, em evento na USP, em 2008, igualmente desenvolvia raciocínio que desemboca nessa encruzilhada. Perguntava ele: como substituir a ironia pelo humor? "Há, na ironia, uma pretensão insuportável: a de pertencer a uma raça superior e ser a propriedade dos mestres (...). O humor se reclama, ao contrário, de uma minoria, de um devir-minoritário: é ele quem faz uma língua gaguejar, que lhe impõe um uso menor ou constitui todo um bilinguismo na mesma língua" (Deleuze \& Parnet, 1998: 56). Para humor, estilo; para estilo, humor suporíamos. Mas, como dizia nessa ocasião, o desafio aqui será atingir estilo, humor, sensibilidade, enfim, trabalhando em um lugar onde nada disso é muito bem-vindo atualmente - não pelos ameríndios, mas por todo o entorno não indígena. 
Pouco mais de um ano depois do bom encontro com Clastres, conheci a professora Beatriz Perrone-Moisés, minha condutora, desde então, pelos caminhos da formação acadêmica e, não por acaso, admiradora da obra - e do estilo - de Clastres.

De modo que, talvez, minha motivação primeva para a pesquisa não pareça tão original. Sou mais um desses cidadãos retratados por La Boétie (1982), um servo (in)voluntário, em vertigem diante da ideia de liberdade teimosamente cultivada por gente como os Guarani, ao longo destes séculos. Ironicamente, ao mesmo tempo em que começava essa trilha, deixei-me levar pela vida talvez, um erro de interpretação das cartas, pelo qual assumo totalmente a responsabilidade - e fui parar, exatamente, num centro do poder: Brasília.

E foi ainda por lá que comecei a arquitetar a volta à planície, como se costuma dizer no Planalto Central. Entre 2006 e 2007, escrevia para o sítio Real Hip Hop. Voltava a me inteirar do movimento de que tinha me afastado, anos antes, em função da febre. Com a explosão de música e vídeo que a internet proporcionou, me chegavam, por meio de "Police State", uma canção do grupo norte-americano Dead Prez, as palavras do ativista Omali Yeshitela, sampleadas a título de introdução:

"You have the emergence in human society of this thing that's called the State. What is the State? The State is organized bureaucracy. It is the police department. It is the Army, the Navy. It is the prison system, the courts and what have you. This is the State: it is a repressive organization. But the state - and well you know you've got to have the police because if there were no police, look at what you'd be doing to yourselves, you'd be killing each other if there were no police -, but the reality is: the police become necessary in human society only at that juncture in human society where it is split between those who have and those who ain't got."

Em paralelo, ocorreu, já não lembro bem em que momento, um importante diálogo peripatético com Bia - em mais um capricho da memória, recordo perfeitamente que caminhávamos

\footnotetext{
${ }^{5}$ Como se trata da introdução a uma canção, indicarei aqui a tradução. Para as referências seguintes de obras em inglês, normalmente apresentarei traduções feitas por mim em primeiro plano. Preservarei somente as citações em espanhol. "Você tem a emergência, na sociedade humana, dessa coisa que é chamada de Estado. O que é o Estado? O Estado é burocracia organizada. É o departamento de polícia. É o Exército, a Marinha. É o sistema prisional, as cortes de Justiça etc. Isso é o Estado: é uma organização repressiva. Mas o Estado - e, bem, vocês sabem que vocês precisam de polícia porque, se não houvesse polícia, olhe o que vocês estariam fazendo contra si mesmos, estariam se matando uns aos outros se não houvesse polícia -, mas a realidade é: a polícia se torna necessária na sociedade humana somente naquela conjuntura em que ela está dividida entre aqueles que têm e aqueles que não têm".
} 
pela Avenida Paulista, mas não sei aonde íamos. Falávamos das formas políticas ameríndias, de Clastres, de uma série de ideias que ela, então, gestava e que, hoje, como se verá aqui, já estão vindo à luz, mesclando-se às pesquisas de seus orientandos.

Tudo isso girava, no redemunho de minha cabeça, junto com a limitada possibilidade de campo que tivera no mestrado, em função dessa experiência de deixar-me atrair para o centro. Na defesa da dissertação, em outubro de 2006, já havia algo lá - gerando uma expressão um pouco estranha no rosto de Eduardo Viveiros de Castro -, essa ideia de que os Guarani podem ter tido algo no "estilo cacicado" no período pré-colonial. Eu compreendia o estranhamento dele, mas não podia, naquele momento, expressar-me melhor, pois o que poderia dissipar aquela reticência só aqui está devidamente formulado.

Em suma, para tentar compor algo que auxilie o leitor a entender o vero ponto de partida disto tudo: tratava-se de entender como um grupo humano pode organizar-se sem Estado e - por conseguinte, pensava eu, então - sem polícia.

Mas, mais além, havia outro elemento nessa história toda. Ele esteve sempre lá, mas não aparecia nunca, exceto, talvez, em meus agradecimentos: o Exército Zapatista de Libertação Nacional (EZLN). O levante zapatista aconteceu em $1^{\circ}$ de janeiro de 1994, o mesmo ano em que eu me transferia para São Paulo, a fim de iniciar a graduação em Jornalismo. A atração centrípeta me impediu, por esses anos, de dedicar a devida atenção ao profundo impacto que o movimento indígena mexicano deixou no debate político mundial, mas é inegável que sua imagem persegue, fazendo virar rápido para o lado, a fim de buscar o vulto no canto do olho.

A dívida intelectual com o zapatismo já começa a ser paga neste trabalho, em função, sobretudo, da oportunidade de um estágio-sanduíche junto à Universidade Nacional Autônoma do México (Unam), entre 2010 e $2011^{6}$. Já o dívido com o movimento negro ainda terá de esperar.

\footnotetext{
6 E da preciosíssima convivência com os amigos jornalistas do Desinformémonos (www.desinformemonos.org), coletivo do qual me aproximei por intermédio de minha esposa, Joana Moncau. A partir da colaboração com o Desinfo, tive a oportunidade de, num curtíssimo período de tempo, fazer contato com um grande número de experiências do movimento indígena mexicano, o que tornou o estágio acadêmico algo verdadeiramente único.
} 


\section{"While there is a lower class, I am in it \\ While there is a criminal element, I am of it \\ While there is a soul in prison, I am not free"7}

\section{Eugene V. Debs}

O texto era um entre os muitos que cobriam as paredes e caibros do alojamento onde armei a rede. Como se costuma fazer em lugares turísticos, tudo no barracão de madeira estava repleto de frases, versos em várias línguas, desenhos, grafites, assinados por gente do mundo todo. Mas, este lugar é um pouco diferente. Tudo aqui tem a ver com política. Até um mero "A" pode ser um símbolo poderoso.

Estava, enfim, em um caracol zapatista - um dos cinco que surgiram em 2003 e permanecem, teimosamente, até hoje, como centros administrativos das chamadas Juntas de Bom Governo, um dos pilares da auto-organização dos mais de $1.000^{8}$ grupos locais chamados de "bases de apoio" do movimento. O lugar era Morelia, a meio caminho entre San Cristóbal de las Casas e Ocosingo - esta, uma das cidades que foi palco de alguns dos mais cruentos confrontos entre o EZLN e o Exército mexicano, em 1994.

Em maio de 2011, visitei, em San Cristóbal de las Casas, um núcleo avançado da Universidade Nacional Autônoma do México, o Proimmse (Programa de Investigaciones Multidisciplinarias sobre Mesoamerica y el Sureste). Aproveitei a oportunidade para participar de um evento na Universidad de la Tierra, centro autônomo onde costumam acontecer os encontros de intelectuais que acompanham o movimento em Chiapas e, por acaso do destino, presenciei a maior manifestação pública dos zapatistas desde 2006 até então, uma gigantesca marcha contra a política de Guerra ao Narco, mantida nos últimos anos pelo governo de Felipe Calderón (2007-2012).

Em meio a tudo isso, fui conhecer os caracóis. Cada um deles tem sua própria administração, e é preciso pedir autorização à Junta de Bom Governo para poder permanecer ali. Os alojamentos para os chamados acampamentistas surgiram ainda nos anos 90, antes mesmo da constituição dos governos autônomos, quando os Caracoles ainda eram conhecidos como Águas Calientes. O objetivo era o de manter, nessas bases, grupos de observadores nacionais e

\footnotetext{
${ }^{7}$ Não por acaso, a citação é famosa, em função da sutil poética. Numa tradução aproximada: "Enquanto houver uma classe mais baixa, estarei com ela. Enquanto houver um elemento criminoso, participarei dele. Enquanto houver uma alma na prisão, não estarei livre".

8 Estimativa do jornalista Herman Bellinghausen, correspondente do La Jornada em San Cristóbal e região. Ele acompanha desde 1994 o conflito em Chiapas.
} 
internacionais da sociedade civil, a fim de coibir abusos por parte do governo, das forças armadas mexicanas e dos paramilitares ligados a partidos políticos e outros grupos.

Os caracóis estão situados em pontos estratégicos e oferecem diversos serviços aos grupos filiados ao movimento em sua região. Há atendimento de saúde, manutenção da rede de energia elétrica, escola, um pequeno comércio - cada um deles tem sua conformação própria, na realidade. Há alguns anos, os zapatistas mantêm, ainda, um sistema autônomo de Justiça. Bem ao lado do barracão onde me hospedei, estava uma cadeia, onde dois homens se encontravam presos.

A disciplina dos que prestam serviço na junta (são turnos de uma semana, geralmente cumpridos por homens e mulheres jovens) é estrita. Numa passagem rápida, é difícil que a conversa se abra. Não pude saber de que eram acusados aqueles presos, que tipo de pena cumpriam. Como era maio, um mês em que ninguém, praticamente, viaja pela região, estava sozinho, de modo que meu único diálogo mais longo foi, literalmente, com as paredes.

O contraste, pois, era entre aquela prisão autônoma ${ }^{9} \mathrm{e}$ as frases gravadas por jovens, sobretudo mexicanos, argentinos, franceses, italianos e espanhóis (particularmente bascos e catalães, das duas regiões autônomas do país cujos habitantes costumam se identificar com as reivindicações dos indígenas chiapanecos). “Todos los policias son bastardos”, registrara outro dos acampamentistas naquelas paredes, bem perto da famosa frase do líder socialista norte-americano citada no início do relato.

Lá fora, os grafites estampavam os tradicionais ícones zapatistas: a Comandanta Ramona, o Subcomandante Marcos, os Mártires de Morélia, figuras e mais figuras com seus pasamontañas. Mas, havia também os reis maias: Zotz Choj (Tigre Morcego), considerado por alguns o mais importante senhor de Toniná - cidade cujas ruínas estão bem próximas dali, o que levou os zapatistas a batizar a região autônoma com esse mesmo nome.

Se a memória não trai, em algum lugar vi Pakal, o mais conhecido de todos os reis maias, em virtude da popularidade dos belos edifícios e esculturas de Palenque, cidade cujas ruínas estão um pouco mais ao norte de Ocosingo, perto do caracol mais setentrional, Roberto Barrios. Mas posso estar errado. Palenque e Toniná eram grandes rivais. Pakal e Zotz Choj não foram

\footnotetext{
9 Poucos pesquisadores têm obtido autorização para estudar esse sistema in loco. Entre os raros textos disponíveis, estão os de Fernández (2009). Ver, ainda, os textos reunidos por Baronnet, Mora y Stahler-Sholk (2011). Ainda que não seja considerado um completo autogoverno, o mais pesquisado sistema de justiça autônoma no México segue sendo o da Polícia Comunitária de Guerrero (www.policiacomunitaria.org). Ver, a respeito, Quintana \& Gasparello, 2009.
} 
contemporâneos, mas as cidades associadas a eles mantêm, até hoje, os murais, estelas e esculturas que testemunham batalhas e mais batalhas, com estátuas de governantes feitos cativos, suas mãos amarradas para trás a, vertiginosamente, lançar-me memórias dos testemunhos coloniais sobre os ritos canibais tupi ${ }^{10}$.

Retomando o fio: como, afinal, se constitui esse diálogo tão raro que os coletivos indígenas traçam, em seus movimentos, ao fazer o que convencionamos chamar de política? Vozes alternas que passam a soar-nos como familiares, como ecos de nossa própria revolta com o Estado? Seres fantásticos, capazes de fazer o que nós não ousamos, de ser tão solidários e unidos e valentes como nunca seríamos, de enfrentar privações que não encararíamos jamais... Tal qual chefe clastriano, as lideranças indígenas discursam. Enquanto seus pares as ignoram, nós é que aplaudimos? Mas, afinal, o que querem os ameríndios?

Nessa conversa sui generis, nem mesmo os termos ficam muito claros. Afinal, quando falamos em uma "política indígena", do que se trata? Muitas vezes (provavelmente, quase todas), não da mesma coisa que eles estão dizendo quando usam o termo "política". Afinal, que termo poderia expressar essa ideia em guarani ou numa língua maia, por exemplo? Mas, no meio da conversa, pode ser que, no fim das contas, nós mesmos nos demos conta: o que é que estávamos querendo dizer com "política"?...

A presente tese parte desse (des)encontro, buscando encontrar caminhos para desenvolver uma conversa que seja uma real troca de ideias. Com os ameríndios? Os primitivos? Os Contra o Estado? Quiçá. No caso, humildemente, se lograr encontrar alguns brasileiros dispostos a encarar a aridez de uma tese de doutorado para entender um pouco mais os Kaiowá e Guarani, neste momento tão grave por que passa esse povo, já estaria de bom tamanho.

Para afiar o gume do estilo, método. Partimos aqui de uma abordagem etnográfica. Aquela mesma de Malinowski ${ }^{11}$ ? Mais ou menos. Ao retornar à academia, em 2008, tive a grata surpresa de perceber que a pós-modernidade já não é mais a mesma de quando iniciei a graduação, em 1994. Eu mal sabia, e, à época ninguém me avisou, mas, na França, àquela altura, Bruno Latour já sussurrara: "Jamais fomos (sequer) modernos".

Nos últimos anos, autores como Marilyn Strathern, Roy Wagner, Eduardo Viveiros de

10 Realizamos uma excursão a essas ruínas sob orientação do epigrafista Hugo García, da Escola Nacional de Antropologia e História (Enah), especialista na decifração das inscrições maia.

11 Contemporâneo mui próximo do também polaco Korzeniowski/Conrad, é sempre bom lembrar. 
Castro, Márcio Goldman, David Graeber, Tim Ingold, entre outros, têm revirado o solo outrora tão compactado e ressequido da teoria e do método (teoria-método, formularia um falante de guarani?) antropológicos. O presente trabalho é, também, tributário de toda essa movimentação - ou, ao menos, procura sê-lo.

Esta tese busca, então, por meio do trabalho de campo, uma teoria política, construída em diálogo principalmente com os Kaiowá e, por vezes, sobretudo no que tange à discussão sobre as assembleias, também com os Guarani ${ }^{12}$. A proposta é, como sintetiza Viveiros de Castro (2004: 4), considerar os ameríndios como "agentes teóricos", não como sujeitos passivos. Nesse sentido, tratase de escolher um caminho que assume a possibilidade (inevitável, como mostra esse autor, e entendida não como algo negativo, mas como a própria condição de existência do discurso antropológico) de equívocos - políticos.

Trata-se, pois, de buscar fazer uma antropologia que compare a fim de traduzir, e não que traduza a fim de comparar (idem: 5$)^{13}$. A tradução aqui, no âmbito da antropologia política que proponho, segue o rastro de uma traição - uma boa traição, como a sinalizada por Benjamin ${ }^{14}-$, cometida por Clastres.

Ao definir o campo do "contra o Estado", Clastres abre uma senda, e é por ela que busco seguir. Afinal, como sugere Viveiros de Castro, é preciso deixar que essa boa tradução/traição

\footnotetext{
${ }^{12}$ Isto ocorre porque, no período em que residi junto a comunidades, em 2009, estive em região mais marcadamente kaiowá, a bacia do rio Apa, com pouquíssima presença guarani. No âmbito das Aty Guasu - grandes reuniões -, contudo, tive contato também com integrantes de grupos predominantemente guarani, que estão mais ao sul, nas proximidades do rio Iguatemi.

$13 \mathrm{E}$, nesse sentido, trata-se de inverter o projeto da velha antropologia política (leia-se, para contraste, Balandier, 1969).

14 Walter Benjamin (2008: 66), em seu célebre "A Tarefa do Tradutor" (tarefa-renúncia, na tradução de Kampff Lages), perguntava: "Mas aquilo que está numa obra literária, para além do que é comunicado (...) não será isto aquilo que se reconhece em geral como o inaferrável, o misterioso, o 'poético'? Aquilo que o tradutor só pode restituir ao tornar-se, ele mesmo, um poeta?". Viveiros de Castro (2004: 5) ressoa Benjamin, sobre a boa tradução: “(...) é aquela que trai a linguagem de destino, não a linguagem fonte. Uma boa tradução é aquela que permite aos conceitos alheios deformar e subverter a caixa de ferramentas conceituais do tradutor. Assim a intenção (intention) da língua original pode ser expressada dentro da nova" (tradução minha). Em outra possível elaboração, Visan (2008) descobre inspiração na teoria confucionista da tradução - predominante na China, ao longo do primeiro milênio da era cristã, aproximadamente -, no diálogo entre as tradições budistas e taoístas. Aí, a ideia de que é possível traduzir preservando a diferença, pressupondo-se reciprocidade e a simetria nas trocas: "Cada parceiro afeta e se faz disponível ao outro parceiro para aceitar a diferença como diferença". O chamado "método geyi" era usado na tradução dos sutras budistas, por exemplo. "O método pressupõe a reconciliação das tradições taoístas e budistas pela interafecção: um é lido por meio da perspectiva do outro". Trata-se de uma "transvaloração": "A relativização dos próprios princípios e a troca em um par binomial interdependente (yin-yang) - um mútuo tornar-se, ou devir". O resultado do processo é o atingimento da virtude confucionista do ren (máxima relação).
} 
clastriana deforme e subverta nosso próprio vocabulário político. Um exemplo mirado: a partir das possibilidades abertas por Clastres, entre outras, Graeber imagina uma teoria de entidades políticas que não são Estados; uma ecologia das associações voluntárias; uma teoria da felicidade política...

\begin{abstract}
“É válido chamar a atenção para tais questões porque Clastres é, sob vários aspectos, um romântico ingênuo. Desde outra perspectiva, porém, não há aqui nenhum mistério. Afinal, estamos falando do fato de que a maioria dos ameríndios [Amazonians, no original] não quer dar a outros o poder de os ameaçar fisicamente se eles não fizerem o que for mandado. Talvez fosse melhor se estivéssemos nos perguntando o que isso diz sobre nós mesmos, visto que sentimos que tal atitude precisa de algum tipo de explicação"15 (Graeber, 2011: 45).
\end{abstract}

De forma que, em Clastres, em Graeber, encontro um ponto de identificação com minha própria visão da política, que orienta meu olhar na pesquisa etnográfica. Creio que, num estudo como este, tem rendimento operar esse tipo de indicação, no sentido de refinar as possibilidades de comparação. Nas palavras de Strathern:

"O procedimento comparativo, ao investigar variáveis que cruzam diferentes sociedades, normalmente descontextualiza os construtos locais para trabalhar com construtos contextualizados analiticamente. O estudo dos sistemas simbólicos apresenta uma problemática diversa. Se o interesse teórico está voltado para a maneira pela qual as ideias, representações e valores são contextualizados localmente, a descontextualização não funcionará. As generalizações analíticas devem ser obtidas por outros meios. Não se trata de imaginar que seja possível substituir conceitos exógenos por correspondentes nativos; a tarefa é, antes, a de transmitir a complexidade dos conceitos nativos com referência ao contexto particular em que são produzidos. Consequentemente, opto por mostrar a natureza contextualizada dos construtos nativos através da exposição contextualizada dos construtos analíticos. Isso exige que os próprios construtos analíticos sejam situados na sociedade que os produziu. Para os membros dessa sociedade, por certo, tal desvendamento de pressupostos

15 E o que diz sobre nós? As perguntas de La Boétie (1982) seguem atuais, quanto a essa matéria, como mostra a reflexão de Sahlins (2008) a respeito. 
acarretará a revelação do propósito ou interesse.” (Strathern, 2006: 33)

Evidentemente, o que se tem aqui é uma obra de escopo bastante diverso da dessa autora, a qual já está relacionada à produção de uma reflexão sobre o "contexto geral" da "socialidade melanésia", não com a elucidação de "contextos locais específicos para eventos e comportamentos" (idem: 36). Entretanto, é com referência a esse tipo de lição sobre a importância (o rendimento?) de considerar o contexto de construção de meus próprios construtos teóricos/analíticos que, creio, faz sentido expor a visão de política que orienta meu trabalho aqui.

Antes de seguirmos com uma análise mais pormenorizada do particular recorte político que orienta o olhar neste trabalho, detenhamo-nos numa análise mais geral acerca da produção acadêmica com a qual dialogamos.

Em primeiro lugar, vale dizer, este trabalho integra um esforço mais amplo de reflexão coletiva sobre as "formas políticas ameríndias" (Perrone-Moisés, 2006, 2012; Perrone-Moisés \& Sztutman, 2010):

"Se a classificação das formas políticas ameríndias (do período précolonial até os dias atuais) dá tanta margem a debate e discordância, talvez. isso se deva não apenas à dificuldade inerente à proposta de uma linha evolutiva orientada, mas, sobretudo, à tentativa de caracterizar mundos alheios às nossas (ocidentais) preocupações com identidades, essências, cristalizações e permanências” (Perrone-Moisés, 2006: 8).

O tema, considerado pela autora como "praticamente abandonado" pela etnologia das terras baixas sul-americanas desde a proposta clastriana, retorna, pois, nos trabalhos do grupo (Pimentel, 2010; Soares, 2012; Drago, 2012). Mas não apenas. Outras pesquisas, a partir de perspectivas teóricas (mais - ou menos) diversas, como as de Fernandes (2004, 2006), Vieira (2008), Ribeiro (2010) e Guerreiro Jr. (2011) têm promovido a volta dessa discussão à disciplina. Ao longo dos seguintes capítulos exporemos nosso debate e diálogo com os referidos trabalhos, entre outros.

Num âmbito um pouco mais geral, é preciso, ainda, destacar a relevância, para o presente trabalho, de algumas reflexões teóricas e metodológicas advindas do grupo conhecido como Antropologia da Política, e particularmente dos escritos de Goldman, autor que participou desse 
coletivo e que tem desenvolvido, ao longo dos últimos anos, importante diálogo com o campo da etnologia ameríndia.

"O termo [antropologia da política], cunhado por Moacir Palmeira, visava precisamente evitar conceber a política como domínio ou processo específicos, definíveis objetivamente de fora. Tratava-se, ao contrário, de investigar fenômenos relacionados àquilo que, 'do ponto de vista nativo', é considerado como política. (...) Não podemos esquecer, inicialmente, que abordar a política a partir 'do ponto de vista nativo' não significa ficar aprisionado nas elaborações locais, mas produzir teorias etnográficas (...)” (Goldman, 2006: 40-1)

Essa ideia de "teorias etnográficas", Goldman a pensa, sobretudo, a partir de Malinowski:

“Uma teoria etnográfica, de seu ponto de vista, não se confundiria nem com uma teoria nativa (sempre cheia de vida, mas por demais presa às vicissitudes cotidianas, as necessidades de justificar e racionalizar o mundo tal qual ele parece ser, sempre difícil de transplantar para outro contexto), nem com o que Malinowski viria a denominar mais tarde 'uma teoria cientifica da cultura' (cuja imponência e alcance só encontram paralelo em seu caráter anêmico e, em geral, pouco informativo). (...) Uma teoria etnográfica tem, portanto, como objetivo central elaborar um modelo de compreensão de um objeto social qualquer (linguagem, magia, politica etc.), o qual, mesmo produzido em e para um contexto particular, possa funcionar como matriz de inteligibilidade em e para outros contextos. Nesse sentido, permite superar os conhecidos paradoxos do particular e do geral, assim como, talvez, os das praticas contra as normas ou das realidades em oposição aos ideais. (...) Uma teoria etnográfica procede um pouco à moda do pensamento selvagem: emprega os elementos muito concretos coletados no trabalho de campo - e por outros meios - a fim de articulá-los em proposições um pouco mais abstratas, capazes de conferir inteligibilidade aos acontecimentos e ao mundo" (op.cit: 28)

Tais formulações estão, ainda, relacionadas ao que Lévi-Strauss propõe como traço distintivo da antropologia, diante da sociologia: a busca, por aquela, de uma "ciência social do 
observado", e não da do observador (que seria objeto desta):

"Enquanto a sociologia se esforça em fazer a ciência social do observador, a antropologia procura, por sua vez, elaborar a ciência social do observado: (...) mas tentando extrair um sistema de referência fundado na experiência etnográfica, e que seja independente, ao mesmo tempo, do observador e de seu objeto.” (1967a: 404 - cf. Goldman, 2006: 30).

O que aponta Lévi-Strauss nos parece especialmente relevante para a compreensão desta tese, no que tange a uma distinção deste trabalho em relação a outras etnografias recentes realizadas entre os Guarani e Kaiowá, mantendo perspectivas outras a respeito da natureza da antropologia as quais serão discutidas no próximo capítulo.

Vale comentar, antes de seguirmos: a opção por definir, aqui, a busca por uma teoria etnográfica, dá-se no sentido de tentar minimizar as dificuldades assinaladas por autores como Taylor (1993). A autora comenta os riscos de chegar a exageros ou deturpações, quando se tomam as rédeas na elaboração de uma reflexão dita nativa em campos quanto aos quais claramente o grupo com o qual se dialoga não tem uma "teoria explícita". O etnógrafo, reflete ela, acaba encaixando peças para montar uma lógica que esteja sob "práticas aparentemente disparatadas e discursos lacônicos", em vez de aparecer em "explicações e comentários indígenas" - ainda que, como ela aponta em relação a seu próprio texto, exista a "esperança" de que suas interpretações “descrevam de forma acurada a gramática cultural implícita que informam tanto os discursos jívaro como suas práticas observadas" (op.cit: 658).

O que aí é visto como "gramática implícita", algo projetado para os nativos, por assim dizer, assumimos como uma elaboração resultante do trabalho do etnólogo, da produção de um devirnativo $^{16}$ : uma teoria etnográfica, portanto. Como no método confucionista de tradução, "um é lido pela perspectiva do outro". Bem entendido: eu, etnólogo, aqui, não sou apenas um, sou outro também. E sou outro, inclusive na medida em que questionarei, ao longo do texto, alguns pressupostos básicos de certa tradição política ocidental, moderna (democrata, liberal...).

16 Sobre o devir-nativo: "o devir (...) é o movimento pelo qual um sujeito sai de sua condição por meio de uma relação de afetos que consegue estabelecer com uma condição outra" (Goldman, 2006: 31). Nesse processo de mão dupla, destaca o autor, ocorre uma "dupla captura", "duplo-devir" ou "bloco de devir" (idem: 49, nota 16): "este processo (...) talvez sirva para lançar mais luz sobre as complexas relações entre etnógrafos e nativos do que os lugares-comuns repetidos, tanto acerca da objetividade científica quanto da autoridade etnográfica". 
Ainda que este trabalho se relacione, claramente, a um esforço coletivo - e, portanto, remeta a outras pesquisas, no que tange a certas perspectivas -, creio que cabem, aqui, algumas breves palavras sobre como ele se relaciona a uma tradição de grande relevo na antropologia.

Goldman (op.cit: 39-42) traça um breve histórico da chamada antropologia política bastante útil aqui, em função de seu poder de síntese. Ele lembra que, apesar de haver uma tendência a considerar que os estudos específicos nesse sentido apareceram a partir da década de 40, "a questão do poder sempre esteve no centro da antropologia, desde a própria constituição da disciplina", "principalmente, porque a antropologia se constituiu a partir de uma 'grande divisão', separando sociedades 'políticas' e 'não políticas"' - uma reflexão a partir da qual remete, por exemplo, a Clastres. Isolando o político, continua Goldman, a antropologia constituiu seus objetos preferenciais: a religião, a economia primitiva e, sobretudo, o parentesco, esta "contraface do político nas sociedades sem Estado".

O autor identifica duas tendências gerais, então, nessa subdisciplina: um substantivismo aplicado pelos funcionalistas - a procurar instituições que substituem o Estado, como é o caso das linhagens na África - e, posteriormente, um formalismo processualista/marxista/etc., que identificará a política como "um aspecto de qualquer relação social”. Para Goldman, o perigo aí é que, reduzindo todas as múltiplas dimensões da vida social às relações de poder, se perca de vista a "experiência total da qual a política é apenas um aspecto".

A crítica de Viveiros de Castro (1999) aos chamados contatualistas vai ao encontro dos comentários de Goldman, ao propor a "desnaturalização" da própria noção de política - na visão daquele, ela deveria preceder qualquer tentativa de "desnaturalização das categorias antropológicas e dos fenômenos sociais" ${ }^{\prime 17}$ :

"Com efeito, é difícil desnaturalizar o que quer que seja a partir de uma concepção violentamente naturalizada do 'político', que o vê como uma espécie de éter do mundo social, substância mística a mediar universalmente as ações humanas. Nada mais característico de certos impasses da antropologia contemporânea que esse processo conceitual de

17 Nesse sentido, destaca Viveiros de Castro, há um "programa mais interessante", ao qual já passaram os "etnólogos clássicos" e outros, o de "desnaturalizar a natureza", ou seja, de encarar uma politização da natureza, em vez de uma naturalização da política. A chave aí seria uma problematização da "distinção - política, naturalmente entre humanos e não-humanos, cultura e natureza, sociedade e ambiente" (1999: 200). O presente trabalho dialoga com essa perspectiva, sobretudo, no capítulo 3. 
essencialização da política, expressão, por vezes, de um naturalismo sumário (na verdade, uma teoria da natureza humana) (...). Os partidários desse politicismo generalizado pretendem estar desnaturalizando a sociedade, mas apenas para melhor renaturalizá-la no elemento universal do político (talvez na ilusão de que ele seja naturalmente desnaturalizado), que passa então a funcionar como segunda natureza, isto é, como o equivalente naturalizado da 'cultura', nos termos do tradicional dualismo 'natureza/cultura'. Essa antropologia política, com sua retórica préfabricada do 'conflito', das 'estratégias' e dos 'recursos' é bem diferente de uma verdadeira antropologia da política (Goldman \& Palmeira, 1996), que só começa quando se pergunta o que pode ser uma dimensão do 'político' em sociedades diferentes da nossa. Pois não é possível pôr a cultura na política sem pôr o político na cultura." (Viveiros de Castro, 1999: 198)

Quando, por parte de Goldman, há referência aos anos 40 como marco na antropologia política, não se duvide: é de Sistemas Políticos Africanos, de Evans-Pritchard e Fortes (1940), que se está falando. Na história dessa subdisciplina - ao menos segundo alguns -, esse livro é quase um marco (um quase-marco?) fundacional. Preocupado em entender o que se escreveu - e se silenciou - a respeito dos Jê, em termos de suas formas políticas, Drago faz interessante análise a respeito de tal obra, em função de encontrar nela o marco para a criação da fenda com/sem Estado, a partir de certa fusão entre as ideias de Estado e governo - entendidas de forma bastante distinta por autores clássicos como Morgan e também por certa tradição americanista ${ }^{18}$ :

“Ou seja, quem equacionou Estado e governo, dando origem ao Grande Divisor criticado por Clastres e outros ${ }^{19}$ ? 'Verificar-se-á que os sistemas políticos descritos neste livro se arrumam sob duas categorias principais', a saber, um grupo A composto de '[...] sociedades que têm autoridade

\footnotetext{
18 Voltaremos, oportunamente, a essa distinção, para melhor destrinchá-la. Por ora, interessa-nos assinalar esse marco, a fim de orientar a leitura dos capítulos seguintes.

$19 \mathrm{E}$, para que comecemos a alterar-nos, vejamos, no manifesto de Bellegarrigue (1850), outras possibilidades de encadeamento lógico: "Com efeito, quem diz anarquia, diz negação do governo; quem diz negação do governo, diz afirmação do povo; quem diz afirmação do povo, diz liberdade individual; quem diz liberdade individual, diz soberania de cada um; quem diz soberania de cada um, diz igualdade; quem diz igualdade, diz solidariedade ou fraternidade; quem diz fraternidade, diz ordem social; então, quem diz anarquia, diz ordem social. Ao contrário, quem diz governo, diz negação do povo; quem diz negação do povo, diz afirmação da autoridade política; quem diz afirmação da autoridade política, diz dependência individual; quem diz dependência individual, diz supremacia de casta; quem diz supremacia de casta, diz iniquidade; quem diz iniquidade, diz antagonismo; quem diz antagonismo, diz guerra civil; então, quem diz governo, diz guerra civil" (em francês, disponível em www.panarchy.org)
} 
centralizada, aparelho administrativo e instituições judiciais - em suma, um governo - e nas quais as distinções de riqueza, privilégio e status correspondem a distribuições de poder e autoridade' (Evans-Pritchard \& Fortes, 1940: 31-2); e outro, 'que referimos por grupo B, consiste naquelas sociedades a que falta autoridade centralizada, aparelho administrativo $e$ instituições judiciais constituídas - em suma, não têm governo - e nas quais não existem divisões agudas de categoria, status e riqueza” (idem: 32). E a sinonímia entre 'sociedades primitivas' e 'sociedades do parentesco' teria, por acaso, gênese distinta? 'Nas sociedades do grupo B os laços de parentesco parecem assumir um papel mais proeminente na organização política [...]' (idem: 34)” ${ }^{20}$ (Drago, 2012: 43)

(Re)inventa-se, assim, uma "sociedade primitiva" algo distinta. Como Drago assinala, essa nova versão tem ainda como características o fato de que, ali, a soberania não repousa sobre nenhum indivíduo ou grupo:
“(...) o político, como função, está distribuído - dissolvido - na própria estrutura social (Goldman \& Lima 2003:12) - o “fator estabilizante” não é uma organização jurídica ou militar muito ordenada, mas é simplesmente a soma total das relações entre linhagens segmentares (Cardoso 1995:130). '(...) nestas sociedades primitivas a regulação política surge como 'automática' (já que prescinde de qualquer princípio mediador de sua vigência ou de sua efetividade)', o que nos leva a concluir que nelas 'a 'função política', seria, ao fim e ao cabo, apenas aquele aspecto da ordem social encarregado de sua autorregulação espontânea ou - é preciso dizer - natural'(idem:132).” (Drago, op.cit: 44)

Todo esse quadro é complementado por "símbolos sagrados", "valores místicos" e um "sentimento público" cultivado por meio de cerimônias periódicas - sem as quais o senso de interesse comum tende a esvair-se. "Não é o antiquado evolucionismo que se insinua aí, mas algo diferente e pior" (idem: 44). Drago ajuda-nos a desvelar a origem do notável descompasso entre certa antropologia política e a trajetória independente dos estudos sobre as formas políticas ameríndias.

20 Drago utiliza a edição portuguesa do livro, lançada em Lisboa pela Fundação Calouste Gulbenkian, em 1981. 
Desenvolveremos, nos capítulos 2, 3 e 4, algo sobre três das figuras que sustentam, a nosso ver, uma espécie de teoria (etnográfica) kaiowá da política. A primeira delas relaciona-se ao lugar da chefia ameríndia, vinculando-se, portanto, a uma determinada tradição que, se não remete a uma produção volumosa, da maneira como se comentou acima, possui, sim, grande influência talvez sua força mesma tenha limitado a geração de novos trabalhos, pois é inegável que, à primeira vista, tem-se a sensação de que não há muito mais a dizer sobre o tema, após ler os textos de Lowie, Lévi-Strauss e Clastres a respeito.

Existe um chefe ameríndio canônico que emerge desses três trabalhos, basicamente - por isso, vale a pena uma revisão mais atenta desses estudos, e particularmente dos dois primeiros. Isto porque as citações aos estudos de Clastres certamente acompanharão todo o nosso percurso, de alguma forma, em virtude da grande influência de suas ideias acerca do lugar do chefe ameríndio e suas relações com a ideia de contrapoder/contra o Estado. Os demais, menciono-os desde já, porque nem sempre tornarão a aparecer ao longo de nossa reflexão.

Primeiro, há o clássico texto de Lévi-Strauss (1967b) sobre a chefia entre os Nambikwara de Mato Grosso, produzido ainda em sua estada nos EUA, nos anos 40. O artigo foi reeditado, posteriormente, no mesmo volume que reproduz a conhecidíssima síntese de Lowie (1967) tratava-se de uma coletânea dedicada à diversidade de formas políticas em sociedades "préindustriais", dos Inca e Asteca aos Eskimó/Inuit e Nambikwara, passando por grupos africanos que vão de reinos aos caçadores !kung do deserto de Kalahari.

O caso nambikwara, destaca Lévi-Strauss, oferece-nos a preciosíssima oportunidade de estudar "uma das mais simples formas concebíveis de organização social e política". "Chefes e chefia existem, entre todos os grupos humanos, sob diferentes formas" e "existe, indubitavelmente, uma função na chefia”, diz ainda o autor francês (1967b: 47), esclarecendo-nos a respeito de sua perspectiva funcionalista, à época da redação do artigo.

O colapso demográfico que haviam vivido esses indígenas, explica Lévi-Strauss (seguindo números de Rondon, ele estima que os Nambikwara se reduziram, em cerca de 30 anos, de algo entre 10 mil e 20 mil pessoas a pouco menos de 2 mil), não afeta a análise a ser realizada, pois "a estrutura política nambikwara põe a nu algumas funções que permanecem escondidas em sistemas de governo mais complexos e elaborados" (idem: 50). 
A situação que se descreve a fim de caracterizar a chefia é definida pela alternância entre estação seca e chuvosa na região onde os Nambikwara vivem, sendo que, durante o período em que não é possível fazer roça (sete meses ao ano, segundo o autor, um período de escassez em que se realizam coletas e caça de pequenos animais ${ }^{21}$ ), a aldeia se dispersa em pequenos grupos familiares, guiados por um líder. A respeito dessa dispersão dos grupos, lê-se:

\begin{abstract}
"Há, no grupo inicial, vários homens reconhecidos como líderes (que provavelmente adquiriram essa reputação a partir de seu comportamento durante a vida nômade) e que compõem os núcleos relativamente estáveis em torno dos quais os diferentes agregados se reúnem. A importância, bem como a permanência do agregado ao longo de anos sucessivos, depende em grande parte da capacidade de cada um desses líderes para manter sua posição e, eventualmente, para incrementá-la. Assim, pode-se dizer que a liderança não existe como resultado das necessidades do grupo (band), mas, em vez disso, que o grupo recebe a sua forma, o seu tamanho, e mesmo a sua origem, do líder potencial que o antecede" (op.cit: 51)
\end{abstract}

O chefe, explica Lévi-Strauss, será “inteiramente responsável pela gestão (management) de seu grupo". Ele determina o início do período em que se abandona a aldeia para perambular pelo cerrado; traça as rotas, os pontos de parada e a duração dos acampamentos; ainda, "ordena e organiza" pescarias, caçadas e expedições de coleta, bem como as atividades de roça, no período das chuvas; também gerencia as relações do grupo com os vizinhos.

O consentimento, dirá o autor, é a origem de sua liderança, e a única medida de sua legitimidade. Sua sustentação no cargo depende de sua habilidade para "fazer o sentimento público coincidir com sua própria opinião" (op.cit: 53), pois ele não dispõe de poder coercitivo. Por isso, ele precisa demonstrar continuamente uma habilidade para manter sua "maioria flutuante" 22 em vez de se mostrar um "soberano poderoso" (over-powering ruler).

\footnotetext{
21 É interessante perceber como o autor compõe esse quadro de escassez por meio de sua descrição. Por exemplo, os Nambikwara comem animais que ocidentais só comeriam em caso de completa falta de alternativas, como lagartos, cobras, morcegos, aranhas e gafanhotos. Mas, será que são animais que têm a mesma conotação para os indígenas? Grilos e gafanhotos são iguarias em outras regiões. A temporada de chapulines (grilos, comidos torrados com chile e limão), no México, é aguardada - e mais ainda a de larvas como escamoles e gusanos. Os franceses, oras, comem caracóis. Em certo momento (op.cit: 56), dá-se a entender que os gafanhotos seriam comida indesejável, mas ainda assim mantenho a dúvida sobre a generalização. É bem sabido que, em matéria de preferências culinárias, o que é abjeto para uns pode ser até uma iguaria refinada para outros.

22 Significativamente, fala-se em consentimento (consent), mas não em consenso (consensus). Essa menção a uma "maioria" ganhará novo sentido no capítulo 4.
} 
Em virtude, ainda, do fato de que há numerosos bandos circulando pelo território nambikwara, o chefe tem que enfrentar uma espécie de competição: "Não é suficiente fazer bem; o chefe deve tentar - e seu povo conta com ele para isso - fazer melhor que os outros".

Finalmente, depois de traçar esse quadro, Lévi-Strauss enumerará certas características do chefe nambikwara que conformam o nosso cânone. São, segundo ele, os "instrumentos de poder" do chefe - uma vez que ele não conta com o poder coercitivo, como vimos.

O primeiro desses instrumentos é a generosidade. A descrição dessa virtude é bem conhecida: o chefe tem de dar tudo o que lhe caia à mão, e está sempre tão "pobre" como da primeira vez que o etnólogo o encontrou. Uma comparação interessante é feita pelo autor a respeito de situações em que a coisa passa do aceitável, levando o chefe a uma condição desesperadora em que ele anuncia seu limite: "A recusa a dar joga o mesmo papel, nessa democracia primitiva, que a ameaça de renunciar seguida por um voto de confiança num parlamento moderno"23 (op.cit: 54-5).

Outra associação interessante que Lévi-Strauss realiza é entre a generosidade e o xamanismo, a partir da percepção de que o chefe deve cultivar o dom do engenho (ingenuity), expressão intelectual da generosidade. Da mesma forma que prepara curare para as flechas de todos, faz bolas de borracha para os jogos coletivos, ou canta e dança para animar o grupo, o chefe também pode curar, como forma de prestar favores a seu povo (op.cit: 55). Isso, ainda que, segundo o autor, a vida mística fique em segundo plano no cotidiano nambikwara e pareça mais comum que chefe e xamã sejam, normalmente, ali, figuras distintas.

Da generosidade, salta-se à poligamia, outro item clássico das descrições de chefes ameríndios, vista como uma espécie de "recompensa intelectual e moral" pelos seus pesados encargos cotidianos e, ao mesmo tempo, uma forma de auxílio, já que as esposas trabalham, junto com o chefe, pelo grupo. Os demais casamentos que seguem o primeiro, contudo, são verdadeiras uniões, mas "de um tipo diferente", de acordo com o autor. A primeira mulher as considera "filhas ou sobrinhas" (op.cit: 57), já que, usualmente, pertencem a uma geração posterior. O autor as percebe como uma espécie de empregadas (tomboy girls), mas também namoradas do chefe, com uma relação que não carrega a "atmosfera conjugal” do primeiro casamento.

Outro trecho que me parece relevante é o que demonstra, em especial, com que tipo de

23 Mais uma vez, encontramos uma imagem que nos leva à ideia de manutenção de uma maioria em apoio ao governante. 
material Lévi-Strauss está dialogando e por que, afinal, o artigo se denomina "Os aspectos sociais e psicológicos da chefia numa tribo primitiva"24.

“Os dados nambikuara contribuem, junto com muitos outros, para destruir a crença originada pelos primeiros antropólogos, e temporariamente revivida pela psicanálise, de que o chefe primitivo poderia encontrar seu protótipo em um pai simbólico, e que as formas mais simples do Estado poderiam ter progressivamente surgido a partir da família." (op.cit: 58)

A partir daí, Lévi-Strauss volta a dissertar sobre como a percepção, nesse quadro, do consentimento, origem e limite da chefia, introduz, na realidade, algo inteiramente novo em relação aos dados biológicos. Ao consentimento se opõem as "relações unilaterais", como "direito de idade", "poder autocrático", que só apareceriam em "grupos com estrutura mais complexa".

Chega a fazer uma comparação com a ideia de "contrato social", conforme a concebe Rousseau. Embora resguarde as diferenças entre os Nambikwara e as sociedades de que fala o filósofo, exalta a percepção deste a respeito do papel fundamental que jogam elementos como o consenso e o contrato: "Eles são matérias-primas da cultura, e é impossível conceber uma organização social em que eles não estariam presentes" (op.cit: 59).

O autor segue dissertando sobre como a reciprocidade entre o chefe e o grupo expressa cotidianamente o consentimento que funda essa relação. Afastando-se de Malinowski, diferencia, porém, o tipo de reciprocidade entre o chefe e o grupo. Para ele, trata-se de um circuito especial porque, diferente dos demais, que são relações entre membros isolados do coletivo, aqui se estabelece uma relação entre "o grupo considerado como grupo (e não uma coleção de indivíduos) e seu governante".

Logo em seguida (op.cit: 59-60), aparece um argumento algo complicado, que usa a própria distinção desse circuito resultante na poligamia do chefe para mostrar que estaria, aí, a chave para o entendimento mesmo do "contrato social". Por receber várias mulheres, o chefe está obrigado a fornecer segurança, ou "garantias contra necessidades e perigos" que ameacem o grupo. A moderna

\footnotetext{
24 Kracke (1978) é um autor que retoma, mais tarde, essa perspectiva de um estudo sobre "aspectos psicológicos" da chefia. Haveria toda uma pesquisa a ser feita aí, sobre o sentido desse encontro entre psicologia/psicanálise e antropologia, no que tange aos chefes ameríndios, mas creio que a perspectiva deleuze-guattariana (e a de Clastres, na leitura desses autores - e dos anarquistas em geral, como veremos), ao bater de frente com a psicanálise (propondo, por exemplo, uma esquizoanálise - vide Guattari, 1988), esvazia essa possibilidade. Como veremos adiante, e como já anuncia Graeber no trecho citado umas páginas acima, é pura e simplesmente de desejo que se trata, ao fim e ao cabo...
} 
concepção do Estado como uma espécie de "sistema de seguridade" 25 seria um retorno, então, à "natureza básica da organização política e social”,26.

$* * *$

Lowie (1967), por sua vez, realiza, ao longo de 24 páginas, um enorme esforço de síntese comparativa da "gama de variações" de organização política encontradas entre os ameríndios claramente inspirando-se no quadro composto pelos artigos organizados por Evans-Pritchard e Fortes em 1940, a respeito do continente africano.

Em primeiro lugar, ele distingue o "controle legítimo da força física",27 como apenas um dos componentes das organizações políticas para afirmar: "Uma sociedade simples pode ser diferenciada a fim de dispor de um governo, ainda que o elemento coercitivo esteja faltando" (op.cit: 64). Drago, como vimos, alerta para esse aspecto: Estado e governo, aqui, não são a mesma coisa.

Lowie segue identificando que "uma tendência ao separatismo era geral" (op.cit: 65), o que, de largada, já diferenciaria as Américas da África. Quanto à Confederação Creek e a Liga dos Iroqueses, por "muito barulho" que se tenha feito a seu respeito, "suas realizações não devem ser superestimadas", ainda que tenham envolvido "uma cooperação política mais ampla". Para justificar sua opinião, o autor cita um episódio em que um grupo Creek se recusou a lutar na confederação porque um povo não Creek (mas seu aliado) estava do outro lado na guerra, em 1793. Quanto aos Iroqueses, lembra que, durante a Revolução Americana, cada grupo tinha liberdade para escolher qual seria sua posição no conflito ${ }^{28}$. Ele agrega, ainda, dados de demografia histórica: a liga nunca teria envolvido uma população superior a 20 mil pessoas (op.cit: 66). Teria tido destaque na história, enfim, unicamente pela falta de algo mais amplo nas Américas.

E o autor continua, então, arrolando dados sobre diversos grupos, sempre no sentido de mostrar a prevalência das tendências separatistas. Por toda parte, "a unidade política é

25 Nesse sentido, o texto, publicado originalmente em 1944, menciona especificamente a discussão pública lançada, sobretudo, na Inglaterra, pelo Relatório Beveridge, de 1942. O documento é considerado chave na criação de um Estado do bem-estar social (welfare state) no país. Sobre esse "retorno", vale conferir a visão de Murra (1978: 191) sobre o império Inca, como um "estado redistributivo".

26 Lévi-Strauss ainda realiza algumas considerações finais que serão oportunamente comentadas ao longo deste trabalho, concluindo com a necessidade de uma aproximação entre antropologia e psicologia, a fim de refinar os estudos sobre chefia.

27 Apenas para aclarar, Weber (1968) é, sim, uma referência aqui.

28 Abordaremos no próximo capítulo um caso semelhante, referente à Confederação dos Tamoios, e discutido por Perrone-Moisés \& Sztutman (2010). 
incomparavelmente menor que a linguística" (op.cit: 67). Quando algum autor menciona a existência de um grande chefe, é sempre para agregar que sua autoridade é "insignificante". A explicação para a dispersão pode, inclusive, ter a ver com a necessidade de "explorar o ambiente" na maior parte do ano, conforme, destaca ele, Durkheim (2003 [1912]) e Mauss (2003 [1906]) já haviam apontado.

Quanto às "altas civilizações” das Américas, só o Império Inca poderia ser considerado uma exceção, por ter abrangido, possivelmente, 6 milhões de pessoas, nas contas de Lowie. Quanto à Mesoamérica, ele cita os episódios da conquista espanhola sobre os Astecas da mesma forma que havia se referido aos Creek e Iroqueses, não se deixando impressionar (Lowie, op.cit.: 69-70).

Quanto às ligas chefiadas por Pontiac (1763) e Tecumseh (morto em 1813), provariam que, "sob excepcional estímulo emocional, os nativos poderiam e de fato visualizavam uma cooperação de escopo mais amplo" (op.cit: 70). O mesmo tipo de "talento organizacional" de alguns indivíduos estaria nas raízes do imperialismo andino.

A ocorrência de poder coercitivo entre os ameríndios é algo "atípico", dirá Lowie - tanto como a completa "anarquia" dos Fueguianos, Eskimó (Inuit) e grupos do noroeste da Califórnia. "Uma condição intermediária representa a norma" (op.cit: 70). "Com isso eu quero dizer: uma condição com diferenciação de um ou mais indivíduos como cabeças (headmen), ainda que seu poder verdadeiro seja circunscrito ou insignificante", completa ele.

Para melhor definir essa condição, Lowie distingue "chefes titulares" e "chefes fortes" estes sendo, no caso, os que teriam "autoridade inquestionável”. O autor organiza novo panorama das possíveis variações em torno da figura dos "chefes titulares". Uma série de episódios curtos, das mais distintas fontes, serve para mostrar que a definição é vaga e, grosso modo, quer dizer que o chefe em questão não tem poder coercitivo, tendo que, muitas vezes, submeter-se a conselhos e assembleias. A descrição deriva para a constatação de casos em que a voz do chefe tem mais o sentido de um aconselhamento do que de uma ordem, ou em que tem poder na organização de uma festa, mas não na punição de qualquer delito (op.cit: 72). No caso tsimshiam, o chefe será responsável por indenizar a família de um morto em batalha, sob seu comando. Entre os Oglala Dakota, os soldados/policiais podem punir delitos, mas não o chefe.

Por toda parte, portanto, o mais comum é que o chefe "trabalhe como ninguém", tenha "autoridade limitada" e nenhum indicador de status superior, não podendo impor penas, comandos 
ou interferir em assuntos privados. "Em resumo, o típico chefe ameríndio goza de posição social, mas lhe falta a soberania" (op.cit: 73). É, ainda, um pacificador, um moderador cujas tarefas estão divorciadas da disciplina e da violência - uma polaridade generalizada, segundo ele. O autor apresenta, inclusive, casos norte-americanos em que há chefes de guerra e chefes de paz, claramente distinguidos. Já na América do Sul, lembra ele, é comum que o chefe de guerra torne-se insignificante quando volta para casa. E Lowie prossegue:

\begin{abstract}
“Em suma, as concepções de liderança civil e militar eram distintas na América. Havia tirania esporádica mesmo nas sociedades democráticas das Planícies do Norte, mas isso surgia da intimidação individual, geralmente apoiada por um corpo poderoso de parentes ou pela sanção sobrenatural putativa, não a partir do golpe de estado de um capitão embriagado com sucesso e cheio da ambição de um déspota." (op.cit: 74)
\end{abstract}

Além disso, Lowie traça um panorama sobre a generosidade e a oratória como valores/talentos associados à chefia. Juntamente com a capacidade de pacificar, eles compõem a tríade de qualidades de um chefe titular. Como destaca o autor, contudo, existe um número pequeno, mas significativo de grupos que contam com "chefes fortes" ${ }^{29}$. Esses casos estão relacionados à existência de "populações materialmente avançadas", segundo ele, com uma ou outra exceção ao sul da América do Norte (op.cit: 76-7).

O autor especula ainda sobre o que chama de "germes evolucionários". Inicialmente, trata de circunstâncias excepcionais em que os grupos aceitam, temporariamente, juntar-se sob a orientação de um só líder. É o caso dos Yahgan, que, quando encontram uma baleia encalhada, se juntam num grande grupo, sob a direção de um chefe cerimonial, enquanto dure a carne do animal (op.cit: 78) - destaco o caso porque me fornece uma boa metáfora para o resto do texto. É, ainda, o caso dos Nambikwara, conforme retratado por Lévi-Strauss, indica Lowie (op.cit: 79).

Em alguns exemplos, "as atitudes igualitárias do cotidiano retrocedem, suplantadas por uma suserania (overlordship) transitória”. É o que ocorre, por volta de 1820, entre os Cheyenne, e é o que acontece também, segundo Lowie, durante algumas festas, como entre os Crow e Hopi (idem).

Além disso, também se desenvolve algo sobre autoridades não relacionadas aos chefes.

29 E aparece nova referência ao African Political Systems, reafirmando que, agora, sim, ao tratar do strong chief, se falará das sociedades do tipo A, conforme a classificação proposta por esse livro (ver, acima, comentário de Drago). 
“Talvez as mais notáveis instâncias de autoridade, de pleno direito e não completamente efêmeras, aparecem em conexão com importantes empreendimentos econômicos, os quais devem ser salvaguardados segundo o interesse comum". Nesse caso, cita-se o exemplo dos Apinajé, onde "dois homens que representam as metades" 30 cantam e zelam pelas roças. Em outros casos anotados, previne-se a coleta excessiva e disciplinam-se as caçadas.

Finalmente, há o "fator religioso". Para Lowie, o poder coercitivo se associa à atribuição de divindade ao governante supremo. Era isso que Lowie via nos Inca (e no caso anômalo dos Natchez) e que lhe fazia distingui-los de todos os demais ameríndios. Para ele, as crenças religiosas formam a "base psicológica" para sistemas políticos mais complexos. Um "chefe inescrupuloso" se associa a um "xamã cúmplice" e voilá, dá-se um golpe. Pode-se, inclusive, verificar a associação, em uma mesma pessoa, dessas duas figuras, dirá ele. O texto chega a citar um caso guarani como exemplo, o do líder Oberá, o qual, em 1579, ordenou que seus seguidores parassem de plantar para segui-lo, cantando e dançando (op.cit: 86$)^{31}$. Em momentos determinados da história, um profeta pode mesmo adquirir poder de vida e morte sobre seu povo, assinala o autor.

Só na conclusão do texto a carta na manga é mostrada: é, afinal, a partir de uma associação entre liderança e ingredientes como "hipnose da exaltação religiosa", "coação moral”, "sanção sobrenatural inspiradora de assombramento" que surge um "governo por direito divino" semelhante ao dos Inca. Aí está o “esboço de uma provável linha de desenvolvimento" que levaria desde os Fueguianos sem chefe até os Inca. A fundação de um Estado, supõe Lowie, finalmente, se deve a homens que "ao mesmo tempo imaginaram uma unidade além daquela do parentesco imediato e da contiguidade e que simultaneamente tiveram sucesso em investir sua missão com o halo do sobrenatural". Assim é que se poderia superar o separatismo e o libertarismo dominantes entre os ameríndios para criar um Estado moderno.

\footnotetext{
30 A resistência de Lowie em reconhecer figuras como essas como xamãs impressiona. Entre os Kaiowá, cantar pelo bem de uma plantação é uma das mais notáveis tarefas de um rezador (ñanderu/ñandesy). Drago (2012) disserta largamente sobre a relação entre essa negativa e um determinado modelo teórico que deveria ser mantido a todo custo - afinal, os Jê eram "grupos marginais", em relação aos Tupi e, por isso, entre eles, o "religioso" não deveria oferecer manifestações significativas. Vale observar que, na composição do paradigma sul-americano apresentado por Lowie neste trabalho, os Jê têm enorme peso, em função de todo o envolvimento do estadunidense com a edição do material coletado por Nimuendaju.

31 Retornaremos ao caso de Oberá no capítulo 3.
} 


\begin{abstract}
Além
Essa figura do "chefe titular" de Lowie, personificada no chefe nambikwara de Lévi-Strauss, atravessa a obra clastriana e chega forte até nós, mesmo mais de meio século após sua composição. Goldman \& Lima (2001: 296) traçam essa trajetória, refletindo sobre o diálogo que Clastres inicialmente realiza com os dois autores supracitados em "Troca e poder: filosofia da chefia indígena”, ensaio de 1962 (Clastres, 2003: 45-62), bem como os desenvolvimentos posteriores, em sua obra, das ideias que, a partir desse ponto, se desdobram.
\end{abstract}

Como apontam os autores, depois de mirar uma reflexão localizada, em relação à qual persistem os questionamentos, Clastres acerta um alvo muito maior:

\begin{abstract}
“(...) tendo atingido um nível de generalidade profundo, no qual pôde descobrir a relação negativa entre o político e a troca, e concluir de modo justo que o poder é contra o grupo, Clastres desvendava, sem se dar inteiramente conta, uma propriedade do político que é geral, ou seja, independente de ser o seu regime de funcionamento selvagem ou estatal. Pretendeu, em seguida, singularizar a chefia indígena por meio de uma exterioridade que é também um fenômeno geral - pois não sucederá o mesmo a um poder que é potente?” (Goldman \& Lima, 2001: 297)
\end{abstract}

A intuição certeira do autor francês é confirmada, anos depois, em um notável ensaio de Deleuze \& Guattari, "Micropolítica e Segmentaridade" (1996 [1980]), o qual demonstra como a reflexão clastriana poderia servir como suporte para uma poderosa crítica ao sistema ocidental como um todo - o que o próprio autor já apontava, alhures, como objetivo final da antropologia (ver Goldman \& Lima, op.cit.).

Não me deterei, aqui, em uma discussão pormenorizada da obra de Clastres, a qual tem sido alvo da merecida atenção, nos últimos anos. Com a reedição de suas duas principais coletâneas no Brasil, vieram à tona, acompanhando esses tomos, as reflexões de Goldman \& Lima (2003) e Viveiros de Castro (2004b). Outros trabalhos se somam, nesse conjunto mais recente (Lanna \& Graeber, 2005; Barbosa, 2005). Além disso, há os escritos recentes de autoria de Perrone-Moisés \& Sztutman $(2010,2011)$ e, agora, também, reunidos pela dupla na Revista de Antropologia n. 54-2 $(2011)^{32}$. Na França, ainda, há o recente volume organizado por Abensour \& Kupiec (2011) -

32 Destaquem-se, ainda, ensaios de Cardoso (1995) e Lanna (2005). 
aquele já havia contribuído, nos anos 80, com outra coletânea recentemente reeditada na Argentina (Abensour, 2007). O rendimento da extensão da reflexão clastriana para além dos domínios da etnologia indígena é atestado por trabalhos de Goldman (2011), Ferrari (2011), Graeber (2004) e Morris (2007), entre tantos outros.

Por mais que tenha efetuado uma "revolução copernicana" no âmbito da Antropologia, o fato é que os elementos básicos da caracterização do chefe ameríndio canônico não mudam após a passagem de Clastres: o chefe tem como atributos a oratória, a generosidade e a capacidade de manter a paz e tomar iniciativas. E há, claro, a poliginia, que continuará a ensejar reflexões infindáveis.

Sztutman (2005) realizou revisão geral da bibliografia etnológica sobre as figuras do chefe e do profeta ameríndios, destacando alguns pontos que serão importantes para a compreensão e debate acerca dos dados etnográficos a serem apresentados nos capítulos subsequentes. Vale anotar os principais parâmetros teóricos destacados pelo autor, pois se extrai daí um quadro bastante representativo. Note-se que falaremos aqui com/de autores presentes no citado trabalho para além de Clastres e de seus comentadores - um conjunto que também é lido em detalhe por Sztutman e que será ocasionalmente citado ao longo de nossos capítulos seguintes.

Em primeiro lugar, então, há o modelo de Deleuze \& Guattari (1996), o qual, na boa síntese de Sztutman, "redefine a política", passando ela a consistir, portanto:
“(...) num jogo simultâneo de duas 'tendências' opostas que definem tensões: a sobrecodificação/ reterritorialização - criação de unidades estáveis que coincidem com um território fixo $-e$ a codificaçãol desterritorialização — produção de um estado de instabilidade que impede a cristalização de unidades e territórios.” (Sztutman, 2005: 34-5)

Essa ideia de um jogo entre forças centrípetas e centrífugas comparece, aqui, como uma espécie de ponto de partida para a reflexão. Afinal, foi a partir da leitura desse citado ensaio que elaboramos nosso projeto de pesquisa, cinco anos atrás. Sugere-se aos leitores a comparação entre esse modelo e a operação das figuras políticas kaiowá/guarani efetivamente aferidas em campo, a serem apresentadas nos próximos capítulos. 
Outro conceito que compõe a análise de Sztutman é o de socialidade, segundo usado, por exemplo, por Strathern (2006) - uma forma de fugir da clássica oposição ocidental indivíduo x sociedade, possibilitando novas leituras de paisagens como os da Melanésia (ou da Amazônia), em que a ideia de uma totalidade abrangente é desafiada. A noção é trazida ao debate sobre a obra clastriana por Barbosa (2005). Como avisa Sztutman: "Não se trata aqui de encontrar no pensamento clastriano uma crítica a Durkheim, mas antes de testar a sua vitalidade mediante novos quadros teóricos" (2005: 58). Ele diz, ainda:

\begin{abstract}
“A concepção durkheimiana da sociedade como um todo que antecede as partes, que são os indivíduos, imersos em psicologismo, deixa de fazer sentido para a apreensão da maneira pela qual funciona a maquinaria 'contra o Estado'. E isso justamente porque essa maquinaria não pode ser definida por uma instância que antecede às pessoas concretas, visto que, ao mesmo tempo em que as constitui, é constituída por elas" (idem)
\end{abstract}

Nesse diálogo com os melanesistas - pensadores que são de uma realidade em que "as categorias relacionais sobrepõem-se às representacionais" -, outras contribuições são, ainda, trazidas por Sztutman. Uma delas é decorrência direta do emprego da ideia de socialidade:

“Não se trata mais de uma 'sociedade contra o indivíduo', ou vice-versa, mas de uma socialidade que define um tipo de pessoa 'dividual' ou "fractal" (Wagner 1991), ou seja, na qual as relações externas com a alteridade tornam-se internas, e para a qual a identidade individual não aparece senão como uma arbitrariedade, um momento congelado, uma 'instanciação', no fluxo de relações" (Sztutman, 2005: 59)

Há, ainda, outras decorrências do emprego desse tipo de ideia, como a distinção entre pessoa e agente que Strathern (2006) propõe. De todo modo, note-se, toda essa gama de reflexões forma o solo de onde brota nosso trabalho. Como numa espécie de caixa de ferramentas conceituais, várias (nem todas) dessas noções serão chamadas conforme a necessidade (nem sempre), ao longo deste trabalho - mas, vale observar uma vez mais, o foco principal, aqui, serão as próprias ideias dos Kaiowá.

Importante é sublinhar que a decorrência última que Sztutman extrai de todas essas elaborações sobre a pessoa na Melanésia é a ideia de "magnificação", aplicada aos chefes e xamãs. 
Em relação aos antigos Tupi, por exemplo, o autor afirma:

\begin{abstract}
"Para além do âmbito residencial, organizado em torno de um líder-sogro, a magnificação obtida pelo ritual guerreiro permitia a extensão de homens que, para usar uma expressão de Marilyn Strathern (1991), viam-se capazes de 'conter outros homens' $e$, assim, de se estender para âmbitos mais amplos, tal o do grupo local populoso, o da expedição guerreira e mesmo da 'província' ou confederação de aliados" (Sztutman, 2005: 196).
\end{abstract}

Essa ideia de magnificação, como formula o autor, também se relaciona à descrição que Godelier faz da vida política baruya (1986) e, ainda, ao que Taylor percebe, entre os Achuar, como uma questão de "magnitude" ligada ao "acúmulo de relações" que o chefe realiza (Sztutman, 2005: 60). É também a "magnitude" que se refere Wagner (1991), para falar sobre sua ideia da pessoa na Melanésia como "fractal".

Como veremos no capítulo 2, a ideia de que o chefe é "principal" ou "grande" não é estranha aos grupos falantes de guarani, que usam termo bem próximo ao que os antigos Tupi tinham para referir-se a seus líderes, mburuvicha ou tuvicha. Procuraremos demonstrar, ao longo da tese, que essa ideia, apesar de não ser estranha ao repertório da teoria política kaiowá, não parece ter grande rendimento para pensar o que se observa atualmente. De qualquer forma, registre-se, essa foi outra questão importante em nosso ponto de partida.

Em outros trabalhos recentes que envolvem a ação política ameríndia, nota-se uma tendência a derivar ora para essa linha do modelo clastriano-deleuziano (Vieira, 2010; Fernandes, 2006 - no caso deste, incorporando, ainda, discussões sobre parentesco), ora para as discussões da Antropologia da Política, tal como descrevemos essa linha de pesquisa acima (Ribeiro, 2010). Isso, ao que parece, independe do objeto, pois Fernandes e Ribeiro são dois exemplos de autores que analisam a participação indígena em eleições municipais, com orientações teóricas consideravelmente distintas.

Particularmente, vale destacar, ainda: os trabalhos de Fernandes $(2004,2006)$ e de Guerreiro Jr. (2011a/b) têm demonstrado que o diálogo com as teorias do parentesco ainda traz rendimento. Em seu estudo entre os Kalapalo, por exemplo, este autor encontra, em sua análise das redes de parentesco, evidências para questionar a imagem clastriana de um chefe "prisioneiro do grupo", por ser receptor de mulheres: ali, o que se constata é que o chefe é um doador de esposas (2011a). 
Já Fernandes encontra, no sistema de parentesco kaingang, dados para questionar a clásssica separação entre "sangue" e "solo" que fundamentava, na Antropologia anterior ao African Political Systems, a distinção entre sociedades da política e do parentesco. Em comum, há, por exemplo, o fato significativo de ambos os autores depararem com imagens arbóreas para explicar a prevalência do chefe - um grande avanço na identificação de recorrências, em relação ao predomínio das imagens ocidentais que grassam pela antropologia política em geral. A ideia de chefe como "tronco" também aparece nas etnografias de Brightman (2010), entre os Trio, das Guianas, e de Costa (2010), que fez pesquisa entre os Kanamari ${ }^{33}$. Aquele, por sinal, faz referência ao trabalho de Grupioni (2002). Entre os próprios Kaiowá, por sinal, a ideia de tronco ou esteio pode aparecer, também, em reflexões sobre a família (vide Pereira, 1999).

Outros elementos teóricos de rendimento pontual ao longo de nossa argumentação serão oportunamente apresentados. Por ora, vale anotar um avanço justamente na direção do registro da forma como os próprios grupos ameríndios definem e percebem essa instituição da chefia, em seus múltiplos sentidos. E, se outro aspecto da vida política kaiowá e guarani que será aqui objeto de atenção em nosso capítulo 3, o xamanismo, é onipresente nas etnografias das Terras Baixas feitas nas últimas décadas, o exato contrário se poderia dizer das assembleias, sobretudo no que diz respeito à vida política multicomunitária - tema do capítulo 4. Essa tríade - chefe, xamã, reunião baliza a apresentação de uma teoria política (de inspiração) kaiowá a que se dedica esta tese.

33 Fausto (2008) faz algumas considerações sobre essa e outras imagens, num contexto ligeiramente distinto do debate sobre chefia que aqui propomos. Oportunamente, ao longo desta tese, nos vamos servir de análises do autor. 


\section{O contexto do campo}

O trabalho de campo que sustenta esta tese se realiza num contexto político bastante tenso, mas particularmente produtivo para a discussão da temática indígena no país. Entre agosto e dezembro de 2008, ano em que iniciamos a pesquisa bibliográfica, ainda em São Paulo, aconteceram os lances decisivos do julgamento, pelo Supremo Tribunal Federal, de mais de 30 ações judiciais questionando a demarcação da Terra Indígena Raposa Serra do Sol, homologada em 2005 com 1,74 milhão de hectares, no norte do estado de Roraima.

Ao fim e ao cabo, o STF, que, pela primeira vez, desde a nova Constituição de 1988, julgava o mérito de uma demarcação de terras indígenas - e, por extensão, analisava a possibilidade de certos questionamentos sobre o próprio trabalho antropológico nas identificações de terras -, decidiu manter a demarcação em área contínua ${ }^{34}$ e julgou improcedentes todas as ações que questionavam o processo administrativo.

O julgamento de Raposa/Serra do Sol levou os temas relativos aos povos indígenas novamente ao destaque no debate público brasileiro e foi considerado um marco histórico, por reafirmar os princípios constitucionais relativos às terras indígenas. Os jornais de circulação nacional, as televisões acompanharam os acontecimentos que o cercaram e, ao mesmo tempo, deram espaço a defensores e críticos das demarcações de terras - bem mais a estes que àqueles, certamente.

Enquanto o caso amazônico ganhava todos esses holofotes, em Mato Grosso do Sul, iniciava-se, já antes do julgamento do caso Raposa, outro lance importante para a definição do jogo político. De modo que os Kaiowá e Guarani estavam quase todos os dias em destaque na imprensa local quando cheguei ao estado, em fevereiro de 2009.

Os Guarani-Kaiowá, considerados como um conjunto, são, hoje, o maior grupo indígena do

\footnotetext{
34 Isto é: além da paranoia nacionalista, amplamente difundida por militares e aliados à época do julgamento, derrubou-se a tese, defendida pelos fazendeiros e políticos do estado, de que a demarcação não poderia se dar no perímetro que abrange as cerca de 200 comunidades indígenas que conformam Raposa/Serra do Sol. O argumento contrário era que cada uma dessas comunidades deveria ter seu próprio perímetro, sendo o espaço entre elas liberado para a implantação de atividades econômicas não indígenas, como fazendas de criação de gado bovino e plantio extensivo de cereais. A coletânea organizada por Miras et al. (2009) oferece material amplo sobre o caso. Para uma visão sobre as ideias antropológicas que embasaram as demarcações de terras em área contínua, ver Seeger \& Viveiros de Castro, 1979. Paulo Santilli (ver Santilli, 1999) foi o antropólogo que coordenou a identificação e a delimitação de Raposa/Serra do Sol. Ao longo de 2008 e 2009, participamos desse debate por meio de eventos, artigos e entrevistas na imprensa e também cursos e palestras que promovemos.
} 
país fora da Amazônia ${ }^{35}$ (o segundo maior do Brasil) e têm oferecido aos defensores dos direitos humanos um enorme desafio, nos últimos anos. Essa população é, hoje, um triste destaque nas mais recentes pesquisas que relacionam violações de direitos de povos indígenas, não apenas no país, mas também internacionalmente.

A tônica do debate entre 2008 e 2009 era bem outra, contudo. Os ânimos dos poderosos locais permaneciam acirrados desde a publicação, pela Funai, em 10 de julho de 2008, de seis portarias $^{36}$ para a instalação de grupos de trabalho responsáveis pela confecção de relatórios de identificação de pelo menos 39 áreas reivindicadas como de ocupação tradicional indígena, em 26 municípios da região sul do estado ${ }^{37}$. Resultado da pressão do movimento indígena e do MPF, essa medida da Funai era fruto de um Termo ou Compromisso de Ajustamento de Conduta assinado no final de 2007, depois de anos de estudos, debates e negociações ${ }^{38}$.

Desde a redemocratização do país, nos anos 80, a recuperação das terras reivindicadas pelos Kaiowá e Guarani como de ocupação tradicional tinha ocorrido "a conta-gotas". Grupos locais, inicialmente de forma isolada, e posteriormente com apoio do movimento Aty Guasu, ocupavam uma área da qual haviam sido despejados (ou, em casos como o Pirakuá, resistiam a deixar o local) e, logo em seguida, a Funai, pressionada, tomava providências. Até 2008, portanto, as demarcações na região seguiram o modelo de "ilhas", ou seja, eram garantidos para os indígenas apenas pequenos fragmentos de alguns poucos milhares de hectares da preciosa terra vermelha da região. Para se ter uma ideia, até agora, a menor terra indígena guarani ou kaiowá homologada após a Constituição de 1988, Jaguari, tem 404 hectares, e a maior, Nanderu Marangatu, 9,3 mil hectares ${ }^{39}$.

Avaliado no julgamento da demarcação de Raposa Serra do Sol pelo STF como inadequado segundo os critérios antropológicos, esse modelo de ilhas é, no entanto, consagrado no Mato Grosso do Sul, desde os tempos do SPI. Entre os anos de 1915 e 1928, o órgão reservou para os indígenas cerca de 18 mil hectares de terra.

\footnotetext{
35 Segundo números do Censo do IBGE de 2010, os Guarani-Kaiowá são 43,4 mil, considerando-se, já, a soma entre os Kaiowá e os Guarani. Os Tikuna, o maior grupo indígena amazônico, são 46 mil.

36 Portarias da Funai n. ${ }^{\circ}$ 788, 789, 790, 791, 792, 793, de 10 de julho de 2008, publicadas no Diário Oficial da União em 14 de julho de 2008, para estudos de identificação e delimitação das terras tradicionalmente ocupadas pelos Guarani Kaiowá e Ñandeva na região das bacias denominadas Amambaipeguá, Dourados-Amambaipeguá, Iguatemipeguá, Brilhantepeguá, Nhandevapeguá e Apapeguá, situadas no estado do Mato Grosso do Sul.

37 "Pelo menos" porque o Compromisso de Ajustamento de Conduta assinado (ver anexo) previa que novas áreas poderiam ser incorporadas aos relatórios de identificação, caso fossem localizadas, ao longo do processo, reivindicações não aferidas anteriormente.

38 A pressão pelo CAC certamente teve relação com o escândalo, na imprensa nacional, entre 2005 e 2006, em torno do aumento do número de crianças desnutridas entre os Guarani e Kaiowá. Falaremos mais disso, adiante.

39 Conforme lista oficial dos decretos de homologação de terras indígenas, fornecida pela Funai.
} 
Uma leva de migrantes, estimulada, sobretudo pelo governo de Getúlio Vargas, "dividiu" as redes sociais ao formar fazendas que, por um lado, dificultaram a comunicação entre os núcleos guarani e kaiowá e, por outro, englobavam as comunidades. Em certas regiões, num raio de algumas dezenas de quilômetros, podiam-se encontrar, segundo os relatos, dezenas de pequenos coletivos indígenas, organizados em grandes famílias. Originalmente, na concepção kaiowá, as famílias habitavam, cada uma, uma só casa grande em que cabiam às vezes mais de uma centena de pessoas. Logo, essas grandes famílias passaram a viver em grupos de pequenas casas de famílias restritas, ou nucleares, normalmente organizadas em torno de um casal de idosos - avô e avó, tamõi e jary de todos os que ali habitavam ${ }^{40}$.

Depois de dividir os coletivos, foi a vez de esparramá-los: progressivamente, à medida que as propriedades eram "abertas" - desmatadas e equipadas para a pecuária e a monocultura extensiva -, os indígenas eram expulsos/atraídos para as áreas demarcadas pelo SPI, ou para a beira da estrada. Logo, nos anos 80, as oito reservas, antes minimamente suficientes para sustentar pequenos grupos, estavam superlotadas, e se intensificaram os problemas, como os suicídios, assassinatos e a desnutrição. Ao mesmo tempo, as mazelas também ganharam visibilidade, graças a fatores como a proximidade das cidades e a redemocratização do país ${ }^{41}$.

A ação de 2008 significava, por isso, a reversão de um histórico iniciado havia quase cem anos. Foi depois de toda uma discussão promovida pelo MPF com o movimento indígena, contando ainda com a assessoria de antropólogos e historiadores ${ }^{42}$, que se chegou ao modelo adotado nas novas portarias: para superar o modelo de "ilhas", as demandas territoriais seriam pensadas a partir das bacias hidrográficas da região - de afluentes do rio Paraná (Iguatemi, Amambai, Dourados e Brilhante) e do rio Paraguai (Apa), procurando chegar a demarcações conjuntas, e não mais isoladas umas das outras ${ }^{43}$.

\footnotetext{
40

O estudo mais clássico sobre a organização das famílias kaiowá foi realizado por Watson (1944); discussões mais recentes a respeito foram realizadas por Thomaz de Almeida (2001) e Pereira (1999).

$41 \mathrm{O}$ retrospecto histórico, aqui resumido, será retomado e problematizado no capítulo 1. O que está aqui baseia-se, sobretudo, na obra de Brand (1997, 2001). Para uma discussão antropológica focada na problemática da violência que emerge nos anos 80, e particularmente os suicídios de jovens, um problema recorrente entre os Kaiowá e Guarani desde meados dos anos 80, ver Pimentel, 2006. Destaquem-se, ainda, os trabalhos acadêmicos recentemente produzidos por indígenas, que têm agregado, à discussão sobre esse processo histórico, interessantes componentes oriundos de sua experiência pessoal (Benites, 2009; João, 2011).

42 Em diversas fases, entre 2000 e 2007, o diálogo, convocado pelo MPF, incluiu, segundo apurei, os seguintes profissionais: Antonio Brand, Levi Marques Pereira, Rubem Thomaz de Almeida, Fábio Mura, Alexandra Barbosa da Silva, Celso Aoki e Marcos Homero F. Lima.

43 Para uma compreensão sobre como isso foi elaborado, em termos antropológicos, ver Pereira, 2005, e Mura, 2006 - este, em diálogo com Lehner, 2002, que havia pensado questões semelhantes para o lado paraguaio da ocupação Kaiowá/Paĩ.
} 
Os políticos e fazendeiros receberam a edição das portarias com uma saraivada de declarações públicas, ações judiciais e viagens a Brasília. Filiado ao PMDB, o governador do estado, André Puccinelli, dispunha de uma enorme capacidade de pressão política. No plano federal, os escândalos de 2005, envolvendo uma guerra de denúncias sobre pagamentos em dinheiro a parlamentares e financiamento ilegal de campanhas, lançaram, definitivamente, o governo petista de Luiz Inácio Lula da Silva no colo do partido de Puccinelli, o único, na conjuntura política de então, capaz de garantir uma governabilidade tranquila ao PT.

Essa simbiose entre PMDB e PT tornava frágil qualquer iniciativa federal que contrariasse os interesses de um governo peemedebista como era o do Mato Grosso do Sul. Adicionalmente, mencione-se que o estado foi governado entre 1999 e 2006 por José Orcírio dos Santos, o Zeca do PT, o qual favoreceu os indígenas em ações no campo da educação, por exemplo, mas não teve atuação expressiva, para dizer o mínimo, em favor da demarcação das terras.

A principal polêmica em 2008 envolveu a extensão da área a ser identificada. Os veículos de comunicação, principalmente os do estado, passaram a difundir a falsa ideia de que a integralidade das áreas dos municípios mencionados nas portarias da Funai - uns 11 milhões de hectares, ou quase um terço do estado - poderia ser demarcada como terras indígenas ${ }^{44}$. É fato que somente a conclusão dos relatórios de identificação trará uma ideia mais exata da extensão territorial demandada pelos indígenas, mas, em 2008, estimativas iniciais dos antropólogos davam conta de que as terras a serem demarcadas poderiam chegar a cerca de 600 mil hectares ${ }^{45}$.

Rapidamente, o clima de hostilidade alcançou níveis alarmantes. O principal jornal do MS, o Correio do Estado, o indicou, em 13/11/2008: na capa, a foto de uma fazendeira usando a bandeira do Brasil como manto, no plenário da Assembleia Legislativa, sob a manchete: "Produtores declaram guerra aos índios".

44 Da revista Dinheiro Rural n. 47, de setembro de 2008: “A agricultura brasileira pode estar diante de uma das maiores distorções da história da luta pela terra. De um lado, nada menos do que 26 municípios que podem virar uma enorme reserva indígena, com mais de dez milhões de hectares, numa das áreas mais ricas de Mato Grosso do Sul. Do outro, a Funai, que tenta alocar 42 mil índios, principalmente da etnia guarani, nesse pedaço de chão. Entre ambos um imbróglio jurídico e político que está apenas começando”. Disponível em http://www.terra.com.br/revistadinheirorural/edicoes/47/artigo103077-1.htm . Outra versão do mal-entendido surgiu quando a imprensa entrevistou o antropólogo Rubem Thomaz de Almeida (um dos coordenadores dos GTs então criados pela Funai, e um dos profissionais com maior experiência na realização de relatórios de identificação de terras indígenas em MS) em sua chegada a Campo Grande, em 31/7/2008. Ele teria dito, na ocasião, que as terras dos Guarani e Kaiowá poderiam ser ampliadas para "até 3 milhões de hectares" (http://ti.socioambiental.org/\#!/noticia/58968).

45 Para combater o pânico gerado pelos boatos em torno dos 11 milhões de hectares, foi publicado no jornal $O$ Estado de São Paulo, no dia 06/9/2008, um artigo do então presidente da Associação Brasileira de Antropologia (ABA), Carlos Caroso, dando conta dessa estimativa (http://ti.socioambiental.org/\#!/noticia/60268). 
Os fazendeiros atuaram em várias frentes. Por um lado, intensificaram a batalha na Justiça, conseguindo liminares que atravancaram o processo ${ }^{46}$. Também o governador, juntamente com a bancada federal do estado, fez gestões em Brasília para tentar suspender a atuação da Funai. Essa estratégia do "tapetão" persistia até a conclusão desta tese. Num primeiro momento, foram estabelecidas conversações no âmbito do Ministério da Justiça, com o objetivo de destravar o processo, mas as negociações foram interrompidas com a manutenção das ações dos fazendeiros do estado na Justiça (sendo retomadas mais recentemente, como explicaremos adiante).

O precedente de Roraima projetou uma sombra de dúvida sobre o destino dos Kaiowá e Guarani. Ao mesmo tempo em que ratificou a demarcação de Raposa/Serra do Sol, a Corte Suprema do país cedeu à sugestão de um dos seus ministros mais conservadores, Carlos Alberto Menezes Direito, e impôs 18 condições - mais tarde transformadas em 19, devido à intervenção do então presidente do STF, Gilmar Mendes - a serem aplicadas a todos os futuros processos de demarcação de terra no país. Algumas dessas condições poderiam afetar diretamente os Kaiowá e Guarani, especialmente o veto à ampliação de áreas já demarcadas, e a imposição da participação de estados e municípios nos processos administrativos de demarcação ${ }^{47}$.

Em setembro de 2008, após muita pressão política, o governador de MS conseguira arrancar um acordo, celebrado em reunião com o presidente da fundação, Marcio Meira. A Funai se comprometeu a integrar representantes do governo do estado aos grupos de identificação de terras ${ }^{48}$. Por meio de uma série de expedientes, contudo, e apesar do suposto acordo, os trabalhos dos GTs foram sendo dificultados, desacreditando as sinalizações públicas de que estariam concluídos já no início do ano seguinte (quando iniciei o trabalho de campo) ${ }^{49}$.

46 Conforme Rocha (2011: 51), um levantamento da Procuradoria Regional da República, feito no final de 2009 , localizou, na Justiça Federal, 143 ações envolvendo disputa de terras entre índios e fazendeiros no Mato Grosso do Sul (87 ações no Tribunal Regional Federal da $3^{\text {a }}$ Região, em São Paulo, e as demais nas Varas Federais de primeira instância.

47 No final de 2009, Gilmar Mendes se amparou nessas 19 condições para conceder liminar que suspendeu a homologação da terra indígena Arroio Korá, dos Guarani, em Paranhos-MS (http://www.stf.jus.br/portal/cms/verNoticiaDetalhe.asp?idConteudo=118707). Até a conclusão desta tese, estava indefinida a aplicabilidade desse documento às futuras demarcações em MS. O MPF, por exemplo, questiona a extensão das 19 condições. Em julho de 2012, a Advocacia Geral da União lançou a portaria 303, validando quase integralmente a lista de Meneses Direito, após pressão dos ruralistas de MS (segundo eles mesmos assumiram em textos publicados na internet). Após uma saraivada de críticas e protestos, a portaria foi suspensa, por pedido da Funai, a fim de haver tempo para que os povos indígenas fossem consultados a respeito dela. Até a conclusão desta tese, a portaria permanecia suspensa. 48 http://www.funai.gov.br/ultimas/noticias/2_semestre 2008/setembro/un2008 003.html

49 A grande quantidade de ações dos fazendeiros dificulta o registro pormenorizado do xadrez na Justiça - quanto mais que parte das decisões costuma ser obtida em caráter liminar (temporário). Muitas vezes, as liminares são derrubadas e demora um tempo até que os atores envolvidos se deem conta (isso acontece até mesmo com os próprios órgãos governamentais, segundo consta). Por exemplo, durante certo período, o trabalho dos GTs foi 
No segundo semestre de 2009, portanto, os indígenas já estavam muito aborrecidos com a demora, e diversos grupos decidiram partir para o confronto direto, ocupando as terras reivindicadas. Nesse período, aconteceram novas retomadas e uma série de conflitos, deixando o saldo de pelo menos três mortos, dois desaparecidos e cinco baleados, além de diversos episódios de espancamentos, atropelamentos suspeitos e pelo menos um acampamento de beira de estrada incendiado. Foram registrados pelo menos cinco casos graves envolvendo as comunidades ${ }^{50}$ de Laranjeira Ñanderu ${ }^{51}$, Kurusu Amba ${ }^{52}$, Mbaraka' ${ }^{53}$, Ypo' ${ }^{54}$ e Apyka' ${ }^{55}$. Depois de um período de relativa calmaria, no segundo semestre de 2011 voltam as tensões, em função do atraso nos processos de identificação, e outro grave episódio, em Guaiviry ${ }^{56}$, completou esse conjunto. Em

dificultado por decisão da Justiça segundo a qual a Funai precisaria notificar um a um, e com antecedência, todos os fazendeiros cujas terras seriam visitadas pelos grupos de identificação das terras indígenas. A solução exata para esse tipo de impasse ainda é incerta.

50 Todas as comunidades aqui citadas foram visitadas pelo pesquisador entre 2009 e 2011, em variados contextos (em alguns casos, acompanhado da Força Nacional, em comitivas oficiais). Também foram mantidas várias conversas com integrantes desses acampamentos no âmbito de reuniões da Aty Guasu, sobretudo.

51 Acampamento no município de Rio Brilhante, iniciado em 2008 por grupo que deixou a TI Panambi. Depois de serem despejados em setembro de 2009, eles permaneceram por cerca de 20 meses na beira da rodovia BR-163, voltaram à área reivindicada, onde aguardam a conclusão dos estudos de identificação de sua terra, com autorização judicial. No período em que estavam na beira da estrada, tiveram duas crianças mortas por falta de assistência médica, além de dois mortos por atropelamento, e dois por enforcamento.

52 Acampamento no município de Coronel Sapucaia, iniciado em 2007 por grupo que saiu da TI Takuapery e outras áreas próximas a Amambai. O grupo sofreu, desde o primeiro momento da retomada, uma série de violências. Ali, já houve, desde 2007, quatro mortos em casos de conflitos com pistoleiros ou em casos com fortes suspeitas de motivação política. Três crianças, ainda, morreram por falta de atendimento médico. Além disso, os indígenas da área sofrem com iniciativas que buscam criminalizá-los: quatro pessoas foram condenadas por suposto roubo, e num caso surreal, uma liderança da comunidade foi processada por ter supostamente atirado nos próprios companheiros em 2007 - os quais relatavam ter sido alvejados por fazendeiros, em episódio que contou com dezenas de testemunhas. Atualmente, aguardam na área reivindicada a conclusão dos estudos de identificação de sua terra, com autorização judicial.

53 Acampamento kaiowá que hoje está na área conhecida como Pyelito Kue (contígua a Mbaraka'y), depois de ter sofrido violenta expulsão em dezembro de 2009 (mais de 50 pessoas vendadas, amarradas e espancadas; um adolescente desaparecido; um idoso morto em 2011, em função das sequelas de ferimento a bala na ocasião), voltando em agosto de 2011 à terra reivindicada, onde permanecem até hoje, sofrendo constantes ameaças e ataques por homens usando armas com balas de borracha. Fica na região entre Tacuru e Iguatemi. Os fazendeiros da região obtiveram na Justiça recente ordem de despejo (escrevo isso em 18/10/12), e a situação permanece incerta.

54 Acampamento no município de Paranhos. Na primeira retomada, em outubro de 2009, dois professores guarani, Rolindo e Jenivaldo Vera, foram sequestrados, torturados e mortos por homens armados. O corpo de Jenivaldo foi encontrado em um córrego da região, poucos dias depois. O de Rolindo permanecia desaparecido até a conclusão desta tese. Em setembro de 2011, um suposto funcionário de uma fazenda que incide sobre a área de Ypo'i matou, com golpes de facão, e diante de testemunhas, à luz do dia, outro integrante do grupo, Teodoro Ricarte. Depois de retornar ao local após a expulsão de 2009, o grupo permanece acampado, com autorização judicial, aguardando a conclusão dos estudos de identificação de sua terra.

55 Acampamento no município de Dourados, à beira da rodovia BR-463 (caminho para Ponta Porã). Em setembro de 2009, um grupo de homens armados incendiou as casas do grupo. Um idoso foi baleado na ação. O grupo permanece na beira da estrada até hoje (já estão ali há cerca de dez anos, segundo consta - nota técnica 001/2009, do MPF de Dourados).

56 Acampamento, hoje, em área no município de Aral Moreira. Durante vários anos, permaneceram na TI Amambai, aguardando providências quanto à demarcação da terra que reivindicam. Depois de pelo menos duas tentativas em que foram retirados da área pretendida com auxílio de funcionários da Funai, retornaram a seu tekoha no início de novembro de 2011. Poucos dias depois, foram vítimas, em 18 de novembro, de um ataque de homens armados que 
agosto de 2012, diante da morosidade nos processos relativos às terras já identificadas, grupos em Arroio Korá e Potrero Guasu (ambas terras indígenas em Paranhos, uma já declarada, a outra já homologada) voltam a realizar ocupações. No caso de Arroio Korá, ocorrem constantes ataques de homens armados: no dia 10, durante a ocupação, um homem do grupo desapareceu.

Alguns desses ataques tiveram repercussão internacional (casos de Ypo'i e Guaiviry). Outros aconteceram sem que nem a imprensa local noticiasse (caso de Mbaraka'y). Em função da repercussão dos conflitos de 2009, contudo, uma série de relatórios de direitos humanos deu destaque ao caso dos Kaiowá e Guarani.

Primeiro, em janeiro de 2010, documento lançado pelas Nações Unidas ${ }^{57}$. Também, um relatório da ONG inglesa Survival International, exclusivamente sobre o tema ${ }^{58}$, lançado em março. O relator especial das Nações Unidas para Direitos Humanos e Liberdades Fundamentais dos Povos Indígenas, James Anaya - advogado e professor da Universidade do Arizona (EUA), e também indígena, do povo apache - visitou os Kaiowá e Guarani em 2008 e também deu destaque ao caso:

\begin{abstract}
"Tensões entre povos indígenas e colonos não indígenas têm sido particularmente frequentes no Mato Grosso do Sul, onde os povos indígenas sofrem pela falta de acesso às suas terras tradicionais, pela extrema pobreza e pelos problemas sociais daí decorrentes; a situação deflagrou uma série de atos violentos, marcados por grande número de assassinatos de índios, bem como pela perseguição criminal aos indígenas que lutam por esse direito" 59
\end{abstract}

Por sua vez, o documento da Survival, ONG que acompanha a situação dos indígenas do Brasil há 40 anos, destacou:

“A ocupação e usurpação de suas terras pela indústria e ações

\footnotetext{
vitimou o líder Nísio Gomes. Dois jovens também desapareceram na ocasião - dada a dispersão que o pânico pelo ataque gerou, o grupo permaneceu por meses em dúvida sobre o destino desses dois menores. Segundo informações, não é a primeira vez em que homens armados levam crianças e adolescentes de uma comunidade após um ataque como esse. Em caso anterior, envolvendo Kurusu Amba, as crianças foram deixadas na cidade de Amambai, horas depois do episódio.

57 "A Situação dos Povos Indígenas do Mundo", documento publicado pelo Secretariado do Fórum Permanente sobre Questões Indígenas das Nações Unidas.

58 "Violação dos Direitos dos Índios Guarani no Mato Grosso do Sul, Brasil - Relatório da Survival International para o Comitê para Eliminação da Discriminação Racial da ONU”.

59 "Report on the situation of indigenous people in Brazil" (p. 29), adendo a relatório de James Anaya apresentado ao Conselho dos Direitos Humanos da ONU em 14/8/2009.
} 
governamentais têm resultado em uma situação desesperadora na qual os Guarani sofrem por detenção injusta, exploração, discriminação, desnutrição, intimidação, violência e assassinato, além de uma taxa de suicídio extremamente alta. (...) A situação dos Guarani no MS é uma das piores entre todos os povos indígenas da América"60.

Estamos falando de 43,4 mil pessoas, como se viu, a ocupar, hoje, pouco mais de 42 mil hectares de terra ${ }^{61}$. Nos lugares onde a situação é mais crítica, como Dourados $-11,1$ mil habitantes em 3,5 mil hectares -, a densidade populacional alcance índices que tornam impraticável uma subsistência em grau aceitável de autonomia, do ponto de vista de boa parte dos Kaiowá e Guarani.

O Mato Grosso do Sul tem a 2a maior população indígena do país (77.025 pessoas, segundo o Censo de 2010), só perdendo para o Amazonas (183.514), e representa, provavelmente, a realidade mais extrema que enfrentam os indígenas não amazônicos do país - nem sempre pela particularidade de sua situação, mas, sobretudo, pela escala dos problemas que enfrentam. Desde o Censo de 2010, já se sabe que os indígenas da Amazônia Legal deixaram de ser maioria. Hoje, correspondem a 48,4\% do total de 896.917 pessoas autodeclaradas indígenas encontradas pelo $\mathrm{IBGE}^{62}$. Enquanto os indígenas não amazônicos correspondem a 51,6\% do total, têm a seu dispor como áreas demarcadas cerca de 1,5\% dos quase 112,8 milhões de hectares (cerca de 13,3\% do país) reconhecidos, hoje, como terras indígenas. Essa situação tem se agravado com a forte recuperação demográfica ${ }^{63}$ - a população indígena no país era de 294.131 no censo de 1991 -, que aumentou a superlotação em terras já pequenas.

Quando concluo esta tese, em setembro de 2012, passaram-se quatro anos da nomeação dos GTs e nenhum dos relatórios, ainda, foi publicado. Em abril, a Funai ganhou nova presidente, a antropóloga Marta Maria Azevedo, velha conhecedora da situação dos Guarani e Kaiowá64. A

60 P. 2 do supracitado relatório da Survival.

61 Dados retirados de Cimi et al, 2001. Não são totalmente precisos porque, numa boa parte dos casos mais recentes, os indígenas estão ocupando pequenas faixas de terra para esperar decisões judiciais. É o que ocorre em terras como Ñanderu Marangatu (130 hectares), Arroio Korá (700 hectares), Guyraroka (58 hectares), Jatayvary, Potrero Guasu (1.000 hectares), Kokuei. O presidente Lula homologou apenas três terras guarani-kaiowa (Ñanderu Marangatu, Arroio Kora e Panambizinho). Fernando Henrique, apenas uma (Sucuriy).

62 Tabelas em anexo.

63 Note-se que, além da reversão do choque epidemiológico, influi aí também o fato de que aumentou a taxa de autodeclaração, critério do censo.

64 Vide Azevedo, 1991, texto que analisamos em nosso estudo sobre a questão dos suicídios entre os Kaiowá e Guarani (Pimentel, 2006). 
promessa atual é que parte dos relatórios será publicada ainda em 2012. A conferir ${ }^{65}$.

Os prazos estabelecidos pelo CAC de 2007 para a conclusão dos trabalhos de identificação já foram ampliados e, mesmo assim, já se esgotaram. Atualmente, a Funai está sujeita a pagamento de multa, pelo descumprimento desse acordo. Enquanto isso, diante da demora, novas ocupações de terra podem acontecer a qualquer momento.

\section{Direitos humanos}

Cabe, ainda, aqui, uma breve introdução sobre como os problemas dos Kaiowá e Guarani passaram a ser considerados uma questão de direitos humanos, nos últimos anos. Isso não somente porque, como já destacamos, há uma grande quantidade de material (e de ações públicas) produzida nessa chave, mas também porque parte de nossa inserção no campo dialogou intensamente com essa abordagem.

Em 2010, participamos, a convite de um órgão de Estado, o Conselho de Defesa dos Direitos da Pessoa Humana ${ }^{66}$, e na qualidade de antropólogo e jornalista, de uma missão em Mato Grosso do Sul, destinada a avaliar a situação dos Kaiowá e Guarani, no rastro dos conflitos de 2009. Tratavase da segunda viagem de representantes desse órgão ao estado em menos de cinco anos. Além de ter podido realizar importante pesquisa documental junto ao conselho, a missão deu-me a rara oportunidade de encontrar pessoalmente, ainda que em conversa breve, interlocutores fundamentais no debate político em torno das terras indígenas em MS (como o governador e seu secretariado, além de representantes dos fazendeiros).

Foi em 2005 que a situação no estado passou a ser tratada pelo CDDPH, depois de apelos principalmente do $\mathrm{MPF}^{67}$. Naquele ano, a crise humanitária que atinge esse povo já era grave, e ganharam destaque na imprensa os casos de mortes de crianças em decorrência da desnutrição. Conforme relatório da Funasa ${ }^{68}$, o número de mortes de crianças indígenas com até 5 anos no Mato

\footnotetext{
${ }^{65}$ Atualizando a informação, no momento de revisão da tese para publicação na internet: em 09/01/13, foi publicado no Diário Oficial da União o primeiro relatório relativo a esse grupo de GTs de 2008. O trabalho coordenado por Alexandra Barbosa da Silva propôs criar a Terra Indigena Iguatemipegua I, com 41,5 mil hectares, incluindo-se as áreas de Pyelito Kue e Mbarakay, que tiveram grande projeção depois que, em outubro, uma carta escrita pelo grupo foi divulgada pelo grupo, sendo interpretada como uma ameaça de suicídio coletivo. Esse documento gerou enorme comoção, com manifestações em mais de 50 cidades brasileiras e no exterior no início de novembro. 66 Para uma melhor compreensão sobre a atuação do CDDPH na questão indígena, ver Pimentel, 2010.

67 Há registros de pedidos de atenção do CDDPH ao caso feitos pelo MPF desde, pelo menos, 1998.

68 Fundação Nacional de Saúde, responsável pela saúde indígena em todo o país até 2010. Em função dos muitos problemas com o órgão ao longo dos últimos anos, foi substituída pela Secretaria Especial de Saúde Indígena (Sesai), vinculada ao Mnistério da Saúde. Os dados são da "Análise da Mortalidade na População Indígena residente
} 
Grosso do Sul praticamente quadruplicou entre 2000 e 2004 (passando de 48 casos para 190).

Forte debate público se seguiu à divulgação da ligação desse aumento nas mortes com a desnutrição entre os Kaiowá e Guarani ${ }^{69}$. Havia grande confusão sobre o número exato de óbitos efetivamente relacionados à mazela ${ }^{70}$, mas, sobretudo na imprensa e nos meios políticos, ficou marcada a questão da desnutrição. Na Assembleia Legislativa do Mato Grosso do Sul, chegou a ser instalada uma Comissão Parlamentar de Inquérito da Desnutrição e Mortalidade Indígena. No final de 2007, CPI semelhante foi criada na Câmara Federal.

Além da alta mortalidade das crianças, há duas décadas, chamam a atenção as taxas de suicídio entre jovens indígenas ali, como já mencionamos - em alguns anos, já se registrou índice superior a 100 mortes por 100 mil habitantes ${ }^{71}$-, quase vinte vezes acima da média brasileira, de 5,7 por $100 \mathrm{mil}^{72}$. O índice de assassinatos, por sua vez, é também muito superior à taxa nacional e supera mesmo a das áreas mais violentas do país ${ }^{73}$.

Dado esse conjunto de problemas, já em 2005, o CDDPH começava a estudar a situação ${ }^{74}$, mas foi em 2006 que o conselho resolveu que era preciso ir a campo e intervir diretamente na situação. Nesse ano, na tarde de $1^{\circ}$ de abril, um sábado, grave episódio envolvendo a luta pela terra chamou a atenção do conselho, que rapidamente organizou uma missão ao estado, para verificar in loco a situação. Dois policiais civis armados foram mortos e um terceiro ficou gravemente ferido após luta corporal com indígenas que estavam acampados na área conhecida como Paso Piraju, próxima a Dourados.

A área havia sido retomada pelos índios dois anos antes, e, após acordo com o Ministério Público Federal, eles ocupavam uma pequena faixa de 40 hectares até que a disputa com os

no Mato Grosso e Mato Grosso do Sul", elaborada pela Coordenação de Informação e Análise Epidemiológica/Departamento de Análise da Situação de Saúde - SVS/MS.

69 Em 2005, estive no estado por uma semana, como jornalista, para realizar uma série de reportagens sobre o tema para a Agência Brasil - agência pública de notícias, vinculada à então Radiobras, hoje EBC (Empresa Brasil de Comunicação).

70 Conforme o "Quadro Executivo da Intensificação das Ações da Funasa/MS no DSEI Mato Grosso do Sul”, documento do Departamento de Saúde Indígena da Funasa de 26/4/2005, entre as ações destinadas a enfrentar o aumento das mortes de crianças indígenas, na época, estava, por exemplo, um programa de controle da leishmaniose em várias aldeias e uma investigação sobre a ligação de parte das mortes com a intoxicação por agrotóxicos, mostrando que o problema era bem mais complexo do que se debatia na imprensa, na época.

71 Ver supracitado relatório da Survival.

72 Dado referente a 2006 (Lovisi et al., 2009).

73 Levantamento do Cimi indica que, entre 2003 e 2010, houve mais assassinatos de indígenas em Mato Grosso do Sul do que em todo o restante do país (250, contra 202) - ver Heck \& Machado, 2011.

74 Com a resolução n. 6 de 20/4/2005, o então ministro da SEDH, Nilmário Miranda, autorizou a criação de uma comissão especial para estudar o assunto. Outros órgãos de governo também estudavam a situação, naquele momento. 
fazendeiros fosse resolvida, com a identificação antropológica da terra, pela Funai. Segundo o relato dos indígenas, os três brancos haviam chegado à área sem se identificarem como policiais, à paisana e usando armas pesadas, em pleno sábado à tarde. Assustados com as ameaças dos homens, que julgavam serem pistoleiros contratados pelos fazendeiros, os indígenas acabaram entrando em luta corporal com o grupo, resultando nas duas mortes e em graves ferimentos para o terceiro.

O episódio deflagrou uma onda de indignação na imprensa local, além das prisões de nove indígenas. Os detidos relataram ter sido torturados pela polícia. Foi nesse momento que chegou a Dourados a comissão do CDDPH. Entre os participantes, o advogado Percílio de Sousa Lima Neto, da Ordem dos Advogados do Brasil (OAB), vice-presidente do conselho, a coordenadora do comitê gestor que o governo federal constituiria para dar conta da crise na região, Rosângela Gonçalves de Carvalho, e representantes da Funai e do MPF, atores que também seriam fundamentais nos encaminhamentos a serem dados ao caso.

A situação era de muita hostilidade contra os índios e, só depois de muita negociação no Judiciário local, a comissão teve autorização para encontrar os detentos na Penitenciária Harry Amorim Costa, em Dourados ${ }^{75}$. Superlotado, o estabelecimento penal viveu uma rebelião, poucos dias depois da passagem da missão ${ }^{76}$.

Os indígenas presos denunciaram ter sofrido espancamentos dentro da delegacia da polícia para onde tinham sido levados antes de chegar ao presídio. Também reclamaram das condições enfrentadas ali ${ }^{77}$.

A comissão ainda manteve diálogo com representantes da polícia local. Para demonstrar boa-vontade com os policiais, alguns dos quais parentes diretos dos mortos, os representantes do CDDPH propuseram uma reunião mais geral com os policiais do estado, a qual ocorreu duas semanas depois em Campo Grande. O evento contou, inclusive, com a participação do policial que sobreviveu ao conflito, o qual, posteriormente, teve encontro em separado com a missão.

75 Ainda assim, o jornal O Progresso, de Dourados, destacou, no dia seguinte à visita, a seguinte reportagem: "Comissão dos Direitos Humanos visita índios - Eles omitiram verdadeira intenção, dizendo que a visita era generalizada à unidade prisional". No texto, o repórter acusava o CDDPH de ter tido atitude "obscura e antidemocrática" com a imprensa local.

76 A dita rebelião aconteceu na esteira da onda de revoltas promovidas pelo PCC nos presídios de São Paulo. A região de Dourados está na rota do contrabando e do tráfico internacional de drogas, e há fortes ligações entre os presos dos dois estados.

77 O relatório de 30 de maio de 2006 registrou as queixas da principal liderança do Paso Piraju ali presa, o cacique Carlito de Oliveira. "Reclamou ele de dores nas costas e na garganta. Perguntado, mencionou que já teve tuberculose e que, constantemente, tem crises de pneumonia". 
Entre as providências recomendadas pelo relatório final da comissão, estava o desaforamento do processo contra os índios, em função do sentimento "escancaradamente contrário aos indígenas acusados" na comunidade local, bem como a garantia de intérpretes para os réus.

O documento da comissão listou, ainda, uma série de demandas mais gerais ao Poder Público, dada a percepção de que aquele conflito não era localizado, e sim o sintoma de um problema bem mais geral na região. Recomendou-se a identificação, pela Funai, da Terra Indígena Paso Piraju; a implantação de ações estruturais de combate à discriminação racial na região; a nomeação, pela Advocacia Geral da União, de procuradores federais para defender os interesses indígenas; a instalação de um núcleo da Defensoria Pública da União em Dourados.

Poucos meses depois da visita a Dourados, foi instituído oficialmente ${ }^{78}$ o Comitê Gestor de Ações Indigenistas Integradas para a Região da Grande Dourados, com a participação de 14 órgãos federais, incluindo dez ministérios. Coordenado pelo Ministério do Desenvolvimento Social e Combate à Fome, o comitê tinha o objetivo de coordenar, articular, avaliar e monitorar as ações federais desenvolvidas junto aos Guarani e Kaiowá. Extraoficialmente, o comitê já vinha atuando desde 2005.

A atuação no combate à crise alimentar trouxe efeitos colaterais. Hoje, segundo avalia a Funasa local, $80 \%$ das famílias guarani-kaiowa dependem das cestas básicas para viver (Azevedo et al., 2008: 246). Quando, em 2007, o serviço de fornecimento foi suspenso temporariamente, sete crianças indígenas morreram em consequência da desnutrição no MS.

A dificuldade de estabelecer ações estruturais tem relação direta com a escassez de terras. Não há política pública capaz de superar esse problema. Por isso mesmo, entre as ações mais importantes que derivaram de toda essa ação esteve a formulação do plano de regularização das terras indígenas na região, o qual resultou na assinatura do CAC de 2007.

Além da questão fundiária, considerada a raiz dos problemas dos indígenas, como se viu, outras ações tomadas pelo governo federal também foram ao encontro das recomendações traçadas pelo CDDPH (embora quase nunca tenham tido alcance suficiente), como a reestruturação da Funai - parcialmente efetivada em 2010, com concurso que destinou vagas prioritárias para a região -, ações para superar a falta de documentação dos indígenas e capacitações para servidores públicos encarregados de atender os indígenas, com o objetivo de superar o preconceito racial.

78 Por meio do decreto presidencial, em 19 de abril de 2007. 
Esse quadro de conflitos crescentes, por um lado, e paralisia no processo de reconhecimento das terras, por outro, era o que aguardava a chegada de nova comissão do CDDPH enviada ao Mato Grosso do Sul em março de 2010. Se, em 2006, o desafio era compreender a complexidade de um quadro de problemas - desvendando, sobretudo, a conexão entre a falta de terras e os casos de mortes de crianças -, agora a dificuldade era entender onde e como foi que travou o processo de reconhecimento das áreas de ocupação tradicional, estabelecendo uma mediação.

A primeira visita da comissão foi, justamente, ao Paso Piraju. A comissão reencontrou o cacique Carlito, que espera o julgamento pelo episódio dos policiais em prisão dentro da própria aldeia, em construção feita especialmente para esse fim. Em fevereiro de 2009, mesmo já estando detido na comunidade, ele foi acusado por um policial de receptação de objetos furtados de um rancho de pesca próximo ao local e levado ao presídio em Dourados, onde ficou preso até setembro $^{79}$.

À comissão, o cacique Carlito relatou diversos abusos praticados durante o episódio da prisão em 2009, como ameaças, ofensas e espancamentos. "Hoje eu estou aqui com meu povo como escravo, amarrado", reclamou ele. "Nós estamos num chiqueiro, igual porco. Não podemos sair pra lado nenhum sem correr o risco de tomar um tiro, não podemos ir à cidade sem sofrer ameaça", emendou outra liderança do local, Valmir Savala.

O Paso Piraju, que foi incluído no CAC de 2007 entre MPF e FUNAI, está, hoje, cercado de plantações de cana-de-açúcar, e os índios continuam reclamando das hostilidades cotidianas que sofrem dos fazendeiros vizinhos, bem como das falhas na assistência em campos como saúde, educação, água potável, eletricidade - o local já possui, hoje, certa infraestrutura, mas certos agentes públicos se negam, por vezes, a atendê-los em função de a terra não ser regularizada.

Em função do cerco pela cana ali no local, o procurador Marco Antonio Delfino fez relato aos enviados do CDDPH sobre as gestões que o MPF tem feito no sentido de cobrar de órgãos financiadores como o Banco Nacional de Desenvolvimento Econômico e Social (BNDES) e o Banco Mundial que exijam dos projetos que financiam a garantia de respeito a terras indígenas já reconhecidas - o que não vem ocorrendo em vários casos, no $\mathrm{MS}^{80}$.

79 Carlito conseguiu voltar à aldeia após mutirão carcerário promovido pelo CNJ em agosto de 2009, e continua no Paso Piraju cumprindo a pena de prisão provisória.

80 Para mais detalhes sobre o plantio de cana em áreas guarani-kaiowa já reconhecidas como terras indígenas, ver o relatório "O Brasil dos Agrocombustíveis: Os Impactos das Lavouras sobre a Terra, o Meio e a Sociedade. Vol. 6 Cana-de-açúcar 2009”, produzido pelo Centro de Monitoramento de Agrocombustíveis, da ONG Repórter Brasil. 
Outra visita foi à comunidade de Laranjeira Nanderu, em Rio Brilhante, a $65 \mathrm{~km}$ de Dourados. Desde setembro de 2009, quando haviam sido despejadas por ordem judicial da fazenda Santo Antonio, que ocuparam em março do ano anterior, as cerca de 140 pessoas da comunidade aguardavam as providências da Funai, enquanto lutavam para manter a integridade física e a sanidade física e mental num contexto extremamente adverso: alojados em barracas de lona cujo interior atinge mais de $50^{\circ} \mathrm{C}$ durante o dia, eles estavam em uma área alagadiça, convivendo com insetos e sanguessugas. Se não bastasse tudo isso, reclamavam de sofrer ameaças constantes dos fazendeiros e eram atingidos por pulverizações displicentes de agrotóxicos na lavoura vizinha. Não havia pudores: enquanto a comissão visitava o local, um trator realizava uma pulverização a poucos metros das barracas, sem se perturbar com os visitantes. Ali, na beira da estrada mesmo, a comissão do CDDPH também recebeu outros coletivos guarani-kaiowa, como Ypo'i e Kurusu Amba, onde, além da violência, se enfrenta o problema da criminalização de suas lideranças ${ }^{81}$.

A comissão também foi recebida pelo presidente da Federação de Agricultura e Pecuária de Mato Grosso do Sul (Famasul), Eduardo Riedel, acompanhado de outros diretores da entidade. Visto sob o prisma dos fazendeiros, o problema fundiário no MS é intrincado, mas passa fundamentalmente pela questão financeira. É elevado, hoje, o valor das terras na região sul do estado e, ao mesmo tempo, uma boa parte dos fazendeiros originalmente se instalou ali por conta de incentivos dos governos federal e estadual - sem falar que, na maioria dos casos, os títulos de terra já trocaram de mãos várias vezes. Por tudo isso, é muito difícil separar o joio do trigo e determinar antigos casos de esbulho contra os índios - denunciados à exaustão nos depoimentos dos indígenas coletados pelos antropólogos, e muitas vezes corroborados por documentos do antigo SPI ou da Funai -, ou mesmo eventuais casos de grilagem.

Esse conjunto de fatores fortalece nos fazendeiros a disposição de lutar até o fim pelo direito à propriedade. Tudo isso se soma ao fato de que o caso guarani-kaiowa é certamente o mais grave, mas não o único fator de disputa pelas terras na região. Há outros grupos indígenas que lutam por terras, como os Terena, além de áreas desapropriadas para a formação de reservas ambientais, regularização de comunidades remanescentes de quilombos e assentamentos da reforma agrária. Nas contas da Famasul, são 39 áreas em litígio, afora as novas terras a serem identificadas.

\footnotetext{
Ali se analisam, particularmente, os casos das TIs Jatayvary e Guyraroka, ambas próximas a Dourados. Segundo o procurador Delfino, o Banco Mundial já exigiu estudo antropológico como condição para financiar uma usina da multinacional LDC em MS.

81 A criminalização das lideranças indígenas é outro problema no MS, estado com o maior número de indígenas presos - 148, segundo levantamento divulgado na imprensa em 2009, a partir de relatórios do Ministério da Justiça e da Agência Estadual de Administração do Sistema Penitenciário (Agepen), órgão do governo do estado.
} 
A comissão também manteve encontro com o governador André Puccinelli e parte de seu secretariado $^{82}$. Ele afirmou, na reunião, que teria disposição para retomar o diálogo - o que é visto com desconfiança pelo movimento indígena, evidentemente. O governador defendeu os agricultores não indígenas do estado, em função do histórico de colonização da região: "São terras dadas pela União e convalidadas pelo estado, compradas, pagas. Não é grilo, é suor do trabalho". Disse acreditar na viabilidade da compra de terras, em parceria entre governo federal e o estado, mas defendeu a análise "caso a caso". "Resolvamos concomitantemente as pendências judiciais, porque há coisas se arrastando há anos”, pediu ainda.

Pelas normas atuais, a União não pode pagar pelas terras identificadas como indígenas - há apenas a indenização pelas benfeitorias - e uma mudança nessa regra é condição para resolver a disputa em MS, como diagnosticou o relatório preliminar da comissão ao CDDPH:

"Na verdade, o que se infere é que não há possibilidade de prosseguir no diálogo se não houver sinalização positiva e concreta do Governo Federal em encontrar saídas para o pagamento do valor das terras tituladas, principalmente as terras que já estão em processo de regularização fundiária pela Funai”,83

Desde 2011, uma comissão especial do CNJ- criada após articulação do CDDPH - busca criar um espaço de negociação, com participação de representantes dos indígenas e dos fazendeiros. Até o momento (julho de 2012), não foram apresentados publicamente resultados desse processo. Em fevereiro de 2012, a Assembleia Legislativa de MS aprovou a criação de um Fundo Estadual de Terras Indígenas, destinado a financiar o pagamento de indenizações pelas demarcações. $\mathrm{O}$ alcance desse novo instrumento ainda é uma incógnita.

82 Autoridades do Judiciário e do Legislativo, além do MPF e representações de órgãos federais como Incra e Polícia Federal também foram visitadas pela comissão.

83 "Relatório de impressões sobre a condição de vida dos Guarani Kaiowa na região de Dourados, MS", apresentado ao CDDPH no dia 12 de maio de 2010. 


\section{Linhas guarani}

"Nós, antes, íamos bem reto por esses caminhos, como os catetos, como os quatis. Mas aí chegaram os fazendeiros: cortando tudo...”.

Salvador Reinoso 


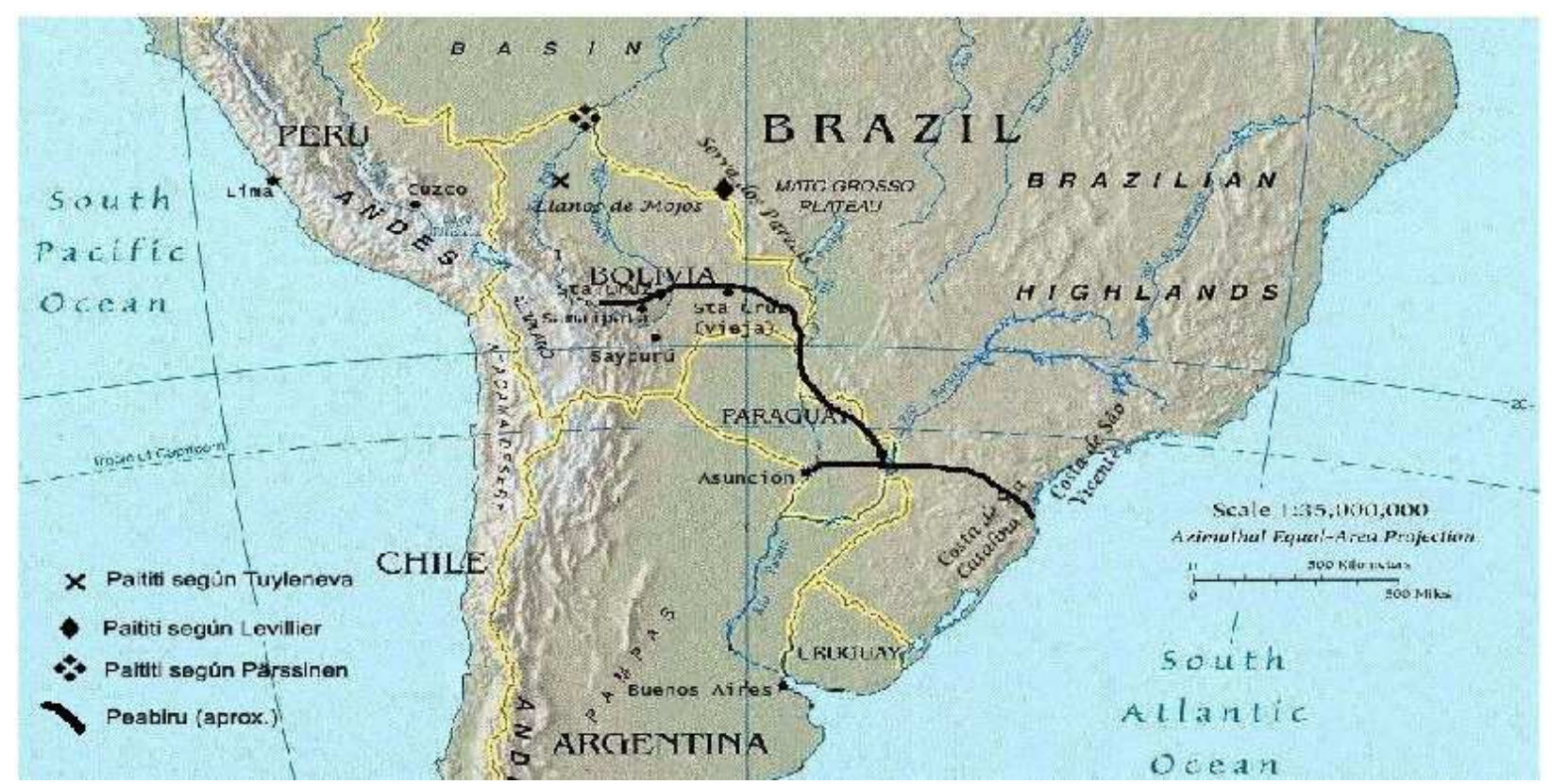

Peabiru e Paititi, in Combès, 2011b: 62.

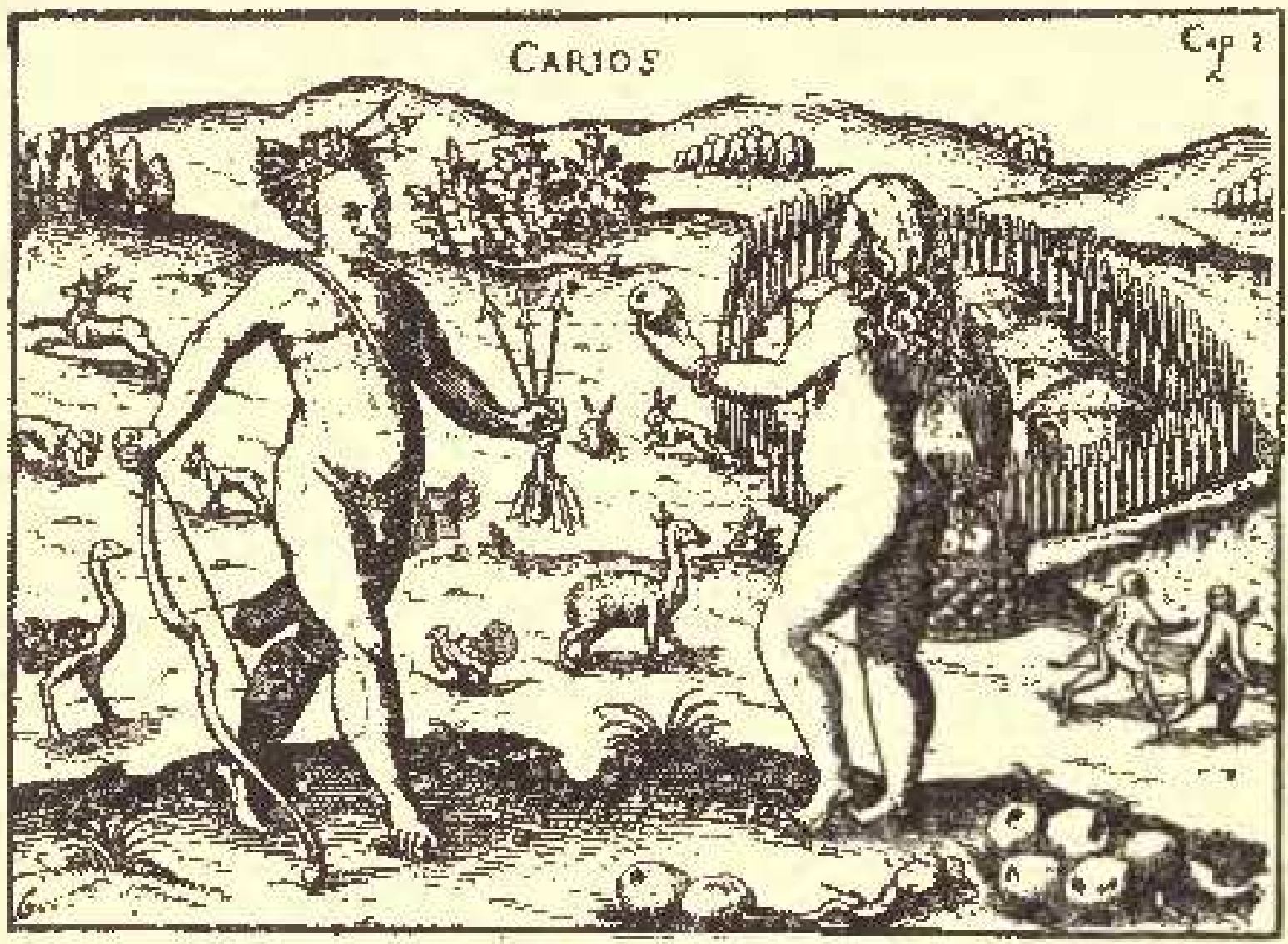

Die Carjos in Paraguay (1539).

Os Cario, da região onde hoje está Asunción, apud Schmidl, 1903 [1567] 


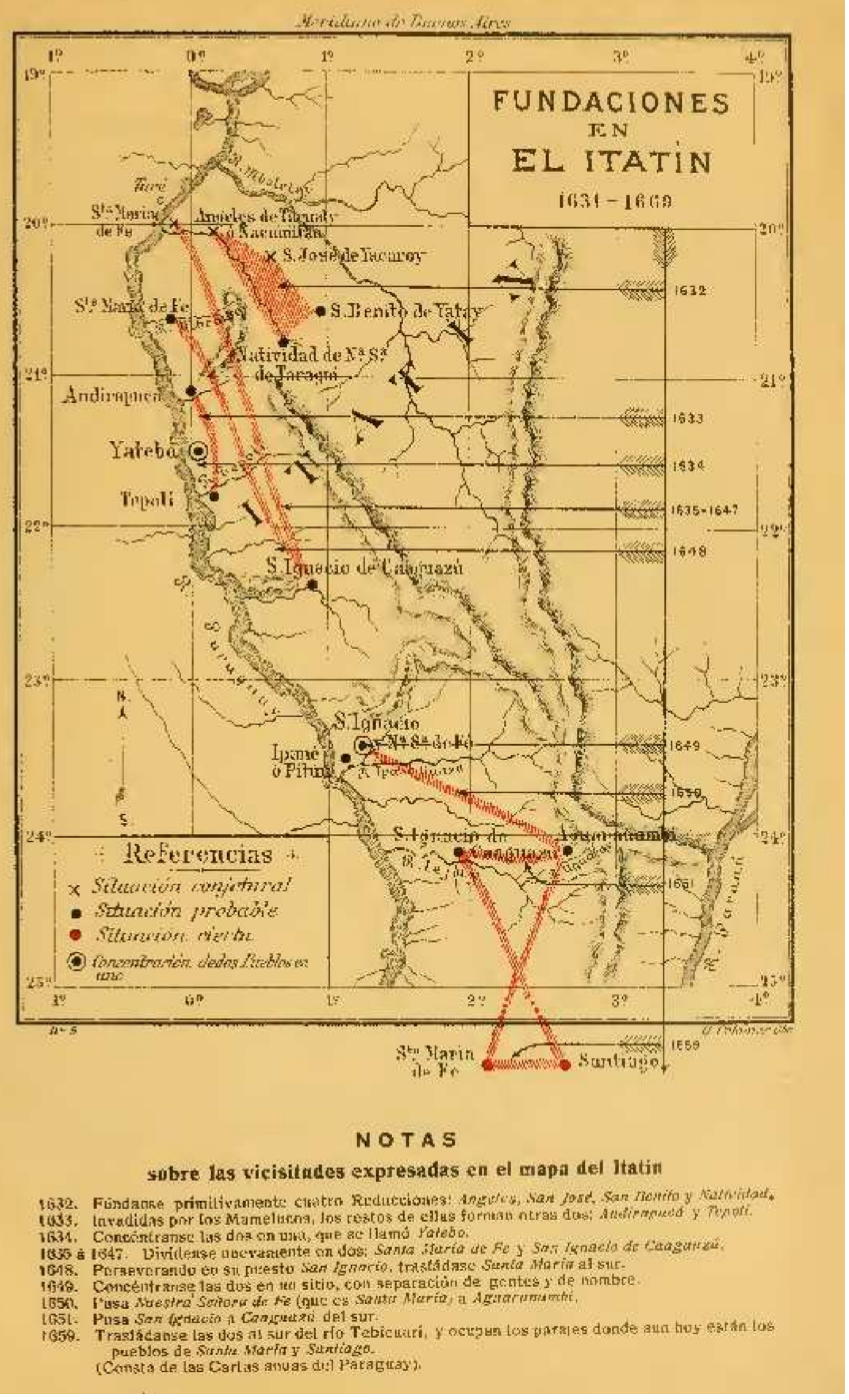

Mapa da província de Itatim, in: Hernández, 1913. 
Já se tornou uma espécie de cânone dentro da etnologia dos Kaiowá e Guarani certa apresentação da história registrada ao longo do período colonial na área que hoje corresponde ao sul e oeste de Mato Grosso do Sul. Eu mesmo já construí minha própria versão desse relato (Pimentel, 2006). Grosso modo, essa versão reconhece que a região era, desde onde se possa lembrar, atravessada por tensões e contatos de todo o tipo - com os povos Mbaya-Guaikuru, Chané e outros grupos chaquenhos, encomenderos espanhóis, bandeirantes paulistas, jesuítas etc.

Ao mesmo tempo, a história canônica enfatiza a ausência de um povoamento permanente de não indígenas na região até o século XIX, indicando que as condições geográficas favoreciam a manutenção do isolamento de vários coletivos kaiowá e guarani até pouco depois da Guerra da Tríplice Aliança (1864-1870). “Até 1850, poucos contatos foram mantidos com os Kaiowá”, afirma Brand (2001: 96). A região de Dourados, particularmente, permanecia em "isolamento" até a dita guerra (idem: 97). O processo de evasão diante dos intentos jesuíticos, por sua vez, é descrito sem nuanças. Como se fosse possível pensar que as duas únicas opções eram ser reduzido, ou "permanecer no mato".

Para Thomaz de Almeida, as informações sobre os Kaiowá até o século XIX dão conta de que se "escondiam", usando matas e "lugares de difícil acesso", "distanciando-se e evitando o contato com o branco". O autor endossa observações de Koenigswald, segundo o qual "poucos viajantes entraram em contato com os arredios Cayuas" (apud Thomaz de Almeida, 2001: 18). Outra avaliação enfática de Koenigswald que aparece aí citada expressa essa espécie de consenso que se estabeleceu na bibliografia: "Os Cayuas amam demais sua liberdade e sentem qualquer intromissão dos brancos como uma restrição de seus direitos" (1908: 3, apud Thomaz de Almeida, idem).

Trata-se de concepções que têm recebido críticas recentes, como as de Wilde. O autor comenta, sobre a historiografia tradicional em torno do período missioneiro, que, até os anos 40 do século XX, era comum os estudos considerarem fato inconteste que, após o fim das missões, os Guarani haviam abandonado em massa os povoados para voltar à selva, onde teriam retomado seus "antigos costumes". "Supuestos de este tipo comenzaron a ser matizados a partir de los años cincuenta, cuando algunos trabajos pioneros revelaron, a partir de nueva documentación, que la selva había sido sólo uno de los tantos destinos, y probablemente el menos común (...)” (2001: 71).

Ele observa que os documentos parecem indicar, isto sim, que o próprio espaço missioneiro 
era "permeável" e marcado pelas estratégias dos grupos indígenas para manter sua autonomia:

\begin{abstract}
“Los llamados 'indios infieles', todavía son considerados como 'bárbaros' perturbadores del orden social misionero. Por otro lado, son tomados en bloque, sin considerar sus diferencias internas marcadas por estrategias y contextos politicos concretos. En ellos se han resaltado generalmente las actitudes de hostilidad. Pero las fuentes locales nos llevan a matizar estas interpretaciones clásicas dando a entender que las actitudes de estos grupos en relación con los indios reducidos eran más bien ambivalentes Por otra parte, la relación de los grupos reducidos con los diversos elementos externos, en muchos casos era más abierta de lo que se cree” (Wilde, 2009: 93-4)
\end{abstract}

Veredictos taxativos, como os de Koenigswald, geraram uma espécie de ideia padrão sobre os Kaiowá e seu modo de vida "tradicional" ou "costumeiro", ou ainda de sua "identidade" ${ }^{\circ 4}$. Mais recentemente, ainda, novos estudos sobre a documentação existente para o século XIX em Mato Grosso têm revelado nuanças do processo de povoamento do sul do estado, região dos Kaiowá e Guarani. De qualquer modo, escritos que eram de conhecimento dos pesquisadores há algum tempo já davam elementos para questionar esse cânone do isolamento. É o caso dos relatórios de Joaquim Francisco Lopes, explorador cujas expedições em companhia do também famoso viajante José Henrique Elliot tinham relação com os planos do Barão de Antonina de registrar em seu nome terras devolutas na região, além de determinar rotas capazes de ligar o Mato Grosso ao litoral atlântico (vide, a respeito, Antunha Barbosa \& Mura, 2011; Antunha Barbosa, 2012; Chamorro, 2009).

Lopes, em suas expedições, acha grupos distantes da versão canônica, que fala em indígenas "arredios", meticulosamente escondidos. Encontra receptividade e muito medo dos ataques dos Terena entre os grupos de língua guarani já deslocados para a vertente oriental das serras do sul de Mato Grosso, habitando, como fazem até hoje, as margens de rios que desaguam no Paraná.

De um grupo kaiowá que habitava a margem do Ivinhema, o viajante, encarregado que fora, pelo Barão de Antonina de "explorar a melhor via de comunicação entre a província de São Paulo e a de Mato Grosso pelo Baixo Paraguai", ouve que, em quatro dias de caminhada, dali, se chegava a

84

O termo é empregado por Brand, mas com sentido um pouco distante do que se usa na antropologia. Por exemplo, ele afirma a certo ponto: “A identidade dos Caaguá vem do período anterior ao processo colonial e missioneiro, mas é influenciada por esse processo" (2001: 94). 
"uma grande água" - provavelmente o Pantanal -, "mas que encontrando por ahi os índios cavalleiros, de quem se temem e contra quem têm guerra aberta, não têm ido lá mais vezes" (Lopes, 1850: 321). Segue a jornada, que havia sido empreendida no início do ano anterior, 1849, e, pouco depois do encontro com os Kaiowá, o explorador viaja em direção à região de Miranda - até hoje habitada pelos Terena - para, então, registrar:

“A 2 de janeiro continuei a viagem, e a 3 encontrei dois índios, um de nação Layana e outros Terena, que vinham de fazer uma correria nas matas do Iguatemi, nas margens do Paraná. O fim destas correrias é captivar outros, que sujeitam ou vendem como antigamente se praticava com os infelizes indios, dando-lhes o nome de administrados.” (1850: 322)

A partir dessa composição paradoxal - sobrepondo uma rica história de contatos de toda espécie e a suposição da possibilidade de um isolamento que poderíamos qualificar como radical -, a etnologia dos Kaiowá e Guarani construiu uma versão também canônica da "cultura tradicional" desses grupos. A formulação que provavelmente está entre as mais citadas pode ser vista no famoso estudo que Meliá realizou com os Grünberg (2008 [1976]), o qual, não por acaso, já no título se imbui daquela famosa fórmula fundacional, tão consagrada na Antropologia, "Os Paĩ-Tavyterã". Dentre as características do grupo descritas na obra, está sua definição de tekoha, ou "comunidade", na tradução dos autores:

“El tekoha es 'el lugar en que vivimos según nuestras costumbres', es la comunidad semi-autónoma de los Paĩ [Kaiowa]. Su tamaño puede variar en superficie (...) y en la cantidad de familias (de 8 a 120, en los casos extremos), pero estrutura y función se mantienen igual: tienen liderazgo religioso propio (tekoaruvicha) y político (mburuvicha, yvyra’ija) y fuerte cohesión social. Al tekoha corresponden las grandes fiestas religiosas (avatikyry e mitã pepy) y las decisiones a nível político y formal en las reuniones o asembleas generales (aty guasu). El tekoha (...) tiene um área bien definida, delimitada generalmente por cerros, arroyos o ríos, y es propiedad comunal y exclusiva (tekoha kuaaha); es decir, que no se permite la incorporación o presença de extraños. El tekoha es una institución divina (tekoha ñe'e- pyru jeguanjypy), creada por Ñanderu. El tekoaruvicha es el vicário y lugarteniente de Dios-Creador, Ñane Ramõi Jusu Papa, quien es el 
Como se nota, a imagem de unidade é forte. "Semiautônoma" soa como eufemismo, porque tudo, nessa definição, leva o leitor à ideia de total autossuficiência - consagrada pelo fato de que há, até mesmo, uma assembleia geral que toma as decisões coletivas, numa espécie de democracia participativa de um pequeno país. Ao tekoha correspondem, inclusive, as grandes festas (mas, para que fazer uma festa se não há convidados de fora?!!!). A "propriedade” é comunal e exclusiva (!!!).

Em texto que foi incorporado à reedição da obra supracitada, Lehner atualiza essa definição, sintetizando-a de maneira ainda mais contundente:

\begin{abstract}
“Así, la organización sociopolítica del tekoha pai, la unión de vários grupos locales bajo el liderazgo de um tekoharuvicha (líder religioso) y un mburuvicha (líder político) que gobierna con el consenso del Aty Guasu (asamblea general), se mantiene vigente em la comunidade pai." (Meliá, Grünberg e Grünberg, 2008: 91)
\end{abstract}

O mburuvicha se torna um "governante". Olhando assim, parece um pouco estranho. Mas, o fato é que esse tipo de formulação persiste até hoje. Mesmo quem fez a crítica ao modelo proposto por Meliá, como Mura $(2006: 121)^{85}$, continua sustentando que a noção de tekoha, tal como defendida pelos indígenas atualmente, tem essas características, sendo uma "unidade política, religiosa e territorial”, e não "mera projeção de concepções filosóficas pré-constituídas ${ }^{86 " .}$

Traduzindo para outras bases teóricas, poderíamos dizer que Mura se refere a um processo de objetivação da relação dos Kaiowá e Guarani com o território. Um processo semelhante foi observado entre grupos tupi da Amazônia de contato recente e que, por sinal, usam termos linguisticamente muito semelhantes aos que os Kaiowá elaboraram, como zo'e rekoha, no caso dos

$85 \mathrm{O}$ autor considera que é preciso contextualizar historicamente a noção, e relaciona-a, especificamente, ao período atual, em que o processo de territorialização dos povos indígenas - ele usa esse conceito seguindo a linha de Oliveira (1998) - empreendido pelo Estado brasileiro exige deles uma definição de territorialidade. Assim, ele sintetiza sua formulação: "Em poucas palavras, [no passado] não era necessário exprimir medidas; simplesmente vivia-se com base na própria tradição, ou seja, respeitava-se e implementava-se as regras do teko: o modo de ser guarani. É então em decorrência das demandas por terra que os índios passam a dar extrema relevância ao espaço entendido como superfície fisicamente delimitada, e isto é por eles expressado através da categoria tekoha" (op.cit: 116).

$86 \mathrm{O}$ autor em relação a quem Mura constrói um contraste conceitual nesse trecho é Pereira (2004). Para aquele, ao "entender esta categoria sob uma ótica primordialmente político-religiosa, considerando os assentamentos comunitários como efeito de circunstâncias e arranjos históricos devidos ao relacionamento interétnico", este "acaba por exacerbar as características a-históricas relevadas na definição de tekoha apresentada por Melià et al.”. Como veremos adiante, acredito que o dilema sustentado aí, entre história e estrutura, já foi superado teoricamente há várias décadas nas obras de Sahlins e Carneiro da Cunha. 
Zo'e do Pará. Tal caso foi bem documentado e analisado por Gallois (2004). Como já assinalou Pereira (2004), trata-se de material bastante útil para o entendimento do caso aqui discutido. De qualquer forma, na verdade, creio que a discussão é um pouco mais complexa; voltarei a ela mais adiante.

Outro exemplo de como essa imagem de autossuficiência e de unidade política e religiosa a partir do território é projetada para o plano da cultura (afinal, ela corresponderia ao teko, o modo de ser tradicional) está na discussão que Mura promove a respeito das mudanças introduzidas no modo de vida dos grupos guarani a partir da adoção das ferramentas de metal trazidas pelos europeus. Ele se vale de uma carta jesuítica de $1620^{87}$, para traçar o cenário da época entre esses indígenas.
“(...)as populações se organizavam a nível local em grupos não muito numerosos, famílias extensas vivendo sob um único teto. As atividades tecno-econômicas, por seu turno, requeriam a exploração e o conhecimento de espaços territoriais diversificados, a maioria deles sendo não muito distante dos assentamentos (...). Isto quer dizer que o grupo doméstico podia ter à disposição um amplo leque de elementos materiais para desenvolver suas atividades cotidianas, sem ter que recorrer a longos traslados. Os próprios integrantes desses grupos locais podiam construir todos os objetos e instrumentos necessários para a vida tecno-econômica, não sendo necessária a presença de especialistas, visto que, dependendo da divisão social do trabalho, o grupo era amplamente independente para com os outros grupos da região, aliados ou não." (Mura, 2006: 49-50, grifo meu)

Ora, os documentos disponíveis mostram que esse estilo de vida à la Robinson Crusoé ${ }^{88}$ está muito longe da realidade verificada na região sul de Mato Grosso do Sul. Como já dizia antes, a própria versão canônica do relato histórico que acompanha as etnografias kaiowá e guarani já contém a maioria dos fatos que dão conta do que proporemos a seguir. Há, contudo, uma questão da perspectiva em relação a esses fatos, e é a partir do que propõem autores como Carneiro da Cunha (1992) e Ingold (2007) que vamos tentar recompor e revigorar nosso olhar sobre a área onde, há quase cinco séculos, se registram relatos sobre a ocupação por grupos de língua guarani.

\footnotetext{
87 Extraída dos Manuscritos da Coleção De Angelis, v. 1 (Cortesão, 1951: 166-8).

88 Em analogia com a visão que Watt (1997) propõe sobre o personagem. Agradeço ao professor Nicolau Sevcenko por me apresentar a essa leitura.
} 
Antes de iniciarmos, vale registrar que procuramos, sobretudo, avançar nessa descrição histórica rumo à documentação disponível sobre o período, realizando prospecções a partir de indicações presentes não só em alguns dos trabalhos antropológicos mais recentes sobre os Guarani e Kaiowá (Mura, 2006; Pereira, 2004; Vietta, 2007), mas também buscando os documentos relacionados pelos autores dos estudos históricos mais conhecidos e utilizados entre os especialistas na região, como Meliá (1993), Susnik (2011), Brand (1997), Chamorro (1995, 2008), Gadelha (1980) e, principalmente (por motivos que ficarão evidentes), Combès $(2011,2011 b)$.

É preciso compreender que não se trata, aqui, de um estudo bibliográfico exaustivo. O escopo principal de nossa pesquisa, afinal, foi a etnografia, não a história. Não temos a pretensão de esgotar as possibilidades de leitura dessa documentação tão rica. A intenção é, sobretudo, apontar caminhos, novos horizontes, mostrar que é possível enxergar a história dos povos indígenas da bacia do Paraguai, e particularmente, os grupos de língua guarani, de forma bastante distinta da que, ainda hoje, se costuma difundir. Os elementos para essa mudança de ponto de vista estão na própria documentação, como pretendo demonstrar.

\section{Por uma etnografia das linhas}

"O que andar, tecer, observar, cantar, contar histórias, desenhar e escrever têm em comum? A resposta é que todas essas atividades se dão ao longo de linhas, de uma maneira ou outra". Assim é que Ingold inicia a introdução a Lines - A Brief History (2007), livro que ele considera lançar as fundações para uma "antropologia comparativa da linha" (op.cit: 1).

A proposta pode parecer até exótica, mas adquire tons de profunda crítica política quando consideramos com um pouco mais de atenção. Para Ingold, nós não apenas traçamos linhas no papel, nós também vivemos ao longo de linhas, seja no espaço - ao caminhar, viajar etc. - ou no tempo - ao imaginar uma linha de descendência, por exemplo.

Preocupado em desconstruir a ideia - que atribui, genericamente, a "antropólogos" - de que o Ocidente moderno é "essencialmente linear", em oposição aos não ocidentais, aos quais as linhas de toda espécie seriam resultado de imposições da colonização, Ingold argumenta:

“A alteridade, somos ensinados, é não linear. O outro lado dessa moeda, no entanto, é assumir que a vida é vivida autenticamente no local, em lugares 
em vez de ao longo de caminhos. No entanto, como poderia haver lugares, eu me perguntava, se as pessoas não vêm e vão? (...) A vida é vivida, pensava eu, ao longo de caminhos, não apenas em lugares, e os caminhos são linhas de algum tipo. É ao longo de caminhos, também, que as pessoas cultivam um conhecimento do mundo ao seu redor, e descrevem esse mundo nas histórias que elas contam. Colonialismo, então, não é a imposição de linearidade sobre um mundo não linear, mas a imposição de um tipo de linha sobre outro. Opera primeiro convertendo os caminhos ao longo dos quais a vida é vivida em fronteiras dentro das quais ela é contida, e depois juntando estas agora comunidades fechadas, cada uma confinada a um ponto, em conjuntos (assemblies) integrados verticalmente. Viver junto é uma coisa, juntar-se é algo completamente diferente.” (op.cit: 2-3)

Vemos aqui três linhas de argumentação, grosso modo: 1) uma crítica ao preconceito etnocêntrico de supor que sociedades não ocidentais não têm nenhum tipo de linearidade; 2) a observação de que esse nosso preconceito também nos leva a privilegiar, entre os não ocidentais, os lugares, em detrimento dos caminhos e trajetórias; 3) a lembrança de que todo esse nosso complexo de ideias e preconcepções nos faz imaginar o colonialismo como um processo de imposição de linhas a sociedades não lineares ${ }^{89}$.

Poder-se-ia fazer várias objeções a uma série de pontos do livro, mas, seja como for, Ingold comparece aqui pelas várias inspirações que trouxe a esta tese. Suas observações me parecem perfeitamente aplicáveis a boa parte das etnografias produzidas sobre povos de língua guarani, e particularmente ao contexto sul-mato-grossense. Em primeiro lugar, é possível, sim, perceber, ao longo da história, uma série de linhas traçadas pelos povos de língua guarani que habitam a região e acompanha-las pode ser extremamente revelador. Essas linhas não se restringem ao território do Mato Grosso do Sul. São rotas que indicam centros não apenas na própria região, mas também os Andes e outros focos de concentralização ${ }^{90}$, como aldeias fortificadas, xamãs de prestígio regional, grupos que exerciam vassalagem e escravização sobre os demais etc., como veremos a seguir.

Como destacam Deleuze \& Guattari (1996), e observando as ressalvas que acabamos de

\footnotetext{
89 Carneiro da Cunha, igualmente, alertava, sobre o Brasil indígena de hoje: "são fragmentos de um tecido social cuja trama [era] muito mais complexa e abrangente" (1992: 12).

90 Tento, nessa tradução, conciliar-me com a ideia de Deleuze \& Guattari (1996) sobre o fato de que não se trata de processos de centralização e sim da formação de círculos concêntricos. Daí, "concentralização”.
} 
fazer, não se trata de dizer que não se atentou, até hoje, a nenhuma espécie de linha. Poderíamos dizer, isto sim, que, ao mesmo tempo em que se reconhecem aos povos guarani, aí, as segmentaridades circulares e binárias, negamo-lhes as segmentaridades lineares. De modo que não ignoro a importância do binário e do circular, já destacado entre os povos guarani em outros trabalhos, apenas friso que se devem acrescentar outras segmentaridades, aí, para refinar nossa compreensão a respeito de seu passado e seu presente.

Como lembra Sahlins, não se deve esquecer que, do ponto de vista dos Guarani, "o sistema global é que é periférico, não o deles" (1999: 412). Na geografia paĩ/kaiowá, o Centro do Mundo (Yvypyte) está bem ali em sua região (Meliá, Grünberg e Grünberg, 2008). E nas redes guarani, parece bem conhecido o fato de que, em oposição ao centro onde vivem, está a região do litoral atlântico, beira do mundo, com tantas ressonâncias cosmológicas (vide, por exemplo, Nimuendaju, 1987).

A consequência de uma visão que enfatiza um estilo de vida (teko) plenamente desenvolvido apenas em lugares específicos $(\text { tekoha })^{91}$ é, sobretudo, a formação dessa versão canônica a respeito dos coletivos guarani/kaiowá, retratados como unidades autossuficientes e tradicionalistas. O problema é que, como lembra Sahlins no artigo supracitado, "as culturas são largamente estrangeiras em sua origem e distintivamente locais em seu padrão" (1999: 412).

Embora Sahlins faça esse apontamento de forma genérica, note-se que a afirmação tem sentido especial quando se trata dos povos ameríndios. Por aqui, como já apontou Lévi-Strauss (1993), a exterioridade é fundante e motriz do socius. Entre os ameríndios, a dinâmica gerada pela contínua incorporação da diferença é convertida em valor, em celebração constante (quando, no mundo europeu, enfatiza-se identidade e autoctonia) $)^{92}$.

É bem verdade que, como o próprio Sahlins adverte nesse texto, os hibridismos, muitas vezes, só aparecem quando se lhes analisa a história, não na descrição etnográfica de uma situação atual. O problema, quando estudamos a bibliografia sobre os Guarani e Kaiowá, é que esse quadro contemporâneo - em que "as externalidades são indigenizadas" e o que vemos é uma espécie de

91 Nesse sentido, a crítica de Mura à noção canônica de tekoha é procedente. Porém, como explicaremos a seu tempo, ela está, por um lado, demasiado encharcada do discurso produzido nos processos de identificação de terras indígenas e, por outro, ainda fortemente presa a uma visão da história que imagina o mundo pré-colombiano/précabralino como "não linear", no sentido proposto por Ingold (2007).

Tara uma discussão sobre a condição fundante da diferença no pensamento ameríndio, conforme sugerido por Lévi-Strauss, ver Perrone-Moisés, 2006b. Sobre as ideias europeias que se opõem a esses princípios, como a ênfase na autoctonia, veja-se Detienne, 2004, 2005. 
todo coerente -, é projetado sobre o passado para frisar continuidades, permanências.

Por exemplo, como mostraremos adiante, é comum considerar que o testemunho de um jesuíta ou de um viajante sobre uma forma de assentamento ou sobre o porte de determinados objetos sinaliza uma inexorável continuidade entre os grupos falantes de guarani do período colonial e os atuais Kaiowá e Guarani. As linhas fundamentais da hipótese de uma continuidade focada na descrição etnográfica atual ${ }^{93}$ - estão claramente formuladas logo no início da obra de Meliá, Grünberg e Grünberg (2008) ${ }^{94}$.

Por outro lado, são numerosíssimas as evidências de que a trajetória dos grupos de língua guarani do atual Cone Sul de Mato Grosso do Sul foi, até onde a vista alcança, completamente atravessada pelas relações com numerosos grupos sociais não falantes de guarani (ou mesmo grupos "guaranizados", que passaram a falar guarani em função de tais relações). A seguir, apresentaremos alguns traços dessas relações e, logo após, discutiremos as implicações dessa visão transformada da história para a descrição etnológica dessas populações.

\section{Itatim}

A região sul de Mato Grosso do Sul corresponde, principalmente, ao que, no período colonial, era conhecido como Itatim. Como e onde aparece esse nome? Combès, pesquisadora que vem trabalhando intensamente sobre a documentação colonial referente, grosso modo, às relações entre a bacia do Prata e o Chaco Boliviano, com foco na região de Santa Cruz de la Sierra, assim explica o termo:

\footnotetext{
93 Para que se perceba a fragilidade dessa abordagem convencional: boa parte dos brasileiros olha para indígenas como os Kaiowá e traça outras linearidades. Em vez de observar as cruzes ou o corte de cabelo, veem as roupas, as casas, a alimentação e, para eles, a continuidade não é predominantemente indígena. De modo que, para superar esse dilema (do tipo "copo meio cheio/meio vazio"), é necessário, creio, buscar outros elementos, como uma discussão mais aprofundada da relação dos Kaiowá e Guarani com o território - fugindo das armadilhas típicas das demarcações de terras em ilhas (discutindo se um lugar específico tem vestígios arqueológicos, por exemplo, para que se defina o direito ou não dos indígenas a ocupá-lo - esse tipo de debate é infrutífero, do meu ponto de vista). 94

Essa observação que faço sublinha o seguinte: se deslocamos o foco e pensamos numa continuidade (uma linha) que passa pela história e a língua, por exemplo, os deslocamentos rumo ao Chaco, que deram origem aos Chiriguanos, tomam outro vulto. Ao mesmo tempo, uma série de comportamentos dos grupos de língua guarani atuais ganha novo sentido. Chiriguanos, no caso, é a denominação (frequentemente genérica) para o maior grupo falante de guarani da Bolívia, descendente, justamente, das levas de migrantes do Itatim (em forte conexão com grupos de língua arawak - sobre a origem do grupo e sua relação com esses Chané, ver Combès, 2010: 129-38).
} 
“Este nombre significa 'piedra blanca' en guarani". Fue primero conocido por los españoles de Asunción como el nombre de un puerto sobre la orilla este del río Paraguay, más arriba del núcleo de Garabatibi, poblado por indígenas de habla guaraní que fueron designados como 'guaraníes' o 'carios' (pero no 'itatines') en las fuentes quinientistas. Estos indígenas eran caníbales y enemigos de los guaxarapos y guatos ${ }^{96 ”, ~(2010: 172) ~}$

Até aí, tudo conforme: excetuando-se esse detalhe em relação ao qual Combès chama a atenção (de que inicialmente Itatim não designava a região que hoje inclui parte de MS, mas apenas um porto à margem do rio Paraguai, próximo a onde deságua o Apa) não parece haver divergência em relação à versão canônica da história. Mais adiante entraremos em detalhes sobre a presença dos colonos espanhóis e, depois, missionários e paulistas no Itatim. Segundo a clássica coleção de documentos reunida por Cortesão (2010), as encomiendas ${ }^{97}$, na região, aparecem no final do século XVI, e as missões jesuíticas, em 1632, junto com os ataques bandeirantes. Os chamados Itatines incluíam não apenas falantes de guarani, mas também grupos gualachos ${ }^{98}$. No período missioneiro, os grupos guarani que estavam longe do rio eram chamados de Yvytyrygua (os da selva/dos montes?). Os Payagua, que atacavam os Guarani de Assunção, eram ditos aliados ("únicos amigos", aliás) dos Itatines (Ferrer, apud Cortesão, 2010: 69).

Mas, voltando ao texto de Combès, é daí em diante que tudo começa a se afastar consideravelmente de nosso relato padrão:

\section{“ [os Guarani de Itatim] también solían participar a expediciones hacia la 'tierra adentro', en busca del metal. Irala lo enuncia muy claramente en}

\footnotetext{
95 O padre Diego de Ferrer, em 1633 (Cortesão, 2010: 52), dá explicação diferente: seria "pedra pontuda", ou 'com pontas", e não branca. De fato, os dois termos são mesmo bem parecidos, e não me arriscaria a dizer quem teria razão, no caso.

96 Em outro artigo (2011b: 20), a autora complementa: "Algunas de las fuentes paraguayas ayudan a precisar la información, indicando sin ningún equívoco uno de los puntos de partida de los chiriguanaes: la región de Itatín, a la confluencia del río Apa con el Paraguay".

97 As encomiendas eram um dos mecanismos de exploração do trabalho indígena adotados na América espanhola outros eram a mita e o yanaconato. As encomiendas consistiam num contrato do colono com a Coroa, por meio do qual ele adquiria a concessão para "cobrar impostos" (na prática, ao menos na região da qual aqui falamos, tratavase de explorar-lhes o trabalho) de um certo grupo de indígenas, durante certo período. Na prática, tornava-se uma forma de trabalho forçado. Esse mecanismo foi fundamental na colonização do Paraguai, uma vez que, em não encontrando metais na região, os colonos se apoiaram na mão-de-obra nativa como grande possibilidade de geração de riqueza ali. Para um panorama histórico da exploração do trabalho indígena no Paraguai, ver Gadelha, 1980.

98 Termo aparentemente genérico, que incluía, segundo o padre Ferrer - Cortesão, 2010: 67-8 - "todas las naciones que no tienen por propia la lengua guarani”, como "Guanas, Tunus, Bayas, Guaramos etc." Ainda segundo ele, todas também poderiam ser chamadas genericamente de "Guaycurus y Guaycurutis".
} 
enero de 1543: 'antes que García viniese del Brasil ${ }^{99}$ [...] se hizo una gran junta en el puerto que llaman de Ytatyn para ir a buscar el metal' (...). Esta gran junta reunió a diversos grupos guaraní-hablantes, al mando de los principales Ytapua (quien convocó la junta), Pitaguari, Bambaguasu, Yacurananga, Yaguarubay, Taybaçunca, Moqueringuasu, pero también participaron otros grupos como los xarayes ${ }^{100}$. Muchos de ellos regresaron luego a sus lugares de origen, pero otros se quedaron en la 'tierra adentro', al oeste de los xarayes y al noreste de la futura ciudad de Santa Cruz. Los pitaguaris y bambaguasu, por ejemplo, ya vivían en esa región cuando [Ñuflo de] Chaves los encontró luego en 1557. Estos núcleos guaraníhablantes se engrosaron, luego, con la llegada de los carios acompañantes de Chaves: y 'llegados estos indios 30 leguas de Santa Cruz, hicieron asiento en un término de tierra que les pareció conveniente, llamándola Itatin por el nombre de la provincia de donde salieron' (Díaz de Guzmán 1835 [1612]: 133 $\left.{ }^{101}\right)$. Así nació la llamada 'provincia de Itatín' al este y

99

Referência ao português "Alejo" García, que, em companhia de um grupo de Guarani que conheceu em Santa Catarina, chegou até os Andes por volta dos anos 1530. "A decir verdad, los escritos paraguayos del siglo XVI sólo mencionan a 'un' García, portugués, sin darnos a conocer su nombre de pila. Según estas fuentes, este García les habría precedido en el camino hacia el oeste, pero fue matado por los indígenas en su viaje de regreso. Sin embargo, la referencia más famosa a este personaje se debe a Ruy Díaz de Guzmán -es decir a una fuente de inicios del siglo XVII. Según el cronista, 'Alejo' García salió en 1526, con otros tres hombres, desde San Vicente en la costa de Brasil, a descubrir por orden de Martín de Sosa, gobernador de aquella capitanía portuguesa, 'lo que había' en la tierra adentro. García habría llegado hasta Mizque y Tomina en los valles de la actual Bolivia, convirtiéndose así en el primer descubridor del imperio inca, desde el este" (Combès, 2011b: 8).

100 Segundo Combès (2010: 315): “Los xarayes eran una 'generación' del Pantanal, y sin duda la que más impresionó a los españoles de Asunción. Vivían más arriba del Puerto de los Reyes siguiendo el río Paraguay arriba, mayormente sobre la orilla oeste del río, aunque las primeras comunidades encontradas llegando del sur están asentadas en la orilla este". E o texto agrega (323): "En la época prehispánica, los xarayes eran parte activa del comercio del metal (oro y plata) entre occidente y oriente. Junto con los gueno y los ymore, entregaban metal a numerosos grupos del alto Paraguay (...). Conseguían este metal de los grupos 'del interior', vale decir del occidente (Cabeza de Vaca 1944 [1555]: cap. LVII). En 1544, los xarayes de la aldea de Vretobare tenían planchas de plata que habían conseguido de 'un principal que estaba en unas sierras [...] en cierta guerra que le había hecho' (Ribera 2008a [1544]: 18). De hecho, sabemos que los xarayes participaron a una(s) expedición(es) hacia el oeste en busca de metal, acompañados por otros grupos. Con Çaye o Caye, jefe xaray quien 'juntó toda la más gente comarcana', partieron 'en demanda del Candire' los hombres de Bambaguasu y los pitaguari (todos chiriguanaes), los ortueses y los etones. Si bien los xarayes eran enemigos de los guaraníes 'de las montañas' al oeste, tenían entonces buenas relaciones con otros grupos chiriguanaes: de hecho, los chiriguanaes de Bambaguasu solían casarse con mujeres xarayes, y conocemos también el caso de un itatín casado de la misma manera."

101 Em relação a Diaz de Guzman, Combès (2011b: 21) também afirma que seus escritos mostram que "efectivamente hubo varios puntos de origen de las migraciones guaraníes hacia el oeste". "Y nos ayuda en consecuencia a considerar de otra manera a 'los guaraníes' migrantes: éstos provenían de diversas zonas y no constituían un grupo homogéneo. Los 'chiriguanaes' de las fuentes no sólo llegaron de una manera escalonada, que propició las diferencias entre los diversos grupos, y entre éstos y los que quedaron en el Paraguay; no sólo se mezclaron, en la Cordillera chiriguana por ejemplo, con grupos autóctonos como los chanés: también son el resultado del encuentro entre grupos guaraní-hablantes diversos, y de diferentes orígenes". Ela também menciona que o franciscano Bernardino de Nino, no início do século XX, encontrou, entre os Chiriguanos da Cordilheira, 
noreste de la ciudad de Santa Cruz. [...] Contrariamente a sus paisanos del puerto sobre el río Paraguay, estos guaraní-hablantes sí fueron llamados 'itatines' en las fuentes; también se les llamó 'chiriguanaes', 'chiriguanaes itatines' y, a partir de fin del siglo, 'guarayú'. (2010: 172)

O ponto principal é este: Combès recolhe diversos documentos a mostrar que foram várias as expedições de grupos guarani (com aliados de outros coletivos, como os Xaraye), muitos deles tendo saído do Itatim - ou passando por lá -, para buscar metais nas fortificações que guardavam as fronteiras do império Inca, na região de Santa Cruz.

De fato, as viagens guarani rumo a Oeste (sejam migrações ou expedições) são um tema pouco explorado na bibliografia brasileira. Menções a elas são feitas, mas sem maiores detalhes sobre suas motivações ${ }^{102}$. A discussão clássica oscilou entre considerar essas migrações como “crises messiânicas" (Métraux, 1979: 175), oriundas da "aculturação", com a chegada dos europeus, ou, nas obras de Pierre e Hélène Clastres, como um "processo autóctone”, uma reação aos chefes poderosos que surgiam de uma explosão demográfica ${ }^{103}$. Como veremos a seguir, os motivos desses movimentos entre Andes e terras baixas - e o fato de haver cada vez mais evidências de que eles eram muito anteriores à chegada dos europeus, como demonstra Combès (2011b) - são, sim, relevantes para o entendimento de uma série de dinâmicas guarani históricas e atuais e, inclusive, para que se repensem os cânones que estivemos descrevendo até agora.

Esse é outro ponto que Combès examina, em artigo recente (2011). Em primeiro lugar, a autora mostra que, no imaginário colonial, não parecia haver contradição entre buscar o paraíso e obter riquezas materiais - ou seja, ficar rico e ascender espiritualmente não eram metas inconciliáveis, como a alguns de nós pode parecer hoje. Nesse sentido, do ponto de vista dos colonos, é nessa chave que ela irá propor a análise dos documentos que narram as expedições em busca de lugares fantásticos entre a Bolívia e o Peru. Mojos e Paititi, segundo as evidências documentais quinhentistas que a autora apresenta, eram denominações para "terras ricas" buscadas

alguns anciãos "notáveis por sua autoridade" que defendiam que a origem de seu grupo era o Brasil.

102 Veja-se, por exemplo, Meliá, Grünberg e Grünberg, (2008: 16-7), ou Meliá (1993). Mesmo quando se menciona essa questão, como em Monteiro (1992: 484), pode parecer que os grupos guarani simplesmente seguiam os europeus que buscavam o metal.

103 Gloso aqui a leitura que Pissolato (2007: 99-105) faz desse debate. Sztutman, por sua vez, rejeita o termo "messianismo", mas continua centrando a discussão no "profetismo" como "xamanismo feito história" (2005: 410) ou "leitura da história" (op.cit.: 430) feita pelos povos indígenas. No caso chiriguano, ele foca sua análise na obra de Saignes a respeito da história do grupo desde o período colonial e a emergência dos profetas tumpa, que se contrapunham aos mburuvicha. 
pelos espanhóis na região entre Bolívia e Peru - uma espécie de Eldorado, habitado por remanescentes dos Inca:

\begin{abstract}
"Prototipo de la utopía, el paraíso terrenal pudo ser ubicado en cualquier parte todavía incógnita del subcontinente. Lo mismo pasó con El Dorado, primero más localizado al norte de Sudamérica, pero cuyo nombre se volvió, hasta hoy, sinónimo de cualquier 'tierra rica'. Otros nombres tuvieron sin embargo un uso mucho más localizado. Fue el caso, en el centro-sur del subcontinente, de Mojos y Paititi, fabulosas tierras que algunos testimonios asimilaron también, por un tiempo, con Candire' (2011: 100).
\end{abstract}

Com essa menção a Candire, chegamos outra vez à etnologia dos povos de língua guarani. Sim, trata-se do mesmo Kandire que é associado, por vezes, à Terra sem Males, à possibilidade, posta aos xamãs guarani, de, mesmo vivos, tornarem-se imortais. Em autores como Viveiros de Castro (1995: 247, 371) ou Pissolato (2007: 410-11) - entre muitos outros, diga-se de passagem se percebe que é nessa chave cosmológica que a noção permanece na discussão antropológica.

Mas... de onde surge essa palavra e como seu sentido vai se alterando a esse ponto? É, segundo Combès, nas últimas décadas do século XVI que o termo começa a ser usado pelos cronistas crucenhos como um dos nomes desse reino fantástico que abrigaria remanescentes do império Inca. "Si bien la asimilación entre Mojos y Paititi es recurrente en las fuentes, su identificación con Candire sólo aparece en algunos testimonios, y tampoco perdura", explica ela.

Para ela, Candire logo parou de ser mencionado porque simplesmente se constatou que não fazia sentido, pois se estava falando de coisas diferentes. Ela lembra ainda que as fontes paraguaias que diziam respeito às expedições rio Paraguai acima, pouco antes, ainda no século XVI, não citavam nenhum dos três nomes. Mencionavam apenas "un pueblo llamado 'los candires', dueño de muchas riquezas al igual que los 'carcaraes', y que como ellos vivían lejos al oeste de Asunción, al otro lado del Chaco" (2011: 102). E ela segue, então:

\footnotetext{
“Mencionados por primera vez en 1541 [...], los carcaraes o caracaras eran calificados de 'señores verdaderos del metal blanco' (la plata)(...). En cuanto a los candires, vecinos de los caracaras, (...) son llamados 'señores verdaderos del metal amarillo', es decir del oro.” (2011: 102)
} 
E vejam só quem seriam os Candire e os Caracarás, na avaliação de Combès? Nada menos que os próprios produtores do metal que tanto interessava, tanto aos Guarani como aos espanhóis:

\begin{abstract}
“Por su ubicación al oeste, la explotación de minas y la posesión de objetos de metal, por otras descripciones también que evocan por ejemplo las llamas de los candires [...], éstos fueron identificados por casi todos los autores con los incas, y sus vecinos carcaraes con el pueblo homónimo de Charcas (qaraqara [...]), en cuyo territorio estaban ubicadas las principales minas de plata del imperio inca. [...] Intenté por mi parte precisar estas identificaciones, mostrando que los candires probablemente no eran 'los incas' en general, sino más específicamente los del centro de Samaipata en los valles hoy cruceños, y los carcaraes posiblemente unos de los mitimaes (funcionario público) empleados por el inca Condori en las minas de Saypurú en la Cordillera chiriguana. Sugerí, incluso, que el mismo nombre de los 'candires' podría derivar del del Inca Condori. La primera meta de los españoles de Paraguay estaba así situada por ellos - y por sus informantes guaraníes - al oeste (cruzando el Chaco como lo hicieron Ayolas en 1537 e Irala en 1548) y no en dirección a la Amazonía. El objetivo era el piedemonte andino (la futura 'Cordillera chiriguana') con los asentamientos de Samaipata y las minas de Saypurú, fuentes del comercio del metal andino hacia el oriente." (2011: 102-3)
\end{abstract}

O desfecho dessa história não tardou. Em pouco tempo, conta Combès, os assuncenos se deram conta de que o que buscavam na verdade já havia sido controlado pelos espanhóis a partir do Peru. A partir daí, "toda mención a los carcaraes desaparece de las fuentes, y los candires pronto toman el mismo camino. Sólo por un tiempo breve, como lo muestran los testimonios ya citados, su nombre se transforma en el de otra tierra fabulosa (el Candire), que los cruceños asimilan sin más a Mojos (...)".

Mas não é só essa reveladora associação entre Candire e os Inca que Combès põe à luz. Os números relativos às migrações guarani até a região de Santa Cruz, em busca do metal inca, também impressionam:

"Existen, de hecho, noticias tempranas y bastante numerosas sobre las migraciones de los itatines paraguayos (y de otros grupos aliados, como los 
xarayes del Pantanal) en busca de metal hacia el oeste, 'antes que García viniese del Brasil', es decir antes que lleguen los europeos. Buscaban, según sus propias palabras, a los candires y carcaraes, pero algunos de ellos se dirigieron más hacia el norte, hacia Mojos, hacia los parecis, donde les encontrarían más tarde las expediciones cruceñas. ¿Cuál era su meta? ¿La misma 'tierra rica' de cuya existencia se tenía noticia en Perú? Alcaya no duda de ello, cuando indica que de 8.000 guaraníes llegados desde Paraguay, 'dos mil fueron a ver el rey Manco [Inca]' mientras los demás se quedaban por el Guapay y los alrededores de la primera Santa Cruz (2011: $103)^{104}$

Nessa região próxima a Santa Cruz velha (depois a cidade foi refundada, mais a oeste), instalaram-se os grupos guarani que ficaram conhecidos como Itatines, devido a sua procedência. E é a partir de documentos que citam testemunhos de integrantes desses grupos que ganha corpo a associação entre a busca do metal e a da Terra sem Mal, como explica Combès:

\begin{abstract}
“(...) es un hecho que estos chiriguanaes [os Itatines de Santa Cruz] son los únicos entre los informantes de los españoles en asociar el nombre de los candires con algo más que la riqueza de metal: 'aquella tierra era en donde había dado Dios todas las cosas buenas'[...]. Y son también los únicos entre los cuales se registró la existencia de un dios llamado Candir [...]. Como adelanté al inicio de estas páginas, no creo que el investigador deba escoger entre dos metas o entre dos representaciones, y una 'tierra rica' de metal bien puede a la vez ser tierra de 'cosas buenas'." (2011: 103-4)
\end{abstract}

Combès lembra ainda que Métraux já apontava para uma convergência entre as buscas pela mítica Terra sem Males e os Inca - da mesma forma que Saignes já apontava para uma convergência desses movimentos com a busca por metais. Mais recentemente, isso não passou despercebido a autores como Monteiro (1992) e Carvalho (1992), mas o fato é que não se tiraram consequências práticas da existência desses dados para a caracterização dos coletivos indígenas que

104 Em outra ocasião, Combès (2011b: 22) expõe lista organizada por Enrique de Gandia e aceita por Métraux, localizando pelo menos três migrações guarani ao piemonte andino anteriores à chegada dos europeus - a primeira delas teria se dado antes de 1471 (tendo sido mencionada por Garcilaso de la Vega). A terceira teria sido a que foi mencionada por Irala, e envolvia a tal grande reunião em Itatim. 
atuam na história da região ${ }^{105}$.

Por isso, acreditamos que a novidade, em Combès, é evidenciar que essa associação entre a busca do metal e as expedições guarani rumo aos Andes tinha raízes que desafiam a oposição cartesiana entre sagrado e mundano, ou entre razão prática e razão simbólica. Tudo aqui era concomitante, e não havia contradição nisso. "En cuanto a la búsqueda del metal andino, se trata al parecer de un afán demasiado 'materialista' para caber en la imagen idealizada de un paraíso terrenal [a Terra sem Males]", ironiza ela, em outro texto (2011b 27).

Se, por um lado, Combès insiste na não contradição entre busca por riquezas e pelo Paraíso, no imaginário colonial, por outro lado (2011b: 29), também endossa observação de Julien (2007) a respeito da origem dessa associação entre as migrações guarani a Oeste a a Terra sem Males. Esta última demonstra que, para supor a associação entre Kandire e a Terra sem Mal, Métraux e Helene Clastres se basearam numa única passagem de um documento quinhentista ${ }^{106}$ a respeito de uma "terra de fartura" a oeste. Afora isso, esses autores citam a identificação dos Inca como Candire, esta sim espalhada por numerosos textos. Finalmente, Julien mostra que há mais de uma menção, entre os grupos de língua guarani na região de Santa Cruz, na segunda metade do século XVI, a uma entidade sobrenatural chamada Candir. Por fim, ela sintetiza:

\section{"Os documentos relacionados à exploração espanhola e as primeiras glosas de dicionário não sustentam a hipótese de que 'levantes político- místicos' motivaram os movimentos do alto rio Paraguai para o piemonte andino, mas apontam para outras explicações" (Julien, 2007: 265)}

Essas explicações eram a busca por metais e a ânsia por resgatar parentes presos em expedições anteriores - o que, para Julien, demonstra que, em vez de falar em migrações, seria mais produtivo perceber que se tratava de enormes redes de alianças e hostilidades, que inclusive ultrapassavam em muito as barreiras linguísticas:

“Objetos de prata foram encontrados ao longo do que seria conhecido

\footnotetext{
105

Pissolato (2007), registre-se, menciona a importância de superar certos estereótipos (místicos, melancólicos etc.) na descrição dos grupos de língua guarani, mas não envereda pela bibliografia histórica - concentra-se mais na etnografia dos Mbya.

106 Nas notas da expedição de Ñuflo de Chaves, de 1557, em dado momento, na vila de Piritaguari, os espanhóis se deparam com um grupo de pessoas que queriam seguir com eles. Segundo Julien, queriam ir para fazer trocas e resgatar parentes na "terra da abundância". Em suas terras, tudo o que havia era comida, e isso não era suficiente. (2007: 256)
} 
como Rio da Prata. Mais acima dos rios Paraná e Paraguai, prata e outo podiam ser obtidos dos povos nativos. (...) A busca por metais deve ter sido uma razão para viajar a partir do oeste, mas claramente a busca de cativos também era importante. $O$ que vemos é um padrão de excursões esporádicas por metais e cativos no piemonte andino e nas terras baixas adjacentes ao leste" (Julien, 2007: 251, 254).

Diante da evidência da existência de amplíssimas redes sociais atravessando a região do Itatim, apresentada por esses documentos, não parece fazer sentido pensar o sul de Mato Grosso do Sul como uma região propícia ao isolamento, onde a ampla disponibilidade de meios materiais possibilitava que os grupos de língua guarani sobrevivessem "sem ter que recorrer a longos traslados", de forma "amplamente independente".

A questão é que, ao que tudo indica, o metal andino era muito difundido na região do Itatim, e, sim, os indígenas eram capazes de caminhar por centenas de quilômetros para obter - em trocas, ou na guerra - peças ornamentais feitas de itati, a prata, e itaju, o ouro:

Las primeras fuentes paraguayas evidencian un intenso tráfico comercial de occidente a oriente; prácticamente todos los pueblos del río Paraguay poseen algo de metal. Para convencerse de ello, basta con leer las informaciones recogidas por Domingo de Irala en su viaje hacia el alto Paraguay y el Pantanal en 1542 y 1543, que mencionan a un sinfín de etnias dueñas de objetos de oro o plata. Tras las huellas de las fuentes de la riqueza y de los misteriosos carcaraes y otros candires o chimeneos que los indígenas describen como 'señores verdaderos del metal', Ayolas, Irala y sus compañeros buscan guías, y los encuentran. Los indígenas no solamente tienen algo de 'planchas' de metal: muchos de ellos saben exactamente de dónde vienen, y cómo conseguirlas. Así, las rutas de los conquistadores de Asunción hacia la 'tierra adentro' son, primero, las rutas indígenas y prehispánicas del metal.” (Combès, 2011b: 32)

Em busca de traçar esse "panorama geral do comércio de metal" na região do rio Paraguai, Combès agrega: 
“(...) muchísimos pueblos están implicados, sea en el Pantanal, sea a lo largo del río Paraguay, en la actual Chiquitania o incluso Chaco adentro. El metal que circula es 'amarillo' (oro) y 'blanco' (plata). Y los indígenas de las tierras bajas saben perfectamente de dónde viene. Los xarayes del Pantanal, sus vecinos los ortueses y los chiriguanoes de Itatín saben que el metal llega de las sierras (...). Es más, xarayes y chiriguanáes saben perfectamente que la plata sale de las minas, mientras el oro se recoge de arroyos y quebradas (...) Además del oro y de la plata, circulan probablemente también piedras preciosas utilizadas por ejemplo como tarugo labial (tembeta en guaraní) por varios grupos, pero también otros metales como el cobre. Los indígenas de los llanos y del Paraguay saben diferenciar los diferentes metales" (2011b: 34-5)

Parece um sinal claro de que a razão prática burguesa, como dizia Sahlins (2003), segue distante da compreensão plena sobre a sedução exercida por certos bens. Em relação a esse assunto dos metais, a imaginação antropológica e arqueológica, no que tange aos grupos de língua guarani de Mato Grosso do Sul, só foi capaz de alcançar algo sobre o papel do ferro, e a superioridade dos machados feitos de metal diante dos instrumentos de pedra. Não deixa de ser sintomático, pois aí, sim, haveria algo de "produtivo" envolvido (afinal, um machado de metal traz "mais rendimento" ao trabalho) ${ }^{107}$.

Uma crítica similar foi recentemente aplicada ao contexto guianense, onde o paradigma etnográfico do "atomismo social" parecer ter sido levado às últimas consequências nas últimas décadas. Barbosa (2005) observa que são numerosas na literatura sobre a Amazônia as discussões sobre trocas de bens que envolvem ideias como "escassez" ou "necessidade". Ele destaca o caso dos Aparai-Wayana, do Amapá, os quais seguem realizando dispendiosas viagens até o Suriname e a Guiana Francesa para adquirir bens que poderiam ser obtidos "em Macapá, Belém ou até mesmo em suas próprias aldeias" (idem: 81).

O autor relata que, do ponto de vista dos indígenas, não há escassez de intercâmbio, e sim o exato contrário, uma abundância de parceiros possíveis, que são escolhidos. Ele lembra que, em muitos casos, parece ser justamente o oposto do que os atomistas vinham apontando:

107

Como também notou Sahlins (2007b), vale lembrar que os próprios objetivos da expansão capitalista não eram tão práticos assim e se deixavam enredar com mais frequência do que se imagina pelas mercadorias com "valor de prestígio". 
“(...) em vez de [bens como cães de caça e aves domesticadas, canoas e matérias-primas processadas, por exemplo] serem adquiridos alhures quando não podem ser produzidos, eles parecem só ser produzidos pelos próprios grupos quando não há possibilidade de obtê-los por meio de intercâmbios com outrem” (2005: 83)

Parece-me que é esse tipo de perspectiva que faz falta no contexto sul-mato-grossense. Nesse sentido, sobre o uso dos metais andinos pelos indígenas das terras baixas, Combès localiza, nos documentos, uma série de evidências:

"El metal, blanco o amarillo, circula bajo dos formas principales: las 'planchas', y objetos labrados, trabajados. Cabeza de Vaca indica que los tarapecocis tienen vasijas, planchas, brazaletes, coronas y hachuelas y otras piezas de metal. Las cargas traídas por Ayolas consistían 'en planchas y brazaletes, y coronas y hachetas, y vasijas pequeñas de oro $y$ plata'. Cuando los itatines fueron 'tierra adentro' a robar metal, 'en los pueblos que saquearon había habido muchas planchas de plata y oro, y barbotes, y orejeras, y brazaletes, y coronas, y hachuelas, y vasijas pequeñas'. Schmidel menciona 'una corona de plata' entre los xarayes, y 'argollas de plata' entre los ortueses. Los usos dados a estos diferentes objetos, y el valor que se les da, diferían evidentemente según los pueblos. Este tema está documentado, aunque bastante pobremente, para algunos grupos del Paraguay y de los llanos. En Asunción misma, los guaraníes o carios utilizaban, según Cabeza de Vaca, hachuelas de cobre durante el rito caníbal; los mismos se adornaban con planchas de cobre, que reverberaban el sol, para ir a la guerra” (2011b: 36).

Como se vê, são usos "decorativos" aos olhos de um observador ocidental, e muito distantes do que se associa aos machados de metal. Evidentemente, esses bens de prestígio são importantes para constituir/diferenciar pessoas, como demonstra em uma enormidade de casos a literatura etnológica. De qualquer forma, sublinho que, em alguns casos, estamos falando de objetos considerados como marcas de identificação de primeira ordem, como é o caso dos tembeta referidos acima - mais uma evidência de que é preciso repensar certos cânones ainda muito presentes na literatura sobre os Guarani. Afinal, segundo certos padrões ainda perceptíveis no que se escreve 
sobre esses grupos, não haveria nada mais "autenticamente kaiowá" do que um estrangeiríssimo tembeta (lembremos que essa é uma das marcas usadas por Meliá et al. - 2008 - para determinar a continuidade entre Itatines, Cainguás e os Paĩ /Kaiowá). Como dizia Sahlins, "as culturas são largamente estrangeiras em sua origem e distintivamente locais em seu padrão" (1999: 412).

\section{Encruzilhadas}

Os estudos de Combès e Julien nos ajudam a recuperar (recriar) a memória das linhas ameríndias com passagem pelo Itatim. São "datos y elementos que obligan a cuestionar la impermeabilidad de la frontera entre los Andes y las tierras bajas orientales, o incluso su real existencia" (Combès, 2011: 100). Baseando-se nas evidências documentais que reúne a respeito das migrações de grupos de língua guarani para a região ao leste dos Andes, ela afirma: "La presencia guaraní en el piedemonte se incrementó fuertemente muy poco antes de la conquista españolamás que probablemente por las noticias de las recientes instalaciones incas en Samaipata $y$ Saypurú - pero, aunque en menor escala, es sin duda más antigua".

Os numerosos depoimentos que mencionam a existência de expedições guarani ao piemonte andino da região de Santa Cruz são a principal evidência em que se ancoram seus estudos. Pesquisas arqueológicas e linguísticas ainda são incipientes - ela cita uns poucos exemplos: uma escavação na cordilheira chiriguana que encontrou cerâmicas datando de pelo menos 1.000 anos a essa ocupação tupi-guarani (ver Pärssinen, 2005) e os trabalhos de Wolf Dietrich $(1986,1990)$, que defende haver evidências de proximidade linguística entre os Guarayo (grupo guarani da região de Santa Cruz, antigamente conhecido como Itatines, por sua origem) e a língua tupinambá.

A autora também menciona outros pesquisadores que supuseram a existência de migrações guarani anteriores às registradas por historiadores como Gandia. Riester, lembra ela, ouviu de um ancião guarasug'we: "Los antepasados caminaban mucho, buscando a Yaneramai” (Riester 1977: 158). "Es decir a "Nuestro Abuelo", al mismo personaje, dios y héroe civilizador que también conocen los actuales guarayos, y cuya tierra está ubicada al occidente" completa ela, para agregar em seguida:

“Según Riester [...], los guarasug’we o pausernas podrían ser frutos de aquellas migraciones más remotas en el tiempo. Como ya lo sugirió por ejemplo Sanabria Fernández [...], la misma hipótesis podría aplicarse a los 
actuales sirionós y yuquis de Bolivia, sobre cuyas migraciones son mudas las fuentes coloniales" (2011b: 61)

Combès também menciona as conhecidas evidências sobre estradas pré-hispânicas que faziam a ligação entre o litoral brasileiro e os Andes - o Peabiru, relacionado nas crônicas coloniais a São Tomé, em função da identificação, feita pelos jesuítas, entre entidades tupi-guarani como Pai Sumé e Maíra e esse personagem bíblico. Para ela, o caminho feito pelos Chiriguanos até o piemonte andino corresponde "exatamente" ao caminho do Pai Sumé. "Este trayecto fue, hasta donde podemos reconstruirlo, el que siguió el portugués Alejo García en los años 1530 significativamente apodado Maratía (Maire Ata) por sus acompañantes guaraníes" (op.cit: 107) ${ }^{108}$.

A autora finaliza seu artigo expondo o intrincado lio envolvendo as transformações entre denominações pré-hispânicas desses personagens, e as especulações jesuíticas e coloniais, que mesclavam sonhos com terras ricas, paraísos terrestres e interpretações da Bíblia. De qualquer forma, vale reter que seu intento é, mais uma vez, mostrar que há fortes evidências de que relatos como os de Pai Sumé e suas relações com figuras como Maíra, Karai, o Paititi, o "Rei Branco" e, por fim, Tupã (Tunupa nos Andes, Tumpa no piemonte andino) demonstram, acima de tudo, a realidade de intensas linhas pré-coloniais de comunicação e circulação entre Andes e Terras Baixas.

As interpretações clássicas a respeito dessas coincidências e ligações - de que teriam sido obra de uma difusão realizada pelos jesuítas - perdem força diante de estudos mais recentes. São "numerosos demais" para ser considerados "simples fábula", conclui ela, para em seguida afirmar:

"Con sólo admitir, como todo parece demostrarlo, que debajo de los inventos jesuitas existen mitos y creencias indígenas y prehispánicos, pues entonces tenemos que admitir también la evidencia: estamos frente a huellas o fragmentos de un extenso complejo de creencias prehispánicas compartidas entre tierras altas y tierras bajas, un complejo que reúne a héroes civilizadores, metal, rayo y reinos fabulosos. Sirvió por cierto a los indígenas para 'pensar a los blancos' - sea para nombrarles (Maire, Viracocha, etc.), sea para explicar, mediante el mito del reparto de las armas, su superioridad técnica; pero también fue pensado por los cristianos

\footnotetext{
108

Note-se que, para Meliá, Grünberg e Grünberg (2008: 17), Maratía seria uma transformação de García, tão somente. Combès (2011b) mostra que há uma serie de associações de termos compostos por maire, como maire ata ou maire monan, relacionadas ao complexo de figuras sobrenaturais que inclui Pai Sumé, Tupã etc. A associação de maratía a maire ata é feita pela própria Combès. Sobre São Tomé, ver ainda Cavalcante, 2008.
} 
y europeos en general en función de sus propios mitos, creencias y esperanzas - el Pai rey o el Pai santo, el reino de oro o el Edén - en un juego de ecos y espejos entre cosmovisiones." (2011: 110)

\title{
Sem karai não há teko
}

O intertítulo é uma evocação, e a transformação, de uma célebre - entre guaraniólogos formulação de Meliá:

\begin{abstract}
“(...) la categoría del tekoha, lugar de modo de ser, de cultura, de teko, significa y produce al mismo tiempo relaciones económicas, relaciones sociales y organización político-religiosa esenciales para la vida guaraní. En otros términos: la categoría de espacialidad es fundamental para la cultura guaraní, ella asegura la libertad y la posibilidad de mantener la identidad étnica. Aunque parezca un paralogismo, hay que admitir, con los mismos dirigentes guaraní, que sin tekoha no hay teko” (1993: 106).
\end{abstract}

Sem questionar a relação entre modo de ser/qualidade de vida/autonomia e território, que é insistentemente frisada pelos grupos de língua guarani desde tempos coloniais, como veremos no capítulo 3, pretendo, aqui, lançar uma reflexão sobre certo aspecto menos percebido, a relação entre o contato com outros povos - e particularmente, com os karai, os brancos ${ }^{109}$ - e a objetivação e afirmação da "cultura" (Carneiro da Cunha, 2009) - no caso, o teko guarani.

O antropólogo estadunidense Marshall Sahlins não foi o primeiro, mas talvez tenha sido o mais recente entre os grandes nomes da disciplina a frisar a urgência de que a antropologia supere sua insistência em enxergar as "sociedades e culturas como mônadas auto-organizadas", indo além das análises que frisam descontinuidades e singularidades para descobrir o mundo das continuidades e dos regionalismos:

\footnotetext{
109

Karai, como já dissemos, é o termo que os Guarani e Kaiowá usam para referir-se aos brancos. As mulheres brancas são kuña karai. E os Kaiowá, em oposição aos karai, são ava. Trata-se de termos cujos significados deslizaram ao longo do processo de colonização. Karai, no caso, é termo, até hoje, relacionado a personagens sobrenaturais, ou à ação xamânica, entre os Guarani do litoral, e usado como nome próprio. No período colonial, encontra-se entre os Tupi do litoral, a alusão aos caraíba, xamãs que erravam entre as aldeias (Clastres, 1978). Uma observação: entre os Guarani do litoral do Sudeste brasileiro, karai segue sendo um nome para designar seres sobrenaturais e pessoas, e juruá (“boca com pelos”, barbudo) é o termo usado para os brancos.
} 
"O escândalo é que, enquanto culturas foram, assim, concebidas como autônomas e sui generis, elas sempre foram situadas em campos históricos mais amplos de 'outros culturais' e em grande parte formadas em relação umas com as outras. Até mesmo a autonomia é uma relação de heteronomia. Mas nossas principais teorias de ordem cultural, baseadas todas em epistemologias insulares, pressupõem que as sociedades estão todas sozinhas e que as culturas, por assim dizer, fazem a si mesmas" (Sahlins, 2010: 1).

As relações de alteridade são condição para organizar a consistência interna e a identidade de uma cultura, sublinha Sahlins, chamando a atenção para observações pregressas de autores como Barth e Lévi-Strauss. Se essa formulação tem forte apelo quando aplicada às culturas em geral, ainda mais se pode dizer sobre os ameríndios, entre os quais, como já destacamos, a diferença é motriz fundamental do socius (Lévi-Strauss, 1993).

A "perversidade", diz o autor, começa quando Malinowski funda a etnografia moderna com um estudo das articulações internas dos diferentes aspectos da cultura de Trobriand, cuja população "participava de uma vasta rede de trocas envolvendo, entre outras relações intersociais de ordem, modos complementares de produção e uma política de reputação externa" (2010: 2). Para Sahlins, todas as correntes mais conhecidas da antropologia, em alguma medida, incorreram nesse problema, da sociologia durkheimiana aos marxistas: "Claramente, o nacionalismo tem sido um fardo, um nó para a antropologia." (idem).

A oposição entre os conceitos francês de civilização e alemão de cultura, mote do debate intelectual europeu nos séculos XVIII e XIX, está, obviamente, na base disso tudo, argumenta Sahlins. Ou seja, haveria aí um grande paradoxo, pois a ideia de cultura como objeto antropológico constituído "por e para si mesmo" se desenvolveu a partir de uma relação "entre ordens culturais europeias - e mais especificamente, a partir da interdependência de suas diferenças" (2010: 4).

O autor não se limita a criticar. Essas formulações iniciais servem de trampolim para uma série de propostas. Em primeiro lugar, Sahlins relembra que, para além das relações de assimilação e diferenciação entre sociedades vizinhas, existiu, outrora, a ideia de "áreas culturais", "ecúmenos regionais" onde se dava um campo mais amplo de "influências mútuas":

"O dinamismo era inerente ao ordenamento dessas regiões por gradientes 
de autoridade cultural, poder e valor emanando de um ou mais centros estrategicamente situados.” (2010: 5)

Esses focos de "clímax cultural", de onde se irradiam "poder, valor e autoridade cultural" constroem uma hierarquia, uma relação centro-periferia, aponta Sahlins. Estamos acostumados a pensar esse tipo de fenômeno exclusivamente em relação às modernas metrópoles capitalistas, mas o autor adverte: “A maior parte do planeta já foi mapeada por eras em áreas culturais com essa forma hierárquica - envolvendo também distinções invejosas de sofisticação cultural” (idem).

Como exemplos, Sahlins lembra a divisão de áreas culturais entre os indígenas norteamericanos, conforme proposta por Kroeber. Na Melanésia, o autor lembra estudos de Deborah Geertz e Simon Harrison, que constatam fenômenos semelhantes. "Certas noções de desenvolvimento cultural e subdesenvolvimento não nasceram ontem, ou exclusivamente no moderno Sistema Mundial", comenta o americano (op.cit: 6). O fenômeno, segundo o autor, era amplificado quando "centros reais" organizavam o processo, dominando outros grupos étnicos, algo comum em muitas áreas da Ásia, África e, também, das Américas, além da própria Europa, no tempo da expansão colonial europeia.

Esses "sistemas galácticos", como os chama Sahlins, aludindo a estudo de Tambiah sobre realezas do Sul da Ásia, relacionam-se a uma "política cultural da alteridade" que envolve variações da ideia de "rei estrangeiro" (stranger-king). E é uma descrição de um modelo geral para a recorrência dessas formações que o autor realiza a seguir. Nós retomaremos essa parte da exposição de Sahlins no capítulo seguinte, pois ela guarda especial importância para que pensemos a figura do líder entre os Kaiowá. Por ora, interessa-nos pensar essa ideia dos "sistemas galácticos".

Em referência à obra de Tambiah sobre a Ásia meridional, Sahlins lembra que os estudos sobre a região mostram como um centro "civilizatório" pode estabelecer uma dialética de "assimilação e diferenciação" com grupos das periferias "bárbaras”. O sistema tributário, o comércio, tudo isso se entrelaça à concessão de títulos a privilégios a chefes aliados do poder central como forma de firmar alianças e ao mesmo tempo proteger as periferias do império - tratase, na visão do autor de um grande esquema de trocas de valores em que, mutuamente, um lado concede poder ao outro, ao mesmo tempo gerando hierarquias e vantagens materiais e políticas. A "política cultural da alteridade" que aí se instala estabelece um regime de reciprocidade entre as duas partes, centro e periferia, que trocam "poderes vitais" (2010: 20). 
Toda essa dinâmica, por suposto, tem de fazer sentido do ponto de vista da "periferia". O autor lembra que, no plano local, essa apropriação de elementos de poder vindos do exterior tem sua própria finalidade: "A estratégia é vencer na competição nativa utilizando poderes transcendentais em proveito próprio: poderes acima e além da sociedade e suas bases habituais de autoridade" (op.cit: 24). Para Sahlins, tal processo, de "diferenciação pela assimilação", ou "aculturação antagonística".

Em que sentido tudo isso que é dito por Sahlins pode ajudar na modificação de nosso olhar para a história dos grupos de língua guarani de Mato Grosso do Sul? Evidentemente, seria necessário, ainda, discutir em que medida essa ideia de "sistemas galácticos" poderia ajudar na caracterização e na compreensão do quadro pré-hispânico/pré-cabralino, no que tange às relações Andes/Terras Baixas.

Note-se, de qualquer forma, que as evidências reunidas por Combès e Julien trazem incontornáveis questionamentos a respeito dos movimentos e intercâmbios envolvendo populações da bacia platina. $\mathrm{O}$ fato é que, como procuramos demonstrar, os dados da história recuperados pelas citadas autoras $^{110}$, com suas descrições sobre as expedições rumo aos Andes e as redes de circulação de metal e cativos, desafiam os estereótipos sociopolíticos construídos para os grupos guarani.

\section{Pêndulo}

O testemunho de Montoya é, por vezes, utilizado para mostrar que o modo de assentamento dos grupos guarani de Guairá e Itatim se mantém inalterado desde o século XVII:

“Note-se que chamamos 'reduções' aos 'povos' ou povoados de índios que, vivendo à sua antiga usança em selvas, serras e vales, junto a arroios escondidos, em três, quatro ou seis casas apenas, separados uns dos outros em questão de léguas duas, três ou mais, 'reduziu-os' a diligência dos padres a povoações não pequenas e à vida política (civilizada) e humana (...)” (Montoya, 1985 [1639]: 34).

Esse padrão de dispersão das aldeias guarani descrito pelo jesuíta, junto com outros escritos

110 Combès nos lembra que se trata, quase sempre, de documentos que já estavam disponíveis aos autores mais antigos, como Métraux e Nordenskiöld. Portanto, trata-se aqui de uma mudança de olhar, não de alguma descoberta espetacular que traga dados inéditos para nossa análise. 
do mesmo período, costuma ser usado no sentido de demonstrar a "persistência" dos padrões guarani/kaiowá de assentamento. Ocorre que o padrão disperso não era o único possível entre os tupi-guarani.

Entre os Tupi do litoral - se falamos do Guairá, projetando os dados para o Itatim, por que não poderíamos fazer o mesmo em relação ao litoral atlântico? -, outro padrão aldeão foi amplamente documentado e comentado pelos cronistas. Há mesmo famosas gravuras que mostram as aldeias com pátio central, 4 a 7 malocas em volta (vide as que são reproduzidas em Fernandes, 1989). Mas não é somente por lá que as aldeias fortificadas eram encontradas.

Os relatos do marinheiro bávaro Ulrich Schmidl, que participou da fundação de Buenos Aires e Assunção e acompanhou diversas expedições ao longo do rio da Prata entre 1534 e 1552, também mencionam o mesmo tipo de assentamento (grandes aldeias reforçadas por paliçadas) ao longo do rio, e ele é associado diretamente aos Cario (carijó, ou seja guarani) em pelo menos uma das gravuras que ilustraram as primeiras edições de seus relatos (a edição eletrônica que consta da bibliografia também as reproduz). Transcrevo, a seguir, um trecho mais longo sobre Lambaré, uma das aldeias que se localizava onde hoje é Assunção:

\begin{abstract}
“(...) la ciudad de ellos está rodeada con 2 pallersaide (palizadas) de madera, cada poste del grueso de un hombre; y la una pallersaide está a 12 pasos de la otra; los postes están enterrados o clavados en hondura de 6 pies, y se levantan del suelo lo que puede alcanzar un hombre con la punta de su tizona. Iten habían cavado unos fosos, también a distancia de 15 pies del muro de esta su ciudad habían dejado unos hoyos en que podían pararse 3 hombres, adentro habían clavado (como para que no sobresaliesen) estacones de palo duro y puntiagudos como aguja (...)” (Schmidl, 2001)
\end{abstract}

Da edição disponível na internet, constam ainda notas preparadas pelo tradutor D. Samuel A. Lafone Quevedo, em que ele menciona, especificamente, essa descrição das aldeias fortificadas dos Cario. Para o tradutor, contudo, embora a descrição das aldeias guarani seja "minuciosa", as ilustrações do artista não foi fiel ao desenhar paliçadas nas aldeias dos demais povos, isso não estaria no texto, sendo sua "invenção":

Las «demás naciones» no contaban con más palizadas que sus piernas 
largas para huir, cuando no se creían con poder bastante para triunfar del enemigo, cristiano o indio. Esta es una de las grandes diferencias que Schmídel establece con perfecta claridad, porque siempre habla de los pueblos (fleckhen) en general, mientras que a propósito de los carios ya los distingue con esta advertencia: pueblo o ciudad, fleckhen oder stet.” (in Schmidl, 2001)

Não por acaso, Schmidl é comparado ao conterrâneo Hans Staden, justamente o autor cuja obra contém as ilustrações mais comumente reproduzidas quando se trata das aldeias fortificadas dos Tupi do século XVI.

Para que não se imagine que Lambare era um caso isolado, há outras menções a aldeias cario fortificadas ao longo da obra de Schmidl ${ }^{111}$. As cenas narradas ocorrem por volta de 1545 a 1546, e a referida campanha contra os Cario alcançou aldeias até a região do rio Jejuy ${ }^{112}$. No capítulo 33, ele relata a guerra dos espanhois à aldeia de um cacique chamado Tabaré, o qual queria vingar-se dos espanhóis pelo enforcamento de seu irmão, Aracaré. Dois mil e quatrocentos homens saem de Assunção para atacá-lo:

\begin{abstract}
“Mas este Dabere (Tabaré) no quiso ceder ni prestarse; tenía mucha gente reunida y su pueblo bien fortificado con palizadas, que es un muro hecho de maderos; de estos muros tenía el pueblo 3 a la redonda y zanjas muy anchas" (idem)
\end{abstract}

Ao fim, a proteção é superada pela tropa dos espanhóis com facilidade, e Schmidl relata que 3 mil Cario foram mortos na aldeia sitiada. O cacique, então, se rende e jura fidelidade aos espanhóis. Mais adiante, no capítulo 42, ele fala de outra expedição, com 1.350 homens, incluindo combatentes não guarani, os Batatás e Yeperus, enfrentando 15 mil Cario, os quais se refugiam na aldeia do cacique Mairairu, chamada Fronteira (alusão, segundo o tradutor acima referido, ao fato de que a aldeia seria a última dos Cario na região, constituindo-se em fronteira com os Paiaguá/ Guaikuru) após um massacre em que teriam sido mortos 2 mil Cario $^{113}$ :

111 Menção a aldeia guarani fortificada também é encontrada em Cabeza de Vaca (1944: 204).

112 Em cuja cabeceira, encontram-se, atualmente, aldeias paĩ-tavyterã, como se nota em Melià, Grünberg e Grünberg (2008: 58).

113

Os números apresentados por Schmidl são objeto de desconfiança, mas opto por apresentá-los aqui para que se perceba que, de alguma forma, ele indica que não se trata de grupos pequenos, sempre se refere a grandes quantidades de pessoas, grandes aldeias, grandes batalhas etc. 
"Pero sucedía que estos mismos carios habían defendido su pueblo con 3 palizadas construidas de madera, en forma de muro; estos postes eran del grueso de la cintura de un hombre o más, y desde el suelo se levantaban unas 3 brazadas y lo enterrado sería como del alto de un hombre. Ítem más tenían de aquellos hoyos en que habían clavado 5 ó 6 estacas pequeñas, afiladas como agujas, y plantadas en cada hoyo, de las que ya se dijo algo en el capítulo XXI; ahora este pueblo de ellos era muy fuerte, y en él había mucha chusma, para no decir nada de la gente de pelea" (idem)

Os espanhóis e seus aliados indígenas logram romper a resistência da aldeia, e sobrevém novo massacre. Mas, a maioria dos Cario que ali estavam consegue fugir para outra aldeia fortificada, Karaiba. Os colonizadores recebem reforço, são 1750 homens, já:

"Pero a esto nuestros enemigos habían fortificado y asegurado tan bien este su pueblo Karaiba, tal vez como jamás antes se había hecho, es decir con palasaiten (palizadas) y muchos fosos. Ítem más, habían ellos preparado unas cuevas de maderos en forma de trampas de ratones; si éstas hubiesen salido al colmo de sus deseos, cada una de ellas nos hubiese muerto hasta 20 ó 30; de las tales se habían construido muchas cerca de este su pueblo. Mas Dios el Todopoderoso nada de esto permitió; ;sea Él alabado y loado eternamente!" (idem)

Ao fim, mais um grupo acaba sendo derrotado, e a narração adquire tom sarcástico, em função de episódio que lembra o acima discutido sobre os Tamoio e terá outras ressonâncias ao longo deste trabalho:

"Delante de este su pueblo Karayeba estuvimos acampados 4 días, sin poderles sacar ventaja alguna, y al cabo por traición, que nunca falta en el mundo, allá vino un indio de los enemigos carios durante la noche a nuestro real a ver a nuestro capitán Marthin Doménigo Eyolla; era aquél un principal de los carios y a él obedecía el pueblo. Este pidió que no le quemásemos ni destruyésemos su pueblo, que él nos mostraría cómo y de qué manera era de tomarlo; así le prometió nuestro capitán que no permitiría que le hiciesen mal. Después de lo cual este carios nos mostró un camino escusado en el bosque por el que deberíamos nosotros llegar al 
pueblo, y dijo que él encendería fuego en el dicho pueblo cuando llegase el momento de meternos en él. Como que todo sucedió tal cual se había arreglado y mucha gente pereció a manos de nosotros los cristianos y fue destruida (...)” (idem)

Assim, se as descrições jesuíticas sobre assentamentos guarani no Guairá, no século XVII, podem ser utilizadas para amparar nossas etnografias do século XXI, será necessário levar em conta, também, esse tipo de material.

Nossa conclusão é que, para caracterizar devidamente a organização social dos grupos guarani, é preciso trabalhar com uma perspectiva mais ampla e entender essa conformação retratada por Montoya como uma das possibilidades disponíveis de conformação do grupo local, mas não a única. Preferimos assumir aqui uma perspectiva que dialoga com o que Perrone-Moisés (2006) sugere para o caso guianense.

Ali, constata ela, podem-se verificar documentos do período colonial que dão conta da existência, em alguns momentos, de grandes aglomerações (no estilo do que os arqueólogos chamam de cacicado, ou chiefdom), totalmente desfeitas poucas décadas depois. Para explicar a coexistência de possibilidades de organização tão diversas, ela propõe uma interpretação estrutural, a partir da sugestão de Santos Granero (1993) para os Amuesha subandinos (grupo arawak).

Ele observa, ali, uma espécie de oscilação periódica entre tendências centrípetas e centrífugas, comparando-a ao sistema gumsa/gumlao que Leach (1996) mostrou existir na Alta Birmânia (hoje Mianmar). Perrone-Moisés, por sua vez, propõe que os sistemas políticos ameríndios poderiam ser pensados a partir da ideia de uma "transformação constante":

"A pesquisa nas Guianas tem, de fato, indicado que tanto a formação de grandes aglomerados quanto a dispersão de pequenos 'grupos locais' são constantes, de modo que se pode considerá-las ambas 'típicas' na região. (...) A constatação entre os Amuesha certamente pode (e deve) ser tomada como sugestão para a análise de outros casos, e talvez se chegue à conclusão de que, afinal, 'amerindian leadership in general' não equivale diferentemente do que afirma Santos Granero - ao polo 'clastriano' da equação, mas exatamente a essa flutuação. Se a classificação das formas políticas ameríndias (do período pré-colonial até os dias atuais) dá tanta 
margem a debate e discordância, talvez isso se deva não apenas à dificuldade inerente à proposta de uma linha evolutiva orientada, mas sobretudo à tentativa de caracterizar mundos alheios às nossas (ocidentais) preocupações com identidades, essências, cristalizações e permanências. (...) Não se trataria de linha evolutiva que leva fatalmente à máxima concentração do estado, nem tampouco ciclo (que é outra forma da linha), mas de pulsação entre polos de uma constante transformação.” (op.cit: 8)

Essa ideia de pulsação entre polos, Perrone-Moisés a desenvolve a partir da proposta levistraussiana sobre uma "filosofia bipartite" ameríndia, um "dualismo em perpétuo desequilíbrio":

"Se os mundos ameríndios fogem continuamente de definições $e$ caracterizações inequívocas (e não apenas no tocante à sua organização política), é certamente porque sua filosofia bipartite (cf. Lévi-Strauss 1991) supõe o constante jogo entre possibilidades antitéticas. $O$ que significa dizer que seus polos sempre estão presentes, é de sua presença concomitante que depende o bom andar do cosmos. Não são mundos do isso ou aquilo, mas mundos do isso e aquilo. Já em 1952, discutindo exatamente a noção de 'arcaismo', tão presente nas discussões aqui mencionadas, LéviStrauss apontava para a existência de 'discordâncias internas' que caracterizam várias culturas ameríndias, conferindo-lhes sua 'individualidade' (...). Diferença é o que funda as cosmologias ameríndias, diferir é a 'regra de ouro' - o que supõe, antes de tudo, diferir de um 'si mesmo' que é ele mesmo diferença. Mundos concebidos na e pela alternância, no eterno desequilíbrio, escapam, não por acaso, a qualquer unificação analítica. Sempre falta a síntese (...), que na filosofia ameríndia equivaleria à morte” (op.cit: 8$)^{114}$.

É nesse sentido que proponho examinarmos os documentos coloniais que dão conta de

114 Vale notar, o modelo proposto por Perrone-Moisés tem notáveis ressonâncias com as mais recentes conclusões sobre a pesquisa arqueológica na Amazônia. Por exemplo, Heckenberger e Neves resumem da seguinte forma o que supõem ser o cenário político amazônico a partir de 2,5 mil anos atrás: "Sociedades multiétnicas, sistemas sociopolíticos regionais e interação interregional sublinham os diversos caminhos da complexidade social na região. Nesse contexto, povoados permanentes, politicamente independentes, podem ter se juntado periodicamente em confederações regionais mais amplas, por exemplo, em torno de líderes singulares e da guerra. Em outros casos, sociedades regionais mais centralizadas e hierarquizadas estavam integradas através de rituais e trocas de elite, embora tenham mantido diversas estratégias de poder político, como é conhecido de diversas áreas durante o milênio final da pré-história” (2009: 254-5, tradução minha). 
outras possibilidades de formações locais e regionais - e, portanto, outras composições das linhas (centrífugas, centrípetas) - entre os grupos de língua guarani.

$\mathrm{Na}$ obra de Soares, encontramos várias outras evidências de que as linhas guarani précabralinas não se limitavam a essa relação com os Andes e que podiam envolver, ainda, segmentaridades circulares em nível regional, de alguma forma. Mas, antes de prosseguir, um parênteses: o referido autor defende em sua dissertação, voltada para os Guarani coloniais, que a "sociedade guarani" pode ser considerada um exemplo de "cacicado"115:

\begin{abstract}
"A presença de enterramentos diferenciados, de hierarquia entre as chefias (tanto política quanto religiosa), a existência de uma liderança que é reconhecida dentro de uma região, os elos de parentesco sanguíneo e político que ligam as aldeias, a existência de uma agricultura desenvolvida capaz de gerar excedentes, assim como a unidade sócio-política presente nas parcialidades (...) permitem falar em cacicado.” (Soares, 1996: 35)
\end{abstract}

Como já explicado, o que desenvolveremos aqui é a ideia de que se trata, isto sim, de um exemplo de “dualismo em perpétuo desequilíbrio". No entanto, os exemplos e a bibliografia recolhida por Soares e outros nos auxiliam em nossa empreitada em função de os modelos construídos para os Kaiowá e Guarani considerarem, unicamente, um padrão político de dispersão e acefalia como o "tradicional". O que vamos demonstrar aqui é que é possível recolher, nas fontes, exemplos de organização política que desafiam os estereótipos construídos nas etnografias.

Note-se que Soares faz um apontamento singular a respeito do termo boia - em outros lugares, voja (ver Guasch, 2008 e também a tradução oferecida por Montoya para "vassalo, súdito ou menor" - 2002: 394) ${ }^{116}$. Os termos indicariam uma possível relação de subordinação:

115 Soares faz a ressalva de que o "cacicado guarani” não tem todas as características de um chiefdom ameríndio centro ou norte-americano - "no palco das generalizações, encontramos a presença de hierarquia social através de adornos e vestimentas, silos, templos, cidades, centralização de poder político e/ou religioso hereditário (...) que não se adaptam ao caso guarani”" (op.cit: 35) -, mas emenda: "também se sabe que as particularidades do caso Guarani não inviabilizam a instituição do cacicado, pois várias regiões o apresentam (particularidades)". O trecho se encaixa perfeitamente no que questiona Perrone-Moisés (2006) a respeito do conceito de cacicado. A autora observa que a flexibilidade da definição e sua "instabilidade" intrínseca permitem que os defensores do conceito - calcados, como ela demonstra, em uma visão evolucionista - vejam cacicados por todas as partes. "De todo modo, o 'cacicado', essa configuração intermediária entre a 'tribo' e o 'estado', é ao mesmo tempo definida com precisão pelos trabalhos que a ela se dedicam, e suficientemente vaga, por ser uma transição, para abarcar variações” (op.cit.: 6). 116

No Tesoro (1639: 81-2), Montoya, no verbete boya, explana: "mediano, menor, súdito. Aba boya, hombre de mediano cuerpo, o vasallo. Cheboya, mi menor que yo, mi ?, o vasallo, mi súdito. Che arakuaaboya, tengo mediano entendimiento. Igaboya, canoa mediana. (...) Tupã boya, los siervos de Dios (...)". Chamorro (2008: 349) localiza o 
"A relação vassalagem-prestígio é perceptível através dos verbetes che aruçu chebóya rehê- 'tenho muitos vassalos'251.(T:4 $\left.{ }^{117}\right)$, em contraposição à oñembo tigue cheboya chehegui- 'todos meus vassalos acabaram' (T:391) ou ndache apocuêri - 'não fiquei com nenhum vassalo’ (T:63). (...)Talvez outra tradução de Montoya seja mais esclarecedora para esta instituição: gueimochere recóramocherapiâcatû- 'por ser seu caudilho me obedecem', oibamo cherereco - ‘têm-me por seu caudilho' (T:165)’(Soares, 1996: 36).

Relações descritas como de vassalagem são comuns na história dos povos da bacia do Prata e do Chaco ${ }^{118}$. Elas envolviam, em geral, a prestação de tributos em espécie, segundo as fontes. Aqui, para os Guarani, não ficam claros os detalhes do que seria essa relação voja/tuvicha. Em algumas fontes, a tal condição de "vassalo" parece não ter outro sentido que a de súdito - no caso, parente mesmo. Müller, por exemplo, considera que mbodja quer dizer adepto e não súdito. Ele faz a distinção como crítica a uma "tradução errônea" do termo, por parte de Hernández (1913), e logo após afirmar:

"Las leyes políticas fundamentales [entre os Guarani] son, en lo que se refere a asuntos civiles, muy democráticas y no permiten al cacique decretar ninguna cosa importante pasando por sobre su gente. Por eso en el estado indígena no hay súbditos propriamente dicho. Se es adepto al cacique hasta tanto su autoridade no resulte pesada” (Müller, 1989: 57).

Uma pista para o tipo de relação aí envolvido está em Hernández (1913: 112), justamente, quando ele afirma que os "súditos" dos caciques entregavam-lhes suas filhas como "concubinas" ou seja, mais uma vez, a poliginia.

O próprio uso do termo "cacicado" para os grupos de língua guarani pode envolver alguma confusão, pois, muitas vezes, o que se verifica na bibliografia colonial é o uso do termo cacicazgo, como sinônimo da instituição da chefia indígena reconhecida pelo governo espanhol. Nesse sentido, um cacicazgo se relacionava, na realidade, a um grupo local, muito pequeno - e não se referia à associação entre vários líderes locais, no sentido que se empregou recentemente na Arqueologia o

uso de termo correlato entre os Kaiowá, no âmbito da iniciação masculina, o mitã pepy. Ivoja é o iniciando que já tem um irmão iniciado - este, o tuvicha, termo que designa ainda, segundo ela, o primeiro a iniciar-se.

117 T é a abreviação para o título do Tesoro de la Lengua Guaraní, de Montoya (1876 [1639]).

118

Susnik (1989) oferece uma boa síntese sobre a história dos povos indígenas da região, com vários dados a esse respeito. 
termo “cacicado". Soares (1996: 35-6) parece desconsiderar essa possibilidade ${ }^{119}$.

Alguns autores já assumiram formulações mais definitivas a respeito da inexistência de "unidades (sociais) mais amplas" entre os grupos tupi-guarani da costa atlântica, considerando-se os documentos dos séculos XVI e XVII. Na leitura que Fausto (1992) faz de Fernandes (1989), não haveria dados significativos, nos cronistas, sobre a existência de "unidades sociais discretas" para além das aldeias. Nesse sentido, para Fausto, os designativos consagrados pelos europeus nas descrições de "nações", “castas" ou "gerações" ao longo do litoral brasileiro não são "representação acurada da morfologia sócio-política dos Tupi da Costa, muito pelo contrário” (op.cit: 383).

Revendo o trecho de Fernandes que é citado por Fausto, e considerando uma leitura mais conforme ao que propõe Perrone-Moisés, podem-se tirar conclusões distintas:

Sobre a articulação dos grupos locais em unidades mais amplas, designadas como 'tribos' pelos autores quinhentistas e seiscentistas, nada consegui obter de significativo. As referências mais explícitas são as do pe. Abbeville. Pelas indicações deste autor, conclui-se que os grupos locais do Maranhão se vinculavam mais intimamente na base da contiguidade espacial. Contudo, não é possível dizer se os grupos locais da Ilha, os de Tapuitapera e os de Cumá constituíam, em virtude disso, unidades sociais inclusivas. Abbeville apenas assegura categoricamente que todos eram amigos e aliados, 'formando uma só nação, uma confederação unida na guerra às demais nações inimigas'.” (Fernandes, 1989: 72)

No capítulo em que passa por esse tema, vale observar, Fernandes se mostra preocupado com a questão das "unidades sociais" e está falando sobre os "grupos locais" dos Tupinambá, no contexto de um livro sobre "organização social”. No início do capítulo, ele nos dá o seguinte referencial:

“O grupo local, descrito pelos antigos cronistas sob o nome de 'aldeia', constitui uma unidade social de grande importância analítica, quanto aos Tupinambá. É o grupo social que se coloca entre a menor unidade territorial - a 'maloca' - e a unidade territorial inclusiva, a tribo. (...) Para

\footnotetext{
119

Essa incongruência (o fato de que os caciques, na verdade, eram líderes de pequenos grupos locais) foi apontada por autores como Wilde (2003) e Melia (1993) - veja-se discussão a respeito em Mura, 2006: 41-3.
} 
designá-lo poderia também usar o termo tupi-guarani Taba.” (op.cit: 55)

Como se vê, temos aqui, mais uma vez, um autor para quem o conhecimento sobre a unidade é fundamental. No quadro teórico em que refletia Fernandes, a pressuposição de unidades obrigava a tais proposições. Não é o caso de autores mais recentes, como Perrone-Moisés e Sztutman (2010), que apresentam outro olhar sobre situações como a descrita por Abbeville.

Nos últimos anos, os escritos de autores como Latour têm recuperado outras possibilidades de orientação para uma socio-logia, como as aventadas por Tarde (2007), ainda na época de Durkheim. A partir disso, questiona-se o sentido mesmo de uma ciência social - a qual passa a ser menos humana (no sentido que o termo tem para os ocidentais) e mais relacional:

"Se bem que a maioria dos cientistas sociais preferiria chamar de 'social' uma coisa homogênea, é perfeitamente aceitável designar com o mesmo termo uma sucessão de associações entre elementos heterogêneos. Dado que em ambos os casos a palavra retém a mesma origem - da raiz latina socius -, é possível manter-se fiel às intuições originais das ciências sociais ao redefinir a sociologia não como 'a ciência do social' senão como o rastreamento de associações. Neste significado do adjetivo, o social não designa algo entre outras coisas, como uma ovelha negra entre ovelhas brancas, mas um tipo de relação entre coisas que não são sociais em si mesmas”. (Latour, 2008: 19)

Mas é que, aqui, estamos tratando de pensar as associações, de pensar as redes, e é por isso que uma discussão sobre "unidades" ressoa tanto. É que parece, justamente, o tipo de etnologia que precisamos superar para poder compreender melhor não só o que lemos nos cronistas coloniais, mas o que vemos no campo hoje em dia.

A Confederação dos Tamoios (1556-1567) foi um episódio em que, justamente, os grupos de língua tupi do litoral organizaram, temporariamente, o que, do ponto de vista de alguns, poderia ser visto como uma "unidade social mais ampla", aliada aos portugueses e, por sua vez, oposta a outra coalizão tupi aliada aos franceses. Como lembram Perrone-Moisés e Sztutman (op.cit: 408), o ocorrido no Maranhão que é referido por Abbeville, cinquenta anos depois, foi como que uma repetição da guerra dos Tamoios.

No olhar de alguém com formação evolucionista, como destacam os autores, isso certamente 
seria uma prova, ou de que os Tupi poderiam chegar a ter Estado e não o fizeram em função da colonização, ou de que a colonização foi que proporcionou as condições para que isso acontecesse e, na realidade, eles jamais teriam condições de ter um Estado. Afinal, se alguém ainda não é uma unidade, é porque ainda não pôde sê-lo, mas é natural que esse seja seu maior desejo íntimo, seu devir inescapável - na lógica ocidental atual, pode ser quase imperdoável não ser uma unidade. Pois o que se propõe é uma leitura diferente, afim ao que Perrone-Moisés já observara em relação às Guianas (2006, discutido acima):

"O que propomos, diferentemente de Clastres, é que a confederação dos Tamoio não constituía um movimento em direção a um cacicado, um protoEstado, enfim, uma formação do tipo Estado. Sinalizava, antes, a possibilidade de transformações reversíveis, que não podem ser compreendidas como meras reações à Conquista e que dizem respeito a mecanismos pendulares próprios da ação política indígena, esta que teima em subordinar o contorno das formas a forças heterogêneas." (op.cit: 425)

Como se vê, a crítica abrange, também, Clastres na medida em que ele, de certa forma, imaginava que a "recusa do Um" característica das "sociedades contra o Estado" estaria sendo superada, entre os Tupi, naquele momento de sua história, por "formas políticas mais complexas", em um "movimento sem volta". Perrone-Moisés e Sztutman, por sua vez, imaginam que se trata de um movimento (ponto). Não há unidade na confederação, é verdade, mas tampouco há unidade no grupo local. Nem Clastres, nem Florestan, muito pelo contrário:

“Os Tamoio não são uma unidade, pois contêm em si a multiplicidade, essa possibilidade de uma explosão de diferenças, mesmo entre pessoas próximas. No mundo Tamoio, qualquer unidade, local ou supralocal, não importa, conteria em si o seu contrário, ou melhor, traria sempre em si o movimento necessário em direção ao seu oposto, assumindo em seu caráter necessariamente efêmero uma recusa do Uno, da identidade, da fixidez. Toda unidade apresentada, bem como sua representatividade, consistiria numa realidade momentânea já tendendo a uma traição inevitável” (op.cit: $24)^{120}$.

120 Embutida nessa formulação de que o grupo local contém em si o seu contrário está a ideia de uma "incompletude ontológica, na qual existir é devir, mais especificamente devir-inimigo" (idem), conforme escreve 
Um exemplo interessante de como essa questão do tal "domínio regional" de um cacique está no Itatim do século XVII, no caso do líder e xamã Nanduavusu ${ }^{121}$. Logo ao chegar à região do Itatim para instalar as missões jesuíticas, em $1633^{122}$, o padre Diogo Ferrer (substituto, na tarefa, de Antonio Ruiz de Montoya) informava a seus superiores:

\section{“Todos estos Itatines reconocen a un cacique que se llama Nanduabuçu como a principal de todos, el qual dize que todos los Indios Guaranis que ay desde la ciudad de la Assumpcion para aca son todos sus vasallos, y aun los Indios que estan adelante de la dicha ciudad que corren cerca de ciento y cinquenta leguas.” (apud Cortesão, 2010: 53)}

A explicação para o poder atribuído ao cacique não é outra senão a de seus poderes xamânicos. Pois o reconhecimento que lhe tinham era "un poco mas que a hombre": "de suerte que no falta quien diga probablemente que el es el mayor hechizero de toda la tierra" (idem: 58).

Ferrer, então, conta que os padres demoraram algum tempo para conquistar a confiança de Nanduavusu. Os colonos espanhois nem o puderam conhecer, segundo o padre, pois os indígenas o ocultavam e chamavam a outros pelo seu nome, escondendo-o. Já os jesuítas só conseguiram contato com ele depois que os Itatines se deram conta de que a presença jesuíta era uma espécie de anteparo às pretensões dos colonos espanhóis de lhes explorarem o trabalho:

\section{“(...) luego mando que la gente se juntasse y recebiesse a los padres y vimos la honra y respeto grande que le tenian todos, y de alli adelante los demas caciques yvan cada dia por la mañanita a su casa para oyr lo que les mandava." (idem: 59)}

Pouco tempo depois desses fatos, as missões do Itatim - como já haviam sido, pouco tempo antes, as do Guairá - passaram a ser alvo dos bandeirantes paulistas. A primeira tentativa de destruílas e escravizar os índios reduzidos foi de Ascenso Quadros, em 1632. Apoiado pelos habitantes da

\footnotetext{
Viveiros de Castro (2002). O diálogo, além disso, é com os mesmos conceitos deleuzianos que este autor utiliza: multiplicidade, devir.

121 Poderia ser ñandu'a vusu - penacho grande (?).

122 Para uma abordagem específica sobre a história das missões em Itatim, ver Gadelha, 1980, e Sousa, 2002. Em ambos os casos, a recomendação é para o levantamento histórico realizado pelos autores, com ressalvas quanto à utilização dos autores de conceitos antropológicos. Em termos de documentação, há boa edição recente do clássico de Cortesão (2010), organizado sobre os Manuscritos da Coleção De Angelis. O livro reúne dados sobre as encomiendas concedidas na região e cartas dos jesuítas do período missioneiro, entre outros. Vale observar que a fundação das missões em Itatim se insere no contexto das disputas territoriais entre Portugal e Espanha, tendo relações com a contenção da expansão dos bandeirantes paulistas, por exemplo.
} 
cidade espanhola de Santiago de $\mathrm{Xerez}^{123}$, próxima às missões do Itatim, o grupo de paulistas atacou as aldeias e reduções guarani, prendendo vários caciques, inclusive Ñanduavusu.

Os jesuítas intervieram, conseguindo libertar os principais itatines e suas famílias. Os sobreviventes, juntamente com os fugitivos, fundaram duas novas reduções, próximas à confluência entre os rios Apa e Paraguai ${ }^{124}$. E eis que, poucos anos depois, entre 1644 e 45 (Chamorro, 2008: 91), é o mesmo Nanduavusu quem vai ter problemas com os padres. Em função da riqueza de detalhes que nos interessam num estudo como este, sobre formas políticas ameríndias, peço licença para uma citação algo mais longa:

“En la reducción de Santa Fe se alteró la paz, pues los indios, capitaneados por Ñanduabusú, se levantaron contra el gobierno de la Compañía. Los jesuitas recibieron mil insultos y fueron amenazados por los neófitos principales. Borobebe, sobrino de Nanduabusú, dió en la cara con un palo al P. Domingo Muñoz, después que otros habían maltratado á éste de palabra; también hirió en la cabeza al P. Cristóbal Arenas. El mismo Nanduabusó colmó de improperios al P. Vicente Badía porque le reprendió sus malas acciones, y dijo que deseaba transmitir á las generaciones venideras las costumbres de las pasadas. Nantabagua, sobrino de Nanduabusú, porque un religioso le quitó el bastón de mando en castigo de su desvergüenza, irritóse fuertemente y armó un escándalo en el templo; procuró que el pueblo se sublevara y desechase la doctrina de los Padres como opuesta á la tradicional: todos los oyentes se retiraron y dejaron solo al predicador. Así quedó muy quebrantada la autoridad de los misioneros, y la plebe ningún caso hacía de ellos; eran ludibrio de grandes y pequeños; nadie veneraba las cosas sagradas y los hombres sacrílegos las profanaban; hasta los criados nos abandonaron, de modo que ni aun acólito teníamos que nos ayudase en el Santo Sacrifico. En medio de semejantes turbulencias acudieron los tigres y devoraron once neófitos, tres gentiles, veinte caballos y algunos bueyes; sin embargo, los indios de Santa Fe no

123 Santiago de Xerez foi refundada várias vezes. Sua primeira localização, segundo Azara (apud Gadelha, 1980: 81) é determinada em 1582, por Juan de Garay, "nas margens do rio Aquidauana, próxima à serra do mesmo nome, tendo sido fundada por Rui Dias Melgarejo e outros 60 colonos espanhois. No local, encontravam-se os indígenas Ñuara e Guasarapó”. Depois, é, várias vezes, transferida de local, por determinação do governo colonial. A localização exata d(as) ruínas da(s) cidade(s) de Xerez é atualmente objeto de pesquisas arqueológicas.

124 Um resumo dessa história está em Gadelha, 1980: 235-247. 
dejaron su feroz actitud. Nada consiguieron los jesuitas con palabras de amistad ni con amenazas; entonces echaron mano de remedios enérgicos: clandestinamente se apoderaron de Ñanduabusú, de un hijo y dos sobrinos de éste, y los llevaron al Yapeyú, última reducción del Uruguay, distante doscientas leguas, desterrándolos allí para que no huyeran fácilmente. La iglesia, que antes se hallaba desierta en los actos religiosos, se vió frecuentada por grande concurso de gente; los neófitos acudieron á la catequesis, á los sermones y á Misa con la piedad que antes manifestaban. Hubo un verdadero pugilato entre los indios principales, por dedicar sus hijos al servicio del templo. Aboliéronse los bailes deshonestos, los amores ilícitos, la poligamia y los antiguos usos de los bárbaros; á la vez se propagaron las virtudes, el respeto á los sacerdotes, la veneración á las cosas sagradas; en una palabra, todas las buenas costumbres. Tal influencia ejercen en los pueblos sus jefes, que si son piadosos los mejoran, y si malos los pierden. Muchas personas que huyeron de la población cuando en ella moraba Ñanduabusú, regresaron al saber que había sido expulsado. Por aquel tiempo recibieron el Bautismo en la reducción de Santa Fe, trescientas cincuenta personas adultas y más de trescientos niños; en San Ignacio gran número de párvulos y sesenta catecúmenos; otros de éstos quedaron instruyéndose (Del Techo V, 1897, capítulo XIV)"

Que o poder xamânico parecia ser o fundamento do prestígio do cacique Ñanduavusu, isso já ficara claro pela carta de Ferrer. Mas, o que o episódio do sequestro dele nos mostra é que mesmo o "principal de todos" do Itatim estava sujeito a ser vítima de uma traição por parte dos seus aliados.

Afinal, lembremos, os jesuítas não eram mais que uns poucos, em meio a milhares de indígenas, e não poderiam tomar tal iniciativa sem apoio de um grupo de "súditos" de Nanduavusu que resolvesse mudar de lado, por algum motivo que as fontes não registraram. É possível, no entanto, intuir que algum grupo devia estar contrariado com o xamã/principal, tendo em vista que, segundo Del Techo registra, muitos que haviam fugido da povoação quando ele lá estava regressaram após seu sequestro.

Líderes com as características de Ñanduavusu abundam nas crônicas coloniais. Relatos 
como esse registrado por Del Techo, nem tanto. O outro lado da moeda do prestígio é a traição, podemos concluir. Mas, também, vale observar que termos como "cacique" e "principal de todos" são utilizados de forma um tanto frouxa, muitas vezes. Nanduavusu se revelou, mas quantos outros não podem ter permanecido ocultos, sem que nem mesmo seus nomes tenham sido conhecidos pelos europeus?

De qualquer forma, consideramos o episódio representativo, no sentido de jogar um pouco mais de luz sobre essas relações de chefia que abrangeriam mais de uma aldeia. De fato, elas parecem existir, mas é pertinente considerar que o prestígio do líder entre os grupos de língua guarani pode ser altamente volátil, como veremos no próximo capítulo.

Por outro lado, as observações de Perrone-Moisés e Sztutman ganharão novo sentido à luz da discussão que promoveremos no capítulo 4. Ali veremos que, talvez, essa questão da "unidade social" supralocal entre os Tupi e os Guarani deva ser buscada em outro lugar que não na figura da chefia.

$$
* * *
$$

É como uma espécie de transformação da guerra, justamente, que a etnologia ameríndia mais recente melhor tem conseguido compreender as cosmologias tupi do presente - em muitos sentidos, beneficiando-se de uma reflexão sobre as transformações estruturais, e a percepção de uma "longa duração" que está relacionada à ideia de vingança como fundamento da constituição tanto da pessoa como da socialidade tupi (cf. Carneiro da Cunha e Viveiros de Castro, 1985).

É bem verdade que, originalmente, os Guarani considerados dentro do grupo de transformações proposto por Viveiros de Castro (1986) eram aqueles de que fala Hélène Clastres (1978): ascetas em busca da perfeição espiritual, um modelo de pessoa cujo ideal é tornar-se Outro, homens entre "o animal e o divino, essas duas formas simétricas do não-ser social".

Deve-se reconhecer, os modelos amazonistas que se desdobraram a partir dos estudos acima citados podem ajudar-nos a entender uma série de questões relativas aos Guarani atuais frente às quais as etnografias clássicas dos guaraniólogos não demonstravam rendimento. Anoto, contudo, antes de seguirmos, que uma leitura como a de Fausto (2005) não ajuda, ao considerar realidade etnográfica o que sabemos ser, muitas vezes (especialmente em uma situação como a do Mato Grosso do Sul de hoje, conforme já observou Mura - 2006: 300-1), para usar um termo caro aos guaraniólogos, "belas palavras". 
Já realizamos alhures (Pimentel, 2006) uma longa digressão a respeito da validade desse modelo de Viveiros de Castro (1986) para a compreensão da situação atual entre os Kaiowá e Guarani e, particularmente, de uma complexa cadeia de assassinatos que envolve temas como feitiçaria e "suicídios". Como demonstramos, é possível entender, por meio dessa formulação aplicada aos Tupinambá do século XVI, a atual dinâmica de aproximação/afastamento entre os grupos familiares kaiowá.

De qualquer forma, retomarei, agora, alguns elementos dessa exposição, tendo em vista a necessária discussão acerca da relação entre estrutura e história, à qual nos dedicaremos logo em seguida.

Seja por meio de agressões físicas ou da suposição de agressões xamânicas, as famílias kaiowá e guarani mantêm, como fundamento dessa dinâmica social, a ideia de que há conflitos entre os grupos e que é preciso retaliar. Na conjuntura atual, os ciclos de agressão e vingança estão especialmente ativados:

\begin{abstract}
“A transposição aleatória dos te’yi ${ }^{125}$ vindos dos mais variados pontos para as reservas proporciona uma exacerbação da força 'centrífuga', por assim dizer, relacionada à sociabilidade guarani - explicitada nas acusações de feitiço, que, diga-se de passagem, não envolvem apenas os suicídios” (Pimentel, 2006: 95).
\end{abstract}

Boa parte da recente bibliografia etnológica afirma que a guerra fundamenta a própria socialidade tupi-guarani, sustenta toda a lógica social.

\begin{abstract}
“Em termos sociológicos, esse modelo implica a ideia de que o complexo guerreiro-antropofágico sustenta o socius unicamente por meio de uma dinâmica entre aliança e guerra - o que evidencia sua origem como oposição ao estabelecido para os jê-bororo, pelo que as sociedades tupiguarani serão consideradas 'minimalistas'. O autor [Viveiros de Castro] compara esse sistema a uma alça de Moebius (1986: 79): 'O sistema é tenso, tende, e não tem avesso: o morto é o inimigo, o inimigo é o deus, o deus é o morto, e o morto sou Eu. Este é o cogito canibal'. A posição de
\end{abstract}

\footnotetext{
125

Termo normalmente traduzido como "família extensa" (ver Pereira, 1999). Nesta tese, seguirei sugestão de Lévi-Strauss (1986: 83) que me parece adequar-se à realidade kaiowá e, quando estiver me referindo aos te'yi, falarei em família, somente. Quando me referir a família conjugal, aí, sim, será "família restrita".
} 
inimigo funda a sociedade (1986: 668), o rito antropofágico é a própria reprodução do socius, sua atualização”. (Pimentel, 2006: 37)

É extensa e apresenta diversos desdobramentos a discussão sobre o tema. O fato é que entender a guerra como um dos padrões de relação entre os ameríndios - "inscrita no ser mesmo das sociedades primitivas" (Clastres, 2003: 250) - ajuda a entender muito da história dos povos de língua guarani. Pode explicar, por exemplo, por que, em certos períodos eles receberam com muita alegria aos europeus, e em outros não. Por que foram vistos como grandes guerreiros por certos cronistas, e como covardes ou derrotados, por outros. Por que alguns grupos viviam à beira do Paraguai, em certos períodos, e outros escolhiam refugiar-se nas matas das cabeceiras dos afluentes da bacia.

Logo adiante, verificaremos quais as contribuições que a arqueologia pode dar a essa reflexão. Por ora, vale reter que a história guarani na bacia do Prata pode ser resumida, desse ponto de vista, a partir das dinâmicas que alternam alianças e agressões ${ }^{126}$ : muitas vezes instalados pelas margens dos rios da bacia, grupos guarani tinham, no século XVI, força suficiente para empreender vastas expedições em busca de metais ao sopé andino, ou para manter grandes aldeias fortificadas e mobilizar grandes quantidades de guerreiros.

A partir da Conquista, com o choque das epidemias, a traição dos cunhados ${ }^{127}$ espanhóis, as grandes guerras como a de 1545-46, creio ser razoável supor não só que vários coletivos guarani passam a evadir-se, buscar lugares mais distantes, isolados, como que a população indígena passou a ser mais e mais associada a esse tipo de hábitat em função simplesmente do fato de que os grupos que estavam mais expostos pereceram maciçamente, ou seus descendentes foram incorporados à população colonial. Tanto a possibilidade de formar grandes aglomerados como a de evadir-se estava dada, como veremos - dito de outra forma: o contato impõe escolhas, certamente, mas faz isso em diálogo com estruturas que já existiam.

A chegada dos jesuítas introduz um ator novo no jogo: como se viu, tanto no Guairá como no Itatim, os grupos se achegam novamente a esses europeus "diferentes", que se colocavam como aliados diante dos colonos espanhóis. Mas, as grandes incursões dos paulistas, no século XVII, alteram novamente o jogo: já não era seguro permanecer nos lugares mais acessíveis, nas

126 Monteiro (1992: 483) já assinalava como os Guarani consideravam os espanhóis "aliados úteis" para combater outros grupos, conforme os próprios interesses indígenas.

127 O tema da dádiva não retribuída pelos brancos tem grande ressonância entre os Guarani. Pode-se mesmo concluir, genericamente, que os brancos somos fundamentalmente ingratos (vide Pimentel, 2008; Vysokolan, 2010). 
proximidades das linhas terrestres ou fluviais que ligavam a bacia do Paraguai ao Chaco, os Andes, ou ao litoral brasileiro (ver Gadelha, 1980, entre outros).

O recuo guarani e a captura de milhares de pessoas, reduzindo seu poderio bélico, dá espaço para o avanço dos povos chaquenhos sobre vastas áreas de Mato Grosso. Os Guaikuru e seus aliados Chané tomam espaço. Se, na região de Santa Cruz, grupos guarani tomam os Chané por seus vasssalos, deste lado do rio, em Mato Grosso, são eles que farão expedições para capturar outros Guarani.

Lopes (1850), como já citamos, encontra muito medo dos ataques dos Terena entre alguns grupos de língua guarani do sul de Mato Grosso ${ }^{128}$. No século XIX, pois, a chegada dos brancos é novamente saudada por muitos ${ }^{129}$. A paz é imposta aos Guaikuru-Chané ${ }^{130}$, as fazendas de gado começam a instalar-se no sul de Mato Grosso, sobrevém a Grande Guerra. Em seguida, volta a expandir-se a exploração de erva-mate, e os Guarani e Kaiowá, aparentemente, lançam-se massivamente ao trabalho - afinal, possibilitava-lhes um afluxo de bens exteriores ao mesmo tempo em que não lhes exigia um engajamento insatisfatório.

A abertura de mais fazendas de gado, no início do século XX, parece ter sido outro período de alianças de numerosos grupos com os brancos, em relações de compadrio com os "patrões" (Barbosa da Silva, 2010) - ainda que, evidentemente, a adesão não deva ter sido unânime. Ao longo do governo Vargas, entre os anos 40 e 50, a colonização da região tem impulso decisivo, e a população não indígena cresce de forma exponencial. As situações de contato se multiplicam, os problemas e conflitos se acumulam. O impulso final para que haja uma diminuição drástica das possibilidades de aliança entre coletivos indígenas e não indígenas é o desmatamento generalizado da região, seguido pela implantação de monocultura extensiva de grãos - cada vez mais mecanizada e com utilização de agroquímicos - e a transferência massiva dos pequenos coletivos antes espalhados pelos "fundos de fazendas" para dentro das reservas demarcadas no início do século XX pelo Serviço de Proteção ao Índio (SPI) (Thomaz de Almeida, 2001; Brand, 1997).

\footnotetext{
${ }^{128}$ Não quero dizer, absolutamente, que não haja outras possibilidades para a época, como grupos suficientemente fortes para rechaçar esses ataques, ou outros que permanecessem escondidos, conforme a versão canônica. O que busco é desconstruir estereótipos, sobretudo.

129 Outros autores, como Mura (2006: 68-70), chegam a relacionar essa boa receptividade aos brancos no século XIX à oferta de bens como os machados de ferro - algo que já abordamos neste capítulo. Para que se tenha claro, o que estou aqui propondo é que esses jogos de alianças e agressões são fator de grande relevo para a compreensão da história guarani, até porque os machados não fariam sentido meramente em função de noções ocidentais de produtividade e eficiência, conforme já assinalamos.

130 Uma síntese sobre a história desses grupos chaquenhos que tinham relação com os Guarani está em Combès et al., 2009.
} 
Esse ato final de traição, por parte dos fazendeiros que outrora abrigavam em "suas" áreas as famílias indígenas, revive outros momentos históricos de ruptura entre os grupos de língua guarani da região e, não por acaso, resulta em um conflito contínuo e generalizado em busca da demarcação de terras, o qual já dura mais de 30 anos (ver, a respeito, Pimentel, 2010; Pimentel \& Moncau, 2011).

\title{
Situação e estrutura
}

Ao fim e ao cabo, em toda essa discussão aqui empreendida há um ruído de fundo, evidentemente relacionado a uma questão teórica das mais relevantes. Uma curiosidade sobre a etnologia que se faz sobre os povos de língua guarani é que muitas vezes a divergência teórica fica oculta sob uma discussão sobre a "fidelidade" na descrição dos fatos apurados em campo.

Mura, recentemente (2006), polemizou com Pereira a respeito da noção de tekoha, sobre a qual este havia expressado seu ponto de vista pouco antes (2004). Vejamos:

\begin{abstract}
"Segundo este autor (Pereira), seria oportuno desvincular a noção de tekoha do espaço, procurando entender esta categoria sob uma ótica primordialmente político-religiosa, considerando os assentamentos comunitários como efeito de circunstâncias e arranjos históricos devidos ao relacionamento interétnico, fatos estes que, segundo ele, seriam alheios à tradição político-religiosa indígena. Não obstante o fato de os índios vincularem veementemente os tekoha a espaços específicos, ao procurar definir um modelo de relação social kaiowa, Pereira passa a considerar este conceito mais como categoria analítica do que nativa; assim fazendo, o autor acaba por exacerbar as características a-históricas relevadas na definição de tekoha apresentada por Melià et al.(op.cit: 120-1)
\end{abstract}

Mura não cita qual seria o trecho de Pereira a que se refere. A discussão deste autor a respeito do conceito está bastante espalhada no texto citado (2004). Os trechos que selecionamos não dão, necessariamente, conta de tudo o que ele aponta a respeito, mas, de qualquer forma, informam sobre os aspectos criticados pelo primeiro autor.

A análise de Pereira (2004: 168) considera os autores que classicamente trataram do tema 
(Meliá, Grünberg e Grünberg, 2008; Susnik, 1979/1980 etc.), mas também tem como referência atuais autores como Gallois (2004), Descola (1986) e Viveiros de Castro (2002). Para ele, o que "a literatura guarani convencionou denominar de tekoha" são "as redes de aliança entre parentelas" (op.cit: 118). A ênfase que a etnografia de Pereira pretende apresentar é, portanto, nas relações. Nem por isso ele deixa de considerar a importância da questão do espaço, ao contrário do que diz Mura:

\begin{abstract}
"Embora a ênfase na presente descrição recaia no elucidamento das relações que configuram um tekoha, de maneira nenhuma pode ser negligenciada a importância do espaço físico como necessário a sua realização histórica (...) Seria possível aventar a hipótese de que a partir da desesperadora situação de confinamento nas reservas a que foram sujeitas muitas comunidades kaiowá na segunda metade do século XX, e do movimento indígena de recuperação de muitos dos espaços ocupados pelas comunidades expulsas de seus territórios de ocupação tradicional, tenha havido uma transformação no sentido do termo tekoha, passando agora a explicitar com mais ênfase o elemento físico do território. Reforça essa hipótese o fato do termo ter sido incorporado ao vocabulário administrativo da FUNAI." (2004: 121)
\end{abstract}

No segmento final deste capítulo expressarei meu próprio ponto de vista sobre essa controvérsia, a qual me interessa menos pela questão do tekoha em si, como veremos, do que pela discussão teórica que subjaz aí. Por suas formações pessoais, Mura e Pereira expressariam dois polos do debate sobre a "epistemologia política" que atravessa a etnologia ameríndia feita no Brasil nas últimas décadas, como formula Viveiros de Castro (1999: 110). É por isto que essa controvérsia é especialmente produtiva em termos teóricos: por meio dela, entrevêem-se uma série de pontos marcantes da oposição entre os estudos de "etnologia clássica" e os do "contato interétnico" (idem: 111-2).

Em suma, temos aqui, de um lado, alguém que diz que os conceitos são produto de um contexto histórico e, de outro, um autor para quem os conceitos se realizam historicamente. Ora, estamos falando de um dilema secular no campo das ciências humanas e que, na Antropologia, já foi resolvido não por mim, mas por obras que nem Mura nem Pereira discutem em suas monografias. Vou centrar minha exposição em alguns desses autores, os quais, a meu ver, 
apresentam a solução que, em termos dialéticos, resolve essa controvérsia ${ }^{131}$.

Sahlins expõe o foco de sua contribuição teórica já no primeiro parágrafo da introdução de Ilhas de História (1990: 7): a história é "ordenada culturalmente". "O contrário também é verdadeiro: esquemas culturais são ordenados historicamente porque, em maior ou menor grau, os significados são reavaliados quando realizados na prática”, agrega ele. E em seguida, complementa: "A cultura é alterada historicamente na ação".

Temos, assim, um movimento dialético entre cultura e ação: ou seja, de alguma forma, considerando-se o que diz Sahlins, ambos, Mura e Pereira, têm razão, não se pode dizer que um esteja certo e o outro, errado. O tekoha tem, certamente, a ver com "esquemas mentais" "132 que os Kaiowá cultivavam, mas é fato que sua conformação atual, como conceito em circulação, só pode se dar naquelas condições específicas onde ele floresce, quais sejam: uma extrema escassez de terras disponíveis para abertura de novas aldeias, o que inviabiliza a dinâmica política de oscilação centrífuga/centrípeta que caracteriza esses grupos - ou seja, algo próximo do que Pereira apontava (vide citação acima), embora sem explicitar seus referenciais teóricos.

É certo que tudo isso está em diálogo com, digamos, a Funai e os trabalhos para identificação e demarcação de terras, mas não se pode negar que, até onde a mente alcança, a territorialidade kaiowá foi construída a partir do contato intenso entre povos os mais diversos cujas trajetórias e caminhos cruzaram, de alguma forma, as áreas de MS habitadas pelos grupos de língua guarani: desde os impérios/estados andinos, até os fazendeiros atuais, passando pelos povos chaquenhos, bandeirantes, jesuítas, colonos espanhois, portugueses etc.

Já havia linhas antes de os fazendeiros chegarem, por isso alguns Kaiowá com quem convivi utilizam interessante imagem: os brancos chegaram "cortando tudo". Cortando caminhos, trajetórias, histórias de vida, relações entre aldeias, entre povos. E construindo uma nova versão de que, outrora, não havia linhas, os colonos é que as traçaram. Uma versão que, desgraçadamente, boa parte dos antropólogos contribuímos para consolidar.

\footnotetext{
131 Para ser preciso, Mura cita, sim, Sahlins, em um único trecho de sua tese (Mura, 2006: 466), estabelecendo crítica a suas formulações sobre sua teoria dos modos de reciprocidade. Já Pereira, igualmente, cita Sahlins em um único trecho de sua tese (2004: 38), em relação ao chamado "americanismo tropical". Dentre os antropólogos que recentemente trabalharam entre os Guarani e Kaiowá, quem mais utiliza Sahlins como referencial é, de fato, Vietta (2007), que busca registrar a história dos moradores do Panambizinho conforme eles mesmos a contam.

132 Mas aí teremos que explicar bem qual é o conceito de mente que nos parece mais adequado, o que explicitaremos mais adiante. Vale dizer que não podemos ignorar o efeito das graves transformações ecológicas sobre a própria mente kaiowá, um assunto que, ademais, é da ordem do dia entre os indígenas, como veremos.
} 
Mas, sigamos. É preciso observar que essa ideia da estrutura na história tem outras expressões no âmbito da antropologia que fazem sentido para compreender a singularidade da abordagem que estou, aqui, propondo. Afinal, Mura (2006) propõe a ideia de que é possível traçar cinco diferentes "situações históricas" referentes aos Guarani e Kaiowá, e é a partir desse quadro que ele pretende "estabelecer critérios de comparação que permitam reconstruir as características centrais dos contextos sócio-ecológico-territoriais nos quais os Guarani estiveram e estão inscritos" (op.cit: 35). A finalidade de tal empreitada, segundo ele, seria "enfocar as mudanças e/ou a continuidade de determinadas características sociais, ecológicas ou territoriais". Para tal, seria preciso evitar a ideia de que haveria uma espécie de "cultura guarani original", um "ponto zero" da análise, em favor de "variações históricas das configurações desses contextos aqui analisados".

Mura utiliza a noção de "situação histórica", conforme proposto por Oliveira (1988). Tratase de um modelo teórico declaradamente inspirado no trabalho de Gluckman ${ }^{133}$, que declara basearse em um olhar sobre "modelos e esquemas de distribuição de poder entre diversos atores sociais", que fugiria tanto de uma "análise constitucional da política" à la Meyer e Fortes como de "modelos ideológicos", como os descritos por Leach:

"Trata-se de uma construção do pesquisador, uma abstração com finalidades analíticas, composta dos padrões de interdependência entre os atores sociais, e das fontes e canais institucionais de conflito.” (Oliveira, 1988: 57)

Para Oliveira (1988: 58), nesse sentido, o trabalho de Gluckman, realizado na África do Sul, no período da dominação colonial, guarda "muitas similaridades" com o 18 Brumário, de Marx (2011 [1852]), em aspectos como "na tentativa de captar o jogo de alianças e oposições como um resultado de relações de interdependência em contextos específicos"134.

Há, ainda, outro trabalho de Oliveira que é citado no sentido de reforçar uma dita

133 Uma amostra dos conceitos debatidos por Oliveira está em Gluckman, 2010.

134 Vale observar que esse projeto de lançar um olhar que capta, de fora, os diversos ângulos de um quadro político complexo se aproxima mais do que alguns chamam de sociologia do que da antropologia, propriamente, a qual buscaria, segundo alguns (entre os quais me incluo), a 'ciência social do observado" (Lévi-Strauss, 1967a: 404). Zizek, um dos mais incensados autores marxistas da atualidade, em recente livro, de título inspirado, justamente, por uma das mais famosas passagens do 18 Brumário ("Primeiro como tragédia, depois como farsa"), afirma: "O que este livro[o de Zizek] oferece não é uma análise neutra, mas sim engajada e extremamente 'parcial' - pois a verdade é parcial, só acessível quando se adota um dos lados, mas nem por isso menos universal” (2011: 18). Penso que é mais ou menos a isso que se refere a distinção levistraussiana entre as abordagens sociológica e antropológica de uma questão. 
preocupação com a utilização de dados históricos. Trata-se de artigo que contém uma série de recomendações a respeito dos critérios para a utilização de dados extraídos de viajantes coloniais. Para o autor, o emprego desse tipo de material corre o risco de "engendrar um monstro mecânico e artificial" (1987a: 89), ou mesmo de criar uma "colcha de retalhos" (1987b: 157). Os estudos de Fernandes sobre os Tupinambá, por exemplo, para Oliveira só podem empolgar a uma "antropologia funcionalista e anti-histórica" (idem).

De nossa parte, propomos partir da ideia de Perrone-Moisés (2006, 2011) sobre uma estrutura política pendular a operar entre os grupos ameríndios, oscilando entre uma prevalência das forças centrípetas ou centrífugas - mas supondo, sempre, que as duas possibilidades, aglomeração ou dispersão, já estão dadas de saída. Isso nos ajuda a compreender o fato de que, em determinadas conjunturas, grupos como os Guarani podem, sim, ceder a um movimento de concentralização (ou de criação de uma ressonância entre os centros, como diriam Deleuze \& Guatari - 1996). É necessário compreender, porém, que nem sempre essa concentralização se dá no sentido que nosso imaginário político concebe, cristalizando-se, por assim dizer, em uma estrutura como o Estado.

Ao mesmo tempo, procuramos demonstrar que é falsa a noção de que o ideal de afastamento entre os grupos familiares significaria um tipo de "equilíbrio" ou algo como uma forma política mais "estável". Afinal, a dinâmica das festas, a guerra e as expedições para captura de pessoas e objetos, tudo isso opera de maneira a demonstrar que uma tal situação de suposto equilíbrio pode até estar posta no horizonte dos ideais projetados pelo discurso xamânico, por exemplo, mas nem de longe corresponde ao que se observa, ao que se vive junto a eles - não só em campo, mas nos documentos históricos em geral. Como veremos no capítulo seguinte, o ideal da vida social kaiowá está ligado ao movimento, mongu'e.

Vale lembrar, ainda, o que menciona Sahlins (1999). Imaginar, a priori, uma determinação autocentrada de autenticidade é algo contrário à condição social humana normal, e parece mesmo uma projeção da "autoconsciência burguesa":

“A maioria dos povos encontra meios críticos de sua própria reprodução em seres e poderes existentes além de suas fronteiras normais e seus controles habituais. Portanto, os atos de prestígio de adquirir poderes estrangeiros são valores sociais domésticos - muito comumente, de masculinidade. Das jornadas heróicas a esses domínios culturalmente transcendentes, os homens (normalmente os homens) retornaram com 
troféus de guerra ou a caça, com mercadorias ganhas em ataques ou trocas, com visões, canções, danças, nomes, amuletos, espíritos e curas, coisas familiares ou novas que poderiam ser consumidas, sacrificadas, trocadas ou, de outra forma, utilizadas para renovar e enriquecer o modo de vida indigena.” (1999: 411)

É nesse sentido que, se estamos falando de liderança, ou seja, algo que envolve, inescapavelmente, disputas por prestígio entre pessoas e grupos, uma determinação fechada como é o conceito que usualmente se tem de um tekoha não faz o menor sentido. Ele, de certa maneira, pode ser considerado uma forma tão instável como qualquer outra - como as desaparecidas aldeias fortificadas, por exemplo -, no sentido de que esse movimento de busca ao exterior pelos elementos de prestígio, que poderão influenciar na correlação de forças entre os grupos familiares, certamente implica sua desestabilização. E, como pudemos perceber ao longo dessa breve exposição sobre a história da região guarani em MS, as "linhas de fluxo" por ali têm grande intensidade até onde a mente alcança.

Sob essa hipótese da estrutura política pendular, está uma concepção teórica que, à semelhança de Sahlins, pensa a estrutura, como a história. Evans-Pritchard dissertou, certa vez, sobre essa co-relação:

\begin{abstract}
"Eu diria que um termo como 'estrutura' só pode ser plenamente significativo quando usado como uma expressão histórica para denotar um conjunto de relações conhecido por haver permanecido por um período considerável de tempo" (1962: 55)
\end{abstract}

Ou seja, não só "estrutura que permite compreender a história, mas estrutura que se revela tal ao perdurar na história”, como resume Perrone-Moisés (2001: 140). Nessa mesma conferência, Evans-Pritchard citará ainda a Dumont: "História é o movimento pelo qual uma sociedade se revela como o que ela é".

Resumindo a divergência: enquanto Mura dirá que a utilização dos dados coloniais leva a "essencializar e reificar os Guarani, no momento em que subtraem estes indígenas de seus contextos históricos onde eles produzem e reproduzem suas categorias sociais e culturais" (2006: 34), diríamos que, desse outro ponto de vista que apresentamos, o que "essencializa" os grupos Guarani, 
por exemplo, é considerar, por si só, significativo que elementos descritos pelos jesuítas ou outros cronistas indiquem uma permanência/persistência pura e simples de certas formas. A persistência está no movimento, não na forma. Cultura, como demonstram Sahlins (1999) e Carneiro da Cunha (2009), é, afinal, um modo de transformar-se.

\title{
A estrutura no espaço
}

A bacia platina não foi a única onde se viu o tipo de dinâmica descrito acima ao longo da história colonial. Na bacia amazônica, os estudos arqueológicos recentes já deixam evidente a existência um movimento parecido de dispersão de parte das populações rios acima, e terra adentro, em paralelo à chegada dos europeus:

\begin{abstract}
“Ao examinar mapas de distribuição das terras indígenas na Amazônia contemporânea e compará-los com mapas de distribuição de sítios arqueológicos, nota-se que a ocorrência destes é mais ampla que a daquelas. Atualmente, a maior parte das terras indígenas de grandes dimensões está localizada longe da calha principal dos rios Amazonas e Solimões, em áreas como as bacias do alto rio Negro e do alto rio Xingu. Junto aos rios Amazonas e Solimões há, por exemplo, apenas duas grandes extensões de terras indígenas, respectivamente as dos índios Saterê-Maué e as dos índios Tikuna. Fora delas, porém, em locais atualmente desocupados ou ocupados por populações caboclas ou mesmo por cidades, é comum nas margens desses rios a presença de sítios arqueológicos, muitos deles de grande porte. Isso indica que, no passado, essas áreas eram ocupadas por povos indígenas, embora não o sejam, no presente.” (Neves, 2006: 7-8)
\end{abstract}

Neves faz uma observação geral que diversos autores já desenvolveram regionalmente. Taylor, por exemplo, escreve sobre a Alta Amazônia, em território equatoriano:

“As expedições escravagistas - organizadas sob pretexto de recuperar
indios de encomienda fugitivos ou 'apóstatas' das missões - e
principalmente as epidemias provocaram a partir de 1580-90 uma deserção
generalizada das margens dos grandes rios e uma fuga em massa dos índios
em direção às colinas do hinterland, além de uma dissolução das redes de 
O resultado desse processo, como relata a autora, é que os "mecanismos de identificação" vão se modificando e, poderíamos dizer, também lá aparece essa ideia de que os grupos que fogem para as terras altas estão se tornando "selvagens", enquanto os que permanecem ficam associados ao polo da civilização ('andinização', no caso, que envolvia usar o quechua como língua). Ocorre, então, uma "polarização das identidades étnicas" (op.cit: 219) que guarda certa semelhança com o processo que se observa na bacia do Prata.

Porro (1992: 175), por sua vez, identifica, em relação ao alto e médio Amazonas, já alcançando o território hoje brasileiro, um processo de desaparição dos grupos que viviam no início do período colonial nas margens do rio e substituição por novos contingentes indígenas, vindos dos afluentes, que foram levados para ali pelos colonizadores. Como se vê, há tonalidades regionais e locais, mas é possível perceber que, seja a realidade pré-colombiana ou colonial, é ao longo desse eixo calha-afluentes que se organiza o processo, e em torno dos grandes rios, por seu evidente papel de destaque como meio de transporte, estavam os cenários fundamentais.

De fato, é preciso atentar para o fato de que, no espaço, a dinâmica estrutural que descrevemos aqui tem esse sentido de uma oscilação entre dois polos, concentração e dispersão (duas possibilidades que, em certos contextos, coexistem, diga-se de passagem): no primeiro deles, as margens dos rios maiores, de terrenos férteis para a agricultura (e, infere-se, com cultivo facilitado para populações que não dispunham de instrumentos de ferro, em função de não estarem cobertos por vegetação, mas serem periodicamente enriquecidos pelo material orgânico depositado durante as cheias dos rios), fácil comunicação, comércio (e saques abundantes), possibilidade de agregação massiva de população - porém maior vulnerabilidade diante de ataques inimigos; no outro, as cabeceiras dos afluentes da bacia, geralmente correspondentes a zonas de mata densa, com cultivo dificultado, com maior dificuldade de comunicação e de acesso a bens vindos do exterior como o metal andino -, mas, ao mesmo tempo, oferecendo menor assédio de inimigos ${ }^{135}$ e, parafraseando o sugestivo título de Gow (2011), possibilitando que o grupo seja “deixado em paz”.

Para além de todos esses elementos históricos que já destacamos, a arqueologia também tem contribuído na composição de um cenário mais fiel às realidades pré-colombianas e a descrição dos

\footnotetext{
135

Creio que, pensando assim, a ideia de povos agricultores x povos caçadores (que compõe a história da Bacia do Prata contada por Susnik - 1989 -, por exemplo) fica, certamente, relativizada. Suponho que a agricultura possa ser inconveniente ou menos preferível em certos contextos conflituosos.
} 
processos ocorridos durante o período colonial. Noelli $(2004,2009)$ reuniu informações publicadas sobre 2,9 mil sítios arqueológicos considerados como guarani pelos especialistas, em uma enorme área que abrange partes do Paraguai, Uruguai e Argentina, além do Sul do Brasil, parte de São Paulo e o MS.

No caso do Mato Grosso do Sul, é interessante que a maior quantidade de dados está relacionada justamente à região para a qual há menos registros históricos mais antigos, a alta bacia do Paraná. Para essa área, ele apresenta várias evidências que corroboram boa parte das observações que estivemos discutindo: há uma ocupação em rede na região do rio Paraná, com datações que chegam a algo em torno de 1.100 a 1.400 anos A.P. (antes do presente) - ver Noelli, 2009: 78. Quanto ao interior do estado, há, segundo ele, "investigação incipiente" e ainda um "vazio arqueológico" (idem).

De qualquer forma, o que há de mais conclusivo em seu artigo é que "as datações e os dados históricos revelaram que esta área foi continuamente ocupada até o século XX, quando a presença brasileira confinou os Guarani em certas áreas pelo interior” (2009: 78). Chama atenção, também, o que ele considera uma característica geral dos sítios guarani: "Em geral, a duração da ocupação dos assentamentos era mais longa e poderia chegar a mais de cem anos, como demonstram os solos antropogênicos de cor preta" (2009: 73).

Como se vê, é certeira a crítica de Deleuze e Guattari (1997: 118-9) quanto à indiferença dos etnólogos em geral com a arqueologia e sua insistência em "fechar-se" em territórios específicos. "Não admitem confrontá-los com os territórios arqueológicos que comprometeriam sua autarquia. Eles tiram fotos de seus primitivos, mas recusam de antemão a coexistência e a superposição dos dois mapas, etnográfico e arqueológico" ${ }^{136}$. A questão, como lembra esses autores, é que a convivência entre "sociedades primitivas e impérios" ocorre desde o neolítico, e é escandalosa essa recusa ao diálogo.

Será necessário, nos próximos anos, ainda, que estejamos mais atentos a áreas em relação às quais essa percepção sobre as relações políticas entre Andes e terras baixas já está mais avançada sobretudo o piemonte andino peruano, com seus grupos Aruak, Pano e Jívaro. Sztutman apresenta um breve panorama dos estudos sobre essa região (2005: 66-70). O autor comenta:

\section{"Clastrianamente, o que demarcava os limites entre os povos da floresta e}

136

O trecho é destacado por Sztutman (2005: 44 - nota 16) em passagem sobre os Tupi. 
os do Altiplano não era simplesmente uma mudança de ecossistema, mas uma inclinação para a liberdade. Havia, segundo a autora [RenardCasevitz], relações de troca e de aliança política entre ambos os sítios, mas essas relações de amizade não redundavam em vassalagem por parte dos subandinos, que recusavam a lógica do tributo e da anexação territorial, fazendo de seu belicismo um ato de insubmissão" (idem: 70)

Quando se observa a literatura etnológica e etnohistórica, parece ser bem mais evidente a proximidade entre os povos andinos e os da floresta naquela área, mas, será mesmo que não se pode comparar à enorme quantidade de evidências que aqui apresentamos a respeito das redes ameríndias ao longo da bacia do Prata? Creio que, como esperamos haver demonstrado aqui, os indícios de movimentos ao longo dessa área, e até o piemonte andino na região boliviana, são gritantes demais para continuar sendo ignorados.

\section{Redes, hoje}

Para finalizar este segmento, apresento uma breve reflexão sobre as redes atuais entre os coletivos Guarani e Kaiowá em Mato Grosso do Sul, a partir de minha experiência de campo. A ideia, aqui, é superar a simples menção a "redes de parentesco" ou "redes de relação", comumente usadas nas etnografias recentes, e procurar tirar consequências um pouco mais avançadas, explicando melhor do que estamos efetivamente falando quando usamos o termo "redes" e quais as implicações teóricas de seu uso - as quais, como veremos, devem afetar, realmente, nosso vocabulário nas descrições etnográficas de forma mais ampla.

Parte do período em que estive entre os Kaiowá foi passada na região da bacia do Apa, entre os municípios de Antonio João, Bela Vista e Ponta Porã (MS). A região foi visitada por diversos antropólogos desde os anos 70, e esses contatos inspiraram partes de teses (como a de Mura, 2006), bem como subsidiaram estudos para subsidiar processos administrativos (Thomaz de Almeida, 1985, 2000) e judiciais (Oliveira \& Pereira, 2009). Deste modo, a presente reflexão dialoga não só com a minha própria experiência de campo, mas também com as de outros antropólogos.

Inspiram-me, aqui, os interessantes diálogos que mantive com algumas das pessoas mais velhas da região. Provavelmente devido à longa disputa que os Guarani e Kaiowá travam pelas terras em MS, várias das pessoas relacionam os antropólogos diretamente à definição da ocupação 
territorial. As conversas com os mais antigos, frequentemente, chegavam a essas questões, sobre quais eram os lugares de ocupação tradicional dos Paĩ/Kaiowá.

O principal gosto dos meus interlocutores era falar sobre como era a vida na região quando eles eram crianças, antes da "chegada dos fazendeiros" - evento que, na memória deles, deu-se há cerca de seis a sete décadas ${ }^{137}$. Portanto, meus diálogos em torno desse assunto foram com pessoas que, hoje, têm perto de 70 anos de idade, ou ainda mais que isso. Nas conversas em que me iam recitando longas listas de lugares onde moravam os parentes e amigos, apareciam os relatos sobre esse outro tempo, antes de os brancos “cortarem tudo". Hoje, na região, os possíveis locais de moradia reconhecidos pelo Estado como terras indígenas se reduzem a três no Brasil e um no Paraguai, logo após a fronteira.

Os idosos costumavam relacionar os lugares aos antigos moradores. As lembranças mais vivas e recorrentes eram sempre relativas aos anfitriãos famosos por suas grandes festas, ou guaxiré $^{138}$, muitas vezes com periodicidade semanal. As cerimônias mais conhecidas dos Kaiowá, como o mitã pepy, que há muito tempo não ocorre na região, também são lembradas, mas o que me chamava atenção, especialmente, é que não se mencionava tanto esses eventos, como, por exemplo, a festa em que se faz o batismo do milho branco (avati morotĩ), o avatikyry. A ênfase era sempre nos guaxiré, cuja periodicidade semanal ou quinzenal era enfatizada como sinal de uma espécie de "tempo áureo".

As lembranças geralmente giravam em torno de longas caminhadas, em que os grupos familiares saíam de casa para ir até essas festas, parando em certos lugares no caminho e também caçando animais que levariam para contribuir com o guaxiré. Havia mesmo quem me dissesse que não era incomum, ao terminar uma festa em um lugar, já seguir para outro, antes de ir para casa, em função de novo convite para outa festa.

Todas essas histórias me chamaram a atenção pelo descompasso entre esse modo de vida descrito e a imagem dos Kaiowá que emerge das etnografias mais conhecidas, sempre preocupadas em enfatizar a relação de um grupo local com seu tekoha, esse "lugar onde se pode viver conforme os costumes", como já citamos, onde há um mburuvicha, que governa a partir do consenso obtido

137 A datação exata é objeto de polêmica judicial, porque os fazendeiros procuram alegar diante da Justiça que "imprecisões" na memória dos ameríndios deslegitimam suas pretensões às reivindicações pela terra.

138

Guaxiré é uma das modalidades de cantos kaiowá e, aqui, serve como metonímia, como se diz: "Fui a um samba na casa de fulano". Falaremos mais sobre essas danças logo adiante. Sobre as demais festas, ver glossário ao fim do texto, e Chamorro, 2008. 
nas assembleias, aty guasu, e convive com uma espécie de pároco, o tekoharuvicha.

O tekoha, da forma como discutido na literatura, é certamente a objetivação de uma relação com a terra, como já mostramos, ligada ao processo de territorialização promovido pelo Estado (sempre lembrando que, do nosso ponto de vista, não se pode pensar esse tipo de fenômeno simplesmente relacionando-o ao processo de contato com os não indígenas).

Ao contrário do que se possa crer, porém, não se trata do único tipo de reflexão sobre o território que os Kaiowá realizam. Há elaborações bem mais livres do que se possa imaginar somente pela leitura da literatura etnológica sobre os Kaiowá e Guarani, como se pode perceber por esses depoimentos dos idosos da região do Apa.

Antes de seguirmos, contudo, é preciso dizer algo mais sobre as recentes contribuições de Ingold (2000, 2007), com incidência sobre essa reflexão a respeito das redes ameríndias. Trata-se de um debate que vai diretamente ao encontro dessa experiência que tive com os idosos kaiowá e ajuda a percebê-la de forma mais rica e ampla.

No capítulo 3 de sua "breve história" das linhas, Ingold (2007) destaca etnografias sobre o modo como diversos coletivos humanos percebem o ato de viajar, ou caminhar. A partir das sugestões do autor, vou, aqui, apresentar um exercício de imaginação a respeito da territorialidade guarani/kaiowá e refletir sobre a forma como as etnografias recentes têm encarado esse tema.

O sentido do oguata, o caminhar guarani, vem sendo tematizado ao longo dos anos como algo central no ethos dos coletivos de língua guarani. Pensar o caminhar e o viajar como a conexão entre pontos numa linha, em vez de como traço, ou linha, é algo caracteristicamente moderno, sugere Ingold. Assim como o traço não moderno é o registro de um movimento, de um gesto, conforme Ingold propõe - em vez da junção de pontos -, um mapa kaiowá é, na verdade, a memória de numerosos trajetos de pessoas que, quando crianças, tiveram a oportunidade de experimentar a liberdade de ir e vir, "antes de os fazendeiros cortarem tudo", como os idosos kaiowá costumavam me dizer. O contraste com a situação anterior, nas conversas mantidas comigo, era enfatizado por analogias com os animais: os Kaiowá, antes da chegada dos fazendeiros, faziam caminhos retos, eles me dizem, como os bichos do mato (catetos, quatis), sem precisar contornar cercas, buscar estradas.

Uma das etnografias que Ingold analisa é de Bruce Chatwin, sobre aborígenes australianos. Eles “imaginam seu território não como uma área superficial que se pode dividir em blocos, mas 
como uma rede interligada de linhas ou de caminhos através" (2007: 80). Porém, continua Ingold, não se trata exatamente de uma rede como os modernos a pensamos, já que hoje "estamos mais inclinados a pensá-la como um complexo de pontos interconectados que de linhas entretecidas”. E, lembrando que a origem da ideia de rede provavelmente está ligada ao uso de redes de pesca e caça entre os primitivos, Ingold vai fazer emenda à caracterização de Chatwin: sim, se trata de uma rede, mas não de network, e sim de meshwork, uma malha - ou seja, uma rede em que se enfatizam as linhas, não os pontos (linhas que, ao se encontrar, formam pontos - e não pontos ligados por linhas).

Pensar um mapa nesses moldes, porém, é muito diferente de visitar lugares e marcar pontos no GPS, como é comum, hoje, que façamos durante o processo de identificação de uma terra indígena. Trata-se de identificar trajetórias, caminhos, histórias de vida. O que Ingold identifica tem grande proximidade com a maneira que os Kaiowá percebem a área que habitam: afinal, formam uma rede os caminhos que interligam as residências, os diferentes locais habitados por eles e são conhecidos como tape po'i (caminho estreito, literalmente, para diferenciar das estradas largas construídas pelos brancos).

Ingold contrasta dois modelos do que seria um lugar, considerando-se essas diferenças que ele destaca (2007: 98). Na concepção que ele chama de moderna, um lugar é um ponto - vamos dizer, uma aldeia. Numa visão ampliada desse ponto, ele seria um círculo que abriga outros pontos - como as casas (pontos) dentro da aldeia (círculo). Nessa outra concepção ${ }^{139}$, o mapa de um lugar se pareceria mais com um emaranhado de linhas de vida.

Assim, se, outrora, os antropólogos enfatizaram a idéia de lugar (tenda, ou tendápe, em guarani) na definição das terras guarani - ou seja, dos tekoha -, poderíamos dizer que se deixou escapar a possibilidade de traçar mapas que mostrassem as linhas de oguata e as redes de festas, por meio das memórias dos idosos. A partir dessa mudança de perspectiva, pode-se perceber que começam a fazer mais sentido as listas de lugares que os idosos da região do Apa me apresentam.

Nas memórias dos Kaiowá, esses lugares estão todos relacionados por linhas, que são caminhadas. Essas caminhadas, basicamente, visavam à participação em festas de guaxiré. Trata-se de uma metonímia: guaxiré é como são conhecidos, entre os Kaiowá do Apa (pois, mais ao sul e a oeste fala-se em kotyhu) as danças circulares que acontecem nessas festas.

\footnotetext{
139

Ele a chama de "não moderna", mas, sem discutir essa generalização, restrinjamo-nos a considerá-la "outra", apenas. Como mencionei acima, Ingold nos serve aqui, sobretudo, como inspiração.
} 
Normalmente, nos guaxiré, roda-se ao som de frases entoadas coletivamente. Essas frases têm motivos profanos - no sentido de que não são entoadas com finalidade de cura ${ }^{140}$ ou evocação de entidades para fins xamanísticos: muitas vezes estão ligadas ao flerte entre homens e mulheres. Um homem provoca, todos riem. Uma mulher responde, todos riem mais ainda. Nova resposta de outro homem, e assim a roda persiste. Nos intervalos, bebe-se chicha (termo quéchua que os Kaiowá usam de forma corrente), ou kagui (bebida fermentada ou não, à base de milho e/ou, o que é importante, batata-doce, cana de açúcar ou outros produtos).

Os guaxiré são normalmente considerados pelos antropólogos como meros coadjuvantes em rituais onde o que realmente importa são as chamadas "rezas". Boas etnografias sobre as cerimônias kaiowá mais conhecidas, o mitã pepy e o jerosy puku, foram produzidas nos últimos anos, por Chamorro (1995) e Montardo (2009). Muito pouco ali se fala dos guaxiré, num contraste forte com minha experiência de campo ${ }^{141}$. No Apa, ouvia falar de guaxiré quase todo dia, e muito pouca preocupação havia com o fato de não se realizarem mais rituais como o batismo do milho (jerosy puku), ou o batismo das crianças (mitã pepy). O fim dessas cerimônias, muitas vezes, era lembrado mais como uma decorrência das transformações ambientais do que propriamente como algo a se lamentar. Já o fim das festas, isto sim, provocava lamentos frequentes.

Nas memórias dos Kaiowá da região do Apa, caminhava-se até as casas uns dos outros para dançar guaxiré, tomar chicha e comer carne de caça assada. Famílias inteiras faziam isso toda semana, praticamente - em contraste com o que normalmente leva a pensar a descrição dos rituais ligados ao milho, como o jerosy puku, que só acontecem (aconteciam) uma vez por ano. Isso porque, se for contrastar o que me dizem os antropólogos e os Kaiowá que conheci, posso dizer que aconteceu uma confusão: o importante não era o milho, era a festa, e podia-se fazer festa com qualquer coisa que houvesse em casa para fazer chicha e comer assados na fogueira - o imprescindível era que houvesse muita comida para distribuir para os convidados.

Um amigo me conta que havia mesmo, ao tempo de sua infância, uma expressão para quando uma família saía de uma festa e ia para outra, sem ir para casa antes: “Jaha joapyhape!", dizia-se. Literalmente, seria algo como "vamos ao reunidor", pelo que verifico nos dicionários - por sinal, joapykuery se traduz aí por "um atrás do outro". Já ele traduz como "emenda de festa" e

\footnotetext{
140 Ainda que a própria alegria seja considerada algo terapêutico pelos Kaiowá e que exista uma sutil intersecção entre esses cantos "profanos" e a mitologia - com o uso de frases, nesses cantos, que podem ser atribuídas a personagens como Sol ou Lua, em determinados trechos de sua história, as quais também se relacionam a cerimônias importantes.

${ }^{141}$ Recentemente, a primeira autora vem buscando suprir essa lacuna (ver Chamorro, s.d.)
} 
lembra com saudade da primeira chicha a que foi, quando tinha cerca de 12 anos - diz ter 51, hoje. Ficava dois, três dias fora de casa: dormia nos acampamentos, tejupa (não encontrei a palavra em dicionários). No caminho, caçava-se, de modo a já chegar com alguma colaboração para a festa.

Assim, os grandes rezadores, ou os mburuvicha da região são lembrados, sobretudo, pelas grandes festas que promoviam. Os caminhos até suas casas são os mais lembrados porque eram os mais frequentados. Ganha nova dimensão a idéia de "principal", que é a tradução mais comum de tuvicha - termo de que se reveste tanto essa autoridade política do mburuvicha (formada por mbu+tuvicha) como a de um grande rezador (que era dito o tekoharuvicha). O principal era o mais frequentado, segundo as memórias. É lembrado, sobretudo, pelas grandes festas que promovia.

Os trabalhos antropológicos sobre terras indígenas kaiowá e guarani há algum tempo já incorporaram, por exemplo, a idéia da rede de tape po’ $i$ (ver Thomaz de Almeida, 2000; Oliveira \& Pereira, 2009). Até há pouco tempo, contudo, permaneciam presos a uma concepção de tekoha que não percebia nuanças como essas que apresentamos. Só recentemente, durante o longo processo de discussão que precede a edição das portarias de 2008, foi que a Funai aceitou repensar o modelo de demarcação em "ilhas" ao qual está intimamente relacionado essa forma de pensar a territorialidade guarani $^{142}$.

Podemos perceber que, nesse diálogo em busca das formas kaiowá e guarani de estar no espaço, falta o salto sugerido por Deleuze para cortar o vínculo entre "o Conceito e o Estado", como apontado por Viveiros de Castro (2007: 98). Enquanto se mantém forte o entendimento de tekoha como um sistema arborescente, os Kaiowá da região do Apa me contam da existência de um sistema rizomático aberto, onde não se conhecia uma totalidade - "a multiplicidade não é algo maior que um, algo como uma pluralidade ou uma unidade superior; ela é, antes, algo menor que um, surgindo por subtração" (Viveiros de Castro, 2007: 98).

Enquanto insistirmos na idéia de unidade, continuaremos levemente infiéis em sua tradução da forma como os Kaiowá e Guarani concebem-se no espaço. Esses coletivos ameríndios só se mantinham como múltiplos que eram por negarem essa unidade, não porque a sustentassem. A rede, afinal, é uma perspectiva (Viveiros de Castro, idem).

$* * *$

\footnotetext{
142

Algumas contribuições que desembocaram nessa nova forma de pensar a territorialização guarani/kaiowá estão em Mura (2006) e Pereira (2005). Lehner (2002), com seus trabalhos entre os Paĩ Tavyterã no Paraguai, também gerou ideias que alimentaram esse processo.
} 
Uma espécie de transformação do esquema que pensa a territorialidade guarani a partir dos tekoha é apresentada por Mura (2006: 138). A divisão do território kaiowá/guarani em seis tekoha guasu, em associação, aproximada, com as sub-bacias hidrográficas na região (Apa, Alto-Médio Dourados, Médio-Dourados-Amambai, Alto Amambai, Iguatemi, Brilhante-Ivinhema) avança no sentido de permitir, por exemplo, que as novas demarcações de terra que ora se processam na região não deixem perdurar a lamentável situação de demarcações em ilhas ${ }^{143}$. Como já vimos, essa é a ideia aproximada que norteou a organização dos seis grupos de trabalho formados em 2008 (vide introdução).

Mura relaciona essa ideia dos tekoha guasu ao que Susnik elabora sobre os guára, a ideia de que haveria uma noção bem disseminada entre os grupos guarani do período colonial a respeito de origem geográfica (afinal, como lembra Meliá - apud Santos, 1999: 210 -, guára deve ser entendido como o sufixo “-ense", na língua portuguesa). O autor dialoga, ainda, com Lehner (2002), que já havia constatado essa possibilidade de compreensão da rede social pã̃-tavyterã, para além de uma visão que percebe, unicamente, grupos locais. Entretanto, o problema, como se percebe em outro texto de Lehner (2008), é que ela pensa o tekoha guasu, literalmente, como um tekoha grande - mesmo que maior, continua sendo uma unidade, ainda que, no presente, desarticulada.

\section{Yvy rupa}

Ocorre que, como procurei demonstrar, a rede, entre os Kaiowá e Guarani, é também social, não pode ser apenas definida em termos geográficos. Nesse sentido, é que, defendo, ainda resta margem para discussão. Redes de relações trilhadas no ambiente geográfico, nem pura socialidade, nem mera territorialidade ${ }^{144}$. Na própria tese de Mura, um xamã alerta, a certo ponto (2006: 136): desde o rio Paraná até o Paraguai, antigamente, "tudo era tekoha”.

Para demonstrar o que estamos dizendo sobre uma rede social projetada sobre o território, vamos recorrer a um trabalho técnico que realizamos recentemente, o relatório de identificação e

\footnotetext{
143 Um grande avanço, não só levando em conta as demarcações anteriores em MS, mas também considerando o que foi decidido pelo Supremo Tribunal Federal em 2008 a respeito da validade inconteste das demarcações de terras indígenas em área contínua (vide Miras et al, 2009).

144 A formulação nasceu em diálogo com Beatriz Perrone-Moisés, que merece o crédito pelo poder de síntese.
} 
delimitação da Terra Indígena Tenondé Porã, dos Guarani, em São Paulo ${ }^{145}$. Tal grupo, como se sabe, é predominantemente falante do mbya, uma das três variantes da língua guarani encontradas no Brasil.

Seria possível considerar que a bibliografia etnológica sobre os grupos de língua guarani no Brasil como que se bifurcou, nas últimas décadas ${ }^{146}$. De um lado, desenvolveram-se os estudos sobre os Kaiowá e Guarani de Mato Grosso do Sul. De outro, as pesquisas sobre os Guarani falantes de mbya e ñandeva da grande rede que vai do norte da Argentina e sul do Paraguai até o litoral do Espírito Santo, no Brasil. Não são muitos os pesquisadores que persistiram na tarefa de fazer com que as duas vertentes dialogassem ${ }^{147}$, até porque, em cada uma delas, o número de estudos teve crescimento exponencial.

Para deixar a situação ainda mais complexa, vale observar que, se, em áreas mais isoladas, em geral, somente antropólogos e linguistas, se muito, costumam dispor-se a realizar pesquisas junto às populações indígenas, nas áreas guarani, frequentemente próximas demais de cidades, ocorre nos últimos anos um afluxo enorme de pesquisadores das mais diversas áreas, como geógrafos, historiadores, pedagogos, médicos, psicólogos etc.

Esses trabalhos dialogam com a etnologia guarani, mas, em geral, o fazem a partir de perspectivas teóricas tão distantes que muitas vezes o diálogo se dificulta bastante ${ }^{148}$. Em estudo anterior, abordamos um caso exemplar dessa apropriação potencialmente desastrosa dos conhecimentos etnográficos por outras áreas, relativo à questão das mortes de jovens kaiowá por enforcamento (Pimentel, 2006).

Mas, voltando à experiência com os Guarani de São Paulo, gostaria de abordar aqui a interessante objetivação que esse grupo vem fazendo de sua rede social, a qual vem sendo denominada, no âmbito do movimento indígena, yvy rupa. Esse é o termo que vem sendo usado

$145 \mathrm{O}$ dito relatório foi produzido a partir da determinação da portaria da Funai n. 659, de 1/7/2009. Guarani, em São Paulo, é uma autodenominação, principalmente, reivindicada por falantes do dialeto mbya.

146 Estou sendo comedido. Meliá (2004) compara essa bibliografia a uma árvore, vendo nela vários galhos, não só dois.

147 Sem falar no diálogo com a produção na Bolívia, Paraguai e Argentina. Vide, por exemplo, Bartolomé (2009) para um ponto de vista bastante distinto sobre a bibliografia recente, com foco nos Mbya, mas abrangendo também os demais grupos.

148 Como já mencionei alhures, é comum encontrar, por exemplo, trabalhos de história com enormes contribuições para a análise dos documentos coloniais, mas que mantêm uma perspectiva evolucionista ao extremo, ou a apropriação de discussões sobre mitologia ou xamanismo num viés confuso. Um conceito frequentemente apropriado é o de "identidade". A mescla que se faz entre as discussões antropológica e psicanalítica pode ter resultados complicados (quando alguém diz que "o suicídio é cultural", ou "eles se suicidam porque perderam a identidade"). 
pelos Guarani para defender-se do amplo movimento político contrário às demarcações de terra para o grupo, que os acusam, tanto no Brasil como na Argentina (conferir Bartolomé, 2009) de serem “estrangeiros", ou "paraguaios". Desde 2006, os Guarani do Sul e Sudeste do Brasil organizam a Comissão Nacional de Terras Guarani Yvy Rupa.

Como já discutimos, a mobilidade de grupos guarani entre o litoral atlântico e a bacia platina, alcançando os Andes, tem registros aceitos pelos historiadores de quase 500 anos ${ }^{149}$, sendo que se trabalha com a hipótese de que tenha mais de um milênio. Embora o debate nesse sentido seja conduzido, no âmbito da Justiça brasileira, com relativo êxito, por interessados na posse das terras reivindicadas pelos indígenas, o fato é que, academicamente, esse tipo de acusação não tem o mínimo respaldo.

De qualquer modo, surgiu, no âmbito do movimento político guarani, a ideia de yvy rupa já conta até mesmo com certo "reconhecimento oficial". Em fevereiro de 2010, o Ministério da Cultura do Brasil, em parceria com o do Paraguai, patrocinou, no Tekoha Añetete, em Diamante D‘Oeste-PR , o $1^{\circ}$ Encontro dos Povos Guarani da América do Sul, denominado, em guarani, Aty Guasu Nande Reko Resakã Yvy Rupa. O evento marcou o acolhimento oficial da reivindicação, feita pelos diversos grupos guarani, de Brasil, Paraguai, Argentina e Bolívia, de uma discussão, no âmbito do Mercosul, sobre as garantias de seu direito de circular por todo esse território com igual reconhecimento de cidadania por todos os Estados nacionais da região.

Houve, ainda, uma segunda edição do encontro, em 2011, na aldeia Jaguati (Paraguai) e a constituição de um Conselho Continental da Nação Guarani. Encontros internacionais paralelos, nesse mesmo sentido, mas sem o reconhecimento dos governos dos países em questão, também vêm sendo realizados, com apoio de organizações da sociedade civil internacional, desde 2006.

Yvy rupa é a junção dos termos yvy - terra, e rupa - leito, cama, ninho. Obviamente, trata-se de destacar o caráter unitário da terra, o fato de que é uma coisa só, não podendo ser dividida por fronteiras, ou cercas.

\section{“Esse termo, polissêmico, pode ser traduzido literalmente como 'suporte (ou plataforma) terrestre', e abrange toda a extensão do território onde os Guarani estabelecem ou consideram possível estabelecer suas aldeias e}

\footnotetext{
149 O supracitado Schmidl, na volta de sua viagem ao rio da Prata, caminhou de Assunção ao litoral do Brasil em companhia de um grupo de Cario - presumidamente, fez o trajeto contrário ao de "Aleixo" Garcia, usando os mesmos caminhos do Peabiru, porém este não deixou testemunho.
} 
assentamentos. (...) Todo esse território é percebido, concebido e vivido pelos Guarani como um espaço único, essa plataforma terrestre onde os Guarani estabelecem suas aldeias, e que é compartilhado com os diversos outros povos e pessoas que habitam esse território, entrecortado atualmente por um sem número de estradas, cidades, fazendas, empreendimentos, países, em suma, com a sociedade nacional. (...) Os Guarani não concebem fronteiras rígidas na utilização desse espaço, preservando enormes redes de troca de bens (materiais e imateriais) e pessoas, ao longo de todo esse território que inclusive ultrapassa as fronteiras nacionais. Em outras palavras, os Guarani circulam em aldeias presentes em toda extensão desse território para realizar casamentos, rituais e intercâmbios de diversas naturezas. É frequente verificar através da genealogia (...) famílias cujos integrantes encontram-se dispersos desde o Espírito Santo até o Paraguai, evidenciando quão intensa e estreita é essa rede de parentesco. Sobretudo por meio dessas redes de parentesco também se fazem intensas outras redes de troca de bens, sementes e demais cultivos, remédios, rituais, conhecimentos etc." (Pimentel et al, 2010: 33-6)

O termo yvy rupa aparece em depoimentos de lideranças guarani, registrados no trabalho. É o caso de Timóteo Vera Popygua, um dos principais expoentes da aldeia Barragem, uma das que compõem a T.I. Tenondé Porã. Nascido em uma aldeia mbya na Argentina, filho de pai originário da aldeia de Palmeirinha, no Paraná, Timóteo residiu, quando criança, em diversas localidades, conhecendo toda sua rede de parentesco, desde lá até o litoral do Sudeste:

\footnotetext{
“(...) desde criança, eu me lembro que na Argentina eu vivia lá e ficava mais com meu avô, meus avós, ele contava cada história, de manhã, à noite. Falava sobre essa criação do mundo. Como é que Nhanderu fez, pra que que Nhanderu fez. Para não ter uma fronteira, para não ter uma demarcação física. Que para viver, onde Nhanderu fez yvy rupa significa: terra é uma só, não tem divisão geográfica. Então [que a gente] vivesse nesse mundo, e manter sua cultura e manter sua tradição, ele passava isso $\operatorname{pramim}(\ldots)$.
}

A conversa, realizada pelo antropólogo Daniel Pierri, um dos autores do trabalho citado, 
segue com mais uma pergunta sobre como os mais velhos entendem essa ideia de continuidade do território guarani:

"D: Quando você estava contando assim do seu pai, antigamente, que foi do Brasil para a Argentina, da Argentina voltou, trouxe vocês. Ele falava ou explicava porque que saía, de um lugar, ia para o outro? Você tem lembrança disso? Porque que ele voltou para o Brasil, quando ele falou que vinha para o Brasil, você quis vir, se interessou, que que ele contava que estava procurando?

T: Na verdade ele contava que tinha outro avô, porque tinha meu avô por parte de mãe lá na Argentina. Ele contava que meu outro avô ficava no Brasil. Mais vinha na minha cabeça, eu não sabia o que era Brasil. Porque na época eu não tinha esse pensamento de separação, de Argentina e Paraguai. Para mim era tudo... tanto é que na época a gente atravessou o rio Uruguai, Urugua'y que a gente fala, quando eu passei eu pensei como era do outro lado, meu finado pai falou assim: 'Aqui é Brasil'. Eu falei: 'É tão perto, aqui é Argentina, por que é Brasil?' Ele explicava: 'Isso aqui quem fez é juruá, é a mesma terra, só água que separa. Por baixo tem terra ainda, não tem separação, mas juruá fez isso'. Pensava que Brasil era uma coisa instrumental, uma coisa assim. Alguma imagem, sei lá. Eu tinha na minha cabeça isso, mas não pensava que era território. Pensava que era yvy rupa mas continua sendo yvy rupa. Ele explicou tudo isso pra mim."

O que impressiona, também, é a relação da geografia com a cosmologia. Fica muito claro, nas diversas entrevistas, que o centro do mundo está no Paraguai, é o yvy mbyte, ou yvy pyte, assim como a beira dele, concebido como uma espécie de plataforma circular, está no litoral, a beira do mar, yvy apy, ou yvy rembere. O caminho entre o centro e o leste, por sua vez, levando ao litoral, é identificado com as narrativas sobre os tempos primordiais, da criação do mundo. Ñanderu, o criador, deixa a mulher, $\tilde{N} a n d e x y^{150}$, grávida de Kuaray, o Sol, e se dirige ao leste, sendo posteriormente seguido pelos dois.

150 Para os Kaiowá e Guarani, ñandesy. Essa diferença no fonema - s que se torna $\mathrm{x}$ - é uma dos mais comuns entre os dialetos de MS e o mbya do litoral. 
Bartolomé (2009), voltando, após $40 \operatorname{anos}^{151}$, a escrever sobre os Mbya de Misiones, Argentina, chega a explicitamente, em seu texto, assumir como erro, em seu texto anterior, de 1969, a vinculação da origem desses indígenas ao Paraguai.

"De hecho, queda claro que las fronteras estatales, incluyendo la brasileña, eran ámbitos de flujos múltiples, sujetos a los variables contextos políticos y sociales que involucraban a la población nativa. Rectifico entonces mis apresuradas observaciones de 1969, em las que adjudicaba a los guaraníes de Misiones un origen netamente paraguayo. A pesar que la población indígena actual suele señalar su procedencia del Paraguay, ello solo expresa un momento temporalmente acotado de un flujo y reflujo poblacional centenario (o más bien milenario) (...)” (op.cit: 152)

Como se vê, estamos diante de um duplo movimento. Por um lado, os grupos de língua guarani refinam suas elaborações que justificam reivindicações de direitos territoriais, sociais e culturais, em notável sintonia com o processo de integração regional dos Estados nacionais. Por seu turno, os antropólogos têm de rever certas conclusões tiradas em outro momento histórico - o caso sul-mato-grossense não deixa de ter semelhança com essa retificação de Bartolomé, já que o próprio Mura (2006) inicia sua revisão da ideia de tekoha a partir de uma crítica à forma como as identificações de terras indígenas foram conduzidas em períodos anteriores, muitas vezes originando demarcações de faixas de terra evidentemente inadequadas para os Kaiowá e Guarani.

O que nos interessa, particularmente, aqui, é que a discussão sobre a ideia de redes pode influir diretamente sobre essas reformulações ora em curso. Nesse sentido, Bartolomé é o autor que mais avança, uma vez que não apenas trata os Mbya como uma "sociedade de redes", explicitamente, mas também começa a tirar, disso, consequências analíticas e reflexões conceituais mais amplas. O mesmo não poderia ser dito de autores como Pereira (2004) e Barbosa da Silva (2007), em relação aos Kaiowá e Guarani. Discutiremos esse tópico adiante.

Antes, porém, devemos atentar a um interessante aspecto que tem emergido nas pesquisas recentes, especialmente quando se trava diálogo com essa bibliografia sobre os Guarani de outras regiões. Trata-se da constatação de que as versões canônicas sobre a divisão dos grupos de língua

151 Nos anos 70, ele se mudou para o México, onde se tornou pesquisador do Instituto Nacional de Antropologia e História (Inah). Atualmente, reside em Oaxaca, onde o encontrei durante o período de estágio-sanduíche que mantive naquele país. 
guarani em áreas geográficas (Schaden, 1974, sobretudo) já não correspondem à realidade há muitos anos - e certamente nunca corresponderam plenamente.

É, já, bastante conhecida a existência de fluxos de grupos falantes de ñandeva e mbya entre o litoral e as cercanias do yvy mbyte - o centro da terra, pois, seja ele o que é localizado pelos Paĩ/Kaiowá no Cerro Guasu, no Paraguai, ou o que é apontado pelos Mbya, em Mba'e Vera, ou "entre las regiones de Ka'arendy e Chei'rokué", como assinala Bartolomé (op.cit.: 122) ${ }^{152}$, referindo-se a indicações dadas por Cadogan e Lehner.

O que é menos discutido, porém, é que os Pã̃/Kaiowá também apresentam uma mobilidade, ainda que em menor índice que os demais grupos guarani. Não é incomum encontrar famílias kaiowá vivendo em aldeias mbya/ñandeva de São Paulo, por exemplo. Além disso, um levantamento recente do Cimi-MS (2011) a respeito de acampamentos indígenas formados por famílias que abandonaram reservas superlotadas em Mato Grosso do Sul encontrou grupos guarani/kaiowá até mesmo na divisa com São Paulo, em Bataguassu.

Na historiografia, dá-se o mesmo. A simples transposição Itatines/Kaiowá mostra-se, cada vez mais, inconsistente, se tomada ao "pé da letra". Primeiro, no século XVI, há, por um lado, as migrações de Itatines para a região de Santa Cruz, e, por outro, as fugas de grupos inteiros do trabalho forçado das encomiendas - o que certamente levou grupos à região hoje correspondente a MS; depois, há toda a movimentação do século XVII, em função da instalação das reduções jesuíticas e dos posteriores ataques dos paulistas - a destruição das missões no Guairá, por exemplo, levou vários grupos a adentrarem pelos afluentes do Paraná, e o mesmo se deu com os ataques às missões no Itatim, que resultaram em deslocamentos rumo a Assunção, em busca de mais segurança.

Há, ainda, os dados que aponta Bartolomé, citando ao menos três autores, Cadogan, Fogel e Susnik, além da documentação setecentista referente a estes fatos: de que os Mbya de Misiones descendem de um grupo transferido do Itatim, após a destruição de uma missão na região do rio Taruma, no segundo quartel do século XVIII (op.cit: 92-3). Na linha do que já vinha apontando, eu

152 Agregue-se o que Bartolomé observa, a seguir, sobre o yvy mbyte dos Mbya: "Desde el punto de vista mítico reconocen que su estirpe proviente de Yvy Mbyté, el Centro de la Tierra, que está situado em el Ka'a Guazu, la Selva Grande. Esto presenta un problema de identificación, ya que el topónimo Ka'a Guazú es extremadamente frecuente em las regiones selváticas de Misiones y Paraguay (...). Pero los habitantes del teko'ha Pindó Poty de Misiones, me aclararon que no se trata exclusivamente (o solo) de un lugar, sino también de un concepto cosmológico concretado en la figura de un mítico árbol primigenio" (op.cit: 123). É curioso que a mesma dualidade se dá entre os Paĩ Tavyterã/Kaiowá, essa ambiguidade entre geografia e mito. 
acrescentaria que esta pode não ser a única origem, dada a ampla disseminação de grupos de língua guarani por toda a área da bacia do Prata. $\mathrm{O}$ tal grupo que passou pela tentativa de redução pode ter se juntado a outros, facilmente.

É preciso lembrar, ainda, que o guarani no período colonial parecia ser uma espécie de língua franca na bacia do rio Paraguai, o que complica a identificação de certos grupos como falantes de guarani ou não (uma vez que um intérprete podia estar se comunicando com eles sem que necessariamente essa fosse a língua principal do grupo - e, como também havia enorme trânsito de cativos, podia ser que um deles servisse de intermediário, e que os demais habitantes do local não falassem guarani).

Finalmente, como se percebe pelo verdadeiro amálgama entre os grupos Itatim e Chané que formaram os Chiriguanos (Combès \& Villar, $2007^{153}$ ), hoje autodenominados Guarani, as relações entre os diversos coletivos ameríndios na região da bacia do Paraguai parecem ter sido bem mais complexas do que permite alcançar nossa imaginação ocidental/burguesa/moderna. Como já referimos, os próprios jesuítas constataram, ao instalar as missões no Itatim, que grupos como os Payagua eram aliados próximos dos grupos falantes de guarani que ali habitavam - diferente do que ocorria em Assunção, que era frequentemente atacada pelos Payagua, por exemplo.

Mas, em suma, vemos que o que às vezes aparece, basicamente, como um processo de isolamento voluntário (os Itatines voltam ao mato logo após a experiência de redução e, no século XIX, aparecem os Paĩ/Kaiowá) envolve um processo bem mais complexo. Pelo momento, em relação a esse tipo de questão, se contribuímos para pôr em dúvida algumas certezas bem assentadas, já nos podemos dar por contentes.

\section{Do Uno ao fluido}

É por tudo isso que não faz sentido que continuemos tratando os grupos de língua guarani a partir de compartimentos estanques, construídos sobre diferenças linguísticas e elementos tão prosaicos como o modelo das cestas que cada grupo utiliza ${ }^{154}$.

\footnotetext{
153 Ressalve-se que, especificamente sobre a origem do etnônimo Chiriguanos, Combès declara ter alterado suas conclusões desde a publicação desse artigo. Ver, nesse sentido, Combès, 2010.

154 Trata-se da clássica proposta do padre Franz Muller, pioneiro da etnografia guarani, o qual observou que se podia associar cada uma das três parcialidades guarani a um tipo de cesta: adjacá, adjó e pynaku (Müller, 1989: 13).
} 
Como já lembramos alhures: do rio Paraná até o Paraguai, "tudo era tekoha”. Entenda-se por isso: uma gigantesca rede, que, aliás, ultrapassava e seguiu ultrapassando, com a chegada dos espanhois, todos os limites culturais, linguísticos e geográficos que se possa imaginar. No sentido em que apresento aqui, essa realidade das redes sociais indígenas apenas começa a ser explorada e ainda podemos levantar algumas dúvidas sobre o instrumental teórico para fazê-lo.

Mura (2006) fala em "redes de caminhos", "redes de parentesco", "redes de relações". Pereira (2004), por sua vez, fala, mais comumente, em "redes de socialidade" 155 e "redes de alianças", mas também em "redes de relações", "redes sociais", "redes de solidariedade", "redes de apoio (político)", "redes de rezadores". Vietta (2007) faz alguma menção do termo, relacionando-o a artigos de caráter etnográfico contidos em Gallois (2005) - a qual orientou o trabalho da autora. A única antropóloga que recentemente concluiu tese entre os Kaiowá e explicita seu referencial teórico em relação às redes é Barbosa da Silva (2007).

A referida autora dá destaque ao termo "redes sociais", a partir do referencial teórico britânico, pioneiro no desenvolvimento de uma "redologia". O volume organizado por FeldmanBianco (reeditado em 2009) contém as referências básicas utilizadas por Barbosa da Silva - artigos de Michell, Barnes e Mayer, sobretudo. A introdução a esse volume, escrita pela organizadora, é esclarecedora para os não iniciados na chamada "Escola de Manchester". Há um ponto de conjunção entre os trabalhos de Mura e Barbosa da Silva, em torno da utilização de conceitos de Gluckman, os quais, como se viu, também inspiram Oliveira. Um artigo fundamental de Gluckman também está disponível na citada coletânea.

Como fica claro nesses artigos de Barnes e Mayer, a noção de redes sociais aqui presente é a mesma que se desenvolveu nas décadas seguintes, adotando o uso de programas de computador como forma de gerar representações gráficas e estatísticas. Pode-se notar, nesse material, o emprego de diagramas semelhantes aos que hoje são gerados por programas como Pajek e Ucinet, bem como a discussão de critérios técnicos e conceituais para a análise dessas figuras. O estudo dessas redes, como um "instrumental analítico", no dizer de Mayer, constitui hoje todo um campo especializado das ciências humanas:

155 Processos intrínsecos ao sistema social em diálogo com os processos extrínsecos mais globais (relativos ao entorno), que se referem à ampliação das redes de socialidade, p. 31. Chega a definir o tekoha como "redes de alianças entre parentelas" (p. 118) 
“O termo 'rede' foi empregado por Radcliffe-Brown (1952: 190) $)^{156}$, que caracterizou a estrutura social como a 'rede de relações sociais efetivamente existentes' e afirmou também que essa estrutura deveria constituir o objeto da investigação antropológica. (...) Como assinala Firth (1954, p. 4), Radcliffe-Brown usou a noção de rede para expressar de modo impressionista 'o que sentia ao descrever metaforicamente o que via', cabendo a Barnes dar ao termo uma definição mais precisa. Barnes (1954b) vislumbrou a rede como um campo social formado por relações entre pessoas. Essas relações eram definidas por critérios subjacentes ao campo social (...). A rede era ilimitada (a não ser pelas fronteiras delimitadas pela circunscrição territorial da localidade estudada) (...)” (Mayer, op.cit: 1412)

Firth, segundo localiza Mayer (op.cit: 143), interpreta o emprego da noção de rede por Barnes como 'uma metáfora conveniente para descrever os conjuntos de relações pessoais'. Nesse sentido, como destaca Feldman-Bianco em seu texto introdutório, a distinção, sugerida por esse discípulo de Malinowski, entre estrutura e organização social, será fundamental para que se chegue a estratégias metodológicas como essa das redes:

"De acordo com essa distinção, estrutura e organização social são dois aspectos complementares da ação social que correspondem, respectivamente, à forma e ao processo na vida social. A estrutura social envolve o desempenho de papeis e proporciona o contexto para a ação. A organização social equivale à atividade ordenada, que inclui tanto os papeis sociais quanto as atividades decisivas mais espontâneas que não seguem simplesmente o desempenho de papeis. (...) Essa perspectiva possibilitou trazer de volta 'os indivíduos e suas estratégias' ao centro da análise, como as unidades básicas de pesquisas que começaram a ter por referencial indagações relativas a como a sociedade se transforma (em vez de como a sociedade se mantém). Essa ênfase em 'indivíduos e suas estratégias' (em vez de grupos corporativos, comunidades ou localidades) implicou também uma substituição do repertório de termos e conceitoschaves da pesquisa antropológica.” (Feldman-Bianco, 2009: 37-8)

156 Paginações citadas são das edições originais em inglês. 
É num contexto de foco em indivíduos, portanto, que aparece esse estudos de redes sociais, no âmbito da Antropologia Social - ou, no caso, antropologia individual, poderíamos arriscar.

O estudo que aqui desenvolvemos, poder-se-ia dizer, enquadra-se num contexto de renovação da teoria das redes no contexto antropológico no sentido de que, justamente, passamos por um momento de repensamento profundo sobre termos como sociedade e indivíduo. Já se fala em uma Antropologia pós-social (Goldman, 2008), e há mesmo antropólogos que rejeitam qualquer rótulo, seja social, cultural, biológico ou arqueológico (Ingold, 2011: xi).

Trata-se, em primeiro lugar, de buscar livrar-nos de concepções etnocêntricas sobre pessoa (pois “indivíduo" é a forma ocidental, por excelência, de entender a pessoa - vide Dumont, 1993) e sobre sociedade. Esse tipo de reflexão está, hoje, bastante espalhada pela nossa disciplina (vide, por exemplo, Strathern, 2006; Viveiros de Castro, 2002; Villaça, 2005). A etnologia das terras baixas sul-americanas, por sinal, tem contribuído decisivamente nesse movimento, se considerarmos, por exemplo, toda a gama de estudos sobre a pessoa ameríndia ${ }^{157}$.

Incidindo especificamente sobre o estudo das redes, poderíamos localizar algumas contribuições que já nos permitiriam delimitar um campo teórico próprio, alternativo a essa tradição britânica. A partir da mais recente obra de Ingold, tentaremos delimitar esse campo de debates, um estudo de redes não-individuais.

Já é possível até mesmo localizar uma controvérsia: Ingold (2011) expõe suas divergências em relação a Bruno Latour no tratamento das redes. Desde seu livro anterior, Lines (2007), o britânico já começara a desenvolver a ideia de redes sociais como meshwork, e não network, como já mencionamos acima. Agora, ele explicita, inspirou-se no uso que o filósofo Henri Lefebvre faz do termo (Ingold, 2011: 84).

O problema de pensar as redes sociais como network, lembra Ingold, se relaciona significativamente, diríamos - à confusão estabelecida na tradução do termo originalmente usado por Latour, acteur-réseau, para o inglês - quando a teoria se populariza como ANT (actor-network theory). No francês - como, ademais, na língua portuguesa - não há distinção entre o termo usado para uma rede informação ou comunicação - que conecta pontos -, ou uma trama formada por fios 
ou linhas, seja um tecido, uma renda, uma rede de pesca ou de dormir, ou mesmo o sistema nervoso.

O próprio Latour, diz Ingold, observou que "a tradução deu ao termo um significado que não havia sido pretendido" (Ingold, 2011: 85). Por outro lado, critica o inglês: "Latour tem sido um crítico inconsistente de muito que tem se passado como aplicações da ANT, ao ponto de negar que seja mesmo uma teoria e que verdardeiramente lide com redes".

Essa é, aliás, a justificativa para uma parábola que Ingold apresenta, em que suas divergências com Latour são transformadas no diálogo entre uma aranha e uma formiga. Os nomes dos dois animais, em inglês, spider e ant, formam siglas que sintetizariam as posições dos dois autores no debate. No caso, a de Ingold seria "Skilled Practice Involves Developmentally Embodied Responsiveness" (algo como "a prática habilidosa envolve receptividade desenvolvimentalmente incorporada").

O debate proposto por Ingold envolve certos desdobramentos que desenvolveremos melhor no capítulo 3. Por enquanto, nos ateremos ao que diz respeito, mais especificamente, à questão das redes. Em primeiro lugar, vale observar que a obra do filósofo Giles Deleuze - e de seu parceiro mais frequente, Felix Guattari - é uma referência tanto para Latour como para Ingold. Para este, a obra de Deleuze ajuda a desfazer o impasse entre uma "ecologia do real" e uma "fenomenologia da experiência":

\begin{abstract}
“A vida, para Deleuze, não é vivida dentro de um perímetro, mas ao longo de linhas. Ele as chama de 'linhas de voo', ou, às vezes, 'linhas de devir'. Tais linhas forçam uma abertura, assim como ligam o animal com seu mundo. Toda espécie, de fato todo indivíduo tem sua própria linha particular, ou melhor, um feixe de linhas" (2011: 83).
\end{abstract}

Nesse sentido, há uma desestabilização de alto rendimento antropológico no que tange à ideia de rede. Afinal, a própria ideia de vida - e por extensão, como veremos, de pessoa, indivíduo e "rede pessoal" também - está em jogo, como demonstra Ingold. O autor questiona: um organismo do que se trata? A tendência ocidental seria a de definir um perímetro - como na concepção do que seria a mais simples forma de vida (uma bactéria, por exemplo), um espaço interior, demarcado por uma membrana que o separa do mundo. No aparentemente inocente círculo (ou ponto) que costumamos esboçar quando queremos definir um organismo está embutida uma série de concepções que "invertem" uma realidade, segundo o autor: 
"Eu envolvo o organismo em si mesmo de tal forma que ele é delineado e contido dentro de um limite do perímetro, realçado contra um mundo circundante - um ambiente - com o qual ele está destinado a interagir de acordo com a sua natureza. O organismo está 'aqui dentro', o meio ambiente 'lá fora'” (Ingold, 2011: 69)

Ingold propõe, então, que se desenhe uma linha orientada, em vez de um círculo:

“Nessa representação não existe dentro ou fora, e nenhuma fronteira separando os dois domínios. Pelo contrário, há um rastro de movimento ou crescimento. Todo caminho assim revela uma relação. Mas a relação não é entre uma coisa e outra (...). É, antes, uma trilha ao longo da qual a vida é vivida. (...) Essa urdidura é o que quero dizer quando falo de organismos sendo constituídos dentro de um campo relacional. É um campo não de pontos interligados, mas de linhas entrelaçadas” (op.cit: 69-70)

A diferença entre um círculo e uma reta pode parecer banal, mas, observemos, é a partir de pontos e retas que se construiu pela antropologia, nas últimas décadas, um modelo para o estudo das redes. Retas que ligam pontos, temos nesse modelo que pensa as ligações entre indivíduos. Pontos que marcam o lugar onde se cruzam retas, passamos a ter nesse novo modelo que considera esses avanços rumo a uma melhor compreensão das concepções não ocidentais de pessoa.

O curioso é perceber que, para alguns pesquisadores dessa linha "tradicional" da redologia, o novo uso que propomos do conceito é apenas "metafórico", subentendendo-se que haveria outras redes mais "reais" 158 . Por um lado, poderíamos dizer que nos parece mais um sintoma de certo etnocentrismo teórico (ver introdução); por outro, vale reconhecer que essa autodefinição da antropologia como diferenciada da sociologia unicamente pela escala dos fenômenos que observa e uma dita "densidade" descritiva - fazendo-se, assim, uma "microssociologia", por assim dizer - faz parte da história da disciplina e está intimamente relacionada, justamente, a essa linhagem teórica que derivou para a redologia clássica (ver Feldman-Bianco, 2009: 19-35). Não se percebe, aí, qualquer pretensão de destacar uma "teoria nativa" ou algo que o valha.

158 É a distinção feita pelo redologista Zacarías Moutoukías, da Universidade Paris VII, por exemplo (informação pessoal, obtida durante seminário na Universidade Nacional Autônoma do México, em 2010). 
Feitos esses esclarecimentos, concluamos nossa breve análise da maneira como os etnólogos que analisaram recentemente os Guarani e Kaiowá utilizam essa ideia de redes. Algumas contribuições que poderiam ser relacionadas a autores como Latour já vêm sendo incorporadas aos estudos. Geralmente, porém, a discussão sobre o caráter etnocêntrico do binômio natureza-cultura que remete à ideia de atores "não humanos", chave para entender como a ANT pensa essas redes - é relacionada a Descola (1986) e, no caso de Pereira, a Viveiros de Castro (2002). Não é estendida, portanto, ao domínio das redes em si.

Assim, apesar de se falar extensamente em "redes sociais", verifica-se que ainda se carece de uma reflexão teórica mais ampla sobre o sentido do termo - ao menos para quem não se proponha a insistir nessa redologia de matriz individualista, por assim dizer. Um exemplo está no caso da tese de Pereira, autor que tem referências relacionadas às novas teorias, como Viveiros de Castro (2002). Ele define tekoha como a própria "rede supralocal de alianças" (2004). Em dado momento (p. 122), contudo, explicita que está pensando em uma network, não encontrando contradição em relacionar essa ideia de rede de pontos ligados por linhas a uma teoria que rejeita uma visão etnocêntrica de pessoa. A nosso ver, a principal consequência disso tudo, como já se viu, é uma compreensão ainda a ser aperfeiçoada com relação a dinâmicas territoriais, por exemplo.

Enquanto, em relação aos Guarani e Kaiowá de MS, ainda avançamos, com relação à bibliografia sobre os Mbya, por outro lado, temos ao menos um exemplo mais bem desenvolvido quanto ao tema das redes. Muito embora ainda se ampare, em parte ${ }^{159}$, no paradigma tradicional da redologia, Bartolomé (2009) merece menção aqui pelo fato de se dispor a realizar, em sua etnografia, uma descrição mais abrangente desse grupo guarani em diálogo com a ideia de redes.

Bartolomé pensa os Mbya como uma "sociedade de redes" e reflete, além de itens mais

\footnotetext{
$159 \mathrm{Em}$ parte porque, embora não derive para essas novas teorias que mencionamos acima, o autor explicita uma divergência bastante significativa com a redologia tradicional. A certa altura, ele comenta o "pioneiro" artigo de Teves et al. (2002), uma das poucas experiências de pesquisa que encontramos a buscar uma aproximação entre etnografia indígena e a construção de diagramas com auxílio de computador (fora do âmbito dos estudos estritos do parentesco, veja-se bem): "A pesar del sofisticado del análisis, sus conclusiones no son muy diferentes a las obtenidas por el registro etnográfico previo, ya que identifican a 4 o 5 jefes de familias extensas como individuos centrales de la red local y señalan que la mayor interacción se da em el seno de las unidades domésticas. Se trata, entonces, básicamente, de uma comprobación empírica y estadística, con una compleja expresión gráfica, de los datos cualitativos de la etnografía" (2009: 347-8). Vale notar que outro etnólogo com familiaridade com os instrumentos para análise de redes, Michael Houseman, também considera inútil esse tipo de instrumento para outro tipo de estudo etnográfico que não sejam os de parentesco (informação pessoal obtida durante atividade na Universidade Nacional Autônoma do México, em 2011).
} 
obvios como redes parentais, sobre tópicos como "redes associativas e residenciais", "redes de intercâmbios recíprocos", "redes políticas", "redes invisíveis" (xamanismo), "redes da vida ritual", "redes transnacionais" e, finalmente, "a categoria normativa das redes: tekó".

Como em Pereira, o teko'ha, na obra de Bartolomé, é pensado como um tipo de rede. Mas, como se trata, uma vez mais, de uma abordagem sincrônica, do tipo network, novamente temos aí a constatação de "um constante processo de estruturação e reestruturação, devido ao dinamismo e mobilidade das unidades que o integram" (op.cit: 299). Pereira, por sua vez, diz, por exemplo:
"Essas redes perpassam a malha do tecido social formado por parentelas dispostas por localidades distintas, imprimindo uma complexidade estonteante às relações políticas e dando a sensação de um quase desordenamento e caos à vida social. A impressão é de que os vínculos entre as pessoas não seguem nenhuma lógica identificável, pois visam apenas a atingir objetivos imediatos, e de que esses vínculos estabelecidos são logo substituídos por outros mais convenientes.” (Pereira, 2004: 122)

Nos seguintes capítulos, vamos refletir um pouco mais sobre esse tipo de vertigem dos etnógrafos diante das dinâmicas territoriais dos grupos de língua guarani, investigando algumas figuras de sua vida política que ajudam a melhor identificar os sentidos de seu movimento. 


\section{Tendotá}

"El cazicazgo es una especie de dignidad hereditaria como nuestros mayorazgos, pero muy singular porque el que la posee no difiere de los demás indios en casa, vestido, ni insignia; ni exige tributo, respeto, servicio, ni subordinación, y se ve precisado a hacer lo que todos para vivir. Tampoco manda en la guerra, y si es tonto le dejan y toman otro.”

Feliz de Azara (1742-1821), Descripción e História del Paraguay y del Río de la Plata.

"Tendo-lhe perguntado de onde provinha sua ascendência sobre os seus (era um chefe, e nossos marinheiros o tratavam como rei), respondeu-me que tinha o privilégio de marchar à frente dos outros quando iam para a guerra. À minha pergunta: quantos homens o acompanhavam? Mostrou um terreno como para dizer: o que cabia naquele espaço, isto é, cerca de cinco mil homens. Indaguei ainda se nas épocas de paz ele conservava alguma autoridade, e disse-me: "Quando visito as aldeias que dependem de mim, abrem-me caminhos no mato para que eu possa passar sem incômodo.”

Michel de Montaigne (1533-92), “Dos Canibais” (1972: 110). 


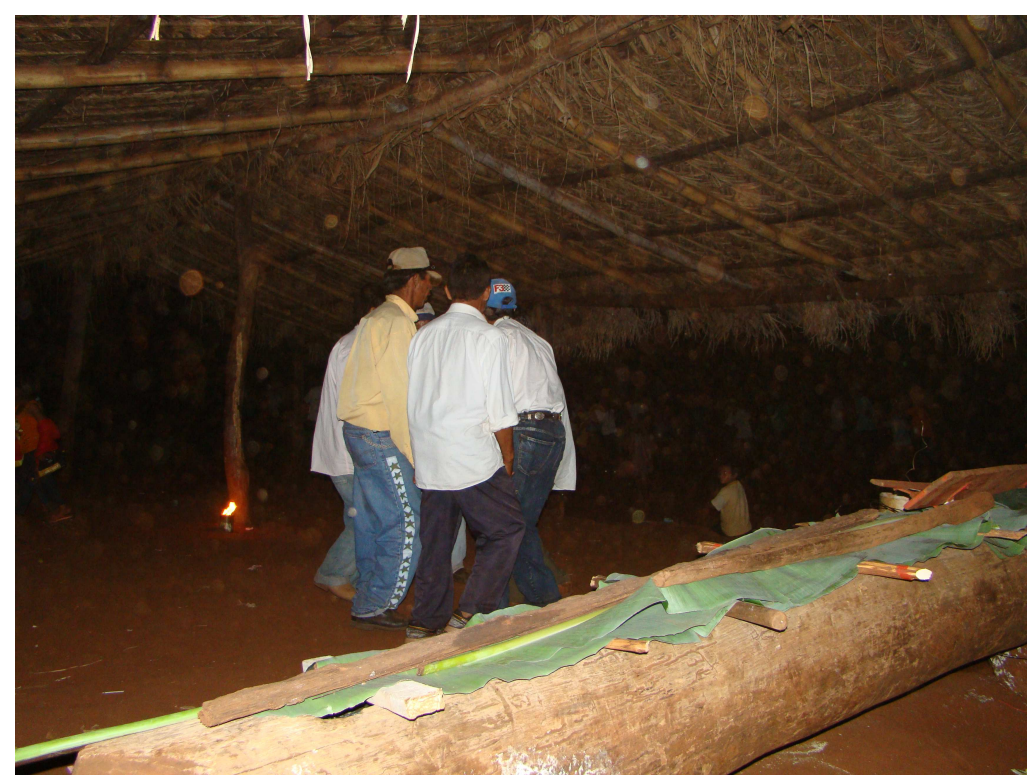

O tendotá deve organizar festas; tomar a frente; manter o diálogo com as autoridades karai...
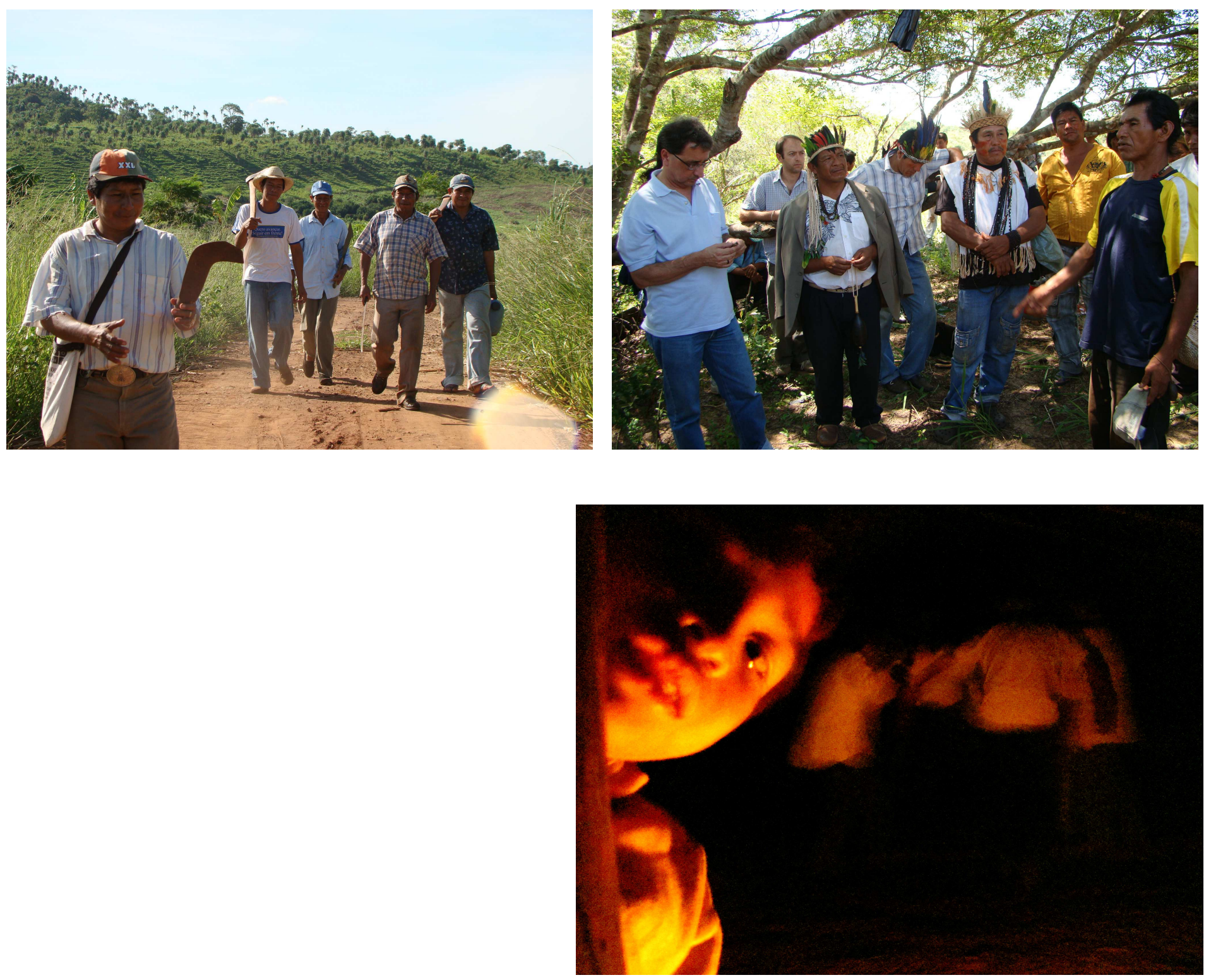

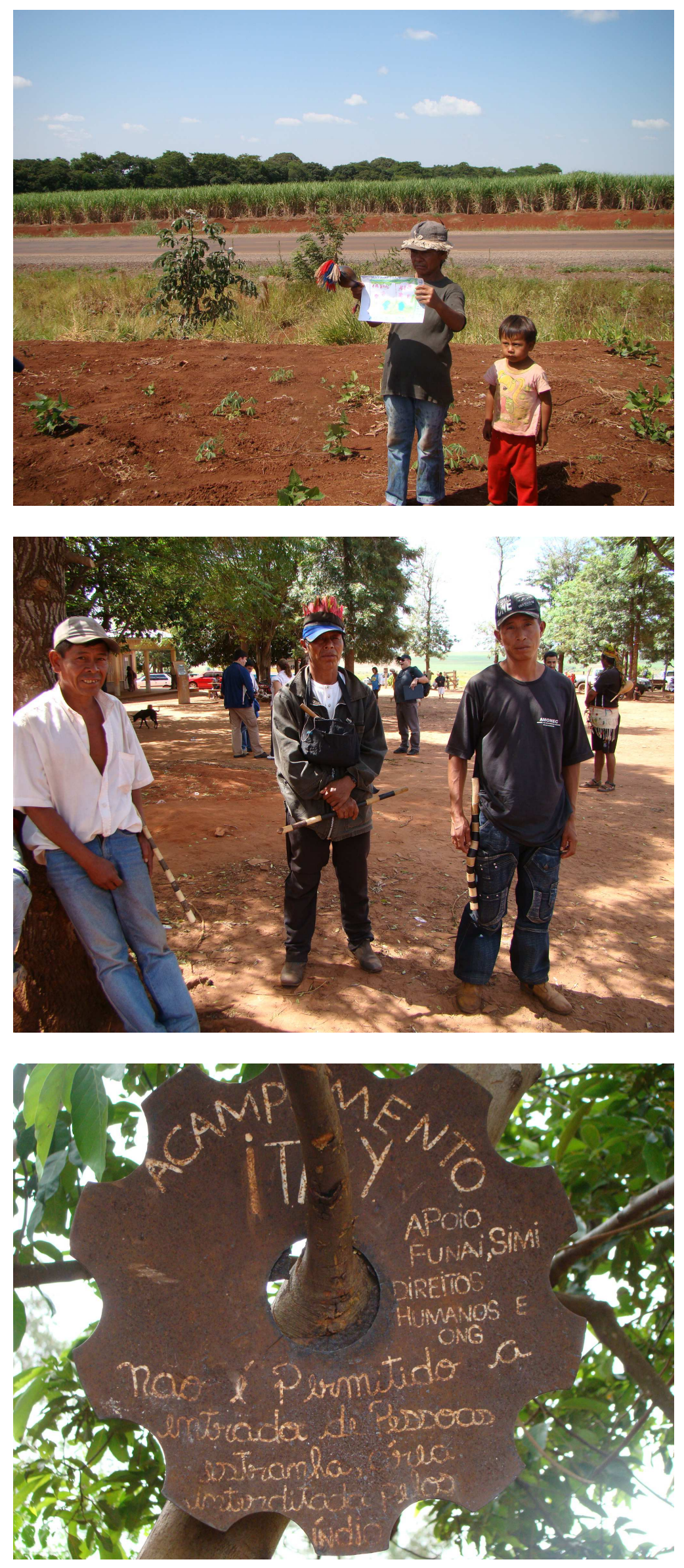

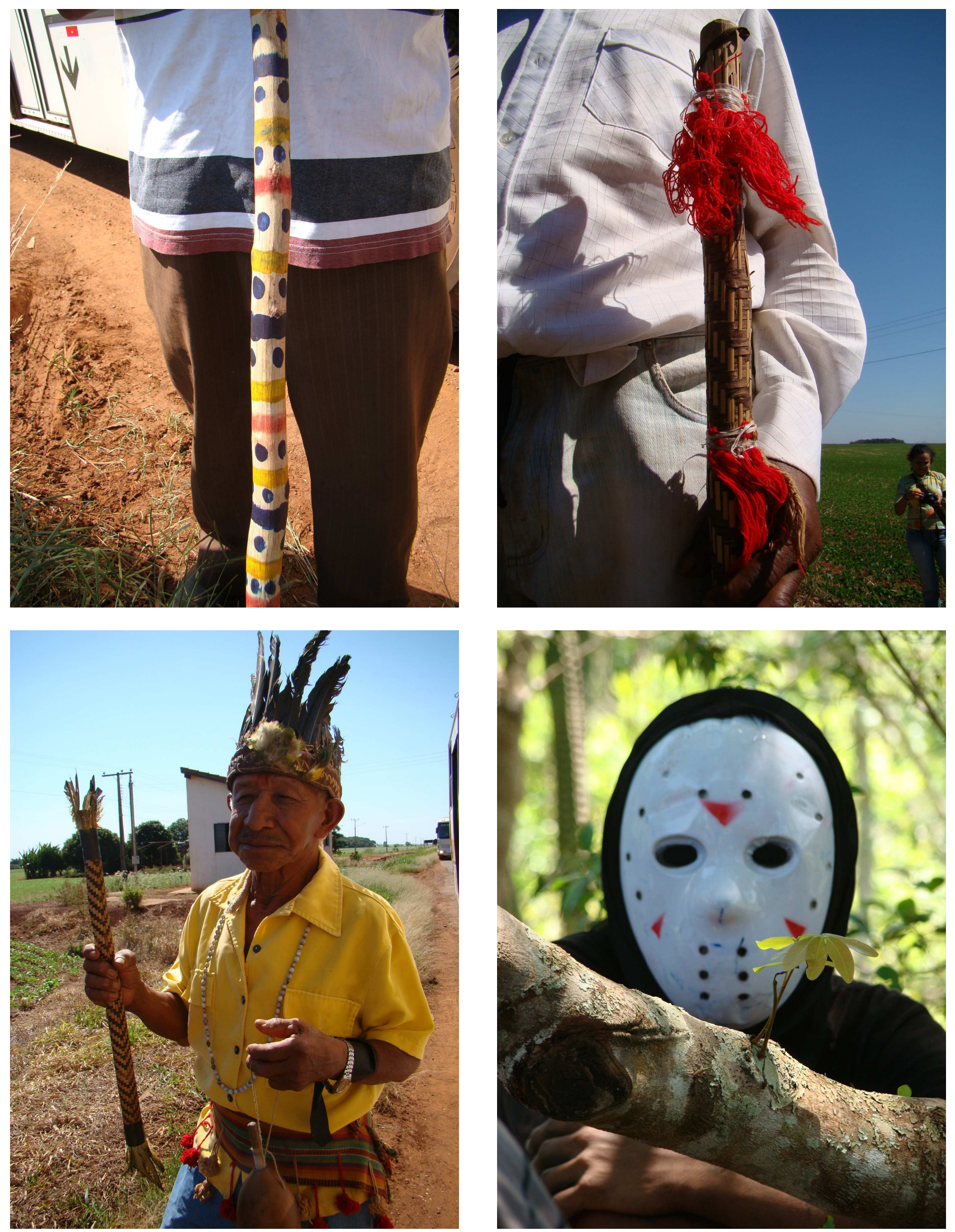

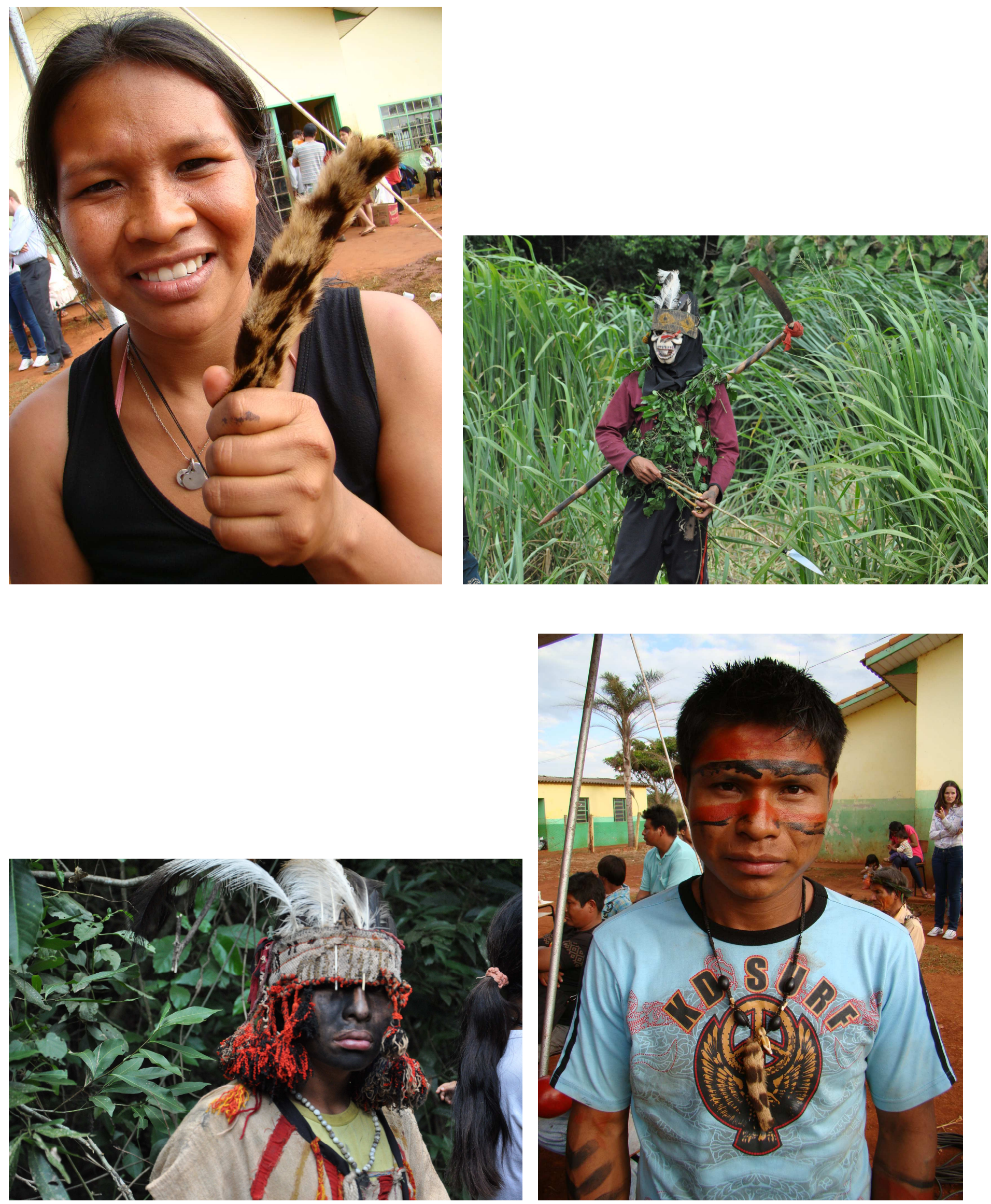
Política é, como se sabe, um termo que evoca muitíssimas interpretações inclusive entre "nós", ocidentais ${ }^{160}$. O que se entenderá aqui por teoria política kaiowá é, em resumo, uma reflexão sobre os movimentos dos coletivos humanos ${ }^{161}$. Os Kaiowá que conheci são muito ciosos a respeito de quem inicia uma ação, de quem vai "tomar a frente", a iniciativa para realizar algo, seja no âmbito familiar ou no grupo local. Estamos falando de ações que vão desde uma roça, uma caçada, uma festa até o diálogo com um prefeito, chefe da Funai ou procurador do Ministério Público, um protesto, uma ocupação de terras etc. etc.

Assim, a primeira figura que surge nessa reflexão política é a figura do tendotá. Esse é o termo kaiowá que designa a pessoa que vai à frente, que inicia uma ação. Encontrei mesmo quem me traduzisse política por tendotá puakapy, ou seja, assunto de tendotá.

Evoca-se, portanto, a figura da fila. Significativamente, segundo indicam os dicionários etimológicos, o termo "fila indiana" pode ser considerado uma corruptela, uma tradução equivocada de "indian file". A expressão norte-americana tem origem na observação dos colonos brancos, generalizada e levada ao senso comum, de que os indígenas (e não os habitantes da Índia) vão à guerra andando em fila (todos pisando no rastro de quem vai à frente, "para dar a impressão de que, por ali, passou um único homem"). Tylor (1881: 244) registrava esse uso, em trecho sobre as guerras indígenas norte-americanas.

Tendotá é, ao mesmo tempo, uma qualidade desejável daquele que está numa posição de liderança. Nesse sentido, é como se fosse ora um substantivo, ora um qualificativo: pode expressar tanto a pessoa real como o que se espera que essa pessoa seja. Um exemplo do emprego corriqueiro do termo, traduzido como liderança, de forma geral, está num texto recente de acadêmicos indígenas, publicado na revista Tellus:

\section{“Atyguasu ha'e peteĩ ñomongetaha ombyatýva tendota kuéry oikóva tekoha Guarani ha Kaiowá retãmy. Atyguasúpy oñomongeta ha'e kuéry oñondivepa, ombojojávo ñe'e yvy rehegua, ikatu haguãicha ojevyjevy pe}

\footnotetext{
160 Usarei recorrentemente o termo "ocidental" com a intenção de evocar os seguintes correlatos: democrata e liberal. A adesão (não necessariamente consciente) a certos pressupostos básicos dessa corrente hegemônica de pensamento, pensamos, explica o desconcerto de boa parte da antropologia diante das formas políticas ameríndias. Essas questões serão mais extensamente desenvolvidas no capítulo 4.

${ }^{161}$ Aqui, perceberá o leitor, estamos diante de uma escolha que transformo em bifurcação: poderia ter perseguido, por exemplo, as ressonâncias do nosso termo "política" para os Kaiowá e Guarani e teria feito outro trabalho. Como observa Pereira (informação pessoal), aí teríamos de falar, basicamente, de fofocas, feitiços, mentiras, brigas, uma série de associações negativas que os indígenas percebem em torno das disputas eleitorais e por cargos públicos.
} 
oyvy guekohaguépy (terra tradicional). Upépy tendota kuéry ohai pe kuatia omondo haguã mburuvicha guasu kuérypy oisambyhýva ko ñane retã guasu Brasil" (Turma de Linguagem da Literatura Indígena Teko Arandu UFGD, 2010: 240) ${ }^{162}$.

Não significa que o tempo todo, sempre, as pessoas chamem o chefe de tendotá. Na verdade, é até raro encontrar alguém usando o termo. Mas, as pessoas cobram de um líder uma série de iniciativas, ações e características, de tal forma que, em certos momentos da conversa, evocam essa ideia. Tendotá não é exatamente um título, como os de mburuvicha - principal - ou capitão. Qualquer homem maduro (e também uma mulher, conforme a situação ${ }^{163}$ ) pode, em princípio, assumir essa posição de tendotá - isto é, puxar uma fila, iniciar uma ação.

No uso cotidiano, na comunicação com alguém de fora do coletivo local - vamos dizer, um antropólogo -, os três termos são aproximadamente intercambiáveis. É na convivência mais prolongada junto a um coletivo kaiowá que se pode perceber que, na prática, não basta ser tuvicha, é preciso ter algo de tendotá para manter a posição de principal. Já as conotações do termo "capitão" hoje variam muitíssimo. Há desde grupos onde o termo mantém a legitimidade, sendo sinônimo de mburuvicha, até outros em que os dois termos se tornaram antônimos - os motivos para essa transformação/ambiguidade serão discutidos mais à frente.

O termo mburuvicha, ou tuvicha, da mesma forma que tendotá, é registrado desde os primeiros contatos entre europeus e grupos de língua guarani ${ }^{164}$. Já o termo capitão costuma ser relacionado, mais diretamente, à política indigenista aplicada pelo Estado brasileiro ao longo do século XX, como veremos adiante. Mas não deveria, considerando-se o uso corrente do termo, já desde o século XVI. Gândavo, em 1576, dizia, a respeito dos Tupi do litoral: "Esta gente não tem

162 A tradução é publicada no mesmo espaço, em coluna paralela à do texto em guarani: "Em Mato Grosso do Sul, a aty guasu é uma reunião geral de líderes de todas as aldeias guarani e kaiowá. $\mathrm{Na}$ aty guasu a liderança conversa sobre a terra indígena tradicional e se organiza para retornar às áreas que se encontram em poder de fazendeiros. Na Aty guasu as autoridades das comunidades escrevem documentos que depois são enviados às autoridades maiores que lideram o Brasil". Sobre as Aty Guasu, ver o capítulo 4. Note-se que, no mesmo texto, o termo "mburuvicha guasu", traduzido como "autoridade maior", dos brancos, também é anotado, em outro trecho, como "tendota guasu" - ou seja, no emprego corriqueiro, os termos podem ser intercambiáveis.

163 Pois em função da morte do marido, uma mulher pode assumir a liderança de um grupo familiar, com auxílio dos filhos homens. Também cargos ocupados nas escolas, por exemplo, podem dar a certas mulheres a possibilidade de uma tal atuação política que pode "puxar uma fila". Deve-se observar, porém, que essa posição expõe muito a pessoa a disputas políticas de toda ordem, de tal forma que, ao menos nos casos em que observei, a mulher procura resguardar-se.

164 No Tesoro, de Montoya (1639b), vemos que o termo tuvicha está relacionado tanto a dimensão como a posição, entre "grande" e "superior". Pode-se dizer che ruvicha, meu chefe (parte dos substantivos em guarani varia com o pronome possessivo). Mburuvicha costuma ser traduzido com o mesmo sentido que tuvicha. 
entre si nenhum rei, nem outro gênero de justiça senão um principal em cada aldeia que é como um capitão, ao qual obedecem por vontade e não por força" (Gândavo, 2004: 137) ${ }^{165}$.

Para aclarar o que se dirá daqui em diante, convém explicar que, basicamente, num primeiro momento, tentaremos mostrar os entrelaçamentos entre os papeis de um condutor e de um principal - tendotá e mburuvicha. Posteriormente, falaremos sobre a figura do capitão, vista por vários antropólogos como decorrência da ação do Estado brasileiro e, portanto, uma figura "externa" e "imposta". Vamos demonstrar que, em alguns contextos, ela também pode ser entendida, do ponto de vista dos Kaiowá, como uma transformação de suas próprias formas de liderança.

\section{Movimento}

Em que sentido o tendotá deve tomar a frente? Acredito que a principal expressão desse qualificativo para os líderes reemergiu com mais força nos últimos anos, no período pósredemocratização do país, em que os Kaiowá tiveram de exercitar com mais decisão as atitudes características do tendotá. O tendotá é o líder, ou seja, aquele capaz de mobilizar uma turma para segui-lo e abrir uma nova aldeia, um novo lugar de residência e vida.

No contexto atual, é impossível pensar que a pessoa que toma uma iniciativa como essa seja algo menos que um líder guerreiro. Atributos militares são requeridos, pois é preciso traçar uma série de estratégias para defender o grupo dos ataques de fazendeiros e homens de empresas de segurança privada, normalmente chamados de "pistoleiros" pelos indígenas.

A figura evocada pelo tendotá, como já dissemos, é a fila. O tendotá é uma figura do movimento. Ele "puxa” uma fila, "puxa” uma turma. Ele é quem dá o impulso inicial de deixar o velho e buscar o novo (tujálpyahu - velho/novo, eis uma dinâmica frequentemente evocada). Sair de um lugar onde as coisas não são boas, onde já não há alegria (vy'a), onde tudo está "envelhecido", para buscar o novo, buscar a alegria.

É evidentemente possível fazer um paralelo com exemplos amazônicos, desde que se lembre, sempre, que a situação por lá por não costuma envolver constrangimentos territoriais

165 Gadelha (1980: 114-5) lembra que, a partir do século XVII, a Espanha usou, diante dos grupos de língua guarani, de uma série de instrumentos para cooptar os líderes indígenas, "institucionalizando", já, esse papel, por meio da concessão de títulos como "Don", por exemplo. Os caciques tornavam-se uma "camada de privilegiados". Note-se que os "cabildos indígenas", introduzidos à época, tiveram uma série de decorrências e desdobramentos nos Andes e na Mesoamérica. 
severos como na área dos Kaiowá e Guarani. Nesse sentido, a ênfase, ao avaliar a capacidade de um líder está, por exemplo, em sua habilidade para abrir novas aldeias, como acontece nos Wajãpi, onde essas pessoas são chamadas de jovijã (Gallois, 2001; Tinoco, 2003), termo traduzido por sábio ou chefe - um correlato de tuvicha, segundo Dominique Gallois (informação pessoal). Ali, também, a capacidade de iniciativa é um fator destacado no desempenho dessas figuras. Evidentemente, a abertura de uma nova aldeia, em meio à mata, não se compara com a dificuldade que significa, hoje, para um grupo kaiowá, entrar em suas áreas de ocupação tradicional, mas os parâmetros de avaliação, vamos dizer, guardam similaridade.

Poderíamos lembrar que esse paralelo evoca o que sugere Meliá (1989) sobre o sentido da Terra sem Mal em uma abordagem "realista", como ele designa. Afinal, se na própria dinâmica da agricultura aparece essa ideia de uma terra que "se cansa", que envelhece (e daí a necessidade de abrir novas aldeias), ainda mais premente se torna a necessidade de buscar novas terras, novos espaços quando, com o impacto colonial, surge toda a calamidade que conhecemos para os grupos de língua guarani. Por sinal, uma passagem desse texto de Meliá evoca diretamente o que mencionávamos no capítulo anterior a respeito das festas:

\section{"La tierra es el soporte fundamental para la economía de reciprocidad que se resuelve paradigmaticamente en la fiesta, la forma de vida a la que el guaraní aspira como plenitud: es buena aquella tierra que permite, en las ocasiones propicias, tener buenas y concorridas fiestas” (Meliá, 1989: 497).}

Certamente a Terra sem Mal, essa construção etnográfica, que transbordou para o senso comum acadêmico sobre os povos de língua guarani de modo geral, tem um profundo sentido cosmológico, mas é inegável que se trata de uma figura que remete diretamente a essa dinâmica territorial. Afinal de contas, como veremos no capítulo seguinte, a dimensão ecológica é inseparável da reflexão xamânica.

Para além do exemplo wajãpi, há uma proximidade notável - inclusive linguística ${ }^{166}$ - com o qualificativo arawete tenetã-mõ, conforme descrito por Viveiros de Castro (1986: 300-20) ${ }^{167}$. Por

\footnotetext{
166 Evidentemente, não podemos restringir os paralelos à ocorrência de correlatos, o que seria enganoso. Mas, não deixarei de registrar alguns casos aqui em que, segundo demonstram as etnografias, o paralelo se dá, também, nas descrições de práticas e relações.

167 Em publicações posteriores (como Viveiros de Castro, 1987), o autor apresenta a grafia tenotã-mõ, que, por sinal, chegou a inspirar o título de um livro sobre o impacto dos projetos hidrelétricas do Xingu (organizado por
} 
sinal, é, também, de "movimentos coletivos" e de "iniciar uma ação" que trata o autor no segmento de seu trabalho em que descreve o sentido desse termo, traduzido sumariamente por "líder":

\begin{abstract}
“Tenetãmõ significa 'em primeiro lugar', 'o que segue à frente', 'o que começa'. Essa palavra designa o termo inicial de uma série qualquer, possuindo conotação espacial e temporal: o primogênito de um grupo de irmãos, o pai em relação ao filho, o homem que encabeça uma fila indiana na mata, a família que primeiro sai da aldeia para excursionar nas chuvas. (...) O líder arawete, assim, é o que começa, não o que ordena; o que segue à frente, não o que fica no meio. Toda e qualquer empresa coletiva arawete supõe um tenetãmõ; não existe começo inocente, acordo 'comum', em que todos estejam na mesma relação com a tarefa. Uma coisa não começa se não houver alguém em particular que a comece." (Viveiros de Castro, 1986: 301).
\end{abstract}

Como se vê, há incrível similaridade na ideia e nas atitudes descritas - muito embora estejamos em um contexto completamente distinto. Por lá, floresta amazônica e um pequeno grupo, de 136 pessoas à época do trabalho de campo do autor (1986: 718). Entre os Kaiowá e Guarani, estamos falando de grupos que chegam a ter, hoje, no contexto do confinamento promovido pelo Estado, mais de 10 mil pessoas.

Entre os caçadores tupi Awa-Guajá, do Maranhão, a impressão se confirma. Garcia, que os visitou recentemente, também nota a proximidade com os comportamentos descritos por Viveiros de Castro e comenta: "A relação entre vontade e ação não possui um centro fixo de irradiação da ação. Não há uma palavra de ordem que os mobilize para a caça ou qualquer outra atividade, e os eventos podem ocorrer como que 'por vontade própria'” (2010: 278). Chama a atenção o desencontro entre os funcionários da Funai e os Awá:

“Por isso, há uma grande dificuldade para os funcionários da Funai em
arregimentá-los para os trabalhos da roça, pois palavras de mando não
surtem o mesmo efeito que uma epidemia de vontades. É comum os
funcionários marcarem uma colheita ou plantio no dia seguinte, e na hora
que estão indo para a roça, alguém anuncia um novo rastro de porcos ou Sevá Filho, 2005). 
um grupo de guaribas, e todos abandonam o 'trabalho', deixando os funcionários sozinhos na roça” (Garcia, 2010: 278)

$\mathrm{Na}$ linha do que sugere Fausto, Garcia fala em "contágio". Eu considero que sim, o que se verifica entre os Parakanã parece próximo do que observamos a respeito do tendotá - por lá, há o cognato tenotara (Fausto, 2001: 278). Ocorre, porém, que Fausto fala em uma "sociedade sem chefia" (idem: 276), e penso que não é disso que se trata. É preciso atentar para a sutileza nas relações políticas que emergem a partir do momento em que se estabelece uma iniciativa.

Além da escassez - da falta de comida, sobretudo -, os desentendimentos entre as pessoas também geram a tristeza e os conflitos que motivam o impulso para vários movimentos coletivos kaiowá. Em casa onde não tem pão, todo mundo briga e ninguém tem razão, reza o dito popular karai. Foi exatamente o que começou a acontecer mais frequentemente nas reservas do SPI - com intensidade crescente a partir dos anos 70. Isso, aliado ao ambiente de redemocratização, com a proliferação dos parceiros dispostos a ajudar os indígenas a construir (na Constituinte que resultou na Carta de 88) e cobrar seus direitos, gerou as condições necessárias a uma proliferação dos tendotá.

O mundo kaiowá é um mundo de movimento. O confinamento poderia ser comparado ao barramento de um rio (vários rios, aliás). O lago se encheu de tal forma que as barragens se romperam. Ficar parado nas reservas pode ser insuportável. Por exemplo, Ndavy'aei, não estou contente, é uma explicação comum para comportamentos que, frequentemente, desembocam em mortes por enforcamento (Pimentel, 2011a).

O contraste entre a tristeza, a desmobilização da vida nas reservas e o vigor do cotidiano nos acampamentos motiva as pessoas. O entusiasmo começa com os idosos e se espalha por toda a família. Para as ocupações de terra, os Kaiowá têm de conciliar dois fatores: por um lado, buscam lugares que mantêm características o mais possível próximas das ideais; por outro, têm de dialogar com as exigências da legislação brasileira, as quais definem o que são "terras de ocupação tradicional". Mais ainda, em função de particularidades históricas do sul de Mato Grosso do Sul, existe uma espécie de tradição de que as terras indígenas resultantes de um processo de identificação não passem de 10 mil hectares (em alguns casos, o total não chega a 1 mil, como é o caso de Sucuriy e Jaguari - de 535 e 404 hectares, respectivamente).

Assim, embora, segundo os critérios de muitos (entre os quais me incluo), toda a região sul 
de MS pudesse ser considerada "de ocupação tradicional"168, em função da farta documentação histórica sobre a presença dos Kaiowá e Guarani na região, o fato é que, nos últimos anos, os indígenas têm tido que buscar especificamente áreas onde já houve, num passado bastante recente (a ponto de ser descrito de forma convincente aos antropólogos, advogados, juízes e outros profissionais karai que analisarão a demanda pela terra), a presença de assentamentos relacionados, de alguma forma, ao(s) grupo(s) familiar(es) que realizam a ocupação. Felizmente, o paradigma que gerou essa demarcação "em ilhas" vem sendo superado no debate recente, como vimos na introdução.

Além da necessidade de considerar essas "regras do jogo" impostas pelos karai, os Kaiowá buscam, nas ocupações, locais que tenham características pyahu: grosso modo, estamos falando de relativa abundância de recursos de flora e fauna, além de um curso d'água e outros fatores ${ }^{169}$. No momento de organizar esse processo de ocupação, o(s) tendotá (muitas vezes, há mais de um tendotá à frente de um processo como esse, como se verá) deve(m) estar em aliança com um ou mais ñanderu/ñandesy. A importância dessa aliança, que é particularmente forte no momento da ocupação da terra, será tema do próximo capítulo.

O tendotá, então, encabeça a fila que se dirige a uma nova ocupação. Ele é o encarregado de se assegurar de que aquele novo local será, objetivamente, capaz de atender às necessidades de seu grupo: água corrente, lenha, madeira para construir casas, solo fértil para plantar e, antigamente, abundância de caça e pesca, entre outros fatores. Hoje, além desses fatores, ele terá o encargo de providenciar comida (cestas básicas), instalação de escola, atendimento de saúde pelo poder público, um poço artesiano fornecido pelo governo etc. No próximo capítulo, veremos por que tudo isso exige estreita colaboração com os xamãs ñanderu/ñandesy.

Finalmente, o tendotá terá, ainda, que manejar as discussões com as "autoridades competentes" para obter autorizações para permanência de seu grupo naquele novo local. Afinal de contas, se antes tudo era tekoha no sul de Mato Grosso do Sul, hoje tudo é fazenda.

O período de mobilização de um grupo pela ocupação de uma área é de muita intensidade,

168 Até o rio Paraná, tudo era tekoha, lembremo-nos. Em se tratando do Mato Grosso do Sul, nunca é demais repetir que não se está defendendo, aqui, que tudo deva ser demarcado como terra indígena. O Estado brasileiro, de qualquer forma, deve um pedido de desculpas aos Kaiowá e Guarani pelo mal que lhes causou ao longo do século $\mathrm{XX}$. Nesse sentido é que, penso, esse reconhecimento seria oportuno.

169 As características ambientais que são eleitas pelos Kaiowá e Guarani para estabelecer seus assentamentos estão exaustivamente descritas nos relatórios ambientais que acompanham os processos de identificação e delimitação de suas terras indígenas. Uma reflexão sobre a síntese dessas características, em relação aos grupos de língua guarani como um todo, é feita por Meliá (1989). 
em todos os sentidos possíveis do termo. As próprias lideranças kaiowá de outras áreas se espantam com a união que surge no grupo durante o processo de retomada de um tekoha. Os porahei (cantosreza) se tornam cotidianos e muito frequentados. Os mais velhos contam histórias aos mais novos sobre o local, como eram as coisas ali, o que se fazia etc. Também falam sobre as árvores, os bichos, mostram às crianças coisas que elas já não têm oportunidade de ver nas reservas antigas. Ali, os mais novos caminham pelo mato, buscam água, coletam plantas para servir como remédio e, às vezes, até podem caçar e pescar.

Mongu'e (movimentar-se) é outra das traduções que me oferecem para "política". E é disso que se trata aqui: o momento de reocupação do tekoha é de movimentação, de agitação frenética. E, por isso, percebemos, favorece a união e as atividades coletivas. Reforçar o coletivo intensificando as sessões noturnas de porahei, realizando repetidos discursos públicos a respeito da importância de se comportar devidamente, para que nada saia errado etc.- torna-se um imperativo de sobrevivência. É preciso que todos se vigiem, porque um descuido pode resultar em tragédia: os atentados praticados por funcionários de fazendas são uma ameaça constante. Jovens desacompanhados, por exemplo, podem ser extremamente vulneráveis.

Esse momento em que o coletivo todo deve permanecer concentrado na luta, em conseguir construir a viabilidade para a permanência naquele local, acaba também se convertendo em oportunidade para a educação política dos jovens. Por um lado, eles vão aprender algo sobre disciplina, pois têm de seguir orientações da liderança e exercer atividades como vigilância, estafeta, comunicação. Além disso, podem perceber-se valorizados pelo grupo, úteis para o coletivo. A falta de sentido para a vida dos jovens nas reservas, repito, é comumente relacionada ao sentimento que leva à violência sem sentido e as mortes por enforcamento (Pimentel, 2006; 2011b).

Essa fase da luta compõe, atualiza, recria relações. É um momento em que o coletivo se (re)compõe, incorpora aliados, expele os que resolvem colaborar com os opositores do grupo, aceitando benefícios sociais e dinheiro em troca de informações ou sabotagens. Quando essa mobilização intensa se enfraquece, cada grupo familiar vai cuidar de sua sobrevivência, e as ações coletivas que demandem maior número de pessoas (ou maior grau de consenso, como veremos no capítulo 4) são mais dificilmente atingidas. 


\section{Ao parar, os problemas}

Uma vez que um grupo está estabelecido num local, poder-se-ia pensar que o papel do tendotá se esgota. É clássica e muito difundida, na etnologia, a percepção de uma distinção entre "chefe de guerra" e "chefe de paz" "170. Em certas conformações, os coletivos ameríndios chegam a separar, formalmente, esses papéis. Não é o que percebi, exatamente, nos Kaiowá. O jogo é mais complexo: é possível encontrar distintos exemplos, tanto de esgotamento como de manutenção da importância de determinada figura. Isso depende da conformação do grupo local, das condições históricas que ele enfrenta etc.

É preciso assinalar, no entanto, que há um número expressivo de exemplos em que líderes que adquiriram grande prestígio durante períodos de mobilização por terras passaram, no momento posterior, em que essa disputa se resolveu, por um processo de desgaste tal que terminaram suas vidas em uma posição muito desconfortável dentro das terras indígenas que ajudaram a conquistar há, inclusive, casos de suicídio ${ }^{171}$.

Nesse sentido, apesar de conhecer exemplos de líderes que conseguiram driblar esse processo de ostracismo automático, uma vez findada a batalha, deve-se reconhecer que, grosso modo, o tendotá guarda semelhanças com o que, na literatura, se conhece por "chefe de guerra" e que o mburuvicha poderia ser considerado uma espécie de "chefe de paz", ainda que tenha de conservar certas características louváveis na personalidade de um condutor (sobretudo, a capacidade de iniciativa, entendida num sentido amplo).

O exemplo mais conhecido de um líder que passou por esse processo de ostracismo após a conquista da terra é o de Lázaro Morel, do Pirakuá, na região do Apa, conforme relatado por Pereira (2003). Lázaro, que se destacou no processo de luta pelo Pirakuá, foi, posteriormente, “destituído de qualquer poder de mando, tornando-se uma liderança comum, com influência restrita ao pequeno círculo de parentes próximos":

$$
\begin{aligned}
& \text { “(...) a comunidade parecia ter realizado um esforço deliberado de } \\
& \text { esquecimento do feito de seu líder, dando pouca importância a esses relatos } \\
& \text { e não o poupando de críticas quando seu comportamento era julgado } \\
& \text { inadequado de acordo com as normas de conduta social do grupo. Com o }
\end{aligned}
$$

170 Ou, para lembrar Lowie (1967), "strong chiefs" e "titular chiefs".

171 Conforme lembrado, em conversa que mantivemos, por Celso Aoki, antropólogo que acompanhou as mobilizações kaiowá e guarani contra os despejos e pela recuperação de suas terras desde o final dos anos 70 . 
tempo, surgiram outros líderes que a comunidade julgava mais aptos para

conduzir os assuntos da coletividade, e Lázaro foi destituído do cargo de capitão (líder oficial do grupo) e relegado a um segundo plano”(Pereira,

2003: 140)

Há alguns exemplos parecidos, mas também situações bem diversas - os Kaiowá e Guarani, lembremos, estão espalhados por dezenas de diferentes grupos locais. Seja ou não a mesma pessoa que se torne o principal durante o período de "acomodação", após o estabelecimento do grupo em uma área, o fato é que recairá sobre ela uma série de exigências envolvendo a necessidade de iniciativa e de "tomar a frente" - comportamentos típicos de um tendotá. Tentarei mostrar como as expectativas em relação ao mburuvicha estão repletas desses elementos.

Um grupo de pessoas vivendo juntas tem vários problemas que aparecem cotidianamente. Um casal se desentende: ele bebeu, os dois discutiram, ele a golpeou. Isso não está certo, pensam os mais velhos. Isso não é aceitável. Aos mais velhos da família cabe o papel de aconselhar o casal. Idealmente, para os Kaiowá, o grupo local é uma grande família - ainda que se reconheçam, em um local de moradia, os diferentes $t e^{\prime} y i^{172}$, supõe-se que foram laços de afinidade, justamente, que levaram esses grupos a morar juntos. Nesse sentido, uma briga de casais, ainda que seja, também, pode ser um assunto diante do qual o principal deve tomar uma atitude ${ }^{173}$.

Ocorre que, hoje, um grupo local raramente é uma grande família, apenas. Dificilmente, há somente um grupo familiar habitando o lugar, e os desentendimentos podem surgir se o mburuvicha fala com esse casal fora do tom. Por isso, talvez, a ênfase em "aconselhar” (ñemoñe'ē). Uma fala ríspida pode gerar um desentendimento, uma agressão. É preciso ter firmeza e tato.

Pode ser que os vizinhos acionem o mburuvicha/capitão e seus auxiliares (policiais chamados, em geral, assim mesmo, no português ${ }^{174}$ ) no decorrer de uma briga. Nesse caso, pode ser

172 Pereira (1999) disserta sobre essa relação entre os te’yi ("famílias extensas", no dizer do autor) e o tekoha, entendido como comunidade, ou grupo local, conforme os Kaiowá e Guarani utilizam, hoje, o termo. A ocupação de terras, penso (e isso, em alguma medida, está presente em quase todas as demais etnografias recentes sobre esses grupos), pode ser compreendida também em relação a essas tensões entre os grupos familiares - lutar por um tekoha é, de certa forma, reivindicar o espaço próprio para um grupo familiar, fugindo aos conflitos com outros grupos nas áreas mais lotadas.

173 Barbosa da Silva (2007: 115) percebe essa atribuição de árbitro na figura do capitão. Para ela, o capitão "recupera as funções que eram esperadas de um mburuvicha/tekoaruvicha". É como se a figura do capitão fosse algo alheio, externo, que se apropria de elementos locais para melhor atuar. O que propomos aqui é uma inversão desse olhar, como demonstraremos adiante.

174 Macedo $(2009 ; 2011)$ discorre a respeito dos xondáro guarani (mbya/ñandeva do litoral). Xondáro, note-se, é uma guaranização do português "soldado" e há vários paralelos que poderiam ser pensados com os policiais 
que se julgue necessário agir imediatamente, em função do perigo de danos físicos a uma mulher ou crianças, por exemplo. Se um homem está bêbado, pode ser necessário que vários outros homens intervenham para contê-lo. Nesses casos, aconselhar é impossível naquele momento. Caso ele insista na violência, é frequente que o principal e seus homens resolvam amarrar o sujeito, até que ele melhore. Pode ser também que o homem adormeça e, nesse caso, não haverá maiores problemas. É no dia seguinte que se espera que ele receba um aconselhamento.

Além das discussões dos casais, há os filhos. Problemas com adolescentes e crianças são outro dos temas recorrentemente levados ao mburuvicha/capitão. Aqui, ele deve tomar a frente porque, nas condições atuais, os jovens se tornaram um problema para a coletividade. Outrora recolhidos à sociabilidade que emerge na família, ao irem para a escola, as crianças e jovens passaram a relacionar-se cotidianamente com integrantes de todos os grupos familiares ${ }^{175}$. Em alguns lugares, os grupos de jovens passam a promover arruaças noturnas que são uma das grandes fontes de dores de cabeça para as famílias. Alguém tem que tomar uma providência! Sim, o mburuvicha/tendotá.

$\mathrm{Na}$ situação desse tipo que presenciei, a solução construída foi a realização de rondas noturnas de um grupo de homens. A medida foi tomada depois de um episódio em que uma adolescente esfaqueou um colega em uma dessas arruaças, causando grande transtorno ao grupo. Não estou dizendo que essa seria a solução aplicada em qualquer situação semelhante, nas dezenas de grupos locais guarani e kaiowá. Trata-se de um exemplo de como funciona a lógica de encaminhar os problemas para o mburuvicha/capitão.

Tentarei fornecer elementos para que se compreenda a complexidade do jogo entre os termos/atributos tendotá, mburuvicha e capitão. Esse tipo de situação que narrei exige mediação, aconselhamento (qualidades de um mburuvicha), mas também iniciativa, imposição de força (relacionados ao tendotá): ou seja, é algo típico dos tempos atuais, em que surgem, justamente, os... capitães.

\footnotetext{
kaiowá/guarani de MS. A questão é que o termo é usado tanto no campo do xamanismo como na vida mundana de uma aldeia. Em MS, por outro lado, note-se que o auxiliar/aprendiz do xamã é conhecido como yvyraija, somente (termo também existente, com sentido parecido, entre os Guarani do litoral), e os policiais estão restritos à atuação junto aos capitães. Por sinal, é mais um elemento considerado, normalmente, uma "imposição do Estado" nas etnografias contatualistas. A experiência dos Guarani no Sul/Sudeste, com os xondáro, é mais um elemento a demonstrar que é preciso repensar essa ideia. Entre os Guarani de Oco’y, no Paraná, Albernaz (2009) encontra o termo tembiguái usado para esses policiais. Em MS, ouvi o termo empregado como "servidor", uma espécie de designação dada a quem está fazendo algum trabalho para o benefício coletivo. 175 Para uma brilhante análise sobre as escolas nas áreas kaiowá, ver Benites, 2009.
} 
Estamos falando de situações que têm uma especificidade, pois as gerações anteriores à atual não vivenciavam o nível de constrangimento territorial que as de hoje experimentam. Como já discutimos no capítulo anterior, não creio que se deva generalizar sobre o passado: é cada vez mais evidente que os grupos de língua guarani participaram, séculos atrás, de assentamentos com características bem diferentes do que a literatura estabeleceu como "tradicional". Porém, não se deve negar que a imposição do confinamento nas reservas do SPI é algo novo - não no sentido de criar grandes assentamentos, mas ao ignorar e impedir a autonomia dos grupos locais. Outras novidades inéditas historicamente são, por certo, a escolarização massiva das crianças e o fácil acesso à aguardente de cana - diretamente relacionado ao maior risco de agressões domésticas, segundo a percepção de indígenas de norte a sul do continente ${ }^{176}$.

Há, ainda, outros momentos em que se exige do mburuvicha uma capacidade de tendotá: é ele quem deve tomar a frente no diálogo com os de fora. Qualquer pessoa estranha que chega ao coletivo deve passar por ele. Hoje, muitas vezes, conforme a configuração da área onde o grupo está, pode ser que determinados assuntos sejam diretamente tratados com os diversos especialistas do coletivo. Por exemplo, a Secretaria de Educação da prefeitura local pode tentar combinar um evento diretamente com o professor que coordena a escola. Ou o mesmo em relação à área de saúde.

Fazer esse contato direto com os especialistas pode parecer mais fácil e rápido, mas, em geral, a pessoa consultada vai encaminhar o karai ao mburuvicha, porque, caso ele não tenha conhecimento do que vá se passar por ali, a situação toda pode resultar em um grande malentendido. Tudo, mais uma vez, tem a ver com o respeito que é necessário manter para com o tendotá. Ele é quem mantém a frente, ele deve manter a frente, deve-se respeitar o fato de que ele deve tomar a frente.

Poder-se-ia objetar que esse respeito à posição de liderança é algo comum tanto a um mburuvicha kaiowá como a Luís XIV ou à presidente Dilma Rousseff, mas persiste a diferença fundamental e diz respeito à ausência da possibilidade de coerção. A autoridade de um mburuvicha depende de seus constantes esforços para manter o contentamento dos que estão ao seu redor. Mas, uma vez que alguém se sinta contrariado, simplesmente, numa situação em que não exista o constrangimento territorial, ele juntará a família e se mudará dali - essa é a especificidade ameríndia. Os "incomodados", literalmente, se retiram... 
Nos dias atuais, ele ainda poderia permanecer naquela localidade, mas dará as costas ao principal e continuará sua vida sem reconhecer-lhe a autoridade. Em função do reconhecimento dos direitos da cidadania no país, há cada vez menos necessidade de passar pela intermediação de um capitão para acessar recursos como a aposentadoria rural ou auxílios como o Bolsa Família.

\section{Privilégio e prejuízo}

Ao lançar seu coletivo numa dinâmica, num movimento, o tendotá também ocupa uma posição ambígua. Uma fotografia, que capte um único momento de sua trajetória, não diz tudo sobre essa condição. Poderíamos arriscar dizer que aí está um motivo por que as descrições etnográficas sobre a condição do chefe indígena são tão ricas e guardam tantos paradoxos.

Ora a condição de chefia pode parecer um lugar de privilégios, ora de prejuízos. Assim como a visão sobre essa condição ora pode apelar para uma visão "desmistificadora", apelando ao conceito de ideologia, ora pode demonstrar, a partir da experiência etnográfica, que os indígenas, na realidade, estão bem cientes de todo esse lio. A dificuldade, aqui, reside em não cair numa interpretação simplória do conceito de ideologia, nem em projetar, por outro lado, aos indígenas um calculismo característico do (ideal de) indivíduo ocidental ${ }^{177}$.

Particularmente, tomando como exemplo o caso kaiowá, acredito que não se trata nem disso nem daquilo (nem mistificação ideológica, nem calculismo). Os Kaiowá que conheci ${ }^{178}$ têm perfeita noção dos privilégios que o líder acumula, mas parecem concordar com a necessidade de que alguém tem que tomar a frente em certas questões de interesse coletivo.

Afinal, quem está na posição de mburuvicha não é apenas (e nem sempre) um privilegiado. Muitas vezes, frequentemente, a tarefa de liderar é um estorvo. É preciso ter a disposição de tratar de assuntos alheios, é preciso estar permanentemente preocupado em agradar. É preciso correr riscos envolvendo-se em disputas que poderiam não lhe dizer respeito, demonstrando coragem e

177 Em Sahlins (2003) tem-se o devido aprofundamento a essa discussão. E Strathern (1998) demonstra que "calculismo" não é um termo assim tão simples quando se trata de pensar o que, de fato, está em jogo nas trocas.

$178 \mathrm{E}$ aqui, vale notar, estou considerando um contexto tomado como razoavelmente aceitável pelos indígenas - não estou falando do contexto de confinamento imposto nas reservas, o qual pesou mais até a década passada, e sim da atual situação, em que já se percebe que o complexo de grupos locais existentes permite um pouco (só um pouco) mais de liberdade de movimento às famílias. Mais à frente, falarei desse contexto das reservas em que, a partir de um congelamento imposto de fora para dentro, o capitão deixa de ser uma figura aceitável. Enfim, essa sinalização deve-se ao fato de que, como explicarei adiante, existe uma demonização tão forte da figura do capitão que alguns considerarão estranho eu falar dessas figuras com tal isenção. 
firmeza.

Por sinal, esse "prejuízo" inerente à posição de chefia está mesmo tematizado nos mitos ameríndios, conformando parte de uma "filosofia da chefia ameríndia", como analisa PerroneMoisés (2011). A autora localiza numa narrativa arawak das Guianas, citada por Lévi-Strauss (2004: 347). O alcatraz (que corresponde, segundo a autora, ao biguá sul-americano), na história, derrota a sucuri e, com os pedaços de sua pele mágica, proporciona cores para todos os pássaros, mas ele mesmo, ao final, é o que permanece com as penas escuras, sem graça. Como chefe, deve-se distribuir até o ponto de tornar-se o mais miserável do grupo - e, se não se faz isso, fica-se repetidamente exposto ao falatório geral.

Uma palavra que vem à mente aqui, como já notou Wagner (2010), é “estratégia" - e, sim, poderíamos dizer que a posição do tendotálmburuvicha, evoca um quiasma, como esse mesmo autor lembra no citado artigo: o chefe tem o privilégio de tomar prejuízo, sempre. Parafraseando a antiga piada soviética - "Nós fazemos de conta que trabalhamos, e o Estado faz de conta que nos paga" - que é lembrada pelo autor, seria como dizer: "Nós fingimos que privilegiamos o chefe, e ele finge que só leva prejuízos com isso".

Se há um cálculo que é recorrentemente citado pelos Kaiowá, em relação a suas ações, é o que diz respeito à perpetuação de sua família. Quando estão reivindicando terras, e falando sobre isso, as lideranças se remetem o tempo todo à importância de garantir um futuro melhor para as crianças do grupo, netos e bisnetos - como já demonstraram outros autores (Pereira, 1999; Mura, 2006), a posição de liderança está fortemente relacionada à condição de avô/avó (tamõi/jary) ${ }^{179}$, normalmente alcançada ao redor dos 40 anos de idade - como ocorre em tantos outros grupos de língua tupi ou guarani, por sinal.

Pode-se perceber, ainda, um reconhecimento generalizado de que os Kaiowá do passado, sobretudo os da geração dos avós das atuais lideranças, cometeram um erro terrível ao dar confiança aos fazendeiros recém-chegados, auxiliando-os no desmate generalizado da região e na formação das fazendas. Movimentos anteriores, como o de mandar crianças para as cidades para estudar, também carregavam essa perspectiva de "um futuro melhor" para as novas gerações. Porém, penitenciam-se vários Kaiowá, foi um equívoco acreditar no projeto dos karai para a região. Hoje,

179 Termo traduzido como avô, ou antigo, mas que "stands for itself", no dizer de Wagner (1986). Seus significados desdobram-se de tal forma que é impossível determinar a origem da analogia. Para uma reflexão a respeito desses apontamentos de Wagner, ver Zea (2010). 
os indígenas tentam reverter tudo isso.

Nesse sentido, mais uma vez, o ator em jogo está muito além do indivíduo. O coletivo kaiowá de referência é, sobretudo, a família, ou te'yi. Em outros momentos, esse "ator coletivo" se amplia até o tekoha, o tekoha guasu ${ }^{180}$, ou, mais recentemente, a própria "etnia" (Kaiowá), ou mesmo a nova denominação surgida a partir do contexto de confinamento, Guarani-Kaiowá181.

As atitudes do tendotá inspiram, muitas vezes, admiração, e, em outras, temor. São assunto nas rodas de conversa por todo o coletivo. Os rumores que emanam como ondas a partir das atitudes tomadas pelas lideranças são também um sinal de que algo distinto está acontecendo. Ao tomar uma iniciativa, o tendotá "se destaca". Ao dar um passo à frente, ele incita os demais a segui-lo. Nesses momentos, o "jogo de figura e fundo" da liderança, entre singularidade e multiplicidade (Wagner, 1987, apud Da Col e Graeber, 2011: xx), alcança seu limite. Em 2007, Sahlins comentava:

\begin{abstract}
"Sabe-se que relatos das sociedades norte-americanas nativas falam em 'selves transpessoais', em contra-distinção, portanto, ao nosso senso comum de indivíduos autocontidos e delimitados. Pois onde as pessoas são membros umas das outras, o self transcende a pessoa e está presente em outras, uma condição de mutualidade do ser que pode tornar funções aparentemente tão individuais como intencionalidade e experiência mais ou menos comunais. Tal mutualidade pode ser encontrada no nascimento, na co- residência, no casamento, na descendência comum, na troca de dádivas, na comensalidade, no compartilhamento da mesma terra, ou em vários outros meios pelos quais o parentesco se estabelece. Não que as relações entre todos os tipos de parentes sejam harmoniosas ou reciprocamente benéficas.(...) Em todo caso, assim como o self participa em outras pessoas, as pessoas individuais devem incluir os múltiplos selves com os quais elas se encontram em tal comunhão. Os outros são predicados da própria existência do indivíduo." (Sahlins, 2007: 4)
\end{abstract}

\footnotetext{
180 Junto com o processo de superação das demarcações em ilhas, e lançamento de GTs de identificação de tekoha guasu, mais recentemente, têm surgido grupos que reivindicam ao mesmo tempo vários tekoha. Em Guaiviry, por exemplo, área recuperada em novembro de 2011, isso tem acontecido. Na prática, os grupos dos diferentes tekoha acampam, dentro da terra ocupada, em áreas separadas algumas centenas de metros uma da outra. A intenção é deixar claro que se trata de uma aliança em função da reivindicação por um território contíguo.

181 Essa série tem até seguido além, a partir da promoção de articulações e encontros internacionais, nos quais tem emergido a ideia de uma "nação guarani", ou "povo guarani", abrangendo os coletivos falantes de guarani (e integrantes das redes de parentesco aí correspondentes) residentes no Brasil, Bolívia, Paraguai e Argentina.
} 
Parece-me que isso ajuda a pensar o que vejo entre os Kaiowá. O mburuvicha é constante alvo de projeções, ele é uma referência cotidiana, mencionada por todos, desde as crianças até os idosos - seja para ressaltar sua proximidade com ele, ou para criticá-lo. Afora, talvez, os xamãs e, hoje, alguns pastores, nenhuma outra pessoa nas comunidades consegue concentrar tanto a atenção geral.

Há um jogo aí, um movimento. Essa figura central (frontal?) estará sempre condenada a ser demais ou de menos: ineficiente, ou impotente, como um chefe clastriano; excessivo, como um desses monstros míticos, ou um capitão de reserva.

Tal dinâmica, entre falta e excesso, entre orgulho ou desprezo pela proximidade com o chefe, nos remete novamente às formulações de Sahlins, conforme anunciamos no capítulo anterior. De alguma forma, aparece, aí, um princípio que poderíamos relacionar às tais transformações da ideia de "rei estrangeiro" (stranger-king) apontadas pelo autor. Afinal, do ponto de vista de um grupo familiar, pode ser conveniente aceitar a liderança de um tendotá vindo de fora, em um dado período de conflito fundiário, para, num período posterior, expeli-lo.

Numa apresentação recente, Da Col e Graeber (2011) buscaram sintetizar todos os "paradoxos comparativos" (Wagner, 2010) que envolvem a posição de liderança no que chamaram, em referência a um comentário de Luc de Heusch, de Fator G -alusão à proximidade dos termos ingleses kingship e kinship.

A discussão pretende ter alcance geral e se relaciona intensamente com várias formulações de Sahlins que já viemos discutindo. A ideia é pensar essa dinâmica por meio da qual a figura do chefe vindo de fora se impõe no sentido de trazer vitalidade, regeneração, mas, ao mesmo tempo, é como que consumida internamente ao ser pouco a pouco envolvida no jogo do parentesco. A figura da "realeza" (entendida num sentido amplo) faz a pluralidade aparecer como "singularidade", ao mesmo tempo em que, enquanto portadora de uma "externalidade vital", permite à sociedade "reter a si mesma em um corpo que existe fora estando 'dentro' dela". É sua alteridade que a torna, justamente, uma "fonte de vitalidade, regeneração, reprodução ou circulação de vida" (Da Col $e$ Graeber, 2011: $x x$ )

Cada um dos elementos que caracterizam a atuação de um chefe ameríndio pode levar-nos a todo um universo de situações etnográficas, descritas ao longo das últimas décadas. Frequentemente, contudo, corre-se o risco de perder o foco. Nesse sentido, uma formulação como a 
exposta acima me chama a atenção por seu poder de síntese, não pelo ineditismo.

Localizo ao menos dois fatores em função dos quais essa ideia de uma oscilação kingship/kinship pode ser útil para pensar o que vemos entre os Kaiowá e Guarani. Primeiro, há a valorização de conhecimentos trazidos de fora: de fato, uma das ações políticas mais comuns dos coletivos, ali, é atrair para perto de si pessoas dotadas de saberes úteis.

Como veremos no capítulo seguinte, o xamanismo é um dos campos em que isso é mais claramente observável. A liderança também envolve uma série de talentos singulares: hoje, para reconquistar as terras tradicionalmente ocupadas pelo grupo, é preciso que um líder saiba lidar com a Funai, o Cimi, os antropólogos, os fazendeiros, a Justiça etc. Se ele não souber, terá de juntar a seu grupo gente capaz de fazê-lo. Evidentemente, a capacidade para lidar com tantos fatores/agentes diferentes e, ainda, manter as pessoas unidas, mobilizadas, tem certamente algo de especial. Não há muita gente capaz de fazê-lo, é certo, embora, em teoria, muitos se acham capazes de ser tendotá.

Como já mencionamos, não é incomum encontrar histórias sobre líderes que tiveram destaque em períodos de recuperação de uma dada terra, mas foram, posteriormente, expelidos (da posição de liderança, ou até mesmo do local) - vide o exemplo supracitado de Lázaro Morel. O impulso trazido pelo tendotá se desenvolve ao máximo no momento da mobilização pela terra, para que, no momento seguinte, ele seja rejeitado.

Parece-me que um fator político determinante entre os Kaiowá e Guarani, e que parece ter elementos em comum com a sugerida dinâmica kingship/kinship, tem a ver com o equilíbrio de forças entre as famílias, em um dado local. Isso tem a ver não só com o número de pessoas, mas, o que me parece mais importante, com a solidariedade de um grupo familiar - e particularmente, de um grupo de irmãos homens. Essa é uma observação "impressionista” deste etnólogo, em função das situações com que tive contato. Obviamente, poderá ser posta à prova no diálogo com estudos de outros etnólogos que trabalharam em detalhe outras regiões ocupadas pelos Kaiowá e Guarani.

As formulações de Graeber e Da Col estão em estreito diálogo com o que vem desenvolvendo Sahlins (2010). Esse autor esboça um modelo geral para a compreensão desse tipo de dinâmica, a qual, a seu ver, como mencionamos, pode ser pensada como uma série de variações da ideia de stranger-king - de presença ubíqua, mundo afora. Isso ocorreria, segundo ele, em função de que, se há algo que pode ser genericamente formulado, a respeito da condição humana, é que ela mantém uma "dependência em relação a forças sui generis de vida e morte, forças que não 
são criadas pela ciência humana ou governadas pela intencionalidade humana" (2010: 7):

"Se as pessoas realmente estivessem no controle de sua própria existência, não iriam morrer. Ou cair doentes. Elas tampouco controlam a biologia da geração sexual ou agrícola. Ou o clima, do qual sua prosperidade depende. Ou, notavelmente, os outros povos com que se relacionam: povos cuja existência cultural pode ser invejável ou escandalosa para eles; mas, em qualquer caso, pela simples diferença que apresentam, estranhos que oferecem, assim, a prova de uma capacidade transcendente para a vida. É como se nada estrangeiro fosse meramente humano. Dotado de poderes transcendentes de vida e morte, o estrangeiro torna-se um ambíguo objeto de desejo e perigo. Daí a ubiquidade - e ambiguidade - das já mencionadas formações do tipo 'rei-estrangeiro'” (2010: 7-8)

Assumindo, assim, o risco de "simplificar" a questão, Sahlins prossegue, formulando uma generalização a respeito dessa onipresença dos esquemas do tipo "stranger-king”, os quais localiza em regiões tão diversas como o Sudeste Asiático, os antigos reinos indoeuropeus, a África e as Américas:

"Os governantes de um número notável de reinos e cacicados

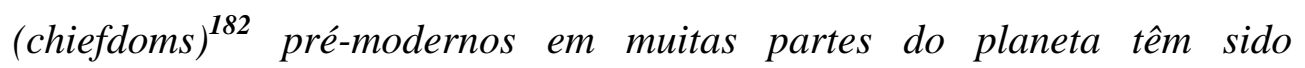
estrangeiros em relação aos lugares e povos que governam. Por suas origens dinásticas e sua natureza hereditária, como exercitado em tradições em curso e promulgado em rituais reais, eles são estrangeiros - que, por esse motivo, devem conceder certos poderes e privilégios para os povos nativos. O efeito é um certo sistema de dupla soberania” (idem: 8)

O efeito disso tudo é, segundo o autor, um sistema de "dupla soberania", equilibrado entre as reivindicações de fundação de um local, de autoctonia, e a capacidade, a façanha desse poder externo ao organizar o grupo local. O que poderia distinguir o "contra o Estado" ameríndio, nesse esquema, é que tais polos seguem se alternando, ao modo de um "dualismo em perpétuo desequilíbrio", conforme já destacamos, referindo-nos ao que Perrone-Moisés sugere em relação aos termos propostos por Lévi-Strauss. Sim, trata-se de uma estrutura, como dirá Sahlins:

182 Eis, aqui, novamente, os cacicados (vide capítulo 1). 
"Por fim, falando de modo genérico, a estrutura que estive descrevendo é intrinsecamente temporal ou diacrônica, seja ou não realmente histórica. Onde os governantes locais assumem identidades estrangeiras, pode ser uma estrutura sem um evento, uma verdadeira invasão estrangeira” (idem:

Assim sendo, o autor defenderá que é possível estender seu raciocínio sobre essa "política cultural da alteridade" a fenômenos como "a caça de cabeças, o canibalismo e outros modos de predação, por meio do comércio ou saque de valores externos, buscas de visões, xamanismo e outros meios de domesticar virtudes vitalizantes de sujeitos exteriores" (idem: 14) ${ }^{183}$. É nesse sentido que suas formulações nos parecem adequadas a uma melhor compreensão sobre a vida política kaiowá.

Anote-se, antes de seguirmos, que há uma tensão aí, entre as formulações levistraussianas sobre a "abertura ao outro" dos ameríndios (1993) e essas novas propostas de Sahlins e Graeber/Da Col, que não se restringem a uma área geográfica - pretendem-se, quase, universais. Há um risco assumido, por sinal - de generalizações excessivas, é verdade, mas, também, penso, a possibilidade de, no mínimo, renovar o comparatismo, para que lembremos o convite de Detienne, do qual falaremos mais no capítulo 4. De qualquer forma, tudo é muito recente, e estamos em pleno debate. Por ora, parece-me que são ideias "boas para pensar"...

\section{Sucessão, cessação, secessão}

E eis que chega o momento em que aparece o problema da sucessão - ou da cessação. Pode vir mais cedo ou mais tarde. Pode ser repentino, ou resultado de um longo planejamento. Pode ser voluntário ou imposto. De qualquer forma, eis, segundo vários relatos colhidos em campo, vindos de múltiplas fontes, lugares e tempos, algumas das possibilidades e fatores envolvidos nessa questão tão delicada.

Há muitíssimos contextos em que o tendotá/mburuvicha pode ter que encarar essa realidade

183 Por sinal, ele inicia todo esse segmento, em sua conferência, a partir de uma citação do trabalho de Viveiros de Castro entre os Araweté: "Se os seres humanos fossem imortais, talvez a sociedade se confundisse com o cosmos. Uma vez que a morte existe, é necessário para a sociedade estar ligada com algo que está fora dela mesma - e que esteja ligada socialmente a esse exterior" (1995:190 - tradução minha). 
da sucessão/cessação (de seu mandato? do impacto mobilizador de seu movimento?). Pode ser que, depois de ter se envolvido na reconquista de um tekoha, ele encare dificuldades em função de pertencer a uma família minoritária dentro daquele novo contexto social. Apesar de não contar, antes, com alguém que fosse capaz de encabeçar uma ação de recuperação de terras (com talentos militares e diplomáticos para tanto), essa(s) família(s) majoritária(s) pode(m) sentir que, agora, a posição de capitão (enquanto reconhecimento externo da condição de principal) lhe(s) é devida, em função de sua superioridade numérica.

Pode ser que ele pertença a uma família grande o suficiente para pleitear privilégios, a ponto de lhe caber o título de capitão, mas que seu procedimento pessoal cotidiano o desmoralize. Se ele consome bebidas alcoólicas e se expõe a vexames públicos, se ele teve algum relacionamento amoroso condenável, se ele tem uma personalidade excessivamente agressiva e se comunica de forma imprópria com as pessoas: são vários os motivos que podem selar uma carreira política...

Como já dissemos, a correspondência entre as figuras do tendotálmburuvicha e a do ñanderu - o líder e o rezador - é comum e historicamente constatada, mas não se trata de algo obrigatório. Sendo o representante de uma família com clara maioria numa dada área, um líder pode manter-se muitos anos na posição de principal caso esteja aliado com um ou mais rezadores de prestígio. O que vai determinar a manutenção da credibilidade de um xamã (e, por extensão, de um líder, ou "governo" - se pensarmos na composição entre chefe, xamãs e outras figuras associadas, como professores, agentes de saúde etc.) será o diagnóstico do coletivo sobre as condições de sanidade/prosperidade do local.

Falaremos mais sobre isso no próximo capítulo, mas adiantemos, em resumo, que há uma associação entre saúde individual, coletiva e do ambiente envolvida com as atividades xamânicas. Assim, as condições sanitárias podem ser consideradas negativas quando acontecem: epidemias, distúrbios psicológicos/espirituais (como o suicídio), fome e miséria, perda das lavouras, conflitos familiares, ataques dos fazendeiros, da polícia ou de grupos rivais, acidentes (como incêndios), enchentes, tempestades etc.

Caso o líder consiga manter o coletivo em clima de prosperidade e harmonia (critérios sempre relativos ao juízo do grupo local, note-se), poderá prolongar indefinidamente seu mandato creio que podemos empregar o termo aqui no sentido de que há, efetivamente, uma espécie de 
autorização por parte do coletivo para que alguém permaneça na posição de liderança ${ }^{184}$.

As tarefas de um mburuvicha que permaneça no cargo por um longo período transcendem em muito a capacidade de qualquer indivíduo. Naturalmente, ele terá de angariar aliados de sua total confiança, sejam filhos ou genros. Um deles, com maior aptidão, será escolhido para suceder o tamõi. Novamente, estamos aqui no limiar entre escolha e opção, entre iniciativa e unção. Basta querer ocupar o lugar? Não. Basta ser designado? Tampouco.

Nos lugares onde a população é hoje mais numerosa, e particularmente nas oito reservas do SPI, surgem fórmulas para regular esse processo de passagem do poder, tornando-o menos conflitivo. Soluções importadas, como as eleições e o estabelecimento de mandatos fixos, limitados, vão sendo adaptadas (traduzidas). Novamente, surgem diversas soluções possíveis, de acordo com a conformação política local, e o momento histórico.

Há aldeias que organizam processos de eleição do cargo de capitão; outras que já aderiram à forma conselho, imposta, em alguns casos, pela Funai, em dado momento, e, em outros, por iniciativa dos próprios indígenas ${ }^{185}$. Na maioria dos lugares, o cargo de capitão sobrevive de alguma forma (seja seu ocupante um integrante do conselho, seja de maneira mais semelhante ao que operava décadas atrás, porém sem respaldo da Funai - mas ainda do governo estadual e de muitas prefeituras).

Onde há eleição, varia-se entre o consenso e a escolha por maioria, e entre um mandato prédefinido ou não. Quase sempre, está posta a possibilidade de revogação automática. Lima, antropólogo do Ministério Público Federal em Dourados, é frequentemente demandado pelas comunidades para arbitrar processos de disputa. A partir dessa experiência, ele produziu nota técnica em que reflete sobre essas eleições para capitão. O MPF não concede, a priori, e desde fora, a legitimidade para esse tipo de processo (Lima, 2007: 1). Esse texto explica os motivos para essa decisão, partindo da desconstrução da noção de "vontade geral” em Rousseau:

"O Ocidente acabou acatando o voto como o instrumento pelo qual a vontade da maioria é tida como legítima. Democracia, no entanto, não consiste apenas em escolher pelo voto, mas, antes de tudo, proporcionar os

\footnotetext{
$184 \mathrm{O}$ que nos levaria à ideia de soberania - a qual, segundo Lowie, faltaria ao chefe ameríndio. Creio que é possível falar, sim, nesse tipo de "autorização". Essa característica, um mandato revogável a qualquer momento, é uma espécie de tabu para a democracia liberal - mas não para os sistemas ameríndios, como sabemos. 185 Veremos algo mais sobre os conselhos no capítulo 4.
} 
meios para que uma escolha seja feita com a devida lisura, o que implica a existência de uma variedade de mecanismos capazes de coibir fraudes diversas. Ademais, é preciso que, após o sufrágio, operem controles sociais para que se evite que as vontades privadas dos eleitos se sobreponham às da coletividade, prevenindo-se, assim, a insurgência de lideranças totalitárias” (Lima, 2007: 2).

O fato é que os Kaiowá e Guarani vêm tentando inventar alternativas, diante da evidência de que alguns anos ainda serão necessários até que os processos de demarcação de terras sejam finalizados. "Já experimentamos de todos os jeitos", explicou-me alguém certa vez, em referência ao movimento Aty Guasu, que, atualmente, adota a forma-conselho. Eu não diria, "é dirigido por um conselho", porque a concepção imperante é que a assembleia manda, e o conselho executa claro que as coisas não são tão cristalinas, o tempo todo, mas a ideia é que isso aconteça. Quem executa esse tipo de trabalho pode, por sinal, ser chamado de tembiguái (servidor, funcionário), em alusão a essa condição de servir à comunidade, ao coletivo, por meio do trabalho na política.

Por enquanto, na prática, dezenas de milhares de pessoas ainda terão que conviver por algum tempo nas reservas superlotadas, e é preciso chegar a acordos sobre como administrar essa situação, pois não é possível esperar até que as terras sejam ampliadas e a autoridade dos líderes familiares possa se recompor.

Há alguns anos, num processo que foi descrito por Mura (2006), a Funai deixou de reconhecer os capitães, ainda que eleitos, como intermediários que falavam em nome da comunidade - e, por ela, podiam receber e repartir recursos recebidos dos governos. A solução oferecida para substituir os capitães foi a formação de conselhos nas aldeias - estimulados pelos órgãos públicos, em muitos casos.

O problema é que, mais uma vez, essa fórmula política foi introduzida sem grandes discussões (e, quando digo isso, estou querendo dizer: sem a formação prévia de um consenso em torno da decisão - o que pode ter desrespeitado a autonomia de alguns grupos ${ }^{186}$ ), o que ocasionou "traumas" em certas áreas, por assim dizer.

Atualmente, depois de algumas reviravoltas (rápidas mudanças de titulares de cargos,

186 A democracia, afinal, como nos relembrou, recentemente, George W. Bush, pode bem ser resultado de uma imposição autoritária. "Vou fazer deste país uma democracia, e, se alguém for contra, eu prendo e arrebento", declarou, certa vez, o ditador brasileiro João Figueiredo (1979-85). 
conforme relatado na introdução), a Funai deixou de impor quaisquer formas e tampouco legitima eleições para capitão. Alguns órgãos do governo estadual e as prefeituras, contudo, ainda estabeleciam, muito recentemente, políticas públicas e distribuição de recursos em diálogo com capitães, o que torna o quadro algo mais complexo. De qualquer modo, as possibilidades de adquirir proeminência continuam aumentando: hoje, é possível eleger-se vereador, conselheiro (em várias instâncias, como os conselhos tutelares municipais, entre outros), tornar-se "acadêmico indígena" etc. etc.

"Indigenizando"187 as figuras sustentadas pelo indigenismo oficial ou pela democracia liberal, sejam capitães, vereadores, conselheiros, ou o que for, os Kaiowá e Guarani, para terem sucesso em suas empreitadas políticas, continuam, de qualquer forma, tendo que se mirar nos critérios em relação aos quais é avaliado, positiva ou negativamente, um mburuvicha ou tendotá. É nesse sentido que continua válida, pensamos, esta elaboração de uma teoria etnográfica da política entre eles.

\section{Ostracismo}

Quando acontece a sucessão, o processo, por vezes, se torna complicado porque questionar a competência da pessoa que foi escolhida para suceder o mburuvicha pode gerar a impressão de que se está iniciando uma disputa. A rivalidade, por vezes, se desdobra em conflito - em certos casos, algo violento ${ }^{188}$.

Esse tipo de confronto é, muitas vezes, evitado, hoje em dia, porque a situação que se vive no mundo kaiowá é de extrema escassez de espaços. Assim, quando alguém parte para a disputa deve ter em mente que, se perder, terá de se mudar daquela área e arranjar um novo local onde morar. É o tipo de situação que gera um efeito-dominó em termos de complicações.

Em primeiro lugar, o derrotado terá duas opções a sua frente. Ou ele se muda com seu grupo

\footnotetext{
187 No sentido em que Sahlins (1997) fala em “indigenização da modernidade”. Para uma série de reflexões a respeito dos limites entre transformação e mudança, em se tratando das formas de liderança entre os Kaiowá e Guarani, ver Albernaz (2003, 2009). Por sinal, além de Sahlins, a autora dialoga com Pereira (2004b), cujas reflexões sobre "novas formas" de liderança entre os Kaiowá e Guarani nos serviram de ponto de partida no projeto desta tese.

188 Outra situação que gera disputas complicadas ocorre quando um capitão não concorda em entregar o cargo. Ele terá fôlego para sustentar um conflito caso se ampare em um grupo suficientemente numeroso dentro da reserva e/ou amparando-se nos privilégios decorrentes da relação com atores karai (políticos regionais, Funai etc.)
} 
para um lugar novo, onde não há aldeia atualmente, ou vai para um lugar onde já há um coletivo estabelecido (nesse caso, por outro, ou outros mburuvicha).

No primeiro caso, ele deve estar preparado para enfrentar uma longa disputa, que envolve, muitas vezes, hostilidades por parte dos fazendeiros, necessidade de se articular com a Funai, o Ministério Público e o Cimi para iniciar um processo de reivindicação pelo reconhecimento dessas terras pelo Estado brasileiro, habilidade para trazer recursos para a comunidade num contexto adverso, enfim. Além disso, é preciso que as famílias do grupo tenham argumentos defensáveis para reivindicar esse local como seu tekoha.

No segundo caso, quando o espaço já é habitado, esse novo local também terá um principal, que deverá ser consultado antes que o novo grupo se mude. Ali, dependendo da dimensão do grupo familiar que o derrotado traz consigo, há uma série de situações que podem ocorrer. A família - e mais especificamente o grupo de germanos (e muitas vezes, com cunhados e outros agregados, como filhos adotados) - é importante para formar uma frente capaz de resistir a hostilidades.

Um homem que se muda apenas com a esposa e os filhos para um novo local onde não conta com o apoio dos irmãos costuma ter muitos problemas. Um simples desentendimento com a esposa pode gerar uma agressão. Que dirá se ele se desentende com um dos cunhados. Sua "carreira política" ficará muito limitada, certamente.

\section{Efemeridade?}

Outros autores chegaram a considerar o tendotá como uma figura que aparece, unicamente, no momento em que a comunidade entra em situação de confronto, de reivindicação de um espaço (cf. Mura, 2006: 155). Note-se que, de certa forma - embora Mura não desenvolva essa ideia de que a situação de luta pela terra é uma espécie de guerra -, seria como manter a diferenciação chefe de guerra/chefe de aldeia que aparece no modelo clastriano:

"Durante a expedição guerreira, o chefe dispõe de um poder considerável, às vezes mesmo absoluto, sobre o conjunto dos guerreiros. Mas, com a volta da paz, o chefe de guerra perde toda a sua potência” (Clastres, 2003: 47)

Como observa Perrone-Moisés (2011), a respeito, exatamente, desse trecho, a visão de 
Clastres sobre o poder oscila entre considerá-lo uma expressão particular do poder político, e tomar esse aspecto como sua própria essência. Eu acrescentaria que os paradoxos e contradições se diluem quando percebemos que o pensamento ameríndio tem o movimento como variável fundamental. As coisas são o que são num dado contexto. Em outro contexto, podem ser o exato contrário do que eram.

Mas, retomando a argumentação, o que estou querendo dizer, em suma, é que essa figura do tendotá, como protótipo do bom líder, também está presente nos parâmetros kaiowá de avaliação de um mburuvicha no cotidiano, porque a vida mundana está repleta de situações que pedem que alguém "tome a frente". Na realidade, se considerarmos o que está posto, não se trata de um "poder coercitivo", mas, simplesmente, de uma questão de iniciativa, de liderança. Retornaremos mais adiante a uma descrição dessas situações cotidianas em que a iniciativa do tendotá é valorizada.

Outra comparação interessante, além da que já expusemos sobre a Amazônia: o termo tendotá é comum no guarani paraguaio contemporâneo. Por lá, como veremos, é possível verificar tanto a ambiguidade que cerca o termo como sua proximidade com o termo mburuvicha. É fácil encontrar na internet textos de jornais mencionando que o tendotá (ou tendotá guasu, ou karai tendotá, ou, ainda, mburuvicha) Fernando Lugo encontrou o tendotá Luiz Inácio Lula da Silva etc. O registro de uma curiosa discussão pública sobre o uso contemporâneo do termo no contexto não indígena está em Boidin $(2007)^{189}$, que descreve as eleições presidenciais paraguaias de 2003 . Na época, o candidato Nicanor Duarte Frutos dizia, em uma entrevista, transcrita pela autora:

“- Lo que quiero decir es que el Paraguay necesita un tendota.

- ¿Qué es «tendota»?

- Ha péa he’ise «motenondehára» (el que muestra el camino)

- ¿Un dictador?

- No. Tendota es el que encabeza el trabajo con el pueblo, el que conoce el dolor y la esperanza de la gente, porque los vivió o porque convive diariamente con el pueblo. Aquí no necesitamos un presidente almidonado, prisionero de sus pactos, sin capacidad de mando y sin oficio de poder. En el Paraguay falta un nuevo orden, con un tendota que tenga legitimidad

189 Agradeço a Graciela Chamorro por me haver chamado a atenção para esse texto. 
popular de origen que haga respetar disciplinadamente los derechos y obligaciones de los ciudadanos, que garantice la transparencia de la administración, su eficiencia y el correcto uso de los recursos del Estado a favor de los más necesitados" 190

Conforme relata a autora, o uso do termo tendotá pelo candidato gerou amplo debate político no Paraguai. Depois de eleito, ele chegou a tentar mudar o nome da residência presidencial paraguaia, de Mburuvicha Roga para Tendotá Roga, o que não logrou, em função da interpretação que a oposição consolidou do termo, traduzindo-o como ditador.

Outrossim, a interpretação de Boidin sobre as evocações do título de karai tendotá que Duarte Frutos se atribui envereda pela interpretação dos termos karai e mburuvicha (este, justamente, o termo que o político recusa, segundo a autora, por lhe faltar certa "dimensão religiosa" (op.cit: 15). Karai, afinal, é termo aplicado aos brancos por vários grupos de língua guarani, e uma espécie de título honorífico no contexto paraguaio, mas também está na raiz de ideias como a dos rituais de batismo guarani - ñemongarai, ñe-mõ-karai, fazer-se karai, sagrado. Solano López e Stroessner, por sua vez, também se faziam chamar karai, lembra ela.

Ao termo tendotá, no fim das contas, Boidin não dispensa grande atenção. Lembra, apenas, que Cadogan, em seus comentários à Gramática Guarani do Padre Antonio Guasch (1987), destacara que o termo é aplicado, hoje, pelos camponeses paraguaios ao líder de uma vara de porcos selvagens (pecaris ou javalis) ${ }^{191}$. Apesar disso, o trabalho da autora nos oferece oportunidade interessante de perceber as ressonâncias ambíguas, toda a tensão que o tendotá inspira. Acredito que isso não acontece por acaso, como esclarecerei a seguir.

\section{Capitão}

Perrone-Moisés (2011) localizou mitos ameríndios diversos que imaginam o que acontece

190 Diário ABC Color, Asunción, 17/4/2003. Disponível na internet em

http://archivo.abc.com.py/especiales/elecciones2008/articulos.php?fec=2003-04-17\&pid=43816

191 Boidin não menciona, mas, nesses comentários, Cadogan endossa a utilização do termo em expressões como "yvaga rembiguái tendota", capitán de los mensajeros del cielo, e "teko mbyaihare rendota", cabecilla de los que provocaron el desorden - ou seja, registra o uso do termo nos contextos cosmológico e político. Note-se, ainda, que Boidin destaca artigo de um jornalista para quem transformar a residência presidencial em Tendota Roga seria como considerá-la uma "cova de javalis". Vale anotar, para os Kaiowá, o termo não possui conotação pejorativa (até porque aos Kaiowá, em muitos contextos, a comparação entre comportamentos humanos e animais não parece chocante). 
quando um chefe adquire poder absoluto. Na imaginação indígena, ele se torna uma espécie de monstro fora do controle. Essa é uma situação a ser evitada. A autora reproduz história encontrada por Morgan entre os Iroqueses ${ }^{192}$, que organizaram, no período colonial, uma famosa liga, ou confederação. Assim é recontada a dita história, por esse fundador da Antropologia norteamericana:

"Quando a Liga foi fundada, um chamado To-do-da'-ho tinha-se tornado um chefe poderoso, o mais eminente e influente dos chefes onondaga, em virtude de seus feitos de guerra. Segundo a tradição, foi ele que derrotou os Cayuga e os Seneca [duas outras nações da Liga iroquesa, ao lado dos Mohawk e dos Oneida]. To-do-da'-ho é representado como um homem com a cabeleira recheada de cobras. Diz-se que, quando se enfurecia, seu olhar era tão terrível que bastava cruzá-lo para cair morto imediatamente. Conta-se que, quando a Liga foi formada, as cobras foram extraídas de sua cabeleira por um sachem mohawk, chamado desde então Ha-yo-went-ha, "o que penteia"; To-do-da'-ho não queria aceitar a nova situação, pois perderia seu poder supremo e seria colocado entre outros, em pé de igualdade. Para ajudá-lo a superar suas objeções, e para celebrar sua grandeza, o primeiro posto de sachem no Conselho dos Sachems, instituição emblemática da Liga, recebeu seu nome e foi honrado por marcas especiais, como a instituição de dois sachem-assistentes que se apresentam atrás do ocupante do posto em todas as suas aparições públicas. Esse posto de primeiro sachem seria superior em prestígio, mas sem poder, pois este é equitativamente dividido entre os 48 postos de sachem que compõem o Conselho. Até hoje, entre os Iroqueses, o nome To-do-da'-ho é a personificação do heroísmo e da dignidade de caráter; seu título sempre foi considerado como o mais ilustre de todos no catálogo da nobreza iroquesa" (Morgan 1922: 63-64, apud Perrone-Moisés, 2011, em tradução da autora)

Para construir a paz, o poder do chefe guerreiro tem de ser retirado. As cobras da cabeleira

192 Os iroqueses, autodenominados Haudenosaunee (povos da casa grande) são grupos ameríndios que habitam a região dos Grandes Lagos na América do Norte, entre EUA e Canadá (principalmente entre o estado de Nova York e a província do Quebec). Entre as denominações de grupos iroqueses estão Seneca, Cayuga, Onondaga, Oneida, Mohawk e Tuscarora. Juntos, formaram, no período colonial, a Confederação Iroquesa, que será objeto de mais atenção de nossa parte no capítulo 4 . 
de Tadadaho não podem se manter. "Tadadaho é o primeiro sachem, mas na medida em que seu poder lhe é extirpado. O chefe é chefe, mas não manda”, explica Perrone-Moisés (op.cit: 6). Para a autora, tal narrativa expressa, de alguma forma, o que Lowie (1967) e Clastres (2003) localizam.

Ela encontra, ainda, nas Guianas outra expressão desse pensamento ameríndio do "contra o Estado". Ali, entre os Wayana, narram-se as proezas de Kailawa, outro chefe guerreiro que alcançou o poder absoluto com seus feitos, conforme versão da autora, a partir de Chapuis \& Rivière (2003):

“Conta-se que Kailawa não podia ser morto, pois dispunha do 'poder poderoso' de matar com seus encantamentos, os hemït. Colecionava os diferentes hemï, espalhados nas coisas do mundo, cada um para uma finalidade específica; guardava principalmente os 'da ferocidade', que o tornavam especialmente malvado. Magicamente invulnerável e poderoso, foi ele que começou as guerras. Andava pelo mundo matando gentes como os Yanapuku, Tiriyó, Piyanai, Tunayana, Alamayana, Alakwayana, Waiwai e muitos outros. Poupava apenas alguns rapazes de cada um dos grupos, que em seguida treinava, para incluir em seu exército de poderosos guerreiros. Kailawa nunca se casou, quase não comia, dormia no mato, não morava em lugar nenhum. Com seus guerreiros, passou a vida matando, gentes $e$ monstros. Certo dia, já bem velho, extinguiu-se. Seus guerreiros receberam dele o conhecimento dos hemït e a instrução de prosseguir a guerra. Kailawa ficou com eles em kalau, canto de guerra, canto de chefe para guiá-los. Resolveram dar seu nome a um dos guerreiros: 'Será como Kailawa, disseram: será um matador, é nosso chefe.' Mas esse 'segundo' Kailawa (que, conforme a versão, é o mesmo, transformado) não é superpoderoso; é matador, é chefe, mas declara o fim da matança: 'Bem! Está bom! Vamos parar com isso! Aquele que me capturou há muito tempo, cujo nome porto, matou muita gente, muita gente mesmo. Mas eu quase já não sou malvado. Chega! Quero fazer amor, beber caxiri, tenho fome!' Tornara-se, em suma, um homem entre outros. Outros que, como ele, descendem das gentes que Kailawa aniquilou, cujos diferentes nomes eles hoje portam. Doravante, viverão em paz e trocarão mulheres"

Para Perrone-Moisés, trata-se de outro exemplo que confirma a percepção de Clastres sobre 
esse impulso ameríndio do Contra o Estado:

“Aqui também o poder é reduzido, esvaziado, no exato momento em que a sociedade que conta o mito descreve seu próprio surgimento; tudo se passa como se, confirmando Clastres, os Wayana também nos dissessem que, com efeito, percebem-se como gerados pela recusa fundante do poder coercitivo (...) Os mitos, lugar de reflexão que delineia o campo do pensável, pensam pois o perigo do poder concentrado, unificado, coercitivo. E descrevem mecanismos para conjurá-lo. Mas esses mitos que contam a transformação do poder em prestígio, o controle, pela sociedade, do poder coercitivo, perigoso porque extremo, não dizem apenas sua recusa. Ou antes: sua reflexão não se funda na recusa pura e dura do poder, pois que ambos formulam igualmente a necessidade do poder. A paz só pode existir sobre fundo de guerra, é preciso que algo permaneça - em nomes, em prerrogativas, em cantos kalau - desse furor guerreiro fundante” (op. cit: 7 8)

A partir de narrativas piaroa sobre a criação do mundo, Overing (2004) também aponta a existência de uma "filosofia política" indígena. No caso, a autora enfatiza que seria focada no "igualitarismo", "único caminho possível para um modo humano de vida social”. "A preocupação política é a de impedir a emergência do tirano", diz ela (op.cit.: 19). Sobre o tempo da criação do mundo, segundo os Piaroa, ela destaca as narrativas sobre "batalhas dos deuses", perdidos em ilusões de grandeza (op.cit.: 16).

Kuemoi, deus piaroa criador de várias artes necessárias à vida social, como a cozinha e a agricultura, é descrito por Overing como um "louco tirânico e grotesco": “(Ele) foi o dono daquilo que os Piaroa chamam de 'caixas de cristal de tirania, traição e dominação'. Kuemoi soltou todos os horrores dessas caixas de poderes primordiais com plena força neste mundo" (idem: 17). O personagem tinha poder e conhecimento em excesso, relata a autora, e, perdido em sua crueldade, usou da força e acabou vencido pela loucura. As forças liberadas por Kuemoi geraram um holocausto superado, enfim, pela atitude da deusa Cheheru, que guarda esses poderes mortíferos em caixas guardadas no espaço celeste, acima das montanhas. Os xamãs piaroa ainda trabalham atualmente com essas forças, mas sempre usando-as com muita prudência. 
Overing sublinha a definição dessas narrativas míticas como grotescas. O grotesco, lembra ela, está mais vinculado ao realismo do que à fantasia, é apenas um exagero sobre coisas bem reais:

"No caso dos Piaroa, o gênero do grotesco revela a loucura do déspota: o déspota enquanto bufão. O tirano a-social, solitário, com poder monstruoso e excessivo (...). Faz a platéia lembrar que o melhor antídoto contra as pretensões de grandeza e avareza é um espírito de irreverência zombeteira. (...)Os Piaroa sabem muito bem os perigos da relação poderosa entre saber e poder. Na vida cotidiana, são sempre atentos para sinais que indicam a emergência de um tirano, daquela tirania e egoísmo, daquele ego cheio de si que se torna desrespeitoso às relações pessoais, que se torna desdenhoso da dignidade dos outros dentro da comunidade onde vivem, que ignora o caráter relacional do poder. A tirania é bobagem, tolice; deve ser ridicularizada. Podemos talvez entender melhor o fato de que o sentido ocidental abstrato de Sociedade, com as suas regras jurídicas, as suas estruturas hierárquicas, os seus mecanismos pesadamente repressivos, a sua impessoalidade - todas essas coisas - são ofensivas para a maioria dos povos amazônicos. Diria que os povos da Amazônia têm uma consciência do poder bem desenvolvida, e uma rica poética para expressála. A liberdade é uma questão política para eles" (Overing, 2004: 21-2).

Em outro trabalho mais recente, Overing (2012) continua desenvolvendo sua argumentação nessa linha - inclusive, dialogando com a obra de Pierre Clastres e com Graeber, que já declarara inspirar-se na autora em suas propostas para uma "antropologia anarquista" (2011). Para ela, em se tratando da Amazônia, seria possível pensar não em uma "sociedade contra o Estado", e sim em “indivíduos contra a tirania” (2012: 57). A ênfase que a autora propõe é nos valores amazônicos de "convivialidade" e na oposição deles à ideia de que a sociedade seja fundada pela violência e a coerção.

Nesse segundo texto, a autora detalha outro trecho da narrativa mítica supracitada. Wahari, irmão de Kuemoi, é quem o mata e, depois, por seus abusos, acaba sendo morto pela população. É esse episódio que deflagra a crise posteriormente resolvida por Cheheru:

"Neste caso, concluiu-se que, pelo bem da sociedade, uma ação coletiva era necessária para matar o grande tirano, para conter sua ação genocida 
de uma vez por todas. Uma solução razoável. No entanto, o assassinato é uma solução extrema, e assassinato por decisão coletiva é algo ainda pior. Entende-se que violência gera violência, o que já é bastante difícil, se por um indivíduo, e um caos se por um grupo de conspiradores" (Overing, 2012: 78)

Creio que cabe aqui uma breve reflexão sobre o aparente paradoxo que conjuro ao citar essas reflexões de Overing. Porque ela fala em "igualitarismo" quando estou descrevendo toda uma teoria que tem a ver com a posição ocupada pelas pessoas: quem vai adiante se destaca, não é como os demais; quanto ao "principal”, tampouco. Há uma percepção da existência de desigualdades, ainda que possamos discutir em que sentido isso se dá ${ }^{193}$.

Entretanto, a hierarquia que se estabelece no caso do tendotá é efêmera, se esvai quando a ação se esgota. Ela só pode perdurar quando o movimento perdura, se renova. Quando o grupo se assenta, por outro lado, surge essa posição do principal, a qual tampouco é rígida, uma vez que depende de um constante fluxo de distribuição de bens (comida, sobretudo), por meio das festas, principalmente ${ }^{194}$. Com o tempo, vão se estabelecendo relações de parentesco, potencialmente mais firmes (tronco ou esteio são duas metáforas que surgem nessa relação com o mburuvicha/tamõi que alcança esse estágio - vide, por exemplo, Pereira, 1999). Ainda assim, quando há liberdade de movimento, os coletivos continuam, sempre, em constante fluxo, de modo que não se pode assumir que exista qualquer hierarquia rígida. O que persiste, sempre, é puro prestígio.

Nesse sentido, o igualitarismo não é o oposto, o antônimo, é simplesmente o outro lado da moeda, um dos possíveis pontos de vista na descrição de um processo como esse. Porque, sim, de fato, numa situação ideal, sem os atuais constrangimentos territoriais que existem em MS, qualquer adulto mantém, o tempo todo, a possibilidade de "revogação imediata" das relações com o tendotá ou o mburuvicha. Overing não foi a única a notar um "individualismo" nesse comportamento. Viveiros de Castro (1992: 66) usa o mesmo termo para definir a forma arawete de agir diante dos movimentos coletivos (conforme já descrevemos acima).

$* * *$

Os Guarani e Kaiowá viveram recentemente (e muitos ainda vivem) uma experiência de

\footnotetext{
${ }^{193}$ Afinal, como intui Clastres, trata-se, para esconjurar o Estado, de "multiplicar os múltiplos" (2004: 185). 194 Aqui, caberia pensar no que Lanna (1996) chama de "reciprocidade hierárquica", ou "redistributiva".
} 
contato direto com monstros semelhantes aos descritos nos mitos localizados por Perrone-Moisés e Overing. São os capitães, uma instituição lançada pelo SPI ${ }^{195}$. No intuito de civilizá-los, os karai acabamos gerando uma imensidão de problemas. O que aconteceu?

O "não poder", a impotência do tendotá reside no fato de que tudo o que ele pode fazer é convencer as pessoas a segui-lo. A qualquer momento da caminhada, alguém pode desistir da viagem e parar pelo caminho, ou retornar ao lugar de onde saiu. Não há nada que o coaja, quando se está numa fila. A ideia sugerida pela imagem casa exatamente com a realidade que se verifica num coletivo kaiowá vivendo em situação de liberdade.

Nas oito reservas antigas do SPI, essa possibilidade de autonomia das pessoas, essa escolha de seguir ou não a fila ficou prejudicada, sobretudo no período em que havia um movimento massivo de expulsão das famílias, sendo levadas para dentro dessas áreas. Aí, esse capitão monstruoso adquire força total. Boa parte das famílias viu-se impossibilitada de escapar ao jugo desses chefes impostos pelo órgão indigenista.

Praticamente todos os antropólogos que realizaram trabalhos entre os Kaiowá e Guarani em situação de reserva, nas últimas décadas, registraram, em algum momento, os abusos cometidos por capitães, algumas vezes em parceria estreita com funcionários públicos. Estamos falando de delitos que vão desde o desmatamento indevido e o arrendamento ilegal nas reservas, até a apropriação privada de recursos públicos (cestas básicas, insumos agrícolas, uso de automóveis) e violências diversas, como assassinatos, estupros, espancamentos, queima de residências, expulsão de famílias.

São práticas relacionadas, principalmente, a uma estratégia de manutenção do poder no local - visando famílias adversárias e potenciais lideranças emergentes, além dos xamãs, cujo discurso tem suficiente autoridade para questionar publicamente as ações do capitão -, mas também envolvem, segundo os relatos, puros abusos de poder, relacionados, por exemplo, à luxúria ou a ganância (bem no tom exposto pelos mitos destacados por Perrone-Moisés).

Note-se que, quando falamos desses capitães, muitas vezes, trata-se, sim, de um tendotá/mburuvicha, alguém que, num contexto em que não houvesse a situação de confinamento, assumiria esse papel de puxar a fila, ou que, na situação de acomodação de um grupo, poderia se consolidar como principal. Mas, o que ocorre é que, para além da legitimidade de que goza diante 
de seu próprio grupo familiar, ao ser imposto a diversos outros grupos que não lhe têm confiança e não aceitaram segui-lo, de livre vontade (e em função do estabelecimento de relações de reciprocidade, parentesco etc.), ele se torna uma figura indesejável - fato que, aliás, como estamos percebendo, acontece em vários outros contextos nessa dinâmica política. Da mesma forma, há excapitães que, diante de adversidades nas reservas, reuniram um grupo, saíram para buscar novas áreas e se tornaram líderes novamente reputados dentro do movimento Aty Guasu. Tudo é uma questão de posição e momento.

Os relatos sobre abusos cometidos por capitães são abundantes na literatura etnológica recente (Mura, 2006; Pereira, 2004 etc.). A compreensão sobre essa figura tem sido pautada por uma análise que a compreende, basicamente, como resultado da intervenção estatal, via SPI. Para Mura (2006: 115), a ação estatal "extrema a importância" do mburuvicha e superpõe a ela o papel "mediador" do capitão. Impossibilitadas de regular os conflitos com um deslocamento livre no espaço, as famílias ficam “encapsuladas” e surgem os problemas.

Barbosa da Silva, autora que trabalha em estreita colaboração com Mura, vai na mesma linha e diz que, por "comodidade", o SPI institui a figura do capitão, gerando uma "concentração de poder nunca antes vista”. Para ela, os próprios mburuvicha eram definidos em função de uma situação específica, como uma guerra, "desfazendo-se" a necessidade de liderança no momento seguinte. O "respeito perene", por sua vez, se liga à figura dos xamãs. De qualquer forma, sua conclusão é que a instituição do capitão "subverte" toda uma "lógica tradicional” (2007: 53).

Mura, ao mesmo tempo, se questiona sobre o curioso fato de que, livres dessa imposição estatal, vários grupos continuam a manter essa figura de capitão, ainda que relativizando esse poder outrora absoluto. Para ele, o que ocorre é que alguns "agentes indigenistas" alimentam o desejo dos indígenas de ocupar o cargo de capitão, numa "projeção" das lógicas sociopolíticas ocidentais (2006: 156).

Como em outros pontos do trabalho de Mura, a explicação para as mudanças vem de fora. Essa visão, em alguns momentos, também estabelece um esquema do tipo harmonia $\rightarrow$ anomia, presente no seguinte trecho dessa análise do autor sobre o capitão:

"Quando os grupos locais tinham a jurisdição sobre a totalidade dos espaços onde estavam assentados ${ }^{196}$, a construção da liderança era

196 Para que se entenda melhor o que estou questionando. "Jurisdição sobre a totalidade dos espaços": quando isso 
centrada quase exclusivamente na valentia e a capacidade de articulação política dos mburuvicha, no sentido de conseguir beneficiar a comunidade política como um todo. (...) O papel de 'capitão' sobrepondo-se, em um primeiro momento, àquele do mburuvicha, e este último sendo subordinado elou coincidente com aquele de tamõi, não modificava a organização política local, sobretudo no que concerne à lógica que sustentava e atribuía legitimidade à liderança.” (idem: 159)

Pereira tem uma análise mais recente e que acrescenta elementos perturbadores ao debate. No contexto de um relatório do Cimi que analisa os dados do período 2003-2010, destacando o aumento da violência nas reservas, o autor opina que a destituição da legitimidade do cargo de capitão, por parte da Funai e do MPF, abriu espaço para um aumento dos conflitos nos espaços superpovoados, em função do vazio organizacional ${ }^{197}$. Criou-se, segundo ele, "um ambiente favorável à expressão de conflitos e a prática impune de delitos":

"Parece existir hoje a carência de líderes com prestígio suficiente para 'encabeçar' parentelas. (...) O enfraquecimento de líderes reconhecidos pelos seus parentes como conselheiros e orientadores intensifica os focos de tensão e violência nas reservas. Pensar soluções para o problema da violência passa necessariamente pelo fortalecimento destes líderes. Para que isto ocorra, duas condições parecem imprescindíveis: cada parentela deve dispor de espaço físico suficiente para sua reprodução e as agências indigenistas devem levar estes líderes em consideração” (Pereira, 2011: 47).

Vale dizer que, sim, neste caso, concordamos com o diagnóstico de Pereira. De fato, parece haver ligação direta entre essa crise dos capitães e o aumento da violência nas reservas, sobretudo na última década. É, porém, no entendimento sobre esse aspecto político da organização de um grupo local que divergimos. Assim diz ele:

“No sistema político destes índios a maior parte das resoluções estão restritas ao âmbito da parentela, liderada por um casal de velhos - ñamõi e

poderia ter ocorrido, desta forma, considerando-se que, até onde a vista alcança, os espaços ocupados pelos grupos de língua guarani foram sempre disputados, e muitas vezes ferrenhamente, com diversos outros grupos, indígenas, ou, depois, europeus?

197 Uma ressalva: não estamos falando de uma relação simples, do tipo causa-efeito. 
jary'i, que não dispõe de nenhum recurso coercitivo para impor o cumprimento de ordens, pois toda decisão deve passar pelo aconselhamento, convencimento e construção do consenso" (Pereira, 2011: 44).

Mesmo nos casos em que a situação de confinamento das reservas foi superada, verifica-se que persistem os problemas relativos a ocorrências cotidianas como as que já descrevemos acima. $\mathrm{O}$ fato é que, além de haver essa imbricação entre tendotá e mburuvicha, conforme descrevemos, novos fatores, como a escolarização em massa ou o acesso a bebidas alcoólicas introduzem dificuldades na manutenção de uma autoridade que dispense completamente o uso da força. Nota-se que mesmo em áreas onde são consideradas satisfatórias as relações entre as famílias kaiowá e guarani, e onde os líderes operam de forma autônoma, até mesmo a proximidade com as cidades da região introduz complicadores. Hoje, os indígenas estão cientes de que é possível acionar a polícia ou a Justiça dos brancos para resolver conflitos com rivais, e há mesmo casos em que essa intervenção externa desequilibra as disputas, por meio da manipulação das acusações ${ }^{198}$.

Talvez os capitães sejam, afinal, "mais kaiowá” do que tem suposto nossa vã antropologia. O tendotá, como parece deixar ver o debate paraguaio sobre o termo, carrega uma inevitável ambiguidade, estendida, cada vez mais à atuação das lideranças, nos novos contextos.

Observo que há mais importância do que normalmente se reconhece nessa figura a que, aqui, nos referimos com o termo tendotá. Acredito que parte da explicação para o fato de pouca atenção ter sido dada a ela pelos etnógrafos tem a ver com o papel altamente negativo assumido pelos capitães ao longo do século XX. Hoje, porém, com um quadro cada vez mais complexo no mundo kaiowá, a partir da recuperação de áreas promovida nos últimos 25 anos, verifica-se uma reemergência do seu papel. Foi, afinal, a partir, sobretudo, da ação de diversos tendotá que se articulou o movimento kaiowá e guarani pela recuperação de terras, nas últimas décadas.

198 Um exemplo breve, obtido a partir da conversa com advogados que costumam acompanhar processos judiciais envolvendo os Kaiowá ou Guarani: sabe-se que é socialmente aceitável, entre esses indígenas, um jovem de 18 ou 19 anos casar-se com uma menina de 13 ou 14 anos. Pelas regras brasileiras, uma situação como essa pode gerar graves acusações de "estupro de vulnerável". Pois, já me relataram casos em que esse tipo de acusação foi feita por adversários, contra jovens indígenas casados com meninas de 13 ou 14 anos, com consentimento dela e de sua família. Ou seja, no jogo "interno" de disputas, esse aparato estatal externo também é usado como arma. Diria que, por sinal, esse tipo de ocorrência está, hoje, fora de controle e, de fato, como sugere Pereira, todo o imbróglio só começará a ser resolvido quando houver uma forte ampliação da discussão sobre formas de consulta às autoridades indígenas, por parte dos três poderes, em todos os níveis de governo, a respeito da atuação, nas comunidades indígenas, de órgãos como polícias, conselhos tutelares e de assistência social etc. 
Outro fator para o destaque com que a figura apareceu na presente pesquisa tem certamente a ver com uma característica especial da bacia do rio Apa, na fronteira com o Paraguai, entre os municípios de Antonio João, Ponta Porã e Bela Vista. Ali, a colonização apresenta alguma peculiaridade, pois há áreas onde os grupos kaiowá (ou ao menos uma pequena parcela deles) conseguiram resistir sem que fossem expulsos completamente. É algo que ocorreu em poucos lugares.

Além disso, deve-se observar, ali, a proximidade com o Paraguai (duas horas de caminhada, em alguns lugares), e o fato de que do outro lado da fronteira está uma região de terreno particularmente acidentado e que, aparentemente, tornou mais lento o processo de formação de fazendas, favorecendo a permanência de refúgios para os indígenas.

Nesse sentido, o da resistência, algumas figuras preservaram as características de lideranças kaiowá surgidas em situação de autonomia, no sentido de que, ali na área em que lideram, até hoje, só permanece quem quer. É certo que o constrangimento imposto pela colonização restringiu as possibilidades de deslocamento entre os diferentes grupos, mas as características da região permitem que siga sendo fácil, em caso de aborrecimento, buscar refúgio do outro lado da fronteira.

O que gera alguns desafios peculiares, por outro lado, é essa substituição do avanço pela resistência como tônica da ação. Em vez de poder "puxar a fila", até hoje, o que a liderança deve fazer é conter o avanço dos fazendeiros sobre a comunidade. Nesse sentido, esse constrangimento também acarreta um acúmulo de exigências sobre o líder.

É em função dessa peculiaridade da figura do tendotá nessa região do Apa que, acredito, aparece a similaridade com uma formulação aparentemente destoante em relação ao que apresentam os demais autores citados. Vietta realizou pesquisa no Panambizinho, outra área onde um tendotá de outrora conseguiu "segurar" um pedaço de terra durante a fase de colonização. Sobre o capitão, ali, ela afirma:

“Função instituída a partir da intervenção do SPI, (...) ele já foi uma figura coercitiva (...). Mas, hoje, o capitão é uma liderança totalmente incorporada às formas de organização kaiowa, geralmente, 'eleita' pela população que representa" (Vietta, 2007: 15)

Como descreve a autora, esse tipo de situação gera uma relação que destoa das descrições 
predominantes a respeito do capitão ${ }^{199}$. Como veremos a seguir, um ponto de divergência em relação ao que observa Vietta se dá em outro campo. "A atuação de um capitão é exclusivamente política, portanto distinta das antigas lideranças xamânicas kaiowa", afirma ela (idem: 15).

\section{(Cosmo)política cotidiana}

O mburuvicha/tendotá se alia a um xamã, ou o xamã que é líder da família o escolhe? Eis aí outro daqueles tantos jogos de figura e fundo que envolvem a política ameríndia. A importância dos conhecimentos xamânicos para exercer, com êxito, a liderança será abordada, de forma mais pormenorizada, no próximo capítulo. Por ora, perguntamos: afinal, qual a incidência cosmopolítica do mburuvicha/tendotá? Em vários sentidos, segundo o que observamos, não se trata, de nenhum modo, de uma figura "exclusivamente política".

Para começar, vale dizer que um dos maiores desafios para a vida cotidiana em um coletivo kaiowá diz respeito às agressões xamânicas, chamadas normalmente de feitiços, ou paje vai ${ }^{200}$. Paje vai (mau pajé, ou pajé à toa) é algo que se pode entender melhor a partir do sentido mais comum em que é usado o termo pajé - até onde entendi, trata-se de uma espécie de amuleto, feito da parte de algum animal, em geral, para conferir habilidade especial a uma pessoa. Por exemplo, para correr mais ou jogar futebol, deve-se usar o dente de certo animal dentro da meia. Para conquistar as mulheres com mais facilidade, guardam-se, na carteira, partes de certa ave conhecida como queroquero (Vanellus chilensis) etc ${ }^{201}$.

A mesma lógica pode ser aplicada ao paje vai. Segundo me contaram, sabe-se que estão fazendo feitiço contra você quando se encontram em casa, ou no caminho, animais peçonhentos, assustadores ou feios. Por exemplo, um sapo, uma cobra... Também, quando se encontra posto na porta de casa um ninho de marimbondo: eis outro sinal de que alguém nas vizinhanças lhe quer mal.

199 Vietta também cita, em nota, o trabalho anterior de Silva, que, em pesquisa no Panambizinho, tinha chegado a conclusões parecidas sobre o papel do capitão ali, destacando, inclusive, que ele "tem características bastante distintas dos outros capitães que conheci em aldeias Guarani no Mato Grosso do Sul: não fala o português, já ocupa esta posição há pelo menos cinco anos - em contraste com outros capitães que ficam pouco tempo no cargo - e é muito bem aceito pelos Kaiowá de Panambizinho. Várias vezes a FUNAI tentou, sem conseguir, nomear outro capitão para substituí-lo" (Silva, 1982: p.55, apud Vietta, 2006, nota 545, p. 344).

${ }^{200}$ Schaden notava já, entre os Kaiowá, exemplos em que a boa atuação da liderança política era associada a essa tarefa de impedir os feitiços (1974: 100-1).

${ }^{201}$ Note-se o paralelo com o que Gallois (1996) relata sobre a ideia, entre os Waiãpi, de que se "tem pajé", não que se "é pajé”, em função de as capacidades xamânicas estarem ligadas a substâncias que se instalam no corpo. 
As menções a esse tipo de coisa são antigas. Montoya (1985[1639]: 54-5) já registrava essa observação sobre o significado de encontrar um sapo (no caso, em uma embarcação) ou de enterrálo, com um espinho atravessando o corpo. Evidentemente, em alguns casos, é tênue a fronteira entre o mau augúrio e o feitiço. Mas, quando há sinal de ação humana sobre o animal encontrado, aí não há dúvida. Soube de um caso em que foi encontrado um sapo com a boca costurada. Algumas pessoas associaram o achado com algum trabalho ligado a cultos afro-brasileiros, mas, como se vê, a ligação entre o sapo e um possível mal recaindo sobre a pessoa ou sua família é bastante antiga e não necessariamente tributária de algum contato com a "macumba", como muitos se referem.

Galvão (1996: 217-8) descreve, igualmente, um tipo de paje vai (por ele chamado de pohã ray - vai? -, remédio mau?) baseado na técnica do "resto de comida enterrado" que remonta também às observações de Montoya: "Os piores e mais perniciosos [feiticeiros] vêm a ser os 'enterradores', cujo ofício é matar, enterrando eles na casa de quem se deseja matar, algumas sobras de sua comida, cascas de fruta e pedaços de carvão etc." (op.cit: 55).

Outra observação de Galvão encontra ressonância com o que observamos em campo: a associação da figura do cão (jagua) com o feiticeiro. Encontrei, por exemplo, a menção à visão do cão em sonho como forma de identificar que se é alvo de agressão. De qualquer forma, chama a atenção o fato de persistir aqui, ainda que transformada, a associação de uma figura xamânica com o jaguar (afinal, como indica a semântica, o cão guarda similaridade com a onça, no pensamento kaiowá).

Enfim, o tema do xamanismo será exaustivamente examinado no próximo capítulo. Por ora, interessa entender que os feitiços são parte importante da vida política cotidiana de um coletivo kaiowá. Quando se desconfia que um vizinho ou conhecido está fazendo feitiço contra si, a vida de uma família fica tomada pela busca obsessiva de enfrentar esse problema. Aqui, como entre os Azande (Evans-Pritchard, 2005), as pessoas se recusam a assumir o acaso como explicação para acidentes ou doenças.

Doenças como o câncer são fortemente associadas ao feitiço. O mesmo se dá com mortes fulminantes, especialmente vinculadas a doenças internas, dores abdominais etc. Acidentes são igualmente suspeitos. Finalmente, a explicação para uma morte por enforcamento também podem estar relacionada. Parte dessas mortes é, muitas vezes, entendida como decorrência de uma espécie de enfermidade mental, as quais também podem ser associadas ao feitiço (Pimentel, 2006). De fato, as causalidades são intrincadas, e só mesmo um rezador de crédito junto à família poderá tecer uma 
explicação que dê conta de todos os fatores.

Há quem diga que se verifica hoje uma divergência crescente entre os papéis do chefe e do ñanderu, no sentido de que, cada vez mais, os líderes políticos estão menos associados aos conhecimentos cosmológicos. De fato, as exigências objetivas que selecionam os líderes de sucesso parecem afastar uma pessoa da "carreira xamânica", por assim dizer. Misturar-se com os karai, em inúmeros sentidos, diminui as possibilidades de obter sucesso como rezador. Falaremos mais a respeito disso no próximo capítulo.

\section{Mistério}

Foi numa noite de outono. Ele apareceu na casa de João", com o machete na mão. "Hoje vou matar cinco. E ninguém vai me pegar”. As pessoas ficaram com medo, e ele seguiu até o lugar onde os homens bebiam. Há, também, quem conte que o morto havia pegado a bicicleta dele sem pedir, e que isso o havia enfurecido. As histórias são desencontradas.

O que todos sabem é que o morto (não foram cinco, afinal - muito embora as pessoas tenham passado vários dias com receio de que o assassino retornasse para cumprir a promessa) levou vários golpes de machete no pescoço e no rosto. Morreu, é óbvio, e foi largado à beira da rodovia. No outro dia, chamaram a polícia para recolher.

Nas semanas seguintes, espalhou-se a versão de que foi o sogro do defunto o autor, junto com dois outros homens, parentes seus, de quem ele havia roubado uma bicicleta. Mas, dias depois, começam a dizer-me que, apesar de o sogro ter anunciado a morte para a mãe do defunto, os culpados seriam dois elementos que ele teria denunciado na polícia, da última vez que ficou preso, por envolvimento com maconha. O sujeito que morreu não era muito apreciado na comunidade. Fazia pouco tempo que havia saído da cadeia, dizem, e já chegou batendo na mulher. Parece que era filho guaxo (adotado), também ${ }^{202}$. De modo que, enfim, não houve grande comoção quanto à sua morte.

O fato de não haver ação imediata do capitão dá margem para que várias pessoas reclamem. Encontro Expedito, um dia, na cidade, e ele me diz que não dá mais, que é o cúmulo, está com

\footnotetext{
* Nomes fictícios

202 Para uma discussão sobre as crianças adotadas entre os Kaiowá e Guarani, ver Pereira, 2002. Sobre as relações da fragilidade da condição de guaxo com a questão dos suicídios entre jovens indígenas, ver Pimentel, 2006.
} 
medo de continuar vivendo ali, assim não pode ficar. Conselheiro depôs na polícia e teria dito que o Capitão não sabia de nada. Isso chega ao conhecimento dele quando vai à policia, e ele se irrita porque mais uma vez parece que lhe estão tomando a frente.

Dizem que o matador e seus comparsas chegaram a sair da área, mas voltaram, estão todos ali, "escondidos". A certeza de impunidade com que o assassino praticou seu crime deixou uma certeza em todos: alguma proteção ele devia ter. E, de fato, muitos associavam: seu pai era conhecido como rezador habilidoso, e um ou outro desconfiava que ele sabia praticar feitiços, também, não apenas as rezas mais comuns. Havia até quem dissesse que a família já havia passado o recado: não permitiriam que o criminoso fosse punido.

A expectativa era sobre a atitude do capitão: será que ele iria, de fato, cobrar o criminoso? Afinal, essa era sua responsabilidade: zelar pela paz entre os que ali conviviam. Por semanas, a discussão seguiu, até que o próprio Capitão revelou: investigando a família, descobriu que o matador (segundo algumas versões, junto ao próprio pai) já havia se evadido para o Paraguai, buscando refúgio em casa de parentes. Havia quem dissesse que não, que ele continuava ali, mas ninguém se arriscava a me levar até a casa da família (instalada em um dos lugares mais inacessíveis da terra ocupada pela comunidade àquele momento) para averiguar o que de fato estava havendo.

O fato de o Capitão não manter boas relações com os rezadores do local (e de não cultivar, ele mesmo, conhecimentos xamânicos reconhecidos) era, também, explicação dada por alguns para essa reticência em agir: afinal, ele certamente se exporia aos feitiços do pai do matador, caso resolvesse agir com mais contundência. O tempo passou, a versão de que o matador se havia evadido para o Paraguai se consolidou, e o assunto acabou esquecido. Foi mais uma morte não esclarecida entre os Kaiowá - uma, entre centenas, nos últimos anos.

\section{Difícil etiqueta}

O crescimento da população kaiowá, aliado à falta de terras, deixa a vida política cada vez mais complicada: é comum que uma mesma área tenha várias pessoas que se consideram com potencial para posicionar-se como tendotá. A coexistência de muitas lideranças em um mesmo coletivo é considerada um complicador da vida social kaiowá. "É política demais", costumam dizer as pessoas, sobre a vida em lugares onde isso acontece. 
Em uma das áreas que conheci, havia pelo menos seis pessoas que se consideravam com potencial para ocupar o cargo de capitão, ou de operar como tendotá. Refiro-me a homens que já haviam sido capitães em comunidades vizinhas, sobretudo. Havia, além disso, pessoas que já haviam desempenhado papéis do tipo "vice-capitão", auxiliando o principal, em algum momento de suas vidas, e, por isso, sentiam-se capazes de tomar iniciativas em prol da coletividade, as quais consideravam urgentes.

Não ver iniciativa em relação a essas tarefas que eles julgavam importantes era algo que, frequentemente, parecia deixá-los angustiados: "Tal coisa tem de ser feita, e alguém tem que tomar a frente para que ela aconteça. No entanto, eu não posso fazer isso porque, se o fizesse, afrontaria o capitão. Por isso, tenho que permanecer em meu lugar e aguentar isso".

O movimento natural, em outro contexto, num caso como esse, seria o de juntar seu grupo familiar e constituir uma nova aldeia. Isso, se se vivesse, ainda, um tempo de fartura em termos de opções de moradia. Como já mencionamos outras vezes, mudar-se, hoje, não é tarefa simples. Não apenas pelas dificuldades de rearranjo social, em função da escassez de terras, mas também pelo fato de que a invasão do modo de vida dos brancos - baseado, entre outras coisas, em inúmeras formas de pressão pela sedentarização - torna cada vez mais complexo o processo de mudança (que hoje envolve desde questões relativas a casa e móveis, até emprego, cadastro em benefícios sociais etc.).

Para lidar com essa situação, o que tem restado aos coletivos kaiowá é, mais uma vez, exercitar a imaginação e criar novas formas de participação e envolvimento nos temas de interesse coletivo. Assim, parece-me cada vez mais frequente que o tendotá considere perfeitamente aceitável que domínios como educação e saúde - os quais envolvem um contato mais especializado com o mundo dos brancos - sejam tratados por outras pessoas dentro da comunidade. Evidentemente, haverá sempre uma ação no sentido de tornar essas pessoas suas aliadas (sejam filhos/as ou genros/noras, para citar o exemplo mais comum de relação entre o líder e esses especialistas).

O problema dessa etiqueta do poder, porém, pode vir à tona quando a escola ou o sistema de saúde promovem iniciativas que sejam consideradas prerrogativas do tendotálcapitão. Um exemplo perfeito pode ser, digamos, uma festa do 19 de Abril, data em que se comemora o Dia do Índio no Brasil. Para ilustrar melhor essa questão, vou recuperar aqui uma história que presenciei. 


\section{Dia do Índio}

O mês de abril começou com a notícia da morte da mãe do capitão, o que congelou as iniciativas para organização da "aty guasu da comunidade". Memória fundamental para o coletivo $^{203}$, a mãe dele tinha sido importante no processo de reconhecimento da terrra indígena.

Com idade avançada, ela já estava adoentada fazia algumas semanas, com algum tipo de problema intestinal que o filho não soube me explicar o que era.Certa vez, cheguei a acompanhar ao capitão e a ela numa consulta com um rezador que morava na cidade, um paraguaio, branco, barbudo, de óculos, sem aparente ascendência indígena, que conversa em guarani com os índios e se diz umbandista. Usa guia alvirrubra no pescoço, é casado com uma paraguaia que é "índia pura mesmo", segundo o capitão. Cobra 20 mil guaranis, ou dez reais, pela consulta.

"Macumbeiro mesmo", segundo o capitão, o benzedor é uma alternativa que ele busca em função de seus desentendimentos ${ }^{204}$ com os atuais rezadores da comunidade. À diferença de seu pai e de seu avô, o líder kaiowá não desenvolveu nenhum saber xamânico de cura (seja de pessoas, bichos ou plantas). Fica, assim, vulnerável numa situação como a doença da mãe, porque tem de buscar a colaboração de outras pessoas com esse tipo de conhecimento na comunidade. Ele me explica, então, que prefere ir à cidade procurar o benzedor porque os ñanderu lhe pedem muito dinheiro para fazer o tratamento da mãe.

Estamos em abril, e a urgência agora é para organizar a festa do Dia do Índio, no dia 19. Há

203 Para que se visualize o quadro: a comunidade referida aqui fica a alguns quilômetros de uma cidade da fronteira, em Mato Grosso do Sul, e abriga algumas centenas de famílias kaiowá. Está, ainda, ao lado de um povoado que é um distrito do município, e hoje tem apenas algumas poucas famílias de moradores não indígenas (a divisa entre povoado e área indígena, é, na prática, inexistente). Na narrativa, vou usar os três termos de forma fluida, sempre me referindo a esse quadro. Além disso, os personagens principais são o capitão, cujo pai e avô "seguraram" uma pequena parcela que hoje eles ocupam (a terra indígena já está em fase avançada de reconhecimento, mas se encontra barrada na Justiça), e a "coordenadora da escola", que é também kaiowá, mas proveniente de outra área (foi convidada a trabalhar ali). Hoje, há brancos que dirigem a escola, acima dela, mas ainda é reconhecida como uma autoridade entre os professores indígenas, e também como interlocutora por parte dos brancos. O terceiro personagem é o "conselheiro", kaiowá que já foi capitão em outra aldeia, é participante ativo do movimento Aty Guasu e, atualmente, mantém atuação política na área, mas sempre esbarrando nos limites dados pela etiqueta kaiowá.

204 Posteriormente, em conversas com diversos dos idosos com conhecimentos xamânicos ali na comunidade, percebi que esses conflitos tinham a ver com o fato de, segundo seus críticos, o capitão manter um comportamento incompatível com os padrões comuns às gerações anteriores. Certa feita, segundo relato, ele ignorou relato de agressão praticada por seguranças de um fazendeiro contra um desses idosos. Episódios como esse fazem com que ele seja questionado. Casos de feitiço dentro do coletivo também reforçam as acusações de inoperância. Finalmente, o capitão não demonstra aptidões xamânicas, outro fator de descrédito perante os valores dos antigos. Normalmente, um capitão tem de se esforçar para demonstrar algum conhecimento das rezas e capacidade para curar. Além disso, bebedeiras e brigas familiares também são mal vistss. Por outro lado, como indica Schaden (1974), o xamã que é de fora parece quase sempre ter mais poder que os locais... 
especial dedicação da comunidade não só porque era tradição das lideranças do coletivo, desde o avô do capitão, promover essa celebração, como também porque foi nessa data que faleceu o pai do capitão, alguns anos atrás.

A comemoração não é pela morte, é para manter a tradição herdada, mas, de qualquer forma, reavivam-se as memórias. As preparações para a festa do Dia do Índio acabam tomando rumo curioso: enquanto o capitão planeja um churrasco a ser feito no pátio de sua casa, a Coordenadora da Escola (que é uma indígena) e os professores articulam na escola outra festa semelhante. No começo, há acerto: este evento será no sábado, dia 18, mais voltado aos estudantes, e aquele, no domingo, 19, será, propriamente, a comemoração da comunidade.

A coisa parece firmada nesses termos, e vou acompanhando os preparativos paralelos. A "aty guasu da comunidade" fica no congelador, por enquanto. Os professores indígenas, juntamente com a diretora kuña karai da escola, fazem lista de compras, articulam com a Secretaria de Educação. Não há menção de realizar atividades na cidade: a comemoração é voltada à própria comunidade, não a qualquer tentativa de diálogo com os não índios, a não ser os que moram no povoado e arredores, os quais são chamados a participar do torneio de futebol que está sendo planejado. Os itens que os professores pedem à prefeitura são os necessários para se fazer um churrasco, acompanhado de chicha, e o torneio (no caso, os prêmios para as equipes vencedoras, que incluem troféus e, para o primeiro lugar, um bezerro).

No planejamento, surge entre os professores até mesmo a ideia de convocar a Polícia Federal para fazer a segurança do evento, mas nada acaba sendo efetivado nesse sentido. Alguém comenta que, no ano anterior, uma mulher chegou a ser esfaqueada no meio da festa. Para ter ideias para compor, graficamente, um convite às autoridades da cidade, como vereadores e prefeito, olham as ilustrações de um livro editado pela Universidade Federal da Grande Dourados: "A Arte dos Índios Kaiowá”, de Lélia Chalib Amin Paschoalick.

No meio dos preparativos para a festa, uma surpresa: no meio da semana, o Capitão, a Coordenadora e o Conselheiro tinham ido a uma cidade vizinha para uma audiência no Fórum. Eles foram incluídos como testemunhas em um processo por assassinato de um indígena de uma área kaiowá em litígio a quase 100 quilômetros dali, sem nem entender por quê. Essas convocações ao fórum ou ao Ministério Público acontecem de forma esporádica e repentina (às vezes por processos como esse, mas também por questões ligadas às disputas fundiárias). 
Enquanto os professores fazem listas de pedidos para a prefeitura, o Capitão tem que dar tratos à bola para descobrir como conseguirá organizar a festa do dia 19, que é sua "obrigação e compromisso", por conta da memória do pai. Para fazer o churrasco que é oferecido à comunidade, aparentemente, houve, outrora, a tradição de pedir uma doação a um fazendeiro vizinho, mas os conflitos fundiários dos últimos anos dificultaram, de forma notável, essas relações.

Ainda tentamos numa fazenda que fica na direção de outra área kaiowá, já em município vizinho, mas a vaca que o pecuarista poderia doar já havia sido entregue aos índios daquela comunidade, mais próxima da propriedade. No caminho, meus companheiros vão olhando os morros e me dizendo os nomes dos lugares outrora habitados pelos Kaiowá, hoje terrenos pertencentes a fazendas, frequentemente cercados de plantações de soja ou milho.

Sem outra solução à vista, o capitão resolve tratar com um pecuarista que mora na cidade e é comerciante. Ele mostra um contrato de parceria que foi firmado entre seu pai e esse homem, muitos anos atrás. O então capitão cedeu a este seis novilhas para engorda - um tipo de negócio comum na região, entre quem tem algum capital para investir nos bichos e quem possui o pasto. Até hoje não foram devolvidas as novilhas correspondentes ao contrato, e chegou a hora de cobrar, acredita o capitão.

O churrasco, portanto, é a essência da festa. Também haverá chicha e mandioca, mas isso não é tão difícil de conseguir. O milho moído para fazer a chicha há de ser doado pelo antropólogo, afinal. Prefeito e vereadores deveriam ser acionados para obter apoio, mas essa parte da coisa simplesmente não anda. Ainda que, em campanha no ano anterior, o prefeito tenha estado ali mesmo, na frente da casa do capitão, para pedir apoio dele e prometer, em troca, um churrasco no dia 6 de outubro, para comemorar a vitória nas urnas, nada é obtido dessa fonte de recursos.

É nesse contexto de plena atividade do capitão que consigo um pouco mais de informação sobre quais responsabilidades ele entende ter em função de sua posição. O Capitão me conta que, quando jovem, foi mandado pelo pai a uma área kaiowá vizinha, para morar com o tio, então capitão de lá. Foi policial ali por algum tempo e, depois, voltou à comunidade para tornar-se vicecapitão - o retorno coincidiu com a morte do tio, evento após o qual predominou a confusão na área vizinha. Hoje, lá, conta ele, há muitas brigas e até mortes. Sua comunidade, antigamente, também era assim, diz. "Aqui era lugar de briga mesmo".

Ele ressalta o contraste entre a situação dali e a da comunidade próxima: ali, sim, podia-se 
confiar nas lideranças, porque havia estabilidade. O Capitão conta que lá, junto ao tio, aprendeu a como chegar para apartar uma confusão, uma briga: tem que saber chegar, conta. Com desdém, fala de um adversário, ex-capitão numa área vizinha, que hoje vive em sua comunidade e tenta armar para tirá-lo do cargo, quando ele mesmo não se manteve lá - vamos chamá-lo aqui de Contrário, um termo usado pelos indígenas para se referir a esse tipo de inimizade; "fulano é nosso contrário", dizem. "Já falei para a comunidade que, se quiserem, podem colocá-lo. Mas ninguém fez isso até agora", sorri com satisfação.

O Capitão dispõe de 15 "policiais" sob seu comando. Não usam termo em guarani, dizem "polícia" mesmo. Encontram-se ali apenas sete deles, porque oito estão trabalhando na cana. Para mantê-los disponíveis, ele, segundo me conta, costuma dar-lhes presentes - alimentos, tabaco quando necessita convocá-los para trabalhar ${ }^{205}$.

Esse período coincide também com as tentativas de aproximação do Contrário. Ele inicialmente se diz um "curioso" e me bajula, diz que há várias coisas que eu, um pesquisador, poderia ajudá-lo a compreender. Resolvo dar-lhe corda para entender melhor essa disputa pelo cargo de capitão. Nada melhor do que a oposição para apontar erros no governo - e fazer-me entender melhor que quesitos são ou não valorizados no desempenho de quem está no cargo de capitão.

O primeiro pedido do Contrário tem a ver com sua preocupação com os riscos por que passam os homens que saem da comunidade para trabalhar nas usinas. Os que, semanas atrás, saíram para trabalhar na usina, no mesmo dia em que houve reunião na casa do capitão, conta ele, estão todos retornando por terem percebido que seriam vítimas de um calote.

O intermediário no contrato foi um menino de Amambai que, segundo ele, ainda é menor de 18 anos de idade. Além disso, ao chegarem à usina, os homens perceberam que todo o quadro que lhes haviam pintado sobre o local de trabalho era falso: o preço pelo metro cúbico de cana era bem menor que o pago em Naviraí (município onde fica usina que é uma das mais tradicionais empregadoras de índios) e, além disso, havia uma cobrança excessiva pela alimentação.

Tendo sido, no passado, capitão, ele, naturalmente, se preocupa com o bem-estar das pessoas

205 Retornaremos, mais à frente, a essas figuras, ainda neste capítulo. Por ora, lembremos que, como diz Carneiro da Cunha, "usar um termo de empréstimo é o mesmo que declarar sua intradutibilidade" (2009: 369). Nessa interpretação, os Kaiowá e Guarani optam por manter o termo em português em função de que isso, por si só, é significativo: indica que a coerção praticada pela polícia é algo próprio de um contexto karai. Por sinal, o mesmo se dá com o termo "capitão". 
da comunidade e, por isso, pede que eu faça algo por eles, caso tenha condição. Até agora, ninguém recebeu dinheiro nenhum pelas semanas que passaram lá. Infelizmente, o Capitão não tem essa preocupação, só quer saber dele mesmo, é "muito parado", mas não deixa o cargo, e uma pessoa bem-intencionada como ele acaba ficando de mãos amarradas etc. etc. etc. Para a Coordenadora, o Contrário só tem elogios: diz-me que, se não fosse por ela, a comunidade estaria bem pior. Mas, no geral, lamenta ele, falta alguém que traga informações sobre as possibilidades que poderia haver de a comunidade melhorar: há tanta terra ali que poderia estar sendo trabalhada, houvesse um trator disponível...

Pouco depois, um episódio aparentemente corriqueiro, envolvendo um boato, expôs as tensões entre o Capitão e o Conselheiro. O "proprietário" de parte da área onde a comunidade está alojada provisoriamente ${ }^{206}$ teria declarado a intenção de pedir essa terra de volta. Caso se confirmasse, a informação seria bombástica - por isso, quando um garoto veio dizer ao Capitão que o Conselheiro teria comentado sobre essa possibilidade, com algumas pessoas, ele ficou muito alvoroçado.

O boato ganhou vida própria. Conversei com o Conselheiro, e ele afirmou que apenas tinha ouvido um peão do tal fazendeiro dizendo algo a respeito, tendo depois, despretensiosamente, comentado com algumas pessoas na comunidade. O Capitão ficou muito irritado: considerou irresponsabilidade do companheiro essa divulgação e passou dias tentando verificar se havia algum fundo de verdade, inclusive pedindo-me que checasse na internet e com o MPF - por coincidência, eu fui a Dourados nesses dias.

Não havia, efetivamente, nada, e o Capitão só ficou de fato tranquilo quando, dias depois, foi tentar pedir ao fazendeiro alguma colaboração para a festa do 19 de abril. O encontro dissipou suas dúvidas, e serviu, até mesmo, para reafirmar a trégua com o fazendeiro - que reforçou sua disposição de ajudar em qualquer coisa que ele precisasse e afastou qualquer possibilidade de pedir a devolução da terra, no relato do capitão. No encontro com o karai, ficou acertado, por exemplo, que haveria livre acesso em suas terras à lenha e o bacuri - isso numa época particularmente complicada, porque, com a aproximação do frio e da chuva (é úmido o inverno na região), os índios costumam renovar a cobertura de folhas dessa palmeira em suas casas. A tensão com o conselheiro, 
por outro lado, ainda permaneceu por algum tempo.

Nos dias seguintes, continuou o processo de preparação das festas do 19 de abril., as quais, vale lembrar, deveriam acontecer em dias diferentes, segundo a previsão inicial de todos. Levei para o Capitão alguns quilos de milho moído, minha colaboração para a chicha. Chicha e guaxiré formariam a parte noturna da comemoração. Os policiais do Capitão também passavam dias ali junto com ele para providenciar um dos elementos atualmente mais trabalhosos de se conseguir em quantidade, a lenha - sem a qual não poderia haver churrasco.

O mais difícil era, então, obter a carne. Depois de algumas tentativas junto aos fazendeiros da região, como dizia, o capitão acabou apelando à velha dívida do comerciante com seu pai. Não sem pesar, porque pareceu um tanto vergonhoso apelar para esse recurso, em vez de conseguir a carne como um presente dos brancos - o sucesso ao angariar recursos fora dos limites da comunidade é quesito fundamental para um líder.

Ocorre que, no meio do caminho, a festa da escola mudou do sábado para o domingo - por conta de a prefeitura entender que o torneio de futebol não seria viável no sábado. Prefeito e vereadores acabaram doando tudo o que poderiam para essa comemoração capitaneada pelos professores: carne, acompanhamentos. A administração municipal aproveitou para promover o motonivelamento e a limpeza das ruas próximas à escola, arrumando, ainda, o campo de futebol. Foi uma verdadeira faxina. A festa do capitão corria risco de ficar esvaziada, e isso o aborreceu de tal modo que ele decidiu, no mesmo momento, que nos anos seguintes seria o único pedir qualquer coisa aos brancos em nome da comunidade.

Acompanhei a turma no dia em que se providenciou a vaca. Depois de combinar com o comerciante, foi preciso arranjar um transporte, porque o animal morto teria que ser levado para carnear já no local do churrasco, em frente da casa do capitão, onde a lenha e o fosso estavam prontos para receber a carne.

No sábado, então, alguns dos homens do capitão o acompanharam à cidade, onde conseguimos uma camionete que faria o transporte, com a vantagem adicional que o motorista também se encarregaria de "sangrar" a vaca - ou seja, matá-la, com um talho de faca no pescoço.

Não foi só a mim que causou choque a cena da execução, em uma pequena chácara a menos 
de $500 \mathrm{~m}$ do centro da cidade. Os companheiros do capitão, alguns evangélicos, saíram rezando na caçamba da camionete em direção da aldeia, acompanhados do corpo da enorme vaca, que ainda devia estar amamentando uma pequena novilha, a qual permaneceu chorando ao lado do corpo agonizante da mãe.

A vaca era excessivamente velha, tinha 12 anos, segundo o comerciante - portanto, com carne dura e escassa -, mas, àquela altura do campeonato, era a única chance de honrar o compromisso de fazer a festa, na manhã seguinte. Depois do trabalho de carnear e pôr para assar as peças, restou ao capitão receber, no domingo, algumas dezenas de convidados da comunidade que devoraram em poucos minutos a carne e a mandioca oferecidas pelo chefe, para, rapidamente, retornar a suas casas. Em pouco mais de duas horas, a praça em frente da casa do capitão estava vazia.

De tarde, mais uma festa, antes das comemorações noturnas: é o aniversário da neta do capitão, e um bolo é oferecido. O bolo, diga-se de passagem, deveria ter sido doado pelo pai da neta, que é não indígena e, há algum tempo, já vivia longe dali. Apesar de a união do sujeito com a filha do Capitão não ter vingado, não parece haver mágoa pela separação - que, por sinal, é algo muito comum entre os Kaiowá. Se problema houver, será pela falta de atenção à criança - e à família do Capitão, por extensão.

Enfim, repete-se a cena: as pessoas permanecem por pouco mais de meia hora, cantam o "Parabéns a Você", em português, comem e retornam para suas casas com rapidez. O destaque é a decoração do toldo coberto por folhas de bacuri, e com o cocho de chicha no lado mais próximo da casa do Capitão: balões coloridos enfeitam o espaço que é normalmente destinado às reuniões e festas.

$\mathrm{Na}$ escola, não foi muito diferente. Em pouco tempo, as pessoas comem e voltam para suas casas. A festa parece fazer-se, basicamente, como uma ocasião para comer carne à vontade - com o adicional do futebol, que rendeu uma novilha como prêmio para a equipe formada pelo marido da coordenadora. Houve torneio masculino e feminino, os times eram misturados: gente dali, jogando junto com os visitantes das fazendas dos arredores.

$* * *$

Tudo isso é o dia. À noite a celebração entre os Kaiowá é outra. Um dos momentos mais significativos na preparação para esse momento é quando, dias antes da festa, os homens do capitão 
viram o cocho de chicha, no toldo em frente da casa. $\mathrm{O}$ banco onde as pessoas normalmente sentam em dia de reunião vira recipiente para a chicha que todos devem beber para dar as mãos e fazer roda para dançar o guaxiré.

Na escola, a celebração noturna acontece no sábado. Há umas cem pessoas presentes. A noite começa com apresentações dos alunos, ensaiadas pelos professores: números de dança guarani - inclusive, algumas inspiradas em CDs gravados pelos Guarani do litoral; polcas paraguaias com letra em guarani, acompanhadas ao violão; uma pequena peça de teatro que reproduz o assassinato de uma liderança kaiowá; uma canção evangélica em português, cantada pelo marido da coordenadora. Tudo é feito em forma de concurso: distribuem-se prêmios, e há jurados, como o secretário de Educação e algumas kuña karai que trabalham na escola. Finalmente, há o ponto alto das apresentações: o concurso de Beleza Indígena. Há desfile de maiô e de "traje indígena" - termo que cada uma interpreta a sua maneira: há desde plumas coloridas, como a de uma passista de escola de samba, até uma roupa feita com saco de aniagem.

Depois dessa parte da festa, que as pessoas acompanharam sentadas em cadeiras, no pátio da escola, acontecem as rodas de guaxiré e guahu. Há quase sempre uma ou mais pessoa mais velhas em cada roda, para puxar as músicas. As rodas maiores têm dezenas de pessoas. Giram rápido, por causa da empolgação das crianças, e levantam uma poeira que encobre tudo no pátio da escola. As rodas de guahu são menores, geralmente só há idosos, mais um ou outro adulto. A língua das canções de guahu é enigmática, ninguém consegue decifrá-la. As pessoas imaginam que seja uma língua guarani muito antiga, hoje inacessível a todos. São mesmo poucos os que as conhecem de cor. Na cantina da escola, é servida a chicha, feita de garapa de cana com milho. De sabor adocicado, com baixa fermentação, é uma espécie de versão infantil da bebida tradicional.

No pátio da casa do capitão, o guaxiré e a chicha acontecem no domingo à noite. Chegam por ali umas trinta pessoas, que formam rodas e cantam até pouco mais de meia-noite, à luz de candeeiros. O capitão não dança nem canta, como já não havia comido, nem festejado: está calado, sentado num canto enquanto todos se divertem ${ }^{207}$.

Três anos depois, retornando à mesma localidade, constato que o quadro da festa mudou 
substancialmente. Quatro reses foram doadas para a festa, e o capitão parece satisfeito - no ano anterior, foram cinco, contam-me ainda. A festa honrou a memória do pai do capitão, por sua fartura, e o prestígio dele segue garantido. Nesse ínterim, o que aconteceu?

Pergunto-me se não teria sido o veto do capitão a que qualquer outra pessoa arrecade doações em nome da comunidade sem sua autorização. Mas, que poder teria tido esse veto? Seria bem um veto? Ele chegou a se efetivar? Observo que, das seis pessoas que pareciam, em alguma medida, ter a capacidade para absorver tarefas cuja responsabilidade deveria ser do capitão, quatro estão fora do jogo. Falemos, então, sobre o destino destes quatro personagens: o Professor, o Contrário, o Conselheiro e o Expedito.

Em primeiro lugar, já não reside ali o Professor, uma espécie de braço-direito da Coordenadora que por ela havia sido trazido à comunidade, anos antes, com a missão de auxiliá-la. Sem maiores laços familiares na comunidade (sua esposa, inclusive, era da mesma Reserva que ele e a Coordenadora, sendo desta parente), sua sobrevivência política sempre fora intimamente atrelada aos movimentos da Coordenadora - ainda que ele tenha ensaiado passos maiores: no ano anterior a minha chegada, ele chegou a se candidatar a vereador, o que causou desentendimento entre as lideranças indígenas, porque o Conselheiro também concorreu na eleição, e, divididos os votos da comunidade entre os dois, nenhum deles finalmente se elegeu ${ }^{208}$.

Cerca de oito meses depois de minha saída do local, o Professor assumiu uma espécie de vice-capitania $^{209}$, com a missão imediata de restaurar a paz na região do Povoado - pólo oposto à região da Retomada, em cujo extremo se instala a casa do Capitão, bem próxima à porteira da fazenda onde reside o principal fazendeiro que se opõe aos indígenas.

Com um grupo de polícias, realizava rondas noturnas no Povoado, a fim de coibir a balbúrdia causada pelos jovens indígenas (ditos “estudantes”) - segundo me relataram, a decisão extrema do Capitão de aceitar o surgimento desse poder paralelo teve a ver com a exigência da comunidade, em assembleia, de que o problema fosse resolvido, em função de um episódio mais grave, em que uma adolescente esfaqueou um rapaz, gerando indignação nas famílias.

Meses mais tarde, o Professor entrou em confronto com gente ligada à Prefeitura, em função

208 Não faltava quem analisasse que essa dupla candidatura havia sido incentivada por políticos da cidade como forma de impedir que um representante dos indígenas chegasse à Câmara - visto que, divididos, os votos seriam insuficientes para eleger quem quer que fosse.

209 Digo "uma espécie" porque, no discurso do Capitão, o Professor era seu vice. No discurso do Professor, ele havia dividido a capitania por área - o Capitão ficaria responsável pela área da Retomada, e ele, pela do Povoado. 
da administração da escola. O resultado foi que, por fim, acabou tendo de mudar-se da comunidade, retornando à Reserva de onde viera (a quase 200 quilômetros dali). Ali, até onde soube, acabou assumindo o cargo de diretor de uma escola, num movimento político que, segundo alguns me relataram, era realizado pela prefeitura local como forma de enfraquecer certos setores indígenas mais aguerridos (por ser de fora, o Professor estaria mais propenso a seguir, sem questionamentos, as políticas dos karai no local). Mas, como não tive mais contato com ele depois que se foi, essa versão fica a descoberto.

O Conselheiro, por sua vez, acabou, por fim, afastando-se da comunidade, depois de cerca de uma década de vida ali. Ele, que já havia sido capitão em uma comunidade vizinha ${ }^{210}$, voltou para lá, levando a família - sua filha já estava residindo nessa outra área e ajudou-lhe a conseguir uma casa construída pelo governo, o que, aparentemente, influenciou sua decisão. Quando conversei com ele, à véspera de sua partida, me dizia, muito emocionado, que se sentia sozinho, abandonado.

A frustração do Conselheiro tem, certamente, relação com a difícil condição de quem se propõe a liderar, mas não dispõe de sustentação familiar em um dado local - remetendo-nos ao paradoxo $k i n(g)$ ship, sugerido por De Heusch. O fato é que essa potência exterior trazida por figuras como a do Conselheiro ${ }^{211}$ é, por vezes, requisitada, mas, no momento seguinte, pode ser, já, indesejável, acabando por ser expelida.

Mas, para além dessa dinâmica, o fato é que, no caso do Conselheiro, também está em jogo certa frustração decorrente da relação entre as dinâmicas locais das comunidades e os apoiadores do movimento indígena. Afinal, nem sempre essas agências externas ${ }^{212}$ terão como intermediário, em um dado local, exatamente o chefe, que muitas vezes não possui as qualidades que permitem um

210 E, aparentemente, saiu de lá, anos antes, em função de problemas políticos bem similares aos que descrevemos acima, em relação aos tendotá que não possuem um grande grupo familiar para lhes dar apoio em momentos de crise. Por outro lado, sua chegada à comunidade cuja história aqui contamos esteve ligada ao momento de "retomada" das terras reivindicadas pelo grupo (em função de que o Conselheiro era um veterano do movimento Aty Guasu).

211 E, no caso em questão, também pela Coordenadora, e, em certa medida, pelo Professor. Também há outra figura aqui não referida na narrativa, em função de já estar ausente da comunidade havia muitos anos no período em que por lá passei: um poderoso rezador que residiu ali por algum tempo, tendo sido requisitado no período de embate mais intenso da comunidade pela retomada das terras, mas que, depois de certo período, acabou caindo em conflito com o Capitão e sua família, retirando-se do local. Aliás, ao que consta, não foi a primeira comunidade em que esse rezador se envolveu com tal tipo de dinâmica política.

212 Há quem atribua esse desencontro político a certos atores dentre os que se relacionam com o movimento indígena, eximindo outros. Nem mesmo os antropólogos estão totalmente livres dessa sorte de equivocação (que atinge a todos, em maior ou menor grau), tanto que conceitos como "conhecimentos tradicionais" têm sido cada vez mais objeto de discussão. 
contato mais facilitado com o exterior (fluência na língua portuguesa, afinidades pessoais e políticas etc.). A potência trazida pela possibilidade de se relacionar com esses atores fica relativizada pela necessidade de uma boa relação com o mburuvicha/tendotá.

Justamente, por haver vivido boa parte da vida na cidade, em função de uma delicada história pessoal de despojo e adoção, o Conselheiro mantinha-se, desde sempre, em boas condições no sentido de manter contato com essas agências karai. Ocupou, por exemplo, certa posição de prestígio diante da prefeitura local, mas suas atribuições, nesse sentido, esbarravam nas prerrogativas do capitão, segundo o ponto de vista deste.

Ocorre que, em função da evolução do processo fundiário de uma dada localidade, altera-se a posição de uma comunidade em relação às prioridades do movimento. Se uma comunidade já está com a situação "resolvida", a tendência é que outros coletivos adquiram maior visibilidade no contexto do movimento, de modo que decai a importância dessa habilidade para manter contato com o exterior no conjunto das habilidades agenciadas pelo coletivo local. Em uma situação em que a disputa pela terra não está em primeiro plano, a relação com políticos locais, fazendeiros e comerciantes, por exemplo, pode ser mais importante do que a que é cultivada com agências como a Funai, ONGs de apoio ou os antropólogos - o exato contrário, portanto, de um período de conflito. Resumindo, pois, a situação política do Conselheiro tornou-se insustentável, ali, a certa altura.

Outro dos atores, aí, o Contrário pertencia à família do Capitão e, até por isso, era, talvez, considerado o principal adversário (não o principal concorrente entre vários, mas, talvez, o que tinha maior potencial de causar confusão, em função do parentesco). Ocorre que sua relação com a linhagem de capitães se dava pela linha materna, o que parecia enfraquecer sua posição em relação ao Capitão.

De qualquer modo, como se percebe por seus discursos destacados acima, o Contrário conhecia perfeitamente as regras do jogo. Ele também havia sido capitão em uma área vizinha, o que reforçava seu discurso sobre a necessidade de conhecimento e experiência específicos para assumir o cargo de capitão. Dizem que chegou, em um ou outro momento, a tentar algum embate direto com o Capitão, praticamente desafiando-o para um duelo, por assim dizer - mas, não foi capaz de desfazer a aliança que seu opositor mantinha ali. De fato, a julgar pelas críticas cotidianas que se fazia ao capitão, ele poderia não sobreviver uma semana no cargo. Não obstante, ele se mantém há muitos anos em sua posição. 
Segundo soube, pouco mais de um ano depois de minha partida, o Contrário se envolveu em uma briga envolvendo questões familiares e, ferido seriamente, acabou retornando à comunidade onde anteriormente fora capitão - e de onde havia saído em função de outra disputa, na qual fora atacado pelos cunhados (caso ilustrativo da conveniência de residir juntamente com seu próprio grupo de germanos para melhor defender-se nesse tipo de disputa, conforme comentado acima).

O último personagem da quadra é o Expedito, a quem assim chamo em função de sua inserção política, basicamente ancorada em sua reconhecida capacidade de encaminhar a resolução de problemas pessoais (assuntos relativos à Previdência e a Assistência Social, documentação etc.), muito requisitada, por exemplo, pelos idosos, que, comumente, têm dificuldades com o português e outros códigos requeridos na cidade (operação de caixas eletrônicos, burocracia estatal etc.). Como já mencionamos, a penúria por que passam os Kaiowá nas últimas décadas torna esse tipo de recurso fundamental para a sobrevivência da imensa maioria das famílias indígenas.

Uma das pessoas que conheci que mais se angustiava com as condições impostas pela longa espera por uma decisão judicial quanto às terras da comunidade, o Expedito, sempre em busca de lenha, folhas de bacuri e outros produtos de coleta, constantemente relatava situações de risco que passava com os seguranças armados que eram contratados para vigiar as fazendas vizinhas à área onde estão os Kaiowá.

Mais de uma vez ele teve que se esconder de tiros (de chumbo ou de borracha? ${ }^{213}$ Quem se expõe a uma arma com aspecto de escopeta calibre 12 para comprovar qual o material de que são feitas as balas?) por conta de um feixe de lenha ou de um ramo de folhas de palmeira que ia apanhar nas árvores de uma área de pasto qualquer.

Outrora auxiliar direto de um capitão na área, o Expedito, cuja família, no local, não era grande, conformava-se com sua condição de possível braço direito do Capitão, em certas épocas e situações. Sua aflição parecia estar relacionada, sobretudo, e isto sim, à quase completa impossibilidade de agir para melhorar as condições de vida das pessoas, diante da frieza e da distância da Justiça dos karai. Apareceu morto, com sinais de enforcamento, em sua própria casa, pouco tempo antes de minha última visita à área.

O que teria havido? Teria sido consumido pela ansiedade, convertida em tristeza? Tal

213 Nos últimos anos, têm sido cada vez mais comuns em MS os episódios de violência contra os indígenas, por parte de empresas de segurança privada, em que se utilizam armas com balas de borracha - as quais, apesar de consideradas "não letais", podem, sim, levar à morte em caso de tiros à curta distância. 
desfecho seria trágico, teria até algum sentido, mas, com esse tipo de coisa, nunca se pode ter certeza, ensinam-me os indígenas. Por regra, como expus alhures (Pimentel, 2006), os Kaiowá são prudentes diante desse tipo de morte. Nunca descartam a hipótese de que tenha sido provocada por um agente externo - seja humano ou não (um feitiço, um fantasma angue etc.). Seguindo tais conselhos, abstenho-me, pois, de tirar maiores conclusões sobre a morte do Expedito.

Ao final, continuam, então, na área, e agindo em colaboração com o Capitão, a Coordenadora e o Cantor. Faltou dizer algo sobre este último: tratava-se de outra pessoa com algum potencial para "puxar" movimentos coletivos. Chamo-o assim em função de seu gosto pelo canto: organizava, em sua casa, cultos evangélicos que consistiam, sobretudo, segundo suas descrições, em longas sessões de cantoria de hinos em guarani. Também era bom conhecedor de cantos guahu e guaxiré. Sempre alegre e disposto, auxiliava em diversos empreendimentos coletivos, como festas e eventos de todo tipo. Ultimamente, começou a frequentar as Aty Guasu. Sua ênfase, até agora, tem sido na atuação local - mais uma vez, sua família não é das maiores na comunidade.

O Cantor converteu-se, recentemente, em auxiliar direto do capitão e tem tido sua permissão para tomar a frente em determinados assuntos - é preciso haver muita confiança entre os dois para que isso ocorra. Mudanças substanciais na paisagem já podiam ser percebidas, como melhorias nas vias de terra que estão no interior da área ocupada pelos indígenas. Até que ponto uma decorrência desse novo arranjo político, ou um efeito da proximidade das eleições municipais ${ }^{214}$ ? Difícil de saber, por enquanto.

O mesmo poderia ser dito em relação a outro fator que pode ter influído para a maior generosidade dos fazendeiros quanto às reses para as festas: segundo me relatam, diminuíram, aparentemente, os episódios de roubo de gado na região. Sendo os indígenas da comunidade, sempre, os primeiros suspeitos apontados - em função de preconceito, diziam-me sempre, mas também do fato de que alguns comerciantes da região poderiam estar arregimentando indígenas para prestar-lhe esse tipo de "serviço", em função da situação de penúria geral da comunidade -, o estancamento desses delitos parece ter melhorado a disposição dos pecuaristas para com eles.

\footnotetext{
214 A morte do prefeito local, algum tempo depois de minha saída da área, também pode ter sido um fator de mudança, segundo uma análise que colhi. A política de fortalecer as festas da escola, em detrimento das da comunidade, parece ter estado relacionada a sua gestão.
} 


\section{A vara enfeitada}

Como já discutimos acima, é constante, na bibliografia sobre os capitães, a ideia de que todo esse "aparato de coerção" tem origem na intervenção colonialista/estatal, com as políticas do SPI para a territorialização etc. Certamente, mas sabemos que nada é recebido sem transformações, sem ser "indigenizado".

$\mathrm{Na}$ prática, essas formas políticas dialogam, muitas vezes, mais do que se parece ter admitido, com os usos ditos "tradicionais". A identidade, afinal, é "simplesmente a percepção de uma continuidade, de um processo, de um fluxo; em suma, uma memória", como nos diz Carneiro da Cunha (2009: 259). Uma cultura não é um conjunto de traços dados, e sim a possibilidade de gerar esses traços, num sistema que está sempre mudando. "Qualquer essencialismo é enganoso", adverte a autora (idem).

Um dos sinais mais evidentes de que a legitimação de um organismo como a polícia indígena tem algo de continuidade está no uso do yvyrapara - a vara enfeitada, desenhada ou listrada. Misto de insígnia de poder e arma de defesa pessoal, é mais um daqueles objetos realizados por indígenas que desafiam as classificações modernas: sim, é um porrete, me dizem; ao mesmo tempo, sim, é benzido pelo rezador, muitas vezes.

Minha investigação sobre a razão para o uso desses desenhos - em geral, listras - renderia, por si só, uma curiosa discussão a respeito dos equívocos na comunicação com os Kaiowá. Quando eu inquiria vários de meus interlocutores sobre por que o yvyra (vara) é para (desenhada, ou listrada), por que tem listras, me respondiam: "É porque nós descascamos a vara e a passamos sobre o fogo, ou cada um decora como quiser".

Mal-entendidos à parte, algumas pessoas identificam, nesses motivos traçados sobre a madeira, os desenhos de animais como serpentes e, principalmente, o jaguar ${ }^{215}$. Considerando que, muitas vezes, essas varas estão presentes em situações de conflito (não só sendo usadas pelos policiais, mas também em retomadas de terras, manifestações políticas etc.), segundo alguns, ainda, por meio de rezas específicas, transfere-se a força do animal ao portador da vara.

Há, também, quem informe que miniaturas do yvyrapara podem ser usadas no pescoço -

215 Segundo o professor guarani Natanael Vilhalva, a vara, entre os Guarani, também pode ser decorada com o motivo de uma espiral ascendente, que remete aos movimentos que levam aves - e xamãs - ao céu, aos patamares superiores do cosmo. 
pelas crianças, sobretudo -, presas por um cordão, como uma espécie de amuleto. Neste caso, também, devem ser devidamente benzidas.

Mura (2010) joga luz sobre certos aspectos relativos aos chiru, varas e cruzes usados pelos Kaiowá aos quais se atribui agência ligada aos deuses ${ }^{216}$. Se, no caso dos chiru, a relação entre aprendiz e mestre (yvyra'ija e ñanderu, ou ñandesy) parece ser determinante para a transmissão da prerrogativa de portar esses objetos (e também para moldá-los), no caso do yvyrapara, há mais flexibilidade. No próximo capítulo, dedicaremos mais espaço à temática xamânica. Por ora, basta estabelecer esse contraste, a fim de explicitar que o yvyrapara é um objeto cuja confecção não indica a filiação a uma escola (xamânica), ou a uma família específica. Como boa parte dos objetos ligados à cosmologia kaiowá (a qual sublinha a importância de usar certos adornos corporais para reconhecido pelos deuses ${ }^{217}$ ), o que essa vara parece fazer é identificar a pessoa como uma autoridade, alguém que está em situação de confronto ou puxando um movimento.

Wilde (2003: 219), por sua vez, ao escrever sobre o diálogo entre indígenas e jesuítas no tempo das missões guarani, no que tange aos "símbolos de poder", coleta uma série de dados que mostram o uso de varas associadas à autoridade xamânica/política entre os grupos de língua guarani. Ele traça um paralelo com a utilização, pelos Mbya contemporâneos, dos popygua e yvyra'i. Indica, ainda, certos apontamentos de Hélène Clastres sobre os escritos de Cadogan, mas o campo semântico de um termo como yvyra'i é por demais amplo para que se possam tirar conclusões a esse respeito.

Müller, cuja pesquisa dá grande foco à cultura material dos diversos grupos guarani, encontrou varas chamadas de mburuvicha popygua entre falantes de mbya e ñandeva. Já quanto às yvyrapara, ele põe certa dúvida sobre seu caráter de "símbolo de soberania" ou autoridade, agregando que são usadas frequentemente pelos "soldados" que "executam as ordens do cacique" ou como varas para dança. Para ele, é "muito mais factível” que as varas em geral sejam uma "importação da época colonial espanhola": "las autoridades de las reducciones y municípios españoles llevaban como distintivo de su dignidad un palo - llamado vara - razón por la cual estas personas de respeto eran llamada “varistas"” (1986: 57).

216 Não vou discutir aqui certas orientações teóricas de Mura que, a meu ver, limitam as possibilidades de compreensão sobre o trato dos Kaiowá com os objetos, particularmente os chiru. Por exemplo, seguindo Turner, ele distingue "objetos" e "símbolos" (2010: 132); fala, quando muito, em "objetos/sujeitos". Acredito que a questão requeira mais esforço no sentido de desfazer esse tipo de dualismo ocidental. Machado e Pereira (2012) continuam, atualmente, essa investigação, desenvolvendo aspectos que, a nosso ver, apontam para a superação desses obstáculos ontológicos.

217 Vide, por exemplo, Chamorro 1995 e 2008. 
De qualquer modo, ao fim e ao cabo, o que procuro demonstrar é que, de alguma forma, a ação dos capitães e policiais indígenas dialoga com outros códigos kaiowá (objetos, atitudes, obrigações), indo bem além da mera imposição colonial. Complementarmente, acrescento: as associações evocadas pelo yvyrapara demonstram, mais uma vez, que os grupos de língua guarani não estão tão "desjaguarificados" como se possa imaginar. 


\section{Johexakáry}

“Dexando pues su tierra y própio assiento

la tierra adentro vino predicando,

no queda de indio algun repartimento,

que no siga su voz y crudo mando:

Con este ímpio pregón y mal descuento

la tierra se va toda levantando,

no acude ya al servicio que solia,

que libertad a todos prometia.

Mandoles que cantassen y baylassen,

de suerte que otra cosa no hazian",218

Martín Barco de Centenera (1602)

218 Versos sobre a rebelião liderada pelo xamã guarani Oberá, na região de Guarambaré, em 1579. Citados por Meliá (1993) e Chamorro (2008: 75). Esta última assim traduz o trecho: "Deixando pois sua terra e próprio assento/ ele veio nestes pagos propagando/ e já não restam índios nenhum lado/ que não sigam sua voz e seu comando/ Com sua pregação e seu conselho/ a terra se vai toda levantando,/ não acudindo já ao serviço que soia,/ pois liberdade ele a todos prometia/ Mandou-lhes que cantassem e dançassem/ de sorte que outra coisa não faziam”. 

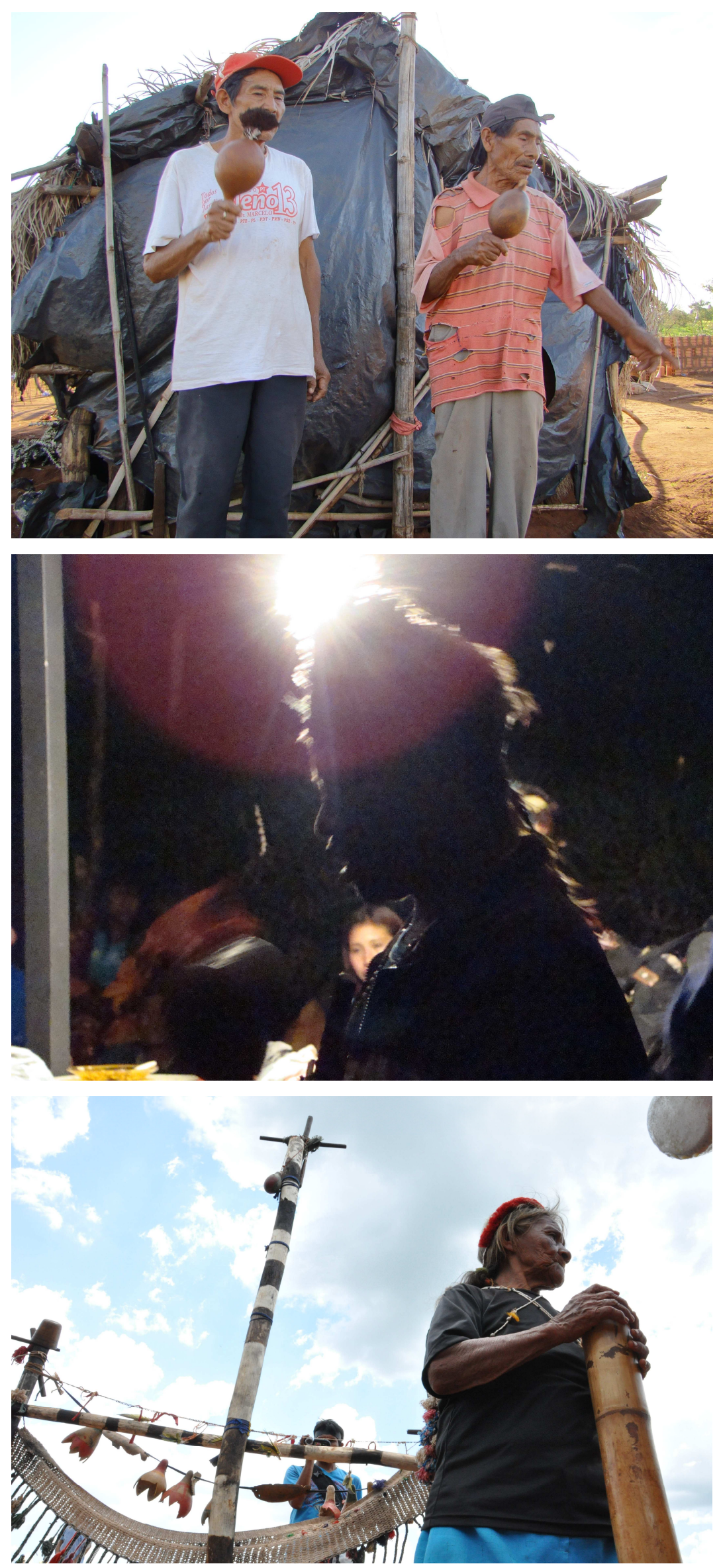

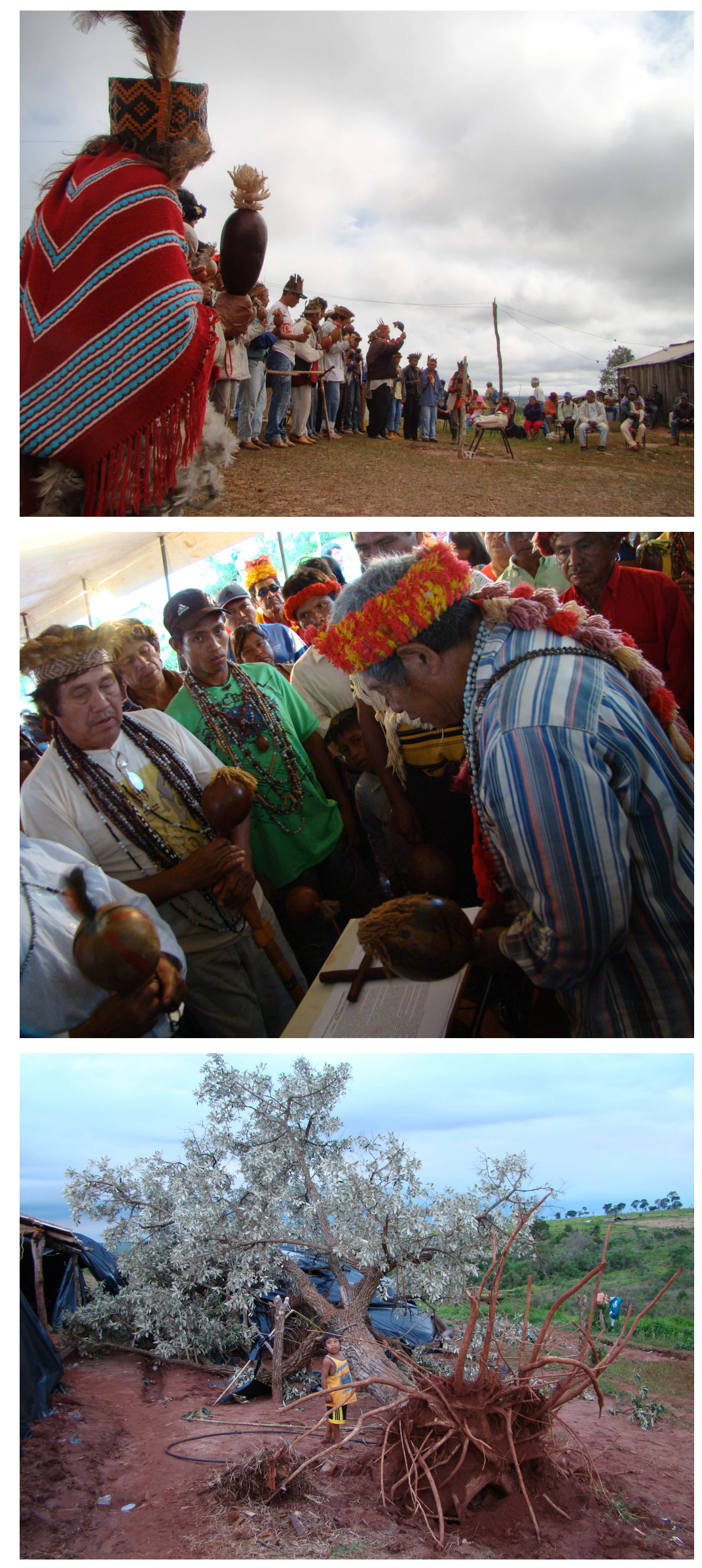

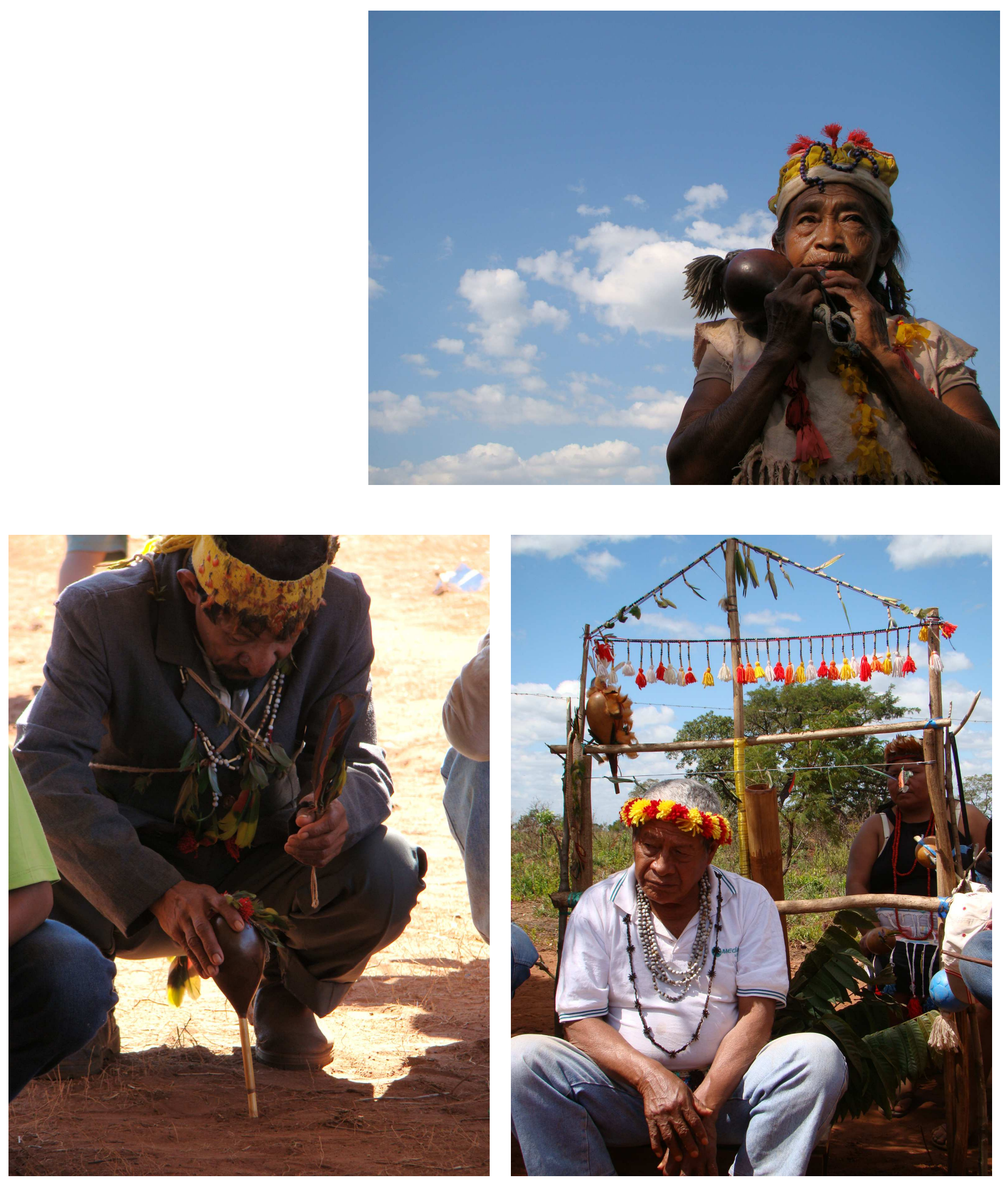

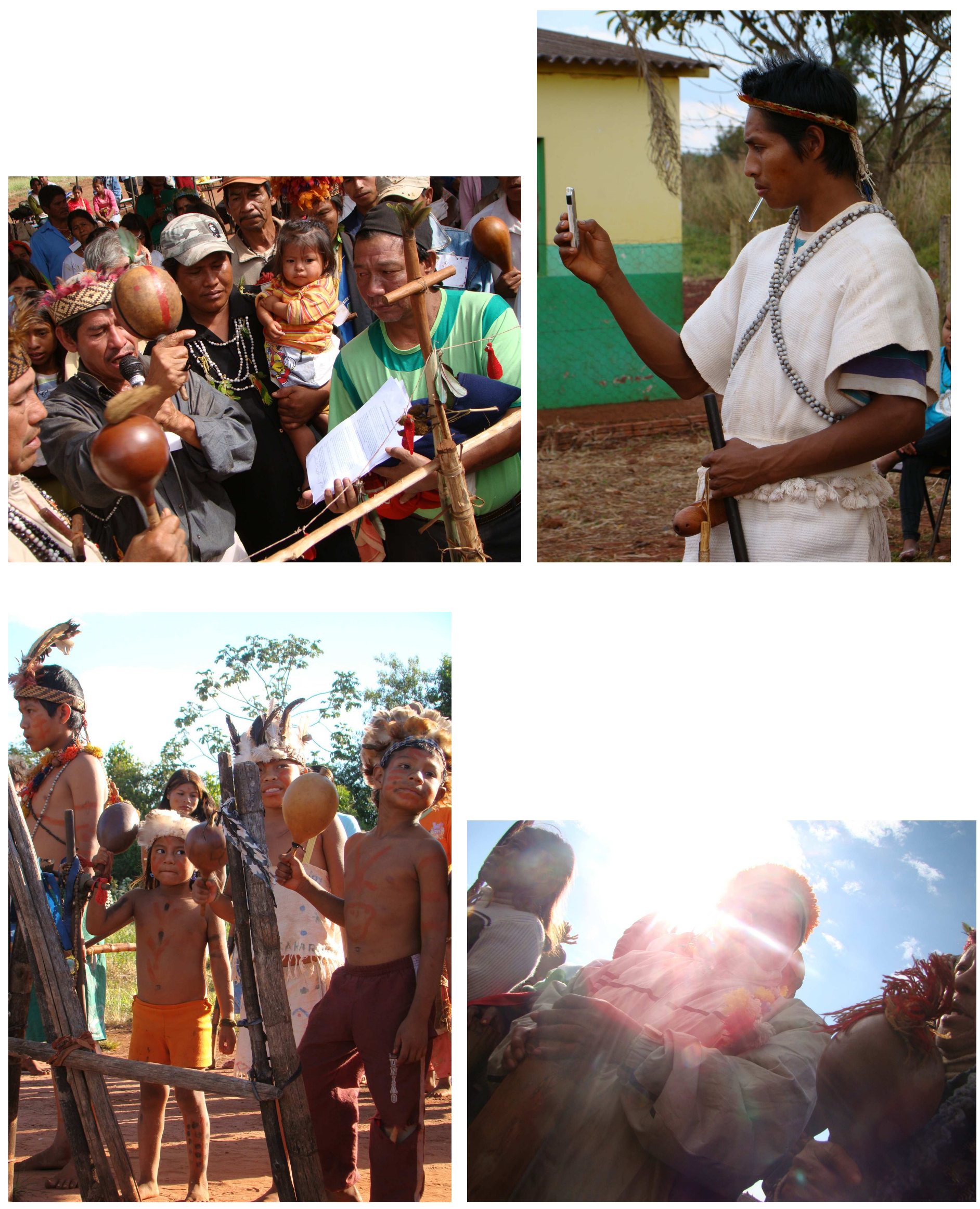

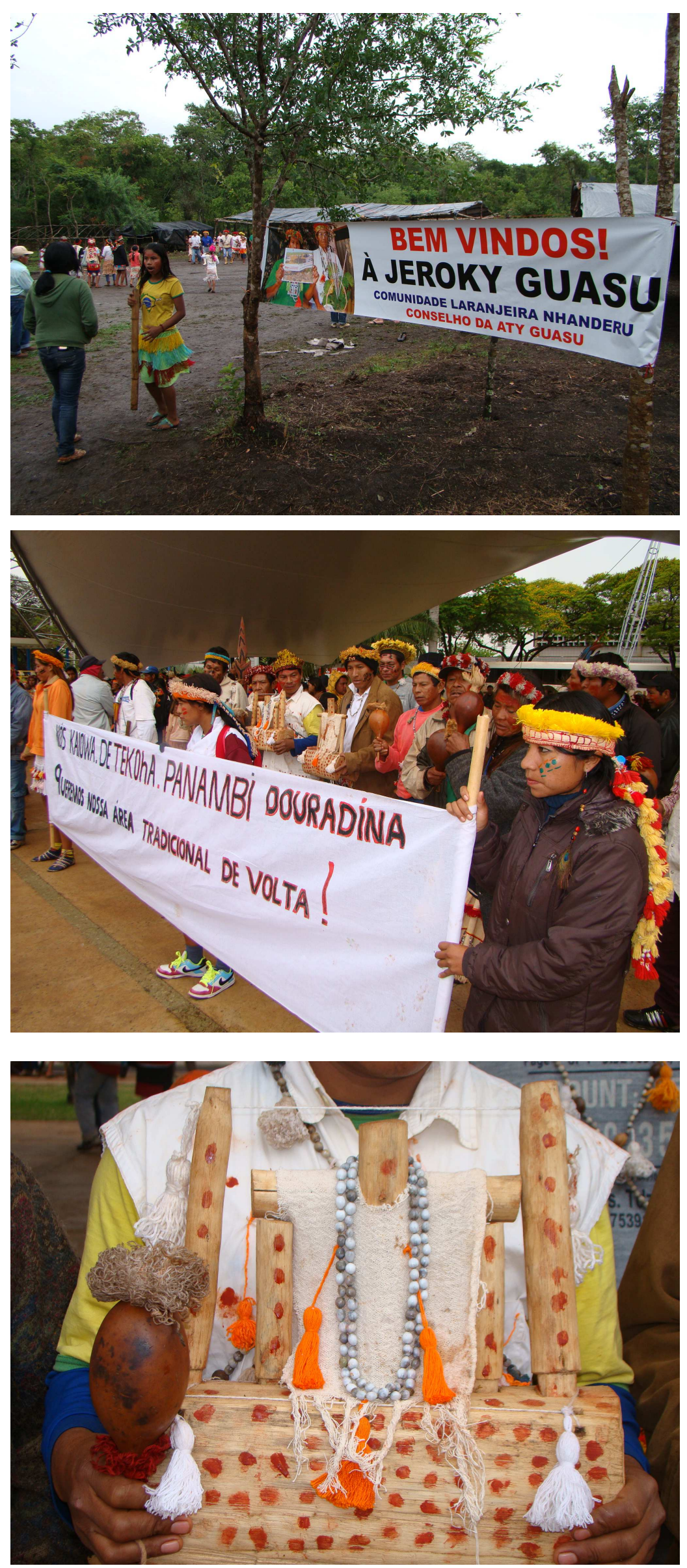
O segundo elemento para pensar uma teoria do movimento coletivo entre os Kaiowá está relacionado à figura do xamã. Chamado de muitos nomes, em função de suas várias habilidades e atributos, o ñanderu (nosso pai), oporaiva (cantor), cacique ou pajé, que pode, ainda, ser considerado um tekoaruvicha (o principal do tekoha), tem como protótipo ideal o johexakáry ${ }^{219}$, termo de uso raro que poderíamos glosar como "vidente". Dentre os atributos possíveis, esse, o da vidência, certamente é o que mais ajuda a entender o aspecto político do conhecimento xamânico ${ }^{220}$, entre os Kaiowá.

Como expusemos no capítulo anterior, a ação coletiva, quando expressa pela fila, demanda uma figura que encabece o movimento. Dentre os talentos de que essa figura de proa necessita, o conjunto de saberes normalmente tido como "xamânico" é o mais importante. O tendotá precisa deter, ao menos, um conjunto mínimo desses saberes, por assim dizer. Isso porque, como já mostramos, a sanidade geral do grupo local e de seu entorno determina, muitas vezes, o sucesso ou o fracasso de uma empreitada política, e são os saberes xamânicos, justamente, que podem influenciar nesse quadro, por meio das fórmulas verbais que curam, ou mantêm saudáveis pessoas, animais, plantas e o clima.

Conforme tem sido amplamente tematizado na etnologia das terras baixas sul-americanas, essa manutenção da sanidade geral tem relação direta com uma espécie de "guerra invisível" travada pelos xamãs (ver, por exemplo, Gallois, 2007; Fausto, 2002 etc.). Além de evitar e defender-se de ataques inimigos (de grupos humanos ou forças não humanas), é preciso também atacar os adversários - o que, no contexto atual que vivem os Kaiowá e Guarani, tem relação direta com a intensa troca de acusações por feitiçaria (ver Pimentel, 2006; Mura, 2006 etc.), mas também com o contexto de luta pela terra, como veremos. Em se tratando de um contexto multilocal tão complexo, podemos dizer que a guerra travada pelo xamanismo não é tão invisível assim, aliás ${ }^{221}$.

219 A grafia oscila consideravelmente entre as fontes. Chamorro (2008: 353) fala em ohechakára. Mura (2006: 313), em oheichakáry; João (2011), em johexakáry. Adotarei a grafia utilizada por este último, com a justificativa que apresentei na nota inicial para o uso do x em guaxiré.

220 Penso, aqui, em conhecimento xamânico da forma como as etnografias das terras baixas têm mostrado que esse saber não está, necessariamente, concentrado em figuras específicas, especialistas, e sim distribuído de forma mais ou menos democrática por todo o coletivo. Para uma discussão, nesses termos, quanto aos Kaiowá, ver Pimentel, 2006. Para uma breve explanação sobre essa forma de entender xamanismo, ver Langdon, 1996.

221 Nas etnografias recentes, os xamãs dos grupos guarani, em geral, aparecem como líderes religiosos, portadores de um discurso conciliatório e que privilegia valores relacionados ao amor, a paciência, a resignação. Fausto (2005) resume a tônica dessa descrição como um processo de "desjaguarificação". Mura (2006) já fez uma série de 
Caso não detenha esses saberes, é fundamental que ele esteja fortemente ligado a uma pessoa que os detenha. Nesse caso, é comum que sejam sua mãe, seu pai, sogra ou sogro, ou, ainda, irmão ou cunhado. Associar-se a um bom xamã amplia as chances de sucesso, e pode mesmo ser determinante. Quando vai expor seu grupo a situações de risco, como a ocupação de um tekoha reivindicado, o tendotá tem que planejar muito bem suas ações. Qualquer revés pode se converter numa crise que desarticula todo coletivo, dispersa-o, às vezes, definitivamente. Reagrupar os aliados pode demorar anos.

Se o ñanderu ou ñandesy tem os atributos de um johexakáry, isso quer dizer que ele ou ela é capaz de enxergar as coisas: sejam os deuses (os Tupanguéry ou Tekojára kuery), as ameaças sobrenaturais (ligadas a mortos, ou outros elementos perigosos), ou as coisas que acontecerão no futuro - por meio de sonhos ou visões.

O historiador kaiowá Izaque João, que realizou pesquisa focada no saber xamânico na região da bacia do Rio Brilhante, assim explica como se dá a formação do johexakáry:

"Para se tornar johexakáry, no sistema tradicional kaiowá, é preciso cantar muitos dias e meses, para eliminar totalmente a impureza do corpo. $O$ Kaiowá costuma se referir como nhande ryke'yrusu (nosso irmão maior) à divindade que o futuro johexakáry invoca com extremo desejo, por meio do canto, ao longo de seu aprendizado. Muitos xamãs, no meio de percurso do seu destino, desistem devido à grande responsabilidade que lhes caberá. Entretanto, como por acaso, em uma noite qualquer, ao atender seu pedido, nhande ryke'yrusu desce do seu reino e purifica a alma do indivíduo aprendiz, eliminando a impureza do seu corpo e retirando dos olhos uma espécie de pele transparente que o impede de visualizar o outro lado do mundo. E do interior do ouvido, após retirar uma minúscula pele, ele recoloca um pequeno objeto para o indivíduo ouvir e entender a linguagem da divindade com maior clareza, em tempo real.” (João, 2011: 70) ${ }^{222}$

ressalvas à generalização dessa imagem. Também já demonstramos alhures (Pimentel, 2006) como uma boa parte dos casos violentos ocorridos entre os Kaiowá e Guarani está relacionada a elementos do xamanismo, os feitiços desconsiderados por boa parte da produção clássica ao longo do século XX. Esse discurso que destaca o amor, a necessidade de união etc. corresponde a apenas uma parcela da incidência dos grandes xamãs nas ações coletivas. Ele, certamente, é o mais fácil de acessar, pois é, em geral, destacado diante dos karai - e ainda mais se considerarmos que boa parte dos etnólogos que trabalhou entre povos de língua guarani ao longo do século XX mantinha algum grau de envolvimento com instituições religiosas.

222 Outros autores já registraram o uso e sentidos do termo, como Brand (1997: 30), ou Mura (2006: 313). 
A existência atual de xamãs amplamente reconhecidos como johexakáry é duvidosa. Boa parte dos discursos parece situar esse grau de conhecimento somente no passado. Mas é fato que vários atributos relacionados ao título de vidente ainda se encontram em algumas pessoas vivas - se bem que sejam poucas.

O que é capaz de ver o johexakáry? Em primeiro lugar, está o campo em que o xamã mais comumente produz provas de sua eficiência ${ }^{223}$ : as curas. Em especial, sobressai aí uma capacidade muito presente em grande parte do que a antropologia registra, desde há muito tempo, sobre o xamanismo ameríndio ${ }^{224}$ : extrair os objetos causadores da doença de dentro do corpo do paciente e exibi-los ao doente e aos demais. "Rezador bom é aquele que 'mostra' a doença", resumem muitos dos Kaiowá e Guarani que conheci. A escassez de xamãs com essa habilidade, hoje, é o mais citado dos índices de que as coisas não vão bem pelo mundo.

Essa capacidade de "mostrar a doença" e de curar fundamenta, em boa parte, a credibilidade de um rezador - a qual está o tempo todo à prova. Um bom rezador é um rezador que produz resultados - constantemente. Quem falha rapidamente pode cair em descrédito. Creio que meus interlocutores divergem do que concluem autores como Barcelos Neto (2008: 274) e Viveiros de Castro (1986: 535). Ambos mencionam a beleza como uma espécie de critério maior para “avaliação da qualidade de um xamã”, mas descartam maior discussão sobre a questão da eficácia.

Não posso afirmar com certeza se essa diferença não estaria relacionada a uma (talvez) maior convivência dos Kaiowá e Guarani com a medicina ocidental e outras práticas, mas o fato é que há uma constante referência às realizações dos "bons" xamãs (prever o futuro, curar, "retirar" doenças dos corpos e até ressuscitar - feito máximo que permanece apenas na memória de alguns, mas que é localizado num passado recente, por volta dos anos 70. É certo que, aqui, também, a beleza é um critério, inclusive no sentido de que o belo e o alegre, por si, curam (e o que cura, por certo, é belo). Mas, algo que pareça belo/alegre e que não surta resultados também pode ser deixado de lado.

Além disso, como lembra Gallois (informação pessoal), há, digamos, círculos de credibilidade. A família é certamente o mais comum: realizar curas entre filhos, netos, sobrinhos é

Baseando-me em minha experiência de campo, creio que essa, de João, é a melhor definição disponível.

223 Evidentemente, não se trata de uma eficiência mensurável por critérios ocidentais ("quantitativos", "científicos"). Está mais ligada a uma espécie de fama do rezador, às histórias que se contam dele.

224 No fundamental artigo de Lévi-Strauss (1967c), percebe-se que a importância desse tema para o xamanismo da América do Norte já era registrada em etnografias do início do século XX. Renshaw (2006) opina, por sinal, que não houve muito avanço em certos pontos relacionados à chamada "eficácia simbólica". 
algo relativamente cotidiano. Os grandes xamãs são aqueles que transcendem o âmbito doméstico e local, tornando-se reputados em toda uma região. Parece-me que um rezador era considerado um tekoaruvicha quando chegava a construir um âmbito de prestígio ampliado ${ }^{225}$ - muito embora, em virtude da desarticulação das redes kaiowá em MS ao longo do século XX, isso seja, em geral, considerado algo pertencente ao passado.

O movimento Aty Guasu tem contribuído para criar certa fama regional para alguns xamãs, como é o caso do sr. Atanásio Teixeira, veterano das assembleias, a quem voltaremos adiante, mas, para além desse contexto, é difícil prever se essa configuração política relativa ao surgimento de um tekoaruvicha, tal como é descrito no passado, poderá se repetir um dia, porque o quadro político é muito distinto hoje.

Agentes de saúde, professores e outros profissionais, indígenas ou não, assumiram tarefas que antes se concentravam em torno do rezador, pulverizando esse prestígio que antes se concentrava em sua figura. É bem verdade que, em muitos casos, os tais novos profissionais são aliados desse rezador, por meio de laços familiares, mas, mesmo assim, parece evidente que as novas práticas de medicina e de educação, sobretudo, contribuem para minar sua autoridade ${ }^{226}$. Voltaremos a esse ponto mais adiante.

225 Não vou chegar, aqui, aos detalhes sobre a questão da transmissão de conhecimentos xamânicos, mas peço licença para assinalar, brevemente, a discordância com as conclusões que Mura (2010) tira, em sua rica explanação sobre os chiru kaiowá (varas e cruzes especiais, cuja posse requer uma série de cuidados e é transmitida ao aprendiz - yvyrayja - junto com o processo de aprendizado dos saberes xamânicos, por um mestre, ñanderu). Ao contrário do autor, não creio que essa relação possa ser comparada à que Barth (2000) descreve para os iniciadores melanésios e seus alunos (pois, segundo Mura, a musicalidade e a poesia da palavra seriam mais importantes que o conteúdo transmitido pela linguagem). Nem tampouco creio que os xamãs kaiowá pudessem ser gurus, a outra categoria sugerida por Barth (por que deveríamos nos prender a uma dicotomia alheia?) O que observo, entre os Kaiowá, é que há grande ênfase, no que tange ao aprendizado dos cantos xamânicos, em aspectos como timbre e tom de voz, além de ritmo e mesmo memória. Uma grande parte dos cantos, ali, tem de ser apreendida em todos esses aspectos ao mesmo tempo, o que requer um treinamento árduo, e conheço vários casos de pessoas que abandonaram seus estudos por considerar que não tinham o "dom" para aprender/memorizar. Concluindo: a relação entre xamã e aprendiz, entre os Kaiowá, forma verdadeiras escolas, linhagens mesmo de xamãs, e, pelo que mostra Montardo (2009: 51), os cantores reconhecem os diferentes estilos e os relacionam aos mestres. A existência dos chiru, a meu ver, só reforça essa relação marcada: há, sim, conhecimento (e artefatos) que têm de ser transmitidos. Uma análise do xamanismo entre os Guarani (falantes de ñandeva) só reforça essa imagem, pois há grande contraste nos modos de transmissão de conhecimento (e, para começar, os cantos guarani, em geral, não têm letra, consistem de vocalizações que podem ser inspiradas por sonhos - fenômeno que, entre os Kaiowá, parece ter bem menos peso no processo de formação do xamã).

226 Atualmente, há grande investimento do movimento político dos Kaiowá e Guarani em tentar aproximar esses novos profissionais dos rezadores, o que, de certa forma, contribui para combater seu desprestígio. Entretanto, o processo de desgaste é muito amplo, e ainda seriam necessários mais investimentos de programas públicos nesse âmbito (para reverter danos trazidos pelos próprios programas públicos - que desacreditam/desencorajam práticas como as das parteiras, por exemplo, muitas vezes ligadas a conhecimentos xamânicos e à manutenção do prestígio diante da família). Como tivemos oportunidade de verificar, os programas da área de cultura, por exemplo, ainda têm visão muito limitada sobre a natureza dos conhecimentos mantidos pelos rezadores. É preciso salvaguardar o sistema, não os elementos, dizia Manuela Carneiro da Cunha em recente conferência (no College de France, em 22/3/12 - disponível na internet). 
Além das curas, há a capacidade de prever o futuro, fundamental para se definir um johexakáry, parece-me. Certa vez, alguém me contava de um rezador que, em seu leito de morte, chamou todos os filhos e concedeu a cada um uma visão do que seriam suas vidas, tudo o que lhes iria passar dali em diante. Pois tudo o que ele previu se realizou, disseram-me.

Como essas capacidades se articulam com as ações coletivas atualmente? Em primeiro lugar, tudo aquilo que se está começando - seja uma plantação, uma casa, uma aldeia (ou a retomada de uma terra tradicional), uma criança - deve ser acompanhado de um canto que garanta seu sucesso. O canto dos xamãs kaiowá e guarani é uma convocação e um apelo às entidades de outros planos de existência para que permitam o sucesso das iniciativas humanas. Essas entidades não são visíveis à maioria das pessoas comuns, mas apenas aos que se preparam durante anos para vê-las, cuidando da alimentação e regrando de forma rigorosa vários hábitos pessoais ${ }^{227}$.

Entre os Kaiowá, sobretudo, os xamãs-cantores, ou rezadores - existe um enlace muito forte entre cantar e rezar, de tal forma que os dois verbos estão intrincados historicamente (porahei) transmitem seus cantos para aprendizes, chamados yvyraija, muitas vezes jovens da própria família do xamã que demonstram vocação para esse caminho e a aplicação necessária no difícil aprendizado, como comentado acima.

Os cantos, quando aplicados às pessoas, servem para realizar curas e prevenir doenças, para eliminar a raiva e o mau humor, para garantir a harmonia na família. A raiva - entre outros elementos do universo, como certos alimentos - é "quente", a calma é "fria". Por isso, diz-se que o canto serve para "esfriar" as coisas ${ }^{228}$. Também há fórmulas específicas para cuidar da lavoura, garantindo uma boa produção e prevenindo pragas. O clima é, igualmente, objeto de cuidados. Pode-se cantar para desviar uma tempestade, ou para atrair a chuva, no momento certo para a plantação. É frequente que, numa aldeia, as pessoas reconheçam "especialistas" - alguém que tem conhecimentos mais aprofundados sobre os cantos usados na lavoura, outro que conhece melhor as fórmulas que curam pessoas etc.

227 O tema é onipresente na bibliografia de todos os grupos de língua guarani, de Nimuendaju (1987) a Schaden (1974), de Clastres (1978) a Fausto (2005) etc.

228 Lolli (2010) descreve, entre os Yuhupdeh (do Rio Negro) uma série de benzimentos de cura e proteção em que se destaca a lógica do resfriamento como forma de cura. Oliveira (2012) também registra cantos que estabelecem essa mesma relação, entre os Wajãpi. 


\section{"Poder sem chefe"?}

Partindo da descrição que traçamos acima, que diálogo podemos tecer com as reflexões mais gerais que a etnologia ameríndia vem traçando a respeito da díade política/xamanismo? Para começar, lancemos um breve olhar sobre o conjunto de imagens que sustenta as mais recentes descrições sobre a relação entre xamanismo e política nas terras baixas da América do Sul.

Descola (1988), vale lembrar, realizara uma leitura de Clastres que influenciou decisivamente a etnologia ameríndia nos anos 90 e 2000: invertendo a ideia de "chefe sem poder" e afirmando mesmo que os Achuar entre os quais pesquisara eram simplesmente uma "sociedade sem chefes"229 -, propôs que se desse atenção ao "poder sem chefes" em que se constituía o xamanismo nas terras baixas da América do Sul.

Após certo refluxo dos estudos a respeito das chefias, chegam as reflexões mais recentes, em uma retomada do tema. Sztutman (2005), como já mencionamos, sublinha a relevância que têm adquirido, nas descrições etnográficas, as articulações entre política e xamanismo. Ele se guia pelo modelo de Deleuze \& Guattari (1996), como vimos, definindo a política como um jogo entre tendências de desterritorialização e reterritorialização, forças centrípetas e centrífugas que também podem ser pensadas como "vetores estatais" e "vetores nômades".

A essa imagem, Sztutman junta a discussão sobre a "verticalidade", "horizontalidade" ou "transversalidade" do xamanismo na Amazônia. Hugh-Jones (1994) propõe que se pode traçar, na região, uma distinção entre um xamanismo horizontal, mais democrático, baseado em conhecimentos amplamente acessíveis, e outro, vertical, associado à composição de liderança religiosa e política. Em muitos casos, lembra ele, ambos os tipos estão presentes numa mesma sociedade, inclusive (como nos casos Bororo, Tukano e Arawak).

Viveiros de Castro (2008) parte dessa distinção para construir uma série de relações entre a teoria clássica do sacrifício (Mauss \& Hubert, 2005), o estruturalismo levistraussiano, conceitos deleuze-guattarianos (devir, rizoma, transversalidade) e a etnologia amazônica. Propõe, então, que o "xamanismo horizontal" da Amazônia, conforme Hugh-Jones, seria melhor descrito como um "xamanismo transversal":

“As diferenças de potencial transformativo entre os seres são a razão de ser

229 Uma descrição sintética que explica essa visão do autor (e também ajuda a entender por que seu texto de 1988 ajudou a desviar a etnologia ameríndia em geral do tema da política) está em Descola, 2005. 
do xamanismo, mas nenhum ponto de vista contém nenhum outro de modo unilateral. Todo ponto de vista é 'total', e nenhum ponto de vista é equivalente a nenhum outro: o xamanismo horizontal não é, portanto, 'horizontal', mas transversal. A relação entre pontos de vista (a relação que é o ponto de vista enquanto multiplicidade) é de síntese disjuntiva ou exclusão imanente, não de inclusão transcendente" (Viveiros de Castro, 2008: 102).

Como aponta Sztutman, por meio desses trabalhos de Hugh-Jones e Viveiros de Castro, é possível aprimorar a compreensão do xamanismo "senão como um fenômeno propriamente político, como algo que opera de modo fundamental na ação política" (2005: 37). Sztutman agrega, essa ação se dá em favor da "pulverização", mas também da "constituição de unidades"230.

Tal associação do xamanismo tanto aos "vetores nômades", como aos "vetores estatais" avança em relação a hipóteses anteriores, sobretudo a de H. Clastres (1978) e P. Clastres (2003), que, baseando-se na projeção dos dados sobre migrações guarani aos Tupinambá pré-cabralinos, sugeriam duas hipóteses, entre o "paradoxo" e a "contradição", como define Sztutman (2005: 46). Aquele vê, no momento da Conquista, em que estaria havendo, entre os Tupi, uma explosão demográfica e uma intensificação das guerras entre as aldeias, uma oposição entre o profetismo tupi e o cenário de emergência de um “proto-Estado", relacionado à ação dos grandes guerreiros ${ }^{231}$. Já para esta, o surgimento de figuras capazes de reunir, em si, o religioso e o político, grandes profetas capazes de arrastar multidões, se daria em função do cenário de calamidade provocado pela irrupção dos europeus.

Tratar-se-ia, segundo a autora, de uma “expressão de desespero", uma "resposta de oprimidos" a uma "situação de exceção", comparável às Ghost-Dances ${ }^{232}$ da América do Norte,

230 Essa ação, diz Sztutman, dá-se na direção tanto de uma "pulverização", como da "constituição de unidades flexíveis, variáveis quanto à sua estabilidade". Faria uma ressalva quanto ao uso do termo unidade, pois, uma vez que apostamos nas ideias de rede e rizoma, estamos diante de movimentos que não implicam formação de unidades, e sim, de "sistemas de n -1 dimensões" (Viveiros de Castro, 2007: 99), ou seja, multiplicidades, em que "o Um opera apenas como aquilo que deve ser retirado para produzir o múltiplo, que é então criado por 'destranscendência"'. Citando Deleuze, o autor conclui: não há "nenhuma necessidade da unidade para formar um sistema" (idem).

231 Ainda que, como anota Sztutman (2005: 44-6), reconhecessem, dadas as grandes multidões que os profetas atraíam, o "germe", aí, de um "discurso de poder", e "sob os traços do condutor de homens que diz o desejo dos homens", "talvez a figura silenciosa do Déspota" (P. Clastres, 2003: 233-4). Vamos discutir essas imagens logo adiante.

232 O relato canônico sobre o fenômeno, extraído da Wikipedia: as ghost dances se disseminaram por diversos povos indígenas da América do Norte na virada do século XIX para o XX, prometendo prosperidade, paz e o fim da invasão dos brancos. Estavam relacionadas a profetas como um Paiute do Norte chamado Wovoka, ou Jack Wilson. 
entre outros fenômenos (H. Clastres, 1978: 55). Em suma, a "divergência” (não uma confrontação, mas um afastamento relativo) entre Pierre e Hélène tem a ver com uma questão histórica: se o profetismo tupi era uma reação à chegada dos brancos, ou à emergência de grandes chefes. Sztutman, como se viu, envereda por uma explicação estrutural - vetores nômades x vetores estatais.

De qualquer modo, aparece, ao longo desse debate, outra questão, esta mais urgente para o que aqui abordaremos: qual a relação que está posta, nos Tupi e Guarani, entre as figuras do chefe e do profeta? Hélène Clastres vê uma incompatibilidade: uma vez que um profeta se torna líder político, perde a possibilidade de "livre trânsito" entre as aldeias (característica notável dos profetas karai), dado seu papel de articulador das guerras e alianças, justamente. Nas palavras de Sztutman:

\begin{abstract}
"A imagem oferecida pela autora do sistema dos Tupi e Guarani antigos é a da separação entre dois 'poderes' de natureza diversa: o político e o religioso. E essa separação atua justamente no sentido de impedir a emergência de um poder efetivo e separado, o poder político propriamente dito, poder de coerção, de mando e obediência. Nesse sentido, ela não se distancia de Pierre Clastres, no que toca ao seu projeto de antropologia política: os indígenas conhecem os perigos do Estado, por isso mesmo cuidam evitar o seu aparecimento. E eles o fazem, garante ela, não permitindo a condensação de papéis [de chefe e profeta]" (Sztutman, 2005:
\end{abstract}

O fato é que, para tirar conclusões como essas, H. Clastres (1978) tece algumas hipóteses: por exemplo, que o chefe "ocupa sempre uma posição precisa no tempo e no espaço" e "não pode estar alheio à comunidade, cuja administração é responsabilidade sua, tampouco à sua rede de parentesco" (apud Sztutman, 2005: 47). Hélène Clastre constrói, ainda, outras dicotomias (religião nômade x religiões do Estado, profetismo x messianismo) para reforçar essa oposição entre política e religião ${ }^{233}$.

A leitura que Sztutman faz disso tudo, no final, propõe, à luz dos avanços teóricos das últimas décadas (Viveiros de Castro, Strathern, Wagner etc.), em lugar de oposições, a existência de

233 Tais dicotomias nos levam de volta à discussão sobre as motivações das expedições de grupos guarani até as fronteiras incas, que, como exposto no capítulo 1, não se deixam reduzir a explicações utilitaristas nem tampouco se encaixam na oposição religião x política. 
relações de "co-extensão", ou "entrelaçamento" entre essas diversas figuras (chefe, guerreiro, profeta):

“O profetismo tupi seria (...) a radicalização da guerra, e o profeta, a radicalização do guerreiro. (...) Os profetas e os guerreiros selvagens, figuras do exterior e do movimento, ao assumirem funções políticas, fazemse figuras-limite da 'sociedade primitiva'. (...) Entre o devir puro da religião profética e a política pura do aparelho de Estado e do motor colonial revela-se um espaço para matizes e cristalizações que, longe de apontarem uma ressonância capaz de instaurar um poder político substantivo, indicam um processo dinâmico e povoado por vetores de reversibilidade." (2009: 156-7).

$* * *$

Entre os textos de Descola (1988) e Sztutman (2005), como se nota, há uma inflexão decisiva e que, certamente, tem a ver com a diluição de dicotomias relacionadas à oposição moderna entre política e religião, ao longo de uma década e meia de intensa pesquisa etnológica na Amazônia. O fato é que, ainda que alguém se dispusesse a seguir ao pé da letra o projeto de Descola, dificilmente se esquivaria de perceber as intensas relações entre xamanismo e política na região.

É dessa forma que, creio, passa a fazer sentido, e a ser cada vez mais intensamente reverberado nas etnografias o último elemento a destacar nesse quadro teórico recente, que é a ideia de cosmopolítica. Termo emprestado, por Bruno Latour (2001, 2004), da filósofa Isabelle Stengers (1996), é assim definido por aquele:

“COSMOPOLÍTICA: Antigo termo dos estoicos para exprimir a filiação à humanidade em geral e não a uma cidade em particular. $O$ conceito adquiriu significado mais profundo com Isabelle Stengers: a nova política, não mais enquadrada no acordo* modernista da natureza* e da sociedade*. Hoje existem diferentes políticas e diferentes cosmos" (Latour, 2001: 347).

No contexto da etnologia ameríndia feita no Brasil, as idéias de Latour e Stengers têm tido grande impacto, principalmente por intermédio da obra de Viveiros de Castro (vide sua coletânea de 2002) e sua noção de multinaturalismo, diretamente decorrente da ideia de cosmopolítica. Em suas 
próprias palavras:

"La etnografía de la América indígena está poblada de referencias a una teoría cosmopolítica que describe un universo habitado por distintos tipos de actuantes o de agentes subjetivos, humanos y no humanos - los dioses, los animales, los muertos, las plantas, los fenómenos meteorológicos, con mucha frecuencia también los objetos y los artefactos -, dotados todos de un mismo conjunto general de disposiciones perceptivas, apetitivas y cognitivas, o dicho de otro modo, de 'almas' semejantes." (Viveiros de Castro, 2010: 34-5)

As decorrências apontadas por Latour são, ainda, fonte de inspiração para o "dossiê" (Viveiros de Castro, 2009: 118) que Sztutman organiza em torno do binômio profetismo/política na Amazônia.

"Lendo esses autores [Latour, Descola, Viveiros de Castro], sempre à luz. das etnografias mais ou menos recentes sobre os povos ameríndios, o problema que me ocorreu era: como (re)pensar a antropologia política tendo em vista essa noção de cosmopolítica, na qual se integram aos coletivos humanos agentes não-humanos? Como, ademais, voltar ao problema da chefia e da guerra ameríndia, ambos temas largamente meditados por Clastres, considerando o xamanismo (e, vale ressaltar, o ritual num sentido mais amplo) e seus corolários?” (Sztutman, 2005: 24)

O diálogo com a noção de cosmopolítica não se restringe aos autores brasileiros e vem se generalizando. Nem sempre, é verdade, está a serviço de algum debate novo, e é preciso atentar que, de algum modo, toda política tem seu aspecto "cósmico", mesmo quando o nega, como no caso moderno $^{234}$. Assim, vale a pena que nos questionemos sobre que projetos vêm orientando a utilização do conceito. Uma tendência mais consistente, até onde observamos, é a que se comenta a seguir.

"Não é possível pôr a cultura na política sem pôr o político na cultura", aponta Viveiros de

234 E aí, para (muito) além de Latour, há, por exemplo, Weber, que já dissertava sobre a relação entre o protestantismo e o capitalismo (1967 [1920]). 
Castro (1999: 198-200), ao expor sua visão sobre a relação entre Antropologia e Política ${ }^{235}$. O autor lembra que a diferenciação objetiva, a distintividade de um grupo indígena (qualquer grupo ${ }^{236}$ ) é operada culturalmente, isto é, politicamente. Ao mesmo tempo, continua, a Antropologia encara o desafio de desnaturalizar e politizar a natureza ${ }^{237}$ - do ponto de vista do autor, um projeto mais “interessante", atualmente, que o de "naturalizar a política".

De fato, em estreita sintonia com esse comentário de Viveiros de Castro, poucos anos depois, Latour proporia o neologismo dingpolitik, como contraponto à conhecida noção de realpolitik, de origem alemã. O texto do autor é repleto de jogos de palavras, a partir dos quais ele propõe pensar, como a ideia de que é preciso mudar o rumo, ou "virar as coisas" (turn 'things' around) e que nos tornemos mais "realistas" (Latour, 2005: 4). No achado feliz de Latour, dingpolitik seria, imediatamente, algo como 'política das coisas', mas ding, ele lembra (idem: 12-3), está relacionado, em várias línguas europeias, a termos que evocam tanto um ser inanimado como uma assembleia, ou os assuntos ali discutidos ${ }^{238}$.

Diante do "irrealismo" que tomou conta da (ir)realpolitik atual ${ }^{239}$ (com sua extrema dificuldade para tomar decisões sérias em relação a temas como as mudanças climáticas), os movimentos indígenas têm ganhado cada vez mais destaque. De La Cadena (2010) explicita como as ações levadas a cabo nos últimos anos pelos movimentos indígenas andinos estão repletas de atores (e agências - humanas e não humanas) e de reivindicações intimamente relacionados a uma "politização da natureza" como a que vem sendo sugerida pelos estudos de autores como Viveiros de Castro e Descola.

235 A qual, por si só, dá margem para toda uma discussão, pois pode ser tomada de muitas formas. Vide uma amostra em Goldman, 2006; Goldman \& Palmeira, 1996.

236 A argumentação se insere no propósito do autor de refutar a categoria de "etnogênese", aplicada por autores como Oliveira (1998b: 53) aos grupos indígenas do Nordeste. Para Viveiros de Castro, o que está em jogo é um devir-indígena, e, nesse sentido, todos os grupos indígenas (em qualquer contexto) estão "virando índios exatamente do mesmo jeito" (1999: 194). Uma apresentação da forma como o autor entende a ideia deleuziana de devir está em Viveiros de Castro, 2008: 103-5.

237 Esse projeto começa com Latour (1994), inspirado, entre outros elementos, por uma leitura de Descola (1986) e é encampado por Lima (1996, 1999) e Viveiros de Castro (2002 - particularmente, para um detalhamento, ver nota à p. 346-7), entre outros.

${ }^{238}$ Latour pergunta, a certa altura: “ Não terá chegado o tempo de trazer a res de volta à res publica?” (2005: 13).

239 Escrevo essa frase um dia depois do Dia Mundial do Meio Ambiente (05/6/2012), quando a presidente Dilma Roussef criticou, em cerimônia, o "egoísmo burro" dos que defendem o desenvolvimento econômico sem se preocupar com a preservação ambiental. A Câmara Federal se organiza para boicotar os recentes vetos da presidente às mudanças no Código Florestal - vetos que impediriam uma anistia generalizada a proprietários rurais que desmataram áreas sensíveis, como a beira de rios, nos últimos anos. A fala de Dilma está em destaque nas capas de jornais. Ao mesmo tempo, por uma pequena nota no Valor Econômico, fico sabendo, também, que a presidente se reuniu com representantes de uma grande multinacional de alumínio para garantir-lhes que reduzirá os custos da energia elétrica usada por eles, garantindo a permanência de duas unidades da empresa no Brasil (!). No mesmo jornal, leio que o Chile terá de ampliar em 50\% sua produção de energia nos próximos anos, para garantir "dezenas de novos projetos de mineração". 
Ao mesmo tempo, a autora também mostra como os atores políticos que confrontam, muitas vezes, esses movimentos estão movidos por interesses que questionam, exatamente, essa politização:
“As 'coisas' que os movimentos indígenas estão atualmente 'fazendo públicas' (cf. Latour 2005) na política não são simplesmente não humanos, são também entidades sensientes cuja existência material - e a dos mundos aos quais elas pertencem - está atualmente ameaçada pelo casamento neoliberal entre o capital e o estado" (De La Cadena, 2010: 342).

A autora reconhece que vários estudos recentes sobre coletivos ameríndios têm discutido a participação desses outros seres (que, no contexto analisado pela autora seriam conhecidos como tirakuna - seres-terra ou earth-beings, como ela traduz) na política em nível local. Porém, aponta a carência de pesquisas que considerem o papel desses atores em nível nacional, mostrando como essas diferentes ontologias podem despedaçar o campo conceitual da política:
“Os seres 'que não são humanos' aparecem no registro etnográfico como 'cultura indígena', não como potenciais divergências a surgir no campo que Mario Blaser (2009) chama de ontologia política” (idem: nota 11)

Em suma, quando se analisa o quadro das lutas atuais dos povos indígenas na região, não há como deixar de perceber uma confrontação que recai exatamente sobre a chamada "natureza" - e as considerações de De La Cadena são bastante oportunas quando percebemos que, em países como Bolívia e Equador, os atores coletivos ameríndios têm, efetivamente, dado o tom do debate político nacional.

De qualquer modo, é fato que, com a retomada do crescimento econômico do continente na última década, em função, sobretudo da demanda asiática por produtos primários (alimentos, metais - e, indiretamente, água, terra, madeira), bem como a commoditização do comércio desses itens (que contribuiu para inflar artificialmente seus preços), a disputa por territórios indígenas e seus recursos naturais (forma como muitos dos Ocidentais pensamos o que podem ser pessoas, ou mesmo coletivos de pessoas, aos olhos indígenas, como florestas, rios e montanhas ${ }^{240}$ ) se

\footnotetext{
240 Por exemplo, uma área sagrada de montanhas para os Wirrárika, como Wirikuta, é vista pelas empresas mineradoras como uma jazida de minérios. Para um panorama da visão indígena mesoamericana sobre as montanhas, ver Broda et al., 2001.
} 
intensificou de forma generalizada ${ }^{241}$ por toda a América Latina.

A crítica à nossa "irrealpolitik" ambiental também é feita pelos movimentos indígenas no Brasil, há vários anos - muito embora nem sempre tenham sido "levadas a sério" (ou seja, "literalmente, e não metaforicamente", como sugere De La Cadena - 2010: 361) as observações das lideranças indígenas a respeito de suas relações com essas "entidades sensientes"242. Num dos registros mais notáveis, dentre os disponíveis na literatura antropológica, estão as reflexões que Albert colheu, ao longo dos anos, com o líder e xamã yanomami Davi Kopenawa. A violência dos brancos, diz Davi a Albert, está ligada a uma ignorância, a uma "escuridão confusa" de um pensamento "plantado nas mercadorias" (Albert, 2000: 248).

Como se verá adiante, as entrevistas que realizamos para o vídeo "Mbaraká - A Palavra que Age" 243 estão repletas de considerações a respeito da ação de seres relacionados à terra, as águas e os fenômenos meteorológicos. Os Kaiowá e Guarani que sustentam as práticas xamânicas ${ }^{244}$ consideram, em primeiro lugar, que as atitudes dos karai - o desmatamento generalizado em MS, a irresponsabilidade com relação aos rios e as terras - são extremamente perniciosas para a saúde e o equilíbrio do cosmo. Além disso, é a própria manutenção das práticas xamânicas, segundo eles, que pode dar alguma chance à própria sobrevivência dos próprios karai, tendo em vista que as

241 O autor acompanha os debates em torno do tema há vários anos, por meio, sobretudo de reportagens jornalísticas e entrevistas realizadas não só no Brasil, mas também em países como México, Bolívia e Venezuela, com foco sobre os movimentos indígenas. Ver, , por exemplo, Pimentel, 2008.

242 Sintomaticamente, o movimento indígena no Brasil, em geral, tem como principais aliados, no meio urbano, os chamados "ambientalistas", e pouco apoio de movimentos camponeses - ao contrário do que acontece no restante da América Latina.

243 As entrevistas aqui citadas foram realizadas em abril de 2010, no âmbito das gravações do documentário "Mbaraká - A Palavra que Age", cujo projeto, de minha autoria (e relacionado à pesquisa que embasa esta tese), foi vencedor do prêmio Etnodoc 2009, edital do Instituto do Patrimônio Histórico e Artístico Nacional (Iphan), em parceria com a Petrobrás. O vídeo, lançado em 2011, foi realizado em parceria com Edgar Teodoro da Cunha (direção) e Gianni Puzzo (fotografia). As entrevistas foram conduzidas por mim e, para a tradução, contamos com ajuda dos seguintes professores guarani/kaiowá: Eliel Benites, Clara Barbosa de Almeida, Devanildo Ramires, Elivelton de Souza e Cajetano Vera, além dos professores não indígenas Elizeu R. Cristaldo e Ana Paula A. G. Leite. As legendas do vídeo contaram ainda com a revisão de Muller Teju Orue, e da professora Graciela Chamorro (UFGD).

244 Há um contingente considerável de Kaiowá e Guarani que se aproximou das igrejas evangélicas nas últimas décadas. Só na reserva de Dourados, há cerca de 60 delas, muitas dirigidas por pastores indígenas. A conversão, é bom lembrar, não tem caráter irreversível (há muita gente que frequenta uma igreja por um período, depois se afasta) nem tampouco necessariamente exclusivo, ao contrário do que percebe o senso comum. Há pessoas que frequentam certas igrejas (elas variam em grau de tolerância), mas também se valem de práticas xamânicas. Vale, aqui, a leitura do ensaio de Viveiros de Castro sobre a conversão dos Tupi (2002: 181-264) - além de outros casos, como os Wari (Villaça, 2008) ou os Guarani do litoral (Pierri, 2012). Por outro lado, não se pode ignorar que há uma série de atos graves de intolerância religiosa, como agressões contra rezadores, queima de residências etc. As manifestações de indignação quanto a esses ataques são frequentes nas Aty Guasu. É interessante observar, como no relato de Benites (2009), que as missões protestantes estiveram intimamente relacionadas ao projeto de confinamento dos Kaiowá e Guarani, com promessas de prestação de serviços de saúde e educação, caso as famílias concordassem em ir morar junto a elas, deixando as terras que ocupavam (em áreas já ocupadas, ou em vias de ocupação por colonos brancos). 
consequências nefastas de nosso descuido (somos como elefantes numa loja de cristais, nessa visão) já são visíveis por todos os $\operatorname{lados}^{245}$.

\section{Discurso e profecia}

Tudo isso posto, o caso guarani/kaiowá nos oferece uma importante oportunidade de observar, em operação, toda essa maquinaria de guerra que envolve política, saberes xamânicos e profetismo aliados na luta pela terra em MS - e num contexto em que dezenas de grupos locais se aliam em torno do movimento Aty Guasu, o que confere uma escala rara, atualmente, nas terras baixas sul-americanas.

Vejamos como é tênue a barreira entre profecia e política, no plano do discurso. Todo o movimento kaiowá e guarani em MS está construído sobre alguns supostos em torno do sentido de voltar a viver em ao menos parte das terras que correspondem ao que a Constituição de 1988 denomina de "tradicionalmente ocupadas". É comum que fazendeiros e políticos questionem a insistência em recuperar essas terras, considerando-se que boa parte delas encontra-se imprestável, hoje, para a prática de atividades consideradas "tradicionais" pelo senso comum dos karai, como caça, pesca e coleta ${ }^{246}$.

O que fundamenta a certeza dos coletivos guarani/kaiowá de que a volta aos chamados tekoha será ambiental e economicamente viável é, entre outras coisas, o discurso profético dos $\tilde{n} a n d e r u$ e $\tilde{n} a n d e s y^{247}$. Um exemplo está na entrevista que fizemos com o sr. Atanásio Teixeira (também conhecido como Ataná), um dos mais conhecidos ñanderu de MS, hoje.

\footnotetext{
245 Note-se o paralelo com outros registros recentes de discursos de xamãs ameríndios, como é o caso dos escritos em que Bruce Albert traduz e interpreta as falas do yanomami Davi Kopenawa (ver Albert, 2002; Kopenawa e Albert, 2010).

246 No debate público sul-mato-grossense, é comum que se atribua aos Guarani e Kaiowá os rótulos evidentemente discutíveis e cada vez mais discutidos no âmbito da antropologia e da arqueologia - de nômades ou seminômades, caçadores-coletores, não praticantes de agricultura etc., como forma de negar-lhes o reconhecimento ao direito à terra. Para uma análise sobre as territorialidades indígenas, ver Gallois (2004).

247 E aqui, sublinho, há uma clara distinção em relação à visão clássica sobre os Guarani, a partir da descrição de Nimuendaju (1987), como um povo "melancólico", ou "pessimista" - por sinal, caracterização com certa atualidade, como se nota em Pierri (2012). "Trata-se de um mundo completamente desgastado pela colonização europeia, cujo fim é tido como certo por todos", descreve o autor, sobre os Guarani do litoral paulista, agregando ainda que se trata de um "contexto de degradação que os Guarani sabem não poderem reverter completamente". Quanto aos Kaiowá e Guarani de MS, note-se, esse discurso sobre a plena possibilidade de recuperação ambiental sustenta a luta pela terra. Por sinal, dizia o rezador Atanásio a Mura, em entrevista gravada em 2000 (2006: 249): “Os crentes anunciam que vai acabar o mundo, mas é mentira; às vezes alguns ñanderu também falam a mesma coisa, mas não é verdade. O único que sabe é Pa'i Kuara” (o Sol).
} 
Atanásio, desde os anos 80, é um dos pilares do movimento pela recuperação das terras kaiowá e guarani. Seu prestígio tem características especiais: ao que parece, ele foi construído, em grande parte, no âmbito do próprio movimento Aty Guasu. São muitas as histórias a respeito de sua atuação em ocupações de terra, ao longo dos anos 80 e 90, executando cantos que garantiram a segurança de todos, evitaram a violência dos brancos, modificaram condições climáticas (favorecendo a organização de eventos) etc. Diz-se, ainda, que ele criou vários cantos utilizados no âmbito das Aty Guasu e introduziu inovações como o batismo dos documentos finais dos eventos ${ }^{248}$ - numa transformação extremamente original do jehovasa/ñemongarai ${ }^{249}$. Ele também formou vários yvyraija - auxiliares - que estão espalhados pelas terras indígenas da região.

Além disso, é um dos poucos conhecedores dos cantos a serem realizados durante festas e cerimônias hoje rasíssimas na região, em função da miséria e da degradação ambiental. Na interpretação xamânica do processo de colonização, os bichos que antes eram tão abundantes nas matas foram escondidos pelos seus donos - os jara, seres responsáveis por cuidar das espécies animais, vegetais, ou dos lugares, comuns em diversas tradições indígenas de conhecimento.

\begin{abstract}
"Esta mata grande sempre foi nossa, este lugar sempre foi nosso. Eles (os brancos) derrubaram todas as matas, só pra depois chamar de Mato Grosso do Sul. Então eles esconderam de nós os nossos remédios, nossas carnes, nossa caça, que era o tatu, a cutia, a anta, o lagarto: esses animais eram todos nossos. Eles esparramaram todos de nós, os donos dos animais ergueram (para o céu) todos. Então os alimentos hoje são fabricados na máquina."
\end{abstract}

O que vem da máquina tem que ser comprado com o dinheiro, e é essa a causa primordial da desgraça dos Kaiowá e Guarani, Atanásio reconhece. Por isso, é necessário recuperar a terra, para que se possa usufruir novamente da comida concedida pelos Tupanguéry, por Pa'i Kuara, o Sol, todos os seres com os quais o xamã negocia para garantir o bem-estar de seu povo, garantindo a boa colheita e a sanidade completa de todos os bichos, plantas e crianças que estão na comunidade.

\footnotetext{
248 As histórias são narradas por inúmeras pessoas. Particularmente, menciono os "causos" contados por Levi Marques Pereira e Tonico Benites, antropólogos que acompanham há bem mais tempo que eu o movimento Aty Guasu. Um detalhado relato pessoal (colhido por Fábio Mura e traduzido por Tonico Benites) de Atanásio, em que conta sobre sua formação pessoal como xamã de maneira muito bonita está em Mura, 2006.

249 Ambos os termos são traduzidos, correntemente, por "batizar", ou "abençoar". No caso do jehovasa, é uma espécie de passe, ou benzimento, aplicado em vários contextos, a pessoas, comidas etc. O ñemongarai, ou nimongarai, por sua vez, é termo, sobretudo, relacionado à cerimônia de nominação das crianças, mas, por vezes, utilizado genericamente. Para uma análise geral dos termos usados na cosmologia, incluindo-se seu emprego contemporâneo na linguagem corrente entre os Kaiowá e Guarani, ver Chamorro, 2008.
} 
"Porque nós não temos dinheiro, nós apenas ficamos olhando à toa as coisas (mercadorias). Então, pra gente não passar necessidade, queremos a nossa terra, para poder plantar, para não se preocupar com as coisas dos outros. Nós queremos o que é nosso, nós vamos nos juntar e produzir nossa comida, para nossa carne vamos criar bichos. Por isso é que nós lutamos para conseguir a nossa terra.”

A expectativa pela recuperação das terras é grande. Atanásio é um lutador incansável. Já colaborou em várias fases do movimento, residiu em uma infinidade de lugares, sempre cantando para ajudar na luta. Ultimamente, as coisas andam difíceis. Em dezembro de 2009, junto a um grupo de mais de 50 pessoas, ele, que já tem mais de 70 anos, foi espancado, ameaçado com armas de fogo, vendado e jogado à beira da estrada na desocupação extrajudicial do tekoha conhecido como Mbaraka'y, em Tacuru (MS), promovido por um grupo de pistoleiros a mando de fazendeiros da região. Nem assim ele perde a esperança, e suas falas adquirem tom profético, quando fala sobre como será boa a vida, no dia em que os Kaiowá e Guarani finalmente recuperarem suas terras:

\footnotetext{
"Então, haverá dança e caminhada até o lugar onde vai renascer a nossa terra, e é ali que nós vamos. Ali haverá novamente os que vão dançar, vão ser arrumadas as casas. Então, nesse lugar eles vão abençoar, trazer coisas boas. Depois de abençoar o lugar, eles (os ñanderu) vão poder trazer de volta as nossas caças, o dono da caça vai chamar os animais, eles vão baixar de novo."
}

As festas kaiowá e guarani, segundo a memória dos mais velhos, estavam relacionadas a um tempo de fartura, antes da chegada dos brancos, quando as colheitas eram abundantes, e as famílias podiam convidar periodicamente os vizinhos para cantar, dançar e agradecer aos deuses pela saúde e a alegria. Esses rituais, como o batismo das crianças ou a passagem dos meninos à idade adulta, sinalizada antigamente por um furo na parte inferior da boca, o tembekua, onde se instalava um fio de resina de certa árvore, o tembeta - estão entre as mais fortes lembranças de Atanásio, e compõem o cenário da terra almejada, onde os parentes um dia poderão voltar a viver do seu próprio jeito, o ñande reko:

"Então haverá novamente o convite à cerimônia das crianças (mitã pepy), haverá novamente a celebração do tembekua, haverá novamente a dança (jerosy), o canto longo (mborahei puku), pra trazer de volta a colheita do 
milho do milho verde (avatikyry). Vão ser abençoados (hovasa) os canaviais, os mandiocais, as crianças. Vamos ter novamente ali todas as coisas, o novo lugar vai ser fortalecido com as rezas, ali não será mais preciso ter outro modo de viver. Ali haverá uma nova vida com danças, vida sadia, e vida em abundância.”

Como demonstra o movimento da Aty Guasu, a resistência relacionada aos saberes xamânicos se exprime, sobretudo, a partir de um discurso sobre o futuro. Uma profecia que os ñanderu e ñandesy repetem incessantemente, a fim de envolver cada vez mais gente com a confiança no poder das suas palavras, e por fim torná-las realidade.

Entretanto - os fazendeiros fazem questão de sublinhar isso -, esse futuro de recuperação das terras passa por uma volta a práticas do passado. Aos olhos ocidentais, trata-se de "romantismo". Mas, um olhar mais amplo sobre o ponto de vista de ameríndio quanto a esse tipo de questão pode revelar algo um pouco diferente. Novamente, subamos os Andes.

Entre os movimentos indígenas andinos, essa ideia de uma volta ao passado como objetivo político não é nada estranha. Em contextos onde essa tradição ocidental de contar o tempo e associar juízo de valor positivo ao progresso não é hegemônica, a ideia de um retorno a um tempo de fartura e de uma recuperação dos elementos da paisagem que garantiam a abundância de comida e o bem-estar de um grupo pode não ser tão absurda como soa por aqui ${ }^{250}$.

O termo quechua pachakuti tem estado bastante presente no debate político andino dos últimos anos - e particularmente na Bolívia. Há um partido Pachakuti na Bolívia (Movimiento Indigena Pachakuti), um movimento Pachakutik no Equador (Movimiento de Unidad Plurinacional Pachakutik/Nuevo País - MUPP-NP ${ }^{251}$ ), além de diversas referências ao termo em obras acadêmicas e políticas de toda espécie, desde panfletos até estudos que buscam reflexão sobre as novas teorias trazidas pela atuação dos movimentos indígenas nesses países, nos últimos anos.

Gutiérrez (2009) disserta sobre o sentido de pachakuti, dialogando com uma série de outros autores que escreveram a respeito - sobretudo Thomson ${ }^{252}$. O esforço dela vai no sentido de melhor determinar o sentido das propostas de certos movimentos indígenas bolivianos, por vezes “mal

\footnotetext{
${ }^{250}$ Para uma breve reflexão a respeito do tempo, no contexto dos estudos etnográficos, ver Silva, 2000.

251 Sobre a história e os dilemas políticos do MUPP-NP, ver Pacari, 2007.

252 Ver Thomson (2006), reprodução de parte do volume organizado pelo autor em parceria com Hylton, Patzi e Serulnikov (2003).
} 
traduzidas", por assim dizer. Particularmente, há uma questão relativa à "inversão da ordem política”. Do que se está falando exatamente?

\begin{abstract}
“El término Pachakuti puede traducirse literalmente como 'vuelta o inversión' del tiempo y del espacio y se utiliza, por lo general, para referirse a un tiempo mítico de redención en el cual volverán a reinar, de manera general, los principios que hoy rigen sólo la convivencia social al interior de las comunidades en medio del conjunto de relaciones de dominación y explotación liberales padecidas por todos." (Gutiérrez, 2009: 108) ${ }^{253}$
\end{abstract}

Enfim, a autora propõe que essa inversão proposta pelos indígenas não se reduz ao clássico sentido enxergado nos movimentos de esquerda, de fazer subir ao poder os que estão abaixo - e, nesse sentido, ela critica a ideia de Thomson de que se trataria, sobretudo, de estabelecer um tempo em que "só reinassem os índios" (frase que o autor extrai de documento colonial para tentar explicar o sentido global das revoltas ocorridas na Bolívia, no século XVIII). O Pachakuti implicaria, ainda, segundo Gutiérrez, um movimento de estender "para fora" as regras hoje vigentes "para dentro" (das comunidades).

Nesse sentido, ela lembra que é necessário compreender a complementaridade (a alternância) entre kuti e tinku, "uno entendido como el momento de la confrontación entre contrarios y el otro como tiempo de encuentro entre opuestos". Em suma, o processo sugerido pela ideia de pachakuti tem a ver, segundo ela, com "la necesidad de establecer un nuevo 'pacto', de determinar y consolidar los términos de un nuevo 'acuerdo' para habitar el mundo en condiciones nuevas" (idem: 109).

Além dessa outra temporalidade ${ }^{254}$, há a relação com o que nós costumamos compreender

253 Em nota, Gutiérrez esmiúça a discussão semântica, a partir de escritos de Bouysse-Cassagne, sobretudo. Segundo esta autora, o pacha kuti também pode ser dito "awqa pacha", ou "tiempo de las guerras". "BouyesseCassagne aclara, además, que el término awqa 'pone en juego toda una serie de relaciones entre dos elementos o dos grupos humanos'. Para ello, glosando a Bertonio, señala: awqa: 'contrario en los colores y elementos, y de las cosas así, que no pueden estar juntas, v.g., contrario es lo negro de lo blanco, el fuego del agua, el día de la noche, el pecado de la gracia'. Según esta misma autora, los caminos posibles para la convivencia de estos contrarios son, o bien la alternancia - kuti - o bien el encuentro - tinku (Bouysse-Cassagne, 1987: 194 y ss.)".

254 Ver Sanjinés (2007), para uma reflexão acerca do que o autor chama de "crise do tempo histórico", no contexto do encontro (kuti? tinku?) das noções ocidentais de revolução e progresso com as aspirações dos movimentos indígenas e sua "peculiar relação com o passado e o futuro" - a reflexão parte da frase destacada por Thomson $(2003,2006)$ de documentos coloniais relativos a rebeliões indígenas na Bolívia, em que se dizia, no contexto de um levante, que "já era outro o presente”. Essa “disputa pelo tempo" é comentada também por Gómez (2005). É significativo que o confronto ocorra com o que este autor chama de "tempo do Estado". Como se observa, por exemplo, nos detalhados relatos sobre a relação política entre Iroqueses e europeus, no período colonial, negociar 
como a "questão ambiental" - e, novamente, voltamos à dita "politização da natureza" sugerida por Viveiros de Castro. A hipótese de Gutiérrez, sobre a necessidade de levar "para fora" o que já é vigente "no interior" dos coletivos indígenas, anuncia algo sobre o conteúdo ético dessas mobilizações políticas, de sua relação com elaborações a respeito das boas normas para uma socialidade, como o "ñande reko" guarani - boas normas que, como já destacou Pereira (2004), envolvem, também, elementos que nós, ocidentais, costumamos incluir na paisagem, e não no meio social, como plantas, fontes d'água, morros e animais.

Ambas as discussões, tempo e ambiente, nos levam à obra do peruano José Carlos Mariátegui (1894-1930), pioneiro na busca de um diálogo entre o pensamento indígena e a teoria política revolucionária ocidental. Não por acaso, Löwy (2005) lembra que se pode defini-lo como, fundamentalmente, um romântico - e eis um ponto que nos pode interessar, pois se trata da mesma acusação feita aos movimentos indígenas em locais como o Mato Grosso do Sul. O romantismo do peruano mirava, sobretudo, o mundo pré-hispânico dos Inca - ele falava em um "comunismo inkaico" (Mariátegui, 2008 [1928]: 48):

\section{"El pasado incaico ha entrado en nuestra historia [de Peru], reivindicado no por los tradicionalistas sino por los revolucionarios. En esto consiste la derrota del colonialismo, sobreviviente aún, em parte, como estado social —feudalidad, gamonalismo-, pero batido para siempre como espíritu. La revolución ha reivindicado nuestra más antigua tradición. „255}

Esse contato entre Mariátegui e o mundo indígena carrega vários equívocos ${ }^{256}$, é certo. Ao mesmo tempo, tem algo de diáfano, como demonstram as impressões de Tible (2009) ou Alimonda (2007): como este último autor aponta, nem sempre há correlações diretas (com o tema ambiental, por exemplo), mas a inspiração oferecida pelos escritos do peruano é inegável. É como se, com toda a dificuldade que o autor teve, em sua curta vida, para realizar essa ponte entre o marxismo e o pensamento ameríndio, ele tivesse alcançado uma espécie de sintonia. Como se explorasse um “devir-indígena”, deixando-se afetar pelos congressos e rebeliões indígenas que presenciou logo após sua volta da Europa, em 1923 (cf. Leibner, 1994 e 1997).

politicamente era negociar tempos para decisão(vide, a respeito, Perrone-Moisés, 1996: capítulo 3). No Brasil, em casos que envolvem grandes obras como a da hidrelétrica de Belo Monte, é, em certa medida, disso que se trata, pois o Estado não está disposto a esperar que se forme um consenso em torno de uma posição.

255 “La tradición nacional”, artigo publicado originalmente no jornal Mundial, de Lima, em 02/12/1927. Disponível na internet. Citado por Löwy (2005: 19)

256 No sentido que dá ao termo Viveiros de Castro (2004). 
O romantismo apontado pelos fazendeiros parece fazer sentido para Mariátegui, mas, certamente, não se aplica aos Guarani e Kaiowá. Veremos a seguir em que se fundamenta a tese dos xamãs de que é possível retornar às antigas condições ambientais/ sociais ${ }^{257}$ que proporcionavam a fartura em suas terras.

\section{A natureza, essa multidão}

Analisemos, pois, os esforços dos xamãs kaiowá em relação aos movimentos coletivos. Em primeiro lugar, poderíamos dizer que a situação atual no sul de MS nos permite agregar algo em relação à dinâmica vetorial sugerida pela teoria deleuziana - adotada recentemente por tantos autores brasileiros como matriz explicativa. O movimento, como mostra a situação dos Kaiowá e Guarani, nem sempre dispersa ou desfaz um coletivo. Ele também pode, pelo contrário, fundá-lo e garantir que perdure. Se a ação do tendotá é fundamental nesse sentido, a do ñanderu, não o é menos, dada sua incumbência de zelar pelo bem-estar geral - nesse sentido se pode entender uma das mais comuns denominações para o xamã como um "pai geral” (ñande ru - nosso pai, sendo nosso aqui, inclusivo, em oposição ao nós exclusivo, ore $^{258}$ ).

Embora seja costumeiro supor a sedentarização (e toda uma série de formulações correlatas) como fator de estabilização de um coletivo, o caso kaiowá/guarani nos mostra que bem pode ocorrer o contrário: sem o movimento, o grupo tende a dispersar-se. É nesse sentido que se percebe o esforço dos xamãs de pregar a volta ao ñande reko, nosso modo de ser, de agir ${ }^{259}$. "Pegar o jeito do branco", uma expressão comum de se ouvir, é o perigo.

O ñande reko, o jeito kaiowá/guarani de ser, de fazer as coisas, está intimamente ligado às práticas xamânicas. Retomar as áreas de tekoha é, como se viu, recuperar hábitos e práticas dos antigos, hoje impossibilitadas pelo ambiente (cada vez mais) urbano das grandes reservas. Essas práticas dos antigos, justamente, dependem de elementos que nós designamos por "natureza". Nesse sentido, há uma relação direta entre a luta pela terra, o xamanismo e a política (movimentos - que compõem - coletivos). Terra, aqui, é muito mais do que o mero suporte para a "produção" que nela

257 Esse ponto de vista desafia (mais) esse marco divisor moderno, como veremos adiante.

${ }^{258}$ Tendo em vista que nossa referência é a do constante movimento, observemos que constantemente se está oscilando entre ore e ñande - cf. Pereira, 1999; Chamorro, 2008 etc. O alcance do ñande é instável, contextual...

259 Que, na esteira do que dizíamos, também pode ser ore reko, exclusivo. Note-se que, em certos contextos (em momentos de desmobilização após a resolução de um embate territorial, por exemplo) pode surgir com força a ênfase apontada por Benites (2009) no teko laja, o modo que cada família tem de agir e de ser. 
vêemos karaí. De todo modo, o fato é que o projeto, teoria ou filosofia kaiowá da política passa, de forma decisiva, por aquilo que chamamos de natureza. E isso não apenas no sentido "romântico" identificado pelos fazendeiros, de uma "volta à natureza". A natureza, essa multidão, é também aliada no processo de luta pela terra.

A capacidade dos xamãs de se comunicar com os seres que os autodesignados modernos, ironicamente, despersonificamos (dissolvemos) na noção de natureza, é bem conhecida dos etnólogos que atuaram entre os Kaiowá e Guarani ${ }^{260}$. Ela aparece, por exemplo, no seguinte trecho de entrevista realizada no acampamento de Laranjeira Ñanderu, em Rio Brilhante, com dona Maria Joana, mãe de Faride, uma das lideranças do grupo de 150 pessoas, junto com o cacique Zezinho.

Depois de cerca de um ano e meio acampados às margens da BR 163, na proximidade do rio Brilhante, foram removidos e, recentemente, voltaram a ocupar parte das terras onde já haviam entrado em 2008, e de onde foram expulsos, por ordem da Justiça, em setembro de 2009. Em 2012 conseguiram permissão da Justiça para permanecer no local até a conclusão dos estudos de identificação da Funai. Dona Maria Joana falou conosco ainda enquanto prepara seu apito ritual, o mimby, o mbaraka, e a cruz, kurusu, ou chiru, para entoar o som agudo de propriedades mágicas:

\begin{abstract}
"Posso cantar com o meu mbaraka para chover... Mimby é o vento que faz o som, e para de chover. O grande vento. Posso mexer o meu mbaraka e o chiru pra não chover mais. Sou ñandesy. Todas as pessoas doentes eu curo, qualquer doença. Pode ser o que for: machucado, faço levantar de novo. Têm que rezar os Guarani Kaiowá, porque tem bastante serpente, e daí desaparece e nem tem mais. As doenças que as crianças adquirem, vômito, você reza no doente, e ele sara. As crianças com coalho virado [indisposição provocada por um movimento brusco da criança], coloca de um jeito, e elas saram, e nunca mais apresentam esse sintoma”.
\end{abstract}

Aí se percebe a gama de possibilidades de emprego dos cantos-reza kaiowá. Esse tipo de canto descrito pela xamã - para fazer ou acabar com a chuva, para curar, para prevenir doenças com o consumo de certas comidas etc. - está presente em volume organizado por Garcia (2003) e já era documentado na obra de Cadogan (Cadogan \& López Austin, 1965). Mas, para além dos usos

\footnotetext{
260 Ironicamente porque, na origem traçada por Hadot (2006: 46), Natureza, na tradição ocidental, é um nome de mulher: ela já foi pensada como uma deusa em diversos momentos da história. Ainda seguindo distinção sugerida por esse autor (idem: 117), é como se, no embate entre os Kaiowá/Guarani e os fazendeiros, estivesse em jogo uma visão prometeica, destes, e outra, orfeica da natureza, por parte dos indígenas.
} 
descritos por ela - cruciais num contexto de penúria como a beira de estrada onde eles permaneceram em péssimas condições -, a situação de conflitos de terra também tem evidenciado um uso guerreiro dos cantos. Na fala de outro xamã de Laranjeira Nanderu, Olímpio, pai do cacique Zezinho, aparece a menção a esse outro emprego para os cantos:

\section{"Eu canto para as crianças e canto o ñengarai ${ }^{261}$ para os brancos ficarem mansinhos (...) Já estávamos em nossa terra um ano e seis meses e nos tiraram de lá. Não aconteceu nada de ruim quando tiraram, então foi até bom”.}

Ele se refere ao episódio da expulsão da fazenda que o grupo tornou a ocupar recentemente, operada com autorização judicial, pela Polícia Federal, em 2009. O fato de não ter acontecido "nada de ruim" às pessoas do grupo (mortes, ferimentos) é uma evidência que os Kaiowá e Guarani costumam apresentar como comprovação dos resultados práticos da ação xamânica.

Há casos em que, em reuniões políticas, foi considerado que o fato de um grupo não ter cantado devidamente antes de realizar uma ocupação em uma fazenda resultou em violência dos fazendeiros contra o grupo - por isso, se diz que o canto pode "amansar" os inimigos. De modo geral, veteranos do movimento político ali explicam o fato de a resistência dos fazendeiros ter se fortalecido nos últimos anos exatamente pelo abandono progressivo das práticas xamânicas, por parte de alguns grupos locais.

Além de propiciarem uma oportunidade de discussão política no sentido que nós estamos acostumados a entender, as reuniões da Aty Guasu (a que voltaremos no próximo capítulo) também são um espaço para que os xamãs mais experientes realizem rituais de canto propiciando bênçãos e curas coletivas e pessoais, ao mesmo tempo em que auxiliam na interpretação cosmológica dos fatos que estão ocorrendo.

Em 2009, ocorreu uma Aty Guasu na terra indígena Yvy Katu (entre Iguatemi e Japorã). Na noite anterior ao início dos trabalhos, uma forte tempestade ocorreu na região. As lonas que estavam armadas para o evento foram totalmente arrasadas pela chuva e os ventos. Uma árvore caiu sobre as barracas de lona onde dormiam participantes.

261 É um dos termos usados para esse tipo de canto que "amansa" o inimigo. Note-se que o atual contexto de confrontação com os karai, devido à luta pela terra, parece trazer à luz esses conhecimentos, cuja utilização era, até recentemente, considerada como exclusiva dos "antigos" (vide Mura, 2006: 287). Ainda que, claro, as numerosas acusações de feitiçaria já demonstrassem que esse tipo de declaração não era factível. Ñengarai seria, segundo o glossário preparado por Chamorro (2008), o oposto de ñengarete, "oração verdadeira”. Ver, ainda, Chamorro, s.d. 
Rapidamente, foi realizada uma reunião fechada, petit comité, em que um dos xamãs mais experientes tranquilizou as lideranças, explicando que aquilo fora uma espécie de "bênção" (jehovasa) dos seres ligados à tempestade, e que não devia ser interpretado como um mau sinal. Pelo contrário, o fato de o acesso ao local ser prejudicado ajudaria a afastar os fazendeiros que poderiam tentar fazer mal aos indígenas.

Além dos cantos que podem amansar os inimigos, vários outros são citados pelos veteranos do movimento de recuperação das terras kaiowá e guarani. Há, por exemplo, cantos destinados a tornar os indígenas invisíveis aos inimigos, durante ocupações de fazenda; os que multiplicam os indígenas aos olhos de seus adversários; os que convocam ou afastam tempestades e ventos.

É comum que a organização das assembleias do movimento Aty Guasu exiba vídeos relativos à luta pela terra nas noites dos eventos, logo após o fim da sessão de discussões diurnas, o banho e o jantar. Um dos vídeos mais pedidos nessas ocasiões, justamente, é o documentário "Semente de Sonhos", realizado a partir de gravações do conflito entre um grupo de fazendeiros e os Guarani de Yvy Katu (município de Iguatemi-MS), durante a operação de retomada de parte da área correspondente a essa Terra Indígena, no final de 2003.

As cenas são impressionantes; trata-se de uma das poucas sequências de conflito aberto entre indígenas e fazendeiros com registro em vídeo. As imagens foram gravadas por um jornalista que realizava reportagem na região e cedidas para o Cimi, que montou o documentário. Um dos motivos por que os Kaiowá e Guarani tanto gostam do vídeo é pelo fato de ele registrar o exato momento em que uma forte tempestade (na mesma região da supracitada Aty Guasu de 2009) se abate sobre os indígenas e fazendeiros que se enfrentavam na ponte entre a cidade e a terra indígena $^{262}$.

Comenta-se, a esse respeito, que a tempestade certamente havia sido convocada pelos rezadores, a fim de "esfriar" os ânimos e impedir um confronto mais violento, no qual os indígenas seriam prejudicados, por não portarem armas de fogo. A tormenta não é, aí, "fenômeno natural", é resultado da ação dos deuses, aliados dos indígenas. O exemplo guarani e kaiowá demonstra a dificuldade de distinguir usos "pacíficos" ou "guerreiros" dos conhecimentos xamânicos. ${ }^{263}$

\footnotetext{
${ }^{262}$ Chamorro (s.d.) disserta sobre as ressonâncias míticas desse yvytu marãny, o "vento destruidor", uma referência recorrente.

263 Presente nas reflexões de quase todos os etnólogos que trabalharam junto aos Kaiowa e Guarani recentemente o tema é bastante presente no cotidiano atual das aldeias, em função dos numerosos assassinatos, grande parte deles relacionada a acusações de feitiçaria -, a questão também é tematizada por inúmeros etnólogos amazonistas.
} 
Os entrelaçamentos como o que citamos acima, entre cantar e rezar, bem como o fato de os Guarani e Kaiowa costumarem se referir aos rituais xamânicos como "batismos", estão evidentemente ligados à sua longa história de contato com as tradições cristãs, que gerou diversas "traduções recíprocas", como denomina Pompa (2003).

Em Aty Guasu recentes, pode-se observar uma transformação interessante: o documento final de cada reunião é "batizado" ou abençoado pelos ñanderu presentes. Há casos em que, durante esse batismo, são convocadas as famílias que têm crianças pequenas ali e que também são abençoadas. Da mesma forma, são abençoadas as autoridades que visitam os eventos, os antropólogos que vão escrever relatórios de identificação de terra, os automóveis ou ônibus que levam as pessoas em viagens (potencialmente perigosas) etc. etc. etc. A continuidade entre o uso "civil" e o guerreiro é explicitada, com claras intenções (cosmo)políticas.

A aplicação do jehovasa a tudo que seja de interesse para a luta pela terra seria, assim, mais um exemplo da persistência de processos e esquemas culturais "próprios" na geração de novos "traços culturais" ao longo do tempo (Carneiro da Cunha 2009:261). Como se sabe, desde que os europeus começaram a frequentar estas terras, seus esforços concentraram-se em batizar os indígenas. De modo que o termo "batismo" tem ressonâncias muito fortes e, mais uma vez, os xamãs dos grupos guarani foram mestres em "indigenizar" as novidades. Desde suas primeiras rebeliões, registradas pelos cronistas espanhóis, no século XVI, eles realizavam as cerimônias de "desbatismo" ou "contrabatismo" ${ }^{264}$. Como registra o padre Montoya, em 1639, referindo-se aos seguidores de um desses grandes líderes subversivos da era colonial:

“Construíram eles igrejas, nelas colocaram púlpitos, faziam as suas práticas e chegavam a batizar. Era esta a fórmula de seu batismo: 'Eu te desbatizo!' E com isso lavavam todo o corpo dos 'batizandos'. As práticas endereçavam-se ao descrédito da fé e da religião cristã, ameaçando aos que a recebessem e aos que, tendo-a recebido, não a detestassem, pois seriam devorados pelos tigres. Além disso haveriam de sair de suas cavernas os fantasmas formidáveis, armados de ira e munidos de espadas amplíssimas de pedra, a fim de tomarem vingança." (1985: 237)

Chamorro (2008: 87-8) fornece indicações sobre o contexto em que tais episódios ocorriam. 
No caso considerado pela autora, trata-se dos seguidores de Jeguacaporu, xamã guarani que entrou em confronto com os jesuítas na redução de Jesus Maria (no atual município de Candelária-RS), em meados da década de 1630. O emprego dessas cerimônias de "antibatismo", "desbatismo", ou “contrabatismo" por parte dos xamãs guarani parece ser registrado por todos os lados, no período, conforme a autora aponta, listando diversos exemplos. Um dos casos era o de Juan Cuara, cuja história ela encontra no tomo III da obra de Del Techo (1897):

“Juan Cuara avaliou muitas das novidades culturais às quais os Guarani estavam expostos na missão. Na sua opinião, os missionários eram inimigos jurados dos índios, o sal do batismo era um veneno e o óleo do crisma uma mancha. A confissão não passava de uma maneira de saber da vida alheia, adorar imagens de santos não era uma boa prática e a monogamia era uma forma de evitar que os índios se propagassem - tornando-os mais vulneráveis à dominação. Juan Cuara instava os índios da redução, que se dirigiam todas as noites a seu esconderijo para escutá-lo, a deixarem de frequentar os sacramentos, a tratarem os missionários com insolência e a voltarem a viver conforme seus antigos costumes, tendo cada um quantas mulheres pudesse alimentar. A ameaça constrangedora com que angariava a obediência de seus seguidores era que, se não o obedecessem, seriam convertidos em sapos e rãs" (Chamorro, 2008: 81)

A citação acima, além de mencionar a questão do batismo, também aponta outro traço persistente no discurso dos xamãs guarani: a insistência na necessidade de "voltar a viver conforme os antigos costumes". Pode-se verificar essa ênfase no ñande reko nas entrevistas expostas em "Mbaraká - A Palavra que Age", entre tantos outros textos construídos em torno do discurso dos xamãs. Como discutimos acima, esse retorno ao passado nada tem de romântico e explicita, penso, o cerne da questão posta pelos indígenas: o movimento pela recuperação das terras em MS é, sobretudo, cultural, no sentido que os ocidentais costumamos dar a essa palavra.

O que os xamãs compreendem e enfatizam é que só uma maior disponibilidade de terras poderá dar suporte à retomada dos antigos costumes. Não se trata de um simples cálculo de área disponível por pessoa - tão ao gosto de certos setores, conforme se vê por tabelas recentemente difundidas em certos órgãos da imprensa. Está em jogo a possibilidade de relacionar-se com os elementos que conformam essa multidão chamada natureza. O que nos leva a nosso próximo tópico. 


\section{Xamanismo e paisagem}

No contexto em que estão inseridos os Kaiowá e Guarani atuais, essa definição de cosmopolítica como uma "politização da natureza" (de uma crise ligada à "natureza") faz sentido de múltiplas maneiras.

Um bom xamã, como dizíamos, é, ainda, capaz de prever o futuro, atingindo tal complexidade em suas relações com o meio ambiente que fica difícil determinar até que ponto ele adivinha, ou foi avisado, ou sabe que determinado evento, como uma tempestade ou uma geada, vai acontecer ou não ${ }^{265}$. E é justamente nesse grau de interação com o que chamamos de natureza que reside um dos maiores desafios para a reprodução e a continuidade da sabedoria xamânica entre os Guarani e Kaiowá. A maior parte do território de ocupação tradicional desses indígenas está, hoje, completamente degradada. As florestas desapareceram quase completamente, dando lugar a pastagens para o gado e grandes lavouras de soja e cana, que poluem os rios e afastam os animais que os indígenas antes caçavam.

Entre os Kaiowá mais pessimistas, há quem duvide da possibilidade de perpetuação dos saberes xamânicos, tamanhas as modificações ambientais. Estes acreditam que os mais jovens já estão demasiadamente envolvidos pelo teko (modo de ser) dos brancos, que envolve hábitos e tecnologias incompatíveis com os que os xamãs devem adotar para, após décadas de estudo árduo, serem capazes de enxergar e conversar com as entidades invisíveis aos comuns - chamados genericamente de Tupã Kuéry ou Tupanguéry (kuéry ou kuéra é marcador de plural), ou Tekojára kuéry (de teko, "modo de ser", e jára, "dono") embora exista um verdadeiro panteão delas ${ }^{266}$.

Uma de suas características mais marcantes é a de incluírem os jára (donos ou senhores) de diferentes domínios ou seres (como as nascentes e rios, ou determinadas árvores, ou animais, ou plantas da lavoura) ${ }^{267}$. Aos jára cabe cuidar de determinado lugar, ou espécie, ou gênero de coisas. Entre os deuses maiores, fala-se de Ñandejára (o Senhor de todos). Também se fala, genericamente, dos Tekojára (donos do “modo de ser”). Já os karai, os brancos, são os platajára, donos do dinheiro - ou seja, trata-se de uma ideia de escopo verdadeiramente amplo.

265 Evidentemente, inspiro-me aqui em Ingold (2000) e Bateson (1972).

266 Como já referimos, um estudo mais amplo sobre o uso contemporâneo desses termos está em Chamorro, 2008.

267 Para uma análise comparativa dessa noção de jára e correlatos em outras línguas, na região amazônica, ver Fausto (2008). 
Não por acaso, como dizíamos, uma das características, justamente, desse discurso xamânico que prevê o futuro é de referir-se, frequentemente, a elementos do que denominamos clima, agricultura, fauna e flora. De modo que o discurso profético sobre a recuperação das terras tradicionais adquire feições ecológicas, fala frequentemente das consequências desastrosas das alterações ambientais geradas pela ação dos karai, por um lado, ao mesmo tempo em que exalta a recuperação do meio ambiente - e dos poderes e forças relacionadas aos xamãs, consequentemente - que advirá com a recuperação dos tekoha.

Um exemplo disso pode ser encontrado no grupo conhecido como Guaiviry - o nome da área de onde eles dizem ter sido expulsos, décadas atrás, no município de Aral Moreira. Por vários anos, permaneceram precariamente instalados na reserva de Amambai, sob barracos de lona preta, em uma área imprestável para a agricultura. A principal liderança do grupo era a ñandesy Odúlia, morta em 2009 268 . Em novembro de 2011, o coletivo do Guaiviry deslocou-se para o local reivindicado por eles como sua terra de ocupação tradicional e, pouco mais de duas semanas depois (18/11/11), o grupo foi alvo de um ataque de homens armados que vitimou Nísio Gomes, viúvo de Odúlia.

Odúlia e Nísio morreram sem realizar o sonho de voltar a viver em paz em seu tekoha. Deixaram herdeiros, como Valmir, portador de muitos dos ensinamentos da sogra. Em 2010, pouco tempo depois da morte de sua professora e madrinha, como ele costuma denominá-la, encontramos Valmir muito triste e revoltado com as privações infligidas a sua família. As mudanças ambientais e climáticas por que passa a região, depois do desmatamento intensivo das últimas décadas, são um aviso para os brancos sobre a contrariedade dos deuses com o que vem acontecendo por ali:

"Eles ficam nervosos quando veem que suas cidades estão se acabando e a chuva que os mantém ali. Pode observar: por onde os índios andarem, as cidades se acabarão. Assim faremos pela nossa terra: eles se acabarem! Não vai sobrar nenhum desses brancos, aconteça o que acontecer. Nós temos tido paciência, mas eles acham que nos têm na palma da mão. Eles serão destruídos. Nós temos pressa pela nossa terra, estamos ansiosos para poder alimentar os nossos familiares, nós não somos de ficar pra lá e pra cá pedindo. Nós queremos plantar! Mas os brancos não querem devolver a nossa terra. Eles são estrangeiros, nós somos os verdadeiros donos da 
terra. E, se ficamos bravos, a terra vai ficar ruim. Esse dinheiro dos brancos não vale nada, porque o dinheiro se acaba, mas nós não. E assim nós nos levantamos da terra, da sepultura, mas eles são cinza, não prestam para nada, nós somos os verdadeiros homens. Se fizermos trovejar, eles vão se assustar."

Estive no local da morte de Nísio no mesmo dia do ataque que o vitimou, acompanhando um grupo de lideranças ligadas à Aty Guasu. Nessa e em outras ocasiões em que pude visitar a área onde o grupo do Guaiviry mantém, até o presente momento, seu acampamento (tekoharã, "futuro tekoha" - segundo se tem recentemente utilizado no âmbito do movimento de luta pelas terras), ficou evidente como a ânsia de retornar às terras reivindicadas evoca motivações ligadas ao que chamaríamos de questão ambiental e sua relação com a qualidade de vida (outra tradução - por que não? - para teko pora $\tilde{a}^{269}$, o modo bonito de viver).

Um mês e meio antes, de passagem por Amambai, eu estivera brevemente com Nísio. Não pudemos conversar muito, porque cheguei ao acampamento dos de Guaiviry exatamente quando uma tempestade começava a se abater sobre a região. Naquele dia, a cerca de 100 quilômetros dali, era enterrado no acampamento de Ypo'i o corpo de Teodoro Ricarte, guarani da família dos professores Jenivaldo e Rolindo, mortos em conflito em 2009. Comentei o fato com Nísio, e ele rapidamente fez a relação: "Então é por isso essa tempestade toda. Eles não gostam quando acontece esse tipo de coisa com os Guarani”.

Mal sabia eu que pouco mais de 40 dias depois disso, estaria olhando para o chiru que Nísio deixara ainda posto no alto de seu yvyra'i marangatu (altar), depois de ter sido baleado e levado por pistoleiros, menos de 48 horas depois de um grupo ligado à Aty Guasu ter realizado uma visita de solidariedade ao acampamento de Guaiviry. O altar marcava a entrada do caminho, no meio da mata fechada, que leva até o local onde as famílias construíram suas barracas, pouco mais de 200 metros adiante. A mais alguns passos dali, estão um córrego e uma pequena queda d'água. Para chegar ao local onde Nísio deixou sua cruz, é preciso sair da estrada entre Amambai e Ponta Porã e atravessar uma lavoura de soja até chegar àquele típico resquício de mata ciliar que os fazendeiros da região costumam deixar no fundo dos locais de plantio.

$269 \mathrm{Na}$ etnologia dos grupos guarani, as diferentes qualificações do teko, evocadas nos discursos políticos/xamânicos, foram alvo de extensas discussões e exegeses. Vide, por exemplo, Meliá et al. (2008: 101-3), em que se fala sobre teko katu ("autêntico e verdadeiro modo de ser"), teko marangatu ("o modo de ser religioso") e teko porã ("concretização do sistema", "a nível de normas e valores éticos"), como diferentes aspectos do ñande reko, concebido como "ideologia". A mim me parece difícil estabelecer certas distinções. 
É notável o contraste desse ambiente em Guaiviry com a área que o grupo ocupava meses antes, na reserva de Amambai. Ali, uma capoeira baixa, empobrecida por décadas de ocupação contínua, com um solo imprestável, era o que cercava as barracas de lona onde esses indígenas sobrevivem há anos das doações do governo e do pagamento por serviços realizados nas fazendas próximas ou na cidade. Impressionavam-me a raiva e a frustração no olhar e na fala de crianças de 4, 5 anos de idade. Em contraste, aparecia a serenidade com que Nísio conduzia o grupo e o afinco com que cuidavam de manter, na família, os cantos transmitidos por Odúlia e conhecimentos musicais relativamente raros de se encontrar na região atualmente - Valmir, por exemplo, fabrica e toca o instrumento guyrapa' ${ }^{270}$ com facilidade.

O ambiente gerado pela ação dos karai é, em quase todos os aspectos, um obstáculo à constituição de xamãs, conforme a visão dos Kaiowá e Guarani. Para começar, há a questão do saber oral versus a escrita. É comum, em narrativas do tipo "mito da má escolha", associar os brancos à escrita, e os Kaiowá ao saber oral, representado pelo mbaraká - instrumento cujo ritmo está associado à memorização dos cantos-reza ${ }^{271}$.

Além disso, há as questões relativas à própria língua. O conhecimento xamânico está na língua, afinal - deixá-la é abandonar a possibilidade de chegar ao pleno domínio desses saberes. Conheci algumas pessoas que haviam começado a treinar os cantos com xamãs, mas acabaram por abandonar esse treinamento - ao menos temporariamente - em função da dificuldade de reproduzir as palavras com o tom e a pronúncia adequados.

Há, ainda, a questão da alimentação. Idealmente, um xamã, para alcançar as mais altas possibilidades de acesso às entidades invisíveis para os demais, deve estar muito atento aos alimentos que consome. Além de evitar o sal, o açúcar e outros temperos, há a questão da origem dessa comida e, mesmo em se tratando de carne de caça e peixe - "comida tradicional" - pode haver certas regras, como se vê pela entrevista de Atanásio a Mura (2006: 306). Há toda uma teoria aqui sobre o corpo, com ressonâncias amazônicas, mas, também, importantes peculiaridades.

Até mesmo os cultivos kaiowá e guarani demandam, para continuar a existir, a constituição

270 "Pequeno arco", uma espécie de violino de boca, formado por dois arcos cujas cordas são friccionadas uma contra a outra, usando-se a boca como caixa de ressonância. Pode-se vê-lo sendo tocado no documentário "Mbaraká - A Palavra que Age".

${ }^{271}$ A transcrição de uma narração do tipo "má escolha” entre os Kaiowá está em Garcia (2003: 174-6). Ali, os brancos optam, no tempo da origem, pelas ferragens e pela espingarda, enquanto os indígenas escolhem os adornos, o mbaraká, o arco e a flecha. Para uma reflexão sobre essas narrativas, ver Pimentel (2008b). Muito além dessas narrativas, essa alusão a uma diferenciação entre brancos e indígenas por meio dos objetos é algo recorrente nas conversas cotidianas. 
de um espaço próprio e adequado. Um dos alimentos mais significativos, o milho branco (avati morotĩ), é considerado o mais exigente dos cultivos. Nos lugares mais lotados, já é considerado inviável plantá-lo, pois não é possível que a lavoura se desenvolva devidamente se há pessoas desconhecidas chegando perto dela, por exemplo ${ }^{272}$.

O conjunto de práticas e afirmações que observei indica que o ambiente verdadeiramente ideal para o desenvolvimento dos saberes xamânicos se caracteriza pelo isolamento, a reclusão, a tranquilidade. Encontrei mesmo quem me dissesse que a manutenção desses conhecimentos é completamente inviável no mundo atual, porque um verdadeiro rezador não poderia nem mesmo andar de automóvel ou ir à cidade. Evidentemente, essa opinião não é unânime, e mesmo xamãs reputados (que já não são muitos, é preciso deixar isso claro, “estão se acabando") como Atanásio, mantêm, sim, algumas dessas atividades que inviabilizariam seus poderes. De um modo geral, os limites e os alcances do xamanismo são objeto de um debate permanente entre os Kaiowá e Guarani.

\section{Concorrência desleal}

A crise de credibilidade por que passam os rezadores kaiowá, como já dissemos, está certamente relacionada à concorrência que sofrem, hoje, por parte de diversos profissionais, com saberes que competem com os conhecimentos xamânicos. Afinal, o escopo de ação dos cantos-reza kaiowá e guarani é incrivelmente amplo: começando pelas lavouras (da obtenção de sementes à manutenção da sanidade da plantação, até o batizado das colheitas), passando pela caça, as viagens de qualquer natureza, a alimentação em geral, as doenças, a tristeza, a violência, o mau tempo etc. Isso, sem falar no papel dos rezadores na educação das crianças.

Assim, é fato que os saberes trazidos por agrônomos, professores, médicos, agentes de saúde, praticantes de artes místicas ou de religiões cristãs (de pastores evangélicos a pais-de-santo), ou mesmo conhecimentos acessíveis publicamente no mundo dos karai, como a previsão do tempo, competem diretamente com o que, nos tempos antigos, era responsabilidade dos rezadores. Simplesmente, há gente que considera que o saber dos karai é mais eficiente que o dos Kaiowá, dá mais resultado.

272 Ver, a respeito: João, 2011. Não apenas o milho branco, mas o próprio arroz exige restrições: quanto à aproximação de mulheres grávidas, por exemplo, segundo me explicaram certa vez. 
Além disso, há a questão das relações: usa-se o serviço de um rezador com o qual se tem algum tipo de contato, familiar principalmente. Nas reservas do SPI, ou onde os laços sociais estão mais esgarçados pelo jopara (mistura) resultante dos processos impostos pelo Estado brasileiro no século XX, certos rezadores podem decidir cobrar em dinheiro de algumas pessoas pelo serviço que prestam, o que contribui para acirrar os ânimos e levar pessoas que não dispõem de rezadores em seu círculo familiar a buscar benzedores ou pastores nas cidades.

Nesse sentido, é preciso, ainda, perceber, que joga contra os rezadores a cornucópia do Estado brasileiro. Sobretudo há a gratuidade do sistema de saúde: afinal, numa situação em que estão esgarçados os laços entre as pessoas, em função dos processos de esbulho e territorialização promovidos com apoio do Estado, a saúde gratuita se apresenta como algo claramente estimulante.

Já a comida e o dinheiro concedidos aos Kaiowá e Guarani pelo Estado como forma de abafar os protestos decorrentes da falta de terras se voltam, até certo ponto, contra a possibilidade de emergência de qualquer liderança política indígena, para além do xamanismo, uma vez que a distribuição de bens e alimentos está na base da atividade de chefia e, por isso, mais uma vez, temos uma concorrência.

O mburuvicha será inevitavelmente instado a se tornar um "buscador de recursos", diante desse quadro, mas, mesmo assim, estará, com isso, gerando a própria ruína porque a maneira como o Estado distribui, individualmente, joga contra a forma-família. O diálogo com os líderes familiares seria uma solução? Até certo ponto, somente, pois a prevalência do apoio estatal às famílias restritas (nucleares) dará sempre um impulso à fragmentação dos te’yi, caso não haja o suporte da terra que possa fazer a balança pender para o lado dos mburuvicha e ñanderu/ñandesy.

Os ataques ao xamanismo podem se dar de forma sutil: a escola, por exemplo, hoje é percebida por alguns rezadores como um fator negativo, por afastar as crianças da possibilidade de acessar diversos conhecimentos ligados à agricultura e à vivência nos espaços da mata e das roças. Cada vez mais, eles percebem que os jovens que completam sua passagem pelo sistema escolar cresceram sem ter contato com diversos elementos do ñande reko ${ }^{273}$, expondo, perigosamente, os ava a transformarem-se em brancos. Há, também, é verdade, rezadores que se dispõem a colaborar com as escolas, tentando fazer com que elas se tornem um fator de fortalecimento do acesso aos conhecimentos dos antigos, mas o fato é que está aí outro forte foco de discussões intensas entre os

273 Um discurso comum, entre os grupos de língua guarani, desde os primeiros embates com os karai, ainda no século XVI, como se pode perceber nas obras de Meliá, Gadelha etc. 
Kaiowá e Guarani.

Em campo, acompanhando os longos debates a respeito, eu frequentemente me lembrava do que autores como Bateson (1972) e Ingold (2000) propõem discutir a respeito da educação, de como se trata de um processo que envolve mesmo uma experiência de estar no mundo e tecer relações - e não, simplesmente, "absorver" informações. Num recente encontro de professores, os xamãs presentes enfatizavam como, se eles queriam mesmo aproximar-se dos "saberes tradicionais", tinham de passar a frequentar sessões diárias de canto (porahei) nas casas dos rezadores em suas aldeias, aprendendo a cantar juntos e desenvolvendo a prática xamânica - a sugestão foi apresentada como contraponto à ideia de que o contato com esses saberes possa ser algo apreendido simplesmente por palestras dos rezadores nas escolas, por exemplo.

Finalmente, afora todas essas dificuldades, há um problema maior e que ultrapassa os limites do aceitável. A desmoralização dos saberes xamânicos, hoje, é promovida não só pela ciência moderna, mas também por saberes concorrentes que provêm do campo religioso. Não é incomum ouvir sobre ataques de evangélicos, sobretudo os pentecostais, aos rezadores. Os episódios incluem, em alguns casos, até mesmo violências como queima de casas e agressões.

O discurso de alguns pastores, relatam os indígenas, estimula essas hostilidades ao afirmar que tudo o que não for relativo à Bíblia, em termos de conhecimentos do sagrado, provém de fontes demoníacas. Há casos bastante recentes e não se pode vislumbrar outra solução para coibir os abusos que não passe pelo combate à impunidade: é preciso dar um basta à intolerância religiosa. Para dizer com todas as letras: o que algumas igrejas promovem hoje em Mato Grosso do Sul são crimes de ódio.

\section{Amadurecendo conclusões}

Em seu extenso dossiê sobre chefia e xamanismo, tantas vezes aqui referido, Sztutman aborda também a questão do profetismo ameríndio (2005: 399-456), analisando as várias formulações feitas a respeito do fenômeno ao longo das últimas décadas, mas, sobretudo, discutindo as ideias de Hélène Clastres (1978).

Uma vez mais, procurarei partir da própria observação, dos dados, para então considerar as propostas teóricas em questão O caso kaiowá/guarani é oportuno, penso, para afetar nossa visão 
acerca de toda essa discussão sobre o profetismo. Em primeiro lugar, a incidência política da ação do xamã kaiowá certamente se intensifica numa situação de crise como a atual, mas, como se pode ver claramente entre os Guarani do litoral (e de forma menos clara entre os Kaiowá e Guarani de MS, em função dos atuais constrangimentos territoriais), a própria dinâmica de abertura de novas aldeias, em função de cisões políticas, ou mesmo da simples necessidade de um grupo de ter novas roças etc. está, frequentemente, associada ao xamanismo, por meio das visões em sonho e de sua interpretação, por exemplo.

Nesse sentido, em primeiro lugar, qualquer abertura de uma nova aldeia poderia ser considerada como fruto de uma "profecia"274. Uma série de atividades aparentemente prosaicas poderiam ser consideradas como frutos de profecias, por sinal. Por exemplo, um xamã pode ler uma série de sinais e concluir que é tempo de plantar, porque, no dia seguinte, começará a chuva. Se, efetivamente, chove, não teria havido uma profecia? Um sonho pode anunciar que a viagem de um parente é inoportuna, em função dos riscos de acidente: se essa pessoa ignora os avisos, viaja e se acidenta, não teria sido previsto o futuro?

Independente do que nós consideremos uma profecia, é fato que a autoridade de uma pessoa, enquanto xamã, está, exatamente, ligada a fenômenos como esse, sendo enfatizada a realização efetiva de algo que havia sido previsto como a prova da capacidade de um ñanderu ou ñandesy. Qual seria a diferença entre esses exemplos ou uma situação que um rezador indique o dia exato em que se deve ocupar uma terra reivindicada, e que seus cantos zelem pela segurança de todos?

O segundo elemento aí presente a oxigenar nossa visão sobre os "profetismos" guarani diz respeito à relação do discurso-ação dos xamãs com a luta pela terra. Trata-se, penso, de uma demonstração cabal a solapar o descolamento surgido, ao longo do século XX (com ajuda da etnologia, diga-se de passagem), entre os discursos acerca da "terra sem mal" e a chamada "realidade concreta" - como se fossem dois domínios distintos, separados, antagônicos ${ }^{275}$.

O que demonstra o envolvimento dos ñanderu e ñandesy kaiowá e guarani na luta pela terra em MS é que a "boa terra", tão tematizada nos discursos xamânicos pode, sim, ter existência

274 Curiosamente, embora essa caracterização me pareça evidente, não encontro alguma proposição desse tipo em autores que recentemente escreveram sobre os Guarani do litoral, como Pissolato (2997) ou Macedo (2009). Ramo y Affonso (2012), sim, associa a atividade dos xamãs guarani ao que chama de "antecipação". Macedo, que também dialoga com a obra de Sztutman, menciona constantemente essa questão do profetismo, mas não percebe caráter profético nesse tipo de fenômeno cotidiano que estou destacando. Ela verifica, entre os Guarani do litoral, uma sorte de "disjunção" entre "os eixos vertical e horizontal da existência" (2009: 113).

275 Observe-se que essa crítica, com diferentes tonalidades, vem sendo feita por uma série de autores, como Noelli (1999), Combès (ver capítulo anterior), Pissolato (2007) etc. 
concreta e, por sinal, aferível por meio de processos administrativos conduzidos pelo governo federal. É preciso olhar de outra maneira os movimentos guarani em que, historicamente, coletivos inteiros foram conduzidos a uma desterritorialização radical - não estaríamos falando de momentos em que esses grupos estiveram diante de ameaças igualmente graves, como guerras e epidemias? Enquanto não refinarmos nosso entendimento sobre esse tema, continuaremos sob ameaça de discursos preconceituosos que desviam a discussão sobre a "cultura" para seus próprios fins. Já é comum há anos, em Mato Grosso do Sul, que o reconhecimento da diversidade cultural relativa aos povos indígenas sustente afirmações como: "Eles se suicidam porque é de sua cultura. Eles acreditam na 'terra sem mal' e é para lá que querem ir, não veem motivo para permanecer por aqui”.

Como já mencionamos no trecho sobre o "romantismo" dos movimentos indígenas, não se trata, tampouco, penso eu, de vermos aí "utopias", uma vez que, como pudemos depreender dos depoimentos de xamãs aqui relacionados, a expectativa pela recuperação dos tekoha envolve a perspectiva bastante concreta de uma retomada da vida comunitária, das festas e da abundância trazida pela possibilidade de voltar a praticar devidamente a agricultura.

Talvez, de alguma forma, o relato mais contundente seja o de Thomaz de Almeida (2001) a respeito do período entre 1977 e 1979, aproximadamente, em que foi implantado na aldeia kaiowá de Takuapiry (Coronel Sapucaia) um projeto de roças comunitárias, ligado a uma estratégia para fazer com que os homens não mais precisassem ir à changa (trabalho remunerado nas fazendas).

O autor conta como gerou surpresa, entre os antropólogos do projeto PKN, inicialmente imbuídos de ideias desenvolvimentistas, o fato de que, com as primeiras colheitas, o que se viu na comunidade foi uma profusão de festas: "Os resultados (do projeto) não se fizeram esperar. Vieram, entretanto, em um formato diferente do esperado, nas cerimonias do avati kyry (batismo do milho e das plantas novas)" (2001: 112). E ele continua, reproduzindo trechos de seu caderno de campo em que descreve a fartura em uma dessas grandes festas:

“Todos os homens estavam paramentados com seus jeguaka, jasaha, ponchito, [e traziam] seus mbaraka (...). As mulheres todas com seus takuarusu. Bem animado estava ontem o jeroky. Se continuar nesse ritmo, na sexta-feira o pátio não será suficiente para todas as pessoas que se espera. Passam a noite toda cantando. (...) Chamavam minha atenção a variedade de tipos e formas de preparação do milho, que até então eu conhecia apenas através da literatura (...). Havia também muita fartura de 
mandioca (...). Lá estavam jety (batata-doce) e takuare’e (cana-de-açúcar), preparadas de várias maneiras. Muita chicha. A cerimônia e a festa qeue se seguiram (o guaxiré) vinham sendo preparadas e comentadas há meses, $e$ havia grande expectativa pelo acontecimento. Com efeito, houve muito investimento dos índios no plantio do avati morotĩ (milho branco) e outros produtos, produzindo uma quantidade de alimentos fartamente consumidos nas duas semanas de preparo e realização do avati kyry” (idem: 112-3).

Essa terra de que fala Atanásio não está tão distante assim, afinal. Com um pouco de boa vontade e trabalho duro, é possível reverter muitos dos problemas que hoje afligem os Kaiowá e Guarani. Essa é a certeza que sustenta o movimento Aty Guasu: não se trata de utopia, mas de um projeto político conduzido por pessoas que efetivamente podem prever o futuro. É disso que se trata.

Ao contrário do que percebia uma autora como Hélène Clastres (1978), não há contradição entre religioso e político aqui: é somente por meio da ação política em prol da recuperação das terras que o antigo modo de ser, o ñande reko, pode ser consumado - tanto no que tange ao processo de luta, em que a união do grupo parece acentuar-se, segundo a observação de vários Kaiowá e Guarani com quem conversei, como no que se refere à possibilidade de, em novo solo, conseguir o suporte físico para que o grupo mantenha as relações adequadas aos bons costumes $(\text { teko porã })^{276}$.

Como clama Noelli (1999), é preciso, urgentemente, aprimorar nossa discussão sobre a mobilidade dos grupos tupi-guarani. Em primeiro lugar, lembra ele, temos de diferenciar "migrações" e "processos de expansão". "Somente em situações de crise os grupos indígenas considerados guarani adotaram a mobilidade espacial como estratégia para 'resistir' aos outros", destaca Chamorro (2008: 169), em relação a essas ideias do autor, que busca, sobretudo, desfazer a confusão construída ao longo do século XX, a partir de Nimuendaju (1987) e Métraux (1927).

O processo em Mato Grosso do Sul deve ser, assim, compreendido como algo que está entre essas duas opções: nem migração, nem expansão propriamente dita, mas uma "reconquista" de espaços dos quais, anteriormente, os grupos kaiowá e guarani foram expulsos. O refinamento dessa abordagem histórica sobre a mobilidade dos grupos guarani poderá, talvez, no futuro, deixar mais

\footnotetext{
${ }^{276}$ Cf.., ainda, Chamorro, 2010.
} 
claro em que medida o caso sul-mato-grossense pode ajudar a jogar luz sobre outros processos por que passaram os grupos tupi-guarani ao longo da história. 


\section{Aty}

"Los miles de índios reunidos em la plaza lanzaron un grito como producido por uma sola garganta enorme, contestando así el saludo que el nuevo jefe les enviaba, agitando el cetro de um lado para outro. Aquel grito enorme partia del pecho de un pueblo que desafiaba al poder extranjero que había atentado contra sus tradiciones. Era la respuesta dada a la codiciosa opresión de los intrusos. La multitud, sabedora de lo que ocurriría después, se había preparado para emigrar. El grito de triunfo era el último acto de un pueblo unido. (...) la multitud empezó a dispersarse en pequeñas tribus, grupos familiares e individuos. Cada quien había escogido su rota y su meta. Unos, al sendero hacia la alta montaña; otros, al atajo que conducía al barranco, a la pradera o a la selva. La multitud se dispersó con rapidez tal que, en menos de media hora, la amplia plaza quedó tan vacía como si el viento hubiera barrido todo objeto y todo rastro humano" Bruno Traven, in Gobierno ${ }^{277}$.

277 Novela publicada originalmente em inglês, em 1931, narra fatos ocorridos no fictício povoado tzeltal de Bujvilum, em Chiapas, México. 


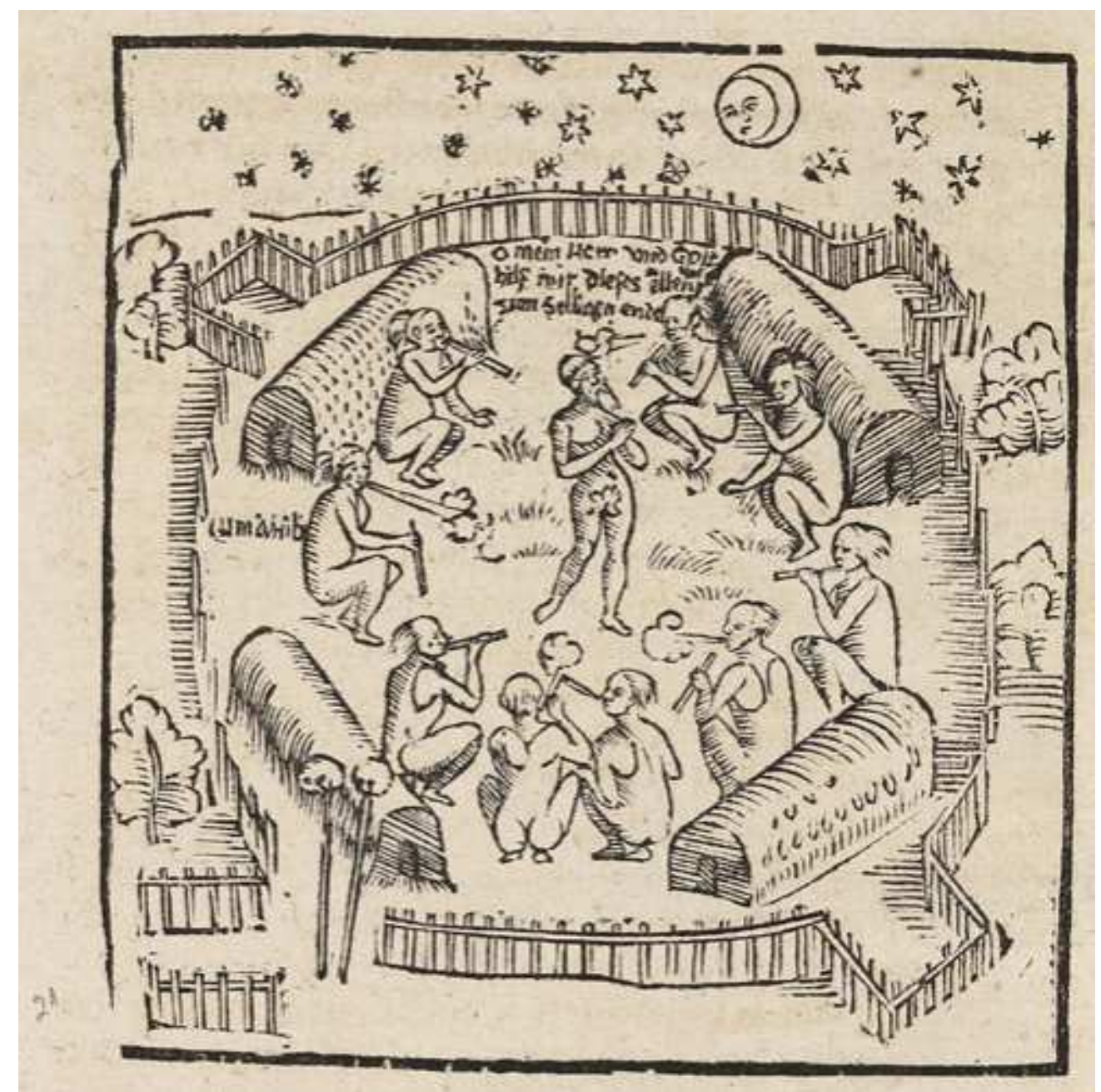

Reunião tupinambá do conselho de anciões, in: Staden, Cap. 30, 1557. 

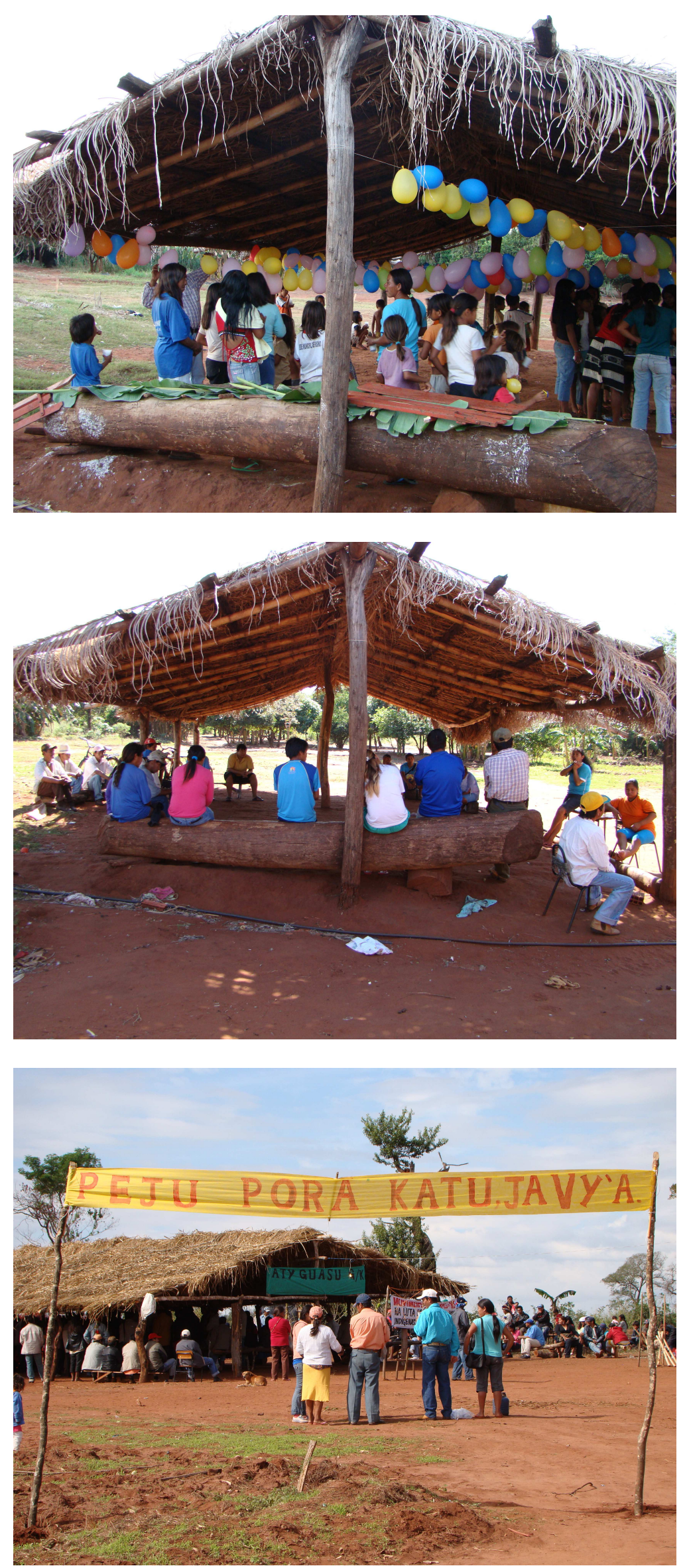

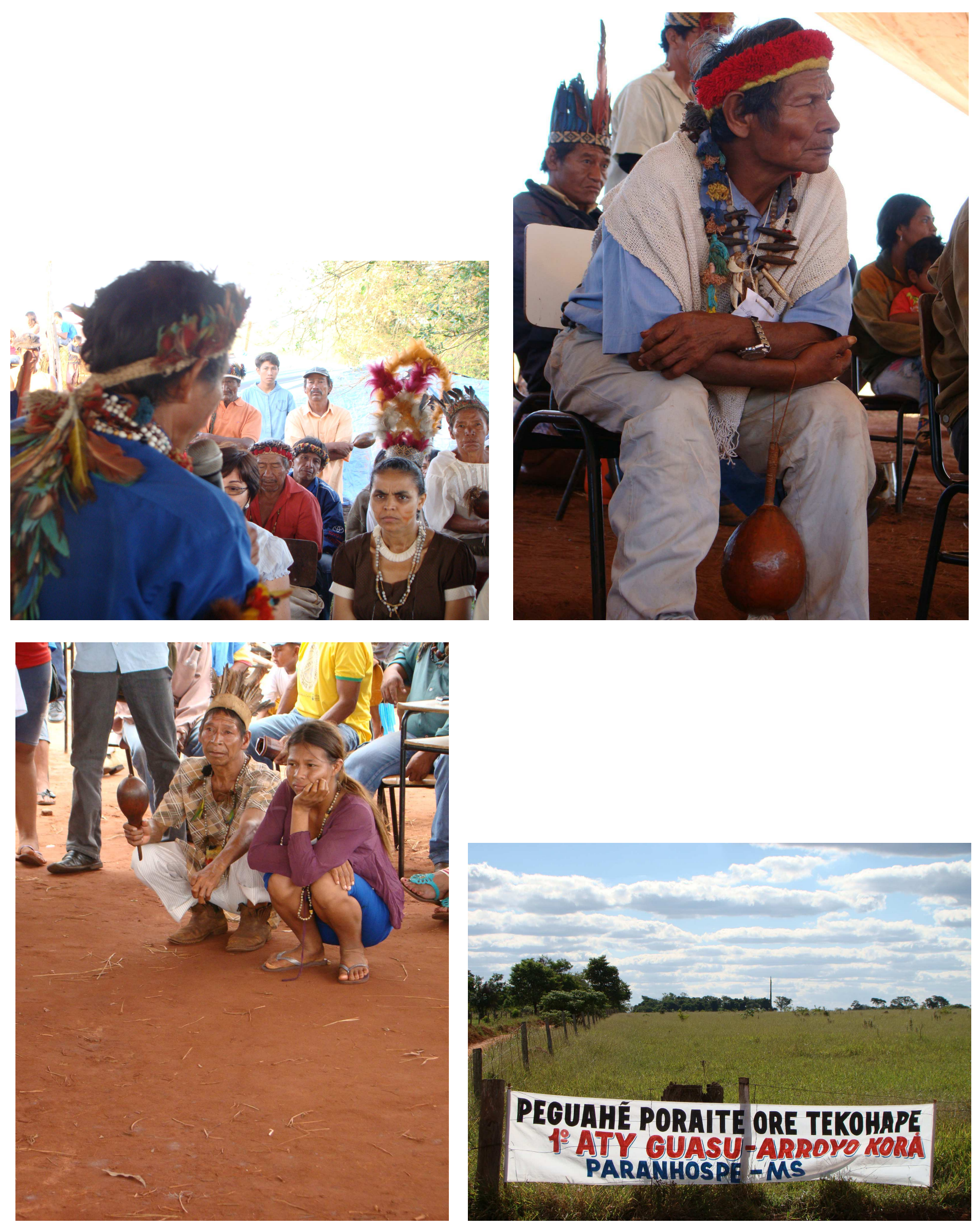

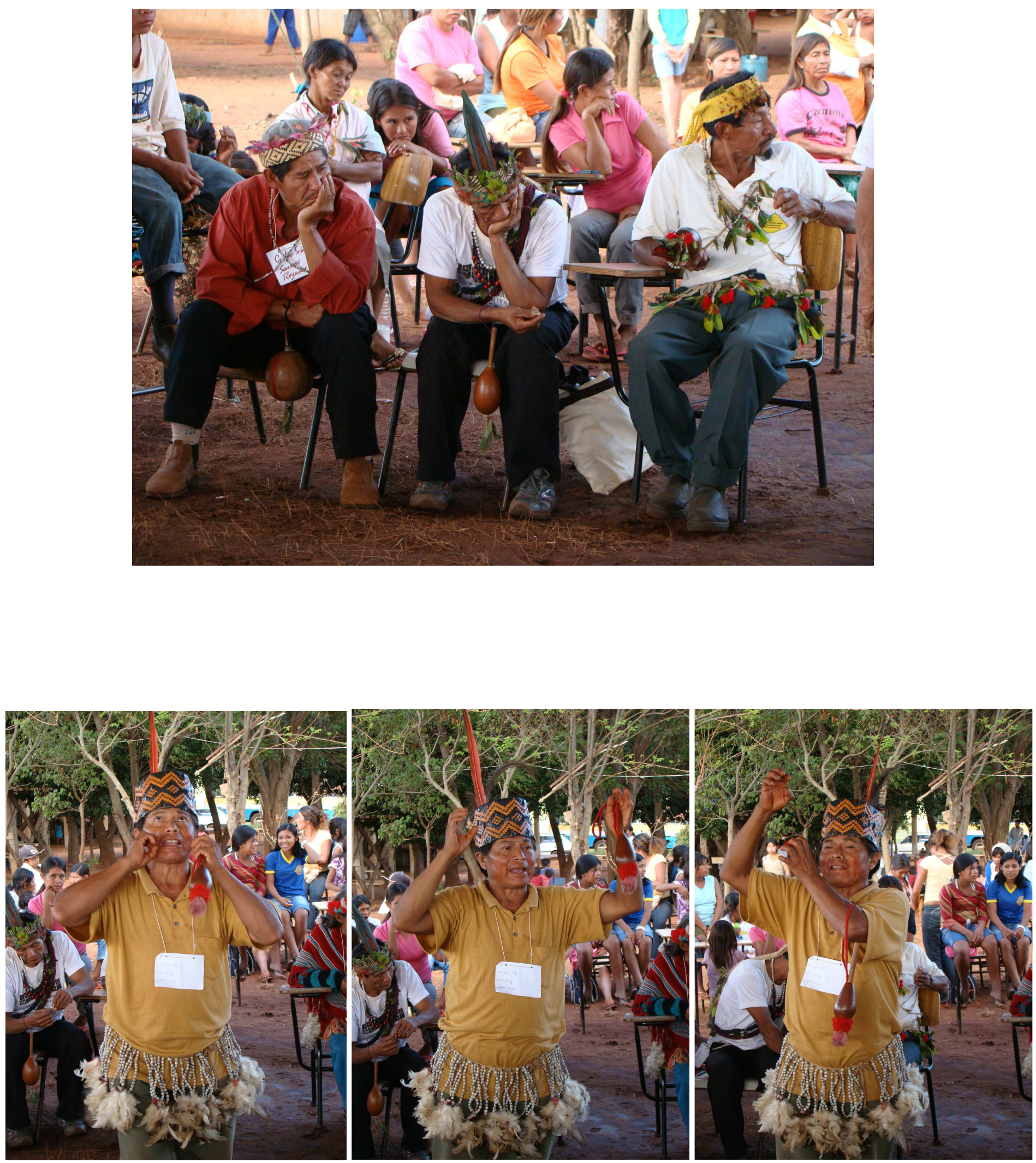

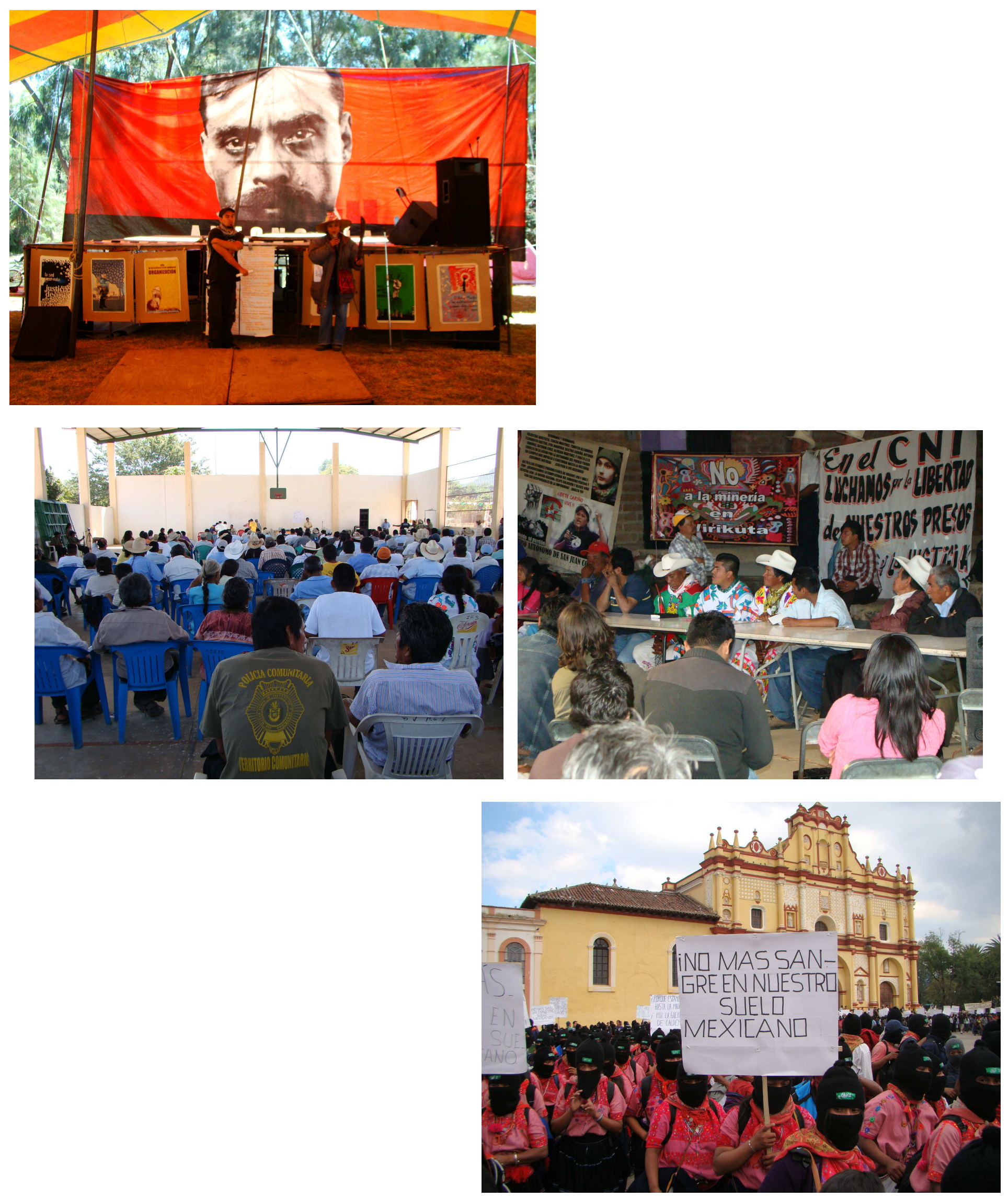

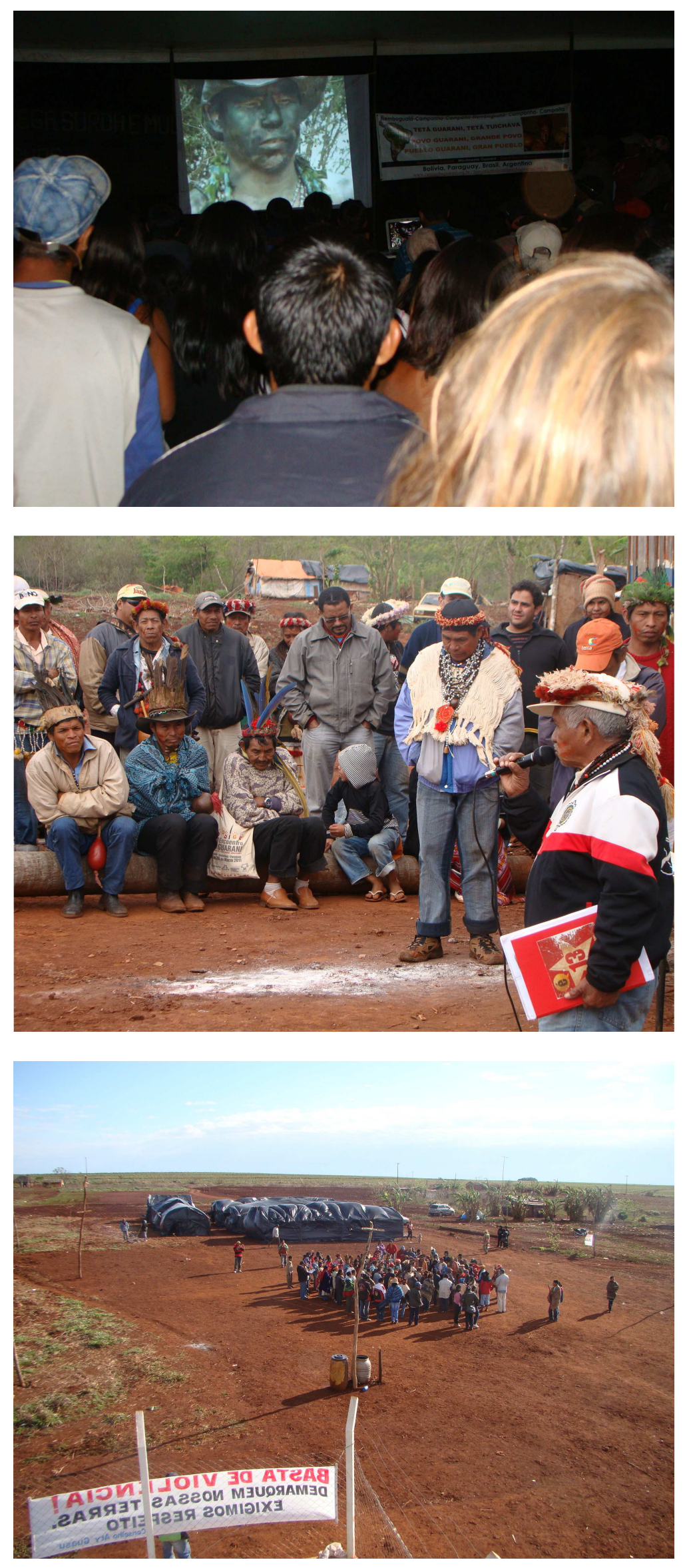

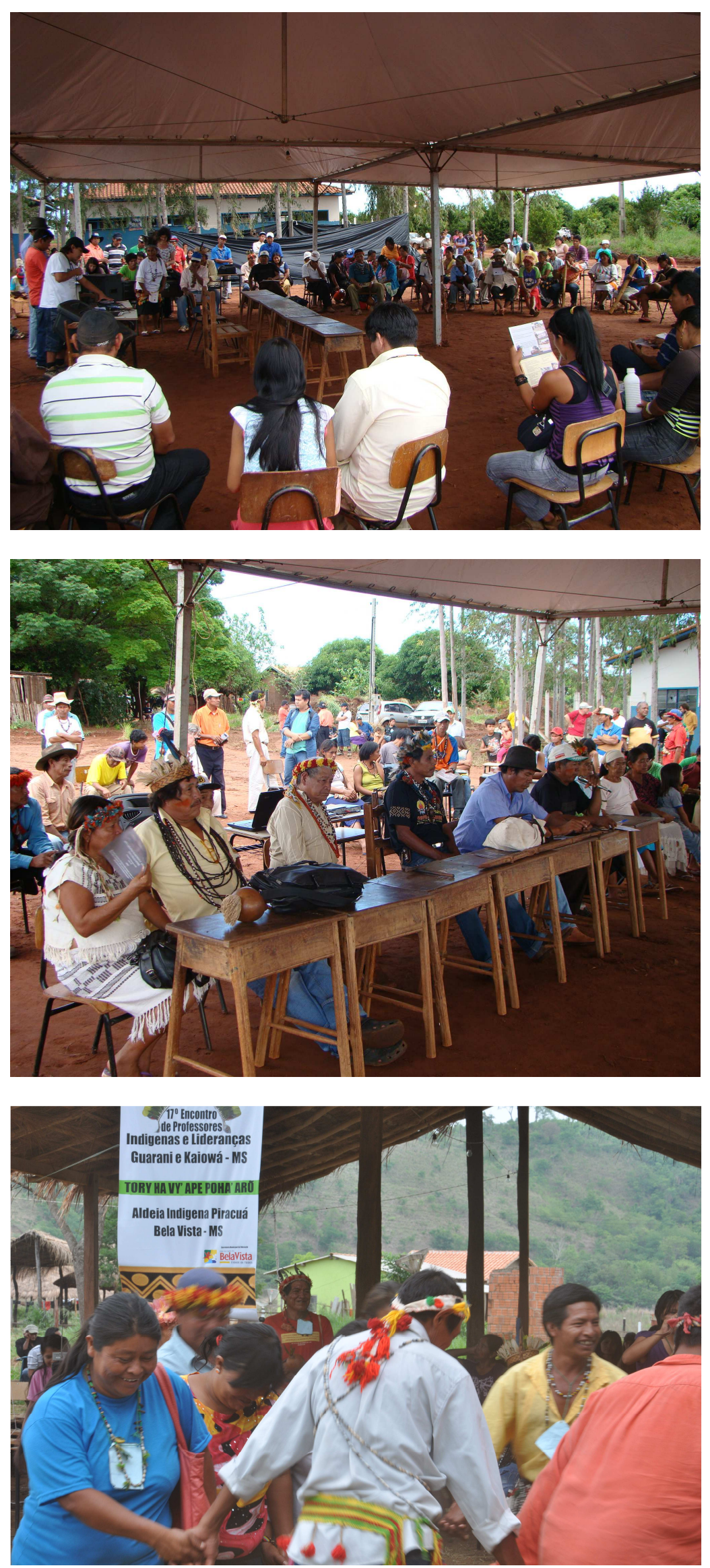
O terceiro elemento necessário à compreensão de uma teoria kaiowá da ação coletiva é a aty - reunião, ajuntamento. Diferente dos primeiros dois elementos aqui abordados, a aty não foi, aparentemente, objeto de tanta reflexão antropológica. Pode-se delinear uma tradição na reflexão acerca da chefia e do xamanismo, mas não da forma-reunião, enquanto figura da política ameríndia. Isso acontece não só no âmbito dos estudos guarani, mas, também, de uma forma mais geral: o fato é que a etnologia ameríndia, aparentemente, não deu tanta atenção à reunião. O que ocorre?

Arriscaremos uma hipótese, mais adiante. Pelo momento, aclaremos: o que é a aty? Para que se realiza uma reunião? A reunião costuma ser tomada, no modelo clássico do tekoha (vide capítulo 1), como um foro de decisões da comunidade local, uma espécie de microassembleia de uma democracia em escala local. A evocação da ágora grega é evidente.

O entusiasmo ocidental com essa associação pode ser comprovado desde as origens da Antropologia, com o já citado estudo de Morgan sobre a Liga Iroquesa (1904 [1851]). O autor, como é sabido (Kuper, 2008; Drago, 2012), comparava, por diversas vezes, os Iroqueses e os gregos, enquanto partícipes de uma linha evolutiva cuja máxima expressão encontrava-se, contemporaneamente, entre os próprios norte-americanos. Abordaremos de forma um pouco mais detalhada uma versão contemporânea desse encanto, voltando aos zapatistas.

Por ora, cabe explicar que, a partir da clássica definição de tekoha (vide cap. 1), passou-se ao entendimento de que toda comunidade kaiowá organiza, periodicamente, suas assembleias impressão que discutiremos a seguir. Ao mesmo tempo, nos anos 80, emerge em Mato Grosso do Sul o movimento Aty Guasu, organização que se destaca no cenário da redemocratização do país ${ }^{278}$. Significativamente, como veremos, o movimento Aty Guasu gira em torno da organização das Aty Guasu. Evento e movimento se fundem, são um só. O objetivo central das reuniões, por sua vez, tem sido, desde os anos 80, a recuperação das terras guarani e kaiowá, ou tekoha.

Uma primeira versão da história do movimento foi estabelecida por meio do trabalho de Thomaz de Almeida (2001). Ele coordenou, no final dos anos 70, o Projeto Kaiowá Nandeva (PKN), ação indigenista que começou dando suporte à produção agrícola nas reservas então

278 A emergência do movimento indígena guarani/kaiowá também pode ser pensada em relação a um quadro mais geral, latino-americano, como traça Fernández (2009). Nesse sentido, a despeito de sua incidência preponderantemente local, a Aty Guasu pode ser considerada em relação a toda uma série de outros movimentos, na Bolívia, Equador, México, Chile etc. Uma das poucas tentativas de tomar essa perspectiva está em Ortiz (2008), que constrói uma comparação entre o movimento guarani/kaiowá e o mapuche. 
existentes e, progressivamente, seguindo apelos dos Kaiowá e Guarani, passou a apoiar, de diferentes formas, a mobilização política que resultou nas Aty Guasu.

Entre os indígenas veteranos do movimento, as opiniões e relatos são variados ${ }^{279}$. A depender da trajetória da pessoa, emerge um ou outro elemento com mais vigor: não apenas a participação nas atividades do PKN, mas reuniões de formação política realizadas em colaboração com o Conselho Indigenista Missionário (que começou a atuar em MS num período muito próximo ao do início do PKN), ou o contato pessoal com Marçal de Souza, morto em 1983, como se viu. Cada um compõe uma história desse período conforme sua trajetória pessoal. Cada um apresenta uma perspectiva própria.

É muito lembrada a participação no enfrentamento em torno da área de Pirakuá, entre 1984 e 1986, uma das primeiras a serem demarcadas pelo governo federal, depois de décadas de esbulho e confinamento nas reservas do SPI. Pirakuá foi a primeira experiência de apoio amplo, de gente vinda de várias aldeias, a uma luta local pela permanência em uma área tradicionalmente ocupada $^{280}$. Nesse sentido, foi uma experiência marcante: ali, muita gente percebeu que o momento era propício para uma maior união entre os diversos grupos locais, em prol da luta pela terra.

Desde 1979, duas mobilizações em torno das áreas conhecidas como Rancho Jakare (em Laguna Carapã) e Paraguaçu (Paranhos) haviam levado aos jornais de circulação nacional as denúncias sobre os despejos forçados a que eram submetidos os grupos de Kaiowá e Guarani ${ }^{281}$. Mas, àquela altura, não chegaram a ocorrer mobilizações em que pessoas de várias aldeias atuavam em favor de um grupo local. Havia a luta por um determinado tekoha e a presença dos apoiadores.

O Cimi atuou principalmente em Rancho Jakare, e o PKN, em Paraguaçu. Segundo o antropólogo Celso Aoki ${ }^{282}$, que participou do PKN junto com Thomaz de Almeida, essa divisão acontecia naturalmente, pois a base do projeto estava em Amambai, enquanto o Cimi se voltava mais à região de Dourados. Como evidencia a leitura das notícias da época, bem como do relato de Thomaz de Almeida (2001), os grupos reagiam às tentativas de expulsão com uma veemência

279 Nos baseamos, aqui, sobretudo, em uma série de entrevistas realizadas com veteranos do movimento, ao longo da realização do documentário "Mbaraká - A Palavra que Age”. A história das Aty Guasu deverá ser abordada com maior profundidade em trabalho futuro. Para o objetivo aqui estabelecido, basta apreender que são, em linhas gerais, esses acontecimentos os que são citados pelos veteranos das assembleias para compor sua história.

280 Como já mencionado anteriormente, Pereira (2003) escreveu a respeito dessa experiência do Pirakuá. Vale, ainda, a leitura do relatório de Thomaz de Almeida (1985) que embasou a demarcação da área.

281 As notícias da época a respeito desses casos podem ser acessadas no arquivo mantido online pelo Instituto Socioambiental (ISA), em www.socioambiental.org

282 Em entrevista ao autor, em agosto de 2012. 
costumeira. Não é que a presença de apoiadores como Cimi e PKN tenha levado a alguma mudança: esse fator novo simplesmente evidenciou publicamente o que já vinha ocorrendo. Ou seja, os indígenas resistiam a sair de suas terras como já vinham fazendo havia muito tempo. Simplesmente, o ambiente é que se tornava mais democrático. Quem mudava era o país, não os Kaiowá e Guarani. Estávamos, é bom lembrar sempre, em plena "abertura lenta, gradual e segura”, promovida ao longo do último governo dos militares, o de João Figueiredo. Os movimentos sociais ressurgiam por todo o país, nos mais variados setores, e entre os indígenas não era diferente.

\section{Como funciona}

Depois dessa contextualização, vamos a uma breve descrição sobre como acontece uma assembleia do movimento Aty Guasu. Procurarei fazer uma espécie de retrato genérico, incorporando informações absorvidas ao longo de quatro anos frequentando essas reuniões. Ao todo, estive presente, nesse período, a sete Aty Guasu plenas, mais dois encontros do "conselho ampliado"283. Eventos paralelos - como encontros de professores indígenas, um encontro de acampamentos, eventos acadêmicos etc. - também foram muito úteis para construir nosso entendimento acerca da dinâmica da política kaiowá e guarani e as redes sociais que ela envolve.

Nem sempre acompanhei integralmente as reuniões, mas, ainda que estivesse impossibilitado de permanecer todo o tempo, procurei inteirar-me do teor das discussões e entender o sentido em que os eventos se desenvolviam. A verdade é que, embora seja possível encontrar invariâncias, cada assembleia tem traços únicos, em função da conjuntura política em que se realiza, das pessoas presentes e dos apoios que viabilizam o encontro.

Em primeiro lugar, toda Aty Guasu começa com uma espécie de bênção (jehovasa) conduzida pelos xamãs presentes, aos quais se juntam, em alguns momentos, quaisquer adultos que se disponham a empunhar o mbaraka ou o takuapu, ou mesmo a totalidade dos presentes - quando

283 O conselho da Aty Guasu foi constituído em 2010 e, em sua forma atual, reúne "representantes" das "sete microrregiões" componentes da área guarani/kaiowá, bem como assessores, indígenas e não indígenas, em caráter consultivo. Essa entidade passa por constantes transformações - pode não ser, já, o que vi durante meu trabalho de campo. Parece-me que tem caráter executivo, sobretudo. No segundo semestre de 2011, realizaram-se duas reuniões do "conselho ampliado": ao conselho propriamente dito, somou-se um determinado grupo de lideranças mais velhas (xamãs e líderes históricos da luta pela terra), chamado a opinar em um momento crítico, quando se intensificavam as agressões contra grupos que haviam ocupado terras reivindicadas. Por sinal, uma das diretrizes que o "conselho ampliado" determinou como reação aos ataques foi a realização de grandes sessões de reza (jeroky guasu) nas áreas de conflito. O termo é usado desde os anos 80. As jeroky guasu realizadas logo após o episódio em Pirakuá foram precursoras das Aty Guasu propriamente ditas. 
se gira em torno do altar, yvyra marangatu, mais para o final da performance de abertura.

Os cantos variam conforme os presentes, pois cada xamã tem seu próprio repertório, mas pode-se dizer, de forma geral, que esses porahei de abertura têm relação com o ato de chegada ao local - é preciso "esfriar" as coisas quando se está chegando, pois viajar é algo potencialmente perigoso - e a convocação dos deuses para proteger o evento. A sessão normalmente se inicia com cantos kaiowá e termina com cantos guarani - marcando a atual união política entre os dois grupos, penso eu. No final, todos fazem gestos circulares com as mãos, como que afastando para os lados as “coisas ruins". É para “aliviar”, diz-se, correntemente.

A letra dos cantos guarani não tem um significado apreensível pela audiência comum, ao contrário dos porahei kaiowá ${ }^{284}$. Os cantos fazem menção à convocação pelos xamãs, e à chegada dos seres brilhantes, nossos irmãos maiores. Eles são convocados para apoiar o desenrolar dos acontecimentos. Os seres do outro plano são brilhantes, reluzentes. Eles apoiam nossas ações da mesma forma que Sol apoiava Lua nas histórias que contam de sua passagem por esta terra. Essa relação entre os irmãos aparece reiteradamente em situações envolvendo a atuação dos xamãs (Montardo, 2009; Chamorro, 1995; Pimentel, 2006).

Três exemplos de letras de cantos kaiowá apresentados no início de uma Aty Guasu ${ }^{285}$ :

\section{Jahami jahecha ikua'akuaha rendy}

Vamos ver o fulgor de seus kua'akuaha (faixas coloridas, usadas na cintura).

\section{Ha'e ojekuaa mo'ã. Ha'e ou jevy}

Ele quase apareceu. Ele vem de volta.

Jegua renonde che ryke'y.

Meu irmão mais velho é o precursor do primeiro adorno.

Parcela considerável dos presentes, sejam os xamãs, ou os demais, usa os adornos de cabeça conhecidos como jeguaka, além de peças e colares variados, no peito e ombro. Em boa parte das

\footnotetext{
284 Vide comentários de Macedo (2009) e Montardo (2009) a respeito dos cantos entre os diversos grupos guarani, dos três dialetos existentes no Brasil.

${ }^{285}$ Transcritos e traduzidos com ajuda de Clara Barbosa de Almeida e Graciela Chamorro, às quais muito agradeço.
} 
coletividades guarani/kaiowá, hoje, é impossível conseguir as penas de arara, papagaio ou tucano que seriam desejáveis para confeccionar uma peça dessas, portanto é de lã colorida a maior parte dos adornos. Outra parte é de penas de galinha tingidas.

É comum que, logo após esse início dos trabalhos, se realize uma espécie de autoapresentação dos que vieram à reunião. Não são todos que falam numa ocasião como essa - mais comumente, tomam o microfone para anunciar-se os principais de cada coletivo, além de lideranças veteranas cuja presença não "representa" uma aldeia, propriamente (esse tipo de pessoa tem uma espécie de autoridade moral, independente da conjuntura política e oriunda de sua trajetória no movimento).

Os rezadores costumam ser mais reservados, mas têm a prerrogativa de falar quando, e se acharem necessário. Costumam expor-se, ainda, os vereadores e, eventualmente, alguns acadêmicos indígenas. Além disso, há um grupo variável de membros do conselho ${ }^{286}$ que coordena a reunião e costuma anunciar a pauta e fazer comentários mais longos, explicando determinados tópicos que serão discutidos. Professoras, geralmente, ficam encarregadas de registrar uma ata, na qual vão anotando resumos das declarações feitas ao longo da reunião.

Após a abertura, que frequentemente envolve movimentos circulares de todo o grupo em volta do altar, yvyra marangatu, os participantes dispõem-se em círculos. Caso não sejam adversas as condições climáticas, o normal é que se arme uma tenda de lona, bastante ampla, sob a qual as pessoas se arranjam em círculo - mas, como que reproduzindo a disposição kaiowá e guarani de autonomia pessoal, há grupos que se dispõem em lugares mais afastados, e mesmo quem permaneça de pé, fora da tenda. Em suma, não há grande formalidade, exceto pelo fato de que a fala de quem está com o microfone é sempre muito respeitada. Discussões ou brigas são algo que nunca se vê numa Aty Guasu - o que pode haver, sim, são discursos inflamados, mas jamais interrompidos.

Normalmente há 200, 300 pessoas numa Aty Guasu, mas, conforme o local, a quantidade pode ser bem maior (quando a reunião acontece nas proximidades de alguma aldeia mais populosa, como Dourados, muita gente vai até o evento de forma independente, não permanecendo durante toda sua duração, como deve fazer quem vem de longe). O rol dos participantes é sempre variável, pois nem sempre as informações sobre a realização das reuniões chegam devidamente às pessoas, e é frequente, também, que o transporte, nos últimos anos providenciado pela Funai, passe muito 
rápida e repentinamente pelas aldeias.

Segundo a tradição, durante a reunião se escolhe o local do próximo evento. Para muitos, sobretudo os mais antigos, receber em seu lugar de residência a Aty Guasu é uma honra. O comportamento das principais lideranças do local que sedia o evento lembra, realmente, o de anfitriãos de uma festa ${ }^{287}$. Há muito trabalho a fazer e, mesmo que, hoje, haja apoio da Funai para realizar o evento, ainda assim há uma série de coisas que as pessoas do local deverão proporcionar. $\mathrm{O}$ rodízio de locais normalmente tem relação com a conjuntura da luta pela terra. É comum que a explicação para a realização de uma Aty Guasu, em um determinado lugar, tenha a ver com a necessidade de "dar uma força" à luta daquele coletivo - ainda que, ali, não se deem as melhores condições em certo momento, do ponto de vista de um karai. Em agosto de 2011, por exemplo, enquanto se realizava uma Aty Guasu em Paso Piraju (Dourados), homens armados disparavam tiros - supostamente para o alto - em um rancho vizinho ao acampamento.

É comum que uma pessoa tenha querido ir à Aty Guasu, mas só descubra que o transporte passou por sua comunidade depois que ele já partiu. Além disso, há a questão das vagas disponíveis: se o capitão de uma determinada aldeia resolve ir, ele pode convidar algumas pessoas, e outras acabam ficando de fora. Essa questão dos convites, por sinal, costuma dar margem a confusões e mágoas. Enfim, devido a uma quantidade enorme de fatores, oscila consideravelmente o grupo presente a uma Aty Guasu.

Entre os presentes, costumam comportar-se com maior desenvoltura as lideranças reconhecidas pelas comunidades como "capitães", ou mburuvicha, dependendo da situação do grupo local - muito embora, como se viu (p. 113), se fale, genericamente, em tendotá kuéry, para os que participam dessas reuniões. É mais raro ver pessoas jovens tomando a palavra - excetuando-se, por exemplo, casos em que recebem delegação da liderança de seu grupo para estar ali presentes levando reivindicações ou denúncias. Os rezadores são ouvidos com grande deferência. E, nos últimos anos, as mulheres têm se imposto ${ }^{288}$.

\footnotetext{
${ }^{287} \mathrm{Na}$ percepção da aproximação entre chefes e anfitriãos, ligada à centralidade da festa, tiveram papel fundamental as conversas que vêm sendo realizadas desde 2010 com minha orientadora, Beatriz Perrone-Moisés. Para as reflexões dela, a respeito do tema, ver Perrone-Moisés, 2012. É a aproximação com essa reflexão de escopo mais amplo que tenho em mente quando ressalto o termo "anfitrião".

288 Aliás, em função das insistentes reivindicações por espaço para discutir temas de interesse das mulheres, iniciaram-se em 2012 as Kunhã Aty Guasu, ou "aty guasu das mulheres". A primeira aconteceu em maio, na reserva de Dourados. Na esteira dessa novidade, apareceram também as "Aty Guasu dos jovens" - a primeira ocorreu também em maio, em Pirajuí (Paranhos). No momento, não se pode assegurar que a iniciativa terá perenidade, mas ela sinaliza a necessidade de "fazer públicas" outras vozes e outros temas. Na Aty Guasu de fevereiro de 2012, em
} 
Após a abertura, acontecem sessões em que as pessoas se inscrevem e tomam o microfone, uma após a outra. Nessas falas, as pessoas anunciam, geralmente, por que vieram à reunião e clamam por informações sobre como está o processo de demarcação de sua terra, ou denunciam situações de violência, ou descaso. É frequente que se peça o respeito a um determinado tempo de exposição, mas o resultado costuma ser muito variável, entre outras coisas porque alguns relatos são frequentemente emocionados, e gera-se um constrangimento quanto a interromper a fala da pessoa. Como pedir respeito ao tempo a quem está narrando um assassinato e denunciando a total omissão, ou mesmo a cumplicidade dos agentes públicos?

A presença de autoridades, como representantes da Funai regional ou nacional, procuradores do MPF ou antropólogos (ligados ao MPF, à Funai ou encarregados de relatórios de identificação de terras) obedece a essa mesma lógica de compartilhamento de informações, muitas vezes, mas também tem caráter de cobrança. Os discursos podem tornar-se bastante acirrados quando um grupo local resolve questionar a Funai, sobretudo. Quanto aos demais atores, em geral, é menos comum que haja discursos mais ríspidos.

Enquanto os discursos em guarani, em geral, vão de um tom ameno e respeitoso ao emocional, nas falas em português, direcionadas às autoridades, o tom pode subir bastante. Deve-se notar, contudo, que no momento atual, em função da conjuntura política, a Funai não é vista como um órgão "inimigo" na maioria das situações ${ }^{289}$. No passado, já foi diferente - as Aty Guasu tinham tom de subversão, em alguns momentos. Hoje, os eventos contam com apoio oficial, em itens como transporte a alimentação. A dificuldade ainda é chegar a acordos sobre, por exemplo, a distribuição dos recursos ao longo do ano para apoiar as atividades - em função das peculiaridades do orçamento público, a autonomia tem seus limites, nesse sentido.

\footnotetext{
Jaguapiré (Tacuru), houve uma espécie de "rebelião" das mulheres numa das tardes de discussões. Acusando os moderadores do conselho de cercear-lhes a palavra, um grupo de mulheres tomou o microfone e, diante de representantes da Funai, elas passaram várias horas em discursos inflamados. O dilema atual das mulheres, pareceme, é como colocar em pauta temas como saúde, educação, alimentação, sem tornar-se refém do discurso do governo do Estado, que, como se viu, considera que essa discussão sobre acesso a políticas públicas deve se sobrepor e substituir a reivindicação pela demarcação de terras.

289 O que não a exime de cobranças, por vezes muito duras. Simplesmente, o que se nota é que os Kaiowá e Guarani percebem a maior permeabilidade das estruturas políticas, atualmente. É preciso lembrar sempre que meu trabalho de campo se dá em conjuntura totalmente marcada pelo acordo que levou ao lançamento dos seis grupos de trabalho de identificação e delimitação de terras de 2008. Ainda há, de qualquer forma, casos em que o procedimento de gente ligada à Funai é absurdo e inaceitável: em julho de 2012, a Polícia Federal incluiu um funcionário do órgão entre os 23 indiciados pelo ataque que vitimou o líder Nísio Gomes. Na Aty Guasu que aconteceu nesse mesmo mês, o coordenador da Funai em Ponta Porã, Silvio Raimundo da Silva, lamentava o fato e informava aos indígenas que uma investigação interna determinaria punições administrativas, caso fosse comprovada a participação apontada na investigação.
} 
Considero que a Aty Guasu é, hoje, na prática, uma "instância representativa" dos Kaiowá e Guarani, conforme reconhece a Convenção 169 da Organização Internacional do Trabalho (OIT). Houve notável avanço, nesse sentido, com a consolidação do diálogo do movimento com a Secretaria Geral da Presidência da República, no exato período em que eu realizava a última etapa prolongada de meu trabalho de campo, no segundo semestre de 2011.

A criação do Comitê Gestor de Políticas Indigenistas Integradas do Cone Sul de MS, em novembro desse ano, foi um marco, nesse sentido. O comitê criado pelo governo federal anteriormente, em 2006, na esteira do escândalo pelos casos de desnutrição infantil (vide introdução), não estruturou diálogo semelhante, e boa parte do seu naufrágio esteve certamente relacionada à inevitável inconsistência de suas ações, em função dessa deficiência. Por enquanto, há, sobretudo, expectativa - os avanços só serão visíveis, efetivamente, quando os relatórios de 2008 vierem a público.

Essa peculiar representação instalada pela Aty Guasu, observemos, tem características importantes para o debate sobre os direitos indígenas no Brasil no sentido de que, aqui, trata-se de reconhecer um "sujeito de direito" que não precisa constituir uma associação de sociedade civil como se tem visto nas últimas décadas na Amazônia, sobretudo (ver Carneiro da Cunha, 335-6) - e que, portanto, não visa obter "projetos", basicamente persiste na luta pela terra.

Procurando pensar nos termos postos pela autora, uma vez que a Aty Guasu não se "cristaliza" com a formação de uma associação, permanece suficientemente flexível para que não se fortaleçam as contradições entre as "autoridades legítimas" e seus "representantes legais" - na verdade, as pessoas que parecem melhor adaptar-se ao trabalho no conselho da Aty Guasu têm sido as que têm clareza de que o grupo deve, sobretudo, executar o que a assembleia determina, como servidores e porta-vozes dela. O desafio para o futuro, porém, é garantir que apoios como os que a Funai, hoje, dá para a realização das assembleias poderão se manter independente das mudanças de governo (considerando os deveres estabelecidos para os países pela Convenção 169, como o de dar suporte a essas iniciativas). Só o tempo dirá, também, se será possível manter sob controle os equívocos nesse diálogo.

$$
* * *
$$

Outra constante nas Aty Guasu é o espaço para os relatos dos antigos, em que as pessoas rememoram os acontecimentos relativos ao processo de luta pela terra em seus tekoha. É explícita a 
intenção didática, de compartilhar experiências, motivar os mais novos e, sobretudo, orientar os grupos locais que tomaram há menos tempo a decisão de recuperar suas terras de origem.

Por exemplo, rendeu muita discussão um caso recente em que houve violência por parte dos fazendeiros contra o grupo que realizava uma ocupação. Conversava-se, fora das assembleias, sobre os motivos pelos quais o episódio ruim teria ocorrido - as hipóteses giravam em torno da desunião entre as duas famílias que formavam o grupo, ou pela presença de evangélicos intolerantes, que teriam impedido os xamãs de rezarem devidamente. Da parte das lideranças que refletem sobre as estratégias menos relacionadas ao campo xamânico, havia preocupação com o fato de que o coletivo havia decidido realizar a ocupação sem muitas consultas aos veteranos do movimento, e em função disso acabaram expondo-se perigosamente, pois não conheciam certas medidas de segurança que é preciso tomar.

O fato é que, em público, na assembleia, toda essa preocupação se traduz em uma conversa muito sutil, um aconselhamento mesmo, no melhor estilo da política kaiowá e guarani - jamais poderia haver repreensão, o que geraria constrangimentos e só faria o grupo afastar-se ainda mais do movimento. O sentido desses relatos didáticos foi comentado recentemente, em artigo de Tonico Benites $^{290}$ :

\begin{abstract}
“As Aty Guasu são também um lugar de transmissão de saber. As narrações das lideranças guarani-kaiowá no evento reafirmam que, após a chegada dos europeus, a vida desses indígenas foi marcada por diversas interferências de agentes colonizadores portugueses e espanhóis. A narração das lideranças vai ao encontro da literatura histórica e confirma que os povos indígenas foram vítimas de dominação dos missionários, dos encomenderos e dos bandeirantes. Os discursos das lideranças apontam que, diante desses fatos marcantes suscitados pelas ações colonialistas, as lideranças indígenas, por meio de sua organização política e religiosa, passaram a discutir os novos problemas e se articular, e no decorrer da história reagiram de diversas formas em defesa dos seus territórios e da vida e cultura dos seus grupos. Em todas as assembleias (...), as lideranças guaranis idosas reafirmam em consenso que nossos antepassados foram
\end{abstract}

290 Além de antropólogo, doutorando no Museu Nacional do Rio de Janeiro, Tonico integra o Conselho da Aty Guasu. Sua família é do Jaguapiré, uma das primeiras áreas a serem reconquistadas pelos Kaiowá e Guarani do movimento. 
heróis guerreiros, que lutaram, sofreram e morreram ao tentar defender os seus territórios e o modo de ser e viver guarani. Frente a essa luta histórica difícil, nos eventos, os mais velhos exigem frequentemente da nova geração que mantenham o orgulho de serem Guarani” (Benites, 2010: 10).

As discussões frequentemente enveredam para temas ligados ao xamanismo. É frisada, constantemente, a importância de manter-se apegado ao ñande reko e à prática dos cantos, porahei, como forma de garantir sucesso nas empreitadas políticas, manter a união do grupo, a harmonia e impedir a ocorrência de adversidades.

O vaivém dos processos de regularização das terras kaiowá e guarani é extremamente complexo. Qualquer um que não tenha intimidade com a linguagem do Direito terá dificuldades de acompanhar a infinidade de ações e decisões liminares e reversões e agravos e cautelares etc. etc. que envolvem, às vezes, a simples possibilidade de permanecer num pequeno pedaço de terras, de 10, 30 ou 50 hectares, enquanto o grupo aguarda o resultado dos estudos de identificação e delimitação das terras.

Em função disso, antropólogos, advogados, procuradores do MPF e da Funai que estejam presentes são muito requisitados, à parte da reunião, para prestar esclarecimentos sobre as dezenas de ações judiciais que afetam as terras reivindicadas. Não é incomum que surjam confusões envolvendo processos administrativos ou jurídicos em relação aos quais ninguém presente possa falar. Com centenas de pessoas presentes, os boatos - e mal-entendidos - acabam aparecendo, inevitavelmente.

É frequente que se aproveite a infra-estrutura das escolas presentes no local da reunião. Evidentemente, as condições sanitárias costumam entrar em colapso, e os lugares para pernoite são precários. Ainda assim, não costuma haver reclamações, exceto se há atrasos na comida. As refeições são preparadas por uma equipe de mulheres, normalmente. Já ouvi discursos severos, por parte de veteranas do movimento, clamando pelo reconhecimento a elas pela realização dessas tarefas normalmente invisíveis a olhos masculinos desatentos. Nos primeiros tempos das assembleias, sobretudo, lembram elas, as condições eram muito precárias.

Não é incomum que, após o almoço, antes que volte a assembleia, alguém tome do microfone para contar uma piada ou cantar uma música. E não se espante se, meia hora depois, ouvir um discurso emocionado, de alguém em prantos, ou uma fala inflamada, de uma liderança que 
cobra atitude da Funai. Assim é o mundo dos Kaiowá e Guarani, repleto de intensidade.

Os trabalhos do dia podem ser encerrados por mais uma sessão de porahei, ou por alguma apresentação de um grupo de dança da comunidade local. Após o jantar, frequentemente se organiza uma sessão de vídeos, projetados em algum telão ou numa parede - a predileção é por gravações em que as próprias comunidades apareçam, em seu processo de luta pela terra. Não se exige sofisticação: o que as pessoas parecem querer é ver-se na tela. Também são apreciados os vídeos que trazem imagens de líderes dos tempos antigos, como Marçal de Souza, ou que mostrem cenas de viagens feitas pelas lideranças para atividades como os Acampamentos Terra Livre, em Brasília $^{291}$, ou a Conferência Rio+20.

Enquanto a sessão de vídeo vai se esvaziando, o som dos cantos e do mbaraka se amplifica. Os xamãs presentes costumam realizar uma sessão noturna de porahei. Pessoas buscam suas bênçãos e rezas para obter curas - frequentemente, trazem crianças no colo. Mais algum tempo, e outra vez o ambiente se transforma. Surgem as rodas de guahu, puxadas pelos mais velhos, e de guaxiré, reunindo dezenas de jovens. Daí, se o tempo não estiver frio ou chuvoso, a festa segue até o amanhecer. $\mathrm{O}$ que não impede que os xamãs abram os trabalhos de um novo dia de assembleia às 8 horas da manhã, rigorosamente.

O dia final da assembleia costuma ser um pouco mais congestionado, em função da pressa para voltar para casa. O documento final, composto por um grupo ligado ao conselho, é lido para todos. Algum reparo pode ser feito, conforme a ocasião, mas dificilmente haverá conflito (vide, adiante, o único caso em que vi uma situação de confrontação durante uma Aty Guasu). Os rezadores encerrarão os trabalhos da assembleia, como de hábito, realizando o batismo do documento - e, frequentemente, também abençoando as crianças presentes, especialmente bebês de colo, e quem mais se apresentar a eles.

\section{Assembleias na história}

Há algumas (poucas) tentativas de traçar uma história mais profunda das Aty Guasu. Meliá localiza, entre os documentos do século XVII, a "primeira Aty Guasu da história a ser

291 Esses acampamentos acontecem em Brasília, principalmente, e reúnem lideranças do movimento indígena de todo o país, para discutir a conjuntura política e dialogar o governo federal e outras autoridades. 
registrada" ${ }^{292}$. Seria uma assembleia dos trabalhadores indígenas nos ervais de Mbaracayú, realizada em 1630 (Cortesão, 1951: 352-61). Ao final do evento, aparentemente, foi redigida uma carta, em guarani, com um apelo e uma denúncia às autoridades, a respeito das péssimas condições de trabalho que enfrentavam os indígenas na extração da erva-mate. $\mathrm{O}$ documento tem trechos antológicos, que aparecem em diversos estudos históricos ("aquellos yerbales de Mbaracayú están de todo llenos de los huesos de nuestra gente"). Meliá chega mesmo a considerá-lo "el primer texto largo auténticamente guaraní” (2004b: 88).

Azara, no século XVIII, visitou diversos grupos indígenas na bacia platina. A certa altura ${ }^{293}$, ele diz ser válida para os Guarani a descrição que faz das assembleias charrua, a qual segue:

"Los varones cabezas de familia se juntan todos los días al anochecer, formando círculo sentados en sus talones, para convenirse en las centinelas que han de apostar y vigilar aquella noche, porque nunca las omiten, aun cuando nada teman. Dan cuenta allí de si en lo que han caminado aquel día han descubierto indicio de enemigos, y hace cada uno relación de los campos adonde irá a cazar o a pasearse el día siguiente para deducir quién le ocasionó la muerte u otra desgracia si le sucede. Si alguno forma un proyecto común como mudar a otra parte la toldería, atacar a otra nación o defenderse de ella, lo propone. La asamblea de[l]ibera, y verifican la idea los que la aprueban, sin asistir los que no aprobaron, y muchas veces tampoco algunos de los aprobantes, los cuales no incurren en pena ni están obligados a cumplir lo que ofrecieron. Las partes interesadas componen las diferencias particulares que rara vez les ocurren, sin que nadie se entrometa en ellas. Pero si no se avienen, se acometen a puñadas ensangrentándose las narices y alguna vez arrancándose o rompiendo algún diente, hasta que cansados vuelve el uno la espalda, y nadie habla más del negocio. En estas cosas nunca intervienen armas ni he visto ni oído que un charrúa ni otro indio silvestre haya muerto a otro de su misma nación por ningún motivo." (Azara, 2002: cap. X, § 20)

292 O autor fez essa consideração durante a conferência "Uso político de la escritura guarani en el siglo XVIII", ministrada no VIII Encontro Sobre Leitura e Escrita em Sociedades Indígenas, em Dourados-MS, em 28/5/2010. O referido documento é analisado por Meliá em outros de seus escritos (2004b).

293 No cap X, § 54: “Cada pueblo se dirige por una asamblea igual a la citada en el núm. 20 en la que suele adoptarse el dictamen del cacique, si este es reputado por sagaz y valiente". 
O problema é que Azara não nutria grande simpatia pelos grupos que chamava de Guarani, de modo que não é possível tirar maiores conclusões sobre muitos pontos que ele descreve. A certa altura, dispara: "La pusilanimidad es el carácter que más resplandece y distingue los guaranís de las otras naciones” (idem: § 61). O que arrisco dizer é que a descrição de coletivos de língua guarani amedrontados pela perseguição empreendida por outros grupos indígenas condiz com o cenário que a história traça para a região da Alta Bacia Platina no século XVIII, quando Azara faz suas viagens. Afinal, como sabemos, trata-se do período em que os Guarani ainda amargam uma enorme redução populacional em função da perseguição dos paulistas e da experiência missioneira frustrada, ao mesmo tempo em que sofrem com a invasão dos grupos Chané e Guaikuru vindos do Chaco: "Como si quisiesen ocultar sus pueblos, todos estaban inmediatos y dentro de grandes bosques, o a lo largo de ríos donde hay siempre mucho bosque; si estaban en campiñas francas era cuando distaban mucho de otra nación diferente” (idem; cap X, § 52).

A influência e o prestígio de lideranças sobre toda uma área ("guára”, como diria Susnik), bem como sua articulação em iniciativas guerreiras, são amplamente registrados pelos documentos coloniais, como já vimos. Não se tem, contudo, para a área guarani, a riqueza de detalhes obtidos entre os Tupinambá da costa menos de um século antes. O fato é que, apesar dessa ausência de detalhes, a articulação de grupos guarani em uma rede multilocal não parece algo estranho ou novo ${ }^{294}$, a não ser na escala (e intensidade ${ }^{295}$ ) que é alcançada com os novos meios à disposição dos Guarani e Kaiowá hoje (transporte rodoviário, telefones - agora, celulares e internet -, apoio de órgãos públicos e de ONGs etc.). Nesse sentido é que, creio, pode-se entender por que as atuais Aty Guasu são vistas, ao mesmo tempo, como uma novidade e como algo "tradicional".

No Paraguai, dentre os Paĩ Tavyterã, segundo Friedl Grünberg (1988: 20), as assembleias aty guasu começam em 1975. Por lá, como se sabe, foi desenvolvido nos anos 70 e 80 o Projeto Paĩ Tavyterã (PPT), junto ao qual Thomaz de Almeida estagiou e de onde tirou a inspiração para propor o PKN. Grünberg assim relata:

“En mayo de 1975 tuvo lugar el primer 'aty guazu' - asamblea de los Paĩ-, de la cual participaron 21 lideres religiosos y políticos de 12 C.I. La iniciativa partió de uno de los dirigentes políticos de Yvypyte, la reservación establecida por el Ministerio de Defensa. Este mburuvichá tenía buenos

\footnotetext{
294 Como já apontamos em relação às mortes por enforcamento entre os Kaiowá e Guarani (2006), não é porque não se tenha registros na memória sobre alguma coisa que ela não pode ser considerada familiar. 295 Mas posso estar sendo cronocêntrico aqui: seria a intensidade uma função da velocidade das interações?
} 
contactos con los militares y con un movimiento iniciado a mediados de los '70 (Proyecto Marandú), que buscaba estimular la organización de los indígenas en el Paraguay (...).” (1988: 20)

A antropóloga tem essa mesma impressão, descrita acima, de que o ato de reunir-se para discutir os problemas em comum é visto com naturalidade pelos indígenas:

"Es de suponer que este tipo de reuniones no era nuevo para los Paĩ, pero probablemente sí era nuevo tener una asamblea de índole regional como ésta, puesto que, sin medios de transporte y ayuda de afuera, una reunión de estas proporciones significaria enormes gastos y esfuerzos para los Paĩ, debido a las grandes distancias existentes. Probablemente este tipo de asamblea era sólo era realizado ante amenaza de guerra o transgresiones territoriales, así como cuando se elegia un 'cacique de guerra' para toda la duración de una guerra, el cual sobrepasaba en autoridade a los líderes políticos y religiosos” (1988: 20)

Falando de modo genérico sobre os Guarani, Schaden fala, também, em uma "assembleia dos chefes de família", "hoje com as características de senado informal”, com "função consultiva e deliberativa", sem "grande autoridade". "Sua importância talvez tenha diminuído por influência da instituição do capitanato", sugere ele, sobre experiência de campo que teve nos anos 40 (ver 1974: 100). O autor chega a mencionar que participou de uma sessão desse "senado" em Jacareí (a reserva de Porto Lindo, hoje Terra Indígena Yvy Katu), em Iguatemi (MS). Müller, que originalmente publicou seus artigos nos anos 30, também menciona um “conselho dos homens reunidos" (1989: 57).

Em sua forma atual, as Aty Guasu do lado brasileiro se iniciam em algum momento dos anos $80^{296}$, que varia conforme o interlocutor. De um lado, havia as ações do PKN em torno das "roças comunitárias", que ofereceram às lideranças indígenas os meios para incrementar sua articulação; de outro, as ações dos grupos em torno do Cimi parecem ser lembradas, sobretudo, por haver proporcionado o que se costuma chamar, nos movimentos sociais, "formação política” a jovens

296 Desde 1978, acontecem reuniões que Thomaz de Almeida considera serem "aty guasu", mas elas estavam relacionadas ao projeto de apoio à produção agrícola que o PKN tocava. O tema da terra vai, pouco a pouco, sendo imposto pelas lideranças nessas reuniões, mas, nos primeiros anos, várias pessoas avaliam que não havia, propriamente, uma articulação multilocal em torno da luta pela terra. Num primeiro momento, o que ocorrem são episódios de apoio pontual às lutas do Paraguasu (em torno de 1978, em Paranhos), por parte do PKN, e Rancho Jakare (a partir de 1977, aproximadamente), por parte do Cimi e outros atores. 
indígenas letrados - além do apoio logístico a várias iniciativas das lideranças.

Do ponto de vista dos atores não indígenas ligados a cada um desses "lados" (muito embora, no passado, eles não estivessem tão claramente definidos), trata-se de ações, por vezes, opostas. Sobretudo, certo discurso antropológico frisa a inutilidade e a inadequação de uma educação política diante das "formas tradicionais" de política guarani/kaiowá. Mura, por exemplo, resume o que seria a argumentação de um desses lados, dizendo que, diferente do Cimi, os antropólogos preferiam "dar suporte às aty guasu organizadas segundo a tradição indígena” (2006: 175), em vez de tentar dar-lhes "formação política".

Do ponto de vista dos indígenas, contudo, essa interação entre as duas formas de lidar com o tema (Cimi/PKN) não é vista como algo contraditório, necessariamente. Tanto que, até hoje, antropólogos e missionários do Cimi (bem como vários outros grupos que se apresentem, desde a extensão universitária até o proselitismo evangélico) são igualmente requisitados no apoio à luta pelos direitos dos Guarani e Kaiowá.

O que é sempre frisado - aí, sim, há uma constante - é que a iniciativa das lideranças guarani e kaiowá é que determina a história. Ao fim e ao cabo, creio que acerta Pereira ao sublinhar o protagonismo dos coletivos indígenas na história do movimento pela recuperação das terras, em contraponto a "alguns mitos que predominam em determinados setores da política regional de que os índios que se envolvem nessas disputas estariam sendo 'insuflados e dirigidos' por interesses escusos de determinadas organizações indigenistas" (2003: 144). Thomaz de Almeida (2000b), nesse sentido, também afasta aproximações indevidas com a agência política do Movimento dos Sem-Terra (outro dos acusados de "influenciar" os indígenas, além dos próprios antropólogos, claro).

Numa espécie de dança das cadeiras, os apoiadores mudam, constantemente, de posição (o que nos parece bastante apropriado à lógica política guarani e kaiowá). Explico-me: com coletivos fazendo-se e refazendo-se a todo momento (em função de conflitos, alianças, movimentações), é conveniente que haja uma diversidade de aliados. Cada um será útil a um determinado coletivo, conforme suas possibilidades e as necessidades do grupo, conforme a fase do confronto. O Cimi é útil a grupos (e em situações) que a Funai não tem tanta condição de amparar; da mesma forma, os antropólogos colaboram em determinadas tarefas que um grupo evangélico não teria como apoiar, mas isso não quer dizer que a distribuição de bens que esses religiosos oferecem não seja útil a certos grupos, em determinados momentos. 
Na realidade, o apoio de qualquer um desses atores pode ser requisitado ou não, de acordo com o que um dado coletivo está vivendo ${ }^{297}$. A observação não é leviana: a necessidade por que passam os coletivos guarani/kaiowá é simplesmente desesperadora, em diversos momentos. Estou falando de fome, sede, doenças, desesperança, terror, racismo, violência, mortes - de idosos, de crianças, muitas vezes. Não se trata de ser mais ou menos tradicional, mais ou menos politicamente consciente, mais ou menos apegado ao "teko". Trata-se, na maioria das vezes, e isto sim, de necessidade pura e simples.

Importante, sobretudo, é reter o que comenta Friedl Grünberg sobre a forma como a luta pela terra é vista: como uma espécie de "guerra latente", que, de alguma forma, parece evocar antigas práticas dos Paĩ/Kaiowá para enfrentar a situação de conflito com os karai:

“Esto parece relacionar la antigua tradición de las grandes asambleas en tiempos de amenazas territoriales con la situación actual. La garantización de tierras siempre fue uno de los principales temas de los 'aty guazú que desde 1975 tienen lugar (en períodos irregulares)” (1988: 20).

\section{Consenso}

O objetivo da realização de uma assembleia, entre nós, é frequentemente entendido como um jogo - uma votação, da qual um dos dois lados sairá vitorioso. No caso de uma assembleia ameríndia, o objetivo, em geral, é bem outro: alcançar aquilo que denominamos consenso. Não encontrei ninguém que me definisse uma tradução para o termo, em guarani. As pessoas preferem explicar o processo que ocorre durante a assembleia como um progressivo "pensar junto", ou "chegar a uma só ideia”.

No momento histórico em que realizei a pesquisa que embasa esta tese (2009-2012), praticamente não havia grandes dissensos, no âmbito das Aty Guasu. Desde 2009, os Kaiowá e Guarani estão em compasso de espera, por conta dos grupos de trabalho constituídos pela Funai em 2008. De maneira que tive poucas oportunidades de observar algum processo mais amplo de construção de consenso a partir de uma situação mais complexa. Em função da dificuldade de

297 Em suma, tomar partido em determinadas disputas é simplesmente ingênuo. Mas a ingenuidade é, também, algo bem-vindo, tanto como uma larga experiência em trabalho na área. Pessoas recém-chegadas, que não estão inteiradas das disputas entre grupos, podem ser particularmente requisitadas. 
presenciar esse tipo de processo, narro a seguir de forma pormenorizada um episódio em que o confronto emergiu com muita intensidade.

\section{Ato I}

Como já abordado anteriormente, o momento em que se inicia o trabalho de campo que apoia esta tese era extremamente delicado. É por isso que foi logo após nossa chegada, conforme narramos na introdução, que se deu a situação mais interessante - nos termos concernentes ao presente capítulo - presenciada ao longo de nossa investigação. O relato a seguir diz respeito à primeira Aty Guasu que acompanhei durante a pesquisa.

Naqueles primeiros dias da pesquisa, em fevereiro de 2009, um grupo de indígenas formado predominantemente por Terena e Guarani, das comunidades de Jaguapiru e Bororó, de Dourados, acampava em frente da sede da Funai na cidade. Eles exigiam a saída de Margarida Nicoletti ${ }^{298}$ do comando da fundação na região, acusando-a de negligenciar a assistência às aldeias e de cometer uma série de irregularidades na administração, incluindo o superfaturamento de compras e o descaso com automóveis e com os produtos adquiridos para as cestas básicas distribuídas nas aldeias.

Outros grupos de lideranças indígenas, por sua vez, acusaram os manifestantes de estarem a serviço de políticos e fazendeiros da região que tinham interesse em dificultar os trabalhos da Funai a fim de atrasar o processo de demarcação de terras. O protesto seguiu por todo o mês de fevereiro, até que a Polícia Federal retirasse os manifestantes, que saíram pacificamente. Poucos dias depois, o Ministério Público Federal anunciou que abriria investigação para apurar suspeitas de apoio ao

298 Nicoletti, que é assistente social, chegara ao cargo durante o período de atuação do Comitê Gestor de Ações Indigenistas Integradas para a Região da Grande Dourados, lançado por volta de 2005, com a participação de 14 órgãos federais, incluindo dez ministérios. Coordenado pelo Ministério do Desenvolvimento Social e Combate à Fome, o comitê tinha o objetivo de coordenar, articular, avaliar e monitorar as ações federais desenvolvidas junto aos Guarani e Kaiowá. Sua criação fez parte da reação do governo federal ao escândalo que surgiu no bojo das notícias sobre um suposto aumento das mortes de crianças indígenas por desnutrição em Dourados, em 2005. O MDS foi convocado para apagar o incêndio, mas não tinha estrutura interna para assumir a tarefa. O resultado é que, tão logo o escândalo se dissipou, em 2007, o fôlego da reação diminuiu, e a sustentação política de Nicoletti se esvaiu (o que se traduzia em uma morosidade no atendimento de demandas administrativas, liberação de recursos etc.). A situação só se estabilizaria a partir de 2010, com a chamada reestruturação da Funai (a partir do decreto presidencial 7.056, de 28/12/2009, uma série de medidas administrativas que reorientou ações do órgão em nível nacional, provocando protestos em várias regiões, mas tendo sido bem recebida no sul de MS, uma vez que redirecionou recursos - humanos, sobretudo - à área guarani/kaiowá). 
protesto por parte de políticos e fazendeiros contrários aos GTs de demarcação ${ }^{299}$.

Não era preciso investigar com muito afinco para encontrar os laços com políticos. Alguns dos líderes indígenas da manifestação eram candidatos derrotados ao cargo de vereador poucos meses antes, pelos mesmos partidos que, publicamente, já haviam declarado oposição às demarcações. Por sua vez, não é segredo que, entre os que se posicionavam contra a ocupação, havia também indígenas filiados a partidos ligados ao governo federal - particularmente o PT. Mas, vale observar, do ponto de vista kaiowá/guarani, não é o partido que "usa" as pessoas: elas é que se filiam ao partido que apoiará sua luta - seja ela a demarcação de terras ou a obtenção de benefícios sociais $^{300}$.

Estive no local no dia da retirada dos manifestantes, ordenada pela Justiça. Não era interesse dos envolvidos por parte do governo federal que houvesse qualquer ato de violência e, felizmente, da parte dos manifestantes - provavelmente pelo receio da prisão e das complicações judiciais decorrentes de enfrentar a PF -, tampouco houve resistência. Depois de um bom par de horas de conversas e performances em diálogo com a imprensa presente, eles concordaram em passar ao outro lado da rua, sublinhando que continuariam o protesto até a saída de Nicoletti do cargo de administradora da Funai na região.

"Senhor Presidente da Funai, Marcio Meira: só sairemos depois que Margarida for exonerada do cargo de chefe", estampava uma faixa, em frente do prédio da Funai. E assinavam-na: “Indígena Kaiwá, Guarani e Terena - MS”. Essa designação genérica não é, evidentemente, casual. Existe, sempre (com maior ou menos intensidade e alcance), uma disputa em torno de quem é reconhecido como "liderança" ou "representante" na interlocução com o Estado.

Nesse processo de reconhecimento, opera de forma adicional a mídia regional, porque é a projeção de tal ou qual grupo nas TVs, rádios e jornais que pode justificar a convocação desta ou daquela figura para uma reunião, ou o fechamento de um acordo ou convênio com esta ou aquela entidade - em Dourados, já há diversas ONGs que atuam junto aos indígenas, ou mesmo são dirigidas por alguns deles ${ }^{301}$.

299 Meses mais tarde, o MPF confirmou ter encontrado indícios de que políticos (cujos nomes não foram citados publicamente, até onde tenho conhecimento) ligados aos ruralistas da região tinham apoiado os protestos com transporte e alimentação para os manifestantes.

300 Para um estudo sobre a participação de indígenas em eleições que dialoga teoricamente com vários elementos aqui citados, ver Ribeiro, 2010.

301 No plano federal, verifica-se uma estabilização muito recente nessa relação. Durante um período, ela se deu por meio da aproximação de lideranças indígenas do PT, como forma de construir a legitimação da Aty Guasu 
No contexto imperante em Mato Grosso do Sul entre 2008 e 2010, era visível que o poder estadual tentava desviar o debate sobre a questão indígena da demarcação de terras. O governador e alguns de seus aliados costumavam dizer que os índios "não querem tanta terra assim como dizem por aî" e que os Kaiowá e Guarani estariam mais interessados em ações de assistência social, como saúde, educação, projetos de desenvolvimento. Nesse sentido, criticar, digamos, os atrasos na entrega das cestas básicas que deveriam ser fornecidas pela Funai poderia ser conveniente inclusive porque PMDB e PT disputam espaço nas representações estaduais dos órgãos federais.

Enquanto a imprensa entrevistava duas indígenas que falavam pelo movimento ${ }^{302}$, um funcionário da Funai sussurrava para mim: "Você acha que esse pessoal aqui representa os mais de 40 mil Guarani-Kaiowá?" Chorando, uma senhora contava aos policiais e à imprensa, de forma confusa, que, "por ordem da coordenadora", um grupo de índios tinha derrubado sua casa. Outros reclamavam com os policiais e denunciavam à imprensa que a Funai estava dando "combustível e trator" "só para quem apoia ela". "Dão até duas cestas básicas por mês pra quem apoia ela", um diz ao policial. "Hoje em dia, tudo funciona na base da pressão, o sr. entende, né?"

Maioria, minoria e totalidade se confundem na experiência de uma política que busca o consenso. De qualquer modo, por ora, poderia dizer que, no contexto em questão, como não se calculam quantas pessoas pertencem a qualquer grupo que tenha uma opinião em particular, cada um deles usa o espaço de que dispõe para dizer-se portador do juízo que é da totalidade da população indígena. Alguns usam o espaço público que conseguem para vender a ideia de que é a sua razão a que vale pela totalidade dos Guarani e Kaiowá.

Enquanto vago a esmo pela calçada, ouvindo as conversas dos diferentes grupos, aproximase de mim uma mulher que me revela ser parente do líder guarani Marçal de Souza, morto em 1983. Me espanto ao perceber que associa a memória dele àquilo que me parece completamente oposto a tudo o que ele defendeu em vida (até onde sei, claro): a conciliação com os fazendeiros e a abdicação da luta pela terra. "Já choramos demais pela morte dos nossos líderes", ela justifica. "Você ia gostar que alguém entrasse em sua casa e pegasse o que é seu?", emenda, dizendo compreender a revolta dos fazendeiros com o processo de demarcação de terras indígenas - uma

(atravessada, contudo, por essas relações). Só mais recentemente, contudo, o próprio Conselho da Aty Guasu tem assumido uma interlocução crescente - mas ainda de forma muito dependente do entendimento de pessoas específicas no governo federal (nada garante, por enquanto, que, caso elas abandonem seus cargos, esse quadro não se alterará).

302 Uma delas, à época, segundo consta, candidata derrotada a vereador pelo Democratas - ex-PFL - e dirigente de uma ONG dirigida por ela e pela filha de uma liderança guarani/kaiowá já falecida 
frase usada publicamente por mais de um fazendeiro em declarações contrárias aos processos de reconhecimento de terras.

$\mathrm{Na}$ ocupação também estavam presentes, em número menor, algumas lideranças de áreas para as quais o processo de identificação de terras iniciado em 2008 não era relevante (em função de suas áreas já estarem em estágios mais avançados de reconhecimento jurídico). Para esse tipo de caso, pesavam mais os problemas com a Funai do que a percepção de que a ocupação atravancava o trabalho dos grupos que realizavam a identificação das novas áreas. Além disso, segundo alguns depoimentos que posteriormente coletei, várias dessas pessoas alegam só ter se dado conta tarde demais de que estavam ali servindo aos objetivos de gente que trabalhava em alinhamento com os fazendeiros e políticos de direita da região.

\section{Ato II}

Cheguei à reserva de Amambai na tarde de quinta-feira, 26 de fevereiro de 2009. A Aty Guasu era emergencial, tinha sido marcada às pressas porque era necessário encontrar uma solução política para o impasse alimentado pelo grupo que ocupara a Funai até poucos dias antes. Persistiam as notícias na mídia regional sobre as lideranças indígenas que insistiam em pedir a saída da coordenadora da Funai, e os que se opunham a isso queriam rapidamente mostrar que esse não era o desejo dos Guarani e Kaiowá em seu conjunto.

A convocação dessa reunião de emergência foi, então, articulada por lideranças, à época, participantes da estrutura de representação dos indígenas junto à Funai - como o Conselho Nacional de Política Indigenista, CNPI -, bem como de outros indígenas que hoje ocupam cargo de vereador em alguns municípios da região, com apoio do $\mathrm{Cimi}^{303}$. O grupo que havia organizado a ocupação do prédio da Funai em Dourados, por sua vez, também se fazia presente. Alguns chegaram na própria quinta-feira, outros na sexta, quando a reunião já começava.

A reunião aconteceu nas dependências de uma das escolas da terra indígena. A maior parte dos participantes dormia nas salas de aula, alguns montaram barracas no pátio. Às oito da manhã da sexta-feira se inicia a sequência ritual que abre os trabalhos, os quais vão se dar na quadra coberta

303 Ainda não estava formalizado, à época, o Conselho da Aty Guasu. 
da escola. Parte da performance é puxada pelos xamãs kaiowá, e parte, pelos guarani ${ }^{304}$.

Só depois de findado esse trabalho dos xamãs pode ser iniciada a reunião. Ela começa com a composição da mesa de trabalhos, que destaca veteranos da luta pela terra. Também são convocadas duas professoras para redigir a ata do encontro. Em seguida, há a auto-apresentação, e a mesa inicia os trabalhos com a divulgação da pauta. Até aqui, a maior parte das falas ocorre em guarani. Fica evidente que não se faz questão nenhuma que os karai presentes entendam o que está sendo discutido.

A primeira proposta da mesa é dividir os cerca de 300 presentes em dez grupos de discussão. O primeiro tema é "terra e sustentabilidade", segundo a coordenação. Alguém passa numerando as pessoas de 1 a 10. É dito que cada um deverá se juntar ao grupo correspondente ao número que lhe foi atribuído, mas isso só causa muita confusão, porque não houve aviso prévio, e boa parte das pessoas já esqueceu qual foi o número que ganhou.

Em vez de observar essa divisão imposta, os presentes começam a formar grupos conforme a afinidade e a vizinhança do lugar onde estão sentados. As pessoas que coordenaram a ocupação da Funai formam o "grupo 1". Uma liderança desse coletivo vai até a mesa, toma o microfone e diz, usando mais português do que a maioria fazia, que "sustentabilidade" era conseguir tratores, assistência técnica e apoio público para as lavouras, e que não se devia fugir do assunto - em um discurso que vai ao encontro do que pregam os partidos de direita e os fazendeiros no estado ("Para que mais terras, se a Funai não dá conta de assistir os índios nas terras que já existem?” Etc.).

Um líder kaiowá toma a palavra e sugere, em guarani, que se abandone a ideia de dividir os participantes em grupos e que façam, todos juntos, a discussão proposta. A sugestão é acatada, e são abertas as inscrições para falas de dez minutos cada. Começa a ficar difícil para mim acompanhar as longas falas em guarani. Combino o entendimento de alguns trechos com a ajuda dos que estão sentados perto de mim.

O dito líder, um dos principais aliados da Funai à época, defende a necessidade de demarcações de terras, inclusive o seu tekoha, em processo de identificação desde 2008. Um mburuvicha de outra terra indígena a ser demarcada nos atuais GTs cobra resultados e uma resposta definitiva em relação ao direito sobre as terras. Outra liderança familiar que espera, em Dourados, a

304 A diferença é nítida porque os Kaiowá costumam recitar frases nos porahei, enquanto os Guarani somente entoam sequências vocálicas que não têm significação propriamente verbal. 
demarcação das terras de origem para poder abandonar a reserva superlotada, pede união entre os Kaiowá, para que não se prejudique o importante momento de luta pela terra.

Outro presente fala de Kurusu Amba, área que foi palco de diversos conflitos recentemente, resultando em mortes e prisões de lideranças. Antes de chamar o próximo orador, o coordenador da mesa avisa que a gravação em vídeo que está sendo feita se destina à escola. "Kaiowá é muito desconfiado", brinca, em referência aos curiosos que vinham lhe perguntar sobre quem eram os responsáveis por aquela câmera de vídeo que ali estava. Uma liderança de uma área ocupada e, então, em litígio, lembra que dali a alguns dias o coletivo que reivindica a área onde reside completaria dez anos de luta. Outra pessoa pega o microfone para homenagear De Lo Santo, xamã guarani recentemente falecido. Alguns batem palmas, outros agitam o mbaraka.

Uma das figuras ligadas à ocupação em Dourados volta ao microfone e relembra a história recente das demarcações de terras dos Kaiowá e Guarani. Critica a Funai e a coordenadora. Aponta negligência com a entrega de cestas básicas e apresenta o que diz serem recibos encontrados durante a ocupação do órgão para mostrar que existe "superfaturamento" nas compras da Funai. Num caso específico, conta que 30 cabos de enxada foram comprados por R $\$ 500$, o que significa que um cabo encontrado no comércio da região por R 2 está sendo comprado pela fundação por $\mathrm{R} \$ 16$. Fala em guarani, mas a necessidade de usar vários termos técnicos em português colabora para que eu entenda a maior parte do que diz.

A fala da mulher não parece gerar comoção nenhuma. Os demais continuam a discursar como se nada tivesse havido. Alguém critica as lideranças que se vendem por qualquer $\mathrm{R} \$ 50, \mathrm{R} \$$ 100 ou R\$2 200. Outra pessoa que esteve na ocupação na Funai fala em português e repete o argumento: não é contra as demarcações, mas o problema é que a fundação não está cumprindo com sua obrigação de prestar assistência nas comunidades. Há famílias nos "fundos" das aldeias que estão sofrendo sem as cestas básicas. Para completar, diz ainda que a Funai repassou um trator que deveria servir os índios para um assentamento da reforma agrária.

Uma liderança do Paso Piraju volta a bater na tecla das demarcações. "O importante é a terra", diz, em português, para depois emendar trechos em guarani. Falam vários outros que reforçam a ideia resumida por um dos coordenadores da mesa: "O eixo principal é a demarcação de terras”. Amilton Lopes, veterano da Aty Guasu, lembra que, em 2010, completam-se 100 anos do confinamento dos Kaiowá e Guarani - por conta do centenário do SPI, que foi o órgão responsável pela política de aldeamento dessas comunidades e demarcação das reservas em "ilhas" na região. 
O intervalo para o almoço ocorre pouco depois de meio-dia. Logo na volta, os organizadores do protesto na Funai exibem um vídeo com as imagens que gravaram durante a ocupação do órgão: são cenas em que tentam mostrar que há negligência da fundação com seus automóveis e com as cestas básicas que o órgão tem a incumbência de distribuir nas comunidades indígenas.

Na sequência, um líder do Guyraroká pede a palavra e parece reafirmar que nada do que o grupo anti-Funai mostra tem importância diante da necessidade de concluir as demarcações ainda este ano (pois, em 2010, ocorrem eleições gerais, e os índios sabem que quase tudo no poder público fica paralisado nessas ocasiões).

Os participantes são divididos, agora, em quatro grupos, conforme a proximidade em que estão instaladas suas cadeiras - desistiu-se da atribuição arbitrária de números. Acompanho o grupo onde estão alguns conhecidos - ali, ao todo, são cerca de 20. Todos concordam que a prioridade é a luta pela terra - não há representantes dos ocupantes da Funai no grupo.

O líder de Guyraroká é o mais falante: diz que, na comunidade dele, apesar de haver pouca terra (eles aguardam o processo administrativo sobre a terra reivindicada - 11,4 mil hectares acampados à beira da fazenda que está em disputa com eles, em cerca de 60 hectares), todas as possibilidades de cultivo são aproveitadas. Portanto, explica, é tudo uma questão de trabalho duro. "Quem chora, mama”, resume.

A cesta básica, diz ele, é prejudicial e não deve ser o foco das mobilizações. Tirar a coordenadora do cargo, nesse momento, não vai resolver nada, só vai prejudicar o processo de demarcação. Para ele, há um comportamento típico de quem é de Dourados, o qual ele logo reconhece tão logo a pessoa chega a sua comunidade: "Quando a pessoa é de Dourados, é morta de preguiça. Não trabalha, só reclama. Se fizer sabão, nem espuma não dá”. Uma professora emenda: "Sustentabilidade não é cesta básica”. Ele, por sua vez, filosofa sobre o papel do capitão numa comunidade: “A criança chora para o pai e a mãe. A comunidade chora para o cacique".

Em seguida os grupos se dissolvem, e seus relatores ${ }^{305}$ apresentam à assembleia suas conclusões. Falam também vereadores indígenas presentes. Até o fim do primeiro dia de reunião, nenhum debate sobre a saída da coordenadora da Funai, como pedia o grupo que promoveu a ocupação do órgão em Dourados.

305 Até onde pude observar, são geralmente professores, que sabem escrever. Escolhe-se o relator por afinidade com as principais lideranças presentes no grupo de discussão. 
Pela noite, sem alarde, acontece um encontro paralelo de capitães. Ao mesmo tempo, mais porahei e, durante toda a noite, como é de hábito, rodas de guaxiré e guahu na quadra de esportes da escola. As rodas misturam os xamãs mais velhos com as lideranças mais jovens: professores, agentes de saúde. Em tom alegre, alguém me pergunta: "Está gostando da festa?".

Como no dia seguinte, todos voltarão para casa, é bom aproveitar para dançar e se divertir. As crianças e adolescentes presentes estão muito excitados com a possibilidade de uma noite em claro. Correm e gritam pelas dependências da escola a noite toda, em pequenos grupos, divertindose com o clima de carnaval, que certamente possibilita paqueras e amizades. O nevoeiro chegou com força, e as rodas de dança na madrugada fornecem imagens de rara beleza.

\section{Ato III}

A manhã começa com novos porahei. Ao meu lado, um advogado que presta assistência indigenista na região é procurado pela turma de uma área em litígio. Por volta das nove da manhã, chega uma equipe de reportagem da TV Globo local. Rapidamente, o grupo que ocupou a Funai já está prestando informações aos jornalistas. Dizem que a reunião está sendo usada por vereadores e por não índios com finalidades políticas. Denunciam ainda que o Cimi foi quem organizou a reunião e não deixou que o tema da Funai fosse discutido. Ameaçam voltar à Funai dali a pouco, no mesmo dia, caso o assunto não seja posto em pauta. Um deles diz que os "36 capitães" apoiam o movimento. Um conhecido sutilmente se coloca atrás dos entrevistados pela TV, de modo que aparecerá no vídeo quando a matéria for exibida. Peço para ver a lista dos capitães que apoiam o movimento. Quero, depois, averiguar com eles sua posição.

Logo se espalha a notícia de que o grupo estaria disposto a voltar à Funai. Uma reunião é convocada. No espaço entre a horta e a quadra de esportes, estão 18 pessoas. A aty guasu continua acontecendo, enquanto isso, na quadra, com o microfone aberto, como no dia anterior. Diversos assuntos são postos - inclusive uma crítica sobre a visão das mulheres kaiowá que o filme "Terra Vermelha" ${ }^{306}$ promove.

306 Trata-se de longa-metragem de ficção, baseado na situação dos Kaiowá e Guarani. O filme, dirigido pelo ítalochileno Marco Becchis, estreou em 2008, com passagem por festivais europeus, e é estrelado por um grupo de indígenas kaiowá/guarani, selecionados em oficinas de atuação organizadas pelos produtores. Há várias cenas que mostram um comportamento sexual bem "liberal" por parte das mulheres indígenas, por assim dizer, o que incomodou várias delas - por outro lado, o assunto era delicado, várias das atrizes no filme estavam presentes à Aty Guasu. 
Da reunião menor, além de capitães - dos dois lados da disputa -, participam vereadores e também uma única mulher, justamente uma das lideranças da ocupação na Funai - "Tá certo que eu não sou capitã, mas sou presidente de ONG”. Retiro-me antes do fim da reunião, porque era o único branco que ainda se mantinha ali. Não quero atrair animosidades por parte do grupo anti-Funai. "Queremos entender qual o objetivo de vocês", pergunta ao grupo um vereador indígena, no momento em que estou deixando a reunião.

Enquanto isso, em paralelo, na quadra da escola, às 10h30, o antropólogo Levi Marques Pereira fala ao microfone. Ele se apresenta como colaborador dos GTs de demarcação de terras, faz uma retrospectiva dos trabalhos e dificuldades políticas. Ele explica que, por acordo entre o presidente da Funai e o governador do estado, no fim do ano anterior, os trabalhos dos GTs estavam suspensos até que a Funai lançasse uma Instrução Normativa que definisse como trabalhariam os grupos coordenados por antropólogos, com participação de funcionários do Estado, inclusive.

Levi lembra que as definições para o andamento dos trabalhos estão sendo dadas a partir de Brasília, e que a demora não é culpa dos participantes dos GTs, tendo em vista a delicada negociação que se vem operando. Ele lembra ainda das conexões de tudo o que está ocorrendo com o recente julgamento das ações contra a demarcação de Raposa/Serra do Sol.

Outros participantes seguem falando, até que chega a notícia de que foi fechado um acordo com o grupo anti-Funai. Demora até fazerem o anúncio do que foi acordado. Enquanto isso, as pessoas circulam, porque o clima já é de fim de reunião. Encontro um dos capitães cujo nome estava na lista dos caciques que apoiariam o grupo anti-Funai. Ele nega que tenha fechado qualquer acordo, diz que citaram indevidamente o nome dele - "Esses aí são caciques-abobrinha, o único que eu respeito é o fulano, porque, a bem dizer, ele é da minha família, a mãe dele é minha tia" - e que, em sua opinião, se a coordenadora for tirada do cargo, o único efeito será um agravamento ainda maior do quadro, porque, em qualquer transição administrativa, as atividades de assistência social, por exemplo, ficam quase paralisadas. "Quem se prejudica são as crianças”, diz.

Ele ainda reclama da primazia dos Terena de Dourados nesse tipo de ação política. "Eles é que têm de obedecer a gente, porque eles não têm aldeia, estão comendo no prato dos GuaraniKaiowá’. Para dar um exemplo do tipo de prejuízo que teriam com uma paralisação nos trabalhos da Funai, conta que tem $\mathrm{R} \$ 3$ mil para receber de um projeto de educação em parceria com uma prefeitura - "Só ia atrapalhar minha situação". 
Finalmente, a coordenação da mesa começa a apresentar a situação criada pelo grupo antiFunai e o acordo que foi tecido. Falam representantes dos dois lados. A mulher que representa os ocupa-Funai é a única a utilizar o português. Fala que está ali para representar as mulheres e a pedido dos próprios caciques: "Eles me pedem, eu venho". "Nós, mulheres, é que sofremos enquanto vocês saem para trabalhar fora da aldeia ou vão fazer reunião". "Nós queremos, sim, uma Funai melhorada, uma cesta básica melhor, pra que não fiquem dizendo pelo Brasil inteiro que nós não cuidamos dos nossos filhos, deixamos as crianças passando fome". E ainda filosofa sobre as obrigações de uma liderança: "Quer ser liderança, seja de todo mundo, não só do seu bico". "Isso aqui é uma questão política, sim, porque política se faz no dia-a-dia”.

Para entender melhor o que foi acordado, converso com ela, ao mesmo tempo em que é lida a declaração final da reunião, ao microfone. Segundo ela conta, ficou decidido que dois indígenas, um de cada grupo - contra ou a favor da atual administração -, deverão ser contratados pela Funai para "fiscalizar" o trabalho da coordenadora. Caso contrário, o protesto na Funai será retomado dentro de poucos dias.

O acordo anunciado não é unanimidade. O representante de um acampamento em área de conflito ocupa o microfone e diz que, para ele, é errada a decisão, porque o grupo não tem legitimidade: "Quem está a favor da coordenadora é maioria". Um homem do grupo anti-Funai adverte que as pessoas de seu grupo não deveriam assinar o documento final do encontro, porque não estavam sendo dadas garantias suficientes de que o acordo seria cumprido. Outra liderança ocupa o microfone para pedir que as lideranças de antigos tekoha, já demarcados, não prejudiquem a vida de quem está reivindicando novas terras.

Com falas como a do homem anti-Funai que questionava o acordo, e com as pessoas rapidamente se retirando da reunião para dirigir-se a automóveis e ônibus fretados rumo a suas casas, ao final do evento, fica muito difícil entender exatamente o que aconteceu ali. Pergunto a pessoas da organização do evento por que, mesmo percebendo que tinha maioria, o grupo pró-Funai não realizou alguma votação para simplesmente expressar no documento final que a Aty Guasu entendia como prioridade as demarcações de terra e não apoiava qualquer movimento por mudança na administração da Funai naquele momento etc.

E é aí que entendo, a partir do que me diz Jorge, da coordenação da mesa: uma votação desse tipo não faria sentido porque, independente da vontade da maioria, aquele grupo poderia continuar com seus protestos diante da Funai, prejudicando o trabalho dos GTs de demarcação. Ou 
seja, apesar de conhecer os mecanismos da democracia representativa, eles não servem de nada para os Kaiowá e Guarani quando um grupo pode, simplesmente, ignorar a decisão da maioria e fazer o que quiser.

Em 2010, pouco mais de um ano após esse episódio, outro grupo que questionava a Aty Guasu foi formado, mas escolheu estratégia diferente. Significativamente, organizaram uma assembleia paralela, que teve pouca presença (em função, inclusive, das dificuldades de logística). Não estava em Mato Grosso do Sul no período em que aconteceu essa reunião. À época, a disputa passava pelo acesso a organizações indígenas em nível nacional, por parte de um organismo paralelo que estava sendo formado em MS. O fato de haver um descontentamento em várias partes do país com a reestruturação da Funai parece ter sido usado como gancho para tentar tomar a frente na organização de uma Aty Guasu que tinha, entre seus temas principais, o fechamento da unidade da Funai em Amambai (cidade vizinha à aldeia onde se organizou a reunião) ${ }^{307}$.

A transferência da unidade de Amambai para Ponta Porã gerou, efetivamente, grande desorganização administrativa ao longo de 2010. Basta dizer que a primeira pessoa nomeada para coordenar a nova unidade da fundação foi presa durante a campanha eleitoral daquele ano por propaganda política irregular ${ }^{308}$. Somente em 2011 é que a situação parece ter se estabilizado.

De qualquer modo, essa disputa parece ter ensejado, pouco mais de um mês após a Aty Guasu dissidente, a criação do já referido Conselho da Aty Guasu ${ }^{309}$. O conselho tem se mantido desde 2010, com caráter executivo - dedica-se, sobretudo, a organizar as grandes assembleias e encaminhar demandas consensuais junto aos órgãos públicos. Ressalte-se (ressalve-se?) que esse

307 Segundo texto publicado na ocasião no blog da Articulação dos Povos Indígenas do Brasil - Apib (organização junto à qual atuava parte dos organizadores do evento dissidente): “A unidade, que foi implantada no município há 23 anos, já havia sido rebaixada de administração regional para núcleo de atendimento e agora, através do decreto presidencial baixado em dezembro do ano passado (2009), foi extinta para dar lugar à criação de uma coordenadoria regional, na cidade de Ponta Porã. Até a extinção, a unidade da Fundação era responsável pelo atendimento de 23 aldeias espalhadas em 11 municípios da região de fronteira com o Paraguai. Com o fechamento da unidade, cerca de 27 mil indígenas, segundo estimativas da própria Funai, estão sem atendimento. Os Guarani exigem que a Funai volte a Amambai imediatamente".

308 Segundo o www.campograndenews.com.br, Arlete Pereira de Souza "foi presa pela Polícia Federal transportando junto com as cestas distribuídas aos indígenas material de campanha do marido, o então candidato a deputado estadual Dirceu Longhi [PT]. O casal também esteve envolvido em outro escândalo. Longhi é vereador e foi preso na Operação Uragano, em setembro do ano passado [2010]. Ele é acusado de receber propina para atender interesses do grupo do ex-prefeito Ary Artuzi [de Dourados, preso numa gigantesca operação da PF que desmontou um esquema generalizado de corrupção na cidade, o qual alcançava boa parte do secretariado e dos vereadores]. Ela foi flagrada transportando adesivos, panfletos e banners de Longhi, em carro oficial da Funai. Depois de apreender o material, Arlete foi liberada". Ela foi exonerada em janeiro de 2011.

309 Discutida durante Aty Guasu realizada em Arroio Korá, em abril de 2010. 
período em que a pesquisa foi realizada corresponde ao estabelecimento de certo consenso em torno do processo de identificação e delimitação de terras indígenas iniciado em 2008. Em um período de intenso conflito com os fazendeiros e políticos, justamente, as tensões internas se aliviam.

\section{Concertação e desconcerto}

"Antigamente não existia reunião, só existia festa". A frase, dita pelo sr. Salvador, um kaiowá idoso da região do Apa, certa vez que conversávamos em sua casa, pode ser um ponto de partida para nós. De fato, as reuniões mais populares, em nível local, são festas, e é nelas, como se viu no capítulo 1 , que se visualiza algo do que, aos olhos ocidentais, poderíamos entender como “social”. O social, poderíamos dizer, é, aqui, eventual - ou seja, da ordem do evento.

Nesse sentido, as Aty Guasu atuais emulam as festas. Na realidade, essas assembleias são, de certa forma, grandes festas que dificilmente aconteceriam em outro contexto, pois quando se poderia imaginar reunir tantos convidados, vindos de tantos lugares diferentes, em um mesmo lugar, ao mesmo tempo, e sem maiores dispêndios?

Não há Aty Guasu em que, de noite, logo após o fim da assembleia, que dura todo o dia, não se realize uma grande confraternização em torno das rodas de canto e dança. Grandes reuniões dos rezadores presentes ao evento também acontecem, e, conforme o clima da reunião, os cantos porahei, em suas várias modalidades, também seguem até a madrugada. Em paralelo, os jovens se reúnem nas brincadeiras de guaxiré e guahu ${ }^{310}$, que proporcionam muitas risadas, frequentemente, até o dia raiar.

Os Kaiowá e Guarani teorizam, frequentemente, sobre as condições que propiciam o surgimento de um determinado fenômeno. É uma espécie de teoria de agricultores: que tipo de suporte (jekoha), digamos, é necessário para que determinada planta brote (itymby) ${ }^{311}$. Poderíamos estender aqui esse raciocínio e dizer que as Aty Guasu proporcionam o ambiente necessário para que essas rodas de brincadeira apareçam. Nesse sentido, é fundamental que os anfitriãos da Aty Guasu forneçam, sobretudo, a chicha necessária ao surgimento das rodas de dança.

310 Os guaxiré, como se viu, são eminentemente festivos e mais abertos à invenção. Já os guahu constituem um conjunto fechado, de pouco mais de 100 cantos, na concepção dos mais velhos e, portanto, dependem da memória de algumas pessoas "especializadas". As letras dos guahu, como já mencionamos, não são decifráveis por qualquer um. Já os guaxiré podem ser criados na hora, envolvendo um jogo de gracejos entre homens e mulheres, sobretudo. Geram risadas, muitas vezes, de grande sutileza.

311 Termos muito usados na linguagem esotérica guarani, de forma geral, como mostra Chamorro (2008). 
Nessa coincidência ontológica entre reunião e festa verificada no caso kaiowá, talvez, encontremos uma possível explicação para o pouco destaque obtido pela temática das assembleias ou reuniões na etnologia ameríndia. Afinal, as festas, de certa forma, são reuniões, e, da mesma maneira, as reuniões são uma espécie de festa. Se as assembleias são ainda pouco etnografadas, por outro lado, o caráter político das festas, na Amazônia, está bem registrado - ainda que, como vimos no capítulo 1, certos "paradigmas insulares" impeçam, por vezes, uma apreciação mais "livre" desse fenômeno, vamos dizer ${ }^{312}$.

Em primeiro lugar: quando é que um grupo kaiowá que convive em um dado local chamemo-lo de tekoha, se quiserem - convoca uma "reunião", ou aty (guasu, aqui, será sempre algo relativo)? No imaginário ocidental, um encontro de tal natureza pressuporia, por exemplo, a discussão de propostas e a votação.

Mas, não é bem assim. Na realidade, esse tipo de situação acontece raramente. Afinal, se o principal atributo de um chefe é puxar a fila, qualquer deslize na tarefa de concertação, de criação de um consenso, poderá causar defecções e, nesse sentido, é preciso manejar com cuidado esse tipo de situação em que a divergência entre grupos pode gerar o rompimento da fila.

Além disso, trata-se, aqui, de pessoas coletivas, as famílias, no seio das quais uma divergência em maior grau significa, igualmente, o rompimento - frequentemente, definitivo. Por isso, as dissonâncias têm de ser administradas, menos que expostas e colocadas em jogo. Em analogia com a distinção proposta por Lévi-Strauss, trata-se menos de um jogo que de um ritual ${ }^{313}$. Dividir o grupo entre ganhadores e perdedores só contribuiria para acirrar, ainda mais, as assimetrias:

"No caso do jogo, a simetria é pois pré-ordenada; e ela é estrutural, já que decorre do princípio de que as regras são as mesmas para as duas equipes. A assimetria por sua vez é engendrada; decorre inevitavelmente da contingência dos acontecimentos, dependam eles da intenção, da sorte ou

312 Provavelmente, seja possível verificar que, na maioria dos casos amazônicos, a situação local etnografada não propiciasse o suporte para o surgimento das grandes assembleias supralocais - coisa que, somente em alguns lugares, se verifica (como no caso do Conselho Indígena de Roraima - CIR, e seu envolvimento em Raposa Serra do Sol, a Federação das Organizações Indígenas do Rio Negro - Foirn etc.)

313 Agradeço ao professor Márcio Silva por chamar-me a atenção para esse ponto. Para um aprofundamento a respeito dessa díade jogo/ritual, num contexto ameríndio, vide Vianna (2001). 
Em grande parte das vezes, uma reunião é convocada para socializar informações. Por exemplo, vamos dizer, o capitão e outras pessoas convidadas participaram de uma Aty Guasu, ou de outro evento supralocal. Na semana seguinte ao evento, é praxe que se organize uma reunião como forma de repassar ao maior número possível de pessoas da comunidade um resumo do que se discutiu na ocasião. Nem sempre isso ocorre de forma sistemática, e é na capacidade do grupo local de organizar esse tipo de difusão das informações que se estabelece alguma diferenciação na maior ou menor agilidade com que se reage a fatos novos.

Frequentemente, em função dessa dinâmica de relação com o Estado ou outros centros como o próprio movimento indígena, que, por sua vez, é uma organização que busca estabelecer um diálogo com o Estado em nome de um "povo" ou "etnia" -, o grupo local precisa se apresentar como "comunidade". Por exemplo, é necessário produzir documentos com uma lista de assinaturas das pessoas do local, indicando que há um consenso em torno de uma determinada ideia.

A vida política dos coletivos guarani e kaiowá tem sido, nesse sentido, uma interminável sequência de abaixo-assinados, direcionados às "autoridades competentes". São inúmeras as reuniões que têm de ser organizadas para que um documento seja gerado para posteriormente ser levado à Funai, à Funasa (agora Sesai), à prefeitura local, ao MPF etc ${ }^{314}$. Um abaixo-assinado, por sinal, é nada menos que... uma fila. Pode-se assinar ou não, pode-se ingressar ou não nessa fila de nomes.

Obviamente, como já sublinhamos mais de uma vez, estou me referindo a uma situação em que o grupo local tenha se formado a partir de uma dinâmica autônoma, sem maiores interferências do Estado (sobretudo, entenda-se, sem a nomeação de capitães impostos de fora para dentro). Nas áreas de confinamento, a situação é consideravelmente distinta da que aqui descrevo - e, hoje, praticamente nenhum ator em quem se perceba boa fé é $^{315}$ deixaria de reconhecer que essa distinção é crucial a qualquer consideração a respeito da vida política kaiowá e guarani.

Numa aula de antropologia dada em um curso de formação de professores guarani e kaiowá,

314 O documento é geralmente redigido com a ajuda dos professores locais, em colaboração com o mburuvicha, e, de preferência, com a concordância (bênção) dos rezadores.

315 Para alegar cumprimento de determinações como as constantes da Convenção 169 da Organização Internacional do Trabalho sobre o direito das comunidades indígenas de serem consultadas antes de qualquer ação pública que venha a lhes afetar, funcionários ligados ao governo estadual por vezes alegam ter em seu poder "cartas de caciques" fazendo pedidos ao poder público. 
um dos estudantes, certa vez, em 2009, perguntava algo como: "Eu queria entender melhor o que vocês querem dizer quando falam em comunidade. Porque a comunidade para mim pode não ser o que é para ele, nem para o outro. Como se define uma comunidade?”

Justamente, quando se trata de definir a vontade da "comunidade", ou a "vontade geral", como lembra Lima (2007), em uma área de confinamento (alguma das antigas reservas do SPI, sobretudo), essa necessidade incessante que o Estado cria de que sejam tomadas decisões em nome da "comunidade" se complica muito. Cada decisão pode dar margem para uma nova disputa.

Como observa Carneiro da Cunha (2009: 335), introduz-se, aí, um "sistema de representação". Como uma espécie de contrato, esse fluxo de políticas públicas, enquanto forma de troca $^{316}$, cria sujeitos. Não apenas o capitão, já abordado em capítulo pregresso, mas também a própria comunidade, que surge nessa interação com o Estado. Não estamos lidando aqui com a situação que descreve a autora, o pipocar das associações indígenas na Amazônia, muitas vezes surgindo e chegando ao ocaso com a execução de um único projeto. Mas, uma coisa é certa: se há uma forma de "construir" uma "forma de representação legal e legítima" entre os Guarani e Kaiowá, essa forma é a aty - com a ressalva de que suas virtudes políticas só podem ser plenamente alcançadas em situações em que o grupo local foi constituído de forma autônoma.

No México, a obra de um intelectual mixe, de Oaxaca, Floriberto Díaz, mostra que esse desencontro quanto às ideias sobre comunidade é mesmo amplo:

\begin{abstract}
"Pero la ley, hecha com mentalidad occidental, no entiende de igual manera la comunidad: para ella es la suma de individuos, para nosotros es la tierra que nos comuna; es decir, nuestra comunidad es geométrica, no aritmética (...). Como puede verse, la tierra define a la comunidad, que es univocamente gente-pueblo-tierras. No es el individualismo el que define qué es comunidad." (Díaz, 2007: 26/29)
\end{abstract}

Poderíamos lembrar que a situação na Mesoamérica se distingue da das Terras Baixas da América do Sul em ao menos um sentido: por lá, as definições pré-colombianas de territorialidade foram amplamente mantidas - ainda que com transformações. A colonização aparece como mais um

316 Sim, do ponto de vista nativo, uma forma de troca, e não "direito", uma vez que, como é evidente para muitos Kaiowá, em troca de receber as doações em dinheiro ou serviço que o Estado lhes dá, eles têm que passar por uma série de constrangimentos. Ainda assim, aceita-se a barganha em muitos casos. Mas, às vezes, não. Em diversas ocasiões, agentes públicos já propuseram a grupos que abandonassem suas demandas territoriais em troca da obtenção de benesses como comida, casas. Houve recusas, mas, também, acordos. 
reordenamento das linhas (de impactos colossais, por certo, mas como parte de uma série cujas origens se perdem nos séculos - vide, a respeito, López Austin \& López Lujan, 1996 e 1999; Gruzinski, 2003, capítulo 3).

\section{Um homem, um voto?}

Ao fim e ao cabo, talvez, o motivo da confusão esteja numa incompreensão a respeito do que é uma assembleia. Na tradição ocidental, é por demais forte a ideia de "um homem, um voto". Mais ainda, passamos por todo um processo histórico para chegar à igualdade de voto entre homens e mulheres, por exemplo. Hoje, pode-se votar a partir de 16 anos, no país. E, também aqui, somente a Constituição de 1988 outorgou direito de voto aos analfabetos.

Ocorre, porém, que a assembleia indígena não é, necessariamente, democrática, do ponto de vista de uma classificação ocidental. Para iluminar esse ponto, recorreremos a uma digressão, desviando, por umas páginas, de nossa descrição sobre os Kaiowá.

Considerada a tradição grega, que percebia três tipos de governo, a Liga Iroquesa, observava Morgan, era um exemplo de oligarquia - "governo de poucos". O americano evoca Aristóteles (1904: 121), que reconhece três sistemas políticos: monarquia, aristocracia e democracia; respectivamente, o governo "de um", "de poucos" e "de muitos". Uma oligarquia (governo de "poucos”), por sua vez, seria, na visão aristotélica, uma "degeneração" da aristocracia (governo dos "melhores").

Morgan contorna essa qualificação. Para ele, o governo dos iroqueses era uma "oligarquia liberal" (ou simples - idem: 125), porque, aqui, ela se "alarga", ou "liberaliza", com a admissão de "homens de capacidade a uma posição igual". "O governo assume um espírito mais brando", alterando-se a aristocracia, de fato, mas não de forma a se tornar uma "facção" (o que estaria na raiz da ideia aristotélica sobre uma "degeneração"). O motivo principal para essa distinção, contudo, é mesmo a inexistência de uma classe que se apropriasse da terra, único marco real da fundação de uma aristocracia, segundo o autor. Além disso, os sachems não tinham títulos ou privilégios hereditários, agrega ele: "Seu sistema, contudo, era o governo 'dos poucos'. Era uma aristocracia liberalizada, estava à beira da democracia” (idem: 125-6).

Mais adiante, Morgan, o evolucionista (não nos esqueçamos desse detalhe), imagina a 
constituição do sistema iroquês a partir de uma "superação" da forma mais primitiva de governo, a de 'chefe e seguidor', bem como da monarquia. Na hipótese do autor, as várias tribos se unem emu ma nação, por meio dos casamentos, que leva a um poder comum dos chefes. Isso gera, segundo ele, a forma aristocrática ou oligárquica de governo. O passo seguinte foi a união das várias nações na liga, várias oligarquias unidas numa oligarquia mais abrangente (idem: 129-30).

A democracia, diz Morgan, é o sistema de governo "verdadeiramente iluminado" (idem: 129). Mas, nem por isso, ele deixa de exaltar a oligarquia iroquesa, tal qual a descreve. Era um governo não somente superior a seus similares da Antiguidade grega, como dificilmente comparável a qualquer outro em termos de justiça, em função de estar associado ao "estado de caçador", o estágio primordial da evolução humana, associado à liberdade absoluta:

“"O espírito que prevaleceu nas nações e na Confederação era o da liberdade. As pessoas parecem ter assegurado para si toda a liberdade que o 'estado de caçador' tornou desejável. Elas apreciavam plenamente seu valor, como evidenciava a liberalidade de suas instituições. O homem vermelho sempre foi livre da sujeição política e, mais digno ainda de memória, seus membros livres nunca usaram grilhões - seu espírito nunca poderia se curvar em servidão. Na linguagem de Charlevoix, os iroqueses estavam 'totalmente convencidos de que o homem nasceu livre, que nenhum poder sobre a terra tinha o direito de fazer qualquer ataque contra sua liberdade, e que nada poderia ele fazer para corrigir sua perda.' Seria difícil descrever qualquer sociedade política, em que houvesse menos opressão e descontentamento, mais independência individual e liberdade ilimitada." (idem: 130-1) ${ }^{317}$

A tal ponto de perfeição chegou o sistema iroquês, segundo Morgan, que, se sua sociedade não fosse, progressivamente, formando cidades, comunidades maiores, ele teria "indubitavelmente retido sua forma oligárquica ao largo de muitas gerações". "Teria durado até que o povo tivesse abandonado o 'estado de caçador"' (idem: 132). A grande razão por que o "homem vermelho" mantém esse "estado de caçador", explica Morgan, é a ausência, em seu espírito, do "poder do lucro", essa "grande paixão do homem civilizado" (idem: 131).

317 Podem-se perceber, em uma descrição como essa, vários dos traços de certa forma clássica de descrever os ameríndios que desembocaria em quadros como os pintados por Clastres: a paixão pela liberdade, a ausência de opressão e pontos ainda mais duvidosos, como a ausência de distinções familiares, ou da propriedade. 
Afinal, o outro aspecto importante a se destacar no sistema de governo da Liga é a independência das comunidades, em nível local, em relação à confederação ${ }^{318}$. Uma decisão de escopo geral tinha de retornar às bases e ser discutida e aceita para que pudesse ser referendada (1904: 58). Vale reter essa característica, pensando que ela dialoga com a tal definição de "estado de caçador". Mais adiante voltaremos a esse ponto.

Em sua grande síntese evolucionista, Ancient Society, Morgan retomará, ainda, a comparação entre gregos e iroqueses, comentando, especificamente, a certo ponto, a questão da ágora. Ali, ele destaca um limite da assembleia iroquesa, em relação a seu similar grego: aquela não fora capaz de alcançar o "poder de aceitar ou rechaçar medidas de ordem pública submetidas ao conselho [de chefes]" (1974: 231) - esse poder da ágora, exalta Morgan, estava ligado à "defesa das liberdades".

Entre os iroqueses, unicamente, "o povo submetia seus desejos ao conselho de chefes por meio de oradores escolhidos por ele mesmo (o conselho), e nos negócios da confederação se fazia sentir uma influência popular" (idem). Tomando trechos de peças de Eurípedes e Ésquilo, Morgan conclui, ainda, que, no caso grego, “depois de ouvir a discussão do assunto apresentado, na qual podia tomar parte todo aquele que o desejasse, a assembleia popular tomava sua decisão, nos termos antigos, geralmente, levantando as mãos" (ibidem).

As observações de Morgan podem ser aproximadas do que escrevia Florestan Fernandes sobre os Tupinambá quinhentistas e sua "gerontocracia", baseada num "conselho de chefes" figura praticamente deixada de lado nas revisões bibliográficas que se seguiram (Carneiro da Cunha e Viveiros de Castro, 1985; Fausto, 1992, 2000). Fernandes, contudo, considera o conselho uma “instituição política básica da sociedade tupinambá” (op.cit: 261), o que nos poderia causar ainda mais estranhamento quanto à ausência desse item nas discussões mais recentes ${ }^{319}$.

Do ponto de vista funcionalista de Fernandes, como já vimos, trata-se de entender qual é a unidade social em jogo, e, para ele, é justamente o conselho de chefes quem promove "o ajustamento dos indivíduos como membros de certo grupo local ou como membros de uma confederação de grupos locais" (idem).

318 Para uma discussão sobre a aplicabilidade e o sentido desse termo, ver Perrone-Moisés \& Sztutman, 2010. 319 Poderiamos especular sobre a dificuldade que seria conciliar com essas descrições sobre a gerontocracia uma visão como a de Clastres, a respeito da "sociedade contra o Estado". 
O autor, vale destacar, evoca o African Political Systems para delimitar o campo dos "sistemas políticos": situado entre o direito e a guerra. Uma instituição como a "vingança regulamentada" tupinambá, justamente, oscila entre esses dois polos, segundo Fernandes. Tendo abordado, em outros momentos de seu texto, a questão da guerra, resta, pois, de acordo com ele, encarar a dinâmica que envolve as formas de retaliação e seu controle pela gerontocracia (onde, infere-se, residiria o direito).

Em sua descrição, Fernandes recolhe indícios de uma presença generalizada dos conselhos de anciãos entre os distintos grupos tupi do litoral quinhentista. Ele discorre sobre os atributos guerreiros e xamânicos na aquisição de status entre os Tupinambá. A gerontocracia, concebe-a segundo formulações de Max Weber (op.cit: 271-2), entendendo-a, ainda, como uma forma de "dominação tradicional” e "carismática”. Evoca, também, Frazer, para defini-la como oligárquica. O carisma, aí, não é "revolucionário", segundo Fernandes, porque "tanto o grande guerreiro, como o pajé excepcional, nos momentos críticos, agiam de acordo com a tradição" (op.cit.: 272).

Fernandes observa que, segundo os exemplos apresentados pelos cronistas, o conselho e a chefia são instituições que se complementam: “(...) os caciques não eram, necessariamente, os homens mais velhos de um grupo local":

\footnotetext{
“Graças à correlação existente entre o tempo necessário para corresponder satisfatoriamente às provas tribais de peneiramento e a elevação de status, os velhos concentravam em suas mãos todas as possibilidades de mando. Na sociedade tupinambá, os velhos apresentavam-se não só como os únicos portadores qualificados dos conhecimentos e tradições tribais, mas, ainda, como as únicas pessoas que tinham larga experiência prática sobre a eficácia de tais conhecimentos e um seguro tirocínio sobre a conveniência da observância das tradições e ritos tribais” (op.cit: 276)
}

É interessante notar, nos trechos destacados por Fernandes em cronistas como D'Abbeville, Thevet e Staden, que há enorme contraste com o que se lê e se observa, normalmente, a respeito do tratamento dado ao chefe ameríndio (vide capítulo 2). Esse apagamento do conselho de chefes na discussão recente se confirma quando percebemos a disparidade entre a larga difusão das cenas de antropofagia e guerra tomadas das gravuras originais da edição do livro de Staden e a raridade de 
ver reproduzida a cena do conselho de chefes que aparece em Fernandes (op.cit: 280$)^{320}$. Vale, aqui, retomar na íntegra a descrição que Fernandes faz de uma dessas reuniões de chefes a partir de trechos de cronistas, e particularmente de Soares de Souza (1987):

“(...) quer fosse no terreiro, ao ar livre; quer fosse no interior da casa dos homens, a reunião processava-se de acordo com as normas costumeiras. 'Quando o principal da aldeia quer praticar algum negócio de importância, manda recado aos índios de mais conta, os quais se ajuntam no meio do terreiro da aldeia, onde em estacas, que têm para isso metidas no chão, armam sua rede de redor da do principal, onde também se chegam os que querem ouvir estas práticas, porque entre eles não há segredos'. Os simples ouvintes 'assentam-se em cócoras', em torno dos chefes; enquanto estes, 'em virtude de sua hierarquia, proveniente da linhagem ou de outro qualquer motivo, se conservam sentados em suas redes'. Eram os indivíduos que possuíam maior parentela, maior renome guerreiro e idade mais avançada. $O$ cacique expunha publicamente as razões da convocação dos companheiros. A seguir, os velhos opinavam sobre o assunto. As regras de polidez obrigavam os gerontes a expor seus pontos de vista sem tumulto e cada um por sua vez. Um orador se propunha a tomar a palavra quando o antecessor desse por terminada sua intervenção. Apesar disso, parece que as discussões nem sempre eram serenas, pois Gabriel Soares informa 'que têm suas alterações muitas vezes'. Um dos rituais básicos destas reuniões consistia na fumagem coletiva. Alguns principais possuíam 'cangoeiras de fumo', as quais levavam consigo. (...) as reuniões abrangiam, às vezes, gerontes de vários grupos locais. O mecanismo de interação, nestas ocasiões, conservava-se inalterado. Apenas os gerontes assumiam a obrigação de relatar integralmente os acontecimentos $e$ as resoluções práticas, nos conselhos de seus próprios grupos locais.”(op.cit: 281-2)

O autor também faz algumas considerações interessantes a respeito dos poderes e atribuições do conselho:

“As atribuições dos conselhos de chefes, por sua vez, eram bem limitadas.

\footnotetext{
${ }^{320}$ Reprodução de Staden, 1998: 43, ilustração do cap. 30 - "Como os chefes se reuniram à noite sob o luar".
} 
Como foi visto acima, a solução das disputas e dos conflitos de indivíduos pertences ao mesmo grupo tribal, subordinava-se a princípios definidos no direito costumeiro (retaliação, vendetta, ação das famílias do ofendido e do ofensor, responsabilidade coletiva etc.) Parece que os gerontes só deliberavam sobre certos incidentes excepcionais, sem grande base comparativa nas tradições tribais (...). Embora Thevet afirme categoricamente que o conselho se reunia para tratar de qualquer grande empreendimento, 'quer bélico ou não', deliberando sobre todas as questões de importância coletiva, as indicações explícitas referem-se simplesmente a oportunidade do sacrifício ritual dos prisioneiros e a fixação da data em que devia ser realizado. E escolhiam os inimigos a serem atacados, designando o local e a época do ataque (...). Posteriormente, comunicavam as resoluções práticas aos demais membros do grupo local.” (op.cit: 282-3)

Para Fernandes, os relatos demonstram que as resoluções do conselho "fossem quais fossem, deviam ser obedecidas, pois a ninguém mais competia discuti-las ou modificá-las”. Ele reconhece que faltam nos relatos coloniais elementos sobre a forma como essas resoluções eram recebidas, mas acredita que, dado o fato de trazerem "o cunho sagrado das normas tradicionais" 321 , as orientações do conselho deviam ser seguidas sem grandes objeções. Para amparar sua hipótese, o autor cita fala de Japy-Açu, registrada em D'Abbeville:

"Bem sei que esse costume [antropofagia] é ruim e contrário à natureza, e por isso, muitas vezes procurei extingui-lo. Mas todos nós, velhos, somos quase iguais e com idênticos poderes; e se acontece um de nós apresentar uma proposta, embora seja aprovada por maioria de votos, basta uma opinião desfavorável para fazêe-la cair; basta alguém dizer que o costume é antigo e que não convém modificar o que aprendemos de nossos pais" (D'Abbeville, : 234 apud Fernandes: 283)

Outra vez, chegamos ao consenso como raiz desse sistema político. O que, para Fernandes, mostra o peso da tradição, poderíamos entender, primeiro, como prova de que, acima do conselho, está esta regra de ouro: se não há concordância total, não há possibilidade de união - e, para retomar uma imagem que já utilizamos aqui outras vezes, com isso, dispara-se um movimento de linha, que

321 Desnecessário comentar os termos, que evidenciam as referências funcionalistas de Fernandes. 
dissipa o círculo.

Dentre os autores recentes, Sztutman é dos poucos a desenvolver algo um pouco mais extenso a respeito da gerontocracia tupi. Para ele, a ênfase dada por Fernandes a esse elemento desenvolve, sobretudo, uma tese de Thevet (Sztutman, 2005: 104), a qual se relacionava a uma imagem "altamente hierarquizada" dos Tupinambá. O maior exemplo, segundo o autor, seria a forma como é retratado, pelo francês, o chefe Cunhambebe, sendo seus adornos comparados a “vestimentas reais", e sua maloca, a um "palácio".

Seguindo interpretação de Lestringant, Sztutman entende que as divergências entre as visões de Thevet e Lery a respeito do sistema político tupinambá poderiam refletir, de alguma forma, suas próprias posições em relação ao debate político-religioso na França naquele momento histórico:

\begin{abstract}
"Thevet tinha na monarquia indígena um mito indispensável para erguer o projeto político da França Antártica, no qual a aliança política com os novos povos deveria dar sequência à instauração de uma jurisdição sobre o seu território. Em suma, o cosmógrafo apropriava-se politicamente de uma ficção. Contrariamente, Léry, como os demais huguenotes presentes na região da Guanabara, repudiava a monarquia tirânica e recusava a sujeição à Coroa francesa. Conforme Lestringant, Léry alimentava-se de uma utopia social e militar baseada em um governo sem reis nem príncipes, passível de ser encontrado entre os selvagens da costa, em que o poder, jamais coercitivo, estaria nas mãos do velho dono da casa, participante das decisões comunitárias e, sobretudo, um bom anfitrião. Se ambos Léry e Thevet falam de 'principais' - termo que, no Quinhentos, definia de modo bastante geral 'aquele que chefia' - , o sentido atribuído por cada um deles é bastante variável." (Sztutman, op.cit: 104)
\end{abstract}

Parece-nos que, no debate antropológico dos últimos anos, tomou-se o partido de Léry e minimizaram-se as constatações de Thevet. Ni muy muy, ni tan tan. Em detrimento de uma reflexão sobre a rede, a Antropologia optou pela discussão sobre as figuras do profeta e do principal - o que, talvez, tenha sido facilitado pelo fato de que, em geral, as etnografias continuam presas às “epistemologias insulares” de que fala Sahlins. Não é à toa, portanto, que, enquanto Fernandes vê Thevet como um autor superior a Léry, o contrário, justamente, parecia, segundo Sztutman (op.cit: 105), a Lévi-Strauss - autor que, como vimos, construiu a versão canônica do chefe ameríndio, a 
partir de sua descrição sobre os Nambikwara.

De qualquer modo, a seguir, Sztutman considera o conselho enquanto coletivo de "guerreiros que desenvolveram o dom da oratória" (nota 9 - Sztutman, op.cit: p. 34 do caderno de notas), sem maiores considerações sobre o que assinala Fernandes em torno da gerontocracia/oligarguia tupinambá. Ou seja, permanece o interesse na figura do chefe, do guerreiro, do xamã. Falta, a nosso ver, uma reflexão mais sistemática. Munido de análises como as destacadas acima, é o que se propõe aqui.

Como já destacamos, Fernandes não expõe a visão de um sistema "hierarquizado" ao reproduzir a ideia de Thevet sobre a centralidade do conselho de anciãos. Não creio que ele se comprometa com uma visão taxativa nesse sentido. A declaração de Japy-açu registrada em D'Abbeville bem o mostra: qualquer possibilidade de dominação amparava-se nas normas "tradicionais" e dependia inteiramente do consenso, sendo de grande fragilidade.

De maneira que chegamos, com essa digressão, à necessidade de encarar isto: uma real compreensão sobre esse dilema local/geral requer um olhar mais amplo sobre esse sistema político multilocal. O que nos levará de volta a Chiapas, pois.

$$
* * *
$$

Como as missões jesuíticas, a Confederação dos Tamoios ou a Liga Iroquesa, a rebelião zapatista de 1994, em Chiapas, México, foi um evento singular no processo de encontro entre ideias ocidentais e ameríndias a respeito da política. Não por acaso, essa peculiar união de militantes socialistas (nada ortodoxos, por certo, e muitos já disseram: inclassificáveis) e indígenas de grupos maya $^{322}$ gerou uma massa enorme de reflexões, a ponto de se falar até mesmo em uma "revolução teórica zapatista” (Mignolo, 1997).

Aqui, os zapatistas comparecem no sentido de terem gerado considerável volume de material a respeito do sistema de decisões que o Exército Zapatista de Libertação Nacional (EZLN) implantou em seus núcleos de base, durante a articulação do movimento, em diálogo com formas de assembleia que já existiam nas comunidades.

É bem verdade que a grande massa de escritos sobre o EZLN mira os comunicados

322 Aqui, nos estamos comedindo. Ao gosto de Latour, poderíamos enormemente estender essa lista, começando pelos seguintes itens: um ícone camponês nacionalista, teologia da libertação, fuzis, pasamontañas, paliacates, montanhas, internet, um grande jornal de esquerda, solidariedade internacional, autonomia, Paulo Freire etc. 
publicados pelo movimento (só desses documentos há pelo menos cinco volumes editados), bem como outros escritos do porta-voz Subcomandante Marcos e entrevistas com ele ou com membros do Comitê Clandestino Revolucionário Indígena (CCRI).

Dadas, inclusive, as dificuldades de pesquisa, por tratar-se de zona de conflito, foi produzido, ao longo desses 18 anos desde que o movimento se tornou público, pouquíssimo material a respeito do cotidiano dos grupos envolvidos na construção das chamadas "autonomias zapatistas", ou de seu "autogoverno". Mais recentemente, contudo, algo que se poderia considerar resultado de um trabalho de campo tem começado a surgir (Fernández, 2010; Camacho Velázquez, 2011).

Não se deve pensar, simplesmente, numa oposição entre assembleias indígenas por consenso como modo tradicional versus uma forma de assembleia não tradicional por votação. Na realidade, o que parece haver, em boa parte dos grupos indígenas do México, são esforços de retomada das assembleias, após décadas de quase abandono dessa forma, em função da pressão do "mau governo" e do sistema partidário, o qual instituiu um sistema clientelista arborescente que tinha, na base, os "caciques".

Esses representantes do "mau governo" minaram, em nível local, as assembleias (ver a respeito, por exemplo, Gonzalez Ruiz, 2011). Nesse sentido, a inovação zapatista poderia ser pensada como uma tentativa de superar uma espécie de "ponto fraco" do sistema gerontocrático, que tinha sido aproveitada pelo governo colonial/nacional para controlar as comunidades:

“En las asambleas que se desarrollan en las poblaciones zapatistas, la voz de los viejos sigue siendo escuchada con atención y en muchas ocasiones son sostén de las posiciones que asumen en el acuerdo, pero la diferencia es que ahora su palavra puede ser la base para las decisiones pero no las toman ellos, lo cual propicia que su sabiduría sea enriquecida con el conocimiento de los jóvenes ( o viceversa) y con esa combinación llegan a acuerdos, aprovechando todos los recursos del conocimiento y la experiencia, evitando la construción de grupos de iluminados que en su proceso de relaciones con partidos políticos, autoridades, mercado, etc., pierdan el sentido original de su existencia” (Camacho Velázquez, 2011: 181) 
Do ponto de vista dos indígenas ligados ao movimento, há uma combinação entre tradição e inovação, poderíamos dizer. Os relatos canônicos a respeito da implantação de uma forma própria de decisões, modificando os sistemas já utilizados pelos indígenas, mencionam o momento crucial para o movimento, entre 1992 e 1993, quando se faz a opção de confrontar publicamente o Estado mexicano. Após consultas em todos os núcleos de base do movimento, uma maioria decide pela "guerra". Uma entrevista de Marcos a Le Bot (1997) assim descreve esse processo, ocorrido, aproximadamente, ao mesmo tempo em que houve amplas manifestações indígenas por conta da celebração dos 500 anos da descoberta da América, em 1992:

"Pero en ese tiempo, en las comunidades se está haciendo una consulta, una explicación en cada poblado, sobre las condiciones en las que están en las comunidades, en las etnias, en las que está la situación internacional, la situación nacional, y la pregunta es si es tiempo de empezar la guerra o no. En esos meses, en septiembre, octubre y todavía la primera quincena de noviembre, se hace la consulta en algo así como 400 o 500 comunidades de las cuatro etnias, entre los tzotziles, choles, tojolabales y tzeltales, precisamente Los Altos, el Norte y la Selva, y la mayoría de la población ya participa en esta consulta. Las mujeres, por primera vez como un sector especial, y los jóvenes, que antes no participaban en las decisiones de las comunidades y menos de este tipo. Se hace una especie de referéndum por medio de actas, y después de la marcha de octubre se hace el conteo.” (Le Bot, 1997: 81)

“Y la votación fue por mayoría?”, pergunta, em seguida, Le Bot, ao que Marcos complementa:

"Sí, fue por mayoría dentro del EZLN. En los pueblos donde nos movíamos en Los Altos, en el Norte, sobre todo en la Selva, la mayoría de la población votó por la guerra. Fue una votación nominal, unipersonal. O sea, no, decíamos tantos pueblos dicen que sí, tantos dicen que no. Sino tantos hombres, tantas mujeres y tantos jóvenes votaron. Cada pueblo tenía que entregar el acta con el voto nominal, voto directo, pero público. O sea, era una asamblea, no era voto secreto, pero hubo discusiones fuertes por ahí. Quedaron guardadas las actas, las actas de guerra, porque los pueblos 
mandaban la votación y mandaban los argumentos que hubo en pro y en contra. Porque teóricamente no podía tomarse la decisión en ese momento, era una consulta. Se supone que el mando consultaba a las comunidades sobre lo que pensaban. Les pedíamos argumentos para que el mando pudiera evaluar. Y entre los zapatistas que votaron no a la guerra, estaba el argumento de que la represión iba a caer sobre las comunidades, que no estaban listos, que había comunidades divididas, que había que esperar; hubo argumentos de peso. En definitiva, una amplia mayoría se pronuncia a favor de comenzar la guerra ahora y las comunidades dan la orden formal al EZLN de hacer la guerra junto con ellas.” (Le Bot, 1997: 81-2)

Esse é, ainda, o momento de criação do CCRI, que, segundo Marcos, corresponde a uma espécie de transição entre o modelo político-militar de decisão e o estabelecimento de canais de consulta às comunidades para "tomadas de decisão democrática" (op.cit: 83). As "chefaturas" nas comunidades dão origem ao comitê. Em uma reunião em janeiro de 1993, lembra o Sub, consolidase a transição: "Entonces los representantes indígenas, en tanto jefes, refrendan el resultado de la consulta, votan la guerra, lo que los pueblos, las comunidades, ya habían votado. Así, toman el mando, de manera formal, del EZLN" (idem).

Como se percebe, a participação de mulheres e jovens nas decisões não é um dado trivial, o que nos poderia levar, novamente, a uma reflexão sobre os limites entre oligarquia e democracia. Em outro trecho dessa mesma entrevista, Le Bot questiona Marcos sobre as assembleias indígenas, seu caráter democrático, e mesmo sua funcionalidade, ao que o Sub comenta:

“Ahora las comunidades aportan su práctica, que tiene sus límites: por lo regular resuelven sus problemas generales por consenso; los discuten en la asamblea y hasta que no salga la unanimidad no hay acuerdo; ni siquiera hay votación. En la mayoría de las comunidades ni siquiera hay votaciones, las decisiones son unánimes o no son. Eso implica una lógica de discusión interna y es válida para los problemas que realmente afectan a todos." (Le Bot, 1997: 117)

O comandante Tacho, membro da CCRI, agrega, em outro momento do livro, ao ser questionado sobre o caráter "não muito democrático" de certas formas de decisão nas comunidades indígenas: 
"Sí, ésa es la realidad. Pero cuando el zapatismo llega a los pueblos empieza a tomar en cuenta, por ejemplo, a las compañeras mujeres. Antes ellas no participaban en las decisiones. Cuando llega el zapatismo empieza a incorporar a todos, las mujeres y los jóvenes. Antes no, nada más los hombres eran los que gobernaban y todos tenían que obedecer lo que dijeran. Pero ahora no. Ahora el representante es el que representa a los demás frente a una institución, a lo que sea, pero en el pueblo sólo es para que organice lo que se va a hacer en el pueblo, pero no es el que manda." (Le Bot, 1997: 126)

Portanto, se, as assembleias, em si, não são uma novidade, a discussão democrática (que admite divergência sem necessidade de separação), sim, é, segundo Marcos:

"Es un proceso nuevo en las comunidades, porque todos los problemas que se enfrentaban estaban relacionados con la sobrevivencia. El proceso de aniquilamiento que viene operando desde hace muchos años ha creado la conciencia de que la única forma de sobrevivir era juntándose y hacer muy fuerte el colectivo, incluso resolviendo siempre el choque entre el individuo y el colectivo en favor del colectivo, de tal forma que si el individuo no aceptaba el colectivo, era expulsado. (...) era la única forma de sobrevivir. No era posible que las comunidades resistieran si existía la disidencia, la crítica interna. Por ejemplo, en la Selva, el que no era católico era perseguido como brujo, y casi toda la región de la Selva es católica, porque no era posible ser de otra religión, no lo permitían.(...) Sin embargo, a nivel interno sí había discusión; no era de una persona la decisión, nadie se arrogaba la representatividad del colectivo y se la imponía a los individuos.

Era realmente el colectivo el que operaba en contra de los individuos y los juzgaba.” (Le Bot, 1997: 117-8)

Evidentemente, eis aí uma teoria a respeito das coisas, que deve ser tomada como uma suposição, de um ponto de vista ocidental e moderno, a respeito de como se deu a história. A formulação nos interessa, sobretudo, ao revelar, ponto a ponto, alguns dos desconcertos dos não indígenas com a forma das comunidades de fazer política. Por exemplo, entre os Kaiowá e Guarani, a perseguição a feiticeiros não parece ter, necessariamente, relação com a presença de cristãos (embora estes tenham se aproveitado, em várias ocasiões, da enorme comoção que as acusações de 
feitiço podem provocar). Igualmente, essa visão sobre o conflito do coletivo x individual, em evidente clave moderna, poderia ser pensada de forma completamente distinta. Afinal, em situações em que não há constrangimento territorial, como vimos, um conflito costuma ser seguido pela abertura de uma nova aldeia, sem que se fale em "expulsão".

O surgimento do EZLN, segue relatando Marcos, enquanto organização supralocal, que exigia a tomada de decisões que não diziam respeito, unicamente, ao nível comunitário ${ }^{323}$, envolve uma série de desdobramentos e, também, a criação de novas cisões (tão características de grupos ameríndios de toda parte, poderíamos observar). A diferença, insiste ele, é que o movimento não promove expulsões - mas, nem por isso, deixa de implicar separações ${ }^{324}$.

E aparece, então, a discussão sobre a "democracia da comunidade" 325 , enquanto forma política. Por aí se vê como o debate sobre formas indígenas de governo, aqui, transbordou para uma discussão política mais geral, que diz respeito ao Estado mexicano e inspirou, sobretudo, jovens europeus na reflexão sobre seus próprios países:

\begin{abstract}
"Yo creo que esta forma de democracia sólo es posible en la vida comunitaria. Funciona en una comunidad indígena porque su organización social hace posible que tenga éxito esta forma de democracia política, pero no creo que sea transferible ni generalizable a otros escenarios, por ejemplo, los urbanos, ni a niveles más grandes, estatales o nacionales. Lo que sí, el control del colectivo sobre la autoridad debe ser un referente. En el caso de las comunidades, este control se da las 24 horas del día. Nadie se puede enriquecer sin que se sepa. Si un dirigente de la comunidad empezara a tener dinero, todos se darían cuenta rápido. Y si alguien no hace bien su trabajo, es remplazado. Evidentemente, esto funciona porque se trata de un pueblo. Pero debe existir un mecanismo, de manera que la sociedad pueda controlar 'a sus gobernantes y sancionados, no en el sentido de castigados,
\end{abstract}

323 Outra vez uma suposição, pois no passado, sabemos, pode muito bem ter havido ocasiões em que as comunidades se uniram - no caso de guerras, por exemplo.

324 Em um caso, lembra Marcos, zapatistas e não zapatistas de uma aldeia passaram a morar em lados distintos de um rio, como forma de distinguir-se: "Y sí había casamientos y se veían, pero, en realidad, eran dos poblados. El zapatismo dividía, pero no confrontaba. La diócesis acusa al zapatismo de dividir y confrontar. Eso es injusto. Sí dividimos, pero no confrontamos. La Iglesia sí dividió y confrontó. Mataron gente por motivos religiosos y aún matan por motivos religiosos. Nosotros no hemos matado a nadie en nombre del zapatismo. Vaya, las comunidades se pelean, se dicen de todo, pero no ha habido choques armados, promovidos por los zapatistas, entre zapatistas y no zapatistas." (Le Bot, 1997: 118)

325 Chamada, no texto, também, de "democracia comunitária”, “de assembleia", ou "direta". 
sino evaluados y decidir, según eso, que continúe o que no continúe, o que se castigue o se premie. Que realmente la sociedad fuera la que controlara a los gobernantes y no los gobernantes controlaran a la sociedad, que es ésa la idea de los teóricos políticos ex salinistas y ahora desmemoriados del salinismo. El papel del gobierno, dicen ellos, es controlar que la sociedad no se disgregue, o sea, que la sociedad tiende al caos naturalmente. Necesita un gobierno fuerte que la controle y la compacte. Nosotros decimos que no. El que tiende naturalmente al caos es el gobierno, a la dictadura, al ejercicio antidemocrático, al autoritarismo, a la corrupción, y es la sociedad la que tiene que exigir cuentas al gobierno. Que el gobierno mande obedeciendo, decimos nosotros. Eso es lo único que pensamos que debiera haber. Pero no recomendaría yo, por experiencia, que se trasladara el modelo de toma de decisiones de un tipo de asamblea comunitaria, por ejemplo, a una universidad. Yo conozco las asambleas universitarias...” (Le Bot, 1997: 120)

A defesa que Marcos faz é, pois, da complementaridade entre a democracia representativa e a comunitária. Ele concorda com Le Bot quando este percebe uma tendência gerontocrática nas comunidades indígenas, e algo de autoritarismo nessa prevalência do coletivo sobre o individual:

"Sí, en eso estamos de acuerdo. Yola que digo es que ese tipo de democracia sirve para determinados problemas, no para todos. Lo que pasa es que la comunidad lo aplica a todos los problemas, al grado de la desesperación. Te vaya poner un ejemplo: Rich se casa con una mujer de un pueblo. Para poder hablar con la muchacha tiene que pedir autorización a la asamblea del pueblo. El Rich tiene que esperar a que la asamblea le dé permiso antes de entrar a pedir la muchacha. Todo el mundo sabe que está enamorado, menos la muchacha. Luego ya lo sabe la familia, ya le dan permiso, así funciona. Este ejemplo es cómico, pero hay otros más complejos, de más alto nivel, en los que pienso que ese tipo de democracia no sirve porque afecta a los individuos." (Le Bot, 1997: 121)

Outra vez mais, esbarramos com os assuntos definidos como "privados" por certo ponto de 
vista moderno ${ }^{326}$. Mas, voltando à exposição de Marcos, ele prossegue a ideia de que é necessário pensar na promoção de um diálogo entre as formas políticas:

"Las mismas comunidades tienen que aprender eso que el país tiene que aprender, que hay otros tipos de democracia que funcionan, que también funcionan en otros lados. Algunas de éstas están empezando a surgir a la hora en que el comité construye esa democracia representativa. Los pueblos eligen a su representante, la autoridad del pueblo, la autoridad zapatista. Las autoridades de varios pueblos nombran a la autoridad de la región. Las autoridades de varias regiones nombran al de zona, los de zona al representante de etnia, y los de etnia nombran a los que van al comité. Ahí sí, como de todas maneras tienen que relacionarse con otras etnias, los problemas que se ven en el Comité no son sólo los de la comunidad, aunque la afecten. Pero ese proceso de aprendizaje es difícil y el horizonte se les empieza a abrir a las comunidades cuando conocen otras experiencias. Por ejemplo, el aprendizaje de la democracia sindical, lo de la lucha, de planillas y todo eso, que han conocido mediante el contacto con los trabajadores electricistas y telefonistas, con quienes hablan de sus experiencias. $O$ con sindicatos de obreros agrícolas, con los que tenían contacto, $u$ organizaciones estudiantiles, sindicatos de maestros, todo esto ha significado un enriquecimiento." (Le Bot, 1997: 121)

O EZLN, como movimento, e como inspirador de uma série de reflexões políticas, opera, portanto, pondo essa forma política em diálogo com outras formas democráticas ${ }^{327}$. Por outro lado,

\footnotetext{
326 Muito embora, o caráter público do casamento seja algo muito mais geralmente verificado, como nos mostra Lévi-Strauss (1986).

327 Esse diálogo tem sido aplaudido por grupos que fazem a crítica da democracia liberal, particularmente os de matriz anarquista. Segundo um folheto anarquista irlandês, o método zapatista de tomar decisões a partir de consultas diretas à base, com voto universal, e possibilidade de revogação do mandato (não remunerado, por sinal) de um representante a qualquer momento, caso não siga o princípio de "mandar obedecendo", "demonstra que métodos similares de tomada de decisão democrática, os quais os anarquistas defendem por todo lado, não são apenas práticos, mas oferecem uma via de organização alternativa a sempre esperar conseguir que um punhado de bons homens sejam eleitos para o parlamento (Flood, 1998). "Essas estruturas são, obviamente, compatíveis com o o anarquismo ou mesmo o sindicalismo revolucionário. As questões-chave sobre mandato e 'recall' estão lá. O fato de que essas estruturas não são conscientemente anarquistas, mas surgem a partir de uma mistura de prática indígena, marxismo e Teologia da Libertação, não deve impedir-nos de nos mantermos em solidariedade com eles. Mais importante ainda, quaisquer que sejam suas origens, elas oferecem um modelo atual, na prática, de algumas das coisas que falamos. Chiapas é isolado e extremamente pobre, o fato de que as estruturas libertárias podem florescer em condições tão difíceis, no meio de uma guerra de baixa intensidade, apenas demonstra quão válidas elas são", escreve o mesmo autor em uma revista anarco-sindicalista estadunidense (Flood, 1999).
} 
temos, nesse encontro, entre duas distintas "democracias", o estabelecimento de uma série de distinções a respeito das assembleias indígenas, ou de um "sistema de governo" indígena, por assim dizer. Poderíamos enumerar algumas dessas características:

1 - assembleias indígenas tendem a ser, do ponto de vista ocidental, oligárquicas e gerontocráticas;

2 - aparentemente, mulheres e jovens têm menos espaço, mais dificuldade de expressar suas opiniões no âmbito da assembleia;

3 - decisões, em geral, são por consenso;

4 - os dissensos podem gerar cisões do grupo;

5 - há uma prevalência da moral sobre a política, e uma indistinção entre privado e público;

6 - mandatos são revogáveis em função da constante fiscalização;

7 - do ponto de vista ocidental, prevalecem decisões em que o coletivo se sobrepõe ao individual.

Nos últimos anos, com o desenvolvimento das chamadas "autonomias zapatistas" (no plural, em função de se considerar que cada comunidade tem liberdade para desenvolver seu próprio modelo), outros princípios desenvolvidos nas centenas de grupos locais do movimento têm chamado a atenção. Fernandez (2009) expõe alguns deles, como a ausência de remuneração para quem cumpre uma função pública, a ideia de que é preciso haver rotação de cargos, para evitar o surgimento de "profissionais" da política etc.

\section{Assemblar/desassemblar}

Há uma questão que, eventualmente, pode surgir aos leitores, em função de certas características comuns a todos esses exemplos (Kaiowá/Guarani, Tupinambá, Zapatistas, Iroqueses): mas, afinal, essa formação multilocal não seria algo típico de períodos de guerra? Noves fora, tudo isso não confirmaria, justamente, que a formação de uma unidade para além do grupo local somente se dá em períodos de exceção? 
O próprio Fernandes, como vimos acima, levanta esse tipo de questão, ao sugerir não haver encontrado indício de que as decisões do conselho tupinambá fossem além do que envolvia a guerra. Poderíamos objetar, lembrando, por exemplo, que ele mesmo assume que as festas eram objeto de discussão do conselho (afinal, os sacrifícios dos cativos eram grandes banquetes, de alguma forma). Mas não me apegarei a essas minúcias. O que gostaria de levantar tem relação com o que Latour (2005) sugere discutir a respeito da política.

Em português, usamos o substantivo "assembleia", mas falta-nos o verbo "assemblar", que o inglês, por exemplo, adotou do francês (assemble). E, indo adiante, Latour agregará: “estar junto pode não ser lá um desejo universal, no fim das contas" (2005: 24). Na coletânea organizada pelo autor, um texto de Descola sobre os Shuar do Equador e sua "recusa à política" serve como lembrete de que nem sempre, afinal, os coletivos humanos consideram que seja necessário reunirse. Frequentemente, por sinal, isso pode ser considerado indesejável, desagradável ou inútil ${ }^{328}$.

Estamos falando, desde o início, sobre a necessidade de alargar nossa imaginação, a fim de compreender melhor esses outros pensamentos políticos. Pois aí está um ponto: é preciso entender que, sim, pode ser completamente cabível para os Kaiowá e Guarani permanecer longos períodos em que cada grupo local está cuidando de seu próprio nariz e, de repente, perceber a necessidade de reunir-se, a fim de discutir algum tema que diz respeito a vários grupos locais. Há uma naturalidade a ser notada nessa oscilação entre assemblar e desassemblar.

Isso não quer dizer que a guerra seja o único fator de assemblagem. Lembremo-nos, um dos exemplos que Lowie (1967: 78) oferecia da ação política concertada em um grupo ameríndio emergia quando os Yaghan encontravam uma baleia encalhada na praia. Normalmente dispersos, eles se juntavam para aproveitar aquela oportunidade extraordinária de alimentação, aceitando a concertação das ações realizada por um chefe e a delegação temporária de poder de polícia a um grupo de homens que ele escolhia. O Estado não seria uma baleia grande o suficiente para atrair as pessoas a uma assembleia? Sem falar, claro, nas festas. Do jeito que Descola (2005) descreve a desassembleia shuar, fica-se com a dúvida: mas, afinal, esse povo não se reúne em festas? Só faz guerras?

328 Diria que me parece faltar a esse texto de Descola (2005) a percepção de que o caráter "desassemblado" dos Shuar, tal como ele descreve, pode ser pensado como um momento histórico do grupo. Por sinal, é notável, à primeira vista, a dissonância entre a descrição desse autor e o que se nota no cenário político equatoriano das últimas décadas, com grande participação dos movimentos indígenas e o surgimento, nos anos 70, de uma Federação Shuar - por exemplo. 
Creio que, se tudo isso não for mais bem compreendido, continuaremos com uma grave lacuna no entendimento das formas politicas ameríndias. "E se uma das causas do fundamentalismo for que todas essas outras formas de juntar-se são, afinal, mal representadas? Como se a roupa da política fosse apertada demais para elas?”, pergunta Latour (2005: 25). O autor direciona sua argumentação para a necessidade de se compreender o dissemble como manifestação do político. Mas, por que não, poderíamos dizer que as modalidades de assemble são igualmente pouco estudadas.

Detienne (2003, 2004), por sua vez, destaca a necessidade de atentar à variabilidade das formas de assembleia, em sua promoção do comparativismo - no caso, aplicado às "formas do político com vocação igualitária” (2004: 122). Em vez de distinguir “formas da 'autoridade' ou do "poder legítimo"” - preocupações marcadamente ocidentais, poderíamos agregar -, o autor propõe um projeto de pesquisa: a comparação entre as "práticas constituintes" da política em diferentes sociedades:

“Nosso ponto de partida é, portanto, o exercício da assembleia observado em sociedades que se ignoram: as deliberações dos guerreiros homéricos à margem das primeiras cidades gregas; os encontros quase cotidianos dos Ochollo em seus fóruns; as reuniões incessantes dos Constituintes que estabelecem o princípio da autonomia parlamentar e que constroem dia após dia um novo político” (Detienne, 2004: 124)

Tendo em perspectiva esses escritos de Latour e Detienne - e juntando a isso as já citadas análises de Perrone-Moisés -, creio que o que vi entre os Kaiowá e Guarani poderia ser descrito como uma oscilação entre assembleia e desassembleia, reunião e dispersão, em que o fator de reunião é determinado pelo momento político pelo qual passa certo grupo local.

Agregue-se que essa oscilação não é automática, porque reunir-se em assembleia supõe, ainda, a possibilidade de definir a pauta do debate. Uma vez que as Aty Guasu concentram-se na discussão dos temas ligados à luta pela terra, o fato é que, uma vez que determinada TI está regularizada, progressivamente o grupo local vai sendo envolvido por uma série de assuntos que se distanciam dessa pauta, e acaba ocorrendo que boa parte dessas pessoas simplesmente se afasta das assembleias.

Ate certo ponto, essas pessoas se desassemblam. Mas, ao mesmo tempo, acabam se 
aproximando de outros foros de discussão, outras assembleias, como é o caso dos numerosos conselhos ligados ao controle social das políticas públicas (saúde, educação, assistência social). Ainda, o grande desafio dos Kaiowá e Guarani é conciliar os interesses das aldeias tuja e pyahu como, às vezes, se costuma dizer nas Aty Guasu. Como se viu no caso dos protestos de 2009, os fazendeiros e políticos locais costumam aproveitar-se dessa situação e usar o interesse nas políticas públicas, por parte das comunidades mais estabelecidas, para jogá-las contra a luta pela terra.

Estamos falando de algo que pode ter desdobramentos muito graves: em um exemplo recente, certa liderança de uma área conquistada pela luta ao longo dos anos 80 e 90 foi indiciada por colaborar com fazendeiros na ação que vitimou Nísio Gomes, do Guaiviry. O sujeito, cujo nome não foi divulgado publicamente até o momento, chegou a ser preso, contou tudo sobre o episódio e, por ter ajudado a Polícia Federal a esclarecer o crime, poderá ter sua pena reduzida. Há anos circulam rumores sobre essa aliança de lideranças de aldeias já estabelecidas com os fazendeiros, conspirando contra novas ocupações de tekoha reivindicados. Esta é a primeira vez em que uma investigação policial obtém dados concretos, e inclusive a confissão do suspeito.

Assim, o fato é que, numa dinâmica de assemblar/desassemblar, o grupo que se reassembla pode já não ser o mesmo de antes, e também a assembleia poderá já ser outra - como no caso em que Carneiro da Cunha percebe a criação de um inédito "conselho de pajés" entre os Krahô (2009: 341-3).

\section{Pensando juntos}

A seguir, vamos detalhar um dos pontos em que, creio, a distinção entre assembleias ocidentais e indígenas é mais notada. Conforme já explicitamos acima, trata-se da ênfase, dos povos indígenas, na reunião como local para se construir um consenso.

Se, a nossos olhos acostumados à democracia liberal chamam, particularmente, a atenção as características que distinguem esses sistemas políticos ameríndios como "oligárquicos", vale observar que as questões fundamentais, do ponto de vista indígena, parecem ser outras. Em primeiro lugar, há a construção de consenso. Não por acaso, é em torno desse ponto que giram algumas reflexões de intelectuais e pesquisadores indígenas que encontramos no México ${ }^{329}$.

329 Entre os mais conhecidos autores mexicanos que escreveram sobre a formação de consenso em assembleias 
Em Chiapas, o sociólogo tzotzil Nicolas Gonzalez Ruiz se dedica a estudar os processos de decisão em sua própria comunidade, San Andrés Larrainzar. Tomando o exemplo da eleição comunitária de "autoridades", ele assim descreve a existência de seis etapas no processo de formação de um consenso:

"En la elección de las autoridades en la asamblea, se escuchan y se toman las voces de quienes fijan posición, y proponen a personas para tomar un cargo, se mencionan varias personas, finalmente son dos los que quedan, esta es la primera etapa; la segunda, se da cuando la comunidad converge para la decisión final, los participantes en la elección dan sus razones y su posición, muchas de las veces se fijan en las personas que no han colaborado mucho en el proceso interno de la consolidación de la resistencia, o bien por la disponibilidad de tiempo de la persona; en la tercera etapa, los responsables locales se encargan de dirigirse a la persona elegida; la cuarta etapa es la negación y regateo de la persona próxima a tomar el cargo, haciendo mención de sus razones, estas regularmente son: la incapacidad e inexperiencia en el manejo del trabajo; la quinta etapa, es el impulso que los responsables locales y los participantes en la asamblea, hacen hacia la persona elegida, aduciendo que nadie es experto en algo, sino que es el tiempo que da la experiencia, y que todos han pasado o tendrán que pasar ese proceso; y la sexta etapa, es la aceptación y convencimiento de la persona, pero antes, pide que si no llega a consolidarse como un sujeto responsable del cargo, la comunidad lo retire y nombre otro, esta es la práctica participativa de la comunidad, es la práctica de la democracia real." (Gonzalez Ruiz, 2011: 13)

Outra forma de pensar a formação do consenso, segundo Gonzalez Ruiz, é que as opiniões individuais vão se agregando em grupos, durante o debate, e que, ao fim, esses grupos se diluem num consenso geral. Enfim, seja como seja, o que quero ressaltar aqui é a constatação de que se repete o que verificamos nas Aty Guasu: a ênfase de uma filosofia política ameríndia parece estar na construção do consenso.

A impressão é confirmada por Lenkersdorf, entre os Tojolabal, outro grupo maya indígenas, está Lenkersdorf (1996, 2004, 2005), que atuou por muitos anos em Chiapas, entre os Tojolabal. 
chiapaneco. Ele, por sinal, diferencia as atitudes verificadas em uma assembleia local ou multilocal. Nestas, observa, o esforço para se alcançar o consenso se multiplica:

"Si la delegación de una de las comunidades no está de acuerdo, no se sacrifica la meta del consenso. Ésta sigue vigente. Por ello, la tarea del convencimento mutuo se dificulta mucho. Puede durar horas y puede fallar.

En este caso la asamblea resulta bloqueada. Otra asamblea tiene que reanudar el assunto para resolver el problema" (1996: 82)

Em uma reunião do Congresso Nacional Indígena (CNI) na comunidade coca de Mezcala, estado de Jalisco, em 2011, o purepecha Juan Chávez, veterano do movimento indígena mexicano, refletia, dessa mesma maneira, sobre o consenso e discorria sobre como essa forma indígena de tomar decisões difere da dialética marxista ou hegeliana. Aqui, o que importa é fazer com que as diversas posições se juntem, coincidam. Compor, na imagem sugerida por Chávez, uma "paisagem das ideias".

O senso comum ocidental, curtido na democracia liberal, tem um trato peculiar com a questão do consenso. A unanimidade total deveria ser a meta de uma democracia que se entende como jogo. Mas, na remota hipótese de que ela seja alcançada, tende a ser posta sob suspeita ${ }^{330}$. Estudos sobre consenso, no contexto ocidental, tendem a associá-lo a fenômenos negativos, como ditaduras $^{331}$. Eleições em que $100 \%$ dos votantes elegem um mesmo candidato? Só em países como o Iraque, nos tempos de Saddam Hussein, por exemplo...

Penso que aí reside o estranhamento ameríndio fundamental com nossa política. É o que explica uma declaração como a do rionegrino Sebastião Duarte, registrada por Soares: "Na tradição, o chefe era o primeiro, o fundador. Hoje se tem uma eleição. A democracia é anticultura, é modo de organização do branco" (2012: 9). Democracia aí, penso eu, refere-se, justamente, à eleição por maioria e a ideia de "um homem, um voto".

330 Significativamente, o Dicionário de Política organizado por Bobbio et al. considera, no verbete sobre o tema (1998, p. 240), que "um Consenso total é um tanto improvável mesmo em pequenas unidades sociais, sendo totalmente impensável em sociedades complexas". Isso, mesmo reconhecendo que "o grau de Consenso varia de uma sociedade para outra e de época para época". Chama atenção, ainda, a avaliação de que influi no "grau de consenso" o "grau de homogeneidade da sociedade sob o aspecto sociocultural". O consenso só aparece como algo positivo no que concerne a momentos de crise, pois "ajudará uma sociedade a superar momentos de dificuldade como, por exemplo, casos de guerra ou de crise econômica". Enfim, o que parece evidente é que a atenção dedicada ao tema na tradição política ocidental é quase irrelevante - no dicionário em questão, são meras três páginas, com menções esparsas ao longo de alguns outros verbetes, segundo me indica uma busca com Ctrl F (isso, em dois volumes de mais de 2 mil páginas).

331 Os volumes organizados por Rollemberg e Quadrat (2010) oferecem diversos exemplos, nesse sentido. 
Simplificando a discussão, poderíamos dizer que há algo estranho em tudo isso, porque a mera inversão de determinados argumentos básicos nos leva diretamente às questões levantadas pelos ameríndios em tantos contextos diferentes, estejamos falando de "sem Estado x com Estado", ou "pelo Estado ${ }^{332}$ x contra o Estado". De fato, esticando o olhar para além da democracia liberal, seria possível, sim, localizar, nas tradições ocidentais de conhecimento, pistas sobre esse outro lado da moeda. Elas estão, como veremos a seguir, nas tradições "hereges", ligadas, sobretudo, ao anarquismo.

O outro tópico caro aos autores que buscam o ponto de vista indígena sobre esse sistema político é a chamada autonomia. Termo verdadeiramente polissêmico, é utilizado hoje em múltiplos sentidos pelo movimento indígena, América Latina afora ${ }^{333}$. Uma das raízes, justamente, da popularidade dessa discussão parece ter relação com o exato fato que desconcerta o olhar ocidental na política ameríndia: como construir um sistema que articula diferentes unidades locais, mas que mantém a independência (autonomia) de cada uma delas?

Esse desafio tem um interessante paralelo na tradição ocidental. Entre nós, ele foi enfrentado, sobretudo, pelos anarquistas, além de algumas correntes marxistas ${ }^{334}$. Quanto à democracia liberal, é possível encontrar importantes dados na obra que marca a fundação do que é considerado por um autor como Morgan como a expressão máxima dessa forma política, a Constituição dos Estados Unidos da América.

Um dos pontos mais destacados de "O Federalista", de Hamilton, Madison e Jay, é, como se sabe, uma crítica à confederação como forma política, em função da instabilidade inerente a ela. Ora, como se vê no $15^{\circ}$ artigo da coletânea, "A insuficiência da presente confederação para

332 Ou, "capturado pelo Estado", como foi dito mais recentemente (Viveiros de Castro, 2011).

333 A discussão sobre as "autonomias indígenas" envolve uma bibliografia imensa. Para um panorama geral do debate, do ponto de vista de intelectuais indígenas, indicamos as obras de López Barcenas (2007) e Luciano (2006). Aqui, não apresentaremos um painel amplo da discussão, a qual nos interessa, sobretudo, em função de uma questão mais geral que o amplo emprego do termo parece indicar (outra abordagem possível seria uma busca dos sentidos particulares que o termo assume em cada contexto, mas isso nos afastaria de nosso escopo aqui - temos buscado esse mapeamento por meio de esforços coletivos, como a realização de simpósios e grupos de trabalhos em encontros internacionais).

334 Como se pode perceber na discussão sobre a ideia de "relações internacionais" apresentada por Bobbio et al. (1998: 1089), é aí, na tradição ocidental/liberal, que está o lugar onde se pensa esse tipo de sistema, em que a "soberania" de cada entidade estabelece uma "situação anárquica" no plano internacional. Vale observar que, talvez por isso, causem tanta polêmica as reivindicações indígenas por autonomia, bem como, em países como o Brasil, a atribuição do termo "nação" a coletivos indígenas. Agradeço ao professor Márcio Silva por compartilhar esse insight, ao longo de nossas discussões sobre as descrições das assembleias guarani/kaiowá, durante nosso exame de qualificação. 
preservar a União" ${ }^{335}$, a Constituição estadunidense instala, justamente, a novidade da república representativa ${ }^{336}$, em que um poder central funciona como uma "superintendência discricionária" (Hamilton, Madison e Jay, 2001: 270).

É notável a influência da organização dos iroqueses sobre o processo de discussão em torno da Constituição estadunidense, a qual, vale lembrar, surge 67 anos depois da transcrição da Gayanashagowa, a chamada Constituição Iroquesa, ou Grande Lei de Paz, que já era conhecida pelos europeus desde o início dos contatos com esses grupos.

"De fato, há um conjunto substancial de evidências - tanto inferenciais como diretas - que suportam a tese de que a democracia norte-americana, da forma como emergiu no século XVIII, é uma síntese de teorias políticas indígenas e europeias.” (Wilkins \& Stark, 2011: 55)

Fato também é que há afastamentos significativos entre as formas iroquesas e as que nascem no debate estadunidense. O maior deles talvez tenha relação com as peculiares ideias europeias sobre uma "natureza humana", como nos lembra Sahlins (2008). O alvo da novidade do poder "superintendente" na Constituição dos EUA são as "facções" 337, assim definidas por Madison, no $10^{\circ}$ artigo, "A união como uma salvaguarda contra facções domésticas e a insurreição":

"Entendo como facção um grupo de cidadãos, representando quer a maioria, quer a minoria do conjunto, unidos e agindo sob um impulso comum de sentimentos ou de interesses contrários aos direitos dos outros cidadãos, ou aos interesses permanentes e coletivos da sociedade. Há dois processos para remediar os malefícios das facções: um, pela remoção de suas causas; outro, pelo controle de seus efeitos. Há, também, dois processos para remover as causas das facções: um, pela destruição da liberdade, que é essencial à sua existência; outro, fazendo com que todos os cidadãos tenham as mesmas opiniões, os mesmos sentimentos e os mesmos interesses. Nada seria mais verdadeiro do que afirmar que o primeiro

335 A Livraria do Congresso dos EUA disponibiliza, online, o texto em inglês. Para alguns termos-chave, cotejo a versão traduzida com o que encontro lá, em http://thomas.loc.gov/home/histdox/fedpapers.html

336 Para uma breve apresentação do sentido dessa novidade na história da política ocidental, ver Limongi, 2001.

337 Sobre o amplo emprego do termo e de seu correlato, "separatismo", na etnologia jê, ver Drago, 2012. Uma rica revisão sobre a ideia e sua aplicação para a análise do caso xerente estão em De Paula, 2000. Note-se, o que estamos sublinhando aqui é que, desse ponto de vista herege (conselhista/anarquista), a ideia de faccionalismo ou facciosismo pode simplesmente não fazer sentido. 
remédio é pior do que a doença. A liberdade é para as facções o que o ar é para o fogo, um elemento sem o qual elas instantaneamente se extinguem. Mas, suprimir a liberdade - que é essencial à vida política -, porque ela alimenta as facções, não seria uma tolice menor do que desejar a eliminação do ar - que é essencial à vida animal -, porque ele confere ao fogo seu poder destruidor. O segundo expediente é tão impraticável quanto o segundo seria insensato. Na medida em que a razão do homem continuar falível e ele puder usá-la à vontade, haverá sempre opiniões diferentes." (Hamilton, Madison e Jay, 2001: 263).

Há certa especulação sobre motivos políticos ou religiosos, mas o autor mesmo admite (no que poderíamos considerar, com a melhor das intenções, um eufemismo, em se tratando de um país, à época, assumidamente escravista) que a distribuição "variada e desigual" da propriedade é a fonte "mais comum e duradoura das facções" (op.cit: 264). Assim é que, poucas linhas depois, a dissertação sobre a natureza humana nos conduz ao ponto essencial:

“A diversidade das aptidões humanas, nas quais se originam os direitos de propriedade, não deixam de ser um obstáculo quase insuperável para uma uniformidade de interesses. A proteção dessas aptidões é o primeiro objetivo do governo. Da proteção de aptidões diferentes e desiguais para adquirir bens, resulta imediatamente a posse de diferentes graus e tipos de prosperidade; a influência destes sobre os sentimentos e opiniões dos respectivos proprietários acarreta uma divisão da sociedade em diferentes interesses e partidos" (op.cit: 264)

É justamente toda essa associação entre facções/desigualdade/propriedade/arbítriosupervisão que é recusada pela tradição intelectual e política que tem condições de dialogar com essas formas políticas ameríndias aqui abordadas. A fundamentação arbitrária dessa opção por uma "autoridade discricionária", "suprema e absoluta", em algumas traduções ${ }^{338}$, fica evidenciada, por exemplo, na obra de Proudhon, para quem "liberdade e ordem" não são inconciliáveis, muito pelo contrário (vide suas considerações sobre a “democracia operária” - 1986: 125-7).

Na obra de Karl Marx, há mesmo a possibilidade de outras leituras, diferentes daquelas que

338 Ao fim e ao cabo, arriscaria dizer que, no mais das vezes, é ao controle dessa entidade que diz respeito o enigmático termo "poder", tão debatido na política ocidental. 
as práticas partidárias e estatais ao longo do século XX canonizaram. O impacto da experiência da Comuna de Paris (1871) sobre Marx é considerado "decisivo” por Tible. Trata-se, segundo este, do “exemplo clássico dos conselhos, inaugural no seio do pensamento marxiano e das práticas dos trabalhadores" (2012: 134).

Uma autora frequentemente citada, no âmbito do debate mexicano, por aqueles que dialogam com essa tradição ocidental, é Rosa Luxemburgo, marxista precursora do chamado "comunismo de conselhos" "339. Há mesmo quem compare o sistema de autogoverno zapatista aos modelos que ela idealizava ${ }^{340}$. A pensadora, justamente, se notabilizou pela rejeição às estratégias centralizadoras e autoritárias adotadas ao longo da Revolução Russa. Logo após a Revolução Alemã de 1918, durante algum tempo surgiram conselhos populares pelo país, e Luxemburgo estava entre os intelectuais que sustentava a ideia de que eles poderiam ser a base para uma nova forma de governo:

\begin{abstract}
"Falar em conselhos significa falar em democracia direta, ou democracia radical (em oposição à democracia representativa). A primeira vez que os conselhos como forma política de organização democrática das classes subalternas surgiu no ocidente foi com a Comuna de Paris de 1871. Era uma tentativa de superar a crise do Estado moderno decorrente das desigualdades da ordem capitalista e da pouca influência dos indivíduos nas decisões que os afetavam. Os conselhos visavam criar uma nova forma de soberania popular e assim pretendiam substituir (ou complementar) o Estado de direito burguês (com sua separação dos poderes) por um novo princípio estatal. Numa democracia conselhista o povo se organiza de baixo para cima em pequenas unidades: fábricas, comunidades, bairros, escolas, etc. que foi o que se viu p.ex., por um curto espaço de tempo, em Munique."
\end{abstract} (Loureiro, 2005: 3)

No desenrolar dos acontecimentos, os conselhos não se mantiveram, a revolução se reverteu em tragédia - incluindo-se aí o assassinato de Luxemburgo, em janeiro de 1919 -, mas essa

339 Um panorama acessível dessa corrente intelectual é oferecido no volume organizado por Authier \& Dauvé (2004).

340 Esse comentário apareceu durante o Colóquio Internacional "Marxismo e Antropologia", na Escola Nacional de Antropologia e História (Enah), na Cidade do México, em setembro de 2010. A obra de Rosa Luxemburgo era citada por Ortega Olivares e Concheiro Bórquez, participantes do evento, em suas apresentações (não publicadas): respectivamente, "Las sociedades precapitalistas desde el marxismo de Rosa Luxemburgo" e "Territorios comunales en la estrategia comunista”. 
experiência política, juntamente com os escritos da autora, se manteve.

Encontramos algo mais sobre suas ideias em torno dos conselhos em seus textos sobre o programa da Liga Spartacus, grupo político-intelectual que integrou à época da revolução alemã de 1918. Em “O que quer a Liga Spartacus”, ela escreve:

"Do degrau mais alto do Estado até o menor vilarejo, a massa proletária tem que substituir os órgãos superados da dominação burguesa de classe (...) - as assembleias, parlamentos, conselhos municipais - pelos seus órgãos próprios de classe, quer dizer, os conselhos de operários e de soldados. Devem-se ocupar todos os postos, fiscalizar todas as funções, medir todas as necessidades oficiais segundo os interesses próprios de classe e os objetivos socialistas. Somente por meio do contato constante, vivo e recíproco entre as massas populares e os seus órgãos, os conselhos de trabalhadores e soldados, pode a atividade do povo preencher o estado com um espírito socialista.” (adaptado de Luxemburgo, 2008: 3)

Eleição por voto universal (a democracia como fim, não como meio, conforme advogavam os soviéticos - Loureiro, 1997) e revogação do mandato do conselho a qualquer momento eram os fundamentos que defendia (idem: 7-8). Em outro texto, "Sobre o programa Spartacus", também de dezembro de 1918, reforça: o sistema de conselhos deveria ser estendido em todas as direções ("Oos conselhos devem ter todo o poder no estado") e seria, certamente, o grande legado da revolução alemão ao mundo: "Um estudo da situação existente nos permite prever com segurança que em qualquer país, depois da Alemanha, onde a revolução proletária irrompa, o primeiro passo será a formação de conselhos de trabalhadores e soldados” (Luxemburgo, 2003: 9).

Como se vê, a almejada aproximação entre etnologia e as teorias políticas como (certo) marxismo e o anarquismo ${ }^{341}$ é plenamente possível, o que falta é delinear corretamente as características de um (uns) "sistema(s) político(s) ameríndio(s)".

\footnotetext{
341 Parece-me que é hora de superar a aversão de autores como Clastres a esse diálogo - até porque, como espero ter demonstrado, estamos falando de um marxismo que, em si, é outro. Como indica Graeber, poucos estiveram buscando (re)construir as pontes que possibilitem trânsito aí. É o que minha geração está buscando realizar (vide Tible, Schavelzon, entre outros).
} 


\section{Convívio}

Uma última questão a enfrentar: o desconcerto trazido pela polícia do "contra o Estado", referido na introdução. Poderíamos, de imediato, lembrar a discussão sobre a necessidade de diferenciar Estado e governo, conforme referido, também no início deste trabalho (Drago, 2012). Mas, uma explicação tão geral não afasta a conveniência de uma descrição mais atenta.

Em primeiro lugar, vale dizer, essa ideia de "justiça comunitária” está, hoje, verdadeiramente espalhada pela América indígena. Pudemos comprová-lo na Bolívia, onde acompanhamos, brevemente, as discussões a respeito do tema entre 2008 e 2009 (período em que se aprovou, em plebiscito popular, a nova Constituição do país, a qual prevê a complementaridade entre a Justiça comum e a que é praticada segundo os costumes de cada coletivo indígena ou camponês) $)^{342}$.

No México, tivemos oportunidade de conhecer a região da Costa Chica e Montanhas do estado de Guerrero, onde grupos indígenas (tlapanecos, mixtecos e nahuas), mestiços e afrodescendentes organizam, desde os anos 90, uma iniciativa de Polícia Comunitária (www.policiacomunitaria.org), considerada a mais ampla e bem-sucedida experiência de autonomia indígena em vigor no país atualmente, afora as comunidades zapatistas ${ }^{343}$. Em 2011, a iniciativa completou 16 anos.

Vídeos etnográficos como K'ixb'al (Vergonha), de Carlos Y. Flores Arenales, que registra processos de julgamento comunitário realizados na comunidade $k^{\prime} i c h e^{\prime}$ de Santa Cruz del Quiché, no norte da Guatemala ${ }^{344}$, também têm demonstrado a ampla difusão desses mecanismos locais de resolução de conflitos, ajudando, ainda, a entender as práticas aí envolvidas.

A curiosidade sobre o tema dialoga intensamente com a experiência de campo entre os Kaiowá e Guarani. O fato é que, além de toda a demanda que recai sobre o tendotálmburuvicha, no que tange a questões “de governo”, por assim dizer, são frequentes, também, nas assembleias locais kaiowá que acompanhei, as questões "internas", relativas, muitas vezes, a normas de convivência

342 Ver, além de Pimentel, 2008, série de reportagens sobre visita a Bolívia durante o plebiscito constitucional, que publicamos, entre 28/01 e 04/02/2009, em www.cartamaior.com.br. Para um estudo detalhado sobre o processo político boliviano, recomendo Schavelzon, 2010.

343 A respeito dessa experiência em Guerrero, há grande volume de produção antropológica. O citado sítio da Polícia Comunitária na internet oferece uma lista de trabalhos. Sobre as experiências de autonomias indígenas no México, recomendo o volume organizado por Quintana e Gasparello (2009), além das reportagens e artigos publicados em www.desinformemonos.org .

344 Sobre essa experiência, ver Flores Arenales, 2012. O vídeo foi concluído em 2010. 
coletiva, a ordem e bem-estar das pessoas.

Por exemplo, há a inescapável - e popular - discussão a respeito das arruaças feitas por jovens - ou estudantes, como também são chamados. Em função da aglomeração decorrente da falta de terras, em várias das áreas ocupadas hoje pelos Guarani e Kaiowá, são frequentes as confusões relativas à confusão causada pelos jovens que passam parte da noite nas ruas, fora de suas casas.

Sobretudo a escola, como percebem eles, gera um tipo de socialidade que é novo e estranho. Sintomático da força que essa discussão tem nas aldeias é o fato de o primeiro Kaiowá a realizar um mestrado em Antropologia ter escolhido esse tema, justamente, para sua dissertação (Benites, 2009).

É importante perceber que, mesmo as áreas retomadas ao longo das últimas décadas, onde a qualidade de vida melhorou em comparação com as reservas do SPI, apresentam esse tipo de problema. Isso porque, na realidade, boa parte dessas terras tem extensão considerada insuficiente, por um lado, e, por outro, como é bem sabido, a própria instalação de equipamentos como escolas e postos de saúde dentro das áreas funciona como fator de atração, gerando maior densidade populacional em seu entorno. É em torno dessa experiência "urbana" que costumam acontecer os maiores problemas.

Os assuntos relativos às crianças e jovens parecem gerar um debate bem mais amplo do que outras discussões mais gerais e abstratas, envolvendo decisões de instância do Estado. Os processos envolvendo a Justiça são particularmente herméticos - como, ademais, para a imensa maioria dos cidadãos brasileiros.

Quase todos os adultos que participam de uma aty têm algo a dizer sobre o comportamento dos jovens e crianças: o que é reprovável, o que denota problemas em casa etc. As pessoas costumam citar seu próprio exemplo, lembrando histórias passadas em sua infância, para sustentar críticas ao modo como, hoje, pais e mães conduzem sua família. A imagem do mburuvicha como pai toma relevo nesse contexto: o entrelaçamento entre as necessidades relativas à manutenção de uma família e a de um grupo local é recorrente nas formulações que surgem no debate das lideranças. É, enfim, com esse tipo de sentido, que a necessidade de "polícia" tem comparecido às assembleias indígenas, em tantos pontos do continente. 


\title{
Sobre corpos e fractais
}

É Latour quem chama a atenção para a importância fundamental da ideia de "corpo político" no imaginário ocidental. De tempos antigos até hoje, o objetivo tem sido o de "unir as pobres assembleias humanas à sólida realidade da natureza" (2005: 27). Além dos órgãos do corpo, lembra ele, os mais variados animais foram, muitas vezes, convocados a sustentar a analogia, mas, argumenta o autor, parece que essa ideia faz cada vez menos sentido: "Sem dúvida que o Corpo Político é um monstro - tanto que nem é um corpo" (idem: 28). Latour cita livro do jornalista Walter Lippman, O Fantasma Público, obra de 1925 que denunciava o caráter ilusório do "público", para depois emendar:

\begin{abstract}
“(...) a maior parte da filosofia política europeia tem sido obcecada pelo corpo e o estado. Os europeus tentaram montar um parlamento impossível que representava realmente as vontades contraditórias da multidão em uma Vontade Geral. Mas essa iniciativa sofreu com uma cruel falta de realismo. A representação, concebida nesse estilo total, completo e transparente, não pode ser fiel. Ao pedir da política algo que ela não poderia entregar, os europeus continuaram gerando monstros abortados e acabaram desencorajando as pessoas a pensar politicamente. Para a política ser capaz de absorver mais diversidade (...), tem que inventar um tipo muito específico e novo de representação. Lippmann o chama de fantasma porque é decepcionante para aqueles que sonham com a unidade e a totalidade" (Latour, 2005: 28)
\end{abstract}

Em primeiro lugar, observemos, assembleias como as Aty Guasu oferecem outra possibilidade de resposta a essa questão do "fantasma público". Como pudemos perceber, os ameríndios não se iludem quanto ao alcance das decisões tomadas nessas reuniões. Quase sempre, não há como obrigar um determinado grupo a seguir diretrizes impostas. Uma votação é algo completamente inútil, na imensa maioria das vezes. O consenso é forçoso, e a alternativa a ele é a cisão $^{345}$.

Talvez por não sustentar esse fantasma, é que se tenha mais tranquilidade para imaginar a construção do consenso como um processo em que pessoas "pensam juntas" até atingir uma posição

\footnotetext{
${ }^{345} \mathrm{O}$ consenso é forçoso, mas não forçado. Ele se impõe, mas não é imposto. Além disso, como bom fantasma, pode se esvaecer rapidamente. Portanto, penso, é preciso encarar nosso incômodo com o termo e tentar observá-lo com leveza.
} 
comum e satisfatória para todos. O que é importante: tudo deve ser feito sem pressa. Lembremonos, essa questão das temporalidades aparece recorrentemente como algo crucial no estranhamento entre ameríndios e europeus. Diferente do que dizem autores como Thomaz de Almeida e Mura (2006: 175), que consideram que os Kaiowá e Guarani têm uma política "acéfala", o que eles me dizem é que, pelo contrário, têm algo que é multicéfalo.

Poderíamos comparar: enquanto os ocidentais imaginamos um "corpo político" composto pelos cidadãos, quando, eventualmente, a imagem do corpo ocorre entre os ameríndios é bem outra: como o xamã marubo que contém malocas em seu peito, na ilustração apresentada por Montagner e reproduzida por Cesarino (2010: 154) ${ }^{346}$. Lembrando a distinção que surge na obra de Floriberto Díaz (op.cit.), a comunidade aparece não como a soma de indivíduos, mas como expressão ligada ao espaço.

E, pensando também no vocabulário, lembremo-nos que, desde o século XVI, os europeus insistiram em usar o termo capitão - originário de termos latinos relacionados à cabeça - para referir-se aos líderes indígenas, quando grupos como os Guarani, justamente, estavam pensando em algo muito diferente: na pessoa que inaugura um movimento, um tendotá, ou naquele que é o mais procurado e frequentado em um lugar, o mburuvicha. Não é por acaso que os poderes outrora delegados aos capitães nas reservas do SPI/Funai renderam tantos problemas... Trata-se de um genuíno mal-entendido de longa duração.

\footnotetext{
346 Por sinal, observemos que, se um esquema como esse dos Marubo pode ser pensado como fractal, conforme nota Cesarino, igualmente o pensamento ocidental o é, pois reproduz, da pessoa ao cosmo, a mesma estrutura hierarquizada em cujo topo está um "cabeça". O correspondente ocidental ao desenho marubo que o autor apresenta poderia ser, por exemplo, a célebre ilustração do frontispício da edição de 1651 de "O Leviatã”, de Hobbes, em que o soberano tem o corpo formado pelos seus súditos.
} 


\section{Conclusões}

hai-kaiowa ${ }^{347}$

$y$

yvy, yvyra

ava vy'a

347 O hai-kai é de minha autoria. Numa possível tradução: "Rio/ terra, matagal/ alegria humanal” . 


\section{Igualitarismo}

A esta altura de nosso percurso, e antes que cortemos o fio, creio que vale a pena uma visita a certo conjunto de formulações etnológicas sobre grupos amazônicos que tem obtido repercussão entre os grupos políticos ocidentais "hereges": trata-se da obra de Joanna Overing, a qual é constantemente citada em estudos antropológicos de inspiração anarquista e libertária, como os de Graeber (2004), ou Morris (2007) - não raro, em companhia de Clastres e de escritos zapatistas.

Em contextos como esses, o que se destaca, geralmente, na obra dessa etnóloga que escreve, desde os anos 70, sobre os Piaroa ${ }^{348}$, são os traços que ela percebe em seu sistema social: alto grau de igualitarismo e autonomia pessoal. Para compreender o contexto em que aparecem esses termos, especialmente o segundo, um texto de Overing, em especial, é bastante útil. Ele aparece em 1993, em coleção da Associação de Antropólogos Sociais da Inglaterra (ASA), numa coletânea organizada por C. M. Hann a partir de material apresentado no encontro da entidade em 1991 - a um ano apenas, portanto, da queda do Muro de Berlim.

O livro se intitula Socialism: Ideals, Ideologies and Local Practice. A relação com o momento histórico por que passava a Europa é forte: a imensa maioria dos artigos tem como tema os regimes socialistas africanos, asiáticos e do Leste europeu. Um africanista. Alan Barnard, comparece com uma reflexão mais etnológica, sobre grupos bosquímanos ("Primitive communism and mutual aid: Kropotkin visits the Bushmen”). Overing, por sua vez, também faz a etnologia amazônica e a teoria antropológica dialogarem com a teoria marxista ("The anarchy and collectivism of the "primitive other': Marx and Sahlins in the Amazon ").

O preâmbulo, como dizíamos, é necessário para que se compreenda em que sentido Overing usa o termo "autonomia pessoal" 349 . Seu diálogo, nesse texto, é, sobretudo, com Sahlins e sua "economia da idade de pedra" (1977) e Marx, com suas notas sobre as "formações econômicas précapitalistas" (1985). O foco da autora recai sobre a formulação marxista de que estas seriam

\footnotetext{
348 Grupo habitante da bacia do rio Orinoco, na Venezuela, e falante de língua da família Saliban (em região predominantemente ocupada por falantes de línguas karib e aruak). São, hoje, segundo o governo venezuelano, pouco mais de 15 mil pessoas. Mais detalhes, em Overing (1975).

349 Note-se que realizo, aqui, uma leitura consideravelmente distinta da que apresenta Sztutman (2005). Pode ser que isso se dê, entre outros fatores, pelo fato de partirmos de textos distintos da autora. De qualquer modo, creio que o artigo de 1993 que discuto mais longamente é especialmente precioso para compreender termos como "autonomia pessoal" - até porque, por essa leitura, fica claro que ela rejeitaria a suposta contribuição para a ideia de um "individualismo" guianense (Sztutman, 2005: 61). "Igualitarismo" é o termo que ela enfatiza - reiteradamente. Da mesma forma, creio que preferiria, como veremos, "informalidade" a "minimalismo" (op.cit: 62).
} 
marcadas por um comunalismo, e que o "progresso produtivo", por meio da divisão do trabalho, se associa com o crescimento do individualismo. Marx chega a dizer que a "consciência tribal" tem natureza semelhante à das ovelhas ${ }^{350}$, ou das crianças:

\begin{abstract}
"Para Marx, o progresso produtivo e o individualismo que cresceu com ele ocasionavam uma maturidade, uma elaboração da 'disposição criativa' (embora 'vulgar e vil, em sua manifestação burguesa), que o 'mundo infantil dos antigos' com o seu apego à forma comunal não poderia atingir" (Overing, 1993: 20-1) $)^{351}$
\end{abstract}

Como se sabe, a noção de criatividade é cara a Overing (2004: 8) ${ }^{352}$. Ao mesmo tempo, a "autonomia pessoal" em questão, insiste ela, é algo bem distinto do individualismo moderno e, nesse sentido, a discussão de uma primazia do coletivo sobre o individual, ou o contrário, é algo que “pertence ao domínio do discurso ocidental” (1993: 21) 353.

Coletividade, dirá ainda a autora, é um forte valor para os indígenas das Guianas, e está longe de ser predominantemente associado a relações de dominação e subordinação. Tem mais a ver, isto sim, com intimidade e informalidade - e, neste sentido, a vida em grupo está "altamente associada" a um credo político igualitário (1993: 23)

Os mal-entendidos, segundo Overing, decorrem, no caso de Marx, do parco conhecimento etnográfico disponível à sua época. Ainda assim, afirma a autora, ele teria sido mais capaz de um salto imaginativo até o ponto de vista do "mundo tribal" do que Sahlins - o qual é criticado por ela em função do estabelecimento da categoria "exploração" como um universal (que, no mundo indígena, corresponderia à ideia de "reciprocidade") (Overing, 1993: 27) 354 .

\footnotetext{
${ }^{350}$ Essa imagem, citada por Overing, aparece em "A Ideologia Alemã” - p. 11 da edição em inglês disponível em www.marxists.org, em pdf.

351 A certa altura, Overing ressalva: tanto Sahlins como Marx reconhecem no mundo tribal a autonomia pessoal em relação ao trabalho, especificamente.

352 Não estou desenvolvendo extensivamente essa discussão aqui, mas endosso a observação. De fato, as experiências dos Kaiowá com as mais variadas formas de decisão e de organização política, quando postas diante de um discurso etnológico do tipo tradicionalista, desarranjam-nas por completo.

353 Portanto, para Overing, note-se, a discussão entre Le Bot e Marcos (vide capítulo anterior) não faria sentido, dados os termos em que é posta.

$354 \mathrm{Ou}$ seja, Sahlins toma partido diante do paradoxo que foi objeto de nossa atenção no capítulo 2, assumindo que o chefe é, sim, um privilegiado. Para Overing, o autor promove uma leitura "cínica" do que escreve Lévi-Strauss sobre o chefe nambikwara (1967b). A opinião da autora sobre o tema parece ambígua. Dez anos antes, em 1983, em artigo célebre (ver republicação em português, em 2002, comentada por Novaes), Overing afirmara, em referência às formulações clastrianas: "Quando uma sociedade ameríndia atinge o ápice de tamanha rejeição à posse das forças da cultura que permitiria um uso coercitivo ou violento e poderia impor, entre outras coisas, um controle sobre a atividade econômica e seus produtos, ela se torna uma sociedade sem economia política, em que não há quem ocupe
} 
De qualquer forma, a autora ressalta, é preciso buscar o próprio julgamento dos indígenas sobre temas como "trabalho, socialidade, maturidade, poder, liberdade e racionalidade". Nesse sentido, ela expõe, é que o ideal de vida dos Piaroa envolve igualitarismo e autonomia pessoal:

\begin{abstract}
"Os Piaroa afirmavam explicitamente que uma comunidade de abundância era aquela que podia oferecer, no cotidiano, flexibilidade nos horários de trabalho e o direito à preferência individual. A abundância era uma questão de alcançar conforto pessoal no trabalho. A conquista de tal riqueza demandava o estabelecimento de uma comunidade que tinha tanto o moral alto como o tamanho que permitia flexibilidade e padrões fluidos de cooperação.” (1993: 31).
\end{abstract}

Nesse ponto, a discussão vai ao encontro do que viemos expondo neste trabalho. A questão é que a manutenção desse alto moral, que sustenta a abundância em uma dada comunidade, dirá Overing, é responsabilidade, justamente, do chefe:

"Os Piaroa repetidamente afirmavam a correlação entre abundância pessoal e o tamanho da comunidade. Uma comunidade muito pequena de 15 pessoas simplesmente não tinha os recursos, em termos de membros, para permitir às pessoas a escolha pessoal e um estado cotidiano positivo de humor e de saúde na realização de todas as tarefas necessárias à sobrevivência diária (...). O tamanho de uma comunidade e, assim, sua riqueza estava relacionado às qualidades de seu líder, pois era sua tarefa atrair para sua comunidade um grande número de pessoas que poderiam também cooperar amigavelmente em uma base diária (...). Enquanto o líder de uma comunidade Piaroa não tinha poderes de coerção sobre o trabalho, e pouco peso na organização diária das atividades econômicas, era seu dever (como era para o chefe Nambikwara ${ }^{355}$ ) manter o moral alto em sua comunidade a fim de que o trabalho e a existência em geral se mantivessem confortáveis para seus membros.” (1993: 31-2)

\footnotetext{
um papel político dirigido a ordenar o trabalho alheio ou os frutos deste" (2002: 121). Em nota referida a este trecho, a autora agrega que sua opinião não estaria "necessariamente, em contradição" com a de Riviére - autor que advoga, explicitamente, a existência de uma "economia política de pessoas", com implicações que discutiremos adiante. Até onde entendo, ela estaria admitindo a existência de um espectro de possibilidades, admitindo-se maior ou menor grau de economia política. O que não fica claro é se percebe a hipótese de sua completa ausência. 355 Sim, a referência é o artigo de Lévi-Strauss sobre os Nambikwara (1967b).
} 
Creio que, em certa medida, é possível comparar as situações dos Piaroa e Kaiowá. Entre estes, como vimos, também está presente, sim, essa "autonomia pessoal", tal qual Overing a percebe. Potencialmente, todo adulto poderia se tornar um tendotá, e isso se infere, por exemplo, por toda essa discussão que fizemos no capítulo anterior, sobre a aty - a questão é como sustentar o fluxo que é inaugurado no movimento de puxar a fila. Como vimos, os imensos constrangimentos ocasionados pela colonização não indígena, e particularmente o intenso desmatamento da região de floresta em Mato Grosso do Sul são, hoje, fatores mais decisivos para impedir uma plena operação desses princípios políticos.

Mas, há a contraparte dessa autonomia, como vimos, que é dada pela etiqueta - a ênfase no respeito a quem inicia uma ação. Overing desenvolve, em outro artigo (2004), algumas considerações que corresponderiam, entre os Piaroa, a essas limitações impostas à autonomia e a informalidade. Ali, contudo, na visão da autora, é a ênfase no lúdico, no humor e nas narrativas grotescas, que ridicularizam o poder, que está a serviço do dito igualitarismo amazônico.

“Embutida nessas narrativas [que ridicularizam o poder], o que podemos perceber através da performance da narrativa é uma filosofia política plena que afirma claramente, e com todas as letras, a necessidade do igualitarismo como o único caminho possível para um modo humano de vida social. A preocupação política é a de impedir a emergência do tirano." (Overing, 2004: 19)

Em sua análise das narrativas piaroa, como se vê, a autora chega a formulações bem parecidas com as que alcança Perrone-Moisés (2012), em sua leitura dos mitos guianenses ou iroqueses (vide capítulo 2). Atingimos, contudo, um ponto cego: essa presença marcante da etiqueta política entre os Kaiowá seria um reflexo da calamidade socioambiental que eles vivem atualmente, ou se poderia considerá-la uma variável cultural (estilística?), por assim dizer? Em outros termos: chegaríamos uma oposição etiqueta x humor (pois, no fim das contas, quem rompe a etiqueta não pode ser ridicularizado, tanto como hostilizado?)?

Outro artigo de Overing (1989) nos ajuda a perceber melhor algumas das possibilidades de nuanças. Esse escrito, por sua vez, é apropriado pelo movimento pacifista ${ }^{356}$ e diz respeito à descrição dos Piaroa como um povo "pacífico". A autora constrói um contraste desse grupo com os

356 Por sinal, está disponível na internet, em peacefulsocieties.org 
Xavante e os Yanomami, por meio das etnografias de Maybury-Lewis e Lizot:

“A despeito de generalizações recentes sobre a violência e a agressão que supostamente tipificam sociedades da floresta tropical na América do Sul (...), esses povos variam consideravelmente no grau e do tipo de violência permitida na vida cotidiana." (Overing, 1989: 80)

Overing retoma a divisão entre sociedades do tipo bride service e bride wealth, para desconstruir a associação obrigatória entre bride service e violência sexual - a seu ver, mais ligada à promoção de valores masculinos ligados à caça e a guerra, realizada "às expensas" de uma possível valoração positiva das mulheres. $\mathrm{O}$ antagonismo de gênero, pois, parece à autora mais decisivo para determinar se uma sociedade será pacífica ou belicosa ${ }^{357}$.

As ideias sobre gênero definem, segundo ela, sistemas de moralidade e "estilos de masculinidade". "Cultura e regras sociais podem compelir os homens a se adequar às ideias de uma dada sociedade sobre um comportamento masculino virtuoso" (idem: 82). Assim, em oposição a toda uma valoração da masculinidade e de atividades típicas dos homens, como a caça, entre os Xavante, Overing escreve, sobre o grupo do Orinoco:

"Para os Piaroa, o ideal de maturidade social é o mesmo para homens e mulheres; é de serenidade controlada. (...) A vida social piaroa é muito informal. Não existem categorias de idade, grupos de descendência, sociedades guerreiras, um conselho formal de homens maduros, ou organizações de metades atuando na vida comunitária. Não existem mecanismos para grupos corporados de tomada de decisão em caso de litígios ou questões econômicas. (...) A sua "informalidade" é também um produto de sua alta valorização da vida pacífica.” (idem: 87-8)

Por contraste (da mesma forma que Overing opõe os Piaroa aos Xavante), poderíamos perceber uma série de semelhanças, mas também características distintivas dos Kaiowá/Guarani, que, por sua vez, embaralham mais o jogo. Por exemplo, estes mantêm um discurso e uma vida ritual com características semelhantes às dos nativos retratados pela autora (ênfase não na masculinidade, mas no autocontrole como virtude necessária ao convívio social - os clássicos teko porã/marangatu). Ao mesmo tempo, há um cotidiano de muita violência interpessoal.

357 Tal como, segundo ela, proposta por Collier e Rosaldo (1981). 
Parece-nos inescapável, então, discutirmos a questão histórica. Até que ponto essas características apontadas por Overing são distinções "culturais"? Nesse sentido, artigos recentes de amazonistas que, no âmbito da tradição britânica, dialogam com a perspectiva da autora, avançam para uma convergência com o que Perrone-Moisés e Sztutman têm apontado sobre um movimento pendular na ação política ameríndia - muito embora não falem em estrutura.

Ruedas (2004) identifica, na organização política dos Marubo, variações sincrônicas e diacrônicas que impossibilitam qualquer classificação do grupo como "hierárquico" ou "igualitário". O artigo traz observações pertinentes, como a de que boa parte dos estudos etnográficos que embasam as atuais formulações da disciplina sobre as formas políticas indígenas foi realizada pouco depois do que foi provavelmente o "pior ponto" da história em termos demográficos para essas populações, entre os anos 30 e 50 do século XX. Isso teria levado os etnólogos a verem, por todo lado, sociedades "pequenas, atomizadas, igualitárias", como se as coisas "sempre tivessem sido assim" (op.cit: 1).

O problema são as conclusões que o autor retira daí: ele, por exemplo, afirma que é possível pensar num sistema de organização social "normal” (op.cit: nota 2), em acordo com os próprios valores nativos - aqueles que os Marubo abraçariam caso estivessem livres das "violentas pressões externas" que assolaram os indígenas da Amazônia ao longo dos últimos séculos e provocaram uma drástica depopulação na região. Considerando-se as observações que já examinamos no capítulo 1, a respeito da persistência de "epistemologias insulares", são formulações que nos levam a becos onde a disciplina já esteve.

Killick (2007) prossegue nessa senda, dialogando, mais diretamente, com autores como Ruedas e Overing, e questionando a possibilidade de falar, no singular, em uma "liderança amazônica”. O estado atual das pesquisas, afirma ele, já indica mais uma diversidade do que um estilo único. $\mathrm{O}$ autor aponta, inclusive, essa diversidade de possibilidades políticas no pensamento de um único grupo, os Ashéninka do Peru.

Ali, ele percebe plena afinidade com as descrições clássicas de Lévi-Strauss e Clastres sobre o comportamento político ameríndio: um grau de autonomia pessoal (na formação de aldeias, por exemplo) que solapa a emergência de um poder coercitivo e resulta em um igualitarismo:

"Eles acreditam que agir de forma independente é a melhor forma de alcançar uma sociedade pacífica e produtiva (...). Pois assim como eles 
explicitamente e implicitamente rejeitam noções de diferença hierárquica eles também contam histórias de pessoas que se tornaram líderes no passado e, como vou mostrar, eles usam exemplos atuais de forasteiros ditatoriais como modelos dessa possibilidade. Esse detalhe final enfatiza que o igualitarismo ashéninka é uma formação política complexa que os indivíduos ativa e conscientemente buscam manter" (op.cit: 466)

Ao mesmo tempo, Killick constata, os Ashéninka são conhecidos por haverem demonstrado, em vários momentos da história, plena capacidade de se articular em grupos maiores, em ação concertada, sobretudo contra ameaças estrangeiras, desde missionários até comerciantes da borracha e grupos guerrilheiros armados. Nesses momentos, ocorre uma "aglomeração hierárquica", que logo se dissolve, voltando a dinâmica de dispersão e igualitarismo. Mas, aqui, chegando a uma fórmula mais afim a nosso ponto de vista, não há "normal" ou "anormal", e sim um só "quadro cultural" (framework) em que as duas possibilidades são previstas.

Killick faz, ainda, na segunda parte do texto, interessante descrição sobre como uma pessoa de fora do grupo pode, muitas vezes, imprimir uma dinâmica de trabalho que alguém de dentro não poderia fazer - ele relata um caso que envolve extração de madeira, comparando a forma de um grupo de Ashéninka trabalhar quando estão somente entre eles com a que ocorre quando estão sob as ordens de um comerciante "de fora" da comunidade. Parece-nos bom exemplo da dinâmica kin(g)ship que traçamos no capítulo 2 - muito embora, em dado momento (op.cit: 476), ele relacione essa momentânea cedência de autonomia à busca de vantagem pessoal. Aliás, para ele, a pessoa somente permanece na posição de liderança se seus seguidores constantemente têm a sensação de que ele ainda tem algo "útil" para oferecer (idem).

\section{Economia política amazônica}

No final do trajeto, voltamos ao início. Uma questão que permanece como forte divisor no debate é a universalidade ou não do controle político sobre a produção - isto é, a chamada economia política. Nos últimos anos, parece ter ganhado espaço em certos meios a ideia de uma "economia política amazônica", que envolveria não o controle sobre a produção de coisas (mercadorias), e sim de pessoas.

Nas palavras de Turner, que parte de sua etnografia sobre os Kayapó para generalizar o 
modelo que propõe, estaria aí a chave para a compreensão do que pode ser a hierarquia, no mundo ameríndio:

\begin{abstract}
“As principais categorias de valor social ('poder' $e$ 'beleza' entre os Kayapó) são produzidas e objetivadas como aspectos das identidades de pessoas sociais que são os principais produtos desse processo. Essas categorias de valor, defendo eu, integram sistemas amazônicos de produção, e, como tal, são aspectos fundamentais das formas culturais específicas de exploração e hierarquia nessas sociedades. A chave para a compreensão da estrutura hierárquica dos sistemas sociais e políticos das sociedades do Brasil Central (um termo geralmente aplicado aos povos de língua Jê e similares, ainda que sem sempre sejam geograficamente contíguos, como os Karajá, Tapirapé, Mundurucu e Bororo), bem como os sistemas menos obviamente hierarquizados de outros povos amazônicos Tupi, Carib, Arawak, Tukano, Záparo e outros grupos linguísticos, em outras palavras, consiste em compreender como as formas de valor social são produzidas no processo de produção de pessoas sociais.” (2003: 11)
\end{abstract}

O autor chega mesmo a falar em um "excedente de produção", resultante da manipulação, operada pelos chefes, dos arranjos conjugais. O fato é que outros pesquisadores têm se alinhado com essa perspectiva (vide Ehrenreich \& Ruedas, 2003; Lorrain, 2000), a qual, por sinal, é frequentemente relacionada a Rivière (2001 [1984]: 123-33), que já falava em uma "economia política de pessoas" ${ }^{358}$ na Guiana - justamente inspirando-se em Turner (1979) e contrapondo-se a Clastres. A linha divisória também fica clara em debates como o que travam McCallum e Mentore (1988) e em revisões como a proposta por Hugh-Jones $(2009)^{359}$.

Sztutman menciona o debate em vários pontos de sua tese (2005: 159, 198, 235 etc.) e também parece endossar o uso do termo, registrado por ele em autores como Menget (1996),

\footnotetext{
358 Formulação a qual, não se poderia deixar de destacar, parece muito afim às ideias de biopoder e biopolítica (Foucault, 1977), que vêm tendo grande repercussão na Sociologia e na Ciência Política em geral. "O biopoder se refere a uma situação na qual o que está diretamente em jogo no poder é a produção e a reprodução da própria vida" (Negri \& Hardt, 2001: 43). Evidentemente, os autores se referem, em geral, ao contexto capitalista ocidental, ou seja, a um poder coercitivo. Faço a menção para que não se tenha a impressão de que, com a negação do marxismo, a Etnologia consiga escapar tanto assim dos debates hegemônicos no âmbito das Ciências Humanas.

$359 \mathrm{Um}$ aspecto desse debate é que ele dialoga, a certo ponto, com as pesquisas realizadas na Oceania, entre Melanésia e Polinésia - num primeiro momento, e sobretudo, a partir da obra de Sahlins, mas também acessando autores assumidamente marxistas (e, nesse sentido, defensores de certa universalidade da economia política), como Godelier - citado por Mentore, no debate com McCallum (1988), a partir de seu trabalho com os Baruya da Nova Guiné (1986).
} 
Gregory (1982) e Heckenberger (1999). Este último faz uso do termo relacionando, ao debate etnológico, alguns dos recentes avanços da arqueologia amazônica ${ }^{360}$ - além de utilizar-se de recursos da Etnohistória. Afora isso, é dos poucos que, claramente, ultrapassa a ideia de que a tal economia política seria "de pessoas" e descreve como, em sua visão, ela está relacionada ao controle de um fluxo de bens, envolvendo "manifestações contemporâneas de estruturas com uma temporalidade muito profunda" e "guiadas por ideologias antigas" (op.cit: 139) - hoje retomadas em função do crescimento demográfico e do grande afluxo material promovido pelo contato com os brancos.

Heckenberger, pois, destaca a quantidade de recursos mobilizados para a realização de um ritual antifeitiçaria kune, relacionado à morte do herdeiro do cacique de dada aldeia altoxinguana (1999: 138-9). A empreitada, que demandou a vinda de um especialista karajá, residente a quase $1.000 \mathrm{~km}$ de distância da aldeia, envolveu despesas de viagem (passagens, gasolina, hospedagem) e pagamentos (em miçangas e outros produtos) ao contratado karajá, além de outras pessoas envolvidas, "um volume notável de riquezas para uma só pessoa (entre uma grande variedade de pagamentos, havia mais de trinta ornamentos de conchas, oito bicicletas, várias panelas grandes de alumínio, uma rede de pesca de cem metros)":

\begin{abstract}
"Projetos externos ou desenvolvidos pelo próprio grupo, equipes de filmagem, pesquisas, ajuda médica, comunicações, equipamento, tudo isso faz circular milhares ou dezenas de milhares de dólares em cada comunidade individual. Essa riqueza passa diretamente para os caciques, os quais em grande parte controlam esses bens e sua distribuição" (Heckenberger, 1999: 139).
\end{abstract}

A pergunta, diante de evidências tão inquestionáveis a olhos ocidentais, é: vamos nos render à contabilidade? Penso que talvez esteja aí um dos limites traçados pela modernidade: justamente, entre interesse e cálculo. Não é trivial essa passagem entre política e economia política, é o que gostaríamos de destacar. Como sublinharam, recentemente, Graeber \& Lanna, em relação ao Ensaio sobre o Dom, de Mauss - concebido originalmente como uma contribuição à teoria socialista, lembram os autores:

“Mauss se contrapôs de modo radical - e até hoje não devidamente

360 Segundo Ruedas (2004), a crítica ao "igualitarismo amazônico” teria se intensificado em função, justamente, do avanço das pesquisas arquológicas, entre outros fatores. 
avaliado - aos liberais da época, criticando um paradigma que reduz a vida social a interesses, competições econômicas elou manipulações políticas. Sua ideia de relações sociais substitui a de contrato. Essa ideia não remeteria a acordos com nossos instintos (e os dos outros) ou com sentimentos e vontades supostamente anteriores aos sociais, mas sim a 'obrigações', simultaneamente coercitivas (para usar o termo de Durkheim) e voluntárias. Ao mesmo tempo, se a vida social não se reduz a ganhos, estes não deixam de estar presentes, para Mauss, na forma de interesses individuais e coletivos" (Graeber \& Lanna, 2005: 502)

O problema, penso, é que boa parte da teoria social nos últimos 150 anos foi construída, justamente, sobre esse solo compacto da modernidade, onde, como lembram os autores, o mercado não é somente "mera técnica para a alocação de alguns tipos de bens" mas "um princípio social básico" (op.cit.: 505). O Ensaio sobre o Dom, por sua vez, deve boa parte de seu vigor ao diálogo que fazia com o importante "experimento" da Revolução Russa. Em 1921, lembram Graeber e Lanna, Lenin anunciava sua Nova Política Econômica, e Mauss, esse socialista herege ${ }^{361}$, chegava a nutrir a esperança de que os bolcheviques colocassem em bom rumo a nau soviética, fazendo o mercado retomar seu devido lugar. Não por acaso, desenvolvem-se nessa época tanto as concepções socialistas como a ideia de "estado do bem-estar social", esta, como vimos, evocada muitas vezes pelos antropólogos e historiadores que observaram realidades políticas ameríndias, dos Nambikwara aos Inca:

"Discordando da naturalização do mercado feita pelos liberais, Mauss se perguntava o que levaria a lógica do mercado a violentar o senso de justiça e humanidade das pessoas comuns. Tentava simultaneamente entender o apelo popular dos partidos socialistas e os programas de bem-estar social, por um lado, e, de outro, examinar a etnografia disponível para revelar o que poderiam ser padrões de justiça que relegavam o mercado a sua função técnica para agrupar decisões descentralizadas, e em que medida este poderia conviver com instituições de tipo totalmente diferente, centradas na 'alegria de doar em público; o prazer do dispêndio artístico generoso, o da

361 Os autores descrevem Mauss como "adepto de um socialismo criado de baixo para cima, por meio de cooperativas e sindicatos" (op.cit.: 504). Sabemos que esse ponto de vista alternativo ao marxismo, na França, tinha longa tradição, desde Proudhon, e está fortemente alinhado com uma série de ideias apresentadas aqui. 
hospitalidade e da festa privada e pública (Mauss, 2003b: 299)” (Graeber

\& Lanna, 2005: 506).

\section{O Outro da economia é a política}

Ponhamos, por um momento, sob suspeita essa insistência em encontrar, aí, (mais) um universal. Voltemos a Clastres: o que ele teria a dizer a respeito (apesar de - ou justamente por não mencionar, em nenhum momento, nos seus dois livros de ensaios, o termo "economia política”)? Em sua entrevista publicada, a título de posfácio, na nova edição brasileira de “Sociedade contra o Estado", ele explicita sua discordância em relação a certa visão marxista. Peço licença para uma longa citação, porque se trata de um ponto crucial:

“Minhas relações com aqueles meus colegas marxistas são marcadas por uma discordância no plano do que se faz, ao nível do que se escreve, não necessariamente no plano pessoal. A maioria dos marxistas são ortodoxos; digo a maioria porque alguns não o são, felizmente; mas os ortodoxos se apegam muito mais à letra que ao espírito. Então, o que vem a ser a teoria do Estado? É uma concepção instrumental do Estado, ou seja, o Estado é o instrumento da dominação da classe dominante sobre as outras; tanto na lógica quanto na cronologia, o Estado vem depois, tão logo a sociedade é dividida em classes e há ricos e pobres, exploradores e explorados; o Estado é o instrumento dos ricos para melhor explorar e mistificar os pobres e os explorados. A partir de pesquisas e de reflexões que não abandonam o terreno da sociedade primitiva, da sociedade sem Estado, parece-me que é o contrário que acontece; não é a divisão em grupos sociais opostos, não é a divisão em ricos e pobres, exploradores e explorados, a primeira divisão, aquela que funda afinal todas as outras; é a divisão entre os que comandam e os que obedecem. Ou seja, o Estado. Porque fundamentalmente é assim, é a divisão da sociedade entre os que têm o poder e os que se submetem ao poder. No momento em que isso existe, isto é, a relação comando/obediência, um sujeito ou um grupo de sujeitos comandando outros que obedecem, tudo é possível; porque quem comanda tem o poder de mandar os outros fazerem o que ele quer, já que ele se torna 
o poder, precisamente. Pode dizer-lhes: 'Trabalhem para mim', e nesse momento o homem do poder pode se transformar facilmente em explorador, isto é, naquele que faz os outros trabalhar. Mas a questão - quando se reflete seriamente sobre a maneira como funcionam essas máquinas sociais que são as sociedades primitivas - é que não se percebe como essas sociedades podem se dividir, quero dizer, se dividir em ricos e pobres. Não se percebe, porque tudo funciona exatamente para impedir isso. Ao contrário (...), várias questões obscuras se esclarecem, se colocarmos primeiro a anterioridade da relação de poder. Por isso, penso que, para poder ver com mais clareza essas questões, convém inverter firmemente a teoria marxista da origem do Estado - é um ponto enorme e preciso ao mesmo tempo - e parece-me que, ao contrário de ser o Estado o instrumento de dominação de uma classe, portanto o que vem depois de uma divisão anterior da sociedade, é o Estado que engendra as classes. Isso pode ser demonstrado a partir de exemplos de sociedades com Estado nãoocidentais, penso particularmente no Estado Inca, nos Andes.” (Clastres, 2003: 237-8)

Como se vê, o ponto central para Clastres é essa oposição/inversão entre economia e política (e não entre economia e economia política, como indicaria a tradução inglesa ${ }^{362}$ ). Logo em seguida, no texto, o francês continua sua exposição com a constatação de que a então União Soviética, onde teria havido a "abolição das classes sociais", havia se tornado uma sociedade "não dividida", mas tendo "acima dela uma máquina estatal (com o apoio do Partido) que detinha o poder"363 (idem). A URSS é, assim, um exemplo perfeito de que é o Estado que engendra as classes, e não o contrário, como resume ele ${ }^{364}$.

Novamente, retornaremos aos hereges anarquistas, pois é aí que encontraremos posições

\footnotetext{
362 A curiosidade é extremamente significativa: na tradução inglesa, de 1977, aparentemente, há um trecho do ensaio que dá título ao livro de Clastres, "A Sociedade contra o Estado", em que se traduz a expressão "l'économie devient politique" como "the economy becomes a political economy" (1977: 166) (e não "the economy becomes politics" - o que dá um sentido bastante diferente). Creio que esse mal-entendido diz muito sobre a discussão que estamos relatando. Observo essa peculiaridade a partir de Colchester (1982: 155).

363 Novamente aparece essa figura superior, que, do ponto de vista de alguém como Clastres, creio, poderia ser tranquilamente comparada com o que é discutido nos artigos de O Federalista, como demonstramos no capítulo anterior.

364 Em outro artigo, “O Retorno das Luzes”, de 1977, Clastres diria: “(...) nunca se interrogou sobre a questão da origem [do Estado], pois, desde sua antiguidade grega, o pensamento ocidental sempre admitiu a divisão social em dominantes e dominados como imanente à sociedade enquanto tal" (2004: 139).
} 
coincidentes com as de Clastres ${ }^{365}$. Carson se refere à ideia de que a "acumulação primitiva" precederia o Estado como um "conto de fadas" que serviu aos capitalistas como "mito legitimador".

"Na verdade, os apologistas do capitalismo raramente abordam a questão, se podem evitá-la. Mais frequentemente, eles tomam a distribuição existente da propriedade e do poder econômico como um dado. Sua linha mais empobrecida de argumentação, normalmente, apenas começa com o fato inquestionado de que simplesmente ocorre que algumas pessoas sejam donas dos meios de produção, e que os outros precisam de acesso a esses meios e progressos para viver, enquanto trabalham. Disto segue que, se os proprietários do capital são gentis o suficiente para 'fornecer' esse 'fator de produção’ para a utilização de trabalho, eles têm direito a uma recompensa justa pelo seu 'serviço' ou 'abstinência'. A inadequação dessa abordagem deveria ser clara até mesmo desde a consideração mais superficial. (...) A questão permanece: como é que aqueles que controlam o acesso aos meios de produção chegam a essa posição?” (Carson, 2004: 138)

Assim sendo, Carson chega, por essa reflexão sobre as origens do capitalismo, à mesma pergunta formulada por Clastres: a questão é como foi produzida essa posição de poder, ela, sim, geradora de classes, e não o contrário. Nesse sentido, o esforço do autor será o de localizar historicamente como foram construídas as condições para que um grupo pudesse ter a capacidade de dizer aos demais, na expressão do francês, "trabalhem para mim".

No caso europeu, justamente, isso se deu, segundo Carson, num sentido que contraria os teóricos das "leis naturais", segundo as quais, num processo histórico "natural”, justamente, a população foi aumentando até que se esgotaram as terras cultiváveis e, a partir daí, surgiram as diferenças de classe e o trabalho assalariado. O autor segue argumentação de Oppenheimer $(1926)^{366}$ para contrapor:

365 Tema que renderia interessante análise, por sinal.

366 A narrativa de Oppenheimer (1864-1943) sobre o surgimento do Estado contrapõe-se diretamente à Teoria do Contrato Social e é chamada de "Teoria da Conquista". "O Estado, totalmente na sua génese, essencial e quase completamente durante os primeiros estágios de sua existência, é uma instituição social, imposta por um grupo vitorioso de homens sobre um grupo derrotado, com o objetivo exclusivo de regular o domínio do grupo vitorioso sobre o vencido, e assegurar-se contra a revolta de dentro e ataques do exterior. Teleologicamente, esse domínio não teve outra finalidade que não a exploração econômica dos vencidos pelos vencedores. Nenhum estado primitivo conhecido na história originou-se de qualquer outra forma." (1926: 15) Pellicani (1994: 104) também nota essa coincidência entre os pensamentos de Oppenheimer e Clastres. Campagno (1998), dissertando sobre o pensamento 
“(...)[Como] Oppenheimer assinalou, a terra não poderia ter sido ocupada por meios naturais e econômicos. Mesmo no século $X X$, e até mesmo no Velho Mundo, a população não foi suficiente para trazer toda a terra arável ao cultivo (...). A terra havia, de fato, sido 'ocupada' - mas não através dos meios econômicos de apropriação individual pelo cultivo. Ela havia sido politicamente ocupada por uma classe dominante, agindo por meio do Estado (...). O capitalismo, surgindo como uma nova sociedade de classes diretamente da velha sociedade de classes de Idade Média, foi fundado sobre um ato de roubo tão massivo como a anterior conquista feudal da terra. Ele tem sido sustentado até o presente pela intervenção estatal contínua para proteger seu sistema de privilégio, sem o qual sua sobrevivência é inimaginável. A atual estrutura de propriedade do capital e organização da produção em nossa economia de 'mercado', por assim dizer, reflete uma intervenção estatal coercitiva anterior a e alheia ao mercado. Desde o início da revolução industrial, o que é chamado nostalgicamente 'laissez-faire', era na verdade um sistema de contínua intervenção do Estado para subsidiar a acumulação, garantir privilégios, $e$ manter a disciplina de trabalho.” (Carson, 2004: 143-4)

O fato é que, seguindo a hipótese clastriana, o surgimento do Estado estaria mais para a emergência de uma política econômica que para uma economia política. O que Clastres está dizendo é que a questão básica é política, é a relação que permite a uma pessoa dar uma ordem a outra: "trabalhe para mim". Nesse sentido, é que a ideia de "contra o Estado" permanece tão forte: sua existência, não a da divisão de classes, é o nó da questão - e, nesse sentido, se pode entender a disputa do autor com os socialistas de sua época, comprometidos que estavam com experiências como a da URSS.

Em seu panorama sobre o estado de arte da antropologia da Amazônia, Viveiros de Castro (2002: 319-44) percebe, aí, três "estilos analíticos principais” nos estudos contemporâneos: 1) uma “economia política do controle" - identificada com autores abordados acima: Turner e Riviére; 2) uma "economia moral da intimidade", que estaria presente na obra de Overing e de seus ex-alunos

de Clastres, inclui Oppenheimer em seu mapeamento das hipóteses que relacionam guerra e surgimento do Estado (além de Carneiro, 1970), mas não tira consequências na linha que aqui apresentamos. A discussão sobre as hipóteses em torno dessas relações é ampla e atual (vide Neves, 2009). O foco aqui, insistimos, é na supracitada visão clastriana. 
como McCallum, entre outros; 3) uma "economia simbólica da alteridade", com a qual ele mesmo se identifica, agrupando aí, ainda, autores como Albert, Menget, Descola, Taylor, entre outros.

Como se pode perceber, as diversas posições na discussão acima apresentada se enquadram nesse esquema com certo conforto. Entretanto, tendo em vista o que acima expusemos, a respeito do grande divisor entre a visão clastriana e a marxista, bem como a repercussão do debate para além dos círculos etnológicos, eu proporia uma reconsideração das denominações desses campos, ao menos no que tange ao tema aqui abordado. O primeiro segmento, afinal, se autodenomina proponente de uma "economia política das pessoas"; quanto a Overing, me parece que sua ênfase, como demonstramos, é no igualitarismo e na autonomia pessoal, estando assentada na bibliografia a denominação de "igualitarismo amazônico".

Quanto ao terceiro segmento, da "economia simbólica da alteridade", parece que o debate sobre essa "política cultural da alteridade", tal qual está sendo proposto por Sahlins (2010), conforme mostramos, solicita certa ressonância com a definição dada por Viveiros de Castro. A questão é saber se o salto proposto pelo norte-americano, mapeando variantes de um mesmo mecanismo nas mais diversas partes do mundo, parecerá satisfatório a grupos que têm reivindicado, por exemplo, a retomada da ideia de "teoria etnográfica" (cf. Goldman, 2006, por exemplo), muito vinculada ao estabelecimento de reflexões de escopo dito amazônico ou ameríndio.

De todo modo, como expusemos, a ênfase particular que é dada pelo grupo de Overing aos citados termos tem a ver diretamente com as formulações clastrianas - especialmente se consideramos o trecho de sua entrevista que destacamos acima. Se não, vejamos a seguinte passagem de McCallum, em sua polêmica com Mentore a respeito de um artigo sobre os Waiwai:

\begin{abstract}
"Como pode um sogro dominar e controlar o genro, quando ele não pode mesmo dar uma ordem a ele? Mentore nos diz que essas 'ordens' são expressas de forma indireta. Um homem diz a sua mulher, que diz a sua filha, que ele deseja fazer algo no dia seguinte. Seu marido deve se oferecer para ajudar, por causa da 'obrigação jural' que ele tem com o sogro. Mas o que exatamente é esse 'poder' quando o 'dominador' não pode nem mesmo dar uma ordem indireta ao 'dominado'?” (1988: 560)
\end{abstract}

Ou seja, é da mesma coisa que estão falando Clastres e McCallum: dessa sutileza que impede que uma ordem seja dada, que se efetive o "trabalhe para mim" que, segundo o francês, 
marca a fundação do Estado. Esse “je ne sais quoi”, como expusemos no capítulo 2, parece-nos uma espécie de etiqueta do poder $^{367}$.

Como já notou Latour (2005: 25) - por sinal, utilizando o mesmo termo que Viveiros de Castro alhures tomou para caracterizar a atitude dos Arawete diante da iniciativa do tenotã-mõ -, pode ser que, afinal, estejamos tratando de indiferenças, e não de diferenças. E, indo um pouco além do que afirma o autor francês, poderíamos perguntar: se nem as diferenças o Ocidente mostrou poder tolerar, que se dirá das indiferenças?

\section{A prevalência do movimento}

Algo que parece perpassar toda nossa explanação sobre as figuras de uma teoria política kaiowá é o movimento. De fato, como já mencionei, a própria ideia de movimentar (mongu'e), como algo que é sinônimo mesmo de política, aparece, na reflexão de alguns indígenas, ocasionalmente. As coisas não vão bem quando "tudo está parado"368.

A força com que esse tipo de formulação apareceu em nossa etnografia, é bem provável, tem a ver com o fato de que a região onde trabalhamos, na bacia do Apa, tinha, à época de nossa pesquisa, uma situação (forçosamente) estável, em termos de ocupações de terra. Os últimos conflitos com fazendeiros tinham sido cerca de quatro anos antes de nossa chegada. Nos diversos coletivos espalhados pela região, disseminava-se, no período em que por ali passamos, a sensação mesmo de que as coisas andavam "paradas"369.

Não nos parece fortuito, contudo, que essa ideia de movimento apareça aí. As figuras da política kaiowá, como vimos, estão, quase sempre, relacionadas ao fluxo. "A imitação é a

367 A esta altura, cabe explicitar que, embora aparentemente, estejamos falando sobre coisas parecidas, o termo "etiqueta" nos parece efetivamente mais adequado do que "moral", conforme é normalmente usado por Overing. Os comportamentos políticos a que me refiro entre os Kaiowá, no âmbito desse debate (quando alguém toma a frente sem respeitar aquele que estava conduzindo certa ação), não implicam uma condenação moral (ao menos quando não esbarram na disputa com alguém com autoridade conferida pelo xamanismo, o que acionaria discursos do tipo "teko katu”, "teko marangatu" etc.); correspondem, sim, a uma provocação. Não há certo ou errado, há somente um código de convivência pacífica: rompê-lo equivale a comprar uma briga - afinal, o que é que se faz quando alguém "fura a fila"?

${ }^{368}$ Poderíamos, aqui, pensar, ainda, em mboguata ("fazer andar"), como nos lembra Chamorro (informação pessoal). Não encontrei quem usasse o termo, mas lembremos que muito já se escreveu, entre guaraniólogos, sobre o caminhar, o oguata, como marca do ethos guarani (cf. Pimentel, 2006).

369 Esse quadro só deve mudar com a publicação de relatório de identificação e delimitação da área chamada Apa Pegua, que corresponde a um dos seis grupos de trabalho constituídos em 2008, conforme relatado na introdução. Tal publicação, prevê a Funai, deve se dar em 2013. 
propagação de um fluxo; a oposição é a binarização, a colocação dos fluxos em binaridade; a invenção é uma conjugação ou uma conexão de fluxos diversos" (Deleuze \& Guattari, 1996: 98).

Arriscando um pouco, seria possível pensar as três figuras políticas apresentadas como relacionadas, predominantemente, a cada um desses itens em questão. O tendotá, ao puxar a fila, propaga um fluxo; ao definir o ñande reko, o ñanderu/johexakáry opera uma binarização (ava/karai), fundamental para a política guarani; já a aty é concebida, por alguns, como uma conjugação de fluxos, justamente, pois a atividade de reunir e debater visa "pensar junto".

Em suas reflexões sobre a liga Iroquesa, Morgan menciona, a certo ponto, a relação do "estado de caçador" com aquela forma ameríndia de fazer política. Fala mesmo em uma "paixão", que impediria a "elevação" do "homem vermelho":

“A condição de caçador é o zero da sociedade humana, e enquanto o homem vermelho foi atado por sua magia, não havia esperança de elevação para ele. (...) Teriam eles [os Iroqueses], na maturidade, se emancipado da estranha paixão por uma vida de caçador; como os Toltecas e Astecas tinham antes efetuado sua emancipação nas latitudes do México? (...)Os iroqueses sempre manifestaram intelecto suficiente para prometer um alto grau de progresso, se fossem despertados e direcionados para as atividades certas. Séculos, no entanto, poderiam ter sido necessários para efetuar a mudança.” (1904: 135)

Ora, a tal "condição", ou "estado de caçador", como se viu no capítulo anterior, era associada à ideia de uma liberdade irrestrita, o que certamente nos remeteria às supracitadas observações de Overing sobre a negatividade projetada pelo pensamento ocidental sobre a vida em comunidade. Morgan, por sua vez, como apontamos, relaciona decisivamente o "estado de caçador" à ausência, no espírito indígena, do "poder de lucro", esta que é a grande paixão do homem civilizado e uma das mais antigas manifestações da mente progressiva ${ }^{370}$.

370 Em seu contexto original, para apreciação dos leitores: "Neste ponto, o traço singular no caráter do homem vermelho sugere que ele nunca sentiu o 'poder do lucro' (gain). O auri sacra fames de Virgílio, o lucri studium de Horácio, nunca penetrou sua natureza. Essa grande paixão do homem civilizado, em seu uso e abuso, sua bênção e sua maldição, nunca despertou a mente indígena. Foi, sem dúvida, o grande motivo de sua permanência no estado de caçador, pois o desejo de lucro é uma das primeiras manifestações da mente progressiva, e uma das paixões mais poderosas a que a mente é suscetível. Ela limpa a floresta, eleva a cidade, constrói o navio mercante - em uma 
Uma tal filosofia política que se orienta entre paixões guarda certa heterodoxia que estimula nossa imaginação. Pois, como um choque, justamente, entre o "estado de caçador" e o "poder do lucro", poderíamos entender esse mau encontro que se opera nas últimas décadas no Mato Grosso do Sul, afetando tão dramaticamente os Guarani e Kaiowá. Como em Quemada! ${ }^{371}$, foi somente depois de desmatar e transformar em propriedade privada toda a região sul de MS que se conseguiu impedir a dinâmica política pendular dos grupos locais. O resultado, aqui, contudo, foi uma crise social sem precedentes, a qual, agora, o Estado brasileiro tem o desafio de enfrentar.

Sim, pois a menção a essa paixão pelo "estado de caçador", como orientadora das formas políticas ameríndias, nos recorda que o espaço é elemento fundamental dessa equação resultante em liberdade, e nos faz lembrar, nestes tempos de paixão mundial pelas cidades $^{372}$, que temas como reforma agrária não podem ser esquecidos.

Esse não é o único ponto em que esse diálogo com as formas políticas ameríndias pode ser produtivo para que olhemos de outra forma para nossas próprias políticas. Desde os anos 90, com a rebelião zapatista, tais ações têm gerado importantes reflexões sobre temas como democracia, participação, controle social por todo o mundo, e particularmente no próprio México e a América Latina em geral.

Hoje, há, no México, uma série de experiências de "autonomia indígena”, como se costuma chamá-las (Quintana \& Gasparello, 2009): a Política Comunitária de Guerrero; os Yaquis, de Sonora; os Triquis, de San Juan Copala, Oaxaca etc. A série segue por países tão diversos como Nicarágua e Guatemala, Equador e Bolívia, variando desde essas experiências autônomas, que não contam com nenhum apoio do Estado, até ações que se mesclam com a própria tomada e indigenização do Estado, tornados plurinacionais (Schavelzon, 2010).

Toda essa atenção crescente que as formas políticas ameríndias vêm ganhando nos dá a oportunidade, também, de repensar o nosso olhar sobre elas, a partir da academia. Afinal, outrora, o conhecimento gerado pelos antropólogos a respeito dessas formas não ocidentais já se colocou,

palavra, tem civilizado nossa raça" (Morgan, 1904: 131).

371 Filme de 1969, dirigido por Gillo Pontecorvo e protagonizado por Marlon Brando. Conta história da política em uma ilha caribenha fictícia (mas claramente relacionada a fatos reais ocorridos na região), no período colonial, com as relações entre rebeliões de escravos negros e a política externa inglesa, interessada em dominar a compra de açúcar produzido na região então dominada pelos portugueses. Para derrotar os grupos revoltosos, que usavam táticas de guerrilha, o governo local, amparado pelos ingleses, adota a estratégia radical de queimar toda a vegetação da ilha.

372 Segundo as Nações Unidas (relatório UN-Habitat - State of the World's Cities 2006/07), vivemos o primeiro momento na história da humanidade em que há mais gente morando nas cidades do que fora delas. 
explicitamente, a serviço de um projeto colonial (Fortes \& Evans-Pritchard, 1940). Aqui mesmo, no Brasil, a colaboração com o Estado ainda é vista hoje, por muitos, como signo maior de engajamento político. Ainda temos, realmente, muito a aprender.

Nesse sentido é que comparece, aqui, a contribuição de antropólogos anarquistas como Graeber, Morris e Clastres: trata-se de um olhar, sobre essas formas, que não as percebe como algo a ser administrado, superado ou observado com exotismo, e sim como uma experiência humana que continua a ter muito a ensinar a todos nós - e que nos desafia a sermos verdadeiramente afetados.

Se essas análises sobre as formas ameríndias do "contra o Estado" são algo que já se avoluma, há, por outro lado, a possibilidade de um olhar sobre as formas estatais, sobre os Estados ameríndios, por assim dizer. Etnografias como as de Schavelzon (2010) já têm conseguido avançar nessa direção ${ }^{373}$, mas, há, ainda, bom espaço para reflexões em torno, por exemplo, das formas estatais pré-colombianas.

Considerando tratar-se de um pensamento que parte de bases muito distintas das ocidentais a respeito do que é a vida em sociedade, como se viu, a aposta é que possamos seguir ao encontro de uma filosofia política de grande originalidade. Entre a concepção do Estado como uma "superintendência discricionária" (Hamilton, Madison e Jay, 2001: 270), tão cara à nossa cosmologia hobbesiana, e práticas já descritas, alhures, como socialistas ${ }^{374}$, há, certamente, muito espaço para discussão, ainda, até que tenhamos um entendimento mais fino sobre o pensamento político ameríndio.

Esse, vale notar, é o horizonte para a continuidade da presente pesquisa. Como intuía Azara $^{375}$ (2002 [1847]: cap. XI, § 61), pode haver muito mais entre os Guarani, os Inca e os Mexica do que nossa história ocidental deixou registrar:

"Es cosa admirable y aun increíble si no se viese, que las naciones Mejicana, Perulera y Guaraní hayan sido las únicas dominadas en América, siendo como son las únicas enormemente extendidas $e$ incomparablemente más numerosas que las que no han querido dejarse dominar. Vendría bien hacer aquí un cotejo de las naciones de Méjico y el

373 E aqui, há mais diálogo com análises sociológicas como a de Santos (2007, 2008, 2008b), para quem essas ideias podem mesmo "refundar" o Estado.

374 Ver Baudin, 1961, que assume essa interpretação, sobre os Inca, além dos comentários de Murra ( 1978: 191). 375 Que, paradoxalmente, tinha uma opinião nada lisonjeira sobre os Guarani, como vimos. 
Perú con la guaraní, las cuales, aunque muy diferentes en idioma y en civilización, se han de parecer en otras cosas (...)” (Azara, 2002 [1847]: cap. XI, §61)

\section{E a polícia, afinal?}

A reflexão que conduz nosso texto, como anunciamos desde o início, passa por uma questão que, talvez, não tenhamos enfrentado. Explico-me: é que, como diria o cobrador de ônibus portenho, citado por Cortázar, creio que avançamos - mas de ladinho.

Parece que há, realmente, algo que desafia o bom senso ocidental no pensamento indígena. Mas, como já notaram outros, esse "algo" não é nada menos que a persistência em enxergar alcances da humanidade, muitas vezes bem onde a modernidade insiste em estabelecer limites. No campo daquilo que alguns de nós chamam de metafísica, ou talvez ontologia, está uma das questões chave: onde muitos de nós vemos separação entre vida e morte, entre natural e sobrenatural, homens e deuses, o pensamento indígena vê alamedas, como já destacaram autores como Hélène Clastres (1978) ou Viveiros de Castro (1986, 1987).

E na política, seria diferente? Enquanto vemos a necessidade premente de um poder "superintendente" como o maquinado pelos Federalistas, para evitar o perigo da "bellum omnia omnes" que fabulava Hobbes, os ameríndios parecem insistir que, sim, é possível um governo em que a soberania não seja roubada a ninguém. O que aqui parece devaneio, heresia, entre povos como os Kaiowá e Guarani é simplesmente razoável, e, diríamos mais, imprescindível.

Sim, chegamos, outra vez, à velha questão levantada por Clastres sobre um e dois. "Todas as coisas que são uma e que não desejávamos, elas são más”, dizia-lhe o xamã guarani (1990). E La Boétie, no bar, emendaria: sim, era disso que eu estava falando! Já comentava Graeber, está na hora de nós mesmos nos perguntarmos por que achamos que uma formulação como essa precisa de algum tipo de explicação...

Bem, e a polícia? Sim, ela pode ser necessária. Mas, ela não deveria ser necessária. E é por isso que, ao sul do Rio Grande, a luta segue. 


\section{Autonomias}

Ao fim e ao cabo, percebemos o enorme relevo adquirido por essa discussão que é pautada pelos movimentos indígenas de toda a América Latina: autonomia é o termo-chave que emerge, de forma inescapável. Autonomia para organizar-se. Autonomia para desorganizar-se. Autonomia para reunir-se em assembleia e ser ouvidos pelo governo, mas também para não ter de se reunir em assembleia e poder ficar em paz em um pedaço de terra que proporcione alegria e bem-estar. Autonomia para produzir a própria comida. Autonomia, afinal, como pedem os Kaiowá e Guarani, para ser do seu próprio jeito.

A ideia de que é possível organizar um sistema político multilocal que prescinde de uma autoridade superior, vigilante, zelosa, pode ser tomada como uma utopia, diante do pessimismo ocidental a respeito da natureza humana ${ }^{376}$. Não é à toa que tantos resistem a ver, aí, qualquer possibilidade de unidade - mas é que se trata de uma unidade que não reduz a Um, respeita a multiplicidade. Da mesma forma, poderíamos dizer, que soa absurdo aos ouvidos ocidentais falar na possibilidade de aceder ao paraíso ainda em vida, ou assumir que animais, plantas e lugares podem ser pessoas.

A condição ocidental e moderna, afinal, parece ser intrinsecamente ligada a uma espécie de castração mental, a assunção, desde a partida, de que tudo isso é mesmo inviável, impossível e, por isso, não merece mesmo uma tentativa.

Nesse sentido, é mesmo enorme o desafio que temos ao propor um olhar para as formas políticas ameríndias. Porque a aposta que os povos indígenas fazem é nas pessoas: em sua capacidade de administrar sua assembleia interna (Overing, 2004); no poder da iniciativa; na capacidade de ação da palavra. Todas ideias contra as quais jogam a ciência, a religião, a política ocidentais, com seu Um opressor.

376 Ver, a respeito dessas ideias ocidentais sobre a "natureza humana", Sahlins, 2008. 


\section{Bibliografia}

ABENSOUR, Miguel (org.)

2007 [1987] El Espíritu de las Leyes Salvajes. Pierre Clastres o uma nueva antropología política. Buenos Aires, Ed. del Sol.

ABENSOUR, Miguel \& KUPIEC, Anne (org.)

2011 Pierre Clastres. Paris, Sens \& Tonka Editeurs.

ALBERNAZ, Adriana C. R.

2003 Tradição, Mudança e o Sentido da História entre os Kaiowá Guarani. Curitiba, dissertação de mestrado, PPGAS-UFPR.

2009 Antropologia, História e Temporalidades entre os Avá-Guarani de Oco’y. Florianópolis, tese de doutorado, PPGAS-UFSC.

ALBERT, Bruce.

2002 "O ouro canibal e a queda do céu - uma crítica xamânica da economia política da natureza". In Bruce Albert \& Alcida Ramos (org.). Pacificando o Branco - Cosmologias do Contato no Norte Amazônico. São Paulo, Ed. Unesp/Imprensa Oficial.

ALIMONDA, Héctor.

2007 “La ecología política de Mariátegui”. Tareas 125.

ANTUNHA BARBOSA, Pablo.

2012 "Las Jornadas Meridionales y la formación de los aldeamientos indígenas de las provincias de San Paulo, Paraná y Mato Grosso entre 1840 y 1889: profetismo y movilidad guaranî’. In Protasio Paulo Langer; Graciela Chamorro (org.). Missões, Militância Indigenista e Protagonismo Indígena. XIII Jornadas Internacionais sobre as Missões Jesuíticas, Vol. II. S. Bernardo do Campo, Nhanduti.

ANTUNHA BARBOSA, Pablo \& MURA, Fabio.

2011 “Construindo e reconstruindo territórios guarani: dinâmica territorial na fronteira entre Brasil 
e Paraguai (Séc. XIX-XX). Journal de la Société des Américanistes 97-2, p. 287-318.

ASSIS, Cecy Fernandes.

$2008 \tilde{N} e^{\prime}$ èryru Avañe'è-Portugel Portuge-Avañe'ē - Dicionário Guarani-Português/ Português-

Guarani. São Paulo, edição da autora ( $2^{\mathrm{a}}$ ed.).

AUTHIER, Denis \&DAUVÉ, Gilles (ed.).

2004 Ni parlamentos ni sindicatos: ¡Los Consejos Obreros!. Sem local de edição, Espartaco Internacional.

AZARA, Félix de.

2002 [1847] Descripción e historia del Paraguay y del Río de la Plata. Alicante, Biblioteca Virtual Miguel de Cervantes (edición digital basada en la de Buenos Aires, Editorial Bajel, 1943). Disponível em www.cervantesvirtual.com

AZEVEDO, Marta M.

1991 “O Suicídio entre os Guarani Kaiowá”, Terra Indígena, 58: 6-28.

AZEVEDO, Carlos; AMARAL, Marina; PIMENTEL, Spensy; DOMENICI, Thiago.

2008 Brasil Direitos Humanos 2008: A realidade do país aos 60 anos da Declaração Universal. Brasília, SEDH/PR.

BALANDIER, Georges.

1969 Antropologia Política. São Paulo, Difusão/ Edusp.

BARBOSA, Gabriel.

2005 “Das trocas de bens”. In Dominique Gallois (org.) Redes de Relações nas Guianas. São Paulo, Humanitas/Fapesp/NHII.

BARBOSA, Gustavo B.

2005 "A socialidade contra o Estado: a antropologia de Pierre Clastres". Revista de Antropologia $(47 / 2)$. 
BARBOSA DA SILVA, Alexandra.

2007 Mais além da "aldeia": território e redes sociais entre os Guarani de Mato Grosso do Sul. Rio de Janeiro, tese de doutorado apresentada ao PPGAS/MN-UFRJ.

2010 "Parentesco e relações patrão-cliente entre os Kaiowa". Belém, Anais da 27ª RBA.

BARCELOS NETO, Aristóteles.

2008 Apapaatai - Rituais de Máscaras no Alto Xingu. São Paulo, Edusp/Fapesp.

BARCO DE CENTENERA, Martin.

1602 Argentina y conquista del Río de la Plata. Lisboa, Pedro Crasbeeck. Disponível em purl.pt

BARNES, J.A.

2009 [1969]. "Redes sociais e processo político". In Bela Feldman-Bianco (org.). Antropologia das Sociedades Contemporâneas - Métodos. São Paulo: Unesp, p. 171-204.

BARONNET, Bruno; MORA, Mariana; STAHLER-SCHOLK, Richard (coord.)

2011 Luchas 'muy otras'. Zapatismo y autonomía en las comunidades indígenas de Chiapas. México, UAM-Xochimilco/Ciesas/Unach.

BARTH, Fredrik.

2000 “O guru e o iniciador: transações de conhecimento e moldagem da cultura no sudeste da Ásiae na Melanésia". In T. Lask (org.). O guru, o iniciador e outras variações antropológicas. Rio de Janeiro, Contra Capa. p. 141-66.

BARTOLOMÉ, Miguel Alberto.

2009 Parientes de la Selva - Los Guaraníes Mbya de la Argentina. Asunción, Ceaduc.

BATESON, Gregory.

1972 Steps to an Ecology of Mind. New York, Balantine.

BAUDIN, Louis.

1961 A Socialist Empire - The Incas of Peru. Princeton, D. Van Nostrand Co. 
BECKER, Ítala Irene Basile.

1992 "Lideranças indígenas no começo das reduções jesuíticas da Província do Paraguay". Pesquisas, São Leopoldo, Instituto Anchietano de Pesquisas (47): 1-197.

BENITES, Tonico.

2009 A Escola na Ótica dos Ava Kaiowa: Impactos e Interpretações Indígenas. Rio de Janeiro, dissertação de mestrado, PPGAS/UFRJ.

2010 “Guarani-Kaiowa resiste!” in Caros Amigos Especial Indígena n. 1. São Paulo, Casa Amarela, p. 10.

BENJAMIN, Walter.

2008 “A Tarefa-Renúncia do Tradutor” (trad. Suzana Kampff Lages) in Lucia Castello Branco (org.). A Tarefa do Tradutor, de Walter Benjamin: quatro traduções para o português. Belo Horizonte, Fale/UFMG, p. 66-81.

BLASER, Mario.

2009 "The Threat of the Yrmo: The Political Ontology of a Sustainable Hunting Program". American Anthropologist 111(1), p. 10-20.

BOBBIO, Norberto; MATTEUCCI, Nicola; PASQUINO, Gianfranco (org.).

1998 Dicionário de Política. Brasília, Ed. UnB, 11a edição.

BOIDIN, Capucine.

2007 "Du Gran Líder Stroessner (1954-1989) au Karai Tendota Nicanor Duarte (2003-2006)". Mots, Les Langages du Politique, 85, p. 11-22.

BOISSEVAIN, Jeremy.

2009 [1974]. “Apresentando 'amigos de amigos: redes sociais, manipuladores e coalizões””. In Bela Feldman-Bianco (org.). Antropologia das Sociedades Contemporâneas - Métodos. São Paulo: Unesp, p. 205-233.

BOUYSSE-CASSAGNE, Thérèse.

1987 La identidad aymara: aproximación histórica, siglo XV - siglo XVI. La Paz/Lima, Hisbol/Ifea. 
BRAND, Antonio.

1997 O Impacto da Perda da Terra sobre a Tradição Kaiowá/Guarani: os Difíceis Caminhos da Palavra. Tese de doutorado em História Ibero-Americana, IFCH/PUC-RS.

2001 “Os Kaiowá/Guarani no Mato Grosso do Sul e o processo de confinamento - a 'entrada de

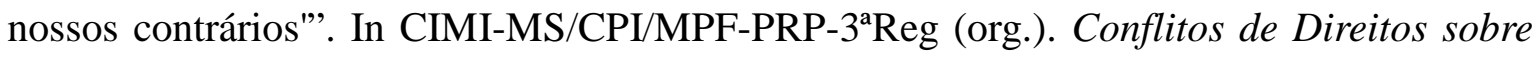
as Terras Guarani Kaiowa no Estado de Mato Grosso do Sul. São Paulo, Palas Athena.

BRIGHTMAN, Marc.

2010 "Creativity and control: property in Guianese Amazonia". Journal de la Societé des Americanistes 96 (1), p. 135-67.

BRODA, Johanna; IWANISZEWSKI, Stanislaw; MONTERO, Arturo (coord.).

2001 La Montaña en el Paisaje Ritual. Ciudad de México, IIH-UNAM/ENAH.

CABALZAR, Flora.

1997 Trocas matrimoniais e relações de qualidade entre os Waiãpi do Amapá. São Paulo, dissertação de Mestrado, PPGAS-USP.

CABEZA DE VACA, Alvar Nuñez.

1944[1555] Naufragios y Comentarios. Madri, Espasa-Calpe.

CADOGAN, León

1987 "Comentários de Leon Cadogan a la Gramática Guarani del Padre Antonio Guasch". Ameríndia 12.

CADOGAN, Leon \& LÓPEZ AUSTIN, Alfredo.

1965 La literatura de los guaranies. Mexico, EJM.

CAIUBY NOVAES, Sylvia.

2002 "Estruturas elementares de reciprocidade" [Apresentação da tradução de um artigo de Joanna Overing]. Cadernos de Campo 10. 
CAMACHO VELÁZQUEZ, Dolores.

2011 El movimiento zapatista y la outra democracia: expresión de las luchas de los 500 años en América Latina. Ciudad de México, tese de doutorado, FFyL/Unam.

CAMPAGNO, Marcelo.

1998 "Pierre Clastres y el surgimiento del Estado. Veinte años despues”. Boletín de Antropología Americana 33.

CARDOSO, Sérgio.

1995 “Copérnico no orbe da antropologia política”. Novos Estudos Cebrap 41, p. 121-42.

CARNEIRO DA CUNHA, Manuela.

1986 Antropologia do Brasil-Mito, História, Etnicidade. São Paulo, Brasiliense/Edusp.

1992 (org.) História dos índios no Brasil. São Paulo: Companhia das Letras.

1998 "Pontos de vista sobre a floresta amazônica: xamanismo e tradução". Mana 4 (1), p. 7-22.

2009 Cultura com Aspas. São Paulo, Cosac \& Naify.

CARNEIRO DA CUNHA, Manuela \& VIVEIROS DE CASTRO, Eduardo.

1985. "Vingança e temporalidade: os Tupinambá”. Journal de la Société des Américanistes, LXXI : 191-208.

CARSON, Kevin.

2004 Studies in Mutualist Political Economy. Fayetteville, Ark (disponível em www.mutualist.org)

CARVALHO, Silvia M. S.

1992 “Chaco: Encruzilhada de Povos e 'Melting Pot' Cultural - Suas relações com a bacia do Prata e o Sul Mato-grossense”. In Manuela Carneiro da Cunha (org.) História dos índios no Brasil. São Paulo: Companhia das Letras, p. 457-74.

CAVALCANTE, Thiago L. V.

2008 Apropriações e resignificações do mito de São Tomé na América: a inclusão do índio na cosmologia cristã. Dourados, dissertação de mestrado, UFGD. 
CAVALCANTI-SCHIEL, Ricardo A.

2007 "Las muchas naturalezas en los Andes". Perifería - Revista de Recerca i Formació em Antropologia 7.

CESARINO, Pedro N.

2010 “Donos e Duplos: relações de conhecimento, propriedade e autoria entre Marubo". Revista de Antropologia 53 (1), p. 147-97.

CHAMORRO, Graciela.

1995 Kurusu Ñe'engatu - Palabras que la Historia no Podría Olvidar. Asunción/ São Leopoldo: CEI-UC/IEP-EST/CMI.

2004 Teología Guaraní. Quito, Abya Yala.

2008 Terra Madura - Yvy Araguyje: Fundamento da Palavra Guarani. Dourados, UFGD.

2009 “O Povo Kaiowá no Século XIX e a ocupação do sul de Mato Grosso pelos não indígenas”. In Luiz F. V. Moreira \& José H. R. Gonçalves (org.). Etnias, Espaços e Ideias - Estudos Multidisciplinares. Curitiba, Instituto Memória, p. 67-89.

2010 "Imagens espaciais utópicas. Símbolos da liberdade e desterro nos povos guarani”. Indiana 27, p. 79-107.

s.d. "A arte da palavra cantada na etnia Kaiowá”. No prelo.

CIMI-MS/CPI/MPF-PRP-3 ${ }^{\text {a Reg (org.). }}$

2001 Conflitos de Direitos sobre as Terras Guarani Kaiowa no Estado de Mato Grosso do Sul. São Paulo, Palas Athena.

CLASTRES, Hélène.

1978 Terra sem Mal - o profetismo tupi-guarani. São Paulo, Brasiliense.

CLASTRES, Pierre.

1990 [1974] A Fala Sagrada - Mitos e Cantos dos Índios Guarani. Campinas, Papirus.

1995 [1972] Crônica dos Índios Guayaki - o que sabem os Aché, Caçadores Nômades do Paraguai.

São Paulo, 34.

2003 [1974] A Sociedade Contra o Estado, São Paulo, Cosac \& Naify.

2004 [1980] Arqueologia da violência: pesquisas de antropologia política. São Paulo, Cosac \& 
Naify.

COHEN, Ronald \& MIDDLETON, John (eds.)

1967 Comparative political systems: studies in the politics of pre-industrial societies. New York: Natural History Press.

COLCHESTER, Marcus.

1982 "Les Yanomami, sont-ils libres? Les utopies amazoniennes, une critique. A Look at French Anarchist Anthropology". Journal of Anthropological Society of Oxford 13 (2), p. 147-64.

COLLIER, J. \& ROSALDO, M.

1981 "Politics and gender in simple societies", in S. Ortner and H. Whitehead (eds). Sexual Meanings. Cambridge, Cambridge Univ. Press.

COMBÈS, Isabelle.

2005 "Las Batallas de Kuruyuki. Variaciones sobre una derrota chiriguana". Boletin del Instituto Francés de Estudos Andinos 34 (2), p. 221-33.

2006 "De los candires a Kandire. La invención de un mito chiriguano". Journal de la Societé des Americanistes 92-1 et 2, p. 137-163.

2010 Diccionario étnico. Santa Cruz la Vieja y su entorno en el siglo XVI. Cochabamba: Instituto de Misionología.

2011 “Pai Sumé, el Rey Blanco y el Paititi”. Anthropos 106, p. 99-114.

2011b "El Paititi, Los Candires y Las Migraciones Guaraníes". Suplemento Antropológico XLVI n 1: 7-149.

COMBÈS, Isabelle \& VILLAR, Diego.

2007 “Os mestiços mais puros. Representações chiriguano e chané da mestiçagem”. Mana 13(1).

COMBÈS, Isabelle; VILLAR, Diego; LOWREY, Kathleen.

2009 "Comparative Studies and the South American Gran Chaco". Tipití 7 (1).

CORTESÃO, Jaime (org.)

1951 Jesuítas e Bandeirantes no Guairá (Manuscritos da Coleção De Angelis Vol. I), Rio de 
Janeiro, Biblioteca Nacional/ Divisão de Obras Raras e Publicações.

2010 Jesuítas e Bandeirantes no Itatim 1596-1670 (Manuscritos da Coleção De Angelis Vol. II).

Campo Grande, Alvorada, Coleção Documentos para a História de Mato Grosso do Sul (LORENZETTO, Mario S.; MARTINS, Gilson ; QUEIROZ, Paulo R. C.; CORRÊA, Valmir B. - ed.).

COSTA, Luiz.

2010 “The Kanamari Body-Owner. Predation and feeding in Western Amazonia”. Journal de la Societé des Americanistes 96 (1), p. 169-92.

DA COL, Giovanni \& GRAEBER, David.

2011 "Foreword: the return of ethnographic theory". HAU: Journal of Ethnographic Theory 1 (1): vi-xxxv.

D'ABBEVILLE, Claude.

1975 História da missão dos padres capuchinhos na Ilha de Maranhão e terras circunvizinhas. São Paulo, Edusp/Itatiaia.

DE LA CADENA, Marisol

2010 "Indigenous Cosmopolitics in the Andes: Conceptual reflections beyond 'politics"'. Cultural Anthropology 25 (2).

DE PAULA, Luís Roberto.

2000 A dinâmica faccional Xerente: esfera local e processos sociopolíticos nacionais $e$ internacionais. São Paulo, dissertação de mestrado, PPGAS-USP.

DEL TECHO, Nicolás.

1897 Historia de la Provincia del Paraguay de la Compañía de Jesús, vol. V. Asunción, A. de Uribe, 5v. Disponível em Biblioteca Virtual de Paraguay - http://www.bvp.org.py/

DELEUZE, Gilles \& GUATTARI, Felix.

1996 "Micropolítica e Segmentaridade”, in Mil Platôs - Capitalismo e Esquizofrenia (vol. 3). São Paulo, ed. 34, p. 83-115. 
1997 “7.000 A.C. - Aparelho de Captura”, in Mil Platôs - Capitalismo e Esquizofrenia (vol. 5). São Paulo, ed. 34, p. 111-77.

DELEUZE, Gilles \& PARNET, Claire.

1998 Diálogos. São Paulo, Escuta.

DESCOLA, Philipe.

1986 La nature domestique. Symbolisme et praxis dans l'écologie des Achuar. Paris: Maison des Sciences de l'Homme.

1988 "La chefferie amérindienne dans l'anthropologie politique". Revue Française de Science Politique 38 (5), p. 818-26.

2005 "No Politics Please". In Bruno Latour and Peter Weibel (eds). Making Things Public. Atmospheres of Democracy. Cambridge, MIT Press, p. 54-57.

DETIENNE, Marcel.

2003 Qui veut prendre la parole? (org.). Paris, Seuil (Collection Genre Humain).

2004 Comparar o Incomparável. Aparecida, Ideias \& Letras.

2005 Como ser autóctono - Del puro ateniense al francés de raigambre. Buenos Aires, FCE.

DIAZ, Floriberto.

2007 Escrito. Comunalidad, Energía Viva del Pensamiento Mixe (comp. Sofía Robles Hernández y Rafael Cardoso JIménez) México, UNAM.

DOOLEY, Robert A.

2008[1991] Apontamentos Preliminares sobre o Ñandéva Guaraní Contemporâneo. Cuiabá, Associação Internacional de Linguística - SIL Brasil (disponível na internet), 36 p.

DRAGO, André.

2012 Formas Políticas Ameríndias - Etnologia Jê. São Paulo, dissertação de mestrado, PPGASUSP.

DUMONT, Louis.

1993 O Individualismo - Uma Perspectiva Antropológica da Ideologia Moderna. Rio de Janeiro, 
Rocco.

DURKHEIM, Émile.

2003 [1912] As Formas Elementares da Vida Religiosa. São Paulo, Martins Fontes (3a ed.)

EHRENREICH, Jeffrey D. \& RUEDAS, Javier.

2003 "Introduction: Politics and Religion in Amazonia". Tipiti 1 (1), p. 3-10.

EVANS-PRITCHARD, Edward E.

1962 Essays in Social Anthropology. Londres, Faber and Faber.

2005 Bruxaria, oráculos e magia entre os Azande. Rio de Janeiro, Zahar (versão condensada por Eva Gillies, traduzida por Eduardo Viveiros de Castro).

FALLEIROS, Guilherme L. J.

2012 Datsi'a'uwẽdzé - Vir a ser e não ser gente no Brasil Central. São Paulo, tese de doutorado, PPGAS-USP.

FAUSTO, Carlos.

1992. "Fragmentos de história e cultura tupinambá: da etnologia como instrumento crítico de conhecimento etno-histórico”. In: Manuela Carneiro da Cunha (org.), História dos Índios no Brasil. São Paulo: Companhia das Letras. pp. 381-396.

2000 Os índios antes do Brasil. Rio de Janeiro, Jorge Zahar.

2001 Inimigos Fiéis - História, guerra e xamanismo na Amazônia. São Paulo, Edusp.

2002 "Banquete de gente: comensalidade e canibalismo na Amazônia". Mana 8 (2).

2005 "Se Deus fosse Jaguar: Canibalismo e Cristianismo entre os Guarani (séc. XVI-XX)". Mana 11-2: $385-418$.

2008 “Donos demais: maestria e domínio na Amazônia”. Mana 14 (2), p.329-66.

FELDMAN-BIANCO, Bela.

2009 (org.). Antropologia das Sociedades Contemporâneas - Métodos. São Paulo, Unesp.

FERNANDES, Florestan.

1989 [1948] A Organização Social dos Tupinambá. São Paulo, UnB/Hucitec. 
FERNANDES, Ricardo Cid.

2004 “Uma contribuição da antropologia política para os estudos sobre o faccionalismo kaingang". in Lúcio T. Motta; Francisco S. Noelli; Kimiye Tommasino (org.). Novas Contribuições aos Estudos Interdisciplinares dos Kaingang. Londrina, Eduel.

2006 “O '15' e o '23': Políticos e Políticas Kaingang”. Campos 7 (2), p. 27-47.

FERNÁNDEZ C., Paulina

2010 “Gobierno autónomo zapatista - Características antisistema político mexicano”. Disponível em enlacezapatista.ezln.org.mx

FERNÁNDEZ F., José M.

2009 "Movimientos indígenas" in Román Reyes (dir.). Diccionario Crítico de Ciencias Sociales. Terminología Científico-Social (4 tomos). Madrid-México, Plaza y Valdés.

FERRARI, Florencia.

2011 "Figura e fundo no pensamento cigano contra o Estado". Revista de Antropologia 54 (2).

FERREIRA, Andrey C.

2009 “Conquista colonial, resistência indígena e formação do Estado nacional: os índios Guaicuru e Guaná no Mato Grosso dos séculos XVIII-XIX”. Revista de Antropologia 52.

FLOOD, Andrew N.

1998 "The mexican zapatistas and direct democracy". Workers Solidarity 55.

1999 "The zapatistas, anarchism and 'direct democracy"'. Anarcho-Syndicalist Review 27.

FLORES ARENALES, Carlos Y.

2012 "Derecho maya y video comunitario: experiencias de antropología colaborativa". Íconos 42.

FORTES, Meyer \& EVANS-PRITCHARD, E. E. (org.).

1987 [1940] African Political Systems. Londres/New York, KPI.

FOUCAULT, Michel. 
1977 A Vontade de Saber. Rio de Janeiro: Graal.

GADELHA, Regina M. A. F.

1980 As Missões Jesuíticas do Itatim - Estruturas Sócio-Econômicas do Paraguai Colonial Séculos XVI e XVII. Rio de Janeiro, Paz e Terra.

GALLOIS, Dominique Tilkin.

1988 O movimento na cosmologia waiãpi: criação, expansão e transformação do universo. Tese de doutorado, São Paulo, FFLCH-USP.

1996 "Xamanismo waiãpi: nos caminhos invisíveis, a relação i-paie". In: J. Langdon (org.), Xamanismo no Brasil: novas perspectivas. Florianópolis, Ed. UFSC. p. 39-74.

2001 "Organização das aldeias e formas de casamento entre os Wajãpi: algumas informações básicas". Texto disponível em www.institutoiepe.org.br

2004 “Terras ocupadas? Territórios? Territorialidades?”. In: Fany Ricardo. (Org.). Terras Indígenas \& Unidades de Conservação da Natureza. São Paulo: Instituto Socioambiental, p. 37-41.

2005 (org.) Redes de Relações nas Guianas. São Paulo, Humanitas/Fapesp/NHII.

2007 “Gêneses waiãpi, entre diversos e diferentes”. Revista de Antropologia 50 (1).

GALVÃO, Eduardo.

1996 [1943]. "Diários Kaioá” In Marco Antônio Gonçalves (org.), Diários de Campo entre os Tenetehara, Kaioá e índios do Xingu. Rio de Janeiro: Editora UFRJ/Museu do Índio-Funai.

GÂNDAVO, Pero Magalhães de.

2004 [1576] A primeira história do Brasil - História da província Santa Cruz a que vulgarmente chamamos Brasil (texto modernizado e notas - Sheila M. Hue e Ronaldo Menegaz). Rio de Janeiro, Jorge Zahar, $2^{\mathrm{a}}$ ed.

GARCIA, Uirá F.

2010 Karawara: a caça e o mundo dos Awá-Guajá. São Paulo, tese de doutorado, PPGAS-USP.

GARCIA, Wilson G. (org.)

2003 Nhande Rembypy - Nossas Origens. São Paulo, Ed. Unesp. 
GENNARI, Emilio.

2005 EZLN - Passos de Uma Rebeldia. São Paulo, Expressão Popular.

\section{GLUCKMAN, Max.}

2010 “Análise de uma situação social na Zululândia moderna”. In Bela Feldman-Bianco (org.) Antropologia das Sociedades Contemporâneas. São Paulo, Unesp, 2a ed, 237-364.

GODELIER, Maurice.

1986 The Making of Great Men - Male Domination and Power among the New Guinea Baruya. Cambridge/Paris, Cambridge Un. Press / Ed. Maison des Sciences de l'Homme.

GODELIER, Maurice \& STRATHERN, Marilyn (eds.).

1991 Big Men and Great Men - Personifications of Power in Melanesia. Cambridge/Paris, Cambridge Un. Press/ Ed. Maison des Sciences de l'Homme.

GOLDMAN, Marcio.

2006 Como Funciona a Democracia - Uma Teoria Etnográfica da Política. Rio de Janeiro, 7 Letras.

2006b "Alteridade e experiência: antropologia e teoria etnográfica". Etnográfica 10 (1).

2008 “Os Tambores do Antropólogo: Antropologia Pós-Social e Etnografia”. Ponto Urbe Ano 2, versão 3.0. Disponível em http://n-a-u.org/pontourbe03/Goldman.html

2011 "Pierre Clastres ou uma Antropologia contra o Estado". Revista de Antropologia 54 (2).

GOLDMAN, Márcio \& LIMA, Tânia Stolze.

2001 "Pierre Clastres, etnólogo da América”. Sexta Feira, 6: 291-309.

2003 "Prefácio". In: CLASTRES, Pierre. A sociedade contra o Estado: pesquisas de antropologia política. São Paulo, Cosac \& Naify.

GOLDMAN, Marcio \& PALMEIRA, Moacir (orgs.).

1996 Antropologia, Voto e Representação Política. Rio de Janeiro, Contra Capa.

GÓMEZ, Luiz A.

2006 “La disputa por el tiempo. El Pachakuti en marcha en Bolivia”. In Raquel Gutiérrez A. \& 
Fabiola Escárzaga (coord.). Movimiento Indígena en América Latina: Resistencia y proyecto alternativo (vol. II). México, Casa Juan Pablos/Ceam/Buap/GDF/Uam/Diakonia /UACM, p. 437-43.

GONZÁLEZ RUIZ, Nicolas.

2011 "Resistencia y construcción de autonomía en una comunidad zapatista de los Altos de Chiapas”. Apresentação no Seminário "El Proyecto de Autonomía Hoy”, San Cristóbal de Las Casas (Chiapas-Mexico).

GOW, Peter.

2011 “"Me deixa em paz’: um relato etnográfico preliminar sobre o isolamento voluntário dos Mashco". Revista de Antropologia 54 (1), p.11-46.

GRAEBER, David.

2011 Fragmentos de uma Antropologia Anarquista. Porto Alegre, Deriva. (Edição original: Fragments of an Anarchist Anthropology. Chicago, Prickly Paradigm Press, 2004).

GRAEBER, David \& LANNA, Marcos.

2005 “Comunismo ou comunalismo? A política e o 'Ensaio sobre o Dom"'. Revista de Antropologia 48 (2), p. 501-23.

\section{GREGORY, Christopher}

1982 Gifts and commodities. London, Academic.

GRÜNBERG, Friedl.

1988 Estudio sobre el proceso de los Pã̃-Tavyterã de 1972 a 1988 - Evaluación de las consecuencias a largo plazo del "Proyecto Paĩ-Tavyterã". Asunción, Servicios Profesionales Sócio-Antropológicos y Jurídicos.

GRUZINSKI, Serge.

2003 A Colonização do Imaginário: sociedades indígenas e ocidentalização no México espanhol. Séculos XVI - XVII. São Paulo, Companhia das Letras. 
GUASCH, Antonio \& ORTIZ, Diego.

2008 Diccionario Castellano-Guarani/ Guarani-Castellano. Asunción, Cepag (13 ${ }^{\mathrm{a}}$ ed., $1^{\mathrm{a}}$ reimpr.)

GUATTARI, Félix.

1988 O Inconsciente Maquínico - Ensaios de Esquizoanálise. São Paulo, Papirus.

GUERREIRO JÚNIOR, A. R.

2010 “Assimetria e coletivização: notas sobre chefes e caraíbas na política Kalapalo (Alto Xingu, MT)”. In: Marcela Coelho de Souza; E. C. Lima (org.). Conhecimento e Cultura: práticas de transformação no mundo indígena. Brasília, Athalaia. p. 119-49

2011a “Aliança, chefia e regionalismo no Alto Xingu”. Journal de la Société des Américanistes, v. 97-2, p. 99-133.

2011b "Esteio de gente: reflexões sobre assimetria e parentesco a partir de depoimentos de chefes kalapalo”. R@U: Revista de Antr. Social dos Alunos do PPGAS-UFSCar, v. 3,n.1, p. 95126.

GUTIÉRREZ A., Raquel.

2009 Los Ritmos del Pachakuti. México D.F., Bajo Tierra/Sísifo.

GUTIÉRREZ A., Raquel \& ESCÁRZAGA, Fabiola (coord.).

2005 Movimiento Indígena en América Latina: Resistencia y proyecto alternativo (vol. I). México, Casa Juan Pablos/GDF/Unam/Uacm/Buap.

2006 Movimiento Indígena en América Latina: Resistencia y proyecto alternativo (vol. II). México, Casa Juan Pablos/Ceam/Buap/GDF/Uam/Diakonia/UACM.

HADOT, Pierre.

2006 O Véu de Ísis - Ensaio sobre a História da Ideia de Natureza. São Paulo, Loyola.

HAMILTON, Alexander; MADISON, James; JAY, John.

2001 "Textos de 'O Federalista”. In Francisco Weffort (org.). Os Clássicos da Política - volume 1. São Paulo, Ática, 13a edição, p. 256-87.

HAUBERT, Maxime. 
s.d. A vida quotidiana no Paraguai no tempo dos jesuítas. Lisboa, Livros do Brasil.

HECK, Egon D.; MACHADO, Flávio D. (org.).

2011 As Violências contra os Povos Indígenas em Mato Grosso do Sul - E as Resistências do Bem Viver por uma Terra sem Males. Campo Grande, CIMI-MS.

HECKENBERGER, Michael.

1999. "O enigma das grandes cidades: corpo privado e Estado na Amazônia” in Adauto Novaes (org.) A outra margem do Ocidente. São Paulo, Companhia das Letras.

HECKENBERGER, Michael \& NEVES, Eduardo Góes .

2009 “Amazonian Archaeology”. Annual Review of Anthropology 38: 251-66.

HERNÁNDEZ, Pablo.

1913 Misiones del Paraguay - Organización social de las doctrinas guaraníes de la Compañía de Jesus. Barcelona, Gustavo Gili.

HUGH-JONES, Stephen.

1994. "Shamans, profets, priests, and pastors" in Nicholas Thomas \& Caroline Humphrey (eds.). Shamanism, history \& the state. Michigan, University of Michigan Press.

2009 "The fabricated body: objects and ancestors in Northwestern Amazonia". In Fernando SantosGranero (ed.) The Occult Life of Things: native amazonian theories of materiality and personhood. Tucson, Univ. Arizona Press, p. 33-59.

Instituto Brasileiro de Geografia e Estatística.

2012. Censo demográfico 2010. Características gerais dos indígenas - Resultados do Universo. Censo Demogr., Rio de Janeiro.

INGOLD, Tim.

2000 The Perception of the Environment. Essays on lilihood, dwelling and skill. London \& New York, Routledge.

2007 Lines - A Brief History. Londres/Nova York, Routledge.

2011 Being Alive - Essays on Movement, Knowledge and Description. Londres/Nova York, 
Routledge.

IZARD, Michel.

1988 “Présentation”. Revue Française de Science Politique 38 (5), p. 693-7.

JAEGER,

Pe. Luís

Gonzaga.

1957 "La Campañia de Jesús en el Antiguo Guairá (1585-1631) -

Localización de sus trece reducciones". Pesquisas 1, São Leopoldo, Instituto Anchietano de Pesquisas .

JOÃO, Izaque.

2011 Jakaira Reko Nheypyrũ Marangatu Mborahéi: Origem e fundamentos do canto ritual jerosy puku entre os Kaiowá de Panambi, Panambizinho e Sucuri'y, Mato Grosso do Sul. Dourados, dissertação de mestrado em História, FCH-UFGD.

JULIEN, Catherine.

2007 "Kandire in real time and space: Sixteenth-century expeditions from the Pantanal to the Andes". Ethnohistory 54(2): 245-272.

KILLICK, Evan.

2007 "Autonomy and Leadership: Political Formations among the Ashéninka of Peruvian Amazonia". Ethnos 72 (4).

KOENIGSWALD, Gustav von.

1908 Die Cayuas. Braunschweig, Globus XCII.

KOPENAWA, Davi \& ALBERT, Bruce.

2010 La chute du ciel - paroles d'un chaman yanomami. Paris, Terre Humaine/Plon.

KRACKE, Waud H.

1978 Force and Persuasion: Leadership in an Amazonian Society. Chicago: University of Chicago.

KUPER, Adam. 
2008 A Reinvenção da Sociedade Primitiva - Transformações de um Mito. Recife, Ed. UFPE.

LA BOÉTIE, Étienne.

1982 Discurso da Servidão Voluntária. São Paulo, Brasiliense.

LANGDON, E. Jean Matteson.

1996 “Introdução: Xamanismo - Velhas e Novas Perspectivas", in idem (org.) Xamanismo no Brasil - Novas Perspectivas. Florianópolis, Ed. da UFSC.

LANNA, Marcos.

1996 “Reciprocidade e hierarquia”. Revista de Antropologia 39 (1), p. 111-44.

2005 “As sociedades contra o Estado existem? Reciprocidade e poder em Pierre Clastres”. Mana, $11(2)$.

\section{LATOUR, Bruno.}

1994 Jamais Fomos Modernos. São Paulo, 34.

2001 A Esperança de Pandora: ensaios sobre a realidade dos estudos científicos. Bauru, EDUSC.

2004 "Whose Cosmos, Which Cosmopolitics? - Comments on the Peace Terms of Ulrich Beck". Common Knowledge, 10:3, p. 450-462.

2005 "From Realpolitik to Dingpolitik or How to Make Things Public". In B. Latour and P. Weibel (eds). Making Things Public. Atmospheres of Democracy. Cambridge, MIT Press, p. 14-43. 2008 Reensamblar lo Social - Una Introducción a la Teoría del Actor-Red. Buenos Aires, Manantial.

LE BOT, Yvon \& Subcomandante Marcos.

1997 El Sueño Zapatista. Disponível na internet. (em português: O Sonho Zapatista. Porto, Asa.)

LEACH, Edmund.

1996 [1954] Sistemas políticos da Alta Birmânia. São Paulo, Edusp.

LEHNER, Beate.

2002 “Territorialidad Guarani. Ensayo sobre la relación territorio-organización sócio-política de los Ava-Guarani y Paĩ-Tavyterã”. Asunción, Servicios Prof. Sócio-Antropológicos y Jurídicos. 
2008 “Algunas observaciones sobre la situación política actual de los Paĩ-Tavyterã”. In Bartomeu Melià; Georg Grünberg; Friedl Grünberg. Pai-Tavyterã - Etnografía Guaraní del Paraguay Contemporáneo. Asunción, Ceaduc/Cepag (2a ed.), p. 88-98.

LEIBNER, Gerardo.

1994 “La Protesta y la andinización del anarquismo en el Perú, 1912-1915”. Estudios Interdisciplinarios de América Latina y el Caribe 5 (1).

1997 "Pensamiento radical peruano: González Prada, Zulen, Mariátegui". Estudios Interdisciplinarios de América Latina y el Caribe 8 (1).

\section{LENKENSDORF, Carlos.}

1996 Los Hombres Verdaderos - Voces y Testimonios Tojolabales. México, Siglo XXI.

2004 Conceptos Tojolabales de Filosofía y del Altermundo. México, PyV.

2005 Filosofar en Clave Tojolabal. México, Porrúa.

LÉVI-STRAUSS, Claude.

1967a [1954] Antropologia Estrutural. Rio de Janeiro, Tempo Brasileiro.

1967b [1944] "The Social and Psychological Aspects of Chieftainship in a Primitive Tribe: The Nambikuara of Northwestern Mato Grosso". In: COHEN, Ronald \& MIDDLETON, John (Eds.), Comparative political systems: studies in the politics of pre-industrial societies. New York: Natural History Press, p. 45-62.

1967c [1949] "O Feiticeiro e sua Magia”. In Antropologia Estrutural. Rio de Janeiro, Tempo Brasileiro, p. 193-213.

1976 O Pensamento Selvagem. São Paulo, Nacional.

1986 [1983] O Olhar Distanciado. Lisboa, Edições 70.

1993 [1991] História de Lince. São Paulo, Companhia das Letras.

2004 [1964] O Cru e o Cozido. São Paulo, Cosac \& Naify.

LIMA, Marcos Homero F.

2007 “A 'Vontade Geral' nem sempre é a 'Vontade da Maioria': Rousseau não conheceu os Kaiowá”. Dourados: Nota técnica/Antropologia/MPF/PPA/MS/FCR/No 01/2007.

2011 "Quando o Capitão assume o Papel de Polícia: Violação de Direitos Humanos em Terras Indígenas”. Texto apresentado no XXVIII Congresso Internacional da ALAS, Recife. 
LIMA, Tania Stolze.

1996 "O dois e seu múltiplo: reflexões sobre o perspectivismo em uma cosmologia tupi”. Mana 2 (2).

1999 "Para uma teoria etnográfica da distinção entre natureza e cultura na cosmologia juruna". Revista Brasileira de Ciências Sociais, 14(40):43-52, 1999.

LIMONGI, Fernando P.

2001 “'O Federalista': Remédios republicanos para males republicanos”. In Francisco Weffort (org.). Os Clássicos da Política - volume 1. São Paulo, Ática, 13a edição, p. 243-55.

LOLLI, Pedro.

2010 As redes de trocas rituais dos Yuhupdeh no igarapé Castanha, através dos benzimentos (mihdïd) e das flautas Jurupari (Tí'). São Paulo, tese de doutorado, PPGAS-USP.

LOPES, Joaquim Francisco.

1850 "Itinerário de... encarregado de explorar a melhor via de comunicação entre a província de São Paulo e a de Mato-Grosso pelo Baixo Paraguai”. Revista do Instituto Histórico e Geographico Brazileiro, v. XIII: p. 315-335.

LÓPEZ AUSTIN, Alfredo \& LÓPEZ LUJÁN, Leonardo.

1996 El Pasado Indígena. México, FCE.

1999 Mito y realidad de Zuyua: serpiente emplumada y las transformaciones mesoamericanas del Clasico al Posclasico. Mexico, FCE.

LÓPEZ BÁRCENAS, Francisco.

2007 Autonomías Indígenas em América Latina. Oaxaca/Cidade do México, Coapi/MC.

LOUREIRO, Isabel

1997 “Democracia e Socialismo em Rosa Luxemburgo”. Crítica Marxista n. 4.

2005 “Os conselhos na Revolução Alemã de 1918-1919”. Crítica Marxista n. 23.

LOVISI, G. M. et al. 
2009 “Análise epidemiológica do suicídio no Brasil entre 1980 e 2006”. Rev. Bras. Psiquiatria [online] 31 (2), p. S86-S93.

LOWIE, Robert.

1927 The Origin of the State. New York, Russel \& Russel.

1967 [1948] "Some aspects of political organization among the American aborigines". In: COHEN, Ronald \& MIDDLETON, John (Eds.). Comparative political systems: studies in the politics of pre-industrial societies. New York: Natural History Press. pp.63-86.

LÖWY, Michel.

2005 “Introdução: nem decalque nem cópia: o marxismo romântico de José Carlos Mariátegui”. in José Carlos Mariátegui. Por um Socialismo Indo-Americano - Ensaios Escolhidos. Rio de Janeiro, Ed. UFRJ, p. 7-24.

LUCIANO, Gersem dos Santos.

2006 O Índio Brasileiro: o que você precisa saber sobre os povos indígenas no Brasil de hoje. Brasília, MEC/Unesco.

LUXEMBURGO, Rosa.

2003 [1918] “On the Spartacus Programme”. Disponível em www.marxists.org 2008 [1918] “O que quer a Liga Espartaco?”. Disponível em www.marxists.org

MACEDO, Valéria.

2009 Cultura e afecção em uma aldeia guarani na Serra do Mar. São Paulo, tese de doutorado, PPGAS-USP.

2011 “Vetores porã e vai na cosmopolítica guarani”. Tellus ano 11, n. 21, p. 25-52.

MACHADO, João; PEREIRA, Levi M.

2012 "Nomes de parentela, objetos e territórios sagrados: uma abordagem dos processos de reprodução social entre os Kaiowá atuais”. Texto apresentado durante a $28^{a}$ RBA, em São Paulo.

MARX, Karl. 
1985 [1857-8] Formações Econômicas Pré-capitalistas. Rio de Janeiro, Paz e Terra.

2011 [1852] O 18 Brumário de Luís Bonaparte. São Paulo, Boitempo.

MAUSS, Marcel.

2003 [1906] “Ensaio sobre as variações sazonais dos Esquimós”. In Sociologia e Antropologia. São

Paulo, Cosac \& Naify, p. 425-505.

2003b[1925] "Ensaio sobre a dádiva. Forma e razão da troca nas sociedades arcaicas". In Sociologia e Antropologia, São Paulo, Cosac \& Naify.

MAUSS, Marcel \& HUBERT, Henri.

2005[1899] Sobre o Sacrifício. São Paulo, Cosac \& Naify.

MAYER, Adrian C.

2009 [1966] “A importância dos 'quase-grupos' no estudo das sociedades complexas”, in Bela

Feldman-Bianco (org.). Antropologia das Sociedades Contemporâneas - Métodos. São Paulo: Unesp, p. 139-170.

MCCALLUM, Cecilia \& MENTORE, George P.

1988 “The ventriloquist's dummy?”. Man 23 (3), p. 560-1.

MELIÀ, Bartolomeu.

1989 "La tierra sin Mal de los Guaraní - Economía y Profecía". America Indigena v. XLIX (3): 491-508.

1993 El Guaraní Conquistado y Reducido - Ensayos de Etnohistoria. Asunción, Ceaduc (3a ed.)

2004 "La Novedad Guarani (Viejas cuestiones y nuevas preguntas) - Revisita bibliográfica (19872002). Revista de Indias, v. LXIV, n 230, p. 175-226.

2004b "Escritos Guaraníes como Fuentes Documentales de la Historia Paraguaya". IberoAmericana Pragensia, año XXXVIII, p. 85-109.

MELIÀ, Bartomeu; SAUL, Marcos Vinicios de Almeida; MURARO, Valmir Francisco.

1987. O Guarani, uma bibliografia etnológica. Santo Ângelo: Centro de Cultura Missionária.

MELIÀ, Bartomeu; GRÜNBERG, Georg; GRÜNBERG, Friedl. 
2008 [1976] Los Paĩ-Tavyterã - Etnografía Guaraní del Paraguay Contemporáneo. Asunción, Ceaduc/Cepag ( $2^{\mathrm{a}}$ ed.).

MENGET, Patrick.

1996. “De l'usage des trophées en Amérique du Sud - esquisse d'une comparation entre les pratiques nivacle (Paraguay) et munduruku (Brésil)". Systèmes de pensée en Afrique Noire (14).

MÉTRAUX, Alfred.

1927 “Migrations historiques des Tupi-guarani”. Journal de la Société des Americanistes 19, p. 145.

1979 [1928] A religião dos Tupinambás - e suas relações com a das demais tribos tupi-guarani. São Paulo, Nacional/Edusp (Coleção Brasilianas, v. 267).

MIGNOLO, Walter.

1997 "La revolución teórica del zapatismo: sus consecuencias históricas, éticas y políticas”. Orbis Tertius II (5).

MIRAS, Julia T.; GONFORA, Majoí F.; MARTINS, Renato; PATEO, Rogério D. do (org.). 2009 Makunaima grita: Terra Indígena Raposa Serra do Sol e os Direitos Constitucionais no Brasil. Rio de Janeiro, Azougue.

MONTAIGNE, Michel de.

1972 [1580] Ensaios (Coleção Os Pensadores, vol. XI). São Paulo, Abril Cultural.

MONTARDO, Deise L. O.

2009 Através do Mbaraka - Música, Dança e Xamanismo Guarani. São Paulo, Edusp.

MONTEIRO, John Manuel.

1992 “Os Guarani e a história do Brasil meridional, séculos XVI-XVII”. In: Manuela Carneiro da Cunha (org.), História dos índios no Brasil. São Paulo: Companhia das Letras. p. 475-98. 1994 Negros da Terra - Índios e Bandeirantes nas Origens de São Paulo. São Paulo, Companhia das Letras. 
MONTOYA, Pe. Antonio Ruiz.

1876 [1639] Tesoro de la Lengua Guaraní. Leipzig, B.G. Teubner [Impr. W. Drugulin].

1985 [1639] A Conquista Espiritual. Porto Alegre, Martins Livreiro Editora.

2002 [1640] Vocabulario de la Lengua Guaraní. Asunción, Cepag.

MORGAN, Lewis H.

1904 [1851] League of the ho-de'-no-sau-nee or Iroquois. New York: Dodd, Mead \& Co.

1975 [1871] La Sociedad Primitiva. Madri, Ayuso.

MORRIS, Brian.

2007 “People without Government”. Anarchy: A Journal of Desire Armed \#63, V 24 (2).

MÜLLER, Franz.

1989 Etnografía de los Guarani del Alto Parana. Buenos Aires, SVD.

MURA, Fábio.

2006 À Procura do Bom Viver: Território, tradição de conhecimento e ecologia doméstica entre os

Kaiowa. Rio de Janeiro, tese de doutorado apresentada ao PPGAS/MN-UFRJ.

2010 “A Trajetória dos Chiru na Construção da Tradição de Conhecimento Kaiowá”. Mana 16 (1): 123-50.

MURRA, John.

1978 La Organización Económica del Estado Inca. México, Siglo XXI.

NEGRI, Antonio \& HARDT, Michael.

2001 Império. Rio de Janeiro, Record.

NEVES, Eduardo Góes.

2006 Arqueologia da Amazônia. Rio de Janeiro, Jorge Zahar.

2009 "Warfare in Precolonial Central Amazonia: when Carneiro meets Clastres". In Axel E. Nielsen \& William H. Walker (ed.) Warfare in Cultural Context - Practice, Agency and the Archaeology of Violence. Tucson, Univ. Arizona Press, p. 139-64. 
NIMUENDAJU, Curt Unkel.

1987[1914] As Lendas da Criação e Destruição do Mundo como Fundamentos da Religião dos Apapocúva-Guarani. São Paulo, Hucitec/Edusp.

NOELLI, Francisco S.

1999 “Curt Nimuendajú e Alfred Métraux: a invenção da busca da 'terra sem mal”". Suplemento Antropológico 34 (2): 123-66.

2004 "La distribución geográfica de las evidencias arqueológicas Guaraní (Brasil, Argentina, Uruguay y Paraguay)". Tellus 7 (2): 15-36.

2009 "O espaço dos Guarani: a construção do mapa arqueológico no Brasil, Paraguai, Argentina e Uruguai”. In Luiz F. V. Moreira \& José H. R. Gonçalves (org.). Etnias, Espaços e Ideias Estudos Multidisciplinares. Curitiba, Instituto Memória, 67-89.

OLIVEIRA, João Pacheco de.

1987a "Elementos para uma sociologia dos viajantes". In João Pacheco de Oliveira (org.) Sociedades indígenas e indigenismo no Brasil. Rio de Janeiro, Marco Zero/UFRJ.

$1987 b$ "Os Atalhos da Magia: Reflexões sobre o Relato dos Naturalistas Viajantes na Etnografia Indígena”. Boletim do Museu Paraense Emílio Goldi. Série Antropologia 3 (2), p.155-188.

1988 O Nosso Governo: Os Ticuna e o Regime Tutelar. S.Paulo/Brasília, Marco Zero/MCT-CNPq. 1998 (org.). Indigenismo e Territorialização - Poderes, Rotinas e Saberes Coloniais no Brasil Contemporâneo. Rio de Janeiro, Contracapa.

1998b “Uma etnologia dos 'índios misturados'? Situação colonial, territorialização e fluxos culturais". Mana 4 (1).

OLIVEIRA, Jorge Eremites de \& PEREIRA, Levi Marques.

2009 Nande Ru Marangatu: Laudo Antropológico e Histórico sobre uma Terra Kaiowa na Fronteira do Brasil com o Paraguai, Município de Antonio João, Mato Grosso do Sul. Dourados, Ed. da UFGD.

OPPENHEIMER, Franz.

1926 The State. New York, Vanguard Press. 
ORTIZ C., Victor Raul.

2008 Etnopolítica, territorialização e história entre os Mapuche no Chile e os Kaiowá-Guarani no

Brasil: um estudo comparativo. Campinas, dissertação de mestrado, PPGAS/IFCHUnicamp.

OVERING, Joanna.

1975 The Piaroa: a people in Orinoco basin. Oxford, Claredon Press.

1989 "Styles of Manhood: an amazonian contrast in tranquility and violence". In Signe Howell and Roy Willis (ed.). Societies at Peace: Anthropological Perspectives. London and New York, Routledge, p.79-99.

1993 "The anarchy and collectivism of the 'primitive other': Marx and Sahlins in the Amazon" in C. M. Hann (ed.). Socialism: Ideals, Ideologies, and Local Practice - ASA Monographs 31. London, Routledge, p.43-58.

2002 [1983] "Estruturas elementares de reciprocidade: uma nota comparativa sobre o pensamento sociopolítico nas Guianas, Brasil Central e Noroeste Amazônico”. Cadernos de Campo 10. 2004 “A reação contra a descolonização da intelectualidade". Ilha 6 (1-2).

2012 "The spectre of the tyrant. Power, violence and the poetics of an Amazonian egalitarianism". In A. Hobart and B. Kapferer (ed.). Contesting the State. Wantage, Sean Kingston Publishing.

PACARI, Nina.

2007 Todo Puede Ocurrir. México, Unam.

PÄRSSINEN, Martti.

2005 “Quando começou, realmente, a expansão guarani em direção às Serras Andinas Orientais?”. Revista de Arqueologia 18, p. 51-66.

PELLICANI, Luciano.

1994 The genesis of capitalism and the origins of modernity. New York, Telos Press.

PEREIRA, Levi Marques.

1999 Parentesco e organização social kaiowa. Campinas, dissertação de mestrado, DCS/IFCH/Unicamp. 
2002 "No mundo dos parentes: socialização das crianças adotadas entre os Kaiowá". In Aracy Lopes da Silva (Org.). Crianças Indígenas: ensaios antropológicos. São Paulo, Global.

2003 “O movimento étnico-social pela demarcação das terras guarani em MS”. Tellus 3(4), 137-45.

2004. Imagens Kaiowa do sistema social e seu entorno. São Paulo, tese de doutorado, PPGAS/USP.

2004b “O pentecostalismo kaiowá: uma aproximação aos aspectos históricos e sociocosmológicos”. In Robin Wrigth (Org.). Transformando os Deuses II. Campinas, Ed Unicamp, p. 267-302.

2005 Relatório Circunstanciado de Identificação e Delimitação da Terra Indígena Taquara.

2011 "Imbricação entre violência nas atuais reservas e a impossibilidade dos Kaiowá e Guarani seguirem praticando seu modelo de organização social" in As Violências contra os Povos Indígenas em Mato Grosso do Sul - E as resistências do Bem Viver por uma Terra Sem Males. Dados 2003-2010. Campo Grande, Cimi-MS, p. 44-47.

PERRONE-MOISÉS, Beatriz.

1996 Relações preciosas: franceses e ameríndios no século XVII. São Paulo, tese de doutorado, PPGAS-USP.

2001 "Conflitos recentes, estruturas persistentes: notícias do Sudão". Revista de Antropologia 44 (2), 127-146.

2003 "Verdadeiros contrários: guerras contra o gentio no Brasil colonial". Sexta-Feira (7), A24-34.

2006. "Notas sobre uma certa confederação guianense”. Colóquio Guiana Ameríndia: etnologia e história, p. 43-50, Ms.

2006b "Mitos ameríndios e o princípio da diferença”. In Adauto Novaes (org.). Oito Visões da América Latina. São Paulo, Senac, p. 241-57.

2011 "Bons chefes, maus chefes, chefões: elementos de filosofia política ameríndia". Revista de Antropologia 54 (2), p. 857-83.

2012 “Festas e guerras”. In PT Redes Ameríndias - Relatório científico 5/2012. Ms.

PERRONE-MOISÉS, Beatriz \& SZTUTMAN, Renato.

2010 "Notícias de uma certa confederação tamoio", Mana 16 (2), p. 401-433.

PIERRI, Daniel.

2012 "O dono da figueira e a origem de Jesus: uma crítica xamânica ao cristianismo". Texto apresentado durante a $28^{\mathrm{a}} \mathrm{RBA}$. 
PIMENTEL, Spensy K.

2006 Sansões e Guaxos - Suicídio Guarani e Kaiowá, uma proposta de síntese. São Paulo, dissertação de mestrado PPGAS-USP.

2008 “Povos originários: novos Protagonismos”. Le Monde Diplomatique Brasil 17, p. 35.

2008b "Kuarahy e Jasy em busca da origem: um olhar sobre o mito dos gêmeos entre os GuaraniKaiowa e as relações de contato". Trabalho apresentado durante a $26^{\mathrm{a}} \mathrm{RBA}$.

2010 "Violência contra os Povos Indígenas". In Vladimir Sacchetta (org.) CDDPH - Conselho de Defesa dos Direitos da Pessoa Humana : uma história de resistência e luta pelos Direitos Humanos no Brasil. Brasília, Secretaria de Direitos Humanos.

2010b "Xamanismo e cosmopolítica entre os Guarani-Kaiowa do Brasil”. Puebla (México), II Coloquio Nuevas Perspectivas sobre el Chamanismo, el Curanderismo y la Brujería.

2011 "Para além dos tekoha: por um plano integrado para os Guarani-Kaiowá". In: Egon D. Heck; Flávio D. Machado (org.). As Violências contra os Povos Indígenas em Mato Grosso do Sul - E as Resistências do Bem Viver por uma Terra sem Males. Campo Grande, CIMI-MS, p. $72-5$.

2011 b "Mortes por enforcamento entre os Guarani-Kaiowá - entre as cosmopolíticas indígenas e as políticas públicas, a história de um mal-entendido”. Texto apresentado na Salsa 2011 Society for the Anthropology of Lowland South America's 7th Sesquiannual Conference. Belém-PA, Brasil.

\section{PIMENTEL, S. \& MONCAU, J.}

2011 "Guarani Kaiowá - Genocídio Surreal”. in Beto Ricardo; Fany Ricardo (org.). Povos Indígenas no Brasil 2006-2010. São Paulo, Instituto Socioambiental, p. 692-6.

PIMENTEL, Spensy; PIERRI, Daniel; BELLENZANI, Maria. Lúcia R.

2010 Relatório de Identificação e Delimitação da Terra Indígena Tenondé Porã (Guarani-Mbya, São Paulo). Documento apresentado à Fundação Nacional do Índio.

PISSOLATO, Elizabeth.

2007 A duração da pessoa - Mobilidade, parentesco e xamanismo mbya (guarani). São Paulo, Unesp/ISA/Nuti. 
POMPA, Maria Cristina.

2003 Religião como Tradução. Missionários, Tupi e Tapuia no Brasil colonial. Bauru: EDUSC.

PORRO, Antonio.

1992 "História Indígena do Alto e Médio Amazonas: Séculos XVI a XVIII”. In Manuela Carneiro da Cunha (org.) História dos índios no Brasil. São Paulo, Companhia das Letras, p. 175196.

PRADO JR., Bento; LEIRNER, Piero de C.; TOLEDO, Luiz H.

2003 “Lembranças e reflexões sobre Pierre Clastres: entrevista com Bento Prado Júnior”. Revista de Antropologia 46 (2), p. 424-44.

PROUDHON, Pierre-Joseph.

1986 "Democracia operária" in Paulo-Edgar A. Resende e Edson Passetti (Org.). Proudhon coleção Grandes Cientistas Sociais. São Paulo, Ática.

QUINTANA G., Jaime \& GASPARELLO, Giovanna (coord.)

2009 Otras Geografias - Experiencias de Autonomías Indígenas en México. México, UAM-I.

RAMO Y AFFONSO, Ana Maria.

2012 “Nomes guarani: entre o milho e o mel”. Apresentação durante a 28 RBA.

RENARD-CASEVITZ, France-Marie.

1992 "História Kampa, Memória Ashaninca". In Manuela Carneiro da Cunha (org.) História dos índios no Brasil. São Paulo: Companhia das Letras, p. 197-212.

RENSHAW, John.

2006 “A eficácia simbólica revisitada. Cantos de cura ayoreo”. Revista de Antropologia 49 (1).

RIBEIRO, Darcy.

1995 O Povo Brasileiro: a formação e o sentido do Brasil. São Paulo, Cia. das Letras.

RIBEIRO, Florbela A. 
2010 Políticas Tenetehara e Tenetehara na política: um estudo sobre as estratégias de uma campanha eleitoral direcionada a uma população indígena. São Paulo, dissertação de mestrado PPGAS-USP.

RIVIÈRE, Peter.

2001 O Indivíduo e a Sociedade na Guiana - Um estudo comparativo sobre a organização social ameríndia. São Paulo, Edusp.

ROLLEMBERG, Denise \& QUADRAT, Samantha Viz (org.)

2010 A Construção Social dos Regimes Autoritários - Legitimidade, consenso e consentimento no século XX (3 vol.). Rio de Janeiro, Civilização Brasileira.

RUEDAS, Javier.

2004 "History, Ethnography, and Politics in Amazonia: Implications of Diachronic and Synchronic Variability in Marubo Politics". Tipití 2 (1).

SAHLINS, Marshall.

1977 Economía de la Edad de Piedra. Madrid, Akal.

1990 Ilhas de história. Rio de Janeiro, Jorge Zahar.

1997 “O pessimismo sentimental e a experiência etnográfica: por que a cultura não é um 'objeto' em via de extinção - Parte 1". Mana 3 (1), p. 41-73.

1999 "Two or Three Things that I Know about Culture". Journal of the Royal Anthropological Institute, 5 (3), p. 399-421

2003 Cultura e razão prática. Rio de Janeiro, Jorge Zahar.

2007 Discurso na UFMG por ocasião do recebimento do título de doutor honoris causa. Transcrição disponível na internet.

2007 b "Cosmologias do capitalismo: o setor transpacífico do 'sistema mundial'”. In Cultura na Prática. Rio de Janeiro, Ed. UFRJ, p. 443-99 (2ª ed.).

2008 The Western Illusion of Human Nature. Chicago, Prickly Paradigm Press.

2010 Stranger-Kings and Stranger-Kin: The Alterity of Power and Vice-Versa. Conferência proferida na EHESS-Paris, 14-4-10, 28 p.

SANJINÉS C., Javier. 
2007 “Tiempo histórico y movimientos sociales del presente”. In vários autores. Democracia Profunda: Reinvenciones Nacionales y Subjetividades Emergentes. Rio de Janeiro, Academia de la Latinidad.

SANTILLI, Paulo

1999 Pemongon Pata: Território Macuxi, Rotas de Conflito. São Paulo, Ed. Unesp.

SANTOS, Boaventura de Souza.

2007 "Para além do pensamento abissal: das linhas globais a uma ecologia de saberes". Revista Crítica de Ciências Sociais 78, p. 3-46.

2008 "A filosofia à venda, a douta ignorância e a aposta de Pascal”. Revista Crítica de Ciências Sociais 80, p. 11-43.

2008b "La reinvención del Estado y el Estado plurinacional". In Pensar el Estado y la Sociedad: desafios actuales. La Paz, Clacso/Comuna/Muela del Diablo.

SANTOS, Maria Cristina dos.

1999 “Clastres e Susnik: uma tradução do 'guarani de papel"”. In Regina A. F. Gadelha (ed.). Missões Guarani - Impacto na Sociedade Contemporânea. São Paulo, Fapesp/Educ, p. 205-19.

SANTOS GRANERO, Fernando.

1993a "From prisoner of the group to darling of the gods: an approach to the issue of power in Lowland South America", L'Homme 126-128, p. 213-230

1993b. "Templos e ferrarias: utopia e reinvenção cultural no oriente peruano" in Eduardo Viveiros de Castro \& Manuela Carneiro da Cunha (org.). Amazônia: etnologia e história indígena. São Paulo, NHII/FAPESP.

SCHADEN, Egon.

1974 Aspectos fundamentais da cultura guarani. São Paulo, E.P.U./Edusp.

SCHAVELZON, Salvador A.

2010 A Assembleia Constituinte da Bolívia: Etnografia do nascimento de um Estado plurinacional. Rio de Janeiro, tese de doutorado, PPGAS-UFRJ. 
SCHMIDL, Ulrich (Ulrico).

2001 Viaje al Río de la Plata (1534-1554) - notas bibliográficas y biográficas por el teniente general don Bartolomé Mitre ; prólogo, traducciones y anotaciones por Samuel Alejandro Lafone Quevedo. Alicante, Biblioteca Virtual Miguel de Cervantes (edición digital basada en la de Buenos Aires, Cabaut y Cía., 1903). http://bib.cervantesvirtual.com/FichaObra.html?portal=0\&Ref=4911

2007 Viaje a España y las Indias. Buenos Aires, Longseller.

SEEGER, Anthony; DA MATTA, Roberto e VIVEIROS DE CASTRO, Eduardo.

1987 [1979] “A construção da pessoa nas sociedades indígenas brasileiras", in João Pacheco de Oliveira (org.) Sociedades indígenas e indigenismo no Brasil. Rio de Janeiro, Marco Zero/UFRJ.

SEEGER, Antony; VIVEIROS DE CASTRO, Eduardo.

1979 “Terras e territórios indígenas do Brasil”. Encontros com a Civilização Brasileira, n. 12.

SEVÁ $\mathrm{F}^{\circ}$, A. Oswaldo (org.).

2005 Tenotã-mõ - Alertas sobre as conseqüências dos projetos hidrelétricos no rio Xingu. São Paulo, IRN.

SILVA, Joana A. F.

1982 Os Kaiowá e a ideologia dos projetos econômicos. Campinas, dissertação de Mestrado, IFCH-Unicamp.

SILVA, Márcio F.

2000 “Perspectivas do Tempo". Sexta Feira n. 5, p. 89-97.

SOARES, André L. R.

1996 Organização sociopolítica guarani: aportes para a investigação arqueológica. Porto Alegre, dissertação de mestrado em História, IFCH/PUC-RS.

SOARES, Renato M. 
2011 “Associações indígenas no Alto Rio Negro, transformações na interação e na organização”. Trabalho apresentado na IX RAM, Curitiba.

2012 Das comunidades à federação: associações indígenas do alto rio Negro. São Paulo, dissertação de mestrado, PPGAS-USP.

SOARES DE SOUZA, Gabriel

1987[1587] Tratado descritivo do Brasil em 1587. Edição comentada por Francisco Adolfo de Varnhagen. Rio de Janeiro, Nacional.

SOUSA, Neimar M.

2002 A Redução de Nuestra Señora de la Fe no Itatim: Entre a Cruz e a Espada (1631-1659). Dourados, dissertação de mestrado em História, UFMS.

SUSNIK, Branislava.

1979/80 Los aborigenes del Paraguay. V. 2: Etnohistoria de los Guaranies. Assunção, Museo Etnográfico Andres Barbeiro.

1989 "Etnohistória de Paraguay". América Indígena vol. XLIX, n. 3, p. 431-90.

2011 El Rol de los Indígenas en la Formación y en la Vivencia del Paraguay. Asunción, Intercontinental.

STADEN, Hans.

1998 "História Verídica e Descrição..." in Portinari devora Hans Staden (tradução do relato original, seguida de desenhos de Candido Portinari inspirados nas xilogravuras que acompanham a obra quinhentista). São Paulo, Terceiro Nome.

STENGERS, Isabelle.

1996 Cosmopolitiques, vol. 1, La guerre des sciences. Paris: La Découverte; Les Empêcheurs de penser en rond.

2005 “The Cosmopolitical Proposal”. In Bruno Latour and Peter Weibel (eds). Making Things Public: Atmospheres of Democracy. Cambridge, MIT Press, p. 994-1004.

STRATHERN, Marilyn.

1991 “One man and many men" in M. Godelier \& M. Strathern (eds.). Big men and Great men: 
personifications of power in Melanesia. Cambridge/Paris, Cambridge Un. Press/ Ed. Maison des Sciences de l'Homme.

1998 "Valor cualificado: la perspectiva del intercambio de regalos" in Caroline Humphrey e Stephen Hugh-Jones (org.). Trueque, Intercambio y Valor - Aproximaciones Antropológicas. Quito: Abya Yala, p. 257-290.

2006 [1988] O Gênero da Dádiva - Problemas com as mulheres e problemas com a sociedade na Melanésia. Campinas, Ed. Unicamp.

SZTUTMAN, Renato.

2005 O profeta e o principal - A ação política ameríndia e seus personagens. São Paulo, tese de Doutorado, PPGAS-USP.

2009 "De nomes e marcas - Ensaio sobre a grandeza do guerreiro selvagem". Revista de Antropologia 52 (1).

2009b “Religião nômade ou germe do estado? Pierre e Hélène Clastres e a vertigem tupi”. Novos Estudos Cebrap 83.

TARDE, Gabriel.

2007 Monadologia e sociologia e outros ensaios. São Paulo, Cosac Naify (org.: Eduardo V. Vargas).

TAYLOR, Anne Christine.

1984 "L'américanisme tropical, une frontière fossile de l'ethnologie?". In Histoires de l'anthropologie: 16e-19e siècles. Paris, Klincksieck, p. 213-33.

1992 "História pós-colombiana da alta Amazônia". In Manuela Carneiro da Cunha (org.) História dos índios no Brasil. São Paulo: Companhia das Letras, p. 213-38.

1993 "Remembering to Forget: Identity, Mourning and Memory Among the Jivaro". Man, New Series, 28 (4), p. 653-78.

TEVES, Laura; CRIVOS, Marta; MARTÍNEZ, María Rosa; SÁENZ, Cynthia.

2002 "Una Aplicación de la Metodología de Redes Sociales a la Investigación Etnográfica". Redes - Revista Hispana para el Análisis de Redes Sociales 2 (6).

THOMAZ DE ALMEIDA, Rubem.

1985 Relatório da area indígena Pirakuá: uma panorâmica sobre o problema e a Noção de terra 
Guarani no Mato Grosso do Sul. Brasília, Funai.

2000 Relatório Antropológico de Identificação e Delimitação da T.I. Ñande Ru Marangatu (MS). Brasília, Funai.

2000b "A 'Entrada' no tekoha" in C.A. Ricardo (ed.). Povos Indígenas no Brasil: 1996-2000. São Paulo, ISA, p 745-8.

2001 Do Desenvolvimento Comunitário à Mobilização Política - O Projeto Kaiowa-Ñandeva como experiência antropológica. Rio de Janeiro, Contra Capa.

THOMSON, Sinclair.

2006 “'Cuando sólo reinasen los indios': Recuperando la variedad de proyectos anticoloniales entre los comuneros andinos (La Paz, 1740-1781)”. Argumentos (Nueva Época) 19 (50).

THOMSON, Sinclair; HYLTON, Forrest; PATZI, Felix; SERULNIKOV, Sergio.

2003 Ya es otro tiempo el presente. Cuatro momentos de insurgencia indígena. La Paz, Muela del Diablo.

TIBLE, Jean.

2009 “José Carlos Mariátegui: Marx e América Indígena”. Cadernos Cemarx, v. 6, p. 97-114.

2010 “Lutas cosmopolíticas: Marx e América Indígena (Yanomami)”. Lugar Comum 30, p. 31-44.

2011 "Lutas contra o Um: notas do diálogo entre uma antropologia e um Marx contra o Estado". $R @ u 3(1)$.

2012 Marx e América Indígena. Campinas, tese de doutorado, PPGS-IFCH/Unicamp

TINOCO, Silvia L. S. M.

2000 Joviña, cacique, professor e presidente. As inter-relações entre os cursos de formação de professores Waiãpi e o conselho Apina. São Paulo, dissertação de mestrado, PPGAS-USP.

2003 “Joviña, cacique ou presidente? Uma aproximação ao Conselho das Aldeias Waiãpi”. Arquivos do Museu Nacional 61 (2), p. 81-7.

TRAVEN, Bruno.

1951 [1931] Gobierno. México, Cia. General de Ediciones.

Turma de Linguagem da Literatura Indígena TEKO ARANDU - UFGD. 
2010 "Yvy oñemongo'i - a terra se levanta". Tellus 10 (18), p. 237-40.

TURNER, Terence.

1979 “The Ge and Bororo societies as dialectical systems: a general model”. In D. Maybury-Lewis (ed.) Dialectical Societies. Cambridge,MA: Harvard Univ. Press.

2003 "The Beautiful and the Common: Inequalities of Value and Revolving Hierarchy among the Kayapó”. Tipití 1 (1).

TYLOR, Edward.

1881 Anthropology - An introduction to the study of man and civilization. London, Macmillan Co.

VIANNA, Fernando

2001. A bola, os 'brancos'e as toras: futebol para índios xavantes. São Paulo, dissertação de mestrado, PPGAS-USP.

VIEIRA, José Glebson.

2008 "Chefia indígena, transformações culturais e novas formas de ação política entre os Potiguara da Paraíba”. Tellus, v.8, p. 113-36.

2010 Amigos e competidores: política faccional e feitiçaria nos Potiguara da Paraíba. Tese de doutorado, PPGAS-USP.

VIETTA, Katya.

2007 Histórias sobre terras e xamãs kaiowa: territorialidade e organização social na perspectiva dos Kaiowa de Panambizinho (Dourados, MS) após 170 anos de exploração e povoamento não indígena da faixa de fronteira entre o Brasil e o Paraguai. São Paulo, tese de doutorado apresentada ao PPGAS-USP.

VILLAÇA, Aparecida.

2005 "Chronically Unstable Bodies: Reflections on Amazonian Corporalities". Journal of Royal Anthropological Institute (N.S.) 11, 445-464.

2008 “Conversão, predação e perspectiva”. Mana 14 (1).

VISAN, Florentina. 
2008 "Representations on diversity. The role of literary translation". Trabalho apresentado na Summer School on Cultural Diversity, Universidade de Bolonha.

VIVEIROS DE CASTRO, Eduardo.

1986 Araweté: Os Deuses Canibais. Rio de Janeiro, Jorge Zahar/Anpocs.

1987 “Nimuendaju e os Guarani”, in Curt Nimuendaju. As Lendas da Criação e Destruição do Mundo como Fundamentos da Religião dos Apapocúva-Guarani. São Paulo, Hucitec/Edusp, p. xvii-xlii.

1992 Araweté - O povo do Ipixuna. São Paulo, CEDI.

1995 From the enemy's point of view: humanity and divinity in an amazonian society. Chicago, Chicago University Press.

1999 "Etnologia Brasileira", in Sergio Micelli (org.). O Que Ler na Ciência Social Brasileira (1970-1995), vol. 1 - Antropologia, 109-224. Brasília, Sumaré/Anpocs.

2002 A Inconstância da Alma Selvagem - e outros ensaios de antropologia. São Paulo, Cosac \& Naify.

2004a "Perspectival Anthropology and the Method of Controlled Equivocation". Tipití 2(1): 3-22.

2004b "Posfácio". In CLASTRES, Pierre. Arqueologia da violência: pesquisas de antropologia política. São Paulo, Cosac \& Naify.

2007 “Filiação Intensiva e Aliança Demoníaca”. Novos Estudos Cebrap 77.

2008 "Xamanismo Transversal: Lévi-Strauss e a cosmopolítica amazônica”. In Ruben Caixeta de Queiroz \& Renarde Freire Nobre (org.). Lévi-Strauss - Leituras Brasileiras. Belo Horizonte, Ed. UFMG.

2010 Metafísicas Canibales - Líneas de Antropologia Postestructural. Madrid, Katz.

2011 “O medo dos outros”. Revista de Antropologia 54 (2).

VIVEIROS DE CASTRO, E. \& SZTUTMAN, R. (Org.).

2008 Eduardo Viveiros de Castro - Série Encontros. Rio de Janeiro: Azougue, 2008.

VYSOKOLAN, Oleg.

2010 La Traición de Papa Réi - 500 años de resisténcia. Asunción, Fondec.

WAGNER, Roy.

1986 Symbols That Stand for Themselves. Chicago, University of Chicago Press. 
1987 "Figure-Ground Reversal among the Barok". In Louise Lincoln (ed.). Assemblage of Spirits: Idea and Image in New Ireland. New York: George Braziller.

1991 "The fractal person". in M. Godelier \& M. Strathern (eds.). Big men and Great men: personifications of power in Melanesia. Cambridge/Paris, Cambridge Un. Press/ Ed. Maison des Sciences de l'Homme (tradução publicada em Ponto Urbe 8 - 2011 disponível em http://www.pontourbe.net/edicao8-traducoes/168-a-pessoa-fractal)

2010 “O xadrez do parentesco e o parentesco do xadrez”. Ilha 12 (1).

2010b [1975] A Invenção da Cultura. São Paulo, Cosac \& Naify.

WATSON, Virginia D.

1944 "Notas sobre o sistema de parentesco dos indios Cayua". Sociologia, Vol. VI, n. 4, p. 31-48.

WATT, Ian.

1997 Mitos do Individualismo Moderno: Fausto, Dom Quixote, Dom Juan, Robinson Crusoé. Rio de Janeiro, Jorge Zahar.

WEBER, Max.

1967 [1920] A Ética Protestante e o Espírito do Capitalismo. São Paulo, Pioneira.

1968 [1919] “A política como vocação”. In Ciência e Política - Duas Vocações. São Paulo, Cultrix.

WILDE, Guillermo.

2001 "Los guaraníes después de la expulsión de los jesuitas: dinámicas políticas y transacciones simbólicas". Revista Complutense de Historia de América 27: 69-106

2009 “Território y etnogénesis misional en el Paraguay del Siglo XVIII”. Fronteiras 11 (19).

WILKINS, David E. \& STARK, Heidi K.

2011 American Indian Politics and the American Political System. Lanham, R. \& Littlefield (3 ed.).

ZEA, Evelyn.

2010 "Sobre a ilusão de ter: reflexões an/tropológicas". Ilha 12 (1).

ZIZEK, Slavoj.

2011 Primeiro como Tragédia, Depois como Farsa. São Paulo, Boitempo. 


\section{Glossário}

aty - reunião, assembleia

ava - pessoa, gente, ou homem, em oposição a kuña, mulher; ou indígena, em oposição a karai, branco

avatykyry - bebida de milho novo e, por extensão, a festa em que é feita e consumida

chicha - bebida feita com milho, cana, batata-doce etc., pode ser fermentada ou não (termo de origem quéchua)

guahu - espécie de canto melancólico associado a dança de roda, entoado em festas (mais detalhes, ver Chamorro, 2008: 348)

guacho - criança adotada, "órfão"

guaxiré - canto alegre associado a dança de roda, entoado em festas

johexakáry - atributo do xamã que é capaz de ver (hecha) - aparece com várias grafias, como ohechakára

jeguaka - adorno de cabeça

jehovasa - abençoar (espécie de passe, feito com as mãos, para limpar, proteger - envolve gestos como os que afastam a fumaça, ou que esfriam alguma coisa)

jerosy - dançar

jerosy puku - dança ou canto longo, associada à festa do avatikyry

kagui - o termo guarani para chicha; cauim

karai - um dos termos usados para designar os brancos, entre os Kaiowá e Guarani de MS; no litoral, diferentemente, é termo associado à cosmologia, ao xamanismo, sendo também usado como nome próprio

kotyhu - dança circular, alegre; pode ser usado como sinônimo de guaxiré, mas, segundo Chamorro (informação pessoal), só se usa kotyhu no âmbito do avatikyry. "Guaxiré parece ser só social, não faz parte de rituais; alguns dizem que é termo de origem paraguaia”, de acordo com a autora. Ela ainda observa que kotyhu é termo registrado por Montoya (koty - peça da casa, $h u$ - encontrar), e guaxiré não.

kuña - mulher

marangatu - adjetivo que designa tudo que é sagrado, santo e demarca o campo que é traduzido como "religião"

mbaere - outro dos termos usados para designar os não indígenas; correlato de maíra 
mburuvicha, ou tuvicha - principal, chefe; pessoa de maior prestígio em dada região; hoje, também está associado ao encargo de "representar" uma dada comunidade junto aos brancos

mitã pepy - convite dos meninos: antiga festa de passagem, em que se furavam os lábios dos jovens para marcar a passagem à idade adulta, pela imposição do tembeta; não é praticada atualmente em MS

ñande reko - nosso modo de ser, nosso estilo, o jeito correto de ser e de agir, em oposição ao jeito dos brancos de fazer as coisas (karai reko)

ñanderu - "nosso pai", uma das designações mais comuns para um homem reconhecido como xamã

ñandesy - "nossa mãe", designação mais comum para a mulher reconhecida pelas habilidades xamânicas

ñembo'e - "reza", fórmula verbal destinada a proteger, curar etc.

ñemoñe' $\overline{\boldsymbol{e}}$ - aconselhar

ñemongeta - conversar, parlamentar

ñengarai - um tipo de fórmula verbal (“oração"), que pode ser associada à proteção diante de agressões, ou à agressão xamânica em conflitos

porã - bom, correto, belo

porahei, ou mborahei - cantar, canto (termo fortemente associado a "rezar")

teko - jeito, modo

tekoha - lugar do nosso modo, literalmente; hoje, designa as terras consideradas de ocupação tradicional, que os Kaiowá e Guarani tentam reconquistar

tekojára - dono do modo de ser, termo genericamente associado aos deuses

tendotá - guia, condutor; aquele que toma a iniciativa, segue adiante

tihã, ou motihã - espécie de fórmula verbal para proteção/agressão

tupã kuéry, ou tupanguéry - termo associado aos deuses

vai - ruim, à toa

vy'a - bem-estar, alegria, conforto

yvyra marangatu - "altar"; construção feita com varas e em volta da qual os xamãs cantam

yvyraija - termo que designa um aprendiz de xamã, auxiliar, ajudante 
Anexos 
Tabela 2.1 - Pessoas indígenas, por sexo e localização do domicílio, segundo as Grandes Regiōes e as Unidades da Federação - 2010

\begin{tabular}{|c|c|c|c|c|c|}
\hline \multirow{5}{*}{$\begin{array}{c}\text { Grandes Regiōes } \\
e \\
\text { Unidades da Federaçāo }\end{array}$} & \multicolumn{5}{|c|}{ Pessoas indigenas } \\
\hline & \multirow{4}{*}{ Total } & \multicolumn{4}{|c|}{ Localizaçăo do domicilio } \\
\hline & & \multirow[b]{3}{*}{ Total } & \multicolumn{2}{|l|}{ Terras indigenas } & \multirow{3}{*}{$\begin{array}{l}\text { Fora de terras } \\
\text { indigenas }\end{array}$} \\
\hline & & & \multicolumn{2}{|c|}{ Condiçăo de indigena } & \\
\hline & & & $\begin{array}{l}\text { Declararam-se } \\
\text { indigenas }\end{array}$ & $\begin{array}{c}\text { Nâo se declararam, } \\
\text { mas se } \\
\text { consideravam } \\
\text { indigenas }\end{array}$ & \\
\hline Brasil & 896917 & 517383 & 438429 & 78954 & 379534 \\
\hline Norte & 342836 & 251891 & 214928 & 36963 & 90945 \\
\hline Rondónia & 13076 & 9217 & 8156 & 1061 & 3859 \\
\hline Acre & 17578 & 13308 & 11651 & 1657 & 4270 \\
\hline Amazonas & 183514 & 129529 & 114695 & 14834 & 53985 \\
\hline Roraima & 55922 & 46505 & 40220 & 6285 & 9417 \\
\hline Pará & 51217 & 35816 & 23680 & 12136 & 15401 \\
\hline Amapd & 7411 & 5956 & 5953 & 3 & 1455 \\
\hline Tocantins & 14118 & 11560 & 10573 & 987 & 2558 \\
\hline Nordeste & 232739 & 106142 & 82094 & 24048 & 126597 \\
\hline Maranhẫo & 38831 & 29621 & 26062 & 3559 & 9210 \\
\hline Piaul & 2944 & - & $=$ & $=$ & 2944 \\
\hline Ceará & 20697 & 2988 & 1627 & 1361 & 17709 \\
\hline Plio Grande do Norte & 2597 & - & - & - & 2597 \\
\hline Paraiba & 25043 & 18296 & 12402 & 5894 & 6747 \\
\hline Pernambuco & 60995 & 31.836 & 24125 & 7711 & 29159 \\
\hline Alagoas & 16291 & 6268 & 4486 & 1782 & 10023 \\
\hline Sergipe & 5221 & 316 & 314 & 2 & 4905 \\
\hline Bahia & 60120 & 16817 & 13078 & 3739 & 43303 \\
\hline Sudeste & 99137 & 15904 & 14727 & 1177 & 83233 \\
\hline Minas Gerais & 31677 & 9682 & 9117 & 565 & 21995 \\
\hline Espirito Santo & 9585 & 3005 & 2580 & 425 & 6580 \\
\hline Rio de Janeiro & 15894 & 450 & 450 & - & 15444 \\
\hline Sầ Paulo & 41981 & 2767 & 2580 & 187 & 39214 \\
\hline Sul & 78773 & 39427 & 35599 & 3828 & 39346 \\
\hline Paranả & 26559 & 11934 & 11290 & 644 & 14625 \\
\hline Santa Catarina & 18213 & 9227 & 7055 & 2172 & 8986 \\
\hline Pio Grande do Sul & 34001 & 18266 & 17254 & 1012 & 15735 \\
\hline Centro-Oeste & 143432 & 104019 & 91081 & 12938 & 39413 \\
\hline Mato Grosso do Sul & 77025 & 61158 & 57428 & 3730 & 15867 \\
\hline Mato Grosso & 51696 & 42525 & 33367 & 9158 & 9171 \\
\hline Goiâs & 8583 & 336 & 286 & 50 & 8247 \\
\hline Distrito Federal & 6128 & . & - & - & 6128 \\
\hline
\end{tabular}


Tabela 3.1 - Pessoas residentes em terras indigenas, por condiçăo de indígena, segundo as Unidades da Federaçăo e as terras indígenas - Brasil - 2010

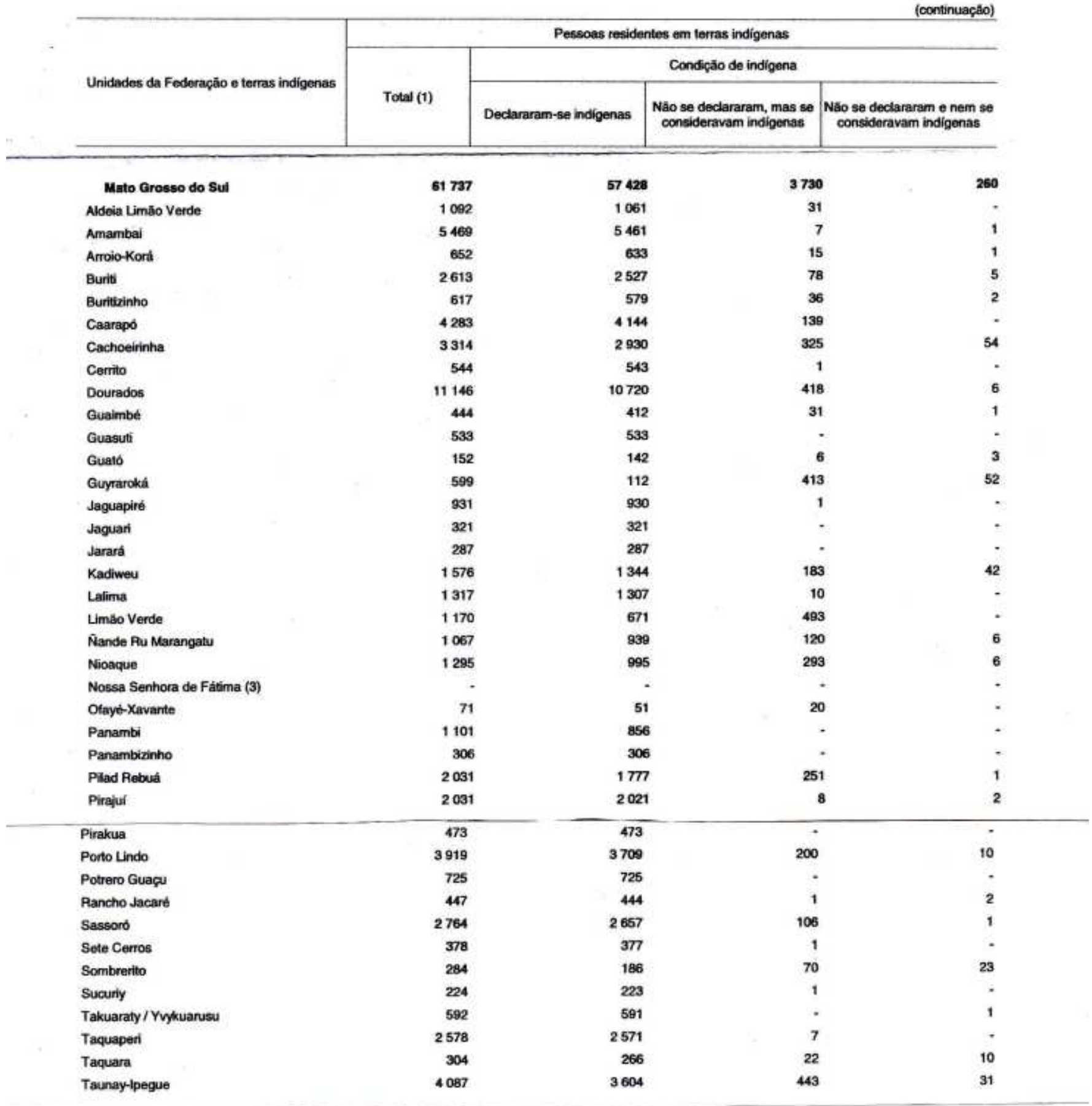

Censo Demográfico 2010

Características gerais dos indígenas Resultados do universo 
Tabela 15 - Pessoas indigenas de 5 anos ou mais de idade com indicação das 15 línguas com maior número de indigenas, por localização do domicilio - Brasil - 2010

\begin{tabular}{|c|c|c|c|c|c|c|}
\hline \multirow{2}{*}{$\begin{array}{c}\text { Nümero } \\
\text { de ordem }\end{array}$} & \multicolumn{2}{|l|}{ Total } & \multicolumn{2}{|l|}{ Nas Terras Indigenas } & \multicolumn{2}{|c|}{ Fora das Terras Indigenas } \\
\hline & $\begin{array}{c}\text { Nome da lingua } \\
\text { indigena }\end{array}$ & $\begin{array}{l}\text { Pessoas } \\
\text { de } 5 \text { anos }\end{array}$ & Nome da lingua indigena & $\begin{array}{c}\text { Pessoas } \\
\text { de } 5\end{array}$ & Nome da lingua indigena & $\begin{array}{c}\text { Pessoas } \\
\text { de } 5\end{array}$ \\
\hline 1 & Tikûna & 34069 & Tikúna & 30057 & Tikúna & 4012 \\
\hline 2 & Guarani Kaiowá & 26528 & Guarani Kaiowá & 24368 & Lingua Geral Amazónica & 3466 \\
\hline 3 & Kaingáng & 22027 & Kaingàng & 19905 & Tukảno & 2670 \\
\hline 4 & Xavánte & 13290 & Yanomàmi & 12301 & Guarani Kaiowá & 2160 \\
\hline 5 & Yanomámi & 12706 & Xavainte & 11733 & Kaingàng & 2122 \\
\hline 6 & Guajajảra & 9502 & Guajajára & 8269 & Guarani Mbya & 2106 \\
\hline 7 & Mawé & 8934 & Mawé & 8103 & Teréna & 1890 \\
\hline 8 & Teréna & 8204 & Teréna & 6314 & Xavante & 1557 \\
\hline 9 & Lingua Geral Amazónica & 7237 & Kayapó & 5520 & Guajajára & 1233 \\
\hline 10 & Tukáno & 7082 & Guarani Nhandeva & 4887 & Mundurukú & 1138 \\
\hline 11 & Kayapó & 6204 & Makuxi & 4675 & Makuxi & 1099 \\
\hline 12 & Makuxi & 5774 & Tukảno & 4412 & Pataxó & 836 \\
\hline 13 & Guarani Nhandeva & 5394 & Lingua Geral Amazónica & 3771 & Mawé & 831 \\
\hline 14 & Guarani Mbya & 5354 & Kaxinawá & 3588 & Wapixána & 801 \\
\hline 15 & Mundurukú & 4701 & Mundurukú & 3563 & Baniwa & 784 \\
\hline
\end{tabular}

Fonte: IBGE, Censo Demográfico 2010.

Tabela 12 - População indígena com indicação das 15 etnias com maior número de indigenas, por localizaçâo do domicilio - Brasil - 2010

\begin{tabular}{|c|c|c|c|c|c|c|}
\hline \multirow{2}{*}{$\begin{array}{l}\text { Nùmero de } \\
\text { ordem }\end{array}$} & \multicolumn{2}{|c|}{ Total } & \multicolumn{2}{|c|}{ Nas Terras Indigenas } & \multicolumn{2}{|c|}{ Fora das Terras Indigenas } \\
\hline & Nome da etnia & População & Nome da etnia & Populaçẩo & Nome da etnia & Populaçầo \\
\hline 1 & Tikùna & 46045 & Tikùna & 39349 & Terena & 9626 \\
\hline 2 & Guarani Kaiowá & 43401 & Guarani Kaiowá & 35276 & Baré & 9016 \\
\hline 3 & Kaingang & 37470 & Kaingeng & 31814 & Guarani Kaiowá & 8125 \\
\hline 4 & Makuxi & 28912 & Makuxi & 22568 & Mùra & 7769 \\
\hline 5 & Terena & 28845 & Yanomámi & 20604 & Guarani & 6937 \\
\hline 6 & Tenetehara & 24428 & Tenetehara & 19955 & Tikúna & 6696 \\
\hline 7 & Yanomámi & 21982 & Terena & 19219 & Pataxó & 6381 \\
\hline 8 & Potiguara & 20554 & Xavante & 15953 & Makuxi & 6344 \\
\hline 9 & Xavante & 19259 & Potiguara & 15240 & Kokama & 5976 \\
\hline 10 & Pataxó & 13588 & Sateré-Mawé & 11060 & Tupinambä & 5715 \\
\hline 11 & Sateré-Mawé & 13310 & Mundurukù & 8845 & Kaingang & 5656 \\
\hline 12 & Mundurukú & 13103 & Kayapó & 8580 & Potiguara & 5314 \\
\hline 13 & Múra & 12479 & Wapixana & 8133 & Xucuru & 4963 \\
\hline 14 & Xucuru & 12471 & Xacriabá & 7760 & Tenetehara & 4473 \\
\hline 15 & Baré & 11990 & Xucuru & 7508 & Atikum & 4273 \\
\hline
\end{tabular}

Fonte: IBGE, Censo Demagráfico 2010. 


\section{㧘}

Cartograma 2 - Populaçāo indigena - Brasil - 2010

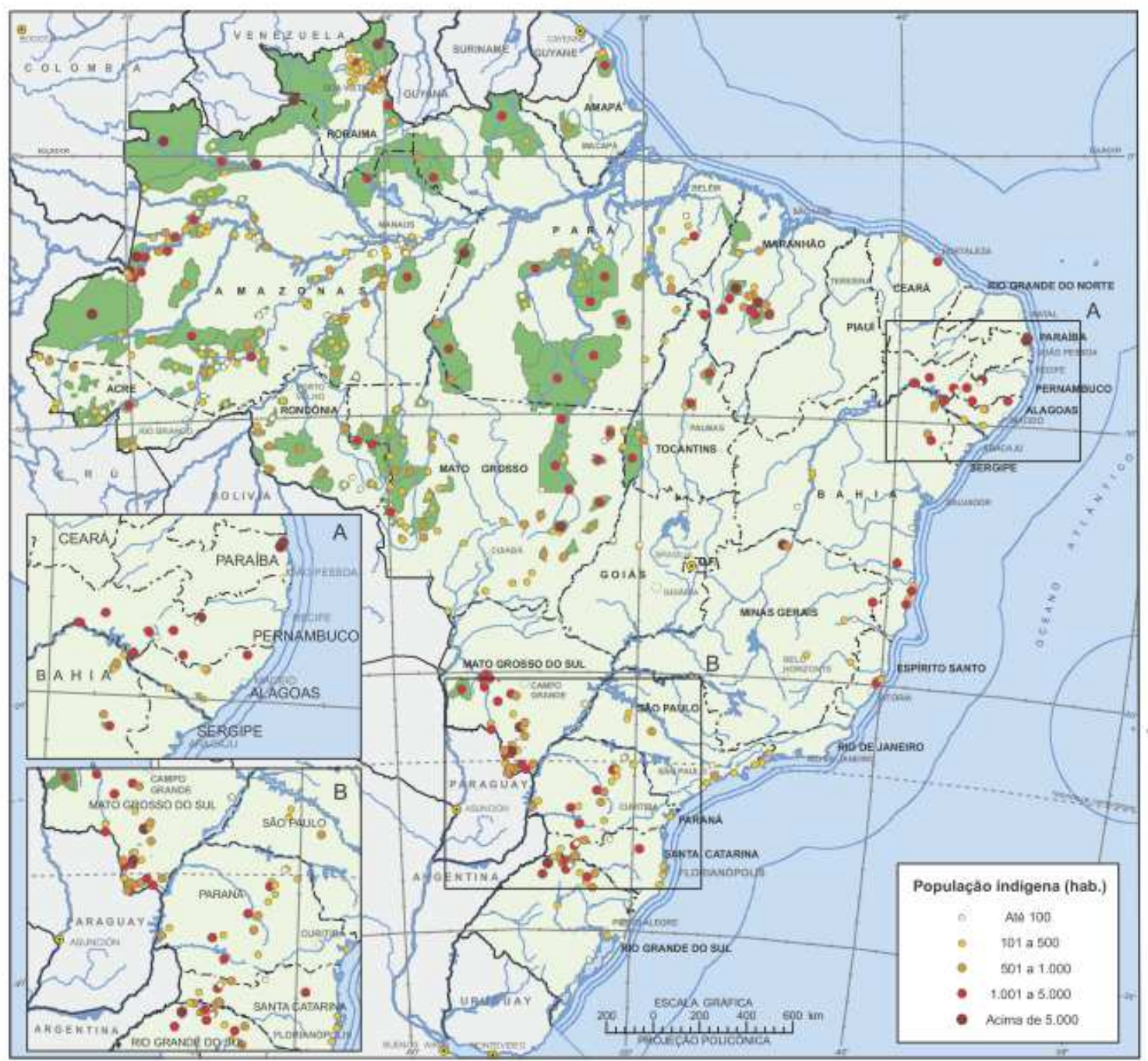

Fonte: IBGE, Censo Demográfico 2010. 


\section{Assassinatos de Indígenas (2003-2011).}

Assassinatos no Brasil
\begin{tabular}{|c|c|c|c|c|c|c|c|c|c|c|}
\hline 2003 & 2004 & 2005 & 2006 & 2007 & 2008 & 2009 & $\mathbf{2 0 1 0}$ & $\mathbf{2 0 1 1}$ & Total & Média anual \\
\hline 42 & 37 & 43 & 58 & 92 & 60 & 60 & 60 & 51 & 503 & 55,8 \\
\hline
\end{tabular}

Assassinatos no Brasil e no Mato Grosso do Sul

\begin{tabular}{|l|c|c|c|c|c|c|c|c|c|c|c|} 
& $\mathbf{2 0 0 3}$ & $\mathbf{2 0 0 4}$ & $\mathbf{2 0 0 5}$ & $\mathbf{2 0 0 6}$ & $\mathbf{2 0 0 7}$ & $\mathbf{2 0 0 8}$ & $\mathbf{2 0 0 9}$ & $\mathbf{2 0 1 0}$ & $\mathbf{2 0 1 1}$ & Total & Média \\
\hline Total Brasil & 42 & 37 & 43 & 58 & 92 & 60 & 60 & 60 & 51 & 503 & 55,8 \\
\hline No absoluto MS: & 13 & 16 & 28 & 28 & 53 & 42 & 33 & 34 & 32 & 279 & 31 \\
\hline$N^{\circ}$ absoluto restante: & 29 & 21 & 15 & 30 & 39 & 18 & 27 & 26 & 19 & 224 & 24,8 \\
\hline MS (\%): & $33 \%$ & $43 \%$ & $65 \%$ & $48 \%$ & $58 \%$ & $70 \%$ & $54 \%$ & $57 \%$ & $62 \%$ & $55 \%$ & 54,5 \\
\hline
\end{tabular}

Fonte: Relatório Violência Contra os Povos Indígenas do Brasil. Cimi, 2011.

\section{Suicídios de Indígenas (2003-2010).}

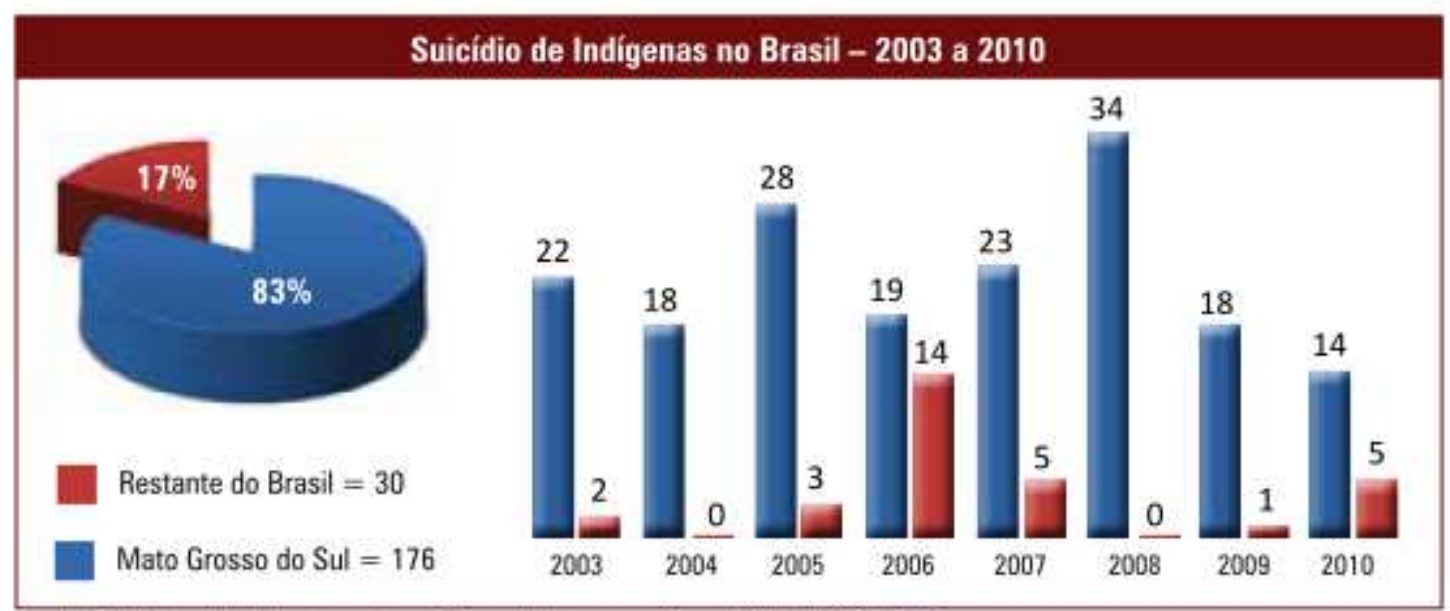

Fonte: Relatónio de Violéncia contra os Povos Indigenas no Brasul. ClMI-2003-2010 